FERNANDO BORGES MÂNICA

\title{
PARTICIPAÇÃO PRIVADA NA PRESTAÇÃO DE SERVIÇOS PÚBLICOS DE SAÚDE
}

\author{
Tese apresentada ao Programa de Pós-Graduação \\ da Faculdade de Direito da Universidade de São \\ Paulo como requisito parcial para a obtenção do \\ grau de Doutor em Direito do Estado. \\ Orientadora: Prof. ${ }^{\text {a }}$ Dr. ${ }^{\text {a }}$ Odete Medauar
}

Faculdade de Direito da Universidade de São Paulo

São Paulo

2009 
FERNANDO BORGES MÂNICA

\section{PARTICIPAÇÃO PRIVADA NA PRESTAÇÃO DE SERVIÇOS PÚBLICOS DE SAÚDE}

Faculdade de Direito da Universidade de São Paulo São Paulo 


\title{
TERMO DE APROVAÇÃO
}

\author{
FERNANDO BORGES MÂNICA
}

\section{PARTICIPAÇÃO PRIVADA NA PRESTAÇÃO \\ DE SERVIÇOS PÚBLICOS DE SAÚDE}

Tese aprovada como requisito parcial para obtenção do grau de Doutor em Direito do Estado no Curso de Pós-Graduação em Direito da Faculdade de Direito da Universidade de São Paulo, pela seguinte banca examinadora:

Orientadora:

Prof . ${ }^{a}$ Dr. ${ }^{a}$ Odete Medauar

Faculdade de Direito, Universidade de São Paulo

Membros:

São Paulo, de 2009. 
A meus pais, Valdir e Maria Inês. 


\section{AGRADECIMENTOS}

Meus sinceros agradecimentos a todos aqueles que de forma direta ou indireta participaram do processo de elaboração deste trabalho, em especial:

À Mariana Morgan, pelo apoio incondicional durante o período de realização das disciplinas do Programa de Pós-graduação.

Aos estagiários Luciana Mânica, Bruno Castanho e Emanuelle Moreira, e à advogada Jaqueline Zanão, pela dedicação extensiva no levantamento de dados.

Ao grupo de pesquisa sobre a saúde em sistemas estrangeiros, pela reunião de vasto material e pela participação nas discussões acerca do tema.

Aos integrantes do TWB, por proporcionarem momentos de confraternização desportiva, essenciais à reposição de forças para o trabalho acadêmico.

Ao advogado Gustavo Tramujas, pela obtenção de trabalhos apenas localizados em bibliotecas européias.

À Antônia Schwinden, pelo auxílio na revisão final do texto.

Ao Prof. Dr. Gustavo Justino de Oliveira, pelo exemplo de dedicação acadêmica.

Ao Prof. Dr. Floriano Peixoto de Azevedo Marques Neto e ao Prof. Dr. Fernando Dias Menezes de Almeida, pelas considerações tecidas no exame de qualificação.

À Prof. ${ }^{a}$ Dr. ${ }^{a}$ Odete Medauar, pela acolhida na Universidade de São Paulo, pela segurança e firmeza no processo de orientação, e pelo incentivo ao desenvolvimento de novas idéias. 


\section{RESUMO}

MÂNICA, Fernando Borges. Participação privada na prestação de serviços públicos de saúde. 2009. 306p. Tese (Doutorado) - Curso de Pós-Graduação em Direito, Universidade de São Paulo, São Paulo, 2009.

A consagração da saúde como direito fundamental pode ser analisada pari passu ao desenvolvimento da ciência médica e à evolução das funções do Estado. A concretização do direito à saúde por meio de atividades estatais demanda o estudo de uma série de categorias do Direito Administrativo, em especial no que se refere à participação privada na prestação dos respectivos serviços públicos. Partindo da análise histórica e da experiência internacional no tratamento da questão, o presente trabalho investiga o desenvolvimento das atividades de assistência à saúde com o objetivo de interpretar a disciplina trazida pela Constituição brasileira de 1988. A garantia do direito à saúde depende, dentre outras atividades estatais, de serviços oferecidos gratuitamente a todas as pessoas que deles necessitam e não possuem condições de obtê-los no mercado. Assim, levar a sério o direito à saúde implica reconhecer a limitação de recursos disponíveis para sua garantia e demanda a delimitação de sua abrangência - tanto no que diz respeito aos beneficiários quanto aos serviços a serem disponibilizados. A prestação de serviços públicos de saúde é expressamente prevista pela Constituição brasileira, que não traz qualquer delimitação quantitativa ou qualitativa da abrangência de tal participação. Compete ao administrador público responsável pela prestação do serviço, com apoio em lei do respectivo ente federativo, a opção pela melhor modalidade de prestação - pública ou privada - para a garantia de tal direito. Os vínculos firmados com entes privados para a prestação de serviços públicos de saúde possuem natureza de contratos de prestação de serviços ou de concessão de serviço público. Da exigência constitucional de contratualização com agentes privados prestadores de serviços públicos de saúde decorre a responsabilidade objetiva por eventuais danos aos usuários e a exigência de manutenção do equilíbrio econômico-financeiro dos ajustes. É imprescindível - tanto para a segurança jurídica dos administradores públicos e dos prestadores privados quanto para a efetiva prestação dos serviços de saúde - que seja elaborada lei nacional contendo normas gerais acerca das hipóteses e dos procedimentos para contratação, prestação e fiscalização dos serviços públicos de saúde por entidades privadas.

Palavras-chave: Direito à saúde; serviço público; complementaridade da participação privada; modelos de ajuste. 


\begin{abstract}
MÂNICA, Fernando Borges. Private Participation in Public Health Services Rendering. 2009. 306p. Thesis (Doctorate) - Postgraduate Course in Law, University of São Paulo, São Paulo, 2009.

The proclamation of human health as a fundamental right may be analyzed pari passu with the development of medical science and the evolution of the functions of the State. The implementation of the right to health through state activities entails the study of a series of Administrative Law categories, especially as regards the participation of private institutions in public services rendering. Based on a historical analysis and international experience in dealing with this issue, this study investigates the development of health provision activities, with the purpose of interpreting the discipline brought about by the Brazilian Constitution of 1988. Safeguarding the right to health depends, among other state activities, on rendering free-of-charge services to all individuals that need them but who cannot afford or obtain them in the market. So, taking the right to health seriously implies recognizing the scarcity of resources available to meet the demand and the limits to their reach - both in terms of beneficiaries and services to be rendered. Private participation in the provision of public health services is clearly acknowledged by the Brazilian Constitution, which does not impose any quantitative or qualitative constraints concerning the scope of such participation. It is up to the public administrator charged with the rendering of a service, and legally supported by the respective federal institution, to choose the best provision mode - public or private - to ensure such right. The links established with private public health rendering institutions are of a service provision contract or public health utility nature. From the constitutional requirement of entering into agreements with private public health service providers emerges the objective liability for occasional harm done to users and the responsibility to keep the economic-financial balance of making adjustments. It is essential - for the legal safety of public administrators and private services providers, as well as for the effective provision of public health services - that a national law be drafted, containing general guidelines on the hypotheses and procedures to commission, provide, and supervise public health services rendered by private institutions.
\end{abstract}

Key Words: Right to Health; Public Service; Private Participation Complementarity; Adjustment Models. 


\section{RESUMÉ}

MÂNICA, Fernando Borges. Participation Privée dans les Prestations de Services Publics de Santé. 2009. 306p. Thèse (Doctorat) - Cours Post-Universitaire en Droit, Université de São Paulo, São Paulo, 2009.

L'affirmation de la santé en tant qu'un droit fondamental pourrait être analysée pari passu au développement de la science médicale et à l'élargissement des fonctions de l'État. En effet, la concrétisation du droit à la santé à travers des activités de l'État, requiert l'étude d'une série des catégories du Droit Administratif, en particulier en ce que concerne la participation privée dans les prestations de ces services publics de santé. Ayant pour le point de départ l'analyse historique aussi bien que l'approche internationale de la question cette recherche fait étudie le développement des activités d'assistance à la santé afin d'interpréter la discipline mise en oeuvre par la Constituition brésilienne de 1988. L'assurance du droit à la santé dépend, parmi d'autres activités de l'Etat, des services offerts gratuitement à toutes personnes qui en ont besoin et qui n'ont pas les conditions d'en réussir par des moyens privés. De cette façon, prendre au sérieux le droit à la santé implique en reconnaître la limitation des ressources disponibles qui puissent et requiert la délimitation de son domaine_aussi bien dans que se concerne le respect aux bénéficiaires qu'aux services à être offerts. La participation privée de la prestation de services publics de la santé é expressément prévue par la Constitution brésilienne, qui ne presente aucunne délimitation quantitative ou qualitative du domaine de cette participation. Il revient à l'administrateur public responsable de la prestation de service, à la lumière de la loi du respectif établissement public fédératif, choisir la meilleure modalité de prestation publique ou privée_afin d'assurer le droit en question. Les liens établis entre les personnes privées pour la prestation de services publics de santé ont la nature de contrats de prestation de services ou de concession de services publics. De l'exigence constitutionnelle du recrutement des agents privés, qui prètent de services publics de santé, il revient la responsabilité objective pour des éventuels dommages aux utilisateurs ainsi que l'exigence de la manutention de l'équilibre économique-financier des ajustements. Il est indispensable, de cette manière_afin d'assurer la sécurité juridique des administrateurs publics et des personnes juridiques prêtant de services privés aussi bien que pour garantir l'effective prestation de service de la santé_que soit élabore une loi nationale contenant des normes générales à propos des hypothèses et des procédures pour le recrutement, la prestation et la fiscalisation des services publics de santé pour des personnes privées.

Mots-clefs: Droit à la santé, service public, complémentarité de participation privée, modèles d'ajustements. 


\section{RIASSUNTO}

MÂNICA, Fernando Borges. Partecipazione Privata alla Prestazione di Servizi Pubblici di Salute. 2009. 306p. Tesi (Dottorato di Ricerca) - Corso di Post-Laurea in Diritto, Università di São Paulo, São Paulo, 2009.

La consagrazione della salute come diritto fondamentale può essere analizzata pari passu allo sviluppo della scienza medica e all'evoluzione delle funzioni dello Stato. La concretizzazione del diritto alla salute per mezzo delle attività statali richiede lo Studio di una serie di categorie del Diritto Amministrativo, specialmente per quanto riguarda la partecipazione privata alla prestazione dei rispettivi servizi pubblici. Partendo dall'analisi storica e dall'esperienza internazionale nel trattamento della questione, il presente lavoro indaga sullo sviluppo delle attività di assistenza alla salute con l'obiettivo di interpretare la disciplina stabilita dalla Costituzione brasiliana del 1988. La garanzia del diritto alla salute dipende, tra altre attività statali, dai servizi offerti gratuitamente a tutte le persone che ne hanno bisogno e non hanno condizioni di ottenerli nel mercato. Così, prendere sul serio il diritto alla salute implica nel riconoscere i limiti di risorse disponibili per la sua garanzia e richiede la delimitazione della sua portata - sia per quel che riguarda i beneficiari sia i servizi da rendere disponibili. La partecipazione privata alla prestazione di servizi pubblici di salute è espressamente prevista dalla Costituzione brasiliana, che non stabilisce qualsiasi delimitazione quantitativa o qualitativa della portata di detta partecipazione. Compete all'amministratore pubblico responsabile della prestazione del servizio, con l'appoggio della legge del rispettivo ente federativo, l'opzione per la migliore modalità di prestazione pubblica o privata - per la garanzia di tale diritto. I vincoli firmati con enti privati per la prestazione di servizi pubblici di salute possiedono natura di contratti di prestazione di servizio o di concessione di servizio pubblico. Dall'esigenza costituzionale di contrattualizzazione con agenti privati prestatori di servizi pubblici di salute decorre la responsabilità obiettiva per eventuali danni agli utenti e l'esigenza di manutenzione dell'equilibrio economicofinanziario degli riaggiustamenti. È imprescindibile - sia per la sicurezza giuridica degli amministratori pubblici e dei prestatori privati sia per l'effettiva prestazione dei servizi di salute - che sia elaborata legge nazionale contenente norme generali sulle ipotesi e sui procedimenti per contrattazione, prestazione e controllo dei servizi pubblici di salute forniti da entità private.

Parole-chiavi: Diritto alla salute; servizio pubblico; complementarità della partecipazione privata; modelli di riaggiustamento. 


\section{SUMÁRIO}

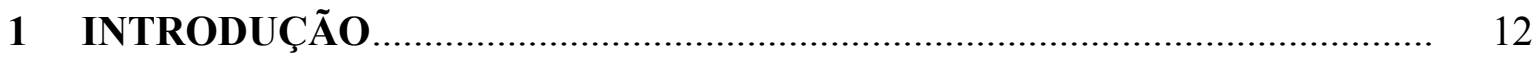

1.1 APRESENTAÇÃO DO TEMA …………………………………………….... 12

1.2 CONTEXTUALIZAÇÃO .................................................................................. 14

1.3 DELIMITAÇÃO DO OBJETO....................................................................... 16

1.4 JUSTIFICATIVA E IMPORTÂNCIA DO ESTUDO ………………………….... 17

1.5 CONTRIBUIÇÃO À CIÊNCIA JURÍDICA ………………………………….... 19

1.6 PLANO DE TRABALHO.............................................................................. 21

2 ESTADO, ADMINISTRAÇÃO PÚBLICA E ASSISTÊNCIA À SAÚDE .......... 23

2.1 A ASSISTÊNCIA À SAÚDE COMO DEVER DA SOCIEDADE....................... 23

2.1.1 Submissão do Estado à Lei, Unidimensionalidade da Administração Pública e Dissolução dos Corpos Sociais Intermédios ..................................................... 24

2.1.2 Intervenção do Estado na Ordem Econômica e Social: Polícia Médica e Fomento aos Serviços Privados de Saúde.......................................................... 28

2.2 RECONHECIMENTO DO DIREITO À SAÚDE: A ASSISTÊNCIA À SAÚDE COMO DEVER DO ESTADO ...................................................... 37

2.2.1 Consagração de Direitos Econômicos, Sociais e Culturais: A Saúde como Função do Estado .................................................................................... 40

2.2.2 Concretização das Normas Constitucionais que Impõem Deveres de Prestação ao Estado e o Desafio da Implementação dos Serviços de Saúde ...................... 45

2.3 TRANSFORMAÇÕES NA ADMINISTRAÇÃO PÚBLICA: A ASSISTÊNCIA À SAÚDE COMO DIREITO DO CIDADÃO E A NECESSIDADE DE ADEQUAÇÃO DAS ATIVIDADES DO ESTADO ......................................... 48

2.3.1 Reconhecimento dos Limites da Atuação Estatal ............................................ 50

2.3.2 Legalidade Material: a Eficiência como Interface com a Realidade ................. 52

2.3.3 Reorganização Administrativa e Responsabilidade Estatal pela Assistência à Saúde .

2.4 SISTEMAS DE SAÚDE EM ORDENAMENTOS ESTRANGEIROS .............. 57

2.4.1 Participação Privada em Sistemas Bismarckianos ............................................ 61

2.4.2 Participação Privada em Sistemas Beveridgeanos............................................. 68

2.4.3 Participação Privada em Sistemas Segmentados .............................................. 81 
3 SERVIÇOS PÚBLICOS DE SAÚDE NA CONSTITUIÇÃO BRASILEIRA.....

\subsection{CONFORMAÇÃO HISTÓRICA DO MODELO DE ASSISTÊNCIA À} SAÚDE NO BRASIL

3.1.1 Direito à Saúde na História do Brasil e a Participação da Iniciativa Privada na Prestação de Serviços Voltados à sua Garantia.

3.1.1.1 Do surgimento do sistema bismarckiano à privatização dos serviços de saúde

3.1.1.2 Transição para o sistema beveridgeano: o movimento sanitário e a Assembléia Constituinte de 1987-1988.

3.1.2 Direito Fundamental à Saúde na Constituição Federal de 1988: de uma Consagração Tardia ao Desafio de uma Efetivação Incompleta

3.1.2.1 Teoria constitucional do direito à saúde: direitos fundamentais e constitucionalização do direito

3.1.2.2 Direito à saúde como direito fundamental derivado dependente de prestações e submetido à lei

3.2 TEORIA DOS SERVIÇOS PÚBLICOS E ASSISTÊNCIA À SAÚDE

3.2.1 Serviços Públicos na Constituição de 1988

3.2.1.1 Referências constitucionais para a criação de serviços públicos

3.2.1.2 A titularidade estatal e as conseqüências da qualificação de determinada atividade como serviço público.

3.2.1.3 A lei como interface entre a Constituição e os diversos estágios de desenvolvimento econômico, tecnológico e social

3.2.2 Sistema Único de Saúde e o Regime Jurídico dos Serviços Públicos de Saúde...... 135

3.2.2.1 Universalidade e igualdade de acesso 138

3.2.2.2 Integralidade do atendimento 146

3.2.3 Relevância Pública dos Serviços de Saúde 152

\section{MECANISMOS E LIMITES DA PARTICIPAÇÃO PRIVADA NOS} SERVIÇOS PÚBLICOS DE SAÚDE

4.1 DELIMITAÇÃO DA PARTICIPAÇÃO PRIVADA COMPLEMENTAR

4.1.1 Complementaridade na Constituição Federal: a Ausência de Dever Estatal de Prestação Direta dos Serviços Públicos de Saúde

4.1.2 Complementaridade na Regulamentação do SUS 176

4.1.2.1 A Lei n. $^{\circ}$ 8.080/90 e a insuficiência da cobertura assistencial 
4.1.2.2 Regulamentação infralegal do SUS e a noção de capacidade instalada

4.2 PREFERÊNCIA PELAS ENTIDADES FILANTRÓPICAS E PELAS SEM FINS LUCRATIVOS

4.2.1 Entidades sem Fins Lucrativos e Terceiro Setor.

4.2.2 Entidades Filantrópicas: Histórico e Perspectivas da Qualificação Legal

4.2.3 Do Fomento à Delegação: o Tratamento Constitucional da Participação Privada nos Serviços de Saúde

\subsection{MODELOS DE AJUSTE PARA A PRESTAÇÃO PRIVADA DE} SERVIÇOS PÚBLICOS DE SAÚDE.......................................................... 198

4.3.1 Hipóteses Constitucionalmente Previstas ..................................................... 204

4.3.1.1 Contratos de direito público ................................................................. 206

4.3.1.1.1 Normas gerais de contratação administrativa: hipóteses de aplicação da Lei n. ${ }^{\circ} 8.666 / 93$ aos serviços públicos de saúde .................................. 213

4.3.1.1.1.1 Contratação interna e concurso público.................................................. 218

4.3.1.1.1.2 Contratação externa, licitação e credenciamento ..................................... 222

4.3.1.2 A natureza contratual dos convênios com a iniciativa privada ..................... 226

4.3.1.2.1 Histórico dos convênios na saúde ............................................................. 231

4.3.1.2.2 Contratos de prestação de serviços e contratos de fomento......................... 236

4.3.2 Modalidades de Contrato Administrativo Recentemente Criadas para

Prestação Privada de Serviços de Saúde ........................................................ 238

4.3.2.1 Contratos de concessão administrativa ................................................... 243

4.3.2.2 Contratos de gestão ................................................................................ 250

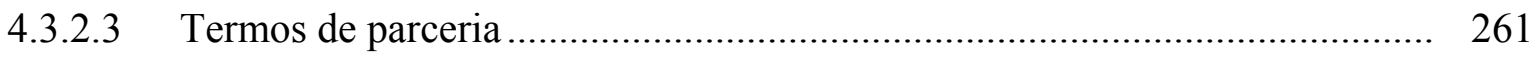

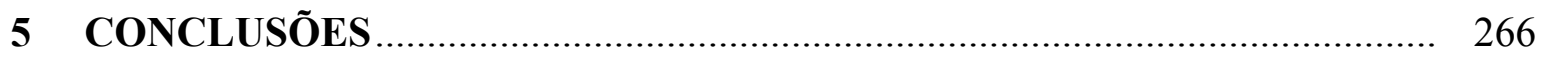

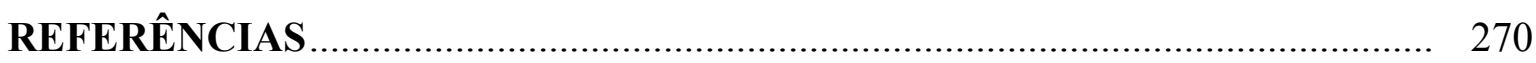




\section{INTRODUÇÃO}

\subsection{APRESENTAÇÃO DO TEMA}

O tema que se apresenta envolve uma série de desafios em relação aos quais o conhecimento científico tem se debatido no decorrer dos séculos. De natureza instintiva, a manutenção da vida tem sido objeto de preocupações humanas desde as mais antigas

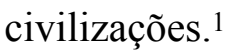

A saúde é hoje entendida como um estado dinâmico do organismo humano que resulta da interação momentânea de fatores internos e externos. ${ }^{2}$ Não se trata de mera ausência de doença, mas da completa condição de bem-estar fisico, mental e social. Esse é o conceito adotado em 26 de julho de 1946 pela Constituição da Organização Mundial da Saúde. Há, pois, um amplo espaço que vai desde a doença até o estado de saúde, o qual varia conforme o padrão genético e comportamental, aliado à condição econômica, social, ambiental e tecnológica em que determinada pessoa se encontra inserida. ${ }^{3}$

Desde o momento em que o Estado assumiu a função de garantir o direito à saúde das pessoas, diversas atividades voltadas tanto à assistência individual quanto à atenção coletiva foram desenvolvidas. ${ }^{4}$ Da polícia médica ao fomento, da prestação direta de serviços à delegação a particulares, numerosas formas de atuação estatal foram postas com

1 ROSEN, George. A History of Public Health. Baltimore: Johns Hopkins University, 1993. p.1-25.

2 Na síntese de George Rosen: "Ao longo de sua história, os homens viveram em unidades sociais maiores ou menores e tiveram que levar em conta as conseqüências destes fatos biológicos para alcançar o bemestar do grupo. As formas pelas quais isto foi realizado foram em grande parte determinadas pela organização econômica e social do grupo e pelos meios científicos e técnicos disponíveis." (ROSEN, George. Da polícia médica à medicina social. Trad. Ângela Loureiro. Rio de Janeiro: Graal, 1980. p.213).

3 Nesse sentido, têm razão Paul Singer, Oswaldo Campos e Elizabeth Oliveira ao afirmar que: "Cada cultura e cada época tem critérios próprios para distinguir o normal do patológico." (SINGER, Paul; CAMPOS, Oswaldo; OLIVEIRA, Elizabeth. Prevenir e curar: o controle social através dos serviços de saúde. Rio de Janeiro: Forense Universitária, 1988. p.69).

4 No presente estudo, a expressão atenção à saúde é utilizada em sentido amplo, para referir-se a todas as atividades estatais das quais resultam a promoção, a proteção e a recuperação da saúde. Já assistência à saúde é empregada para fazer referência à prestação de serviços voltados diretamente à promoção, proteção ou recuperação da saúde das pessoas. Essa é a classificação adotada pela Norma Operacional Básica do SUS n. ${ }^{\circ}$ 01/96, veiculada pela Portaria GM/MS n. ${ }^{\circ} 2.203$, de 05 de novembro de 2006. 
o objetivo de atender a saúde das pessoas, conforme o desenvolvimento tecnológico e científico de cada momento histórico. ${ }^{5}$

No século XX, ao passo em que houve a consagração do direito à saúde em tratados internacionais e em Constituições de diversos Estados, ocorreu importante avanço tanto no conhecimento científico quanto no custo da assistência à saúde. É que, ao contrário do que normalmente ocorre em outros setores, na saúde o avanço tecnológico não implica redução de custos. ${ }^{6}$ Isso se explica, em grande parte, pela própria fluidez do conceito de saúde hoje adotado, o qual, para alguns, refere-se muito mais a um objetivo a ser constantemente buscado do que a uma condição cartesianamente definida. ${ }^{7}$

Conseqüência disso é a dificuldade encontrada hoje pelos Estados em disciplinar os mecanismos de sua atuação com o objetivo de garantir a saúde das pessoas. Tal dificuldade passa, por óbvio, pela premissa de se definir a própria extensão do direito à saúde. Nesse contexto, o discurso do direito à saúde nos dias de hoje não pode ser mantido exclu-

5 Nessa perspectiva, Antônio Carlos Pacheco e Silva, em obra publicada em 1937, assinalou que: "Os benefícios resultantes dos progressos da medicina e pela higiene precisam ser propiciados a todos os entes humanos, razão por que os estados modernos procuram dar grande desenvolvimento aos seus serviços de assistência hospitalar." (SILVA, Antônio Carlos Pacheco e. Serviços sociais. São Paulo: [s.n.], 1937. p.183).

6 Como esclarece Maria Helena Castro: "Nos diversos setores econômicos, a difusão da tecnologia é lenta porque é um fator importante da competição entre as empresas. Assim, aquela empresa que descobre um novo e em geral mais barato método de produção o defenderá da concorrência posto que isto será fator fundamental para o incremento dos lucros, ganhos de 'market share', etc. Por outro lado, trata-se de um processo de substituição: a nova tecnologia ocupa o espaço da velha, que se torna obsoleta, inclusive por ser mais cara. $\mathrm{Na}$ saúde, o processo de difusão é mais rápido, um novo procedimento médico ou uma nova técnica de tratamento são incorporados pelos diversos profissionais de forma acelerada, mas, em compensação, as tecnologias na área da saúde não são substitutas, pelo contrário, são cumulativas. Como se pode constatar no caso da utilização da ressonância magnética que não exclui a tomografia computadorizada nos testes de diagnóstico (...)." (CASTRO, Maria Helena L. A relação entre o público e o privado no sistema de saúde brasileiro: repensando o papel do estado. 2006. Tese (Doutorado em Saúde Coletiva) Instituto de Medicina Social, Universidade do Estado do Rio de Janeiro, Rio de Janeiro, 2006. p.7). Daí Ronald Dworkin, em estudo sobre o tema, concluir que a alta dos preços na medicina não decorre do encarecimento da medicina tradicional, mas do surgimento de novos tratamentos médicos (DWORKIN, Ronald. A justiça e o alto custo da saúde. In: __. A virtude soberana: a teoria e a prática da igualdade. Trad. Jussara Simões. São Paulo: Martins Fontes, 2005. p.433). Nesse condão, não há dificuldades em se perceber que o avanço tecnológico no diagnóstico leva tanto à detecção precoce de doenças quanto à visualização de distúrbios à saúde até então não considerados; além disso, o tratamento precoce e por meio de novos procedimentos conduz a uma vida mais longa e à possibilidade de que outras doenças, outros métodos diagnósticos e outros tratamentos sejam criados e utilizados pelas pessoas.

7 Como se referiu Moacyr Scliar, o conceito atual de saúde aproxima-se do conceito subjetivo de felicidade e configura antes uma imagem-horizonte do que um alvo concreto (SCLIAR, Moacyr. Do mágico ao social: trajetória da saúde pública. 2.ed. São Paulo: Senac, 2005. p.94). 
sivamente no plano da abstração, pois é no plano da atuação concreta, regulada pelo Direito Administrativo, que a questão torna-se especialmente complexa. ${ }^{8}$

Talvez por isso o Direito Administrativo brasileiro encontre dificuldades em lidar com a disciplina dos serviços de saúde, o que se pode comprovar pela escassez de estudos aprofundados sobre o tema, pela dificuldade em se interpretar o ordenamento constitucional da saúde e pelo desencontro da legislação que trata dos mecanismos de participação privada em tais serviços públicos. Considerando cumprir ao Direito Administrativo efetivar direitos constitucionais dependentes da atuação estatal, devem ser estudadas e propostas formas de fazê-lo, começando pela interpretação do texto constitucional e chegando à sua concretização material. ${ }^{9}$ Afinal, o direito hoje não considera, como já o fez outrora, o ser humano como um ente abstrato, sendo que a garantia de seus direitos também não se resolve meramente no plano das generalizações. ${ }^{10}$

\subsection{CONTEXTUALIZAÇÃO}

De acordo com a Constituição de 1988, é dever do Estado proporcionar o acesso a ações e serviços para a promoção, proteção e recuperação da saúde configura a todas as pessoas. $\mathrm{O}$ texto constitucional dedicou à disciplina da saúde toda uma seção e organizou a atividade estatal para sua concretização com base nos princípios da universalidade e igualdade

8 Daí a crítica de autores como Gomes Canotilho ao discurso constitucionalista: "A teoria da constituição revela dificuldades em compreender as lógicas da materialização do direito. Continua a considerar o direito constitucional como 'lugar do supradiscurso social' a partir de uma concepção unilateralmente racionalizada e piramidal da ordem jurídica. Isso justifica a opacidade que alguns autores atribuem a este direito: 'alheia-se' da mudança e da inovação jurídicas, desconhece a 'localização de materialização' em áreas periféricas do ordenamento ou em ordenamentos periféricos." (CANOTILHO, J. J. Gomes. Direito constitucional e teoria da constituição. 7.ed. Coimbra: Almedina, [s.d.]. p.1350). O mesmo autor adota a expressão de origem inglesa 'fuzzysmo' ou 'metodologia fuzzy' para se referir aos juristas "que não sabem do que estão a falar" quando tratam de temas complexos como os dos direitos sociais, no qual se insere o direito à saúde (CANOTILHO, J. J. Gomes. Metodologia "Fuzzy" e "Camaleões Normativos" na problemática actual dos direitos econômicos, sociais e culturais. In: fundamentais. Coimbra: Coimbra, 2004. p.100).

Estudos sobre direitos

9 Tem razão Jaques Chevallier ao advertir que: "(...) os juristas devem ser conduzidos a ampliar as perspectivas: não se trata mais somente de estudar as leis e a jurisprudência, mas ainda considerar, por pesquisas empíricas, as condições de aplicação dessas regras, aproximando-se ao máximo da realidade administrativa: a ênfase é colocada sobre o funcionamento concreto, em determinada situação, da administração." (CHEVALLIER, Jacques. Science administrative. 3.ed. Paris: Presses Universitaires de France, 2002. p.18-19).

10 Conforme Norberto Bobbio, com o surgimento dos direitos sociais, dentre os quais direito à saúde, ao lado do homem abstrato ou genérico, surgiram novos personagens concretos como sujeitos de direito, como a mulher, a criança, o velho, o doente e o demente (BOBBIO, Norberto. A era dos direitos. Trad. Carlos Coutinho. Rio de Janeiro: Campus, 1992. p.72). 
de acesso, integralidade de atendimento, descentralização administrativa, complementaridade da prestação privada e participação da comunidade.

Logo após a promulgação da Constituição, foi elaborada a Lei federal n. ${ }^{\circ} 8.080$, de 19 de setembro de 1990, denominada Lei Orgânica da Saúde (LOS), a qual regulamentou a organização e o funcionamento das ações e serviços públicos de saúde, denominados pela Constituição sistema único de saúde (SUS). Em seguida, foram editadas a Lei federal n. ${ }^{\circ} 8.142$, de 21 de dezembro de 1990, que previu mecanismos de participação social no SUS, e a Lei Orgânica da Seguridade Social - Lei n. ${ }^{0}$ 8.212, de 24 de julho de 1991, que trata tanto da saúde quanto da previdência social e da assistência social.

Enquanto a universalidade e igualdade de acesso aos serviços públicos de saúde foram albergadas pela Constituição brasileira de 1988, países que há algum tempo haviam consagrado tais princípios passavam por um processo de reforma em seus sistemas de saúde. Isso porque os avanços tecnológicos da medicina, aliados ao envelhecimento da população, produziram um aumento significativo dos custos da saúde pública. Em tais países passouse a discutir e implementar reformas institucionais com o objetivo de encontrar um ponto de equilíbrio entre a quantidade, a qualidade e os custos dos serviços de saúde - a partir de renovados mecanismos de ajuste entre o Estado e a iniciativa privada.

Em solo pátrio surgiram inovações legislativas que objetivaram ampliar os modelos de participação privada no setor de saúde, por meio de vínculos com entidades sem fins lucrativos. Dentre elas, podem-se citar a Lei federal n. ${ }^{\circ}$ 9.637, de 15 de maio de 1998, conhecida com Lei das Organizações Sociais (OSs) e a Lei federal n. ${ }^{0}$ 9.790, de 23 de março de 1999, conhecida como Lei das Organizações da Sociedade Civil de Interesse Público (OSCIPs). Mais recentemente, foi editada a Lei federal n. ${ }^{\circ}$ 11.079, de 30 de dezembro de 2004, conhecida como Lei das Parcerias Público-Privadas (PPPs), a qual também prevê a possibilidade de concessão à iniciativa privada, neste caso com fins lucrativos, da prestação de serviços de saúde. Assim, criaram-se novos modelos de ajuste com o Poder público que prevêem a participação privada nas atividades de assistência à saúde - além dos contratos de direito público e convênios, mencionados expressamente no parágrafo primeiro do artigo 199 da Constituição Federal como vínculos aptos a disciplinar a participação privada em tais serviços. ${ }^{11}$

11 Art. 199 (...) $\S 1 .^{\circ}$ - As instituições privadas poderão participar de forma complementar do sistema único de saúde, segundo diretrizes deste, mediante contrato de direito público ou convênio, tendo preferência as entidades filantrópicas e as sem fins lucrativos. 


\subsection{DELIMITAÇÃO DO OBJETO}

A participação privada na prestação de serviços públicos de saúde tornou-se apenas recentemente objeto discussões nas esferas doutrinária e judicial brasileiras, ${ }^{12}$ sendo que os debates têm como pano de fundo uma determinação constitucional: a forma complementar da participação privada no serviço público de saúde. ${ }^{13}$

Qual o alcance da complementaridade prevista no texto constitucional? Existe a previsão legal de instrumentos jurídicos adequados para possibilitar a participação privada? Como devem ser interpretadas as figuras denominadas pelo texto constitucional contrato de direito público e convênio? Em qual dessas categorias se enquadram o contrato de gestão, o termo de parceria e a concessão administrativa? Existe limite quantitativo e qualitativo a essa participação ou pode determinado ente estatal oferecer à prestação privada todo o serviço público de saúde? Em que medida tais instrumentos implicam delegação de serviço público ou mera atividade de fomento a atividades privadas? Qual o alcance e as conseqüências jurídicas da qualificação dos serviços de saúde como serviços públicos e como serviços de relevância pública?

Todas essas questões demandam resposta, a qual depende de uma adequada interpretação da ordem constitucional da saúde e de sua vinculação aos serviços públicos.

Ressalte-se, nesse prisma, que os limites deste estudo são marcados pelo conceito de serviço público de saúde. Como já assinalado, o estado de saúde das pessoas envolve uma série de fatores econômicos, sociais, ambientais e tecnológicos, muitos dos quais passíveis de diversas formas de intervenção estatal. Assim, a participação privada na prestação de serviços públicos de saúde, para os fins deste trabalho, refere-se às atividades de assistência voltadas à promoção, à proteção e à recuperação da saúde das pessoas, que podem ser reconduzidas ao conceito de serviço público - analisado no Capítulo 3 do presente estudo.

12 Veja-se, por exemplo, o teor das discussões levadas a cabo nos seguintes julgamentos: (i) Ação Direta de Inconstitucionalidade - ADIN n. ${ }^{\circ} 1.923$, ajuizada perante o pelo Supremo Tribunal Federal em face da Lei n. ${ }^{\circ} 9.637$, de 15 de maio de 1998 , que previu o contrato de gestão como mecanismo hábil a estabelecer o vínculo entre o Estado e a iniciativa privada sem fins lucrativos para a prestação de serviços como o de saúde; e (ii) ADIN n. ${ }^{\circ}$ 130.726-0/700 ajuizada perante o Tribunal de Justiça de São Paulo, em face da Lei n. ${ }^{\circ}$ 14.132, de 24 de janeiro de 2006, do Município de São Paulo, que instituiu aos moldes da referida lei federal, no âmbito do Município, o contrato de gestão como modelo de vínculo hábil à prestação de serviços públicos de saúde.

13 Por participação privada entende-se no presente trabalho a participação de pessoas jurídicas de direito privado, criadas nos termos da legislação civil de modo independente de qualquer determinação legal. 
É evidente que o funcionamento adequado e a oferta suficiente dos serviços de saúde dependem de investimento público. Esse é um dos grandes desafios do Estado brasileiro e tem sido objeto de discussões no âmbito legislativo, como no caso da não prorrogação da Contribuição Provisória sobre Movimentações Financeiras (CPMF), em 2007, e das discussões acerca da regulamentação da Emenda Constitucional n. ${ }^{0}$ 29/2000, que prevê a vinculação de recursos à saúde, em 2008. Mas não é apenas a questão do financiamento que desafia os serviços públicos de saúde pública no Brasil. Há também o problema do modelo de gestão - que inclui a definição dos mecanismos de participação privada na prestação dos serviços de saúde. O aumento no volume de recursos destinados à saúde é indispensável à melhoria dos serviços prestados; entretanto, sem uma gestão e organização adequadas, os recursos jamais serão suficientes.

Nesse contexto, tanto a definição dos limites do permissivo constitucional quanto a avaliação dos mecanismos existentes no direito pátrio compõem o objeto desta tese. ${ }^{14}$

\subsection{JUSTIFICATIVA E IMPORTÂNCIA DO ESTUDO}

Duas décadas após a criação do sistema único de saúde, ainda que tenha havido importantes avanços, ${ }^{15}$ é possível verificar que das inovações legislativas não decorreram soluções capazes de atender às necessidades de todas as pessoas que dependem dos serviços públicos de saúde.

14 Nesse sentido, seguindo a classificação de Robert Alexy, seguida por Gomes Canotilho, em Portugal, e Luís Virgílio Afonso da Silva, no Brasil, o presente estudo situa-se no âmbito da dogmática normativa, voltada à crítica da práxis jurídica e à solução de questões problemáticas concretas. Para tanto, utiliza-se tanto a dogmática empírica - voltada à descrição do direito, tanto o direito legislado quanto o direito interpretado pelos tribunais, quanto a dogmática analítica, que trata da exploração sistemática do direito vigente, como instrumentos voltados a uma finalidade concreta. Sobre o tema: ALEXY, Robert. Teoría de los Derechos Fundamentales. Trad. Carlos B. Pulido. 2.ed. Madrid: Centro de Estudios Políticos y Constitucionales, 2007. p.12-18. CANOTILHO, J. J. Gomes. Direito constitucional e teoria da constituição. 7.ed. Coimbra: Almedina, [s.d.]. p.1118; e SILVA, Luís Virgílio Afonso da. A constitucionalização do direito. São Paulo: Malheiros, 2008. p.25-26.

15 Estatísticas com os avanços ocorridos a partir da criação do SUS no Brasil podem ser encontradas em: BRASIL. Conselho Nacional de Secretários de Saúde. SUS: avanços e desafios. 2.ed. Brasília: CONASS, 2006. p.29-44. 
Em uma visão mais ampla, é possível notar que o Estado brasileiro, nos últimos anos, apresentou avanço não apenas na oferta e na qualidade de serviços públicos passíveis de exploração econômica, mas também no desenvolvimento de tecnologia jurídica apta a possibilitar tal evolução. Enquanto isso, apesar de algumas inovações legislativas, a efetivação do direito à saúde por meio da prestação de serviços públicos ainda se encontra dependente de uma interpretação e regulamentação do texto constitucional que proporcionem a concretização de tal direito.

Sem uma interpretação e regulamentação claras, precisas e seguras acerca da participação privada nos serviços de saúde, que ofereçam ao gestor público a possibilidade de enfrentar as dificuldades decorrentes da complexidade e do alto custo dos serviços, continuarão a existir no Brasil, de um lado, a insuficiência na prestação de serviços públicos de saúde e, de outro, tentativas inovadoras que, por vezes, ultrapassam o limiar da constitucionalidade. ${ }^{16}$

Considerando que o vínculo com entidades privadas é uma possibilidade constitucionalmente conferida ao gestor estatal para a consecução de suas funções na área da saúde, há que se definir a medida em que ele pode optar por cada uma das hipóteses legais dispostas no ordenamento jurídico, com vistas à efetiva e eficiente prestação dos serviços. Daí a importância de interpretar a ordem constitucional da saúde e estabelecer um modelo de participação privada que garanta viabilidade econômica, estabilidade jurídica e mecanismos efetivos de controle dos serviços públicos de saúde. ${ }^{17}$

É por todos sabido que a discussão sobre a participação do Estado na prestação de serviços, ainda mais em um setor sensível como é o caso da saúde, não raro é impregnada por visões de mundo pré-concebidas. No presente trabalho, não se pretende defender qualquer ideologia privatista ou estatista; tampouco defender a melhor opção para a prestação dos

16 Ou então, o que é pior, tentativas inovadoras com fundamento constitucional, as quais, em face do que a doutrina e a jurisprudência denominam de interpretação retrospectiva, acabam sendo cunhadas como inconstitucionais, quando de fato não o são. Nesse viés, razão tem Diogo de Figueiredo Moreira Neto ao sustentar que: "(...) os adeptos da velha hermenêutica, não poucas vezes, como não encontram na Constituição um dispositivo que lhes seja suficientemente confortável para elucidar um novo instituto ou alguma mudança de paradigmas, preferem, mais confortavelmente, concluir, 'tout court', por sua inconstitucionalidade." (MOREIRA NETO, Diogo de Figueiredo. Quatro paradigmas do direito administrativo pós-moderno: legitimidade, finalidade, eficiência, resultados. Belo Horizonte: Fórum, 2008. p.25-26).

17 Tal pensamento insere-se no que Clèmerson Merlin Clève denomina dogmática emancipatória a qual se contrapõe à antiga, mas ainda propalada, dogmática da razão do Estado. A dogmática emancipatória possui cunho prospectivo, com foco redirecionado, do Estado para a pessoa humana, a qual, nas palavras do autor, é exigente de bem estar físico, moral e psíquico (CLÈVE, Clèmerson Merlin. A eficácia dos direitos fundamentais sociais. Revista Crítica Jurídica, n.22, p.18, jul./dez. 2003). 
serviços de saúde: estatal ou privada. ${ }^{18}$ Pretende-se, mediante análise e crítica da previsão constitucional e da regulamentação da participação privada na prestação dos serviços públicos de saúde, com aportes doutrinários, jurisprudenciais e de direito comparado, colaborar para que, por meio de instrumental jurídico adequado, se efetive a prestação dos serviços de saúde a todos aqueles que dela necessitam.

\title{
1.5 CONTRIBUIÇÃO À CIÊNCIA JURÍDICA
}

O presente trabalho possui como norte o apontamento de Odete Medauar, segundo o qual:

\begin{abstract}
O administrativista contemporâneo tem consciência da diversificação e capilaridade das funções do Estado atual, realizadas, em grande parte, pela atuação da Administração Pública. Por conseguinte, o direito administrativo, além da finalidade de limite ao poder e garantia dos direitos individuais ante o poder, deve preocupar-se em elaborar fórmulas para efetivação de direitos sociais e econômicos, de direitos coletivos e difusos, que exigem prestações positivas. O direito administrativo tem papel de relevo no desafio de uma nova sociedade em constante mudança. ${ }^{19}$
\end{abstract}

Com essa bússola, a contribuição para a ciência jurídica - partindo do pressuposto de que o ordenamento de saúde na Constituição de 1988 possui princípios e racionalidade próprios - consiste na proposição de que se adote em solo pátrio um modelo de participação privada nos serviços públicos de saúde que inclua todas as hipóteses de vínculo e o correspondente regime jurídico. ${ }^{20}$

18 Parte-se, assim, da premissa assinalada por Luís Roberto Barroso, segundo a qual o constitucionalismo é a única ideologia que resta (BARROSO, Luís Roberto. O novo direito constitucional e a constitucionalização do direito. In: Temas de direito constitucional. Rio de Janeiro: Renovar, 2005. Tomo III. p.518).

19 MEDAUAR, Odete. O direito administrativo em evolução. 2.ed. São Paulo: Revista dos Tribunais, 2003. p.267-268.

20 Se a teoria do Direito Constitucional há algum tempo libertou-se de amarras positivo-formalistas, o Direito Administrativo ainda se encontra a elas preso. Tais amarras não se encontram enlaçadas na Constituição, mas em leis que permaneceram às transições constitucionais e em uma teoria que ganhou vida própria, hoje não mais compatível com o Estado democrático e com aquilo que prevê a Constituição da República Federativa do Brasil. A conciliação entre o Direito Administrativo e o Direito Constitucional não configura novidade e tampouco revela uma dificuldade exclusiva do ordenamento jurídico brasileiro. Tanto isso é verdade que Ernst Forsthoff, no prólogo de seu Tratado de Direito Administrativo, escrito logo após a Constituição alemã de 1949, alertou que a falta de correspondência entre o Direito Constitucional e a prática administrativa constituía um dos mais sérios problemas a serem resolvidos pela ciência jurídica da época (FORSTHOFF, Ernst. Tratado de Derecho Administrativo. Trad. Lesgaz Lacambra; Garrido Falla; y Gomes de Ortega y Junge. Madrid: Instituto de Estudios Politicos, 1958. p.5). Note-se que essa dificuldade decorre da contínua necessidade de adequação das atividades estatais às funções consagradas pelas Constituições, como já assinalava em solo pátrio Odete Medauar na primeira edição de sua obra 
Tal objetivo, voltado ao setor da saúde, acompanha a advertência de Carlos Ari Sundfeld, segundo o qual:

\begin{abstract}
Os administrativistas que abandonemos o hábito de viajar por mundos e galáxias com duas ou três idéias românticas e vagas sobre o Estado ideal. A partir de agora, ou nos enfronhamos nas particularidades - não só as normativas, mas inclusive as técnicas e as econômicas - de cada setor da economia, ou nada teremos a dizer sobre o Direito vigente. ${ }^{21}$
\end{abstract}

Se as necessidades humanas ampliam-se, a sociedade se transforma, o Estado se redimensiona, o direito positivo muda,22 o mesmo deve ocorrer com as instituições jurídicas. ${ }^{23}$ A situação de hoje não é de todo diferente de cenários sociais passados, em que guerras, revoluções sociais e científicas colocaram em xeque pensamentos até então tidos como definitivos. A especificidade do momento atual consiste na velocidade em que as transformações sociais e tecnológicas têm ocorrido, especialmente no setor de saúde, o que provoca um descompasso cada vez mais marcante entre o direito e a realidade. ${ }^{24}$ Portanto, a superação de idéias e noções não implica necessariamente seu abandono, mas sua adaptação à

O Direito Administrativo em Evolução (MEDAUAR, Odete. O direito administrativo em evolução. São Paulo: Revista dos Tribunais, 1992). Tal observação possui contornos marcantes nos serviços de saúde no Brasil, mormente em face das grandes transformações promovidas no setor pela Constituição de 1988.

21 SUNDFELD, Carlos Ari. Serviços públicos e regulação estatal. In: econômico. São Paulo: Malheiros, 2000. p.34.

(Coord.). Direito administrativo

22 Como aduz Norberto Bobbio, o "estar em transformação" é o estado natural dos regimes democráticos (BOBBIO, Norberto. O futuro da democracia. Trad. Marco Aurélio Nogueira. 8.ed. São Paulo: Paz e Terra, 2002. p.19).

23 Como assinala Juan Carlos Cassagne: "(...) a instituição jurídica nunca se mantém incólume em face das transformações, pois, ao depender da realidade, não pode sobreviver sem adaptar-se a esta." (CASSAGNE, Juan Carlos. La Intercencion Administrativa. 2.ed. Buenos Aires: Abeledp-Perrot, 1994. p.33).

24 E tal condição não é privilégio da ciência jurídica, pois como consignou há alguns anos o sociólogo Boaventura de Sousa Santos: "(...) a rapidez, a profundidade e a imprevisibilidade de algumas transformações recentes conferem ao tempo presente uma característica nova: a realidade parece ter tomado a dianteira sobre a teoria." (SANTOS, Boaventura de Sousa. Pela mão de Alice: o social e o político na pós-modernidade. 7.ed. São Paulo: Cortez, 2000. p.18). Se na sociologia, conforme o autor, corre-se o risco de a teoria sucumbir ao avanço da realidade, no mundo jurídico também se corre o risco de a realidade desprezar o direito, caso este não evolua. Esta é a advertência de Tércio Sampaio Ferraz Júnior: "(...) este é o material da Dogmática, tratando-se, portanto, da elaboração de um material abstrato num grau de abstração ainda maior. Se isto, de um lado, lhe dá certa mobilidade, certa independência e certa liberdade, como condição do seu próprio trabalho, de outro, paga-se por isso um preço: a abstração e o risco de distanciamento da realidade". E continua o autor: "A Dogmática, transformando-se assim em abstração de abstração, vai preocupar-se, por exemplo, com a função das classificações, com a natureza dos conceitos etc". Por fim, conclui Tércio Ferraz Júnior, em outra passagem: "Esta oposição entre norma e realidade que vai marcar a Dogmática Jurídica, significa, além disso, a consciência de uma necessidade constante de rever o pensamento dogmático, pois o Direito, não repousando apenas nas suas normas, mas tendo outras dimensões, vai exigir da Dogmática Jurídica uma reformulação de seus próprios conceitos." (FERRAZ JÚNIOR, Tércio Sampaio. Função social da dogmática jurídica. São Paulo: Max Limonad, 1998. p.12-13 e 80). 
realidade em que estão inseridas. Esse o desafio do Direito Administrativo, ressaltado por Odete Medauar e Carlos Ari Sundfeld, que se propõe enfrentar no presente trabalho.

É hora de desamarrar o Direito Administrativo, e em especial a interpretação do serviço público de saúde, de uma teoria fundada em premissas não mais albergadas pelo ordenamento constitucional pátrio. Nesse passo, a tese proposta, dentro de sua delimitação e ciente da advertência de Paulo Bonavides acerca da relevância dos princípios constitucionais, ${ }^{25}$ pretende-se reenlaçar as hipóteses de prestação privada do serviço público de saúde à Constituição brasileira e superar alguns entendimentos não compatíveis com a normatização constitucional. Afinal, se "(...) a ciência é construída por aqueles que são capazes de ultrapassar certos limites que hoje são definidos pelo mundo universitário", 26 o verdadeiro cientista é aquele que, sem medo de errar, busca transformar a ciência normal. ${ }^{27}$

\subsection{PLANO DE TRABALHO}

Além desta Introdução e das Conclusões, este trabalho encontra-se estruturado em três grandes capítulos.

No Capítulo 2, busca-se relacionar as formas de atividade estatal na atenção à saúde, a partir do desenvolvimento do Estado e do Direito Administrativo, com o protagonismo da iniciativa privada na prestação de serviços de saúde. Demonstra-se que até a consagração explícita ou implícita do direito à saúde pelas Constituições do século XX, a atuação estatal no setor de saúde ocorreu tanto sob a forma de polícia administrativa quanto sob a forma de prestação de serviços, especialmente, neste último caso, por meio de incentivo a prestadores privados. Em seguida, são analisadas algumas transformações pelas quais tem passado a Administração Pública para torná-la apta a atender adequadamente às novas funções do

25 "Que nunca nos falte, assim, juízo crítico, espírito de análise, energia, convicção e, sobretudo, consciência ética com que sustentar e propagar e defender aquele breviário de mandamentos da democracia e da justiça, que é a filosofia mesma do Estado social em seu consórcio com a soberania participativa do povo." (BONAVIDES, Paulo. Do estado liberal ao estado social. 7.ed. São Paulo: Malheiros, 2001. p.11).

26 FURTADO, Celso. O capitalismo global. 5.ed. São Paulo: Paz e Terra, 2001. p.10.

27 Segundo Thomas S. Kuhn, a ciência normal é aquela que não se propõe a descobrir novidades no campo dos fatos ou da teoria (KUHN, Thomas S. A estrutura das revoluções científicas. Trad. Beatriz Boeria e Nelson Boeira. 9.ed. São Paulo: Perspectiva, 2007. p.77). 
Estado, como a garantia da prestação de serviços de saúde a todos que deles necessitarem. Ao final, são analisados os principais sistemas de saúde hoje vigentes no direito estrangeiro, com ênfase nos problemas enfrentados, nas reformas recentemente implantadas e nos modelos de ajuste que disciplinam a participação privada na prestação dos serviços de saúde.

No Capítulo 3, é analisado o serviço público de saúde tal como previsto na Constituição de 1988. Para tanto, é retomado o contexto histórico da prestação de serviços de saúde no Brasil, com ênfase no período que antecedeu e influenciou a elaboração do texto constitucional hoje vigente. A partir desse estudo, a atenção é voltada à conformação do direito à saúde na Constituição e ao desafio de sua implementação. A segunda parte do Capítulo trata do estudo e adoção de um conceito de serviço público e de serviço público de saúde, a partir dos quais se busca definir o regime jurídico do serviço público de saúde. Ao final, são tecidas considerações acerca da qualificação dos serviços de saúde como serviços de relevância pública.

O Capítulo 4 tem como objeto de investigação o dispositivo constitucional constante do parágrafo primeiro do artigo 199, que prevê a participação de forma complementar da iniciativa privada nos serviços públicos de saúde. Inicialmente são tecidas considerações acerca da complementaridade e da preferência pela participação de entidades filantrópicas e de entidades sem fins lucrativos. Em seguida são analisados os mecanismos expressamente previstos para a atuação privada no serviço público de saúde: o contrato de direito público e o convênio. $\mathrm{O}$ item subseqüente é dedicado ao tratamento das novas hipóteses legais de vínculo com o Estado, por meio das quais a iniciativa privada se torna (ou não) apta a prestar serviços públicos de saúde. Dentre elas, são analisadas a concessão administrativa, o contrato de gestão e o termo de parceria. 


\section{ESTADO, ADMINISTRAÇÃO PÚBLICA E ASSISTÊNCIA À SAÚDE}

\subsection{A ASSISTÊNCIA À SAÚDE COMO DEVER DA SOCIEDADE}

Os principais documentos modernos a proclamar direitos, como o Bill of Rights inglês de $1689,{ }^{28}$ a Declaração de Independência Americana de 1776, ${ }^{29}$ e a Declaração dos Direitos do Homem e do Cidadão francesa de $1789,{ }^{30}$ não fizeram qualquer menção à saúde. Tais declarações, com um espaço temporal de cem anos, marcam tanto no mundo anglo-saxão quanto no mundo continental europeu o surgimento de um modelo de Estado limitado em seu poder e em suas funções, delas excluída a assistência à saúde. ${ }^{31}$

As funções estatais nesse momento histórico possuíam como denominador comum a garantia dos direitos individuais e marcaram a despolitização das relações econômicas. Dentre os direitos proclamados tiveram relevo, por seu caráter universalista, aqueles previstos na Declaração dos Direitos do Homem e do Cidadão redigidos durante da Revolução Francesa: igualdade, liberdade, propriedade, segurança e resistência à opressão. ${ }^{32}$ Além disso, o novo

28 Ao traçar os contornos do modelo de monarquia limitada, o Bill of Rights coroou uma tendência iniciada no mundo anglo-saxônico desde a Magna Carta de João Sem Terra. Trata-se da limitação do poder real por meio de convenções, pelas quais o soberano reconheceu direitos em favor do clero e da aristocracia. Segundo Georg Jellinek, a existência de uma série de revoluções na Inglaterra, desde o século XII, que culminaram com sucessivas concessões reais ao poder de uma aristocracia-burguesa, característica daquela região insular, não quebrou a linha de continuidade no processo de formação histórica daquele Estado (JELLINEK, Georg. Teoría General del Estado. Trad. de Fernando Rios Urruti. 2.ed. México: Continental, 1958. p.509 e segs.).

29 A ausência histórica de uma sociedade estamental em solo norte-americano fez com que a Declaração de Independência Americana e os documentos que a seguiram fossem marcados pela consagração do princípio democrático e do individualismo - o qual, ao contrário do que ocorreu em Estados europeus, não impediu que na própria sociedade fossem criados corpos intermediários de solidariedade. A Declaração de Direitos da Virgínia, de 1776, por exemplo, em seu artigo 4. ${ }^{\circ}$, previa a possibilidade de grupos sociais receberem privilégios estatais em virtude da prestação de serviços ao público.

30 A Declaração de Direitos do Homem e do Cidadão foi o primeiro e mais importante documento elaborado durante o processo revolucionário francês, que durou até o início do século XIX. No período, tiveram vigência na França as Constituições de 1791, 1793, 1795 e 1799. Ao fim da Revolução, com a ascensão de Napoleão Bonaparte ao comando do Estado, tinham-se abolidos os privilégios pessoais ou de natureza corporativa consolidados no período absolutista.

31 BOBBIO, Norberto. Liberalismo e democracia. Trad. de Marco Aurélio Nogueira. 6.ed. São Paulo: Brasiliense, 2007. p.17 e segs.

32 Assim prescreviam os dois primeiros artigos da Declaração dos Direitos do Homem e do Cidadão de 1789: Art. 1. ${ }^{\circ}$ Os homens nascem livres e permanecem livres e iguais em direitos. As distinções sociais só podem fundar-se na utilidade comum. Art. 2. ${ }^{\circ}$ A finalidade de toda associação política é a conservação dos direitos naturais e imprescritíveis do homem. Tais direitos são a liberdade, a propriedade, a segurança e a resistência à opressão. 
modelo de organização social que se instalou foi caracterizado pela aversão aos privilégios estamentais dos corpos intermédios da sociedade consolidados historicamente desde o período feudal e preservados no período absolutista, ${ }^{33}$ os quais configuravam barreira à relação direta entre Estado-indivíduo e ao desenvolvimento do mercado. ${ }^{34}$

Entretanto, a despolitização da economia implicou também a despolitização da sociedade, sendo que, no período em que se consolidou o Estado limitado pelo Direito, pode-se verificar um duplo movimento que abalou os dois mecanismos de atenção à saúde das pessoas até então existentes: (i) de um lado, rompeu-se o caráter assistencial dos Estados absolutistas; (ii) de outro, foram desestimulados ou mesmo reprimidos os corpos sociais que proviam assistência aos necessitados e enfermos. ${ }^{35}$

\subsubsection{Submissão do Estado à Lei, Unidimensionalidade da Administração Pública e Dissolução dos Corpos Sociais Intermédios}

Se é correto afirmar que as transformações pelas quais passou o Estado, por meio das declarações de direitos dos séculos XVII e XVIII e das constituições decorrentes, promoveram a despersonalização do poder, ${ }^{36}$ é também procedente sustentar que tais

33 Por sociedade ou sociedade civil, entende-se no presente trabalho a esfera não-estatal, na qual organizações não-estatais, as quais podem ser denominadas corpos intermédios, e pessoas desenvolvem relações sociais e econômicas. Sobre o tema: BOBBIO, Norberto; MATTEUCCI, Nicola; PASQUINO Gianfranco. Dicionário de política. Trad. Carmen Varriale et. al. 12.ed. Brasília: Universidade de Brasília, 2004. v.1. p.1210.

34 Por mercado, entende-se o conjunto de instituições que permitem [e realizam] a interação entre oferta e a procura, da qual surge espontânea, impessoal e objetivamente os preços de cada produto ou serviço. Nesse sentido: NUSDEO, Fábio. Curso de economia: introdução ao direito econômico. 4.ed. São Paulo: Revista dos Tribunais, 2005. p.118. Uma análise do conceito de mercado em seus diferentes significados: como lugar, como ideologia, como paradigma de ação social e também como instituição pode ser encontrada em: FERRARESE, Maria Rosaria. Diritto e mercato. Torino, Itália: Giappichelli, 1992.

35 Deve-se assinalar que, nos Estados Unidos da América, a ausência de um passado estamental e a necessidade de criar mecanismos para satisfazer necessidades individuais e coletivas fizeram com que naquele Estado fossem criadas associações de todo o tipo, inclusive para assistência à saúde. Aléxis de Tocqueville, no início do século XIX, assim anotou: "Os americanos de todas as idades, de todas as condições, de todos os espíritos, estão constantemente a se unir. Não só possuem associações comerciais e industriais, nas quais todos tomam parte, como também existem mil outras espécies: religiosas, morais, graves, fúteis, muito gerais e muito particulares, imensas e muito pequenas; os americanos associam-se para dar festas, fundar seminários (...) assim também criam hospitais, prisões, escolas." (TOCQUEVILLE, Alexis de. A democracia na América. Trad. Neil R. da Silva. 4.ed. Belo Horizonte: Itatiaia, 1998. p.391-392).

36 REALE, Miguel. Teoria do direito e do estado. São Paulo: Livraria Martins, 1940. p.183. 
transformações implicaram a substituição do interesse do monarca pelo interesse daqueles que participavam do processo de elaboração da lei. ${ }^{37}$ Nessa perspectiva, os interesses da maioria da população, como se um bloco monolítico fosse, foram convertidos em interesse privado, a sucumbir perante o interesse público de um pequeno grupo que participava do processo político. Tal grupo era formado, sobretudo, pela burguesia, ${ }^{38}$ que atuava na condição de denominador comum de todas as classes. ${ }^{39}$

A limitação do poder em decorrência do surgimento do Estado de Direito, denominado por Massimo Severo Giannini Estado monoclasse, ${ }^{40}$ foi caracterizada pela prevalência da participação política da burguesia, a qual definia o limite do poder estatal. Com isso, alcançava-se o objetivo de restringir a atuação do Estado sobre a sociedade, permitindo sua interferência apenas nos casos em que o interesse da classe burguesa assim o exigisse. ${ }^{41}$

37 Afinal, abstraídos os conceitos de volonté general, de Jean Jacques Rousseau e de nação, de Emmanuel de Sieyès, a lei passou a ser imposta aos cidadãos pela forma de inovação legislativa, cuja elaboração contava com restrita participação popular. Sobre o tema: ROUSSEAU, Jean-Jacques. Do contrato social. Trad. Pietro Nassetti. São Paulo: Martin Claret, 2002. p.39-40; e SIEYĖS, Emmanuel Joseph. A constituinte burguesa. Qu'est-ce que lê Tiers État? 4.ed. Trad. Norma Azevedo. Rio de Janeiro: Lumen Juris, 2001.p.1-5.

38 Como explicam Norberto Bobbio, Nicola Matteucci e Gianfranco Pasquino, o conceito de burguesia deve ser compreendido como categoria social dotada de raízes econômicas. Nas palavras dos autores: "Num sentido mais fecundo e mais atual, à luz dos acontecimentos históricos contemporâneos, da Revolução Industrial, da revolução política de 1789 e da revolução social ainda em curso (...) a Burguesia, pois, seria a classe que detém, no conjunto, os meios de produção e que, portanto, é portadora do poder econômico e político. Seu oponente seria o proletariado que, desprovido destes meios, possui unicamente sua força de trabalho." (BOBBIO, Norberto; MATTEUCCI, Nicola; PASQUINO Gianfranco. Dicionário de política. Trad. Carmen Varriale et. al. 12.ed. Brasília: Universidade de Brasília, 2004. v.1. p.119-121).

39 BONAVIDES, Paulo. Do estado liberal ao estado social. 7.ed. São Paulo: Malheiros, 2001. p.67.

40 GIANNINI, Massimo Severo. Il Publico Potere: Stati e Amministrazioni Publiche. Bolonha: Il Mulino, 1986. p.35 e seguintes. Segundo o autor, os adjetivos censitário, liberal ou burguês podem qualificar o Estado conforme a perspectiva de análise, se jurídica, econômica ou política. (p.140).

41 Com o positivismo, consagrou-se um Estado de Direito racional, apto a garantir segurança e previsibilidade à atividade econômica. Com esse novo Estado, as relações passaram a ser reguladas por um direito pautado na perfeição técnica e na coerência lógica, de forma a garantir o exercício da liberdade e a exploração da propriedade. Nos países da Europa continental surgiram os códigos, incorporando a lex mercatoria e institucionalizando mecanismos facilitadores da circulação de mercadorias. Como menciona Gomes Canotilho, os códigos napoleônicos, como o Code Civil, de 1804 e o Code Commercial, de 1807, passaram a fixar, ao invés das constituições, os princípios gerais do direito, remetendo os textos constitucionais a meras 'leis orgânicas dos poderes políticos' (CANOTILHO, J. J. Gomes. Direito constitucional e teoria da constituição. 7.ed. Coimbra: Almedina, [s.d.]. p.121). 
Assim, sob o ponto de vista econômico, o novo direito estatal teve o objetivo de proporcionar o desenvolvimento do mercado, de modo que as Constituições escritas da época traçaram obstáculos voltados a impedir a intervenção estatal em todos os setores sociais - exceto naqueles em que sua atuação fosse indispensável para tornar possível a exploração lucrativa ou a defesa da coletividade. ${ }^{42}$

Sob o prisma jurídico, enquanto nos ordenamentos de matriz anglo-saxônica não foi criado para a Administração Pública um regime de regras derrogatórias do direito comum, entendido como aquele aplicável à generalidade das pessoas; ${ }^{43}$ em berço francês nasceu e desenvolveu-se o Direito Administrativo, concebido como um conjunto de exceções ao regime comum, caracterizado pela existência de limitações e de prerrogativas da Administração Pública. ${ }^{44}$ Tal fato pode ser explicado pelas circunstâncias em que foi levado a cabo o processo revolucionário, marcadas pelos excessos do absolutismo e pela necessidade de manutenção da ordem e unidade do Estado francês. ${ }^{45}$

Assim, se é possível sustentar que o rule of law inglês é decorrente de uma continuidade histórica, pode-se dizer que o Estado de Direito francês nasceu de um movimento

42 Durante esse período, as atividades estatais de atenção à saúde foram desenvolvidas nesse mesmo sentido: apenas e tão-somente na medida em que necessárias à proteção da coletividade e ao desenvolvimento do mercado.

43 Sobre as características do o rule of law, conferir: SÈROUSSI, Roland. Introdução ao direito inglês e norte americano. Trad. Renata M. Cordeiro. São Paulo: Landy, 1999.

44 Essa é a definição de Jean Rivero, para quem: "(...) as normas de direito administrativo caracterizam-se em face do direito privado, seja porque conferem à Administração prerrogativas sem equivalente nas relações privadas, seja porque impõem à sua liberdade de acção sujeições mais estritas do que aquelas a que estão submetidos os particulares." (RIVERO, Jean. Direito administrativo. Trad. Rogério E. Soares. Coimbra: Almedina, 1981. p.42).

45 Ao tratar do tema, Eduardo García de Enterría, assinala que o ideal revolucionário que permeou as transformações dos Estados nos séculos XVII e XVIII conduziu a uma estrutura estatal fundada no tripé leis, tribunais e ordem, sendo que a participação da Administração Pública era diminuta e relacionada apenas ao último pilar: a manutenção da ordem. Para o autor, a configuração da nova Administração e do Direito Administrativo ficou à margem da concepção política atuante na Revolução Francesa. Sua configuração como um poder autônomo de ação permanente, com potestade e jurisdição próprias dotado da faculdade de regulamentação da lei (o que permite manipular seu sentido) e submetido a uma jurisdição própria (o Conselho de Estado) - fugia da idéia subjacente à Revolução (GARCÍA DE ENTERRÍA, Eduardo. Revolucion Francesa y Administracion Contemporânea. 4.ed. Madrid: Civitas, 1994. p.35-36; 41 e segs.). O nascimento e desenvolvimento do Direito Administrativo em solo francês não configuram, assim, resultado natural do ideal que fundamentou o processo revolucionário, mas das condições reais em que ele se desenvolveu. Como assinala François Burdeau, a Administração Pública francesa constituiu o Estado francês na medida em que por meio dela a monarquia impôs ordem e unidade ao corpo social até então fragmentado (BURDEAU, François. Histoire de l'administration française: Du 18. ${ }^{\circ}$ au 20. ${ }^{\circ}$ siécle. 2.ed. Paris: Montcherestien, 1994. p.19). Assim, a manutenção, ainda que parcial, de tal estrutura era imprescindível à manutenção da unidade do Estado francês pós-revolucionário. 
de superação parcial do ancien regime. Isso acabou por fazer com que, neste último, o Direito em geral, e o Direito Administrativo em especial, contivessem características do último estágio do Estado absolutista, mormente no que se refere à organização e disciplina da Administração Pública. ${ }^{46} \mathrm{~A}$ antiga estrutura social de classes privilegiadas e corpos intermédios, admitida pelo antigo regime, foi substituída por uma Administração Pública fortemente hierarquizada, centralizada e autoritária, ${ }^{47}$ nascida no seio do próprio Estado absolutista e que ganhou sua forma mais acabada com Napoleão Bonaparte, que assumiu poder no início do século XIX com uma dupla tarefa: (i) concretizar a superação da monarquia absoluta, com sua estrutura de privilégios e desigualdades; e (ii) manter da unidade territorial do Estado francês.

Esse modelo de Administração Pública, nas palavras de Vital Moreira:

(...) era a administração própria do Estado burguês, encarregado de velar pelos interesses das classes possidentes em geral e da burguesia comercial e industrial em particular, ao qual correspondia uma administração tão unidimensional sob o ponto de vista orgânico-funcional como dos interesses que ela servia. ${ }^{48}$

Acontece que a falta de apoio, e mesmo a repressão às organizações intermédias da sociedade, não apenas produziu efeitos sobre as classes privilegiadas, ${ }^{49}$ mas também trouxe graves conseqüências àquelas entidades da sociedade que prestavam auxílio aos enfermos

46 Como explica Fernando Garrido Falla, a conformação de uma Administração Pública unitária que marca a fase final de consolidação do Estado absolutista foi denominada à época pelo termo polícia. Dependente da vontade do soberano absolutista, as atividades de polícia em tal período eram voltadas ao bem-estar do povo e não se sujeitavam ao controle pelos tribunais judiciários (GARRIDO FALLA, Fernando. Tratado de Derecho Administrativo. 9.ed. Madrid: Centro de Estudos Constitucionales, 1985. v.1. p.45). Daí a utilização da expressão Estado de Polícia (Polizeistaat), para referir da última fase do Estado absolutista, dotado de estrutura, organização e unidade territorial.

47 VEDEL, Georges; DELVOLVÉ, Pierre. Droit administratif. Paris: Presses Universitaires de France, 1984. p.104.

48 MOREIRA, Vital. Administração autônoma e associações públicas. Coimbra: Coimbra, 1997. p.34.

49 Segundo George Rosen, cada classe social, nos tempos do absolutismo, tinha seus privilégios inclusive em relação às doenças, que possuíam denominações diversas conforme a classe. Nas palavras do autor: "A doença não somente tem uma relação causal com a situação econômica e social dos membros de uma determinada população, com os cuidados médicos oferecidos também refletem a estrutura de uma sociedade, em particular suas estratificações e divisões de classe. (...) Como atividade social, tal atenção [médica] entrelaça-se, de formas e graus diversos, com a estrutura da vida comunitária de que faz parte ao lado da família, da religião, da economia, do sistema de valores, etc." (ROSEN, George. Da polícia médica à medicina social. Trad. Ângela Loureiro. Rio de Janeiro: Graal, 1980. p.55-58). 
e necessitados. ${ }^{50} \mathrm{Na}$ Encíclica Rerum Novarum, editada em 1891, o Papa Leão XII fez a seguinte crítica às transformações até então ocorridas:

\begin{abstract}
O século passado destruiu, sem as substituir por coisa alguma, as corporações antigas, que eram para eles uma protecção; os princípios e o sentimento religioso desapareceram das leis e das instituições públicas, e assim, pouco a pouco, os trabalhadores, isolados e sem defesa, têm-se visto, com o decorrer do tempo, entregues à mercê de senhores desumanos e à cobiça duma concorrência desenfreada. ${ }^{51}$
\end{abstract}

Nesse sentido é a observação de Fábio Konder Comparato, para quem a Revolução Francesa significou a emancipação do indivíduo em face dos grupos sociais aos quais ele sempre se submeteu, como a família, o clã, o estamento e as organizações religiosas; mas, em contrapartida, promoveu a perda da proteção familiar, estamental ou religiosa, tornando as pessoas muito mais vulneráveis às vicissitudes das vida. 52

\title{
2.1.2 Intervenção do Estado na Ordem Econômica e Social: Polícia Médica e Fomento aos Serviços Privados de Saúde
}

Considerando que o mercado só existe com mecanismos externos que o garantam, pode-se concluir que a necessidade de sua institucionalização conformou o surgimento do Estado. ${ }^{53}$ Além de garantir o cumprimento de contratos, sustentar direitos e permitir intercâmbios, o Estado atuava em setores nos quais a exploração não era viável pelas

50 'Com esse objetivo, em solo francês, por exemplo, foram editados os conhecidos Decreto D'Allarde e Lei Le Chapelier, ambos em 1791. Sobre o repúdio estatal às associações nesse período, bem como seu posterior reconhecimento e promoção, conferir: LEONARDO, Rodrigo Xavier. As associações sentido estrito no direito privado. 2006. 257p. Tese (Doutorado) - Curso de Pós-Graduação em Direito, Universidade de São Paulo, São Paulo, 2006.

51 Disponível em: <http://www.vatican.va/holy_father/leo_xiii/encyclicals/documents/hf_l-xiii_enc_ 15051891_rerum-novarum_po.html>. Acesso em: 09 jul. 2008.

52 COMPARATO, Fábio Konder. A afirmação histórica dos direitos humanos. 6.ed. São Paulo: Saraiva, 2008. p.53.

53 A assertiva é verdadeira no sentido de que, como assinalou Gaspar Ariño Ortiz: "(...) sem o Estado, a economia não seria possível." (ARIÑO ORTIZ, Gaspar. Princípios de Derecho Público Económico. Granada: Comares, 1999. p.XXIX. Com raciocínio inverso, mas com o mesmo significado, para Maria R. FERRARESE, a institucionalização do mercado aparece como uma fase importante para a passagem à sociedade moderna [e consolidação do Estado] (FERRARESE, Maria Rosaria. Diritto e mercato. Torino, Itália: Giappichelli, 1992. p.72). 
forças do mercado. Ainda no século XVIII, Adam Smith, teórico clássico do liberalismo econômico, ao passo em que acreditava ser o livre mercado o meio apto a destruir as desigualdades e os privilégios de origem absolutista, defendia a intervenção pontual do Estado com o objetivo de proporcionar seu desenvolvimento. Após tratar dos deveres do soberano quanto à segurança e à justiça, consignou o autor:

\footnotetext{
O terceiro e último dever do soberano é a criação e a manutenção daqueles serviços e instituições que, embora possam ser altamente benéficos para uma sociedade, são, todavia, de uma natureza tal que o lucro jamais poderia compensar a despesa para qualquer indivíduo ou pequeno número de indivíduos, não se podendo, portanto, esperar a sua criação e manutenção por parte de qualquer indivíduo ou qualquer número de indivíduos. ${ }^{54}$
}

Nessa categoria de deveres, Adam Smith analisou dois diferentes gêneros daquilo que denominou serviços públicos: (i) aqueles criados com o objetivo de facilitar o comércio, como a construção e manutenção de pontes, estradas, canais navegáveis, portos etc. ${ }^{55} \mathrm{e}$ (ii) aqueles voltados a promover a instrução do povo. ${ }^{56}$

Com essa perspectiva, na segunda metade do século XIX, foram criados serviços públicos em setores dependentes de infra-estrutura de grande porte, como ferrovias, estradas, energia elétrica, gás e telefonia. Por se tratar de atividades que dependiam de vultoso investimento de recursos, que necessitavam da utilização de bens estatais para sua construção ou que possuíam vocação para o monopólio, não era possível à iniciativa privada exercer sua exploração de modo independente. Daí a intervenção direta do Estado, no sentido que José Luis Villar Palasí em meados do século XX deu ao termo publicatio: a retirada do domínio privado de determinadas atividades em relação às quais era vedada a

54 SMITH, Adam. Inquérito sobre a natureza e as causas da riqueza das nações. Trad. Luís C. de Aguiar. 4.ed. [s. 1.]: Fundação Calouste Gulbenkian, 2006. v.2. p.333.

55 SMITH, Adam. Inquérito sobre a natureza e as causas da riqueza das nações. Trad. Luís C. de Aguiar. 4.ed. [s. 1.]: Fundação Calouste Gulbenkian, 2006. v.2. p.333-346.

56 Ao tratar da instrução, o Adam Smith defendeu a oferta de instrução mínima a todos os indivíduos e o financiamento parcial pelo soberano, com co-participação do beneficiário, ressaltou o papel da Igreja historicamente desenvolvido na área de educação e não fez qualquer menção a serviços de saúde. (SMITH, Adam. Inquérito sobre a natureza e as causas da riqueza das nações. Trad. Luís C. de Aguiar. 4.ed. [s. 1.]: Fundação Calouste Gulbenkian, 2006. v.2. p.389-469). 
interferência estatal e a assunção de seu controle pelo Estado com vistas a possibilitar sua exploração. ${ }^{57}$

Percebe-se, pois, que a noção de serviço público nesse período, decorrente da publicatio de determinadas atividades, possuía forte viés econômico, relacionava-se à idéia de limitação das funções do Estado e tinha como pressuposto a vedação da intervenção do Estado na ordem social e econômica. ${ }^{58}$ Não obstante, considerando que a publicatio justificava-se, em grande medida, pela impossibilidade de exploração privada da respectiva atividade, poder-se dizer que a própria noção de serviço público conformou-se como instrumento a possibilitar a exploração econômica de determinados serviços, o que se tornou possível por meio de sua concessão pelo Estado aos particulares. ${ }^{59}$

É bem verdade que a distinção entre os aspectos econômico e social deve ser levada em conta com a devida cautela. Como ressalta Jacques Chevallier, a correlação entre o econômico e o social é lógica, de modo que ambos não constituem domínios separados,

57 VILLAR PALASÍ, José Luis. La intervencion administrativa en la industria. Madrid: Instituto de Estudios Politicos, 1964. p.207-218. Segundo o autor, além das antigas técnicas medievais da publicatio bonorum, (aplicada para casos específicos de confisco e punição) e da publicatio agrorum (adotada para a imposição de privilégios reais sobre determinados bens ou atividades privadas), surge o sentido moderno de publicatio, por meio da qual são criados títulos 'ope proprietatis' de poder sobre atividades privadas, com a finalidade de possibilitar o controle estatal. Para Villar Palasí, o clássico serviço público decorre da publicatio de atividades privadas, sendo que sua prestação pode ocorrer tanto pelo Estado quanto pelo particular, por meio de uma sujeição especial como a concessão, a delegação ou o arrendamento (p.216).

58 Nesse sentido: VERGARA, Patrícia Lopes. Titularidad em el Servicio Público. Revista de Derecho Administrativo, ano 11, n.30-32, 1999.. A idéia de segurança coletiva também exerceu influência sob a concepção de serviços públicos à época, como pode ser visualizada da passagem em que Rafael BIELSA defende a gratuidade dos serviços de saúde: "Os chamados serviços gratuitos são aqueles cuja prestação geral, e até obrigatória, interessa a todos em face da solidariedade humana e da segurança comum. Tais são os de ensino primário, os de assistência médica e de assistência econômica. Nesses casos, até os mais egoístas possuem interesse em que sejam gerais e gratuitos, pois uma sociedade ignorante e atrasada é uma ameaça para todos, por sua incapacidade de produção, de defesa nacional, etc.; pela mesma razão, se o Estado não presta assistência aos que não podem obtê-la, em caso de doenças perigosas ou contagiosas, todo o corpo social fica ameaçado por suas conseqüências naturais." (BIELSA, Rafael. Derecho Administrativo. 5.ed. Buenos Aires: Roque Depalma, 1955. Tomo I. p.554). Como se verá, a noção de serviço público como atividade prestacional ligada à satisfação de um direito de cada pessoa, e não de um interesse público, apenas toma forma no século $\mathrm{XX}$, com a ampliação das funções estatais, a partir da efetivação do sufrágio universal e da consagração de novos direitos fundamentais dependentes de prestações positivas.

59 Pode-se mencionar, nesse prisma, a experiência histórica francesa, na qual: "Registram-se contratos de concessão no séc. XVII na construção de canais (o canal de Midi, lançado pelo empreendedor Jean-Paul Riquet na época de Louis XIV e Colbert) e na secagem de pântanos (cedida por Henrique IV para todo o território nacional). Sobretudo a partir da segunda metade do século XIX, as concessões presidiram esmagadoramente à construção de grandes infra-estruturas como os caminhos de ferro, transportes urbanos (Metro de Paris), redes de eletricidade, de água e esgotos, e de recolha de lixo (...)." (SANTOS, Boaventura de Sousa (Dir. Científico). Parcerias público-privadas e justiça: uma análise comparada das diferentes experiências. Coimbra: Centro de Estudos Sociais, 2007. p.28). 
mas duas faces de uma mesma realidade: enquanto a economia diz respeito a um conjunto de processos de produção, circulação, troca e distribuição de bens e serviços, o social recobre toda e qualquer ordem relativa à vida e às relações de indivíduos e de grupos. ${ }^{60}$ Sob ponto de vista inverso, mas com conclusão análoga, Fabio Nusdeo chega a sustentar que a distinção padece de base científica, já que toda atividade reconhecida como social, geralmente associada ao atendimento de necessidades em relação às quais não há possibilidade de obtenção de lucro, é também econômica, na medida em que se refere à aplicação de recursos escassos para suprimento de determinadas finalidades. ${ }^{61}$ Nesse sentido, as perspectivas econômica e social, no presente trabalho, são levadas em consideração por sua utilidade na análise de uma noção fundamental a este estudo, a de serviços públicos de saúde, ${ }^{62}$ que apenas pode ser compreendida, interpretada e regulada a partir de uma visão integrada entre ambos os pontos de vista, como se verá no capítulo seguinte.

Nessa linha de entendimento, as atividades do Estado em áreas nas quais não havia a possibilidade de exploração lucrativa ocorreram durante o século XIX de maneira pontual, restrita e vinculada à proteção da coletividade. No caso da saúde, considerando que a ciência médica ainda não se encontrava plenamente desenvolvida, a assistência à saúde confundia-se com o auxílio prestado aos desvalidos e indigentes, na medida em que estes poderiam perturbar a ordem e transmitir doenças. ${ }^{63}$

60 CHEVALLIER, Jacques. Science administrative. 3.ed. Paris: Presses Universitaires de France, 2002. p.169.

61 NUSDEO, Fábio. Curso de economia: introdução ao direito econômico. 4.ed. São Paulo: Revista dos Tribunais, 2005. p.96. Assim, por óbvio, as ações e dos serviços de saúde podem ser classificados como bens econômicos, na medida em que envolvem uma conduta pessoal e, normalmente, bens materiais, ambos dotados de escassez, para atendimento de uma necessidade humana.

62 Como se verá no Capítulo 3, em mais de uma passagem a Constituição Federal de 1988, ao contrário do que faz com outros serviços públicos, utiliza a exata expressão serviços públicos de saúde.

63 A separação entre assistência social e assistência à saúde apenas começa a se consolidar em fins do século XIX, com o desenvolvimento da denominada medicina científica, decorrente da incorporação de técnicas e conhecimentos como os da bacteriologia - com influência sobre a etiologia e imunologia, da anti-sepsia e da anestesia. Com isso, os hospitais deixaram de configurar mero abrigo àqueles que dependiam de caridade pública e passaram a ser o centro onde se dispensavam cuidados médicos (SINGER, Paul; CAMPOS, Oswaldo; OLIVEIRA, Elizabeth. Prevenir e curar: o controle social através dos serviços de saúde. Rio de Janeiro: Forense Universitária, 1988. p.29 e 88-89). 
A compreensão das atividades do Estado mencionadas na segunda parte do título do presente item - polícia médica e fomento estatal aos serviços privados de saúde implica a análise de processos distintos que ocorreram paralelamente e que culminaram na assunção pelo Estado do dever de prestar serviços de saúde às pessoas.

Nesse caminho, é importante pontuar que anteriormente às Revoluções dos séculos XVII e XVIII, a proteção da saúde era utilizada como instrumento a favor da manutenção do poder político do Estado.

Conforme explica George Rosen, no modelo de organização social do Estado absolutista, a densidade da população e seu bem-estar configuravam condições de fortalecimento do poder do soberano, daí a idéia alemã de polícia médica, diretamente ligada à constituição e à administração do Estado. Segundo o autor, em escritos apócrifos da época encontram-se consignadas as condições a serem providas pela polícia interna do Estado, dentre as quais uma educação louvável e uma saúde forte. ${ }^{64}$ Nesse sentido é que se fala do Estado absolutista, como um Estado de bem-estar, ${ }^{65}$ de cunho paternalista, ${ }^{66}$ no qual o soberano encontra apoio para exercício de seu poder na oferta de segurança e bem-estar a seus súditos.

Para Michel Foucault, a polícia médica desenvolvida na Alemanha nos séculos XVIII e XIX, denominada pelo autor medicina de Estado, teve como centro de atenção efetivamente a saúde da população e apresentou as seguintes características: (i) desenvolvimento de um sistema completo de observação da morbidade; (ii) regulamentação da prática e do saber médicos; criação de estruturas administrativas para controle da atividade médica; (iii) e nomeação de um corpo de médicos hierarquicamente organizados para assistência à

64 Como já assinalado neste trabalho, a noção de polícia foi utilizada à época do Estado absolutista como sinônimo do que veio a ser a Administração Pública do Estado de Direito. Nesse sentido, citando a obra clássica de Delamare, Michel Foucault sustenta que nesse período a polícia é encarregada de assegurar a ordem, o enriquecimento do Estado e a saúde (FOUCAULT, Michel. A política de saúde no século XVIII. In: __ Microfísica do poder. Trad. Roberto Machado. 25.ed. Rio de Janeiro: Graal, 2008. p.197).

65 GIANNINI, Massimo Severo. Il Publico Potere: Stati e Amministrazioni Publiche. Bolonha: Il Mulino, 1986. p.32.

$66 \mathrm{Na}$ análise de George Rosen: "A relação do soberano com os súditos era entendida como uma relação de um pai com seus filhos. Em consonância com a teoria paternalista, um dos deveres do Estado absolutista a proteção da saúde das pessoas. Mas as pessoas não eram mais do que objeto de cuidado do Estado; tanto na saúde quanto em todas as outras áreas, era o soberano que tinha conhecimento do que era melhor para seus súditos (...)." (ROSEN, George. A History of Public Health. Baltimore: Johns Hopkins University, 1993. p.93-94). 
população. ${ }^{67}$ Esse modelo foi adotado especialmente em Estados que tinham laços estreitos com a Alemanha e que tiveram sua unificação tardia, como Itália, Rússia, Hungria e Dinamarca, ${ }^{68}$ e foi mantido até o final do século XIX, quando os efeitos da industrialização e a evolução das técnicas e os custos da medicina tornaram-no inviável e fizeram com que surgissem organizações de trabalhadores com objetivo de prover auxílio mútuo, inclusive na assistência à saúde.

Já na Inglaterra, onde o Estado absolutista sequer se formou por completo, e na França, onde foi rompido pela Revolução, as atividades de polícia médica foram desenvolvidas com menor intensidade, por meio de prestações voltadas meramente ao controle de doenças epidêmicas, supervisão do saneamento urbano e medidas higiênico-sanitárias. ${ }^{69}$ Esse é o contexto do já mencionado Estado monoclasse, cuja preocupação não reside na saúde das pessoas, mas na proteção da coletividade e no desenvolvimento do mercado. Daí a proeminência de atividades estatais de polícia, entendidas não mais de modo amplo, mas em seu sentido restrito, de limitação de atividades individuais como meio de proteção dos interesse da coletividade. ${ }^{70}$

$\mathrm{Na}$ Inglaterra, a assistência aos necessitados e enfermos era prestada por entidades intermédias eclesiásticas de origem medieval, que receberam tal atribuição pela Poor Law $A c t$ - Lei dos Pobres, editada por Elizabeth I no ano de 1601. Cada paróquia era responsável

67 FOUCAULT, Michel. O nascimento da medicina social. In: Microfísica do poder. Trad. Roberto Machado. 25.ed. Rio de Janeiro: Graal, 2008. p.80-84.

68 ROSEN, George. Da polícia médica à medicina social. Trad. Ângela Loureiro. Rio de Janeiro: Graal, 1980. p.182.

69 Em tais Estados, de acordo com a teoria política liberal dominante no século XVIII, a participação do Estado na assistência à saúde deveria ser ao máximo restrita. Em obra escrita à época da Revolução Francesa e publicada em 1851, o entendimento de Wilhelm von Humboldt, segundo o qual cabia ao próprio indivíduo e à própria sociedade resolver suas dificuldades, sob pena do Estado infringir a liberdade e individualidade, ilustra tal pensamento: "O Estado, por conseguinte, não deve se ocupar, seja de que modo for, com o bem-estar positivo de seus cidadãos e, por via de conseqüência, com suas vidas ou saúde, a não ser quando tais casos estão em perigo pelas ações dos outros. O Estado deve manter um olho vigilante na segurança, embora apenas na extensão em que isso possa sofrer com as tentativas da intenção de tomar a ignorância de outro em proveito próprio." (HUMBOLDT, Wilhelm von. Os limites da ação do estado. Trad. Jesualdo Correia. Rio de Janeiro: Topbooks, 2004. p.270).

70 Ao tratar do tema, Massimo Servero Giannini assim se manifestou: "(...) a atividade higiênico-sanitária era compreendida pelos teóricos de então como uma atividade da polícia; polícia especializada no conteúdo, que era técnico, inteiramente próprio, qual seja das ciências médicas, mas que era ainda uma atividade de defesa do coletivo contra os agentes perturbadores, desta vez, externos; portanto, polícia, segundo o significado que o termo havia assumido com o advento do novo Estado." (GIANNINI, Massimo Severo. Il Publico Potere: Stati e Amministrazioni Publiche. Bolonha: Il Mulino, 1986. p.44). 
pelo atendimento das pessoas domiciliadas em seu território. ${ }^{71}$ Para tanto, a entidade recebia incentivo fiscal da coroa e era subordinada às autoridades reais. Nos termos da Poor Law, as paróquias tinham o dever de prestar assistência aos indigentes, o que com o tempo passou a incluir assistência médica e serviços de enfermagem, os quais eram normalmente prestados por terceiros contratados. ${ }^{72} \mathrm{Com}$ o desenvolvimento do capitalismo inglês no século XIX, tornaram-se- necessárias maior mobilidade e maior oferta de mãode-obra - as quais eram dificultadas pelos amplos benefícios assistenciais e pelo critério do domicílio previstos pela Lei dos Pobres. Diante disso, foi aprovada em 1834 uma emenda à lei em referência, a Poor Law Amendment Act - Emenda à Lei dos Pobres. Conhecida como a Nova Lei dos Pobres, tal determinação legal aboliu o requisito do domicílio (de modo a facilitar a circulação de pessoas) e estabeleceu critérios rigorosos para o atendimento aos necessitados (de modo a deixar de atender àqueles em condições de trabalho).

$\mathrm{Na}$ análise de Karl Polanyi, a Emenda de 1834 acabou por excluir a classe trabalhadora da assistência social e separou-a dos indigentes. ${ }^{73}$ A nova lei impôs às pessoas aptas ao trabalho a venda de sua mão-de-obra para, por meio dela, obter recursos e pagar pela assistência privada, criando, assim, um mercado de trabalho o mais livre possível. ${ }^{74}$ É a consolidação, no campo da saúde, do pensamento individualista segundo o qual a ação estatal contra a pobreza leva à acomodação, sendo que o trabalho, ao invés da assistência, é que deve ser incentivado. Com isso, a sobrevivência das pessoas passou a depender de sua inserção no mercado, com a venda de sua mão-de-obra como meio de

71 A delimitação dos territórios ocorreu por meio do Act of Settlement - Lei do Domicílio, que teve como objetivo impedir a expulsão de pobres pelas paróquias não interessadas em assisti-los.

72 ROSEN, George. Da polícia médica à medicina social. Trad. Ângela Loureiro. Rio de Janeiro: Graal, 1980. p.206. Os principais documentos históricos que marcaram o desenvolvimento da atenção social na Inglaterra encontram-se compilados e comentados em obra de Maurice Bruce (The Rise of Welfare State. English Social Police: 1601-1971. London: World University, 1972).

73 POLANYI, Karl. A grande transformação: as origens de nossa época. Trad. Fanny Wrobel. 2.ed. Rio de Janeiro: Elsevier, 2000. p.202.

74 Tal transição marca a vitória da burguesia industrial ascendente, dependente de uma massa de trabalhadores, em face da em face da aristocracia rural tradicional, cujo poder dependia do fornecimento de bem-estar à população (ROSANVALLON, Pierre. A crise do estado-providência. Trad. Joel Pimentel de Ulhôa. Goiânia: UFG; Brasília: UNB, 1997. p.123-124). 
sobrevivência - condição até então inexistente. ${ }^{75}$ Apenas ao final do século XIX, com o crescimento no número de trabalhadores urbanos, em face da precariedade e seletividade do atendimento proporcionado pela Nova Lei dos Pobres, foram criadas inúmeras organizações mutualistas de trabalhadores, as friendly societies, com o objetivo de garantir um mínimo de proteção social. ${ }^{76}$

Na França, desde o reinado de Luís XIV, no século XVII, o Estado, além de manter hospitais gerais, ${ }^{77}$ ofertava de serviços de saúde por meio de incentivos à Igreja, a indivíduos e a organizações caritativas em nível local. ${ }^{78}$ Não obstante, dada a insuficiência da oferta de assistência no período pré-revolucionário, grande parte da população francesa vivia em estado de miséria, com influência negativa em seu estado geral de saúde. Com a Revolução, a situação dos hospitais tornou-se ainda mais calamitosa, pois do apoio estatal

75 Na crítica de Larry E. Carter, a Nova Lei dos Pobres não foi aprovada para ajudar os pobres, mas para proteger a sociedade deles (CARTER, Larry E. The Emergence of Modern Health Systems. In: Health Care Reform: policy innovations at the state level in the United States. New York: Garland, 1998. p.27).

76 Segundo Loes Van Der Valk, as friendly societies eram entidades de auxílio mútuo inglesas, em sua maioria informais, criadas para amparar os trabalhadores especializados, em situações de doença, velhice e morte. As primeiras friendly societies eram clubes sociais que financiavam funerais e prestavam auxílios com doenças. O processo de obtenção de fundos era precário, e com o aumento dos gastos na medida em que os membros envelheciam várias delas acabaram falindo. Contudo, percebeu-se que com uma contribuição semanal seria possível criar um fundo de reservas para ser utilizado quando necessário, e esta técnica se popularizou ao longo do século XIX. As sociedades obtiveram maior sucesso na área do tratamento médico. Sobre o tema: VALK, Loes Van Der. Public Policy and Private Interests in Social Insurance Legislation: The case of United Kingdom and Netherlands. In: RANDERAAD, Nico (Ed.). Mediators between State and society. Hilversum: Verloren, 1998. p.113-116).

77 É importante notar que o hospital, à época, não era entendido como um local para tratamento e cura de doenças. Como já ressaltado, o conhecimento médico ainda não era desenvolvido e o tratamento privado, prestado por médicos de maior reputação, era prestado principalmente em domicílio. Os hospitais mantidos à época com apoio do Estado serviam muito mais como locais de defesa da coletividade em face da desordem e do perigo do contágio, do que para a recuperação de doentes. Nesse sentido é a análise de Michel Foucault, segundo o qual, até o século XVIII, o hospital era o local destinado tanto à assistência aos pobres, quanto à sua separação e exclusão, a fim de proteger a coletividade. Nas palavras do autor: "O personagem ideal do hospital até o século XVIII não é o doente que é preciso curar, mas o pobre que está morrendo." (FOUCAULT, Michel. O nascimento do hospital. In: Microfísica do poder. Trad. Roberto Machado. 25.ed. Rio de Janeiro: Graal, 2008. p.101). No mesmo sentido: ERRERA, Paul. Traité de Droit Publique Belge. Paris: V. Giard \& E. Brière, 1909. p.549. Segundo George Rosen, apenas no século XX, com o desenvolvimento da bacteriologia e da medicina clínica, é que o hospital passa a ocupar figura central na atenção médica, acomodando pessoal especializado, funções complexas e equipe especializada, o que levou, inclusive, a um aumento considerável em seu custo (ROSEN, George. Da polícia médica à medicina social. Trad. Ângela Loureiro. Rio de Janeiro: Graal, 1980. p.335-370).

78 ROSEN, George. Da polícia médica à medicina social. Trad. Ângela Loureiro. Rio de Janeiro: Graal, 1980. p.244 e 258 . 
partiu-se à repressão aos corpos intermédios, ${ }^{79}$ como já assinalado no item anterior. Durante a Revolução Francesa, o Estado assumiu a propriedade dos hospitais antes pertencentes à Igreja, para depois vendê-los ou transformá-los em hospitais militares. No período, foi proibida a caridade e vedada a mendicância. ${ }^{80} \mathrm{O}$ ideal de exterminar os privilégios estamentais e corporativos, combustível da Revolução francesa, acabou promovendo a poluição da assistência à saúde, transformando-a em responsabilidade individual, desalojada de seus laços sociais e ligada ao novo modelo de organização produtiva que se instalava.

É importante ressaltar que, apesar da Declaração dos Direitos do Homem e do Cidadão, de 1789, não ter feito referência à atenção à saúde, a Constituição francesa de 1791 previu a criação de um estabelecimento geral de socorros públicos para criar as crianças expostas, aliviar os pobres enfermos e prover trabalho aos pobres válidos que não o tenham achado. Trata-se, como assinalou Fabio Konder Comparato, do primeiro documento histórico em que foram reconhecidos direitos humanos de caráter social. ${ }^{81} \mathrm{Na}$ Convenção que sucedeu à Constituição de 1791, surgiu a Constituição francesa de 1793, que em pouco inovou o que previra sua antecessora. ${ }^{82} \mathrm{~A}$ partir de então, considerando que em face dos acontecimentos revolucionários a Constituição de 1793 sequer chegou a entrar em vigor, a assistência à saúde não mais constou como função do Estado até a transição ao século XX, ${ }^{83}$

79 Como informa George Rosen ao tratar do período revolucionário francês: "A receita hospitalar vinha de aluguéis de bens imobiliários pertencentes às instituições; de taxas, multas, loterias e doações ocasionais feitas pelos governos central e local; e da caridade privada sob a forma de heranças e doações. A crise política e econômica afetava todas estas fontes. Medo, emigração, depressão econômica diminuíram a caridade privada. Além disso, a impossibilidade de pagar impostos e um decréscimo dos investimentos hospitalares intensificaram o apuro financeiro destas instituições. Finalmente, em março de 1791, todos os impostos indiretos foram suprimidos e, em 1. ${ }^{\circ}$ de março de 1791, o 'octroi', o principal imposto para a renda hospitalar, foi abolido." (ROSEN, George. Da polícia médica à medicina social. Trad. Ângela Loureiro. Rio de Janeiro: Graal, 1980. p.283).

80 ROSEN, George. Da polícia médica à medicina social. Trad. Ângela Loureiro. Rio de Janeiro: Graal, 1980. p.296.

81 COMPARATO, Fábio Konder. A afirmação histórica dos direitos humanos. 6.ed. São Paulo: Saraiva, 2008. p.153.

82 Aduzia o artigo 21 da Constituição francesa de 1793: "A assistência pública é uma dívida sagrada. A sociedade deve sustentar os cidadãos infelizes, dando-lhes trabalho, ou assegurando os meios de subsistência aos que não estejam em condições de trabalhar".

83 Importante destacar que ainda no século XIX a Constituição francesa de 1848 constituiu, na opinião de alguns autores, importante marco no reconhecimento dos direitos sociais. Apesar de não fazer referência expressa ao direito à saúde, o texto francês de 1848 mencionava em seu preâmbulo a intervenção das instituições e da lei em busca do bem-estar dos cidadãos, inclusive por meio da assistência aos necessitados. Além disso, em seu art. 13, previa o incentivo ao trabalho, inclusive por meio do ensino primário gratuito, 
com a Lei Waldeck-Rousseau, de 21 de março de 1884, que admitiu a criação de associações profissionais, a partir da qual proliferaram entidades por meio das quais os trabalhadores urbanos franceses asseguraram assistência mútua à saúde.

Desse panorama geral, ilustrado pelas experiências alemã, inglesa e francesa, pode-se perceber que:

(i) os serviços de saúde foram prestados pelo Estado absolutista, em especial na Alemanha, como forma de consolidar seu poder, por meio do que se denominou polícia médica;

(ii) os serviços de saúde foram incentivados pelo Estado absolutista francês e pelo Estado inglês por meio de fomento a entidades privadas, sobretudo ligadas à Igreja e à caridade;

(iii) durante o primeiro estágio do Estado de Direito, a prestação de serviços de saúde tornou-se insuficiente, com a abstenção estatal na prestação de serviços e a extinção ou restrição dos incentivos às entidades intermédias;

(iv) no segundo estágio do Estado de Direito, em fins do século XIX, a nova realidade imposta pela industrialização e urbanização conduziu ao surgimento de novas organizações da sociedade voltadas para sua própria proteção, as quais, ao lado daquelas que sobreviveram ao século XIX, acabaram sendo reconhecidas e fomentadas pelo Estado para a prestação dos serviços de saúde.

\subsection{RECONHECIMENTO DO DIREITO À SAÚDE: A ASSISTÊNCIA À SAÚDE COMO DEVER DO ESTADO}

Durante o século XIX, sem a prestação direta de serviços de saúde pelo Estado e sem apoio estatal às entidades intermédias, as pessoas tornaram-se, em grande medida, dependentes do mercado para o atendimento de suas necessidades, inclusive na assistência à saúde. Entretanto, como se sabe, o mercado não é um meio apto de atender às necessidades de todos, pois ele apenas oferece bens e serviços àqueles que dele fazem parte. Como expressou Gaspar Ariño Ortiz: "A 'ordem natural ideal' prevista pelo liberalismo acabou se

\footnotetext{
da educação profissionalizante e da igualdade entre patrão e empregado. Por isso, pode-se dizer que tal Constituição marca a largada do movimento de consagração constitucional da intervenção estatal na ordem privada. Essa é a opinião de Manoel Gonçalves Ferreira Filho, para quem a Constituição francesa de 1848 constitui o principal documento no processo de evolução dos direitos fundamentais (FERREIRA FILHO, Manoel Gonçalves. Direitos humanos fundamentais. São Paulo: Saraiva, 1995. p.45-46).
} 
tornando uma 'desordem natural real', demandando a intervenção estatal na sociedade". ${ }^{84}$ Daí a premência da desmercadorização do indivíduo, ${ }^{85} \mathrm{com}$ o início de um processo de formação de um Estado a serviço da sociedade, como se referiu Michel Crozier. ${ }^{86} \mathrm{Um}$ Estado não apenas garantidor da ordem, da segurança e das operações econômicas, mas incentivador e promotor de atividades diversas daquelas voltadas exclusivamente ao lucro.

Note-se que a assistência à saúde, como visto, foi assumida como mecanismo de manutenção do poder do Estado absolutista e como instrumento proteção da coletividade em face do perigo oferecido por doentes contagiosos na primeira fase do Estado de Direito. Nesse momento histórico, o sufrágio universal ainda não se consolidara, o que aponta para a desvinculação da democracia política do desenvolvimento de atividades sociais pelo Estado, ao menos em sua origem. ${ }^{87}$ Tal observação deve ser tomada em seus devidos termos, pois mesmo que não garantido o sufrágio universal, a pressão popular, impulsionada por idéias socialistas, foi decisiva para a mudança no perfil da atuação estatal que se iniciava - e que foi concretizada com a elevação de tais atividades a deveres do Estado no século XX. ${ }^{88}$

84 ARIÑO ORTIZ, Gaspar. Princípios de Derecho Público Económico. Granada: Comares, 1999. p.10.

85 Segundo Gosta Esping-Andersen: "A desmercadorização ocorre quando a prestação de um serviço é vista como uma questão de direito ou quando uma pessoa pode manter-se sem depender do mercado." (ESPING-ANDERSEN, Gosta. As três economias políticas do Welfare State. Revista de Cultura e Política, n.24, p.102, set. 1991.

86 CROZIER, Michel. Estado modesto, estado moderno: estratégia para uma outra mudança. Trad. J. M. Vilar de Queiroz. Brasília: Fundação Centro de Formação do Servidor Público - FUNCEP, 1989. p.49.

87 O surgimento das primeiras intervenções do Estado para a garantia dos serviços de saúde decorre, portanto, da realidade criada pelo processo de industrialização aliada à pressão dos grupos de trabalhadores. Sua intenção era inicialmente, como sustenta Gosta Esping-Andersen, evitar a realização da democracia (ESPINGANDERSEN, Gosta. O futuro do Welfare State na nova ordem mundial. Revista de Cultura e Política, n.235, 1991. p.94).

88 Na doutrina jurídica, autores como Paul Errera e Léon Duguit defendiam a responsabilização do Estado pela prestação de serviços de saúde. Em obra de 1909, Paul Errera assinalou a transição de uma legislação econômica para uma legislação social e sustentou a competência do Estado pela garantia de serviços públicos de assistência social e de hospitalização - (ERRERA, Paul. Traité de Droit Publique Belge. Paris: V. Giard \& E. Brière, 1909. p.527 e 684). No mesmo sentido, Léon Duguit, em 1911, ao tratar das obrigações positivas do Estado, registrou que este devia assegurar os meios para que fossem tratados os doentes (DUGUIT, Léon. Traité de Droit Constitucionnel. Paris: Fontemoing, 1911. Tomo II. p.159). 
Iniciava-se, assim, o movimento pelo qual o Estado passou a assumir o dever de garantir a oferta de atividades prestacionais - como os serviços de saúde. ${ }^{89}$ Para tanto, a Administração Pública uniu-se a iniciativas da própria sociedade. ${ }^{90}$ Vital Moreira, referindo-se à organização estatal do Estado pós-revolução francesa, assim se manifestou:

(...) [a] concepção unitária, monolítica e centralizada da Administração pública manteve-se durante quase todo o século XIX. Mas a partir de certa altura deu-se a emergência de agrupamentos sociais reclamando do Estado a intervenção nas tarefas administrativas públicas. O Estado propôs a aproveitá-los para aliviar seu envolvimento directo na gestão concreta das novas prestações sociais, como sucedeu na Alemanha bismarckiana, com a segurança social..$^{91}$

As entidades intermédias da própria sociedade - durante algum tempo tidas como entraves à igualdade e à liberdade, por servirem como base para privilégios - passaram a ser utilizadas pelo Estado para a prestação de serviços de índole social, dentre os quais, os serviços de saúde.

Ainda que com o objetivo de remediar os efeitos gerados pela industrialização, cooptar as organizações dos trabalhadores que prestavam ajuda mútua e reivindicavam direitos, e de consolidar o Estado como centro do poder - a política social alemã, em especial aquela prevista pela Lei do Seguro-Doença, de 15 de junho de 1883, ${ }^{92}$ editada por Otto von Bismarck, acabou por configurar o primeiro sistema obrigatório de proteção à saúde e que, como ser verá adiante, é mantido em suas linhas gerais até hoje naquele Estado e em vários outros que seguiram o mesmo modelo.

89 É possível perceber que a assunção de tal dever decorreu de necessidades sociais e que a hipótese era, em certa medida, admitida pela própria teoria econômica liberal. Veja, por exemplo, o pensamento de Adam Smith, acima colacionado, a propósito dos serviços de educação.

90 Não obstante o repúdio estatal às organizações intermediárias, como analisa Avelãs Nunes, seu florescimento no decorrer do século XIX foi inevitável, em especial no que se refere ao surgimento de organizações da classe operária (NUNES, A. J. Avelãs. Os sistemas econômicos. Coimbra: Universidade de Coimbra, 1997. p.101).

91 MOREIRA, Vital. Administração autônoma e associações públicas. Coimbra: Coimbra, 1997. p.16-17.

92 Além da lei sobre seguro-doença, foram aprovadas na Alemanha a lei sobre acidentes de trabalho e a lei sobre seguro velhice e invalidez, em 1884 e 1889, respectivamente. 
2.2.1 Consagração de Direitos Econômicos, Sociais e Culturais: A Saúde como Função do Estado

No plano jurídico, importante transformação ocorreu quando as atividades sociais passaram a residir como dever estatal em textos internacionais e nas Constituições dos Estados. De meras atividades estatais, com a consagração dos direitos econômicos, sociais e culturais, ${ }^{93}$ a atuação administrativa em áreas como a saúde passou a configurar direito constitucionalmente previsto em beneficio de cada pessoa, e não mais como instrumento de poder Estado ou de defesa da coletividade.

Como assinala Pierre Rosanvallon, tal transformação foi conseqüência natural do Estado absolutista, denominado por ele Estado-protetor. Na opinião do autor, de suas tarefas iniciais de produção da segurança e redução da incerteza, que podem ser dimensionadas pelos direitos à vida, integridade física e propriedade, o movimento democrático fez com que novas tarefas fossem sendo assumidas, substituindo-se a incerteza da providência religiosa pela certeza da providência estatal, agora elevada a dever constitucional do Estado. ${ }^{94}$ No

93 De acordo com Jorge Miranda, os direitos econômicos surgem como garantia de dignidade no trabalho, os direito sociais, como garantia de segurança na necessidade e os direitos culturais, como exigência de acesso à educação e à cultura (MIRANDA, Jorge. Manual de direito constitucional. Coimbra: Coimbra, 1988. Tomo IV. p.22-23). Conforme José Afonso da Silva, em entendimento seguido por vários autores e adotado neste trabalho, tais direitos são comumente referidos simplesmente como direitos sociais (SILVA, José Afonso da. Curso de direito constitucional positivo. 22.ed. São Paulo: Malheiros, 2003. p.172). Em estudo sobre o tema, Jose Ramon Diaz reconhece a utilização corrente na linguagem jurídica da expressão direitos sociais para designar duas características comuns da expressão: (i) o reconhecimento de prestações a cargo do Estado e (ii) a aceitação do valor da igualdade (material) como sua finalidade (DIAZ, Jose Ramon. Estado Social e Derechos de Prestacion. Madrid: Centro de Estudos Constitucionales, 1989. p.46). Antonio-Enrique Perez Luño, traz uma definição objetiva e outra subjetiva dos direitos sociais, nos seguintes termos: "Assim, podem entender-se tais direitos, em sentido objetivo, como o conjunto das normas através das quais o Estado leva a cabo sua função equilibradora das desigualdades sociais. Enquanto que, em sentido subjetivo, podem ser entendidos como as faculdades dos indivíduos e dos grupos de participar dos benefícios da vida social, o que se traduz em determinados direitos a prestações, diretas ou indiretas, por parte dos poderes públicos." (PEREZ LUÑO, Antonio-Enrique. Los Derechos Fundamentales. 6.ed. Madrid: Tecnos, 1995. p.183-184). A título de ilustração cumpre lembrar que a Constituição brasileira de 1988 relaciona em seu artigo sexto como direitos sociais: a educação, a saúde, o trabalho, a moradia, o lazer, a segurança, a previdência social, a proteção à maternidade e à infância, a assistência aos desamparados e a moradia (este último trazido pela emenda constitucional n. ${ }^{\circ}$ 26, de 14.02.2000). Além disso, o texto constitucional de 1988 faz a distinção topológica entre a Ordem Econômica e a Ordem Social, sendo que senta última traz a disciplina de uma série de direitos, dentre os quais, além do direito à saúde, o direito relativo à assistência social, previdência social, educação e cultura.

94 Segundo o autor: "É, nesse sentido, o Estado que finaliza sua secularização, transferindo para suas prerrogativas regulares os benefícios aleatórios que apenas o poder divino era suposto poder dispensar. Ele se dá por tarefa resgatar 'hic e nunc' as desigualdades de 'natureza' ou os infortúnios da sorte, o Estado-providência é a última palavra do Estado leigo: depois de o Estado-protetor haver firmado sua soberania emancipando-se do religioso, apaga os derradeiros sinais deste integrando-o. Aos acasos da caridade e da providência, sucedem-se as regularidades do Estado." (ROSANVALLON, Pierre. A crise do estado-providência. Trad. Joel Pimentel de Ulhôa. Goiânia: UFG; Brasília: UNB, 1997. p.18-22). 
mesmo sentido, mas com ponto de partida temporal diverso, para Manuel García-Pelayo, as medidas de adaptação adotadas pelo Estado não constituíram algo realmente novo, mas uma evolução qualitativa de tendências pontuais surgidas ao final do século XIX e início do século XX, as quais sofreram um processo de generalização, integração e sistematização. ${ }^{95}$ O traço de continuidade também foi assinalado por Paulo Bonavides, para quem o modelo de Estado até então existente não sucumbiu ou desapareceu, mas transformou-se, ${ }^{96}$ por meio de uma revolução pluralista e democrática, baseada em uma liberdade formal e também material. ${ }^{97}$

Os dois conhecidos documentos constitucionais que marcaram a consagração de direitos sociais no século XX, foram a Constituição do México, de 1917, e a Constituição Alemã, de 1919. O texto mexicano é reconhecido por ter albergado pela primeira vez em um texto constitucional a previsão de limitações às relações trabalhistas, com vistas à proteção da saúde dos empregados. ${ }^{98}$ Já a Constituição de Alemã, conhecida como Constituição de Weimar, estabeleceu a vinculação da vida econômica aos princípios da justiça e da dignidade da pessoa humana e determinou a proteção à saúde dos assalariados por meio de um sistema de seguros, ${ }^{99}$ o qual, como assinalado acima, já havia sido previsto em lei naquele Estado desde o final do século XIX.

95 Como afirmou García-Pelayo, enquanto nos séculos XVIII e XIX se pensava que a liberdade era uma exigência da dignidade humana, agora se pensa que a dignidade humana (materializada em pressupostos socioeconômicos) é uma condição para o exercício da liberdade; antes se tratava de proteger a sociedade da ação do Estado, agora trata-se de proteger a sociedade pela ação do Estado (GARCÍA-PELAYO, Manuel. Las transformaciones del Estado contemporâneo. 2.ed. Madrid: Alianza, 1988. p.18 e 26-27).

96 BONAVIDES, Paulo. Do estado liberal ao estado social. 7.ed. São Paulo: Malheiros, 2001. p.37.

97 BONAVIDES, Paulo. Teoria do estado. 3.ed. São Paulo: Malheiros, 1999. p.289.

98 Nos termos da Constituição Mexicana: Art. 123. O Congresso da União e as legislaturas dos Estados deverão editar leis sobre o trabalho, fundadas nas necessidades de cada região, sem contrariar as seguintes bases, que regerão o trabalho dos operários, diaristas, empregados domésticos e artesãos e, de maneira geral, todo o contrato de trabalho. (...) XV - O patrão será obrigado a observar, na instalação de seu estabelecimento, os preceitos legais sobre higiene e saúde, e a adotar as medidas adequadas para prevenir acidentes no uso das máquinas, dos instrumentos e do material de trabalho, assim como organizar este de tal forma que resulte para a saúde e para a vida dos trabalhadores a maior garantia compatível com a natureza do estabelecimento, sob as penas que para o caso as leis determinarem.

99 Assim estabelecia a Constituição de Weimar: Art. 161. Para conservação da saúde e capacidade de trabalho, pra a proteção da maternidade e assistência contra as conseqüências econômicas da velhice, da invalidez e das vicissitudes da vida, o Estado Central institui um amplo sistema de seguros, com a colaboração obrigatória dos segurados. 
Mas foi apenas após a Segunda Guerra Mundial que os direitos sociais voltados à proteção da dignidade de cada pessoa humana foram ampliados e positivados em documentos internacionais e em novos textos constitucionais que se seguiram. ${ }^{100}$ Importante fator que influenciou a ampliação do direito à saúde a todas as pessoas, comumente citado em trabalhos sobre o tema, foram as idéias constantes de um relatório elaborado na Inglaterra por William Beveridge, intitulado Social Insurance and Allied Services, que ficou conhecido como Beveridge Report. Até então, a idéia predominante tinha como base a fórmula alemã do seguro-doença, por meio do qual o Estado intervinha na proteção da saúde dos trabalhadores. Foi a Inglaterra, assim, o primeiro Estado a implementar um sistema universal de atendimento à saúde. Ainda que o ordenamento jurídico inglês não possua uma Constituição escrita em que conste tal previsão, a prestação de serviços de saúde como função estatal foi assumida pelo Estado britânico em 1948, com a implantação do National Health System (NHS) Sistema Nacional de Saúde, como se verá adiante.

No plano internacional, 101 após a criação da Organização Mundial da Saúde (OMS) em 1946, ${ }^{102}$ foi aprovada uma série de documentos que consagram tal direito. O primeiro deles foi a Declaração Universal dos Direitos Humanos, editada em 1948 pela

100 Trata-se da transição da liberdade como pressuposto da dignidade para a dignidade como pressuposto $d$ a liberdade.

101 Cumpre salientar que o documento precursor na defesa do direito à saúde no plano internacional foi a Convenção de Genebra de 1864. Trata-se de um documento firmado entre vários reis europeus por meio do qual houve comprometimento recíproco de não agressão bélica a hospitais e ambulâncias utilizadas para a prestação de serviços médicos aos soldados feridos em guerras. Sobre o tema: COMPARATO, Fábio Konder. A afirmação histórica dos direitos humanos. 6.ed. São Paulo: Saraiva, 2008. p.173-176.

102 Proposta pela Carta de São Francisco, a Organização Mundial da Saúde (OMS) teve sua criação formalizada em Nova Iorque no dia 22 de julho de 1946. Com sede em Genebra, seu objetivo é fazer com que todos os povos alcancem o mais alto grau possível de saúde. Na América, atua em coordenação com a Organização Pan-Americana de Saúde (OPAS), organização que pode ser chamada de antena da OMS. Hoje, de acordo com a própria entidade, a OMS conta com 193 Estados membros. Sobre o tema: SEITENFUS, Ricardo. Manual das organizações internacionais. Porto Alegre: Livraria do Advogado, 1997. p.167-169; e http://www.who.int/countries/es. Acesso em 17.07.08. Já a OPAS foi criada em 1902, e é tida como a organização internacional de saúde mais antiga do mundo. Hoje, atua como Escritório Regional da OMS na América. Tem por objetivos melhorar as condições de saúde nos países americanos, combater epidemias, mediante a elaboração de planos e estratégias em conjunto com os países membros. Sobre o tema: <http://www.opas.org.br/opas.cfm e http://www.paho.org/english/paho/member-states.htm>. Acesso em: 17 jul. 2008. 
Organização das Nações Unidas (ONU). ${ }^{103}$ Tal documento internacional, a exemplo do Relatório Beveridge, ressaltou que a saúde consiste em direito de todos e não em privilégio dos trabalhadores. ${ }^{104}$

Ainda no cenário internacional, com o objetivo de desenvolver as idéias previstas na Declaração Universal dos Direitos Humanos, foram firmados em 1966 dois Pactos: o Pacto Internacional sobre Direitos Civis e Políticos e o Pacto Internacional sobre Direitos Econômicos, Sociais e Culturais. ${ }^{105}$ Este último, após reafirmar em seu preâmbulo o princípio da dignidade da pessoa humana, estabeleceu em seu artigo 12 o direito de toda pessoa de desfrutar o mais elevado nível possivel de saúde fisica e mental. ${ }^{106}$

103 A Organização das Nações Unidas (ONU) foi criada logo após a Segunda Guerrra Mundial, em 25 de junho de 1945, com a assinatura por cinqüenta países da Carta de São Francisco. Como afirmado no preâmbulo da Carta, a ONU surgiu para preservar a paz, garantir os direitos humanos fundamentais, afastar a utilização da força como meio de resolução de conflitos e buscar o progresso econômico e social dos povos. Sobre o tema: SEITENFUS, Ricardo. Manual das organizações internacionais. Porto Alegre: Livraria do Advogado, 1997. p.107 e segs.; e <http://www.un.org/spanish/aboutun/unmember.htm>. Acesso em: 17 jul. 2008.

104 O direito à saúde permeia uma série de dispositivos da Declaração Universal dos Direitos Humanos de 1948 e é tratado de maneira direta nos artigos XXII e XXV, que assim dispõem: Art. XXII. Todo o homem, como membro da sociedade, tem direito à seguridade social e à realização, pelo esforço nacional, pela cooperação internacional e de acordo com a organização e recursos de cada Estado, dos direitos econômicos, sociais e culturais indispensáveis à sua dignidade e ao livre desenvolvimento de sua personalidade. (...) Art. XXV. Todo homem tem direito a um padrão de vida capaz de assegurar, a si e à sua família, saúde e bem-estar, inclusive alimentação, e vestuário, habitação, cuidados médicos e os serviços sociais indispensáveis, e direito à segurança em caso de desemprego, doença, invalidez, viuvez, velhice, ou outros casos de perda dos meios de subsistência em circunstâncias fora de seu controle.

105 A elaboração de dois documentos distintos é explicada por Celso Lafer: "A heterogeneidade jurídica que diferencia as liberdades clássicas dos direitos de crédito explica porque, tecnicamente, no plano internacional, foram elaborados dois pactos distintos no sistema de tutela dos direitos humanos na ONU: um para os direitos civis e políticos e outro para os direitos econômicos e sociais. De fato, os direitos civis e políticos comportam processo de reclamação ou petição individuais a um organismo internacional, que pode resultar de uma garantia-coletiva criada pelos Estados-Parte de uma convenção sobre direitos humanos. Já os direitos econômico-sociais e culturais, pelas suas características de 'objetivos' a serem realizados progressivamente por uma coletividade, através da ação estatal, são menos suscetíveis de aplicação imediata." (LAFER, Celso. A reconstrução dos direitos humanos: um diálogo com o pensamento de Hannah Arendt. São Paulo: Companhia das Letras, 2006. p.129).

106 Eis o que dispõe o inteiro teor do dispositivo referido: 1. Os Estados-Parte do presente Pacto reconhecem o direito de toda pessoa de desfrutar o mais elevado nível possível de saúde física e mental. 2. As medidas que os Estados-Parte do presente Pacto deverão adotar com o fim de assegurar o pleno exercício desse direito incluirão as medidas que se façam necessárias para assegurar: a) a diminuição da mortalidade e da mortalidade infantil, bem como o desenvolvimento são de crianças; b) a melhoria de todos os aspectos de higiene do trabalho e do meio ambiente; c) a prevenção e o tratamento das doenças epidêmicas, endêmicas, profissionais e outras, bem como a luta contra essas doenças; d) a criação de condições que assegurem a todos a assistência médica e serviços médicos em caso de enfermidade. 
Verifica-se, pois, a tendência à universalização do direito à saúde, o qual passou a configurar dever do Estado, a ser cumprido por meio de atividades disponibilizadas a todas as pessoas. Na mesma direção, desde a década de 40 do século passado, diversas constituições escritas passaram a tratar expressamente do direito à saúde. Dentre elas, podem ser citadas as Constituições Francesas de 1946 e de 1958, ${ }^{107}$ que o trataram em seu preâmbulo; a Constituição de Alemã de 1949, ${ }^{108}$ conhecida como Lei Fundamental de Bonn, que estabeleceu a competência legislativa para disciplina da saúde; e a Constituição Italiana de 1948, ${ }^{109}$ que assegurou expressamente a saúde como direito fundamental e dever do Estado.

107 As Constituições francesas de 1946 e de 1958 fazem menção ao direito à saúde de em preâmbulo, que é o mesmo em ambas, e assim dispõe: Ela [a Constituição] garante a todos, principalmente à criança, à mãe e aos trabalhadores idosos, a proteção da saúde, a segurança material, o repouso e os lazeres. Todo ser humano que, em razão de sua idade, de seu estado físico ou mental, da situação econômica, se encontre incapacitado de trabalhar tem o direito de obter da coletividade os meios adequados de existência (os grifos não constam do original).

108 A Constituição Alemã de 1949 estabelece em seu artigo 74.1 a competência legislativa concorrente para disciplinar as seguintes matérias: leis trabalhistas, incluindo a organização de empresas, segurança ocupacional e saúde, e agência de empregos, assim como segurança social, incluindo seguro-desemprego. No texto constitucional alemão não consta qualquer previsão constitucional de direitos sociais. Isso se deve ao fato de que, após a Constituição de Weimar, teve ascensão o regime nazista e integrou-se a idéia de que uma carta de direitos sociais cuja concretização não poderia ocorrer, ao menos em curto período, configuraria muito mais instrumento ideológico de dominação do que força para obter sua implementação. De qualquer forma, a denominação adotada nos artigos 20 e 28 da Lei fundamental de Bonn, que consagra a expressão Sozialstaat - Estado Social, é interpretada como princípio constitucional do qual decorre o dever estatal de preservar a dignidade humana, inclusive por meio de prestações de serviços de saúde. Eis o que dispõem tais dispositivos: "Art. 20 (1) A República Federal da Alemanha é um Estado democrático e social. (...) Art. 28 (1) A ordem constitucional dos Estados deve se conformar aos princípios de um Estado republicano, democrático e social governado pela lei, dentro da esfera desta constituição (...)". Como observa Albrecht Weber, o Tribunal Constitucional alemão reconheceu no julgamento BVerfGE 22, 180/204, que a Constituição daquele Estado definiu os objetivos a serem alcançados (o "que"), deixando em aberto os caminhos a serem escolhidos para a consecução de tais objetivos (o "como") (WEBER, Albrecht. Estado social, direitos fundamentais sociais e segurança social na República Federal da Alemanha. Trad. Andréas Sanden e Ana F. Sanden. In: BARROS, Sérgio R. de; ZILVETI, Fernando Aurélio. Direito constitucional: estudos em homenagem a Manoel Gonçalves Ferreira Filho. São Paulo: Dialética, 1999. p.14). Além disso, insta ressaltar, com Robert Alexy, vários Estados-federados alemães tratam explicitamente dos direitos sociais (ALEXY, Robert. Teoría de los Derechos Fundamentales. Trad. Carlos B. Pulido. 2.ed. Madrid: Centro de Estudios Políticos y Constitucionales, 2007. p.443).

109 Além de estabelecer, em seu artigo 117, a competência legislativa concorrente em matéria de tutela à saúde, a Constituição italiana prevê em seu artigo 32 que: A República protege a saúde como direito fundamental do indivíduo e interesse da coletividade, e garante cuidado gratuito aos indigentes (os grifos não constam do original). 
Mais recentemente, é possível mencionar a Constituição Portuguesa de 1976,110 a Constituição Espanhola de 1978,111 e a Constituição Brasileira de 1988. ${ }^{112}$ Tais textos constitucionais, além de elevar a proteção da saúde a dever do Estado e direito de todas as pessoas, disciplinaram de modo mais detalhado as atividades a serem desenvolvidas para sua concretização.

\subsubsection{Concretização das Normas Constitucionais que Impõem Deveres de Prestação ao Estado e o Desafio da Implementação dos Serviços de Saúde}

Ainda que atividades administrativas de assistência à saúde tenham sido exercidas

desde o surgimento do Estado, seu reconhecimento como direito fundamental, ${ }^{113}$ apenas

110 Em Portugal, o texto constitucional de 1976, com alterações posteriores, assim disciplina o direito à saúde: Artigo 64. 1. Todos têm direito à protecção da saúde e o dever de a defender e promover. 2. O direito à protecção da saúde é realizado: a) Através de um serviço nacional de saúde universal e geral e, tendo em conta as condições económicas e sociais dos cidadãos, tendencialmente gratuito; b) Pela criação de condições económicas, sociais, culturais e ambientais que garantam, designadamente, a protecção da infância, da juventude e da velhice, e pela melhoria sistemática das condições de vida e de trabalho, bem como pela promoção da cultura física e desportiva, escolar e popular, e ainda pelo desenvolvimento da educação sanitária do povo e de práticas de vida saudável. 3. Para assegurar o direito à protecção da saúde, incumbe prioritariamente ao Estado: a) Garantir o acesso de todos os cidadãos, independentemente da sua condição económica, aos cuidados da medicina preventiva, curativa e de reabilitação; b) Garantir uma racional e eficiente cobertura de todo o país em recursos humanos e unidades de saúde; c) Orientar a sua acção para a socialização dos custos dos cuidados médicos e medicamentosos; d) Disciplinar e fiscalizar as formas empresariais e privadas da medicina, articulando-as com o serviço nacional de saúde, por forma a assegurar, nas instituições de saúde públicas e privadas, adequados padrões de eficiência e de qualidade; e) Disciplinar e controlar a produção, a distribuição, a comercialização e o uso dos produtos químicos, biológicos e farmacêuticos e outros meios de tratamento e diagnóstico; f) Estabelecer políticas de prevenção e tratamento da toxicodependência. 4. O serviço nacional de saúde tem gestão descentralizada e participada (os grifos não constam do original).

111 A Constituição espanhola de 1978 faz menção ao direito à saúde nos seguintes dispositivos: Artigo 43. 1. Se reconhece o direito à proteção da saúde. 2. Compete aos poderes públicos organizar e tutelar a saúde pública por meio de medidas preventivas e das prestações e serviços necessários. A lei estabelecerá os direitos e deveres de todos a respeito. 3. Os poderes públicos fomentarão a educação sanitária, a educação física e o esporte. Além disso facilitarão a adequada utilização do lazer. Artigo 50. Os poderes públicos garantirão, mediante pensões adequadas e periodicamente atualizadas, a suficiência econômica aos cidadãos durante a terceira idade. Além disso, e com independência das obrigações familiares, promoverão seu bem-estar mediante um sistema de serviços sociais que atenderão seus problemas específicos de saúde, habitação, cultura e lazer. Artigo 51. 1. Os poderes públicos garantirão a defesa dos consumidores e usuários, protegendo, mediante procedimentos eficazes, a segurança, a saúde e os legítimos interesses econômicos dos mesmos (os grifos não constam do original).

112 A disciplina da saúde traçada pela Constituição de 1988 será objeto de análise no Capítulo 3.

113 Segundo Antonio-Enrique Perez Luño, a expressão direitos fundamentais aparece pela primeira vez no período pré-revolucionário francês, ganha especial relevo com sua menção pela Constituição Alemã de Weimar de 1919 e consagra-se a partir da Lei Fundamental de Bonn, em 1949. Nesse condão, importante 
ocorreu na segunda etapa de consagração de direitos pelas constituições, ${ }^{114}$ em meados do século XX. Daí sua classificação como direito fundamental de segunda dimensão. ${ }^{115}$

Assim, se a submissão do Estado ao direito marcou uma inversão na relação entre Estado e cidadãos - da prioridade dos deveres dos súditos à prioridade dos direitos (individuais) do cidadão ${ }^{116}$ - com a consagração dos deveres estatais de prestação, essa relação Estado-cidadão tornou-se muito mais complexa, assim como muito mais complexa tornou-se sua efetivação. ${ }^{117}$

É que a mera consagração constitucional do direito à saúde não implica automaticamente sua concretização. Ao contrário dos direitos classificados como de primeira dimensão,

destacar a já conhecida a distinção entre direitos humanos e direitos fundamentais. Enquanto estes são previstos pela Constituição de um Estado, aqueles possuem dimensão universalista e supranacional, independente de sua consagração em ordenamentos jurídicos concretos (PEREZ LUÑO, Antonio-Enrique. Los Derechos Fundamentales. 6.ed. Madrid: Tecnos, 1995. p.29 e 44).

114 Com razão Paulo Bonavides, para quem: "(...) o vocábulo 'dimensão' substitui com vantagem lógica e qualitativa, o termo 'geração', caso este último venha a induzir apenas sucessão cronológica e, portanto, suposta caducidade dos direitos das gerações antecedentes, o que não é verdade." (BONAVIDES, Paulo. Curso de direito constitucional. 13.ed. São Paulo: Malheiros, 2003. p.571-572).

115 De acordo com entendimento consolidado na teoria constitucional, os direitos fundamentais de primeira dimensão possuem, fundamentalmente, natureza liberal-burguesa. Isso porque se destinam a limitar o poder do Estado em face do cidadão, corroborando os direitos individuais e fixando a autonomia do indivíduo ante o poder estatal. Trata-se dos primeiros direitos reconhecidos pelas Constituições, voltados contra a opressão do monarca absolutista. Tais direitos, por traduzirem fundamentalmente uma abstenção do Estado em relação à esfera jurídica do indivíduo, são chamados também de direitos negativos ou de defesa. Embora se caracterizem essencialmente por sua relação à liberdade, são tidos como de primeira dimensão os direitos a vida, liberdade, propriedade, igualdade, participação política, entre outros, os quais passaram a ser referidos genericamente como direitos civis e direitos políticos. Os direitos fundamentais de segunda dimensão são os direitos econômicos, sociais e culturais. Foram consagrados, como acima delineado, como conseqüência da realidade social advinda do período de industrialização, a partir da segunda metade do século XIX. Partem das noções de igualdade e liberdade materiais e traduzem primordialmente direitos que, para serem concretizados, impõem ao Estado o dever de atuar positivamente, de modo a intervir na ordem econômica e social. Na terceira dimensão dos direitos fundamentais encontram-se os chamados direitos de solidariedade e de fraternidade, cuja consagração decorreu dos impactos ocasionados pela evolução tecnológica e científica. A principal diferença entre eles e os anteriormente citados encontra-se na questão da titularidade. Isso porque, ao contrário das dimensões anteriores, aqui a titularidade pertence a todo o gênero humano, como os direitos difusos e os direitos coletivos. São dessa dimensão os direitos relativos ao desenvolvimento, autodeterminação dos povos, paz, meio ambiente e qualidade de vida, conservação e utilização do patrimônio comum da humanidade - histórico e cultural, e comunicação. Alguns autores mencionam a existência de direitos fundamentais de quarta dimensão, decorrentes da globalização dos direitos fundamentais e que compreendem direitos como a informação, a democracia e o pluralismo. Sobre o tema: BOBBIO, Norberto. A era dos direitos. Trad. Carlos Coutinho. Rio de Janeiro: Campus, 1992; e BONAVIDES, Paulo. Curso de direito constitucional. 13.ed. São Paulo: Malheiros, 2003. p.562-572.

116 BOBBIO, Norberto. A era dos direitos. Trad. Carlos Coutinho. Rio de Janeiro: Campus, 1992. p.3.

117 BARROSO, Luís Roberto. O direito constitucional e a efetividade de suas normas: limites e possibilidades da constituição brasileira. 7.ed. Rio de Janeiro: Renovar, 2003. p.107. 
também denominados direitos de defesa (em face da atuação ilimitada do Estado absolutista), os direitos a prestações dependem da criação de condições objetivas para sua garantia, tanto do ponto de vista jurídico (interposição legislativa) quanto do ponto de vista material (prestação de serviços).

Não obstante, recentemente, percebeu-se que mesmo os direitos de defesa, para sua garantia, exigem a atuação positiva do Estado, como é o caso, por exemplo, da manutenção de contingente policial para garantia da ordem (que possibilita a segurança, propriedade e liberdade dos cidadãos) e da organização de eleições para o exercício do sufrágio (que possibilita a participação no processo político). É nesse sentido que Stephen Holmes e Cass Sunstein afirmam que todos os direitos são direitos positivos. ${ }^{118} \mathrm{Com}$ isso, pode-se sustentar que não existem direitos exclusivamente contra o Estado, mas que todos os direitos são apenas garantidos através dele.

Tal observação é pertinente, de modo que se deve tratar dos direitos fundamentais de primeira e de segunda dimensões como espécies diversas de um mesmo gênero de direitos prestacionais. Nessa perspectiva, a teoria constitucional contemporânea assinala que todos os direitos envolvem uma prestação, e não meramente uma abstenção estatal. Daí a classificação, como aquela adotada por Robert Alexy e difundida na teoria brasileira, entre (i) direitos prestacionais em sentido amplo, os quais se referem aos direitos de proteção e os direitos de organização e procedimento, e (ii) direitos prestacionais em sentido estrito. ${ }^{119}$

Uma das diferenças entre tais direitos, como se verá no Capítulo seguinte, refere-se à vinculação da prestação positiva estatal a destinatários gerais (como é o caso, por exemplo, da manutenção da ordem ou do exercício do sufrágio) e a destinatários individuais (como é o caso, em grande medida, do direito à saúde).

118 HOLMES, Stephen; SUNSTEIN Cass. The Cost of Rights. Why Liberty Depends on Taxes. New York: Norton and Company, 2000. p.35-48. Nessa esteira, ao tratar do custo envolvido na garantia dos direitos, consignou José Casalta Nabais: "(...) do ponto de vista do seu suporte financeiro, bem podemos dizer que os clássicos direitos e liberdades, os ditos direitos negativos, são, afinal de contas, tão positivos como os outros, como os ditos direitos positivos. Pois, a menos que tais direitos e liberdades não passem de promessas piedosas, a sua realização e a sua proteção pelas autoridades públicas exigem recursos financeiros." (NABAIS, José Casalta. A face oculta dos direitos fundamentais: os deveres e os custos dos direitos. Revista de Direito Público da Economia - RDPE, Belo Horizonte, ano 5, n.20, p.165, out./dez. 2007).

119 ALEXY, Robert. Teoría de los Derechos Fundamentales. Trad. Carlos B. Pulido. 2.ed. Madrid: Centro de Estudios Políticos y Constitucionales, 2007. p.393. 


\subsection{TRANSFORMAÇÕES NA ADMINISTRAÇÃO PÚBLICA: A ASSISTÊNCIA À SAÚDE COMO DIREITO DO CIDADÃO E A NECESSIDADE DE ADEQUAÇÃO DAS ATIVIDADES DO ESTADO}

A consagração constitucional do direito à saúde não implica por si sua garantia, a qual depende de prestações positivas individualizadas por parte da Administração Pública. Portanto, na área da saúde, a atividade estatal deve levar em conta tanto a realidade social e econômica quanto a realidade técnica e a condição pessoal de cada pessoa a ser assistida. Com isso, por ser objeto de transformações cada vez mais rápidas e por depender de uma atuação especializada e subjetivada, a prestação de serviços de saúde demanda constante adequação do Direito Administrativo. ${ }^{120}$

Em 1999, Gaspar Ariño Ortiz assinalou que o modelo de Administração Pública espanhola correspondia fielmente àquele herdado do modelo francês consolidado por Napoleão Bonaparte: uma Administração rigidamente hierárquica, autoritária, excessivamente politizada, com vias restritas de responsabilização de autoridades e funcionários públicos, com um sentimento de definição exclusiva do que seja interesse público, dona da verdade e com pouco respeito pelo cidadão a quem devia servir. ${ }^{121}$ Em terreno brasileiro, onde o modelo francês também exerceu grande influência - após assinalar que, mesmo com especificidades locais, os problemas da Administração Pública nos diversos Estados são de caráter geral -,

120 Nesse contexto, em um nível de análise mais amplo, é possível vislumbrar no cenário brasileiro atual um desvirtuamento entre as tarefas do Estado e o Direito Administrativo (e que se torna particularmente grave em um setor sensível e complexo como o de saúde). Tal desconexão há algum tempo vem sendo apontada por autores como Odete Medauar (O direito administrativo em evolução. São Paulo: Revista dos Tribunais, 1992); Diogo de Figueiredo Moreira Neto (Mutações do direito administrativo. Rio de Janeiro: Renovar, 2000); e mais recentemente, Marçal Justen Filho (Curso de direito administrativo. São Paulo: Saraiva, 2005). Este último autor assim resumiu o problema: "O conteúdo e as interpretações do direito administrativo permanecem vinculados e referidos a uma realidade sociopolítica que há muito deixou de existir. O instrumental do direito administrativo é, na sua essência, o mesmo de um século atrás. Talvez se possa encontrar aí uma das causas das dificuldades do próprio direito constitucional brasileiro, cujo ritmo de evolução não é acompanhado pelo direito administrativo. É necessário constitucionalizar o direito administrativo, o que significa, então, atualizar o direito administrativo e eleva-lo ao nível das instituições constitucionais." (JUSTEN FILHO, Marçal. Curso de direito administrativo. São Paulo: Saraiva, 2005. p.13). Nesse contexto, o Direito Administrativo brasileiro encontra-se em grande medida preso a modelos, conceitos e formas não mais adequados ao estudo, interpretação e aplicação do Direito; e o estudo da participação privada na prestação de serviços públicos de saúde, como se verá, desnuda grande parte desse aprisionamento.

121 ARIÑO ORTIZ, Gaspar. Princípios de Derecho Público Económico. Granada: Comares, 1999. p.83-84. 
Odete Medauar questionou a possibilidade de realização de novas tarefas estatais em velhas estruturas. ${ }^{122}$

A resposta para a questão e a solução do problema passam, necessariamente, por transformações do Direito Administrativo. Sobre o tema, alguns autores, em especial no Brasil, ${ }^{123}$ têm se utilizado da noção de paradigma trazida por Thomas Kuhn para sustentar que o Direito Administrativo encontra-se em um momento de crise e de transição paradigmática. ${ }^{124}$ Tal opção metodológica decorre daquilo que acaba de ser mencionado: a disciplina da Administração Pública tornou-se em grande parte inadequada às novas funções assumidas pelo Estado. Por isso, muitos dos conceitos do Direito Administrativo, em diversos Estados, passam por um período de evolução, ${ }^{125}$ decorrente da ruptura paradigmática ocorrida no momento em que direitos a prestações em sentido estrito foram incorporados aos textos constitucionais. Assim, o que vive hoje o Direito Administrativo é o reflexo, ainda não assimilado por completo pela teoria administrativista, do paradigma jurídico contemporâneo delineado no Item 2.2.

Entretanto, não se trata de novos modelos teóricos incompatíveis e confrontantes com os anteriores, mas novas formas de estruturação científica que se agregam ao conhecimento especializado da doutrina administrativista à luz da Constituição. Daí a opção neste trabalho pela expressão transformações do Direito Administrativo, derivadas da consagração de

122 MEDAUAR, Odete. O direito administrativo em evolução. 2.ed. São Paulo: Revista dos Tribunais, 2003. p.129.

123 Dentre os mais recentes: BINENBOJM, Gustavo. Uma teoria do direito administrativo: direitos fundamentais, democracia e constitucionalização. Rio de Janeiro: Renovar, 2006; LEAL, Rogério Gesta. Estado, administração pública e sociedade: novos paradigmas. Porto Alegre: Livraria do Advogado, 2006; MOREIRA NETO, Diogo de Figueiredo. Quatro paradigmas do direito administrativo pósmoderno: legitimidade, finalidade, eficiência, resultados. Belo Horizonte: Fórum, 2008.

124 Segundo Thomas Kuhn, paradigma pode ser entendido como o conjunto de crenças, valores e técnicas partilhadas por determinada comunidade científica em determinado momento. Assim, na transição de um paradigma para um novo, não ocorre um processo cumulativo, por meio da articulação do velho paradigma, mas sim, uma reconstrução da área de estudos a partir de novos princípios, como novas generalizações teóricas e métodos de aplicação, mesmo em pequena proporção (KUHN, Thomas S. A estrutura das revoluções científicas. Trad. Beatriz Boeria e Nelson Boeira. 9.ed. São Paulo: Perspectiva, 2007. p.116-129 e 220-227).

125 Seguindo o pensamento de Thomas Kuhn, na evolução científica, novos conhecimentos são agregados àqueles já existentes, não de modo a substituir conhecimentos anteriores com eles incompatíveis, mas completar espaços de ignorância (KUHN, Thomas S. A estrutura das revoluções científicas. Trad. Beatriz Boeria e Nelson Boeira. 9.ed. São Paulo: Perspectiva, 2007. p.129). 
novos direitos fundamentais e da necessidade de sua efetivação por meio de prestações diretas, efetivas e individualizadas - como é o caso específico dos serviços de saúde.

Há que se ressaltar que em grande parte dos Estados em que o direito à saúde foi reconhecido e prestado a todas as pessoas desde meados do século passado, passou-se a discutir modelos mais adequados a garantir tal serviço à população. Nessa perspectiva lembrando a ressalva de Odete Medauar acerca da similaridade entre os problemas enfrentados pela Administração Pública dos diversos Estados -, a análise que segue tem como objeto as principais transformações a ser submetido o Direito Administrativo brasileiro, de forma a torná-lo apto a cumprir as funções estatais, em especial a garantia do prestação de serviços públicos de saúde, elevada no Brasil a direito de todos pela Constituição de 1988.

\subsubsection{Reconhecimento dos Limites da Atuação Estatal}

No início da década de 80 do século passado, Pierre Rosanvallon iniciava conhecida obra com os seguintes dizeres: "O Estado-providência está doente. O diagnóstico é simples: as despesas com a saúde pública e com o setor social crescem muito mais depressa que as receitas". ${ }^{126}$ No mesmo decênio, Michel Crozier, ao defender a diminuição do Estado francês, enfatizava a necessidade de reconhecimento dos limites impostos pela realidade: "(...) há cinqüenta anos nossas instituições de proteção social se desenvolvem, afastando-se cada vez mais do princípio de realidade que governa toda atividade humana: o reconhecimento dos limites e das imposições de um universo finito". ${ }^{127}$ É que, como menciona Jacques Chevalier: "O Estado providência repousava (...) sobre a conjugação de um mito (o da beneficência e infalibilidade do Estado) e de uma prática (a de um Estado encarregado do desenvolvimento econômico e social) - mito e prática que se alimentavam reciprocamente". ${ }^{128}$

126 ROSANVALLON, Pierre. A crise do estado-providência. Trad. Joel Pimentel de Ulhôa. Goiânia: UFG; Brasília: UNB, 1997. p.7.

127 CROZIER, Michel. Estado modesto, estado moderno: estratégia para uma outra mudança. Trad. J. M. Vilar de Queiroz. Brasília: Fundação Centro de Formação do Servidor Público - FUNCEP, 1989. p.102. Na crítica do autor: "Um Estado arrogante, onipresente e onicompetente, é forçosamente impotente, pois só sabe ordenar a partir de princípios abstratos e de visões gerais. Somente um Estado modesto pode realmente revelar-se ativo, pois ele é o único em condições de ouvir a sociedade, de compreender os cidadãos e, por conseguinte, de servi-los ao ajudá-los a realizarem eles próprios seus objetivos." (p.15).

128 CHEVALLIER, Jacques. Science administrative. 3.ed. Paris: Presses Universitaires de France, 2002. p.233. 
Daí porque Juan Carlos Cassagne defendeu a adoção de um modelo de Estado em que a realidade predomine sobre a ideologia". 129

Ao traçar programas, metas, objetivos e princípios, os textos constitucionais e legais do século XX acabaram por trazer, durante algum tempo, a sensação de que o Estado era capaz de tudo. Acontece que assim como o mercado e a sociedade, o Estado possui limites, os quais devem ser (re)conhecidos, a fim de que suas atividades sejam desempenhadas de modo a alcançar de maneira eficiente aqueles programas, metas, objetivos e princípios traçados pelos textos constitucionais.

Veja-se o caso da saúde: não restam dúvidas de que a prestação de serviços de saúde da mais alta tecnologia a todas as pessoas é capaz de consumir toda a receita arrecadada por um Estado. Portanto, o alcance das funções assumidas pelo Estado depende, em especial na prestação de serviços de saúde, de um triplo reconhecimento de limites: (i) dos limites da Administração Pública; (ii) dos limites do mercado; e (iii) dos limites da sociedade. A partir de tal reconhecimento, com diversos níveis de interação entre as esferas mencionadas, é que as tarefas estatais poderão ser cumpridas com o máximo de eficiência em cada momento de desenvolvimento tecnológico e social.

Ao tratar do tema, Vital Moreira assinalou que a Administração Pública deixou de ser um quadro estável e previsível, de modo que se torna imprescindível uma transformação organizatória apta a proporcionar uma atuação estatal que faça frente às tarefas do desenvolvimento, como é o caso da saúde. Nas palavras do autor:

A passagem de concepções burocráticas da Administração pública para sua consideração como organização prestadora de serviços, obrigada a uma racionalidade 'econômica' na utilização de recursos humanos e financeiros, tem profundas implicações nos modelos organizatórios tradicionais. ${ }^{130}$

Na mesma direção, Jorge Reis Novais advertiu que não basta a eleição da garantia dos direitos fundamentais como dever do Estado, mas também a racionalização de toda a sua atividade em função daqueles objetivos. ${ }^{131}$

129 CASSAGNE, Juan Carlos. La Intercencion Administrativa. 2.ed. Buenos Aires: Abeledp-Perrot, 1994. p. 110.

130 MOREIRA, Vital. Organização administrativa. Coimbra: Coimbra, 2001. p.18.

131 NOVAIS, Jorge Reis. Contributo para uma teoria do estado e do direito: do estado de direito liberal ao estado social e democrático de direito. Coimbra: Coimbra, 1987. p.212. 
Trata-se, portanto, de uma idéia que não é nova, mas que ainda não se encontra consolidada no pensamento jurídico pátrio: superar a noção de que o Estado é o ente mais apto a prestar todas as atividades para consecução de suas funções. ${ }^{132}$

\subsubsection{Legalidade Material: a Eficiência como Interface com a Realidade}

A efetivação dos direitos fundamentais exige, na expressão de Norberto Bobbio, senso de realismo. ${ }^{133}$ Nesse condão - no âmbito da saúde, especialmente - a aproximação da Administração Pública com a realidade deve ocorrer, sobretudo, de três formas distintas:

(i) pelo reconhecimento das necessidades de pessoas concretas;

(ii) pelo reconhecimento das limitações financeiras do Estado vis-à-vis da ilimitação das necessidades sociais assumidas como funções do Estado;

(iii) pelo reconhecimento das possibilidades de atuação conjunta entre a Administração Pública e iniciativa privada.

A eficiência não implica a negação da legalidade. Pelo contrário, trata-se de um componente a mais a ser inserido na interpretação da lei, que conduz à sua vinculação com a realidade. ${ }^{134}$ Nesse sentido, tem razão Alexandre Santos de Aragão quando afirma:

132 Essa percepção equivocada, de que o Estado é o ente máximo de prestação de todas as atividades tendentes à consecução das tarefas estatais, foi ressaltada por Marçal Justen Filho: "Nesses dias, em que se afirma a redução das dimensões do Estado, a sociedade se depara com um impasse. A atribuição de incontáveis funções à estrutura estatal produzia não apenas a redução da autonomia privada, mas também da responsabilidade moral do indivíduo. É que a visão ampliativa das funções do Estado gerava concepções paternalistas que desoneravam os indivíduos. Significava a irrelevância da participação do particular para promover o princípio da dignidade da pessoa humana e os demais valores fundamentais. Aludir a solidariedade humana tornou-se quase despropositado, em fase da ilusão de que algum órgão estatal se encarregaria de atender às necessidades alheias. Sob um certo ângulo, a afirmação de um Estado de BemEstar trazia consigo uma grande comodidade filosófica: a transplantação da responsabilidade social do indivíduo para o Estado." (JUSTEN FILHO, Marçal. O direito das agências reguladoras independentes. São Paulo: Dialética, 2002. p.11).

133 BOBBIO, Norberto. A era dos direitos. Trad. Carlos Coutinho. Rio de Janeiro: Campus, 1992. p.45.

134 Nesse sentido, ao tratar das relações entre a racionalidade jurídica e a racionalidade econômica, este autor consignou: "A racionalidade econômica incorpora-se à racionalidade do intérprete do direito de modo a compor mais um elemento para a construção da norma jurídica. Traz tal racionalidade, partindo do pressuposto econômico de que as necessidades são ilimitadas e de que os recursos são escassos, a preocupação acerca do impacto econômico e social das decisões. Não se afastam, e muito menos se substituem, os princípios constitucionais; mas incorpora-se instrumental e raciocínio aptos a possibilitar uma decisão que da melhor forma concretize tais princípios. Tal consideração implica reconhecer a existência de microssistemas jurídicos, cada qual com uma lógica e princípios próprios. A função do intérprete - e do próprio legislador, com base nos princípios constitucionais, a partir da pauta de interpretação da proporcionalidade - na qual se insere a análise econômica -, é a de aplicar o direito 
O princípio da eficiência não visa mitigar ou a ponderar o Princípio da Legalidade, mas sim de embeber a legalidade de uma nova lógica, determinando a insurgência de uma legalidade finalística e material - dos resultados práticos alcançados -, e não mais uma legalidade meramente formal, subsuntiva e abstrata (mera compatibilidade 'in abstrato' com as regras superiores. ${ }^{135}$

Nessa direção, Gomes Canotilho defendeu a conciliação entre o princípio da legalidade de administração com o princípio da oportunidade ou optimalidade, a fim de que a Administração Pública possa realizar com eficiência seus deveres. Para o autor, o princípio da eficiência da administração ergue-se a princípio constitutivo da legalidade desde que isso não signifique preterição das dimensões garantísticas básicas do Estado de Direito. ${ }^{136}$

Trata-se de legitimizar a legalidade. Segundo Paulo Bonavides, hoje a legitimidade deve ser entendida, em sua essência, como o princípio da constitucionalidade. ${ }^{137}$ É a transformação do princípio da legalidade formal pelo princípio da legalidade material, como resultado da incorporação do princípio da eficiência. A partir dessa conjugação - legalidade/eficiência a disciplina das atividades estatais, corresponda ela ou não ao que se entenda em determinado contexto normativo como serviço público, deve levar em conta a realidade em que a atividade é desempenhada e a pessoa a quem ela é destinada.

É evidente a dificuldade de se encontrar o equilíbrio entre um Direito Administrativo que permita a flexibilidade necessária à concreção de suas funções e a rigidez que impeça desvios e apropriação privada de bens e recursos públicos. Entretanto, como diz Gaspar Ariño Ortiz: "A existência de procedimentos e controles e garantias não é um obstáculo senão uma condição imprescindível para que o Estado, a longo prazo e com caráter geral, seja eficaz. Isto nos parece evidente na contratação e na função pública". ${ }^{138}$ Nesse sentido defende o autor não uma desadministrativização, com o abandono dos princípios do Direito Administrativo, mas sua reformulação, com o objetivo de aumentar sua flexibilidade

conhecendo e respeitando a lógica dos fatos de modo a fazer com que sua intervenção gere, em grau máximo, os efeitos previstos pelo ordenamento jurídico." (MÂNICA, Fernando B. Racionalidade econômica e racionalidade jurídica na constituição de 1988. A\&C Revista de Direito Administrativo e Constitucional, Belo Horizonte, ano 8, v.32, p.131, abr./jun. 2008).

135 ARAGÃO, Alexandre Santos de. Direito dos serviços públicos. Rio de Janeiro: Forense, 2007. p.357.

136 CANOTILHO, J. J. Gomes. Direito constitucional e teoria da constituição. 7.ed. Coimbra: Almedina, [s.d.]. p.735.

137 BONAVIDES, Paulo. Do estado liberal ao estado social. 7.ed. São Paulo: Malheiros, 2001. p.8-9.

138 ARIÑO ORTIZ, Gaspar. Princípios de Derecho Público Económico. Granada: Comares, 1999. p.58. 
quando necessário, porém mantendo sempre garantias de objetividade e boa gestão a que se vinculem os políticos. ${ }^{139}$

\subsubsection{Reorganização Administrativa e Responsabilidade Estatal pela Assistência à Saúde}

A Administração Pública deve respeitar a realidade e (re)conhecer as iniciativas sociais que colaboram com o Estado na consecução de suas funções. Portanto, o Direito Administrativo deve levar em conta o resultado concreto de sua atuação, a ser obtido pelo regime jurídico e pela natureza jurídica da entidade prestadora de serviços mais aptos para tanto. Afinal, interessa no momento atual de desenvolvimento econômico, social e tecnológico, em especial da sociedade brasileira, a implementação de atividades que mais bem realizem as funções estatais. Em estudo recente, não foi outro o entendimento ressaltado por Diogo de Figueiredo Moreira Neto, que assim consignou: "Com efeito, as pessoas de todas as latitudes querem ter seus interesses satisfeitos, pouco importando quem o faça ou deles se ocupe: se uma entidade privada ou governamental e se será uma entidade nacional, multinacional ou estrangeira". ${ }^{140}$

No mesmo sentido é a opinião de Marcos Juruena Villela Souto, que, ao tratar especificamente dos serviços públicos de saúde, assim consignou:

\footnotetext{
Ao indivíduo pouco interessa se o hospital está situado em imóvel próprio do Estado, se foi construído por execução direta ou através da contratação de terceiros, ou se os medicamentos são produzidos por fábricas estatais ou privadas, nacionais ou estrangeiras, o mesmo se podendo dizer do vínculo que une o Poder Público da União, dos Estados ou dos Municípios aos serviços e recursos humanos voltados para a concretização das ações de saúde. ${ }^{141}$
}

139 ARIÑO ORTIZ, Gaspar. Princípios de Derecho Público Económico. Granada: Comares, 1999. p.53-57. Ressalte-se que na disciplina jurídica brasileira da saúde, como se verá nos Capítulos seguintes, não há sequer a necessidade de alteração dos princípios incidentes sobre o serviço de saúde, pois o ordenamento nacional permite a flexibilidade que um serviço eficiente de saúde demanda.

140 MOREIRA NETO, Diogo de Figueiredo. Quatro paradigmas do direito administrativo pós-moderno: legitimidade, finalidade, eficiência, resultados. Belo Horizonte: Fórum, 2008. p.104.

141 SOUTO, Marcos Juruena Villela. Desestatização, privatização, concessões e terceirizações. 3.ed. Rio de Janeiro: Lumen Juris, 2000, p.202. 
Como já mencionado, a idéia de rompimento com o modelo napoleônico de uma Administração Pública unitária e centralizada, não é recente. Autores como Gaspar Ariño Ortiz, ainda no século XX, defendiam uma reformulação das atividades do Estado, por meio da devolução de serviços públicos, como o de saúde, à sociedade:

Desde o ponto de vista organizativo e institucional, isto significa a substituição
do velho modelo de Estado administrativo-burocrático, hierárquico, unitario,
centralizado e gestor direto, por um novo tipo de Administração em que uma
multiplicidade de organizações não-governamentais e empresas privadas - o que
se denominou 'terceiro setor' (público-privado) - assumiram a gestão de serviços
com autoridade delegada do Estado. ${ }^{142}$

Nesse contexto, a própria separação entre atividade pública e atividade privada, entidade pública e entidade privada, perde importância. A distinção, em sua vertente construída no período em que Estado e sociedade configuravam mundos separados, entre público e privado, denominada grande dicotomia por Norberto Bobbio, ${ }^{143}$ bem como todos os seus corolários, há muito tempo deixou de ser útil para a interpretação do direito. Como bem ressaltou Vital Moreira: "(...) a separação Estado/sociedade, público/privado, dá lugar a um espectro de gradações, que vão do Estado ao cidadão, passando por categorias intermediárias, do 'quase-Estado ao quase-não-Estado, conceitos correntes na literatura anglo-saxônica". ${ }^{144}$

142 ARIÑO ORTIZ, Gaspar. Princípios de Derecho Público Económico. Granada: Comares, 1999. p.254. Nesse sentido, ao tratar de serviços como o de saúde, o autor fala de uma privatização organizadora, que deve ocorrer nos seguintes termos: "(...) ainda reconhecendo que esta segue sendo uma 'tarefa pública' (por exemplo, a saúde, a educação universitária, o abastecimento de água, gás e eletricidade, o transporte ferroviário e o transporte urbano, etc...) o Estado não assume diretamente a prestação do serviço, mas contrata empresas privadas para que estas o gestionem, ou também para que realizem ou levem a cabo determinadas atividades auxiliares ou complementares do serviço principal. Isto o Estado poderia produzir internamente, mas prefere buscar sua provisão 'externa' (é o que os americanos denominam 'contracting out policy')." (ARIÑO ORTIZ, Gaspar. Privatización y Liberalización de Serviçios. Madrid: Universidad Autônoma de Madrid, 1999. p.29-30).

143 Dentre as várias observações do autor sobre o tema, podem ser citadas: BOBBIO, Norberto. A grande dicotomia. In: Da estrutura à função: novos estudos de teoria do direito. Trad. Daniela B. Versiani. Barueri: Manole, 2007. p.139-158; e BOBBIO, Norberto. A grande dicotomia: público/privado. In: _ Estado, governo, sociedade: para uma teoria geral da política. Trad. de Marco Aurélio Nogueira. 10.ed. São Paulo: Paz e Terra, 2003. p.13-31.

144 MOREIRA, Vital. Administração autônoma e associações públicas. Coimbra: Coimbra, 1997. p.32. Nas palavras do autor: "O paradigma clássico da separação Estado-sociedade supunha o monopólio estatal do poder público e da administração pública e a exclusão das forças sociais das tarefas administrativas. O estado era o espaço da autoridade, da unidade, do império do interesse geral, a sociedade era o espaço da liberdade, da diversidade, da luta pelos interesses particulares. Entre esses dois mundos não poderia haver mistura. (...) Estabelecer as fronteiras entre o Estado e a sociedade era o mesmo que estabelecer a linha divisória entre a administração pública e os particulares. (...) Na versão liberal teríamos o Estado mínimo e a sociedade civil máxima; na versão do Estado totalitário, teríamos o Estado máximo a sociedade civil mínima. Trata-se somente de dois extremos de um 'continuum', que no 'Estado social' do 
Há que se ressalvar que o novo modelo de organização administrativa, que aproxima os modelos de matriz francesa a anglo-saxônica, não implica a desresponsabilização do Estado pelo cumprimento de suas tarefas, mas o contrário. Como ressalta Gomes Canotilho ao tratar da participação privada na consecução de funções estatais:

\begin{abstract}
A transferência de tarefas para os sujeitos privados não significa um abandono da 'responsabilidade estatal' pela prossecussão do interesse público inerente à realização do princípio da socialidade. Não se trata, pois, de uma desconstrução do Estado Social a favor das forças autoregulativas do mercado livre. A garantia de dimensões prestacionais indispensáveis à realização e concretização de direitos econômicos, sociais e culturais, não assenta já, exclusiva e predominantemente, numa 'tarefa' [atividade] de socialidade do Estado, antes tem como suporte as prestações fornecidas, com caráter de universalidade, por infra-estruturas privadas. ${ }^{145}$
\end{abstract}

Esse é o grande desafio a ser superado pelo Estado contemporâneo em todas as suas áreas de atuação: aproveitar ao máximo a atuação da iniciativa privada, mas garantir que tal atuação ocorra de maneira eficiente e sem desvios. Essa é a questão atual a ser respondida, especialmente em solo brasileiro. A necessidade de flexibilidade da Administração Pública, a superação do modelo procedimental-formalista, a inevitabilidade das parcerias com a iniciativa privada são idéias que já se encontram difundidas tanto na teoria da Administração ${ }^{146}$ quanto na teoria do Direito Administrativo. ${ }^{147} \mathrm{O}$ problema, ressaltado no

capitalismo avançado fez aumentar substancialmente a esfera do Estado e da administração, sem com isso se aproximar da versão dos Estados totalitários protagonizada pelos fascismos e pelos socialismos de Estado. As mudanças na fronteira eram por princípio de soma zero: o que era apropriado pelo Estado deixava de pertencer à sociedade; o que deixava de pertencer ao Estado era devolvido à sociedade. No entanto, as transformações do modelo liberal não ocorreram somente quanto à amplitude da administração pública. Juntamente com a sua dilatação deu-se também um processo de participação das forças sociais nas tarefas administrativas. Primeiro, pela simples integração em organismos administrativos estaduais; depois, pelo exercício delegado de funções administrativas; por últimos, pela investidura, a título, próprio, da competência para a Administração dos seus próprios assuntos. (...) A distinção entre a esfera do Estado e a esfera privada não desapareceu. A separação entre uma e outra continua a constituir a base constitucional do Estado-dedireito de cunho clássico, assente sobre a autonomia pessoal, a propriedade privada e a liberdade de empresa. Só que esta fronteira, outrora nítida, está hoje diluída pelo facto de se ter estabelecido uma esfera híbrida ou mista, caracterizada pelo desempenho de tarefas públicas por entidades formadas por particulares, ou por organismos mistos compostos por representantes do Estado e das forças sociais." (p.24-26).

145 CANOTILHO, J. J. Gomes. Direito constitucional e teoria da constituição. 7.ed. Coimbra: Almedina, [s.d.]. p.354.

146 Peter Drucker, em obra editada originalmente em 1969, assim já se pronunciava: "O objetivo do governo é (...) governar. Isso, como depreendemos de outras instituições, é incompatível com a ação. Qualquer tentativa de combinar o governo com a execução em larga escala paralisa a capacidade de decisão. Qualquer tentativa de obrigar os órgãos que tomam decisões a 'executarem' realmente também implica um 'ação' muito insatisfatória. Eles não se orientam para a execução. Não estão equipados para ela. Não estão fundamentalmente interessados nela. Atualmente há boas razões pelas quais os soldados, os servidores civis e os administradores de hospitais buscam na administração de empresas conceitos, princípios e práticas. Porque a empresa, nestes últimos trinta anos, teve de enfrentar, em escala muito mais reduzida, o problema com o qual se defronta agora o moderno: a incompatibilidade entre o 'governo' e a 'execução"'. 
início deste trabalho, é encontrar os mecanismos adequados, em cada atividade, que proporcionem sua consecução com eficiência. Soluções genéricas e abstratas nem sempre funcionam, pois são incapazes de dar conta da riqueza das necessidades individuais e da sofisticação das soluções que se podem apresentar em cada área de atuação estatal.

\subsection{SISTEMAS DE SAÚDE EM ORDENAMENTOS ESTRANGEIROS}

As transformações das atividades estatais, em especial no setor de saúde, atingiram todos os ordenamentos jurídicos, (i) independente da consagração e da regulamentação do direito à saúde em nível constitucional, (ii) independente do modelo de organização e financiamento dos sistemas de atenção à saúde, e (iii) independente da matriz francesa ou anglo-saxônica do direito que disciplina sua atuação. Isso porque, como assinalado acima, os diversos Estados ocidentais têm buscado nas últimas décadas a conciliação entre a busca

E continua o autor, sustentando que essa técnica de descentralização aplicada ao governo: "Seria, (...) uma política sistemática de utilização de outras instituições, das instituições não-governamentais da sociedade de organizações, para a verdadeira 'execução', isto é, para o desempenho, para as operações, para as atividades." E conclui o autor: "Não estamos diante de um 'definhamento do Estado'. Pelo contrário, precisamos de um governo vigoroso, forte e muito ativo. (...) a esfera econômica não pode ser considerada e não será considerada exterior ao domínio público. Mas as escolhas da economia - bem como de todos os outros setores - não são alvo mais nem da completa indiferença do governo nem de seu controle completo." (DRUCKER, Peter. Uma era de descontinuidade: orientações para uma sociedade em mudança. Trad. J. R. Brandão de Azevedo. Rio de Janeiro: ZAHAR, 1970. p.265 e 273). Trata-se da constante busca por uma atuação administrativa não apenas eficaz, mas eficiente, comum ao setor privado e que deve ser incorporado também no setor público. Ao tratar da diferença entre os conceitos, sob o ponto de vista da Administração Pública, José Matias-Pereira assim consignou: "Eficácia é uma medida normativa do alcance de resultados, enquanto a eficiência é uma medida normativa da utilização de recursos nesse processo. No campo econômico, a eficácia de uma empresa refere-se à sua capacidade de satisfazer uma necessidade da sociedade por meio do suprimento de seus produtos (bens ou serviços), enquanto a eficiência é uma relação entre custos e benefícios. Ela representa a relação entre os recursos aplicados e o produto final obtido: é a razão entre o esforço e o resultado, entre a despesa e a receita, entre o custo e o benefício resultante." (MATIAS-PEREIRA, José. Curso de administração pública: foco nas instituições e ações governamentais. São Paulo: Atlas, 2008. p.59-60).

147 Esse é o entendimento, por exemplo, de Diogo de Figueiredo Moreira Neto, para quem: "(...) a legitimidade deve estar também nos fins e não apenas nos procedimentos, e os resultados também só podem ser considerados suficientemente satisfatórios se atenderem eficientemente as finalidades constitucionalmente cometidas ao Estado (...). Em uma palavra: o que realmente importa é a eficiência aferida pelo resultado." (MOREIRA NETO, Diogo de Figueiredo. Quatro paradigmas do direito administrativo pós-moderno: legitimidade, finalidade, eficiência, resultados. Belo Horizonte: Fórum, 2008. p.30 e 112). 
permanente pela qualidade, eficiência e igualdade na prestação dos serviços e a preservação da viabilidade dos sistemas dentro de um contexto de limitações orçamentárias. ${ }^{148}$

Em todos os casos, o processo de reforma da Administração Pública em sua atividade de prestação de serviços públicos de saúde passa pelo incentivo e pela adoção de novos modelos de participação privada, ${ }^{149}$ o que demanda em grande parte dos casos novas formas de contratualização entre os provedores e os prestadores dos serviços, em especial nos sistemas de origem beveridgeana, já que nos sistemas de origem bismarckiana, a contratualização tem sido historicamente utilizada como forma privilegiada de provisão dos serviços, como se verá adiante.

Apesar de existir grande variação nas relações entre a entidade financiadora/ seguradora dos serviços de saúde com as entidades prestadoras dos serviços, os modelos existentes podem ser reconduzidos a três grandes categorias, como ressaltam Elizabeth Docteur e Howard Oxley:

(i) o modelo público integrado, que combina o financiamento dos serviços por meio de recursos orçamentários, nos quais a função de garantia e de provisão dos serviços é organizada e operada como em qualquer departamento estatal;

148 BOYER, Marcel. Le secteur privé dans un système de santé public: France et Pays Nordiques. CIRANO Working Papers 2008s-06, Montreal, fev. 2008. p.1. É importante destacar, outrossim, que enquanto os sistemas de saúde dos Estados europeus e norte-americanos, de uma maneira geral, alcançaram níveis satisfatórios de proteção à saúde, grande parte dos Estados sul-americanos ainda busca alcançar níveis adequados de oferta, eficiência e igualdade. Tal diferença deve ser levada em conta em qualquer análise comparada, mas não retira a importância dos modelos estrangeiros mais avançados, a fím de que não se repitam equívocos alhures já superados.

149 O que não deixa de ser um fator sintomático, no âmbito da saúde, da indiscutível aproximação entre o Direito Administrativo de matriz francesa e de matriz anglo-saxônica. Por outro lado, o processo de integração da União Européia produziu até o momento poucas alterações nos sistemas de saúde de seus Estados membros. As disposições supranacionais referem-se ao estabelecimento de padrões mínimos a serem alcançados e direitos a serem respeitados por cada Estado, de acordo com as características históricas e sociais locais. Exemplos encontram-se na Carta dos Direitos Fundamentais da União Européia (art. 35), no Tratado de Maastricht (art. 129-129-A) e no Tratado de Amsterdam (art. 3. ${ }^{\circ}$ e 152). Sobre o tema: GERLINGER, Thomas; URBAN, Hans-Jürgen. From heterogeneity to harmonization? Recent trends in European health policy. Cadernos de Saúde Pública, Rio de Janeiro, v.23, s.2, p.133-142, 2007; GUIMARÃES, Luisa; FREIRE, José-Manuel. Los temas de salud en La Unión Europea: su impacto em la sanidad española. Cadernos de Saúde Pública, Rio de Janeiro, s.23, p.143-154, 2007; GUIMARÃES, Luisa; GIOVANELLA, Lígia. Integração européia e políticas de saúde: repercussões do mercado interno europeu no acesso aos serviços de saúde. Cadernos de Saúde Pública, Rio de Janeiro, v.22, n.9, p.1795-1807, 2006; LOUREIRO, João Carlos S. G. Direito à (proteção da) saúde. In: MIRANDA, Jorge. Estudos em homenagem ao professor Doutor Marcello Caetano. Lisboa: Faculdade de Direito da Universidade de Lisboa, 2006. v.1.p.657-692; RODRÍGUEZ MEDINA, Carmen. Salud Pública y Assistência Sanitária em la União Europea: Uma Unión más cercana al ciudadano. Granadada: Comares, 2008. 
(ii) o modelo contratual público, no qual o pagamento pelos serviços é público, realizado por uma agência estatal ou por fundos de seguro, e a prestação dos serviços é privada; e

(iii) o modelo privado de seguro/provisão, no qual seguradoras privadas financiam prestadores privados de serviços de saúde. ${ }^{150}$

Segundo Chris Ham, uma das características mais importantes do processo de reformas no setor de saúde é a transição dos modelos integrados de financiamento e provisão de serviços para um modelo contratual. ${ }^{151}$

Daí a observação de Márcio Martins Alves: "Embora os contratos sejam instrumentos tradicionais de gestão nos sistemas de saúde de estilo bismarckiano, a novidade é que atualmente eles têm sido usados como meio para assegurar o alcance de metas de eficiência e efetividade". ${ }^{152}$

É de se ressaltar, sob um prisma mais amplo, que tal característica marcante no setor de saúde a ela é transcendente e envolve toda a atuação administrativa contemporânea. Conforme assinala Gustavo Justino de Oliveira:

O discurso do contrato permeia os mais recentes (e diversos) processos de reforma administrativa, intentando (i) demonstrar o fortalecimento da denominada Administração Pública consensual e (ii) retratar a conseqüente mudança de eixo do direito administrativo, o qual passa a ser orientado pela lógica da autoridade permanentemente flexionada pela lógica do consenso. ${ }^{153}$

150 DOCTEUR, Elizabeth; OXLEY, Howard. Health-Care Systems: Lessons from the Reform Experience. Paris: OECD, 2003. p.10.

151 Ao tratar do sistema nacional de saúde inglês, abaixo analisado, assim consignou referido autor: "O Serviço nacional de saúde inglês tradicionalmente funcionou por meio de linhas integradas, combinando financiamento público com a propriedade pública de hospitais e emprego assalariado de médicos. O modelo de contrato público, em contraste, envolve seguradores que asseguram que os serviços são disponibilizados aos pacientes pela negociação de contratos com provedores independentes. Esse é o sistema que existe na Alemanha, onde fundos de doença contratam com hospitais e médicos em nome de seus membros. Um terceiro modelo de aproximação é representado pelo reembolso público no qual os pacientes são reembolsados dos custos por seus seguradores, que não mantém contratos com os provedores." (HAM, Chris. The background. In: Health Care Reform: Learning from International Experience. Buckingham: Open University Press, 1997. p.7-8).

152 ALVES, Márcio J. Martins. Sistema Único de Saúde: de que sistema se trata? 2006. 209p. Tese (Doutorado) - Programa de Pós-Graduação em Saúde Coletiva, Instituto de Medicina Social da Universidade do Estado do Rio de Janeiro, Rio de Janeiro, 2006. p.130.

153 OLIVEIRA, Gustavo H. Justino de. Contrato de gestão na administração pública brasileira. 2005. 522p. Tese (Doutorado em Direito) - Curso de Pós-Graduação em Direito, Universidade de São Paulo, São Paulo, 2005. p.159. 
No cenário mundial, um dos poucos modelos de prestação de serviços públicos de saúde ainda mantidos integralmente por meio de financiamento público e prestação administrada de forma vertical, como assinala Eleonor Minho Conill, pode ser encontrado em Cuba. ${ }^{154}$

Nesse contexto, as transformações pelas quais passaram os sistemas de saúde mais avançados, nos quais a consagração e a garantia do direito à saúde ocorreram precocemente em relação ao Brasil, podem ser reconduzidas a duas etapas:

(i) a primeira, realizada preponderantemente nas décadas de 70 e 80 do século passado, teve um escopo mais restrito, visando primordialmente à contenção de custos; e

(ii) a segunda, iniciada na década de 90 do século passado e processada até hoje, com um foco mais amplo, relacionada à obtenção de maior eficiência na prestação dos serviços, maior transparência e maior satisfação dos usuários. ${ }^{155}$

Nessa perspectiva, como sustentam Elizabeth Docteur e Howard Oxley, no primeiro momento, a contratualização da saúde teve como principal objetivo promover a competição entre os prestadores dos serviços, visando obter seu menor custo. Mesmo com resultados não satisfatórios decorrentes da competição, ressaltam os autores, os Estados que aderiram à estratégia da contratualização mantiveram-na, por tratar-se de um mecanismo útil para o fortalecimento do Poder público como financiador dos serviços, de modo a proporcionar maior transparência e soluções mais custo-efetivas. ${ }^{156}$

A seleção dos Estados adiante analisados, agrupados nos três modelos de assistência à saúde mais difundidos em todo o mundo, foi realizada com o objetivo de ilustrar as experiências de reforma em sistemas de saúde em face das transformações sociais, econômicas e tecnológicas ocorridas nas últimas décadas do século XX, com foco na regulamentação da participação privada na prestação dos serviços.

154 CONILL, Eleonor Minho. Sistemas comparados de saúde. In: CAMPOS, Gastão W. de Souza; MINAYO, Maria Cecília de S.; AKERMAN, Marco; DRUMOND JÚNIOR, Marcos; CARVALHO, Yara Maria de. Tratado de saúde coletiva. Rio de Janeiro: Hucitec, 2006. p.597.

155 COSTA, Nilson do Rosário; SILVA, Pedro Luís B.; RIBEIRO, José Mendes. Inovações organizacionais e de financiamento: experiências a partir do cenário institucional. In: NEGRI, Barjas; DI GIOVANNI, Geraldo (Orgs.). Brasil: radiografia da saúde. Campinas: UNICAMP, 2001. p.291-296.

156 DOCTEUR, Elizabeth; OXLEY, Howard. Health-Care Systems: Lessons from the Reform Experience. Paris: OECD, 2003. p.39. 
As observações que seguem demonstram a diversidade de organização dos sistemas de saúde em cada Estado, a qual deve respeitar o contexto histórico e social em que implantada. Assim, o estudo servirá como um dos parâmetros para a compreensão dos objetivos, das dificuldades e dos caminhos a serem seguidos pelo Estado brasileiro na disciplina da prestação privada dos serviços públicos de saúde. ${ }^{157}$

\subsubsection{Participação Privada em Sistemas Bismarckianos}

Os sistemas de assistência à saúde de origem bismarckiana são caracterizados, em linhas gerais, pela existência de uma pluralidade de seguros públicos ou privados, regulados pelo Estado e financiados com recursos públicos obtidos por meio da tributação incidente sobre os salários, com quota de contribuição de empregados e de empregadores.

Como assinalado anteriormente, esse foi o primeiro modelo de assistência à saúde assumido como responsabilidade do Estado, ${ }^{158}$ o seguro-doença implantado por Otto von Bismarck aos trabalhadores vinculados ao mercado na Alemanha recém-unificada em fins do século XIX. ${ }^{159}$ Seu desenvolvimento em solo alemão, e em grande parte dos Estados que o seguiram no início do século XX, ${ }^{160}$ mantém suas bases até hoje. A experiência alemã do seguro-saúde nasceu com o objetivo de evitar a mobilização social que se criava em face

157 Afinal: "Apesar de bons propósitos, das boas intenções, dos bons esquemas teóricos, da retidão e idealismo que inspiraram o nascimento de algumas instituições, quando seus resultados não são bons, deve-se saber retificar (ARIÑO ORTIZ, Gaspar. Empresa Pública, Empresa Privada, Empresa de Interés General. Cizur Menor: Aranzadi, 2007. p.20).

158 Ressalte-se que a inovação de Bismarck consistiu na participação estatal na regulamentação e garantia de serviços de saúde, os quais eram, em grande medida, objeto de proteção mútua por grupos de trabalhadores.

159 Como anota Gosta Esping-Andersen, essa primeira experiência que marcou o início do processo de transformação do Estado, com a consagração do direito à saúde como direito de todas as pessoas, ocorreu justamente com o objetivo de evitar o desenvolvimento da democracia e de um Estado prestador de serviços sociais (ESPING-ANDERSEN, Gosta. As três economias políticas do Welfare State. Revista de Cultura e Política, n.24, set. 1991. p.94). Tratava-se, como assinalou Lígia Giovanella, de uma solidariedade obrigatória imposta aos trabalhadores por um Estado autoritário com o objetivo de submeter as corporações sociais formadas no período pós-revolução industrial ao Estado e de ampliar o controle social do Estado (GIOVANELLA, Lígia. Solidariedade ou competição?: políticas e sistema de atenção à saúde na Alemanha. Rio de Janeiro: Fiocruz, 2001. p.31).

160 Dentre outros Estados, podem-se mencionar: Áustria e Hungria, ainda no final do século XIX; Luxemburgo, Noruega, Sérvia, Grã-Bretanha, Holanda, Suíça, Bulgária, Portugal, Grécia, França e Brasil. 
das precárias condições de trabalho geradas pela expansão do capitalismo. ${ }^{161}$ Para tanto, o governo autoritário de Bismarck implantou uma série de medidas com o objetivo de prover algumas garantias aos assalariados, regulamentando as organizações de trabalhadores que se uniam para auto-ajuda.

O desenvolvimento do modelo, contudo, foi marcado pela progressiva inclusão das pessoas alcançadas pelo seguro-saúde de modo a proporcionar a universalização do acesso aos serviços e a garantia da saúde como direito de todos, em especial na segunda metade do século XX, quando houve a consagração nacional e internacional da saúde como direito de todas as pessoas. ${ }^{162}$

Na Alemanha, a responsabilidade pela assistência à saúde é de instituições autônomas, os seguros de saúde, denominados Caixas de Doença. Tais Caixas são mantidas pela participação compulsória dos trabalhadores assalariados mediante contribuições proporcionais aos salários até um limite máximo definido por lei. Sua administração é autônoma e, em geral, ocorre de forma paritária entre trabalhadores e empregadores. ${ }^{163}$ As Caixas são entidades não-lucrativas e não-estatais reguladas pelo Estado, sendo que possuem certa autonomia para elaboração de seus estatutos e de seus orçamentos, para a contratação de pessoal, para a celebração de contratos com prestadores e associações de prestadores dos

161 Como assinala John Galbratih, atualmente prefere-se, a capitalismo, a expressão economia de mercado para referir-se aos sistemas econômicos hoje vigentes em grande parte do globo. Apesar do mesmo significado, tal modificação de termos, segundo o autor, decorre da conotação menos ideológica da nova expressão, que não conduz à imagem ainda existente de uma disputa já superada entre capitalismo e socialismo. Sobre o tema: GALBRAITH, John Kennet. A economia das fraudes inocentes: verdades para o nosso tempo. Trad. Paulo A. Soares Barbosa. São Paulo: Companhia das Letras, 2004.

162 Nesse sentido, têm razão Sulamis Dain e Rejane Janowitzer ao afirmarem que: "A análise dos países traz a constatação de que a solidariedade constitui um valor subjacente a todos os sistemas de saúde pública europeus, não importando se são norteados pela universalidade de sua construção, com base no princípio da redistribuição entre ricos e pobres, sadios e doentes, empregados e desempregados, jovens e velhos (modelo fundado em taxação), ou pela 'mutualidade' entre grupos sociais e categorias de empregados (próprios dos modelos de seguridade social)." (DAIN, Sulamis; JANOWITZER, Rejane. A saúde complementar no contexto dos sistemas de saúde: a experiência internacional. In: BISOTO JÚNIOR, Geraldo; SILVA, Pedro L. de Barros; DAIN, Sulamis (Orgs.). Regulação do setor de saúde nas Américas: as relações entre o público e o privado numa abordagem sistêmica. Brasília: Organização Pan-Americana da Saúde, 2006. p.20).

163 Segundo Reinhard Busse e Annette Riesberg: "Todos os fundos [caixas] possuem natureza não-lucrativa e autonomia administrativa. De acordo com a lei, todos os fundos de doença possuem o dever de aumentar a contribuição de seus membros, o que inclui o direito de determinar a contribuição necessária a cobrir seus custos." (BUSSE, Reinhard; RIESBERG, Annette. Health care systems in transition: Germany. Copenhagen, WHO Regional Office for Europe on behalf of the European Observatory on Health Systems and Policies, 2004. p.35). 
serviços, e para a definição da taxa de contribuição a ser paga por seus segurados. ${ }^{164}$ As Caixas celebram contratos com hospitais e farmácias, realizam o credenciamento de médicos, dentistas e outros profíssionais. ${ }^{165}$ Todos os serviços de saúde são financiados pelas Caixas às quais são afiliados os usuários, ${ }^{166}$ sendo que $o$ rol de serviços encontra-se delimitado em lei, no livro quinto do Código Social alemão. ${ }^{167}$ Há ainda algumas hipóteses em que é prevista a participação direta do segurado no pagamento de determinados serviços, como na assistência farmacêutica e próteses dentárias. ${ }^{168}$

Mantido em seu caráter geral durante a vigência da Constituição de Weimar, durante o período nazista e após a promulgação da Lei Fundamental de Bonn - nas últimas décadas do século passado, o sistema de seguro-saúde alemão passou por sensíveis reformas, implementadas

164 GIOVANELLA, Lígia. Solidariedade ou competição?: políticas e sistema de atenção à saúde na Alemanha. Rio de Janeiro: Fiocruz, 2001. p.33. De acordo com a autora: "Desde a criação do seguro social, as entidades provedoras são instituições separadas da administração estatal direta. O princípio da administração autônoma para a organização das entidades provedoras do Seguro Social de Doença partiu do modelo das associações cooperativas de auto-ajuda, existentes à época de criação do Seguro Social de Doença, foram organizadas pelos trabalhadores com a finalidade de prestar auxílio a seus membros em caso de doença." (p.88).

165 A vasta maioria dos hospitais, incluindo os privados, com fins lucrativos, fazem parte do sistema público de saúde e são regulados pelas mesmas regras que os demais, sendo que a participação privada lucrativa na oferta de leitos vem crescendo nos últimos anos (BUSSE, Reinhard; RIESBERG, Annette. Health care systems in transition: Germany. Copenhagen, WHO Regional Office for Europe on behalf of the European Observatory on Health Systems and Policies, 2004. p.55).

166 O segurado deve se filiar a uma Caixa de Doença, relacionada ao seu ramo de produção, empresa, profissão ou região. O Seguro Social de Doença, conhecido pela sigla $G K V$, é de filiação obrigatória aos indivíduos previstos no Código Social alemão, em seu quinto livro, o qual regula, especificamente, o referido seguro. Nele constam como segurados obrigatórios: trabalhadores empregados, aposentados da previdência social, desempregados que recebem seguro-desemprego, estudantes universitários, pessoas em formação ou treinamento profissional, aprendizes, participantes de medidas de promoção ou reabilitação para o trabalho, deficientes que exercem atividades em instituições especiais. No mesmo diploma encontra-se definido o âmbito de negociação entre as Caixas e as associações de prestadores dos serviços, principalmente as associações médicas.

167 Assim, ao lado das Caixas de Doença, existem na Alemanha os seguros privados, que são oferecidos (i) tanto para as pessoas que não são obrigadas por lei para contratar um seguro público (ii) quanto para aquelas que optam pela complementação das despesas não cobertas pelos seguros públicos. Por meio desse caráter complementar, cada indivíduo pode adaptar a extensão da cobertura assistencial às suas necessidades (DAIN, Sulamis; JANOWITZER, Rejane. A saúde complementar no contexto dos sistemas de saúde: a experiência internacional. In: BISOTO JÚNIOR, Geraldo; SILVA, Pedro L. de Barros; DAIN, Sulamis (Orgs.). Regulação do setor de saúde nas Américas: as relações entre o público e o privado numa abordagem sistêmica. Brasília: Organização Pan-Americana da Saúde, 2006. p.47).

$168 \mathrm{O}$ que deu origem ao desenvolvimento nos últimos anos de seguros privados complementares, com cobertura voltada aos serviços não cobertos pelo sistema público. 
pontualmente por meio de uma série de leis, ${ }^{169}$ as quais promoveram alterações da seguinte ordem no sistema de saúde germânico: (i) ampliação da competência das Caixas no controle dos serviços de saúde e na negociação com os prestadores, (ii) restrição do rol de serviços e introdução de novas ações preventivas no catálogo de serviços oferecidos pelas Caixas; (iii) reforço da competição entre as próprias Caixas; (iv) aumento da possibilidade de escolha das Caixas pelos trabalhadores, que até então tinham o dever de se filiar a determinada Caixa; ${ }^{170}$ (v) incentivo à concorrência também entre os hospitais. Recentemente, a Lei de Reforma da Saúde, de 2004, restringiu ainda mais o rol de serviços a assegurados; e a Lei para Melhora da Viabilidade Econômica no Fornecimento de Medicamentos, de 2006, buscou estabelecer (i) novas condições na compra e no preço de medicamentos pagos por meio do Seguro Social de Saúde, (ii) a possibilidade de as Caixas estabelecerem contratos de desconto com os fabricantes de remédios e (iii) o incentivo à comercialização de medicamentos genéricos.

Pode-se perceber, pois, as intensas transformações promovidas no sistema de saúde alemão, com o objetivo de adequar os serviços às necessidades da população e mantê-los financeiramente sustentáveis. A implementação da concorrência e a delimitação de serviços garantidos pelas Caixas são tendências claramente verificáveis, ainda que mantida a estrutura original do sistema de proteção. Enquanto o financiamento dos serviços de saúde é predominantemente público, realizado por meio de contribuições e aplicações compulsórias às Caixas de Doença, os serviços são ofertados por prestadores governamentais, privados e filantrópicos, os quais são contratados pelas Caixas, que são impedidas de prestar diretamente os serviços.

Na Holanda, ${ }^{171}$ até 2005 o sistema de saúde possuía funcionamento próximo ao do modelo alemão, com centralização do controle estatal sobre as seguradoras, que eram de natureza pública e forneciam um pacote uniforme de benefícios - que incluía cuidados

169 Dentre elas, podem ser mencionadas: a Lei de Reforma da Saúde de 1988, a Lei de Estrutura da Saúde, de 1992, a Lei de Reordenação do Seguro Social de Doença, de 1997, a Lei de Reforma do Seguro Social de Doença de 2000 e a Lei para a Introdução de um Sistema Global de Casos Orientado por Diagnoses nos Hospitais, de 2002.

170 Pessoas com renda acima de determinado limite, funcionários públicos e autônomos não são obrigados a participar de uma Caixa, podendo contratar seguros privados, que também podem ser contratados por assegurados das Caixas como complemento ao rol de serviços garantidos.

171 Deve-se ressaltar que até a reforma da Constituição holandesa, realizada em 1983, o direito à saúde não era previsto em sede constitucional. A partir de então foram sistematizados e reunidos no texto constitucional os direitos fundamentais, sendo que o direito à saúde encontra-se previsto no artigo 22, I, que assim dispõe: As autoridades devem tomar medidas para promover a saúde da população. 
hospitalares, serviços especializados, diagnósticos, medicamentos e tratamento dentário para as crianças. ${ }^{172}$ Os valores aplicados eram controlados por uma comissão governamental, que delimitava os pacotes de benefícios, contribuições e coberturas. ${ }^{173}$ Em 2006, o Estado holandês promoveu importante reforma nos seguros de saúde, por meio da Lei de Seguros de Saúde, que instituiu uma dupla competição: (i) entre as seguradoras, que passaram a ter natureza privada; e (ii) entre os prestadores privados por elas contratados. ${ }^{174}$

O sistema de saúde holandês é, portanto, de caráter privado, com regulação pública. ${ }^{175}$ As seguradoras privadas são obrigadas a preencher certos requisitos legais e são autorizadas a ter lucro. Elas negociam contratos com os prestadores privados, definindo serviço, preços, conteúdo e organização dos cuidados a serem prestados a seus segurados. Os segurados podem escolher o prestador de serviços contratado que preferirem e têm os gastos reembolsados pela sua companhia de seguros. Assim, pressionadas pelos segurados, as seguradoras buscam negociar melhores preços e maior qualidade nos serviços prestados. ${ }^{176} \mathrm{O}$ seguro público foi

172 TANNER, Michael. The grass is not always greener: a look at the national health care systems around the world. Policy Analysis, Washington (DC), n.613, p.22, mar. 2008.

173 Conforme ressalta Jorine Muiser, os principais instrumentos legais para tal foram a Lei de Provisões Hospitalares, de 1971, e a Lei de Tarifas de Cuidados Médicos, de 1992 (MUISER, Jorine. The new Dutch health insurance scheme: challenges and opportunities for better performance in health financing. Genéve: World Health Organization, 2007. p.9).

174 VEN, Wynand van de. The Netherlands. In: HAM, Chris. Health Care Reform: Learning from International Experience. Buckingham: Open University Press, 1997. p.87.

175 Na Holanda, todos os cidadãos são obrigados a ter um seguro, e as agências seguradoras são obrigadas a aceitar todos os que se inscreverem, em igualdade de termos e condições, sem fazer distinções por sexo, idade ou estado de saúde. O governo se responsabiliza pela acessibilidade e qualidade do serviço prestado. Os segurados pagam um prêmio fixo, chamado prêmio nominal. A seguradora determina qual o valor deste prêmio, mas deve fornecer o mesmo pacote de serviços a todos os indivíduos que pagarem a quantia determinada. Há um plano básico de serviços que devem ser cobertos, estipulado em lei, e que as seguradoras não podem restringir - MINVWS - Ministerie van Volksgezondheid, Welzijn en Sport. The new care system in the Netherlands. [on line]. Den Haag, Holanda, 2006. Disponível em: $<$ http://www.minvws.nl/en/folders /z/2006/the-new-health-insurance-system-in-three-languages.asp >. Acesso em: 11 jun. 2008. Este plano mínimo que deve ser oferecido contém: clínicos gerais, hospitais, obstetras, cuidados odontológicos (gerais até os 18 anos e apenas serviços especializados para maiores), medicamentos, cuidados pós-parto, ambulâncias e serviços de transporte, certos cuidados de fisioterapia, fonoaudiologia, com nutricionistas e terapeutas ocupacionais (KLAZINGA, Niek. The Dutch health care system. In: Descriptions of health care systems: Germany and the Netherlands. [on line] The Commonwealth fund, p.5. Disponível em: $<$ http://www.allhealth.org/briefingmaterials/CountryProfilesFINAL-1163.pdf>. Acesso em: 11 jun. 2008.

176 Além do prêmio, os segurados ainda pagam uma contribuição sobre os salários, descontada diretamente na fonte, restituída pelo empregador, que vai para um fundo único e é redistribuída entre as seguradoras por meio de uma complexa fórmula de risco. Assim, aproximadamente $50 \%$ dos gastos do serviço de saúde são pagos pelos prêmios nominais do indivíduo, e os outros $50 \%$ por impostos sobre salários, que 
reduzido apenas aos cuidados de longa duração. ${ }^{177} \mathrm{Na}$ prestação dos serviços, o Estado responde direta e objetivamente apenas pelos poucos hospitais acadêmicos, vinculados às universidades públicas. Nessa área, o setor sem fins lucrativos tem se mantido historicamente como o principal agente, compreendendo a grande maioria dos hospitais e clínicas, com autonomia para gerir sua administração interna. Seu financiamento ocorre tanto pelo pagamento das seguradoras privadas quanto diretamente por verbas públicas, já que alguns impostos têm sua receita revertida para as companhias privadas de seguro e para os hospitais, com o objetivo de manter níveis viáveis dos prêmios a serem pagos.

Na França, o atual sistema de saúde foi criado em 1945, também por meio de seguros de saúde, ${ }^{178}$ que hoje compreende a obrigatoriedade de filiação dos residentes em território francês. Em sua maioria, os seguros de saúde possuem natureza privada, com

são redistribuídos entre as companhias seguradoras privadas. Isso gerou um aumento do valor do prêmio nominal, que em 2005 era de, em média, 350 euros e já passou de 1.000 euros. Esta alta faz com que os consumidores pensem melhor antes de procurar serviços e usem o sistema de maneira mais consciente. Além disso, como assinalam Rudy Douven, Esther Mot e Marc Pomp, os planos podem oferecer descontos nos contratos assinados por grupos, assim como benefícios extras pelo mesmo preço (DOUVEN, Rudy; MOT, Esther; POMP, Marc. Health care reform in the Netherlands. Die Volkswirtschaft, v.3, p.2, 2007). Este mecanismo de negociação é muito utilizado em face da facilidade de migração de um plano para outro, que pode ocorrer anualmente.

177 Trata-se da Lei de Despesas Médicas Excepcionais - AWBZ, que é o sistema de seguro nacional para cuidados de longa duração. É voltado à promoção de serviços de saúde a pessoas que precisam de cuidados crônicos ou contínuos. Todos os que estão empregados na Holanda recebem deduções em seus pagamentos para este seguro e, portanto, estão segurados. Uma organização independente indica exatamente quais cuidados o indivíduo necessita, e o paciente tem a possibilidade de receber esses cuidados em espécie ou um reembolso em dinheiro. Para a maior parte dos cuidados previstos na AWBZ os pacientes com mais de dezoito anos devem fazer contribuições para os custos. Este sistema é financiado por prêmios pagos pelos segurados, por subsídios governamentais e por contribuições pessoais dos que recebem cuidados. Assim como em outros planos, as pessoas empregadas têm suas contribuições retidas na fonte, com o empregador, que paga os impostos diretamente ao governo (MINVWS - Ministerie van Volksgezondheid, Welzijn en Sport. Exceptional medical expenses act. 2007. Disponível em: $<$ http://www.minvws.nl/en/themes /exceptional-medical-expenses-act/>. Acesso em: 11 jun. 2008).

178 SANDIER, Simone; PARIS, Valérie; POLTON, Dominique. Health care systems in transition: France. Conpenhagen: WHO Regional Office for Europe on behalf of the European Observatory on Health Systems and Policies, 2004. p.115. Segundo as autoras, o sistema de saúde francês possui as seguintes características: (i) situa-se entre o modelo bismarckiano e o modelo beveridgeano, com fundos de seguro saúde sob forte intervenção estatal; (ii) combinação entre seguros públicos e privados, que financiam os mesmos serviços providos pelos mesmos prestadores e para as mesmas pessoas; (iii) combinação entre assistência pública e privada, incluindo prestadores com fins lucrativos; (iv) o sistema de fundos públicos caracteriza-se pela liberdade de escolha e pelo acesso irrestrito de pacientes e pela liberdade de prática profissional; (v) complexidade e pluralidade na administração do sistema com co-administração do Estado e dos fundos de seguro-saúde (p.115). 
administração autônoma e sob a supervisão estatal. ${ }^{179}$ Após uma série de reformas adotadas com o objetivo de aumentar a eficiência do sistema, em especial nos anos de 1996 e de 2004, o modelo francês segue um sistema de reembolso parcial das tarifas, que têm seu valor definido pelo Estado e são pagas pelos segurados aos prestadores vinculados ao sistema público de saúde. Há, portanto, na França, tanto o co-pagamento pelos serviços de saúde, pelas denominadas taxas moderadoras de utilização dos serviços, ${ }^{180}$ quanto a possibilidade de pagamento adicional por possíveis adicionais de conforto pessoal, como quarto individual, telefone e televisão. ${ }^{181}$ Assim, na França, grande parte da população, além do seguro obrigatório, possui um seguro privado complementar, de natureza lucrativa ou não, que financia, conforme negociação individual, a parcela não reembolsada pelo seguro público. ${ }^{182}$

O sistema francês é reconhecido pela coexistência entre prestadores de serviços de saúde de natureza diversa, em relação aos quais é ampla a possibilidade de escolha pelos segurados, ${ }^{183}$ com reembolso pelo seguro de saúde. São prestadores de serviços públicos de saúde na França: (i) entidades públicas dotadas de autonomia administrativa e financeira;184

179 GUEDES, Ana Claudia; DYRDA, Tomasz. Service and site co-operation between private health care centres as a possible response to emerging economic and medical issues. EUROPHAMILIAESCULAPIUS Professional Study, Rennes: ENSP, 2002. p.41.

180 Tais taxas variam de zero a $65 \%$ (sessenta e cinco por cento) do valor do serviço, como em alguns casos de assistência farmacêutica.

181 BOYER, Marcel. Le secteur privé dans un système de santé public: France et Pays Nordiques. CIRANO Working Papers 2008s-06, Montreal, fev. 2008. p.6.

182 É importante destacar que, no ano de 1999, foi criado o fundo de financiamento da proteção complementar da cobertura universal ao risco de doença, conhecido como cobertura médica universal (CMU), direcionado às pessoas sem capacidade econômica para pagar as taxas moderadoras ou contratar seguros privados aptos a cobri-las.

183 GREEN, David G.; IRVINE, Benedict. Health Care in France and Germany: Lessons for the UK. London: Civitas, 2001. p.40.

184 De acordo com o artigo 6141-1 do Código de Saúde francês: Os estabelecimentos públicos de saúde são pessoas jurídicas de direito público dotadas de autonomia administrativa e financeira. Seu objeto principal não é industrial ou comercial. Eles são comunais, intercomunais, departamentais, interdepartamentais ou nacionais. Os entes públicos podem celebrar contratos internos para a realização de serviços de saúde, já que a organização interna é de sua competência. Deste modo, dispõe o art. L6145-16 que: Os estabelecimentos públicos de saúde utilizam procedimentos de contratualização interna com seus pólos de atividade, o que beneficia a delegação de gestão da parte do diretor. O contrato [...] define os objetivos da atividade, de qualidade e de financiamento [...] a delegação de gestão é objeto de uma decisão do diretor. 
(ii) entidades privadas sem fins-lucrativos associadas; ${ }^{185}$ e (iii) entidades privadas com fins lucrativos concessionárias. ${ }^{186}$ Além disso, as entidades privadas podem optar pela não participação no sistema público, de modo que sua remuneração ocorrerá apenas pelo pagamento direto - com possibilidade de reembolso pelo seguro privado do usuário amparado por tal cobertura.

Os sistemas de origem bismarckiana, portanto, ainda que com características próprias, possuem como ponto em comum a prestação dos serviços tanto por entidades públicas quanto por entidades privadas, as quais celebram ajustes com seguradoras públicas ou privadas para prestar os serviços incluídos em rol delimitado pelo Estado. A remuneração pelos serviços prestados é realizada (i) diretamente pelas seguradoras; ou (ii) pelos usuários, que são reembolsados integral ou parcialmente por seu seguro (público, privado, ou ambos).

\subsubsection{Participação Privada em Sistemas Beveridgeanos}

O sistema denominado beveridgeano surgiu na Inglaterra algumas décadas após a instituição do sistema bismarckiano. Até o início da década de 40 do século passado, os Estados que haviam assumido a responsabilidade pela garantia do direito à saúde, o faziam por meio de seguros públicos e privados, os quais mantinham ajustes com entidades públicas ou privadas para a prestação dos serviços de saúde. Nesse período, o governo inglês instituiu um comitê para estudo do sistema de proteção social daquele Estado, que tinha

185 Nos termos do artigo L 6161-6 do Código de Saúde francês, as entidades sem fins lucrativos podem ser admitidas a participar do serviço público de saúde desde que preencham os requisitos fixados em decreto governamental, sendo que sua inadmissão deve ocorrer por ato motivado da agência regional de saúde entidade pública competente para a regulamentação na atividade.

186 As entidades com fins lucrativos podem participar do serviço público de saúde por meio de contratos de concessão, celebrados com o Estado, nos termos do artigo L 6161-9 do Código de Saúde francês, e por contratos de parceria (público-privadas), como previsto pelo Decreto n. ${ }^{\circ} 2004-559$ e pela Lei . $^{\circ} 2008$ 735. Além disso, nos termos do artigo L 6161-10 do Código, a participação de entidades privadas no serviço público pode ocorrer para alcançar um ou mais objetivos determinados, por meio de acordos de associação celebrados com uma entidade pública ou um sindicato inter-hospitalar do local de sua implantação. 
como base seguros sociais restritos a determinados grupos de trabalhadores implantados no início do século e vigentes até então na Inglaterra, ${ }^{187}$ ainda que a prestação dos serviços de saúde fosse fortemente dependente do mercado. ${ }^{188}$

Como resultado do estudo, foi apresentado em 1942 o já mencionado Beveridge Report, que defendia a oferta de serviços de saúde a todas as pessoas, independente de sua vinculação/contribuição a determinada entidade seguradora. ${ }^{189}$ A partir de tais idéias, foram criados em alguns Estados os denominados sistemas nacionais de saúde. ${ }^{190}$ Assim, com apoio de uma sociedade buscando reconstruir um Estado devastado pela Segunda Grande Guerra, o primeiro sistema nacional de saúde, denominado National Health System - NHS, foi implantado em 1948, na Inglaterra, à luz dos princípios da universalidade de atendimento e do financiamento por via de tributação geral. Segundo informações oficiais do próprio sistema de saúde inglês:

\begin{abstract}
Nesse momento, pela primeira vez, hospitais, médicos, enfermeiras, farmacêuticos e dentistas foram colocados sob uma mesma organização para prover serviços que são gratuitos para todos. Os princípios centrais são claros: os serviços de saúde serão disponibilizados e financiados inteiramente por meio de tributação, o que significa que as pessoas pagam de acordo com suas condições. ${ }^{191}$
\end{abstract}

187 Em 1911, com influência de outro conhecido relatório, o Minority Report, elaborado por Beatrice e Sidney Webb, foi implantado na Inglaterra um sistema de seguros-doença.

188 LOBATO, Lenaura de Vasconcelos. Reforma do estado no setor de saúde no Reino Unido e nos Estados Unidos. In: HUSENMAN, Samuel et. al. Reforma do estado no setor de saúde: os casos da Catalunha, Canadá, Reino Unido e Estados Unidos. Brasília: ENAP, 1997. (Cadernos ENAP, 13). p.74.

189 Na Parte VI do Relatório Beveridge, sobre Segurança Social e Política Social, ao tratar da saúde, encontra-se a defesa da assunção pelo Estado de amplos serviços de saúde e reabilitação, por meio de um serviço nacional de saúde que deve assegurar a cada cidadão qualquer tratamento que ele necessite, independente de contribuição ao seguro social (BEVERIDGE, Willian. Social Insurance and Allied Services. New York: The Macmillam Company, 1942. p.158-159).

190 Tal entendimento marcou não apenas a adoção do sistema nacional de saúde por diversos Estados, mas também incentivou a universalização da cobertura oferecida pelos Estados que adotam até hoje o modelo bismarckiano.

191 NHS History. Disponível em: http://www.nhs.uk/aboutnhs /nhshistory/pages/nhshistory.aspx. Acesso em: 11.07.2008. Com a criação do primeiro sistema nacional de saúde no mundo: "Os serviços de saúde passaram a ser financiados por impostos federais sendo totalmente gratuitos no ato do provimento do serviço: $82 \%$ através de impostos diretos, $13 \%$ de impostos na folha salarial e $4 \%$ de taxas impostas aos usuários.24 Os médicos especialistas, enfermeiras e staff dos hospitais passaram a ser empregados assalariados do Estado. Aos médicos especialistas foi garantido o direito de atendimento a pacientes privados nos estabelecimentos do sistema nacional" (ANDRADE, Mônica Viegas; BARROS LISBOA, Marcos de. Velhos dilemas no provimento de bens e serviços de saúde: uma comparação dos casos canadense, inglês e americano. Nova Economia, v.10, n.2, p.84, dez. 2000). 
As dificuldades de ordem financeira, decorrentes, inclusive, do aumento dos custos da saúde a partir da década de 70 do século passado, fizeram com que se promovesse uma série de reformas no sistema de saúde inglês. Sem que se colocassem em xeque seus princípios básicos, o foco das transformações foi o fortalecimento na oferta dos serviços, ${ }^{192}$ por meio da busca (i) pela racionalização de seu uso, (ii) pela contenção dos custos e (iii) pela eficiência em sua prestação. Para tanto, implantou-se o que foi denominado mercado interno ou quase-mercado de atenção à saúde, mediante a separação entre os entes estatais financiadores e os prestadores dos serviços de saúde: de um modelo público integrado a um modelo contratual público. 193

Assim, foram definidos órgãos estatais aptos a contratar com prestadores públicos e privados a oferta de serviços de saúde à população. ${ }^{194}$ Com isso, inseriu-se também no modelo beveridgeano tanto a possibilidade de competição entre os prestadores ${ }^{195}$ quanto a preferência pela contratualização como mecanismo de gerenciamento e controle dos serviços.

Além da contratualização, outra importante alteração ocorreu no processo de reforma do sistema de saúde inglês: trata-se da possibilidade ofertada aos prestadores públicos de se transformarem em entidades privadas, denominadas trusts. Como mencionam Oswaldo Tanaka e Vanessa de Oliveira:

192 HAM, Chris. The United Kingdom. In: Health Care Reform: Learning from International Experience. Buckingham: Open University Press, 1997. p.47.

193 Sobre a distinção, conferir parte inicial deste Item 2.4.

194 De acordo com Maria Célia Almeida, a reforma no sistema inglês promoveu diferentes mecanismos de alocação de recursos, para os hospitais e para o atendimento básico, instituíram-se dois tipos de compradores, as Autoridades de Saúde Distritais - DHAs e os Médicos Generalistas - GPs, e dois tipos de prestadores, NHS trusts - os hospitais transformados em empresas - e os próprios GPs, que passaram a gerenciar recursos financeiros para organizar a assistência aos clientes de suas respectivas listas (ALMEIDA, Célia Maria de. Reforma do estado e reforma de sistemas de saúde: experiências internacionais e tendências de mudança. Ciência \& Saúde Coletiva, v.4, n.2, p.273-274, 1999). Para entender tal sistema é preciso ter em mente que o acesso ao sistema de saúde na Inglaterra ocorre por meio dos GPs, que definem a necessidade de atendimento especializado, fazem o encaminhamento do paciente e negociam com o prestador do serviço. Tudo isso, obviamente, dentro de critérios estabelecidos pelo Estado.

195 Na opinião de Chris Ham, a possibilidade de contratação pelo Estado tanto de prestadores públicos quanto privados trazida pela reforma do sistema inglês configura uma das principais transformações promovidas, apesar de comumente falar-se em mercado interno [ao próprio Estado] (HAM, Chris. The United Kingdom. In: Health Care Reform: Learning from International Experience. Buckingham: Open University Press, 1997. p.48). 
Com a reforma [do sistema de saúde inglês], os hospitais públicos tinham a opção de se tornar fundações autônomas e independentes do NHS - os trusts. Os hospitais que assumissem essa condição não seriam mais financiados pelas Autoridades Distritais Sanitárias com base em orçamentos anuais, mas ofereceriam seus serviços ao mercado, competindo com os hospitais privados. De acordo com a WHO [Organização Mundial da Saúde] (1997), quase todos os 430 hospitais tornaram-se trusts. Eles estavam autorizados a contratar empréstimos, mas dentro de limites pré-definidos. Em contrapartida, ficavam obrigados a estabelecer um processo de auditoria médica, e a qualidade dos serviços passaria a ser monitorada regularmente, assim como o dispêndio de recursos. Ao mesmo tempo, tinham que se guiar por padrões de preços estabelecidos centralmente. Essa forte regulação dos trusts demonstra que a autonomia deles é, na prática, bastante limitada. ${ }^{196}$

De acordo com Marcus André Melo, Nilson Costa e Pedro Luís Silva:

Os trusts são entidades autônomas, do ponto de vista gerencial, embora seu diretor executivo seja indicado pelo Secretary of State. A autonomia que gozam, deve-se, em grande parte, ao rompimento dos vínculos que os provedores mantinham com o nível distrital e regional da administração da saúde. (...) Os trusts são autônomos em matéria de recrutamento e remuneração (número de empregados a ser contratados; definição mix do staff; planos de cargos e carreira). No entanto, eles são fortemente regulamentados em relação às suas decisões de investimento de capital. (...) Essa forte regulação dos trusts significa, na prática, que a autonomia e independência deles é bastante limitada, e que uma perspectiva de curto prazo está embutida no seu regime financeiro. ${ }^{197}$

Além disso, conforme assinala Philippe Cossalter, o National Health Service and Community Care Act 1990, que permitiu a criação dos trusts, autorizou que tais entidades firmassem todos os tipos de contratos que se afigurassem necessários ou úteis ao cumprimento de suas funções. Com isso, passou-se a admitir na prática a pactuação de contratos com o setor privado para a concepção, a contrução ou reforma, a manutenção e a gestão de hospitais. Segundo o autor, com o National Health Service (Private Finance) Act 1997 restou ausente de dúvidas a autonomia dos próprios trusts para celebrar contratos de parceriapúblico privada, ${ }^{198}$ denominados em solo bretão Private Finance Initiative - PFI. ${ }^{199}$

196 TANAKA, Oswaldo Yoshimi; OLIVEIRA, Vanessa Elias de. Reforma(s) e estruturação do sistema de saúde britânico: lições para o SUS. Saúde e Sociedade, v.16, n.1, p.10-11, jan./abr. 2007.

197 MELO, Marcus André; COSTA, Nilson do Rosário; SILVA, Pedro Luís B. Inovações organizacionais em política social: o caso da Grã-Bretanha. Revista do Serviço Público, ano 50, n.3, p.12-13, jul./set. 1999.

198 O tema será tratado sob a ótica do direito pátrio, no Item 4.3.2.3.

199 COSSALTER, Philippe. XXIII - A 'Private Finance Iniciative'. In: TALAMINI, Eduardo; JUSTEN, Mônica Spezia. Parcerias público-privadas: um enfoque multidisciplinar. São Paulo: Revista dos Tribunais, 2005. p.440 e 461. 
Com essas transformações, entidades compradoras dos serviços, mesmo em sistemas nacionais de saúde, passaram a cumprir importante papel para contrabalançar a influência dos provedores públicos e privados (cuja natureza jurídica deixou de implicar grande diferença de tratamento) na definição dos serviços a serem prestados, ao mesmo tempo em que permitiram eliminar o problema do risco moral - moral hazard (superconsumo de serviços pagos por terceiros, no caso, o Estado). ${ }^{200}$ Assim, ainda que a competição entre prestadores em si não tenha promovido grandes efeitos na diminuição dos custos da saúde, sua adoção constituiu meio eficaz a oferecer, sobretudo:

(i) transparência na atuação dos prestadores; e

(ii) possibilidade de comparação entre a eficiência de cada um deles.

Uma série de Estados seguiu o modelo inglês de sistema nacional de saúde, dentre os quais são ilustrativas as recentes experiências do Canadá, de Portugal e da Espanha.

A experiência canadense é mais próxima da inglesa, já que o Canadá não possui um único documento escrito constitucional. Quando se fala em constituição canadense, faz-se referência a dois textos normativos, o Ato da América do Norte Britânica de 1867 e o Ato Constitucional de 1982. Este último contém Carta de Direitos e Liberdades, também chamada de Carta Canadense, que relaciona as liberdades individuais e democráticas, a igualdade, o direito à vida e à segurança, sem fazer qualquer menção ao direito à saúde.

É, pois, no âmbito legal, que é previsto o direito à saúde e são regulamentados os serviços para sua garantia. A Lei Canadense de Saúde, conhecida como Canadá Health Act (CHA), de 1985, define que o objetivo das políticas de saúde canadenses é proteger, promover e restaurar o bem-estar físico e mental dos residentes no Canadá e facilitar o acesso razoável a serviços de saúde sem barreiras, financeiras ou não. O sistema estabelecido pelo CHA, apesar de denominado Sistema Nacional de Saúde, possui caráter altamente

200 MELO, Marcus André; COSTA, Nilson do Rosário; SILVA, Pedro Luís B. Inovações organizacionais em política social: o caso da Grã-Bretanha. Revista do Serviço Público, ano 50, n.3, p.11, jul./set. 1999. Nesse sentido, acordo com Nilson Costa, Pedro Luís Silva e José Mendes Ribeiro, com a contratualização competitiva, houve maior autonomia gerencial aos provedores e o desenvolvimento de mecanismos de responsabilização organizacional - definição de objetivos, metas e sistemas de avaliação. Tais transformações, segundo os autores, foram acompanhadas de maior flexibilidade administrativa, pois as organizações, quando públicas, por meio de contratos, adquirem autonomia de contratação, demissão, gratificação e remuneração de pessoal (COSTA, Nilson do Rosário; SILVA, Pedro Luís B.; RIBEIRO, José Mendes. Inovações organizacionais e de financiamento: experiências a partir do cenário institucional. In: NEGRI, Barjas; DI GIOVANNI, Geraldo (Orgs.). Brasil: radiografia da saúde. Campinas: UNICAMP, 2001. p.301). 
descentralizado, com considerável responsabilidade delegada às províncias e aos territórios.

De acordo com o CHA, os serviços garantidos pelo poder público são delimitados e isentos de pagamento por sua utilização. Apesar disso, a própria lei admite a existência de algumas cobranças, denominadas extra-billings. As cobranças extras são quantias cobradas por médicos ou dentistas acima do valor que é estabelecido para determinado serviço de saúde pelo Poder Público de cada província. ${ }^{201}$

No Canadá existem seguros privados de saúde, os quais devem cobrir despesas por serviços não garantidos pelo sistema público, nos termos das leis provinciais de seguros privados, denominada Health Insurance Acts. ${ }^{202}$ Cerca de $80 \%$ dos habitantes do Canadá possuem um seguro privado, ${ }^{203}$ pago, geralmente, pelos empregadores. ${ }^{204}$

Mais de $95 \%$ dos hospitais canadenses são operados como entidades privadas sem fins lucrativos, administradas por conselhos comunitários, organizações não-governamentais de solidariedade ou sob um regime de autarquias municipais. ${ }^{205}$ As comissões de administração

201 A questão é tratada nas seções 18 a 20 do $C H A$.

202 Essa proibição, contudo, está sendo discutida hoje nos tribunais. Em 2005, a Suprema Corte do Canadá, no caso Chaoulli $x$ Quebec, decidiu que um prestador privado poderia oferecer um serviço assegurado pelo plano de saúde da província, em face da ineficiência do sistema público e das grandes filas existentes (CANADÁ. Supreme Court of Canada. Chaoulli v. Quebec. 09 jun. 2005. [2005] 1 SCR 791, 2005 SCC 35). A decisão, inédita, tem servido de fundamento para outras ações, em outras províncias, pleiteando o mesmo direito, o que gerou um intenso debate acerca da privatização no sistema de saúde do Canadá (TANNER, Michael. The grass is not always greener: a look at the national health care systems around the world. Policy Analysis, Washington (DC), n.613, mar. 2008. p.32).

203 MENDELSON, Michael; DIVINSKY, Pamela. Canada 2015: globalization and the future of Canada's health care. Ottawa: Caledon Institute of Social Policy, 2002. p.4.

204 BARER, Morris L. Hospital financing in Canada. US Congress, Office of Technology Assessment. Hospital financing in seven countries. Washington (DC): US Government Printing Office, 1995. p.21.

205 O setor hospitalar privado com fins lucrativos compreende majoritariamente as clínicas de tratamento médico de longo prazo ou serviços especializados, pois tais entidades apenas são autorizadas a prestar cuidados não garantidos pelas províncias. Os hospitais são expressamente proibidos de tratar ao mesmo tempo de pacientes que pagam diretamente pelos serviços e pacientes que tenham seus gastos pagos pelo seguro provincial. Os hospitais privados têm proliferado no Canadá na forma de parcerias públicoprivadas (PPPs ou P3s). Elas envolvem complexos contratos de concessão entre a administração pública e um grupo de companhias privadas, com finalidade lucrativa, como um único consórcio, tendo por objetivo a construção privada de um hospital. É feita uma licitação, e o licitante vencedor é responsável pelo financiamento, administração e operação do hospital. Em alguns casos, o consórcio privado é proprietário do prédio, e o setor público paga aluguel pelo uso, enquanto em outros ocorre uma espécie de leasing, de modo que o consórcio funciona como um banco. Este modo de P3 é relativamente novo, visto com bons olhos pelo governo, que reduz seus gastos imediatos com infra-estrutura, deixando-os para um longo prazo (CRAWLEY, Corina. Inventory of major form privatization initiatives in Canada's health care system. [s.1.]: CUPE, 2004. p.1). 
incluem, normalmente, médicos, administradores e representantes da comunidade. Os hospitais têm controle sobre a dotação diária de recursos, desde que não ultrapassem os limites orçamentários estabelecidos pelas autoridades regionais ou provinciais. ${ }^{206}$ Devido à grande interferência que o governo exerce sobre os prestadores de serviço de saúde sem fins lucrativos, estes são vistos como organizações quase-governamentais. Sua capacidade de autogoverno é limitada, já que a administração provincial tem competência para dissolver, fundir, ou prevenir a dissolução de instituições nessa esfera. ${ }^{207}$

Em Portugal, a transição de um sistema constituído historicamente por várias vias sobrepostas para o modelo beveridgeano ocorreu apenas na década de 70 do século passado, ${ }^{208}$ em um processo que passou pela consagração constitucional da saúde como direito universal e gratuito, garantido por meio de um serviço nacional de saúde (SNS). ${ }^{209} \mathrm{Com}$ as transformações sociais, econômicas e tecnológicas, além do ingresso de Portugal, em 1986, à Comunidade

206 HEALTH CANADA. O sistema de cuidados de saúde do Canadá. Ottawa, Canadá: [s.n.], 1999. p.2.

207 O Canadá não possui médicos empregados pelo Estado. Em sua maioria são profissionais privados que trabalham em consultórios, individualmente ou em grupos, e gozam de alto grau de autonomia. São os responsáveis pelo atendimento inicial do paciente, e por encaminharem-no ao tratamento adequado. Esses médicos privados são remunerados numa base de pagamentos por serviços prestados, após apresentarem diretamente suas notas de honorários à autoridade responsável pelo plano da província. Alguns médicos trabalham, ainda, em centros de saúde comunitários, em clínicas hospitalares ou ligados a departamentos hospitalares de tratamento ambulatorial (HEALTH CANADA. O sistema de cuidados de saúde do Canadá. Ottawa, Canadá: [s.n.], 1999. p.2). Há ainda o caso de especialistas que são baseados em hospitais, mas sem relação empregatícia com estes. Nesses casos, também podem os médicos ou especialistas receber por serviço prestado, porém é mais comum que tenham um salário ou algum tipo de sistema de pagamento alternativo, raramente vinculados ao orçamento hospitalar (BARER, Morris L. Hospital financing in Canada. US Congress, Office of Technology Assessment. Hospital financing in seven countries. Washington (DC): US Government Printing Office, 1995. p.23). O pagamento aos médicos que apresentam suas notas é feito com base em uma tabela de valores preestabelecidos, negociada diretamente na província em questão, sendo que, ao receber o tratamento, o paciente deve mostrar seu cartão de seguro, para que o médico tenha as informações necessárias para a cobrança.

208 Segundo Maria Ioannis Baganha e Joana Sousa Pires, antes de 1974, a atenção à saúde em Portugal era constituída pelas seguintes entidades: (i) misericórdias, que geriam grande parte das insituições hospitalares em todo o país; (ii) Servços Médicos-Sociais, que prestavam assistência aos beneficiários da Federação de Caixa Previdenciária; (iii) Serviços de Saúde Pública, especialmente voltados a ações de prevenção, como vacinações; (iv) os hospitais estatais, gerais e especializados, principalmente nos grandes centros urbanos; e (v) os serviços privados, dirigidos às camadas sociais mais elevadas (BAGANHA, Maria Ioannis; PIRES, Joana Sousa R. S. O sector da saúde em Portugal: funcionamento do sistema e caracterização sócio profissional. Oficina do Centro de Estudos Sociais da Faculdade de Economia da Universidade de Coimbra, Coimbra, n.182, p.2-3, dez. 2002). Sobre a organização dos serviços de saúde em Portugal até a década de 70 do século passado e as perspectivas de mudança, conferir: FERREIRA, F. A. Gonçalves. Política de saúde em portugal: uma experiência de definição legislativa e de organização dos serviços. Lisboa: Sopime, 1972.

209 O tratamento da saúde na Constituição Portuguesa de 1976 foi mencionado no Item 2.2.1. Sua regulamentação ocorreu pouco tempo mais tarde, por meio da Lei n. ${ }^{\circ}$ 56, de 15 de setembro de 1979 , conhecida como Lei de Bases da Saúde. 
Econômica Européia, foi editada, já na década de 90 do século passado, uma nova Lei de Bases da Saúde. ${ }^{210}$ Desde então, uma série de reformas no sistema de saúde português promoveu importante alteração nas relações entre o Estado e a iniciativa privada.

No que tange à prestação de serviços de saúde, a Lei de Bases da Saúde estabelece em sua

base XII que o sistema de saúde [português] é constituído pelo Serviço Nacional de Saúde e por todas as entidades públicas que desenvolvam actividades de promoção, prevenção e tratamento na área da saúde, bem como por todas as entidades privadas e por todos os profissionais livres que acordem com a primeira prestação de todas ou de algumas daquelas actividades. 211

A participação da iniciativa privada ocorre, portanto, no que a lei denomina rede nacional de prestação de cuidados de saúde, a qual compreende os estabelecimentos do SNS e estabelecimentos privados por ele contratados. ${ }^{212}$

O Decreto-Lei n. ${ }^{\circ} 185$, de 20 de agosto de 2002 , em seu artigo $5 .^{\circ}, 1$, menciona expressamente como instrumentos para os estabelecimento de parceiras com a iniciativa privada em saúde: (i) o contrato de gestão; ${ }^{213}$ (ii) o contrato de prestação de serviços; e (iii) o contrato de colaboração. ${ }^{214} \mathrm{O}$ próprio ato normativo determina que as parcerias podem

210 Trata-se da Lei n. ${ }^{\circ}$ 48, de 24 de agosto de 1990, com alterações promovidas pela Lei n. ${ }^{\circ} 27$, de 8 de novembro de 2002.

211 Lei n. ${ }^{\circ}$ 48/90, Base XII, 1.

212 Nesse sentido, segue a base XII da Lei de Bases da Saúde portuguesa: 3. O Ministério da Saúde e as administrações regionais de saúde podem contratar com entidades privadas a prestação de cuidados de saúde aos beneficiários do Serviço Nacional de Saúde sempre que tal se afigure vantajoso, nomeadamente face à consideração do binômio qualidade-custos, e desde que esteja garantido o direito de acesso. 4. A rede nacional de prestação de cuidados de saúde abrange os estabelecimentos do Serviço Nacional de Saúde e os estabelecimentos privados e os profissionais em regime liberal com quem estejam celebrados contratos nos termos do artigo anterior.

213 O contrato de gestão é regulamentado pelo ato em referência, que trata de questões específicas da área da saúde e pelo Código de Contratos Públicos português - Decreto-Lei n. ${ }^{\circ}$ 18, de 29 de janeiro de 2008. De acordo com Decreto-Lei n. ${ }^{\circ} 185 / 2002$, que qualifica o contrato de gestão como verdadeiro contrato de concessão, ele tem por objeto tanto a prestação de serviços de saúde quanto a concepção, construção, financiamento, conservação e exploração de um estabelecimento ou parte funcionalmente autônoma deste.

214 Tanto o contrato de prestação de serviços quanto o contrato de colaboração devem respeitar, com as necessárias alterações os princípios aplicáveis ao contrato de gestão, sendo cada um dos ajustes disciplinados pelo Decreto-Lei n. ${ }^{\circ}$ 185/2002. 
decorrer de contratos mistos ou da união de contratos e prevê a hipótese de outros mecanismos de vínculo, dentre os quais se podem mencionar as convenções ${ }^{215}$ e os contratos-de-programa. ${ }^{216}$

Questão bastante discutida em Portugal nos últimos anos refere-se à instituição das assim denominadas taxas moderadoras de acesso aos serviços de saúde. ${ }^{217}$ É que, de acordo com o texto Constitucional de 1976, serviços de saúde prestados no âmbito do SNS seriam gratuitos. Inicialmente, foi julgada improcedente Ação de Inconstitucionalidade contra a cobrança das taxas moderadoras, sob o entendimento, firmado pela maioria dos membros da Corte Constitucional portuguesa, de que as taxas moderadoras não implicam cobrança pela prestação dos serviços, mas mero mecanismo racionalizador de sua utilização. ${ }^{218} \mathrm{Com}$ tal argumentação, entendeu-se que tais taxas não retiram o caráter gratuito dos serviços prestados pelo SNS português, especialmente considerando que seu valor corresponde a uma proporção mínima em relação ao custo dos serviços.

Mesmo assim, logo após a decisão da Corte, foi aprovada emenda constitucional que alterou a redação da Constituição portuguesa: de gratuitos os serviços de saúde passaram a ser tendencialmente gratuitos. Tal emenda, contudo, não fez terminarem as discussões acerca da constitucionalidade da cobrança. ${ }^{219}$

215 De acordo com o Decreto-Lei n. ${ }^{\circ}$ 97, de 18 de abril de 1998, entende-se por Convenção o contrato de adesão celebrado entre o Ministério da Saúde, através da Direcção-Geral da Saúde, ou as administrações regionais de saúde e as pessoas privadas, singulares ou colectivas, que tenham por objecto a prestação de cuidados de saúde, em articulação com o Serviço Nacional de Saúde, integrando-se na rede nacional de prestação de cuidados de saúde.

216 De acordo com o Decreto-Lei n. ${ }^{\circ} 11$, de 15 de janeiro de 1993, o Ministro da Saúde pode autorizar a celebração de contratos-programa entre ARS e autarquias locais, misericórdias ou outras instituições particulares de solidariedade social, com vista a recuperar e a gerir instituições ou serviços prestadores de cuidados de saúde; sendo que é aplicável a estes contratos o disposto na lei quanto aos contratosprograma de cooperação técnica e financeira entre a administração central e as autarquias, com exceção das disposições referentes às comissões de coordenação regional e aos planos municipais de ordenamento do território.

217 As taxas moderadoras foram implementadas em Portugal por meio do Decreto n. ${ }^{\circ}$ 57/1986 com o objetivo de moderar, racionalizar e regular o acesso da população aos serviços de saúde.

218 Acórdão 330/89. Em voto vencido, Vital Moreira, à época membro da Corte Constitucional portuguesa, expôs entendimento contrário àquele que prevaleceu, sustentando, inclusive a inconstitucionalidade da emenda constitucional, então em trâmite, que admitiu a cobrança das taxas.

219 Em recente artigo, Vital Moreira, a propósito da nova regulamentação das taxas moderadoras, em relação às quais há faixas de isenção e escalonamento conforme a situação financeira do usuário, uma vez mais manifestou entendimento contrário à sua cobrança, sobretudo: "(...) em face da aleatoriedade dos factores que os tornam [os serviços de saúde] necessários doenças e acidentes e com a insegurança e a desigualdade que a onerosidade instalaria nas pessoas e na sociedade em geral." E conclui o autor: "Se se quer mudar o sistema de financiamento do SNS, criando uma fonte de receitas 'endógena', em 
Além disso, houve nos últimos anos importante mudança na estrutura e na organização da assistência à saúde em Portugal: (i) com a transformação dos hospitais públicos portugueses em sociedades anônimas, ${ }^{220}$ e depois em empresas públicas estatais, ${ }^{221}$ e com (ii) a criação de parcerias público-privadas para a construção e operação de novos hospitais. ${ }^{222}$

Já na Espanha, em um processo similar ao português, o Serviço Nacional de Saúde foi previsto constitucionalmente apenas na década de 70 do século passado, ${ }^{223}$ tendo sido consolidado alguns anos mais tarde, pela Lei n. ${ }^{\circ}$ 14, de 25 de abril de 1986, denominada Lei Geral Sanitária (LGS). Tal ato legislativo compilou uma série de atos normativos que marcaram a transição do antigo modelo bismarckiano para o atual modelo de Sistema Nacional de Saúde. Foram previstos com a LGS (i) o direito de proteção à saúde de todos os espanhóis e

alternativa aos impostos gerais e ao Orçamento do Estado, então mais vale ter a coragem de assumir expressamente uma mudança de paradigma em toda a linha. Seria mais transparente, mais coerente e, se calhar, menos problemático." (MOREIRA, Vital. O fim da gratuidade do SNS. Jornal Público, Lisboa, 14 de setembro de 2004).

220 Segundo José Mendes Ribeiro, à empresarialização dos hospitais seguiu-se a implementação de um novo modelo de financiamento, com base em cinco grande princípios: "1. A criação de uma relação contratual entre o Estado (financiador) e o respectivo hospital, titulada por um contrato-programa que envolve a produção para o SNS; 2. Os cuidados e serviços a comprar estão agrupados por linhas de actividade internamentos, consultas, episódios de urgência e hospital de dia — e têm um preço ajustado pelo índice de case-mix (severidade média das patologias) e por um ponderador de cluster (diferenciação e matriz tecnológica do hospital) que tornam mais justo o preço a pagar, porque tomam em consideração a especificidade de cada unidade hospitalar; 3. O volume de produção contratada tem em atenção a capacidade instalada, permitindo cobrir os custos fixos dos hospitais, na base de um estimador que atende à eficiência média, na afectação de recursos em toda a rede; 4. A produção marginal é paga até um certo limite médio, sofrendo depois uma penalização ajustada e degressiva face aos custos variáveis. As urgências não estão contempladas por qualquer tecto de produção; 5. O contrato-programa deve constituir-se como um instrumento de regulação da procura, pois permite a distribuição estratégica das produções pelas distintas unidades." (RIBEIRO, José Mendes. Reforma do sector público hospitalar: programa de empresarialização de 34 hospitais portugueses. Revista Portuguesa de Saúde Pública, v.4, p.68, 2004).

221 A Lei n. ${ }^{\circ}$ 27/2002 autorizou a transformação dos hospitais públicos em sociedades anônimas de capital exclusivamente público. A partir de então, trinta e seis estabelecimentos hospitalares portugueses foram transformados em trina e uma sociedades anônimas. Com o Decreto-Lei n. ${ }^{\circ}$ 93, de 7 de junho de 2005, tais hospitais foram transformados em entidades públicas empresariais - EPE sujeitos ao regime previsto no Decreto-Lei n. ${ }^{\circ}$ 558, de 17 de dezembro de 1999. Na seqüência, o Decreto-Lei n. ${ }^{\circ}$ 233, de 29 de dezembro de 2005, concretizou tal transformação, definindo critérios gerais a serem seguidos pelos estatutos dos Hospitais EPE. Dentre os dispositivos constantes deste diploma, merecem referência o artigo 9. ${ }^{\circ}, 2$, que permite a contratualização interna e o artigo 12, que trata do financiamento dos hospitais por meio de contratos-de-programa.

222 Conforme previsto no Decreto-Lei n. ${ }^{\circ}$ 185-2002, regulamentado no Decreto-Lei n. ${ }^{\circ}$ 86, de 26 de abril de 2003.

223 O tratamento constitucional da saúde na Constituição espanhola de 1978 foi mencionado no Item 2.2.1. Uma das características do modelo espanhol anterior à Constituição de 1978 era a variedade de redes de assistência à saúde e sua vinculação a diferentes órgãos públicos, sem uma organização adequada, como se reconhece na própria exposição de motivos da Lei Geral Sanitária espanhola de 1986. 
dos estrangeiros residentes na Espanha;224 (ii) o financiamento dos serviços de saúde com base em recursos provenientes tanto da seguridade social quanto do orçamento geral do Estado; 225 e (iii) a integração e descentralização gradual das diferentes redes assistenciais existentes, com a transferência gradual de sua gestão às Comunidades Autônomas (CAs). ${ }^{226}$

Nos termos da LGS, a vinculação de prestadores privados ao SNS pode ocorrer de acordo com um protocolo a ser previamente definido pelo Estado, tanto por meio de convênios singulares com hospitais, detalhadamente disciplinados no referido diploma legislativo, ${ }^{227}$ quanto por meio de acordos (conciertos) celebrados pelas administrações públicas de saúde para a prestação dos serviços. ${ }^{228}$ Neste último caso, a lei determina prioridade a entidades sem fins lucrativos. Não obstante, desde então, uma série de novas transformações tem ocorrido na Espanha, em especial no que se refere à participação privada e às formas de gestão dos serviços de saúde. 229

Com o objetivo de ampliar as formas organizativas de prestação de serviços de saúde, concedendo a ela maior flexibilização e autonomia, foi editado o Real Decreto legislativo n. ${ }^{\circ}$ 10, de 17 de junho de 1996, logo substituído pela Lei n. ${ }^{\circ} 15$, de 15 de abril

224 Artigo 1. ${ }^{\circ}$ da LGS.

225 Artigo 78 e seguintes da LGS.

226 A Espanha é dividida em dezessete regiões - as Comunidades Autônomas (CAs), dotadas de autonomia legislativa e administrativas delimitadas pela Constituição espanhola. Conforme se verifica na exposição de motivos da LGS, o sistema nacional de saúde espanhol é concebido como o conjunto dos serviços de saúde das Comunidades Autônomas convenientemente coordenados (...) Os serviços de saúde se concentram, assim, sob a responsabilidade das Comunidades Autônomas e sob os poderes básicos de direção e coordenação do Estado. A criação dos serviços de saúde das Comunidades Autônomas é, sem embargo, paulatina. Evita-se na Lei saltos no vazio, procura-se a adoção progressiva de estruturas e acomoda-se, enfim, o ritmo de aplicação de sua provisão à marcha dos processos de transferências dos serviços à Comunidades Autônomas. O tema encontra-se disciplinado nos artigo 49 e seguintes da lei em referência.

227 Artigo 66 e seguintes da LGS.

228 Artigo 90 da LGS.

229 Como assinala José Joaquim Juan, nessa época, vários países do sul da Europa realizaram suas reformas no sistema de saúde, como base no modelo inglês de tipo beveridgeano, como Portugal, Espanha, Itália e Grécia. Em contextos históricos semelhantes, a variação do modelo implantando em cada país decorreu da diversidade de antecedentes e teve como marca comum um subseqüente processo de contra-reforma, no sentido de que após a consagração de sistemas nacionais de saúde, com a crise do Estado, que atingiu inclusive aqueles antes referidos, novos mecanismos de racionalização, gestão e participação privada tiveram de ser desenvolvidos ou incorporados aos novos modelos de assistência à saúde (JUAN, José Joaquim. Situação atual da reforma sanitária na Espanha. In: BUSS, Paulo Marchiori; LABRA, Maria Eliana. Sistemas de saúde: continuidades e mudanças. Rio de Janeiro: Hucitec e Fiocruz, 1995. p.158-159). 
de 1997, intitulada Novas Formas de Gestão do Serviço Nacional de Saúde. Esta última estabeleceu a possibilidade de gestão e prestação de serviços de saúde do modo direto ou indireto, mediante contratos, ${ }^{230}$ acordos (acuerdos) ou convênios com entidades públicas (como consórcios, fundações ou outros entes de titularidade ou natureza pública, previstos pelo Decreto Real n. $\left.{ }^{0} 10 / 96\right)^{231}$ ou privadas. ${ }^{232}$

Na virada do século, por meio do Decreto Real n. ${ }^{\circ} 29$, de 14 de janeiro de 2000, ocorreu nova modificação na disciplina da participação privada na prestação de serviços de saúde na Espanha. Este Real Decreto regulamentou em seu artigo 3. ${ }^{\circ}$ novas formas de gestão e administração dos centros, serviços e estabelecimentos de saúde, as quais podem mediante ajustes celebrados com fundações constituídas nos termos da Lei n. ${ }^{\circ}$ 30/1994,

230 Recentemente, a nova lei sobre contratos do setor público, Lei n. ${ }^{\circ} 30$, de 30 de outubro de 2007 , estabeleceu as modalidades contratuais, dentre as quais se encontram aptas a estabelecer vínculo para a prestação de serviços de saúde com entes privados o contrato de gestão de serviços públicos (em relação ao qual há referência específica para a possibilidade de negociação no caso dos serviços de saúde), o contrato de serviços, o contrato de colaboração entre o setor público e o setor privado (parcerias público-privadas) e os contratos mistos.

231 A referência expressa à natureza das entidades aptas a exercer a gestão indireta, que constava do Decreto-Lei real n. ${ }^{\circ}$ 10/96 e incluía as fundações, foi suprimida na redação da Lei n. ${ }^{\circ} 15 / 97$. Entretanto, como assinala Ángel Menéndez Rexach, tal omissão não impede a utilização de tais entidades, nos termos genéricos da Lei n. ${ }^{0}$ 30, de 24 de novembro de 1994, conhecida como Lei de Fundações. Segundo o autor, tais fundações são entidades de direito privado criadas pelo poder público para executar atividades de interesse geral, como o de saúde. Em face das críticas tecidas contra tal possibilidade, continua Rexach, foi editada a Lei n. ${ }^{\circ} 50$ de 15 de dezembro de 1998, que em seu artigo 111, regulou a gestão dos serviços de saúde por fundações qualificadas como organismos públicos, denominadas fundações sanitárias (REXACH, Ángel Menéndez. Formas Jurídicas de Gestión de los Servicios Sanitários. In: PAREJO, Luciano; LOBO, Félix; VAQUER, Marcos (Coords.). La Organización de los Servicios Públicos Sanitários. Madrid: Marcial Pons, 2001. p.75-76). As fundações públicas sanitárias, como ressalta Javier Sánches-Caro, aproximam-se das Entidades Públicas Empresariais, previstas pela Lei n. ${ }^{\circ}$ 6, de 14 de abril de 1997, conhecida como Lei de Organização e Funcionamento da Administração Geral do Estado (LOFAGE), com especificidades relacionadas ao serviços de saúde (SÁNCHES-CARO, Javier. Régimen Jurídico de las Nuevas Formsa de Gestión em la Sanidad Española (la perspectiva del Instituto Nacional de Salud). In: PAREJO, Luciano; LOBO, Félix; VAQUER, Marcos (Coords.). La Organización de los Servicios Públicos Sanitários. Madrid: Marcial Pons, 2001. p.169-170). No mesmo sentido: CAMACHO, Joana M. Socías. Fundaciones del sector público: en especial, el ámbito sanitario. Madrid: Iustel, 2006. p.177-178.

232 Na exposição de motivos da Lei n. ${ }^{\circ}$ 15/1997 encontra-se consignado que: "A presente norma, em linha com o espírito do Real Decreto-Lei n. ${ }^{\circ} 10 / 96$, o qual vem a substituir, deve constituir um importante instrumento de flexibilização e autonomia na gestão da saúde, necessidade inevitável da atual organização pública, com vistas a melhorar a eficácia do Sistema nacional de Saúde, cuja consolidação e modernização são objetivos prioritários de nossa sociedade". 
fundações públicas sanitárias, ${ }^{233}$ consórcios, ${ }^{234}$ sociedades estatais, ${ }^{235}$ ou de qualquer outra entidade de natureza ou titularidade pública constituída para tal fim.

Verifica-se, pois, um processo adotado na Espanha, similar àquele adotado na Inglaterra, no Canadá, em Portugal, e em outros Estados que seguem o modelo beveridgeano, ${ }^{236}$ por meio do qual, com algumas peculiaridades, privilegiam-se a gestão pública dos sistemas e a prestação tanto pública quanto privada dos serviços, por meio de ajustes definidores do regime jurídico de cada ente prestador dos serviços, que em grande medida independem da natureza da entidade prestadora.

Dessa análise, pode-se perceber que, assim como nos sistemas de origem bismarckiana (em que os serviços de saúde são garantidos por meio de seguros sociais dos quais participam a iniciativa privada - tanto no âmbito das seguradoras quanto no âmbito dos prestadores dos serviços), também nos sistemas beveridgeanos, tem crescido a importância da participação privada na prestação de serviços de saúde, por meio de novos mecanismos de ajuste com o Estado e nova formas de gestão das entidades prestadoras dos serviços.

233 Constituídas nos termos da Lei n. ${ }^{\circ}$ 50/98.

234 Nos termos do artigo 46 do próprio Decreto-Lei real, consórcios são organizações comuns, dotados de personalidade jurídica, criados por convênios entre entidades públicas para a gestão de centros, serviços e estabelecimentos de saúde.

235 De acordo com o artigo 54 do Decreto-Lei, são sociedades com finalidade específica, em que a maior parte do capital seja pública.

236 Dentre eles, pode-se mencionar a experiência italiana. Em 1978, com a criação do Serviço Sanitário Nacional italiano (SSN), instituído pela Lei n. ${ }^{\circ} 833 / 78$, foi introduzida, pela primeira vez, a universalização da atenção à saúde na Itália, com base em um processo de descentralização de competências às autoridades regionais e locais. Como nos demais países examinados, as transformações econômicas, sociais e tecnológicas conduziram a uma nova reforma, instituída pelo Decreto Legislativo n. ${ }^{\circ}$ 502/92 (alterado e integrado posteriormente pelos Decretos Legislativos n. ${ }^{\circ} 517 / 93$ e n. ${ }^{\circ}$ 229/99). Dentre as inovações trazidas pela nova legislação, pode ser citada a predeterminação de um sistema de concorrência entre as estruturas públicas e privadas, em relação aos serviços prestados sob o pagamento de tarifa. O serviço público de saúde tem sua gratuidade estendida a todos, mas há hipóteses de cobrança de um ticket de atendimento. Com isso, o serviço privado atende apenas àqueles que têm maior poder aquisitivo e preferem optar por um tratamento diferenciado. Os usuários têm a liberdade de escolher os prestadores do serviço de saúde, no âmbito da estrutura pública e privada disponível. O SSN é descentralizado nas Regiões e estas subdelegam às Comunidades o exercício direto das atividades de gestão da saúde. Estas últimas têm liberdade para prestar a assistência, desde que respeitem os critérios gerais da disciplina estatal. As Comunidades, portanto, podem elaborar mecanismos de ajuste com as entidades privadas para a prestação do serviço de saúde, nos termos do art. 41 a 43, Lei n. ${ }^{\circ} 833 / 78$, inclusive por meio da criação de sociedades mistas, dotadas de capital público e privado. Além disso, o Decreto Legislativo n. ${ }^{\circ} 502 / 92$ previu no art. 9-bis 69 a possibilidade de experimentação de outras formas de gestão, motivadas por razões de conveniência econômica e melhoramento da qualidade da assistência. 


\subsubsection{Participação Privada em Sistemas Segmentados}

Enquanto os sistemas europeus de assistência à saúde possuem caráter majoritariamente público, nos quais a saúde é tida como direito fundamental a ser garantido do modo universal, seja de acordo com o modelo bismarckiano, seja de acordo com o modelo beveridgeano, nos Estados Unidos da América, a saúde não é consagrada constitucionalmente e não é considerada como um direito universal. ${ }^{237}$ Sua garantia pelo Estado, por meio da prestação de serviços voltados à sua proteção, promoção e recuperação, é direcionada a camadas específicas da sociedade, ${ }^{238}$ de modo que para todas as demais pessoas, não raro encontram-se assertivas de que a saúde é tida não como um direito, mas como uma mercadoria. ${ }^{239}$

É que, ao contrário do que aconteceu na Europa em fins do século XIX e início do século XX, nos Estados Unidos da América, sobretudo em face da atuação de entidades corporativas como a Associação Médica Americana (AMA), não foi prevista em lei a garantia pelo Estado do direito à saúde. Grande parte das propostas de intervenção do Estado na área, por meio de seguros públicos ou prestação direta de serviços, foi rechaçada, sob os argumentos principais de que tal intervenção seria própria de regimes socialistas e que, com ela, tanto a qualidade dos serviços quanto a liberdade de escolha dos prestadores e o exercício de profissões de saúde seriam prejudicadas.

237 O chamado Bill of Rights norte-americano, composto pelas dez primeiras emendas feitas à Constituição dos Estados Unidos, em 1791, garante aos estados-membros e aos cidadãos a salvaguarda dos direitos que não estiverem expressamente delegados ao governo central e não forem negados pelas referidas unidades federativas. Não há nenhuma menção expressa no Bill of Rights e tampouco na Constituição americana acerca do direito de saúde. Assim, cada um dos 50 estados-membros regula matéria e tem sua agência responsável pela saúde. Sobre a conformação do sistema de saúde nos Estados Unidos, conferir: NORONHA, José Carvalho de; UGÁ, Maria Alicia Dominguez. O sistema de saúde dos Estados Unidos. In: BUSS, Paulo Marchiori; LABRA, Maria Eliana. Sistemas de saúde: continuidades e mudanças. Rio de Janeiro: Hucitec e Fiocruz, 1995. p.177-188.

238 Daí a classificação do sistema norte-americano como um sistema segmentado, entendido como aquele em que a assistência à saúde é voltada a determinadas camadas populacionais, segundo critérios previamente definidos.

239 Esse é o posicionamento de Larry E. Carter, para quem: "A rede de assistência à saúde americana configura um sistema híbrido que combina o público e o privado tanto no seguro e quanto no tratamento da saúde. Em muitas instâncias, a assistência á saúde é tratada como uma mercadoria cujo preço é controlado pelas forças do mercado. Para a maioria dos trabalhadores americanos, o aumento nos custos da saúde são refletidos no aumento dos prêmios dos seguros. Para outros americanos, a assistência à saúde é um direito. Os mais velhos (Medicare) e as crianças pobres (Medicaid) são dois grupos em que, cumpridas determinados critérios, são apto a receber tratamento de saúde gratuito ou subsidiado." (CARTER, Larry E. Health Care Reform: policy innovations at the state level in the United States. New York: Garland, 1998. p.23. 
Assim, os Estados Unidos não contam com um sistema público universal de saúde. Além de seguros de saúde voluntários, normalmente oferecidos por empresas empregadoras, ${ }^{240} \mathrm{e}$ de alguns hospitais públicos (mantidos, sobretudo, pelos governos locais) e sem fins lucrativos, que atendem a pessoas sem seguro (público ou privado), dois são os principais programas estatais de assistência à saúde, focados em populações específicas: o Medicare e o Medicaid. ${ }^{241}$

O Medicare é um programa federal que oferece, por meio de um sistema de seguro público, assistência à saúde a pessoas com mais de 65 anos, não-vinculadas aos seguros voluntários oferecidos pelas empresas, bem como seus dependentes, e às pessoas portadoras de doença renal em estágio avançado. O programa é composto por duas partes: (i) uma delas é de filiação obrigatória e cobre os gastos com hospitalização, ainda que com pacote de serviços delimitado e com co-pagamento do usuário; e (ii) outra, de filiação voluntária, para cobertura de despesas não previstas pela cobertura obrigatória, ${ }^{242}$ em relação à qual também é exigido co-pagamento dos serviços utilizados, além de prêmios anuais. ${ }^{243}$

Já o Medicaid é um programa de competência federal e estadual, voltado às pessoas de baixa renda, cuja vinculação depende da comprovação de uma série de requisitos, que restringem o alcance populacional do programa. Seu financiamento, que consome a maior

240 Como resumiu Lenaura de Vasconcelos Lobato: "Muitas das grandes empresas têm seu próprio sistema de seguro ou compram os serviços das inúmeras empresas de seguro privado. Estas podem ser empresas comerciais tradicionais de seguro, que reembolsam aos pacientes ou às unidades os serviços utilizados ou podem ser as empresas chamadas de planos de pré-pagamento (prepaid plans), que oferecem pacotes fechados de serviços mediante pagamento prévio mensal e incluem diversas modalidade [de serviços]. Além destas, há as tradicionais organizações Blue Shield e Blue Cross, que possuem planos de saúde para cobertura de médicos e hospitais respectivamente e que até recentemente eram isentas de contribuição fiscal, já que consideradas de caráter não-lucrativo." (LOBATO, Lenaura de Vasconcelos. Reforma do estado no setor de saúde no Reino Unido e nos Estados Unidos. In: HUSENMAN, Samuel et. al. Reforma do estado no setor de saúde: os casos da Catalunha, Canadá, Reino Unido e Estados Unidos. Brasília: ENAP, 1997. (Cadernos ENAP, 13). p.90).

241 Ambos foram criados em 1965, com a aprovação de uma emenda à Lei de Seguridade Social americana, que até então não previa atendimento à saúde. Além deles há outros programas voltados a determianados grupos sociais, como os indígenas. Mais recentemente foi criado o State Children's Health Insurance Program (SCHIP) - Programa Estadual de Seguros à Crianças, criado em 1997, por meio de outra emenda à Lei de Seguridade Social norte-americana.

242 Como, por exemplo, serviços de atendimento domiciliar, transporte em ambulância, honorários de médicos não residentes em hospitais vinculados ao programa, leitos especiais e transplante de órgãos.

243 O financiamento do Medicare, além da parcela de contribuição dos usuários, é de responsabilidade federal e sustentada, sobretudo, por meio de contribuições tributárias incidentes sobre a folha de salários dos trabalhadores ativos. 
parte dos recursos públicos investidos na saúde nos Estados Unidos, advém basicamente de recursos federais e estaduais, de modo que sua organização é complexa, existindo vários pacotes de serviços ofertados a determinados grupos, com possibilidade de co-pagamento pelo usuário.

Ponto comum entre os programas de assistência à saúde norte-americanos é que a execução dos serviços ocorre por meio de entidades privadas contratadas, com ou em fins lucrativos, as quais conformam a imensa maioria dos prestadores de serviços de saúde nos Estados Unidos da América.

As reformas promovidas em solo norte-americano nos últimos anos tiveram como base a transformação das relações entre as seguradoras privadas, os usuários e os prestadores de serviços médicos. O objetivo de tais transformações, no país em que mais se gasta com saúde no mundo, foi a contenção de gastos, racionalização e eficiência na alocação de recursos. Considerando que tal objetivo foi buscado em todos os processos de reformas promovidos nos últimos anos nos sistemas de saúde do planeta, as reformas na regulamentação dos seguros de saúde norte-americanos, iniciadas na década de 70 do século passado, tiveram reflexo tanto nos próprios programas de seguro público de saúde americanos quanto nos sistemas bismarckianos e beveridgeanos.

Noções como as de assistência gerenciada - managed care e de concorrência gerenciada-managed competition como estratégias para alcançar os objetivos acima delineados foram desenvolvidas, sobretudo, nos Estados Unidos e marcaram novos modelos de relação entre os prestadores, financiadores e usuários dos serviços de saúde. ${ }^{244}$ Como já mencionado, se os gastos com a saúde não diminuíram com a contratualização e a modificação no ambiente regulatório dos serviços públicos e privados de saúde (conseqüências das transformações implementadas), a utilização de contratos com prestadores públicos e privados, como mecanismo privilegiado a permitir maior de transparência, controle e mesmo eficiência, restou evidenciada.

244 Assinale-se, por exemplo, o Health Maintenance Organization Act - Lei das Organizações de Atenção à Saúde, aprovado nos Estados Unidos já em 1973, criando novo modelo de gerenciamento das relações entre prestadores do serviço de saúde e usuários, por meio das denominadas HMOs; e mais tarde com a criação das Preferred Priovider Insurence - PPI. Sobre o tema, dentre outros, conferir: ENTHOVEN, Alain C. The History and Principles os Managed Competition. Health Affairs, v.12, 1993. p.24-48. 
Sob tal ângulo, a análise das relações entre Estado, Administração Pública e assistência à saúde demonstra a aproximação entre os sistemas de prestação de serviços. ${ }^{245}$ Tal verificação pode ser comprovada, por exemplo, ao se comparar o modelo holandês - no qual os seguros (cuja filiação é obrigatória para grande parte da população) e os prestadores de serviços de saúde são privados - e o sistema norte-americano - em que a filiação a seguros públicos é obrigatória apenas para determinadas camadas populacionais e voluntária para grande parte dos cidadãos. Em ambos os casos, a possibilidade de negociação e definição das cláusulas do ajuste entre o provedor dos serviços e a entidade financiadora (pública ou privada, de adesão voluntária ou obrigatória) tem sido incentivada. O mesmo se diga para a experiência inglesa e as que a seguiram, como a de Portugal e Espanha, nas quais a vinculação direta, hierárquica e estatutária tem sido substituída por meios contratuais independente da natureza jurídica da entidade prestadora, cujo regime jurídico decorre muito mais da disciplina especificamente estabelecida nos ajustes do que da lei que define sua natureza jurídica.

Críticas a sistemas de saúde são encontradas em todos os Estados em todas as épocas, mesmo porque, como já assinalado, em um sentido amplo, o conceito de saúde consiste mais em um objetivo do que em um dado concreto. De qualquer modo, o consenso parece residir, no atual desenvolvimento social e político, na necessidade de que seja garantido determinado nível de assistência à saúde a todos aqueles que dela necessitarem. As formas para tanto são variadas, mas é possível enxergar um ponto comum: a necessidade de adoção de soluções passíveis de responder a demandas específicas e de possibilitar o mais alto grau de transparência e controle de custos. ${ }^{246}$

245 Essa é uma característica que não se restringe ao setor de saúde, mas estende-se a todos os direitos fundamentais consagrados internacionalmente e objeto de garantia por cada Estado. Como menciona Carlos Ari Sundfeld: "(...) a internacionalização dos direitos humanos, que não só os multiplica impondo novos direitos subjetivos, antes recusados pelos Estados - como conduz a uma paulatina aproximação das ordens jurídicas nacionais, obrigadas a seguir certos padrões semelhantes, exigidos pelo respeito às novas conquistas." (SUNDFELD, Carlos Ari. A administração pública na era do direito global. In: SUNDFELD, Carlos Ari; VIEIRA, Oscar Vilhena. Direito global. São Paulo: Max Limonad, 1999. p.158. Assim, a proposição por parte dos Estados de enfrentar os mesmos problemas (efetivar os mesmos direitos) conduz à aproximação entre os modelos de atuação administrativa mais eficientes, em uma forma de seleção natural e adaptação local das experiências de maior êxito.

246 Nesse sentido, a adoção de soluções contratuais negociadas, dotadas de mecanismos de controle específicos, e de flexibilidade de gestão, revelam-se em grande medida mais eficientes. O que não significa defender aqui, mesmo porque o objetivo do trabalho não é esse, a contratualização de todas as relações entre o poder público e os prestadores de serviços de saúde. O que se defende é a possibilidade, e necessidade, de que haja mecanismos adequados para disciplinar a necessária participação privada na prestação de serviços 
Se, de um lado, é claramente perceptível a defesa da universalização do direito à saúde em Estados que não a têm consagrada, como nos Estados Unidos, de outro, é também evidente que a convivência entre a prestação pública e a prestação privada é inevitável. Esta última característica é comum igualmente aos sistemas de saúde universais e conduz ao desenvolvimento em todos os Estados com economia de livre mercado, de sistemas privados que buscam oferecer serviços diferenciados em relação àqueles prestados pelo Estado. ${ }^{247}$ Ao analisar a questão, Gosta Esping-Andersen assim consignou:

\begin{abstract}
Como alternativa aos comprovadamente pobres e à seguridade social corporativista, o sistema universalista promove a igualdade de status. Todos os cidadãos são dotados de direitos semelhantes, independente da classe ou da posição no mercado. Neste sentido, o sistema pretende cultivar a solidariedade entre as classes, uma solidariedade da nação. Mas a solidariedade do universalismo do benefício uniforme pressupõe uma estrutura de classe historicamente peculiar, onde a vasta maioria da população é constituída de 'pessoas humildes' para quem um benefício modesto, embora igualitário, pode ser considerado adequado. Quando isso deixa de ocorrer, como acontece quando aumenta a prosperidade da classe trabalhadora e surgem novas classes médias, o universalismo do benefício uniforme promove o dualismo inadvertidamente, pois os que estão melhor de vida voltam-se para o seguro particular e para a negociação de benefícios extras para suplementar a modesta igualdade que julgam ser os padrões habituais de bem-estar. Onde esse processo se desenvolve (como no Canadá ou na Grã-Bretanha), o resultado é que o espírito maravilhosamente igualitário do universalismo se transforma num dualismo semelhante ao estado de assistência social: os pobres com o Estado e os outros com o mercado. 248
\end{abstract}

públicos de saúde. A opção, por tal mecanismo é, como se verá adiante, ofertada ao administrador público. Uma breve e importante análise sobre as vantagens e desvantagens da relação contratual em face da relação hierárquica no financiamento e prestação de serviços de saúde pode ser encontrada em: RIBEIRO, José Mendes. Financiamento e desenho institucional no setor de saúde nos Estados Unidos da América. In: BISOTO JÚNIOR, Geraldo; SILVA, Pedro L. de Barros; DAIN, Sulamis (Orgs.). Regulação do setor de saúde nas Américas: as relações entre o público e o privado numa abordagem sistêmica. Brasília: Organização Pan-Americana da Saúde, 2006. p.181-185.

${ }^{247}$ Essa questão é evidente na área da saúde. Recentemente duas produções audiovisuais trataram do assunto sob perspectivas diversas. Enquanto no filme As Invasões Bárbaras, pode-se perceber a crítica ao sistema de saúde da província de Quebec, no Canadá, em face da demora e limitação na prestação dos serviços, falta de estrutura adequada e atraso tecnológico proporcionados por um sistema público universal e igualitário; na obra SICKO, faz-se uma crítica ao sistema privado de saúde americano, por meio do qual as seguradoras privadas atuam de modo a restringir ao máximo o rol de serviços disponibilizados aos segurados, sob os mais diversos argumentos (AS INVASÕES BÁRBARAS (filme). Direção: Denys Arcand. Produção: Daniel Louis. Canadá; França: Astral Films, 2003. 1DVD (99 min). Distribuição no Brasil: Europa Filmes. SICKO (Filme). Direção: Michael Moore. Produção: Michael Moore. Estados Unidos: Dog eat Dog Films, 2007. 1 DVD (123 min). Distribuição no Brasil: Europa Filmes).

248 ESPING-ANDERSEN, Gosta. As três economias políticas do Welfare State. Revista de Cultura e Política, n.24, set. 1991. p.106. Nesse sentido, já à época do Beveridge Report, assinalou Marques Guedes: "Quando se diz que o Plano estabelece um regime de unificação dos Seguros Sociais não deve concluir-se que os actuais serviços voluntários (a cargo de companhias de seguros, associações de socorros mútuos, montepios, fundos, etc.) desapareçam. Pelo contrário, eles poderão e deverão continuar a existir para os casos em que os segurados queiram suprir ou aumentar os benefícios que possam 
A disciplina e as relações entre Administração Pública e prestadores de serviços de saúde, ao que costuma denominar mix público-privado, tem sido objeto de intensas transformações, especialmente nos últimos anos, como se ilustrou neste Capítulo do trabalho. A Administração Pública brasileira insere-se nesse contexto, ${ }^{249}$ que deve ser levado em conta como parâmetro para a interpretação e aplicação do sistema de saúde previsto pela Constituição Federal de 1988, analisado no Capítulo seguinte.

recolher dos obrigatórios." (GUEDES, Marques. O plano Beveridge. 2.ed. Lisboa: Século, [s.d]. p.178). Casos como esse foram ilustrados acima e questões como a demora no atendimento por meio de sistemas públicos são freqüentes em inúmeros Estados que o adotam. Em recente trabalho, com objetivo de fazer um contraponto às idéias lançadas pelo filme SICKO, mencionado em nota anterior, Michael Tanner analisou diversos sistemas de saúde, nos quais ressaltou, dentre outras dificuldades, a demora do atendimento, em especial nos casos de consulta a especialistas e cirurgias (TANNER, Michael. The grass is not always greener: a look at the national health care systems around the world. Policy Analysis, Washington (DC), n.613, p.1-48, mar. 2008). Nesse sentido, tornou-se clássica a idéia de Michael Lee, segundo a qual o paciente o NHS inglês espera para evitar pagar pelos services, enquanto o paciente privado paga para não esperar (LEE, Michael. Private and National Health Services. Policy Studies Institute, London, 1978. p.21-22).

249 Contexto esse que demonstra ser imprescindível para a garantia a todos do direito à saúde, a participação tanto do Estado (direta ou indiretamente) quanto da iniciativa privada. 


\section{SERVIÇOS PÚBLICOS DE SAÚdE NA CONSTITUIÇÃO BRASILEIRA}

\subsection{CONFORMAÇÃO HISTÓRICA DO MODELO DE ASSISTÊNCIA À SAÚDE NO BRASIL}

O sistema público de saúde brasileiro previsto pela Constituição de 1988 e implantado no início da década de 90 do século passado, marcou o início da transição do sistema bismarckiano de seguros sociais adotado até então para o sistema beveridgeano, denominado no Brasil sistema único de saúde (SUS). Entretanto, ao contrário dos modelos de assistência universal analisados no Capítulo anterior, os serviços de saúde na história do Brasil jamais alcançaram a universalidade de cobertura, de modo que, em termos concretos, pode-se sustentar que a assistência à saúde no Brasil sempre foi muito mais próximo dos sistemas segmentados. ${ }^{250}$

Contudo, a segmentação da assistência à saúde no Brasil também não segue o modelo norte-americano, pois, ao invés de focar seus serviços nas camadas menos privilegiadas, como fazem os Estados Unidos da América, o sistema público de saúde brasileiro, supostamente gratuito e universal, acaba por proporcionar a prestação de serviços de alto nível científico e tecnológico, ${ }^{251}$ inclusive com oferta de medicamentos de alto custo, em grande medida, indistinta e gratuitamente, enquanto é incapaz de oferecer serviços de atenção básica de

250 Tal situação pode ser observada pelo percentual de gastos públicos em saúde no Brasil, cujo montante é pouco superior ao total dos gastos privados, em uma proporção muito próxima daquela apresentada pelos Estados Unidos. Se for considerado o fato de que o Brasil possui um contingente populacional dependente de serviços públicos muito maior do que os países analisados neste trabalho, a desproporção entre o nível de investimento público e a suposta universalidade oferecida pelo sistema público de saúde brasileiro fica ainda mais evidenciada. De acordo com dados recentemente divulgados pela Organização Mundial da Saúde - OMS, os gastos públicos em saúde em relação ao total de gastos em saúde no ano de 2004, em cada um dos países analisados no Capítulo anterior, é o seguinte: Inglaterra 86,3\%, França 78,4\%, Alemanha 76,9\%, Itália 75,1\%, Portugal 71,6\%, Espanha 70,9\%, Canadá 69,8\%, Holanda 62,4\%, Brasil 54,1\% e Estados Unidos da América 44,7\% (WHO - WORLD HEALTH ORGANIZATION. World health statistics 2007. Genebra: WHO Press, 2007). Além disso, o investimento público em saúde no Brasil possui características que o distinguem do sistema americano, que é focado em pessoas que não possuem condições de obter os serviços no mercado.

251 Os serviços de média e alta complexidade compreendem o conjunto de ações e serviços que visam atender problemas de saúde da população e que demandem a disponibilidade de profissionais especializados e a utilização de recursos tecnológicos de apóio diagnóstico e terapêutico que não justifiquem sua oferta em todos os municípios, como por exemplo, os serviços de transplante de órgãos. O tema foi regulamentado pela NOAS/SUS, editada por meio da Portaria GM/MS n. ${ }^{\circ}$ 95, de 26 de janeiro de 2001. 
$s$ úd $^{252}$ às pessoas que deles necessitam e não possuem condições de obtê-los no mercado. ${ }^{253}$ Esta é a observação de André Cezar Médici:

\begin{abstract}
Ao mesmo tempo, o SUS paga verdadeiras fortunas com procedimentos e exames de alta tecnologia que são feitos por grupos de classe média e alta, detentores de planos privados de saúde. Como muitos médicos trabalham ao mesmo tempo no SUS e nos sistemas privados, eles realizam exames e procedimentos mais caros através do SUS e as consultas e demais procedimentos mais baratos pelos planos privados, onde o que vale é o atendimento 'vip'. A economia de recursos privados obtidos com esta prática é a contrapartida da escassez de recursos do SUS para resolver graves problemas como a mortalidade infantil e materna e o recrudescimento das endemias imunopreveníveis no quadro epidemológico do país. ${ }^{254}$
\end{abstract}

Pesquisas de opinião pública comprovam que o principal problema do Brasil é a saúde, como demonstram, por exemplo, recentes dados divulgados pelo Instituto de Pesquisas Datafolha: para vinte e cinco por cento dos brasileiros o setor de saúde configura o principal problema do país. ${ }^{255}$

Outro claro reconhecimento da insuficiência dos serviços públicos de saúde ofertados no Brasil pode ser ilustrado por decisão do Supremo Tribunal Federal, em que se concedeu medida liminar para manutenção de convênio entre determinado órgão público e entidade privada prestadora de serviços de saúde com fundamento no eminente perigo que correriam os servidores públicos caso ficassem sem a referida assistência privada. De um lado, a decisão ilustra a situação vivida pelo Podere Público, caracterizada pelo oferecimento de planos

252 A atenção básica à saúde compreende o conjunto de ações e serviços que devem ser disponibilizados por todos os municípios, de acordo com seu perfil epidemiológico. De acordo com a NOAS/SUS, editada por meio da Portaria GM/MS n. ${ }^{\circ}$ 95, de 26 de janeiro de 2001, fazem parte da atenção básica o controle da tuberculose, a eliminação da hanseníase, o controle da hipertensão arterial e da diabetes mellitus, a saúde da criança, a saúde da mulher e a saúde bucal.

253 A dificuldade em obter atendimento no serviço público no Brasil foi ilustrada por Jairnilson da Silva Paim ao mencionar em determinado artigo que os usuários do SUS não o renegam. Ao tratar dessas pessoas, contou o autor: "Há exceções, dizem até que quem usou o SUS, gosta do SUS. Mas quem usou o SUS muitas vezes estava tão acostumado a ser tão excluído de tantas coisas que acha uma dádiva, depois de uma fila de quatro horas da manhã até meio-dia ou duas da tarde, ser finalmente atendido." (PAIM, Jairnilson da Silva. O pensamento do movimento sanitário: impasses e contradições atuais no marco da relação público-privado no SUS. In: HEIMANN, Luiza S.; IBANHES, Lauro C.; BARBOZA, Renato (Orgs.). O público e o privado na saúde. São Paulo: Hucitec, 2005. p.123).

254 MÉDICI, André Cezar. A economia das reformas em saúde. Porto Alegre: IAHCS, 1997. p.158-159.

255 Pesquisa realizada entre 25 e 28 de novembro de 2008. Além da saúde, foram citados na pesquisa como problemas do Brasil o desemprego (dezoito por cento), segurança (dezesseis por cento), educação (nove por cento), fome e miséria (seis por cento), dentre outros. Dados disponíveis em: $<$ http://datafolha.folha. uol.com.br/po/ver_po.php?session=787. Acesso em: 08 dez. 2008. 
privados de saúde a seus funcionários; ${ }^{256}$ de outro, realça com tons gritantes o reconhecimento da imprestabilidade do SUS para oferecer serviços de saúde aptos a promover, proteger e recuperar tal direito fundamental. Eis o teor de referida medida acautelatória:

\begin{abstract}
A impetrante fundamenta a urgência da pretensão cautelar diante da iminência do término (em 31.12.2006) do atual aplano de saúde e da vigência (a partir de $\left.1 .^{\circ} .01 .2007\right)$ do convênio em questão. Assim, se não concedida a liminar, magistrados e servidores do TST poderão sofrer gravíssimos efeitos na adequada prestação da assistência médico-hospitalar. (...)

Com efeito, evidencia-se a possibilidade de risco irreparável a ser sofrido pelos servidores e magistrados do TST, beneficiários da necessária assistência médico-hospitalar, que poderão ser privados dessa assistência a partir de $1 .^{\circ}$ de janeiro de 2007, data da vigência do convênio em questão, aqui impugnado. (....)..$^{257}$
\end{abstract}

Entender tal situação, caracterizada (i) pela previsão constitucional e legal da prestação pública, universal e integral de serviços, (ii) pela efetiva prestação de serviços de alta complexidade de forma gratuita e (iii) pela oferta insuficiente de serviços básicos, demanda uma análise do processo de formação social e constitucional pátrios, bem como das discussões travadas na Assembléia Constituinte de 1987-1988 - as quais permitem também compreender os motivos de um texto que trata a saúde de modo detalhado e complexo. ${ }^{258}$

Não obstante, se a compreensão do cenário social e constitucional pretéritos configura importante elemento para a análise do direito à saúde - tal qual plasmado no texto constitucional - a interpretação de tal direito a ela não pode ficar preso. Afinal a Constituição é um processo dinâmico e a norma constitucional deve ser interpretada pari passu com a realidade social, econômica e tecnológica atuais. Afinal, como sustenta Friedrich Müller:

256 Tal possibilidade é expressamente prevista na legislação, como se verifica, por exemplo, da Lei n. ${ }^{\circ} 8.112$, de 11 de dezembro de 1990, que dispõe sobre o regime jurídico dos servidores públicos civis da União, das autarquias e das fundações públicas federais. Nos termos da lei em referência: Art. 230. A assistência à saúde do servidor, ativo ou inativo, e de sua família compreende assistência médica, hospitalar, odontológica, psicológica e farmacêutica, terá como diretriz básica o implemento de ações preventivas voltadas para a promoção da saúde e será prestada pelo Sistema Único de Saúde (SUS), diretamente pelo órgão ou entidade ao qual estiver vinculado o servidor, ou mediante convênio ou contrato, ou ainda na forma de auxílio, mediante ressarcimento parcial do valor despendido pelo servidor, ativo ou inativo, e seus dependentes ou pensionistas com planos ou seguros privados de assistência à saúde, na forma estabelecida em regulamento (artigo com redação dada pela Lei n. ${ }^{\circ} 11.302$ de 2006).

257 Supremo Tribunal Federal, Mandado de Segurança n. ${ }^{o}$ 26.330/DF, Medida Cautelar, Relatora Ministra Carmen Lúcia Antunes da Rocha, decisão proferida pelo Ministro Gilmar Mendes, Diário de Justiça da União de 05 de fevereiro de 2007 (os grifos não constam do original).

258 Tanto isso é verdade que em vinte anos de Constituição ainda não se interpretou e regulamentou adequadamente a complementaridade da participação privada no serviço público de saúde. 
(...) a normatividade não é nenhuma propriedade substancial dos textos no código legal, mas um processo efetivo, temporalmente estendido, cientificamente estruturável: a saber, o efeito dinâmico da norma jurídica, que influi na realidade que lhe deve ser atribuída (normatividade concreta) e que é influenciada por essa mesma realidade (normatividade materialmente determinada). ${ }^{259}$

Nesse viés, tem razão Romeu Felipe Bacellar Filho ao sustentar que a suposta morte da Constituição de 1988, mencionada por autores como Celso Antonio Bandeira de Mello e Fabio Konder Comparato como resultado das transformações realizadas em seu texto, ${ }^{260}$ não impede sua ressurreição, no sentido de que o texto constitucional deve ser interpretado hic et nunc. Como ressalta Bacellar Filho: "Ao invés de assistir, com tristeza, aos funerais da Constituição de 1988, como se houvesse um 'réquiem' institucionalizado do Direito, é necessário compreendê-la como um processo de construção diária e, por, isso, inacabado". ${ }^{261}$ Daí a importância da análise promovida na segunda parte deste Item, referente ao direito à saúde na Constituição de 1988, com foco na realidade econômica, social, tecnológica e doutrinária atuais.

O texto de 1988 marcou uma mudança radical na disciplina dos serviços de saúde. ${ }^{262}$ Entretanto, nesses vintes anos passados desde a sua promulgação, o caminho tem sido trilhado vagarosamente, com tropeços e sobressaltos, e mais do que isso, com certa falta de interesse

259 MÜLLER, Friedrich. Concretização da constituição. In: . Métodos de trabalho em direito constitucional. Trad. Peter Naumann. 3.ed. Rio de Janeiro: Renovar, 2005. p.130.

260 Sobre as críticas e suposta morte da Constituição, conferir: MELLO, Celso Antônio Bandeira de. Funerais da Constituição de 1988. In: FIOCCA, Demian; GRAU, Eros Roberto (Orgs.). Debate sobre a constituição de 1988. São Paulo: Paz e Terra, 2001. p.35-47; e COMPARATO, Fábio Konder. Réquiem para uma Constituição. In: FIOCCA, Demian; GRAU, Eros Roberto (Orgs.). Debate sobre a constituição de 1988. São Paulo: Paz e Terra, 2001. p.77-87.

261 BACELLAR FILHO, Romeu Felipe. Direito administrativo e o novo código civil. Belo Horizonte: Fórum, 2007. p.21.

262 O atraso em tal consagração não passou despercebido por José Afonso da Silva que, ao tratar do direito à saúde na primeira edição do Curso de Direito Constitucional Positivo publicada após a Constituição de 1988, assim consignou: "É espantoso como um bem extraordinariamente relevante à vida humana só agora é elevado à condição de direito fundamental do homem." (SILVA, José Afonso da. Curso de direito constitucional positivo. 5.ed. São Paulo: Malheiros, 1989. p.271). Além disso, deve-se ressaltar que tem razão Telma Maria Menicucci, ao assinalar que a ruptura trazida pelo texto de 1988 foi marcada por algumas continuidades, como o caso da relação público-privado (MENICUCCI, Telma Maria G. Público e privado na política de assistência à saúde no Brasil: atores, processos e trajetória. Rio de Janeiro: Fiocruz, 2007. p.33-34). 
político em avançar no percurso. ${ }^{263}$ Embora a direção esteja correta, há que se fazer ajustes para que todas as pessoas, independente de sua condição financeira, tenham condições dignas de receber um tratamento de saúde adequado, ${ }^{264}$ seja por quem for. ${ }^{265}$

\subsubsection{Direito à Saúde na História do Brasil e a Participação da Iniciativa Privada na Prestação de Serviços Voltados à sua Garantia}

A participação privada na prestação de serviços de saúde no Brasil possui características próprias e sua compreensão depende da análise do contexto histórico e social, em especial do modelo de prestação dos serviços de saúde adotado nos anos que antecederam a elaboração da Constituição de 1988. ${ }^{266}$ Além disso, o exame do panorama históricojurídico da prestação de tais serviços no Brasil é relevante para destacar dois fatores importantes ao desenvolvimento deste estudo:

263 Como ilustração de tal ausência de vontade política, pode-se fazer referência a dois artigos publicados no mesmo dia em um jornal de grande circulação nacional. Em um deles, o então Ministro da Saúde José Gomes Temporão sustentava ser inconcebível, após vinte anos da criação do SUS, não ter sido definida uma fonte de recursos definida e estável (TEMPORÃO, José Gomes. O desafio de financiar o SUS. Folha de S. Paulo, São Paulo, 03 de junho de 2008, p.A3). No outro artigo, o Deputado Federal Rafael Guerra concluía: "A saúde não é prioridade política. Não é possível estudar sem saúde, trabalhar sem saúde, viver sem saúde; no entanto, no Brasil, educação é investimento, geração de emprego é investimento, mas a saúde é considerado gasto." (GUERRA, Rafael. SOS saúde. Folha de S. Paulo, São Paulo, 03 de junho de 2008, p.A3).

264 Nesse aspecto, tem razão Lawrence Brown ao afirmar que o respeito à dignidade humana implica que ninguém se abstenha de procurar assistência médica por limitações financeiras ou por medo das conseqüências de tal ato (BROWN, Lawrence. Comparing Health Systems in Four Countries: Lessons for the United States. American Journal of Public Health, v.93, n.1, p.52, January 2003.

265 Claudio Lottenberg, em recente estudo sobre a saúde no Brasil, bem resumiu a questão, firmando opinião com a qual se partilha: "O que aponto como erro é o fato de que alguns segmentos da sociedade, ainda hoje, pensam que o desafio deve procurar e encontrar respostas somente em prestadores de serviços governamentais. Esse direito tem de chegar à população e o governo tem de ser o grande garantidor de que isso será feito plenamente, dentro dos princípios de eqüidade, universalidade e integralidade. Cabe a ele, portanto, a garantia disso. E não necessariamente a prestação do serviço, que pode e deve ser feito por quem tem condições de oferecê-la da melhor forma que puder atingir o cidadão." (LOTTENBERG, Claudio. A saúde brasileira pode dar certo. São Paulo: Atheneu, 2007. p.35).

266 Nesse sentido, ao tratar da efetivação dos direitos fundamentais, tem razão José Carlos Vieira de Andrade, ao consignar que: "As considerações de caráter sociológico assumem aqui uma importância fundamental, não apenas porque a interpretação se desenvolve na aplicação ao caso concreto, mas ainda porque não é legítimo utilizar padrões valorativos alheios à história e à vida real da comunidade." (ANDRADE, José Carlos Vieira de. Os direitos fundamentais na constituição portuguesa de 1976. Coimbra: Almedina, 1987. p.133-134). 
(i) os modelos de organização dos serviços de saúde historicamente adotados pelo Estado brasileiro tiveram como base a prestação privada de serviços;

(ii) os mecanismos de ajuste com a iniciativa privada não foram adequados à prestação eficiente dos serviços.

No plano constitucional, o direito à saúde na história do Estado brasileiro até 1988

pode ser resumido em breves linhas. ${ }^{267}$ Seguindo o padrão europeu e norte-americano da época, tanto a Constituição Imperial de 1824268 quanto a Constituição da República de $1891^{269}$ delimitaram as tarefas do Estado brasileiro e não fizeram qualquer menção à

267 Antes disso, no período que antecedeu ao surgimento da independência, a aliança entre o reino de Portugal e Igreja católica na Europa, até meados do século XVIII, fez com que no território brasileiro a Igreja exercesse durante séculos importante papel na ordem civil e assistencial. A assistência aos necessitados e enfermos era prestada em grande medida por confrarias - organizações de participação coletiva reconhecidas pelo direito civil e eclesiástico, criadas no entorno de capelas para ajuda mútua e prestação de auxílio aos necessitados e doentes. Dentre elas, destaca-se a atuação das Irmandades de Misericórdia - responsáveis pela instalação do que vieram a ser os primeiros hospitais em solo brasileiro, como a Santa Casa de Misericórdia de Santos, fundada em 1543 e outras que a seguiram, como a do Espírito Santo, Bahia, Rio de Janeiro e São Paulo. Tais empreendimentos contavam com o apoio da Coroa portuguesa e eram mantidas tanto com dotações do reino quanto com doações de particulares. Sobre o tema: BERTOLLI FILHO, Cláudio. História da saúde pública no Brasil. 4.ed. São Paulo: Ática, 2008. p.11; LANDIN, Leilah. Para além do mercado e do estado?: filantropia e cidadania no Brasil. Rio de Janeiro: ISER, 1993. p.12-16.

268 Na Constituição de 1824, havia a previsão geral, no artigo 179, XXIV, a exemplo do que constava da Constituição Francesa de 1791, de garantia geral dos socorros públicos, e no inciso XXXI do mesmo artigo, a saúde como limitação da liberdade ao trabalho, cultura, indústria e comércio. Em obra originalmente editada em 1857, José Antônio Pimenta Bueno, ao comentar a previsão da garantia dos socorros públicos, afirmava que não havia o dever estatal de sustentar ou manter particulares em circunstâncias ordinárias, mas apenas e tão somente em casos excepcionais e de calamidades, como incêndios, inundações e secas. Por outro lado, segundo o autor, além dos seguros diretos (excepcionais), devia o Estado auxiliar os hospitais de caridade, asilos e outros estabelecimentos pios (BUENO, José Antônio Pimenta. Direito público brasileiro e a análise da constituição do Império. Brasília: Senado Federal, 1978. p.431).

269 É importante ressaltar que a Constituição de 1891 marcou a separação entre o poder temporal e o poder eclesiástico, proibindo quaisquer subvenções oficiais e parcerias entre o poder público e as Igrejas. Nesse período, as entidades vinculadas às Igrejas mantiveram seu protagonismo na prestação de serviços de saúde, financiadas, sobretudo, pela caridade individual. O próprio imperador D. Pedro II prestava relevante auxílio pessoal a atividades de assistência a necessitados, tanto que após a proclamação da República, por meio do Decreto . $^{\circ}$ 5, de 19 de novembro de 1889, ao fím de manter a sobrevivência dos beneficiados pelo auxílio real, o Estado assumiu tais contribuições. Ressalte-se também que, ao lado das entidades ligadas às Igrejas, importante papel na prestação de serviços de saúde foi assumido à época por sociedades beneficentes de auxílio mútuo, criadas por grupos de imigrantes para prestar assistência e amparo a seus associados desempregados, enfermos e inválidos. Durante o século XX, a participação de entidades sem fins lucrativos teve relevante papel na prestação de serviços de saúde, impulsionado por novos mecanismos de incentivo estatal, os quais serão analisados no capítulo seguinte. 
prestação de serviços de saúde. Apenas a partir da Constituição de 1934270 a saúde passou a constar dos sucessivos textos constitucionais brasileiros, em dispositivos que outorgavam competência legislativa para sua regulamentação e a previam como direito dos trabalhadores. ${ }^{271}$ Nesse cenário, nenhum texto constitucional anterior a 1988 fez menção às hipóteses de participação privada dos serviços em referência.

Assim, considerando que a garantia da saúde como direito de todas as pessoas e a organização dos serviços de saúde foram incorporados à ordem constitucional brasileira apenas em 1988, as atividades estatais relacionadas ao serviço de saúde até então promovidas eram disciplinadas pela legislação infraconstitucional. ${ }^{272}$

270 Em passagem da época, Pacheco e Silva, membro da Assembléia Nacional Constituinte de 1934, defendeu a assunção pelo Estado da responsabilidade por assegurar o direito à saúde: "O desenvolvimento inaudito que a medicina, de par com as ciências naturais, tomou no decurso do século XIX, os progressos da física, da química e da biologia se refletem hoje em todos os campos da atividade humana, exigindo que a atenção do legislador moderno se volte para os problemas médico-sociais. Assim, o poder público, pela elevada tutela de que está investido, é obrigado a empenhar os maiores esforços na conservação da saúde do povo, e a este assiste um novo direito - o direito à saúde, e nós não podemos deixar de incluir na nossa magna Carta as garantias desse mesmo direito, dando assim ao povo brasileiro uma prova de elevado sentimento de solidariedade humana, além de despertar para eles a atenção dos legisladores do futuro, cuja missão será a de completar a obra que aqui se vai esboçar." (SILVA, Antônio Carlos Pacheco e. Direito à saúde (documentos da atividade parlamentar). [s.1.]: [s.n.], 1934. p.12).

271 Antes de 1988, dentre os principais dispositivos constitucionais acerca do tema, merecem menção os seguintes. Na Constituição de 1934: Art. 10 - Compete concorrentemente à União e aos Estados: II - cuidar da saúde e assistência públicas; Art. 121 - (...). § 1. ${ }^{\circ}$ A legislação do trabalho observará os seguintes preceitos (...): h) assistência médica e sanitária ao trabalhador e à gestante (...). Na Constituição de 1937: Art. 16 Compete privativamente à União o poder de legislar sobre as seguintes matérias: XXVII - normas fundamentais da defesa e proteção da saúde, especialmente da saúde da criança; Art. 18 - Independentemente de autorização, os Estados podem legislar (...) sobre os seguintes assuntos: c) assistência pública, obras de higiene popular, casas de saúde, clínicas, estações de clima e fontes medicinais. Art. 137 - A legislação do trabalho observará, além de outros, os seguintes preceitos: 1) assistência médica e higiênica ao trabalhador e à gestante (...). Na Constituição de 1946: Art. 5. ${ }^{\circ}$ - Compete à União: XV - legislar sobre: b) normas gerais (...) de defesa e proteção da saúde; e de regime penitenciário; Art. 157 - A legislação do trabalho e a da previdência social obedecerão nos seguintes preceitos (...): XIV - assistência sanitária, inclusive hospitalar e médica preventiva, ao trabalhador e à gestante. Na Constituição de 1967: Art. 8. ${ }^{\circ}$ - Compete à União: (...) XIV estabelecer planos nacionais de educação e de saúde; (...) XVII - legislar sobre: (...) c) Normas gerais (...) de defesa e proteção da saúde (...); Art. 158 - A Constituição assegura aos trabalhadores (...) 1: (...) XV assistência sanitária, hospitalar e médica preventiva; (...) Art 178 - Ao ex-combatente da Força Expedicionária Brasileira, (...) são assegurados os seguintes direitos: (...) f) assistência médica, hospitalar e educacional, se carente de recursos. Na Constituição de 1969: Art. 8. ${ }^{\circ}$ - Compete à União: (...) XIV - estabelecer e executar planos nacionais de educação e de saúde, (...); XVII - legislar sobre: c) normas gerais (...) de defesa e proteção da saúde; Art. 165 - A Constituição assegura aos trabalhadores os seguintes direitos, (...): XV - assistência sanitária, hospitalar e médica preventiva; Art. 197 - Ao civil, ex-combatente da Segunda Guerra Mundial, (...) são assegurados os seguintes direitos: d) assistência médica, hospitalar e educacional, se carente de recursos.

272 Não se pode negar a existência de previsões legais acerca do direito à saúde e do dever do Estado em sua proteção, como se verifica, por exemplo, da Lei n. ${ }^{\circ} 2.312$ - de 3 de setembro de 1954 , que assim dispunha: Art. 1. ${ }^{\circ}$ É dever do Estado, bem como da família, defender e proteger a saúde do indivíduo. Não obstante, previsões que tais, como se verifica da análise adiante levada a cabo, não se concretizaram de modo universal e igualitário. 
3.1.1.1 Do surgimento do sistema bismarckiano à privatização dos serviços de saúde

O Decreto n. ${ }^{\circ}$ 4.682, de 24 de janeiro de 1923, conhecido como Lei Eloy Chaves, é tido como marco inicial da regulamentação pelo Estado brasileiro de atividades de proteção social, que incluíam a prestação de serviços de saúde, que até então era realizada por entidades ligadas às Igrejas e por grupos de imigrantes ou de profissionais de determinadas áreas. ${ }^{273}$ Por meio da referida lei, seguida de outras no mesmo sentido, foram regulamentadas as Caixas de Assistência e Pensão (CAPS) que haviam sido criadas por grupos específicos de trabalhadores de determinadas empresas, sob a forma de seguro social, adotado no resto do mundo à época. ${ }^{274}$ Em 1933 passaram a ser criados Institutos de Aposentadorias e Pensões (IAPs), de natureza autárquica e abrangendo não apenas funcionários de uma empresa, mas toda a categoria profissional, com financiamento baseado tanto na contribuição de empregados e empregadores quanto por recursos públicos.

Com o Decreto n. ${ }^{\circ} 72$, de 21 de novembro de 1966, foram unificados todos os Institutos de Aposentadorias e Pensões, que perderam sua personalidade jurídica e foram incorporados como órgãos do então criado Instituto Nacional de Previdência Social (INPS). O INPS era vinculado ao Ministério do Trabalho e gerenciava aposentadorias e pensões, sendo também responsável pela assistência médica individual dos trabalhadores formais, excluídos os rurais e os do mercado informal de trabalho. ${ }^{275}$

273 Até esse momento, além da prestação de serviços de saúde por iniciativa da própria sociedade, segundo Gilson Carvalho, existiam alguns hospitais públicos instituídos no Brasil a partir do século XVIII e que serviam ao ensino da medicina. Segundo o autor, a presença do financiamento por parte do Estado foi no sentido primeiro de favorecer a elite do próprio Estado e de sua força militar, montando seus hospitais e serviços de saúde paralelamente às Santas Casas de Misericórdia (CARVALHO, Gilson. O financiamento público da saúde no bloco de constitucionalidade. In: ARANHA, Márcio Iório (Org.). Direito sanitário e saúde pública: coletânea de textos. Brasília: Ministério da Saúde, 2003. v.1. p.308).

274 O Decreto em referência previa a criação de uma Caixa de Aposentadoria e Pensões para os empregados de cada empresa de estrada de ferro existente no país. Cada CAP deveria ser gerida por representantes da empresa e dos empregados e tinha seu patrimônio formado por contribuição de empregados, empregadores e de parte do valor das tarifas das estradas de ferro. Incluía, dentre os benefícios previdenciários, socorros médicos em caso de doença ao membro da CAP e a pessoa de sua família que vivesse sob o mesmo teto.

275 Apenas na década de 70 do século passado, foram incluídos trabalhadores rurais (1971), os empregados domésticos (1972) e os autônomos (1973). 
Esse ponto deve ser ressaltado: ainda que as CAPs, os IAPs e o INPS tivessem investido parte de seus recursos na construção e manutenção de estruturas voltadas à prestação de serviços de saúde, a grande maioria de prestadores era privada, sendo que após a década de 60 do século passado, com a unificação das entidades pelo INPS, com a exclusão dos trabalhadores do processo decisório, a influência de interesses estatais corporativos e de interesses empresariais privados determinou o que se costuma chamar de um modelo médicoassistencial privatista, ${ }^{276}$ com base no fomento à prestação de serviços, ${ }^{277}$ por meio de entidades privadas credenciadas. ${ }^{278} \mathrm{Na}$ opinião de Ligia Giovanella e Sonia Fleury, o modelo de assistência à saúde instalado no Brasil, com base em ações médico-hospitalares individuais, possuía caráter privatista e excludente:

Privatista, por privilegiar a contratação, pelo Instituto Nacional de Previdência
Social, do setor privado para a prestação de serviços médicos, principalmente
hospitalares, garantindo diretamente a expansão de empresas de serviços médicos
e, indiretamente, a capitalização da indústria farmacêutica e de equipamentos
médicos. Excludente, por guardar as características do modelo de seguro que
condicionam o direito à assistência médica à contribuição prévia, excluindo do
acesso milhões de brasileiros não vinculados ao mercado formal de trabalho, não
contribuintes da Previdência Social. ${ }^{279}$

276 LIMA, Juliano de Carvalho. História das lutas sociais por saúde no Brasil. Trabalho Necessário, ano 4, n.4, 2006. Disponível em: <http://www.uff.br/trabalhonecessario/ Juliano\%20TN4.htm>. Acesso em: 11 ago. 2008.

277 COHN, Amélia; NUNES, Edison; JACOBI, Pedro R.; KARSH, Ursula S. A saúde como direito e como serviço. 5. ed. São Paulo: Cortez, 2008. p.15; e ACIOLE, Geovani Gurgel. A saúde no Brasil: entre o estado e o mercado. 2005. Tese (Doutorado) - Universidade Estadual de Campinas, Faculdade de Ciências Médicas, São Paulo, 2005. p.167. Como exemplo do incentivo à iniciativa privada pode-se citar o Fundo de Apoio ao Desenvolvimento Social (FAS), criado pela Lei n. ${ }^{\circ} 6.168$, de 9 de dezembro de 1974, regulamentado pelo Decreto n. ${ }^{\circ} 75.508$, de 18 de março de 1975 , por meio do qual foram financiados projetos de construção e expansão de inúmeros hospitais privados no país.

278 Deve ser mencionada também, como incentivo à prestação privada de serviços de saúde, o Decreto-Lei n. ${ }^{\circ} 73$, de 21 de novembro de 1966, que criou o sistema nacional de seguros privados, a partir do qual foram firmados os denominados convênios-empresa, por meio dos quais a empresa assumia a responsabilidade de prover assistência médica a seus funcionários, tendo como incentivo estatal a dispensa do recolhimento de contribuições previdenciárias. Tal modalidade de ação foi impulsionada em 1974, com o Plano de Pronta Ação (PPA), que incentivou a ampliação da cobertura assistencial à saúde. De acordo com Telma Maria Menicucci, como resultado do PPA houve um aumento no número de serviços médicos prestados, com aceleração dos contratos de prestação de serviços com o setor privado (MENICUCCI, Telma Maria G. Público e privado na política de assistência à saúde no Brasil: atores, processos e trajetória. Rio de Janeiro: Fiocruz, 2007. p.93).

279 GIOVANELLA, Ligia; FLEURY, Sonia. Universalidade da atenção à saúde: acesso como categoria de análise. In: EIBENSCHUTZ, Catalina (Org.). Política de saúde: o público e o privado. Rio de Janeiro: Fiocruz, 1996. p.179-180. Tal situação é exemplo agudo que pode ser inserido em um quadro geral de conformação de todo o direito brasileiro nas décadas anteriores à Constituição de 1988, como assinalou 
A Lei n. ${ }^{\circ}$ 6.229, de 17 de julho de 1975, criou o Sistema Nacional de Saúde e acabou por consagrar um modelo dúplice de saúde individual e de saúde coletiva: enquanto o Ministério da Saúde (MS) detinha competência para formular a política nacional de saúde e promover ou executar ações preferencialmente voltadas para as medidas e os atendimentos de caráter coletivo, o Ministério da Previdência e Assistência Social (MPAS) que incorporou o INPS, tinha sua atuação direcionada ao atendimento médico-assistencial individualizado. ${ }^{280}$ Alguns anos depois, por meio da Lei . $^{\circ} 6.439$, de $1 .^{\circ}$ de setembro de 1977 , foi criado o Instituto Nacional de Assistência Médica da Previdência social (INAMPS), também vinculado ao MPAS e com competência para a prestação de assistência médica de acordo com modelo até então adotado. ${ }^{281}$

Não obstante, em face da ausência de uma política clara na área da saúde e da falta de mecanismos legais que definissem os deveres dos prestadores, a participação privada na saúde tornou-se conhecida como fonte de desvios. ${ }^{282}$ A grande expansão no número de leitos

Antonio Carlos Wolkmer: "As diretrizes que alimentaram o Direito Público, na década de 60 [do século $\mathrm{XX}$ ], foram geradas pelas cartas constitucionais centralizadoras, arbitrárias, ilegítimas e antidemocráticas (1967 e 1969), cuja peculiaridade foi reproduzir a aliança conservadora da burguesia agrária/industrial com parcelas emergentes de uma tecnoburocracia civil e militar." (WOLKMER, Antonio Carlos. História do direito no Brasil. 4.ed. Rio de Janeiro: Forense, 2007. p.144-145).

280 Dentre as atribuições do MPAS, voltadas ao atendimento individualizado, constavam: (i) credenciar, para integrarem o subsistema público, instituições de finalidade não lucrativa que prestem serviços de saúde às pessoas; e (ii) prestar diretamente serviços de saúde às pessoas, ou contratá-los com entidades de fins lucrativos ou não, sujeitando-as a fiscalização permanente. Tal orientação, de incentivo à criação e utilização de serviços oferecidos pela iniciativa privada já constava da Lei n. ${ }^{\circ} 2.312$, de 3 de setembro de 1954 , que dispunha sobre normas gerais de defesa e proteção à saúde. No artigo $6 .^{\circ}$ de tal lei, constava que: o governo estimulará e ajudará financeiramente a iniciativa privada, que com ele colaborará, nos serviços de saúde e de assistência, dentro da orientação traçada pelos órgãos competentes. Na regulamentação da referida lei, pelo Decreto n. ${ }^{\circ} 49.974-A$, de 21 de Janeiro de 1961, reafirmou-se o estímulo à iniciativa privada e estabeleceu-se como mecanismo o convênio, figura até então referida na legislação como vínculo a ser celebrado entre unidades federativas. Tal inovação consta do $\S 1 .^{\circ}$ do artigo $7 .^{\circ}$ do decreto em referência, o qual dispunha que: o governo poderá subvencionar a iniciativa privada de reconhecido mérito para a execução de serviços de saúde, firmando convênios para esse fim e exercendo a fiscalização do fiel cumprimento destes. Em seguida, no $\S 2 .^{\circ}$ do mesmo artigo $7 .^{\circ}$, o decreto refere-se a dispositivos contratuais, o que demonstra clara referencia à natureza contratual dos convênios citados no parágrafo anterior. A análise do convênio como modelo de ajuste a disciplinar a participação privada nos serviços públicos de saúde após a Constituição Federal de 1988 será promovida no Item 4.3.1.1.2.

281 Enquanto a prestação de serviços passou à competência do INAMPS, o INPS foi mantido, nos termos da Lei n. ${ }^{\circ} 6.439 / 77$, com competência restrita à concessão e manutenção de benefícios previdenciários e outras prestações em dinheiro.

282 Segundo Cláudio Bertolli Filho, no período foram firmados convênios com 2.300 dos 2.800 hospitais instalados no Brasil. Entretanto, segundo o autor: "Os baixos preços pagos pelos serviços médicohospitalares e a demora na transferência das verbas do INPS para as entidades conveniadas determinaram a fragilidade desse sistema de atendimento à população. Enquanto o governo reduzia ou atrasava os 
disponíveis e de recursos investidos na área da saúde não foi determinada por políticas públicas, mas por interesses mercadológicos dos prestadores privados dos serviços. Assim, ao invés de participar do serviço público de saúde, as prestadoras privadas, sem um vínculo adequado com o Estado, definiam qual era o serviço público de saúde a ser prestado, com ênfase nas atividades de medicina curativa. Dessa forma, não raro encontram-se autores sustentando que os prestadores privados, interessados em ampliar a prestação de seus serviços, é que definiam a própria política pública de saúde. ${ }^{283}$

Essa situação gerou uma dependência recíproca entre Estado e prestadores privados de serviços de saúde, a qual foi abalada pela crise econômica dos anos 80 do século XX. Tal situação - somada (i) à delimitação das pessoas com acesso aos serviços públicos de saúde; (ii) à superposição e desarmonia entre instâncias públicas voltadas à organização dos serviços; (iii) à crise do modelo econômico adotado pelo país; (iv) ao aumento de custos da medicina; e (v) ao aumento da população urbana - configurou o pano de fundo para um movimento de transformação no modelo de assistência à saúde no Brasil.

3.1.1.2 Transição para o sistema beveridgeano: o movimento sanitário e a Assembléia Constituinte de 1987-1988

Nascido na década de 70 do século passado, o assim conhecido movimento sanitário desempenhou importante papel na conformação da disciplina constitucional da saúde hoje vigente. Uma das bandeiras do movimento sanitário era a estatização dos serviços, de modo que o Estado efetivamente assumisse a gestão sistematizada e a prestação dos serviços de saúde, que até então eram objeto de domínio da iniciativa privada.

recursos para a rede conveniada, hospitais e clínicas aumentavam as fraudes para receber aquilo que tinham direito e muito mais. Guias de internação falsificadas, cirurgias desnecessárias e a prática da cesariana em vez do parto normal passaram a ser mecanismos comuns de fraude." (BERTOLLI FILHO, Cláudio. História da saúde pública no Brasil. 4.ed. São Paulo: Ática, 2008. p.55). Assim, a prevalência do atendimento das Santas Casas de Misericórdia, que segundo Elizabeth Barros, até a década de 1960 respondiam por $60 \%$ do total de leitos hospitalares no país, passou a ter a companhia de entidades privadas, que se à época detinham cerca de $10 \%$ dos leitos disponíveis, em 1975, esse número correspondia a $31 \%$ do total (BARROS, Elizabeth. Financiamento do sistema de saúde no Brasil: marco legal e comportamento do gasto. Brasília: OPAS: Ministério da Saúde, 2003. p.20).

283 Na crítica de Juarez de Queiroz Campos, havia uma política sanitária paternalista aliada a uma atuação privada capitalista imediatista, selvagem e inconseqüente (CAMPOS, Juarez de Queiroz. Políticas e sistemas de saúde. São Paulo: Jotacê, 1993. p.9). 
Na Oitava Conferência Nacional de Saúde (VIII CNS), ${ }^{284}$ realizada em 1986, as discussões giraram em torno do que se denominou estatização imediata ou da estatização progressiva, tendo prevalecido a idéia de estatização progressiva - expressão essa que demonstra, como assinalou Jairnilson da Silva Paim, que a discussão teve como principal foco reforçar o papel do Estado na gestão dos serviços de saúde e a sua responsabilidade pela efetiva prestação dos serviços às pessoas. ${ }^{285}$ Uma passagem do Relatório Final da Conferência ilustra o resultado a que se chegou quanto ao modelo de participação privada nos serviços de saúde:

A questão que talvez mais tenha mobilizado os participantes e delegados foi a
natureza do novo Sistema Nacional de Saúde: se estatizado ou não, de forma
imediata ou progressiva. A proposta de estatização imediata foi recusada,
havendo consenso sobre a necessidade de fortalecimento e expansão do setor
público. Em qualquer situação, porém, ficou claro que a participação do
setor privado deve-se dar sob o caráter de serviço público 'concedido' e o
contrato regido sob as normas de Direito Público. ${ }^{286}$

Note-se que, já naquela época, a idéia era da submissão dos interesses dos prestadores privados às políticas públicas - daí as intensas discussões na Assembléia Constituinte, realizada nos anos que se seguiram, acerca dos mecanismos aptos a instrumentalizar o ajuste do Estado com a iniciativa privada e proporcionar a ordenação estatal dos serviços de saúde. 287

284 As Conferências Nacionais de Saúde foram instituídas pelo artigo 90 da Lei n. ${ }^{\circ}$ 378, de 13 de janeiro de 1937. A Oitava Conferência Nacional de Saúde foi convocada pelo Decreto n. ${ }^{\circ} 91.466 / 1985$ e tinha como temário, dentre outros, a reformulação do Sistema Nacional de Saúde. Atualmente denominadas de Conferências de Saúde, elas têm sua convocação a cada quatro anos, conforme determina o artigo $1 .^{\circ}$ da Lei n. ${ }^{\circ} 8.412 / 90$.

285 PAIM, Jairnilson da Silva. O pensamento do movimento sanitário: impasses e contradições atuais no marco da relação público-privado no SUS. In: HEIMANN, Luiza S.; IBANHES, Lauro C.; BARBOZA, Renato (Orgs.). O público e o privado na saúde. São Paulo: Hucitec, 2005. p.114.

286 BRASIL. Ministério da Saúde. VIII Conferência Nacional de Saúde. Relatório final. Brasília: Ministério da Saúde, 1986. Disponível em: <http://portal.saude.gov.br/portal/ arquivos/pdf/8_CNS_Relatorio\% 20Final.pdf $>$. Acesso em: 26 jul. 2008.

287 A desordem no setor de saúde foi relatada na Mensagem do Poder Executivo n. ${ }^{\circ}$ 360/89, que encaminhou o projeto do que veio a ser a Lei n. ${ }^{\circ} 8.080 / 90$. No texto encaminhado pela Presidência da República consta expressamente que: "(...) houve, em verdade, nos anos subseqüentes [ao ano de 1963], uma reversão das expectativas, com a concentração e a expansão previdenciária e a intervenção vertical do Ministério da Saúde, em processo de centralização e burocratização, caracterizado, inclusive, pela proliferação de organismos encarregados da prestação de assistência à saúde. A isto agregou-se o fenômeno da dispersão e superposição de atividades institucionais, públicas e privadas, configurando-se situação cuja correção se impunha, como se intentou com a instituição do programa dos Sistemas Unificados e Descentralizados de Saúde (SUDS), através do Decreto n. ${ }^{\circ}$ 94.657, de 20 de julho de 1987". Referido programa teve como foco a descentralização da assistência à saúde por meio de convênios interfederativos entre a União e os Estados-membros e é tido como um passo importante rumo à criação do sistema único de saúde pela Constituição de 1988. Na síntese de Lenir Santos e Luiz 
A idéia do movimento sanitário era a de que, por meio de contratos de direito público, devidamente firmados, o serviço privado prestado no âmbito do sistema público de saúde seria adequadamente prestado, efetivamente controlado e devidamente fiscalizado pelo Estado. ${ }^{288}$ A estatização defendida, incluía, portanto, a participação privada nos serviços públicos de saúde, ainda que no Relatório Final da Conferência constassem como objetivos a estatização progressiva e a possibilidade de exclusão da prestação em caráter privado dos serviços de saúde. 289

Recentemente, em entrevista acerca da mobilização pela saúde na década de 80 do século passado, Sonia Fleury reconheceu o distanciamento da realidade que permeava setores mais radicais do movimento sanitário, que defendiam a estatização da saúde:

\begin{abstract}
Acho que nós, de toda a esquerda, tínhamos uma visão bastante ingênua de que seria possível um sistema estatal, quando a base material já era toda privada, então, era desconhecer a realidade, a não ser que se nacionalizasse, acabasse com o setor privado, o que seria uma intervenção de uma brutalidade enorme. Ou seja, quando nós vamos para o movimento de criar o sistema único, com base material privada, tinha que ser através de convênios. E essa foi uma tensão muito grande porque nos dividia. Aqueles mais à esquerda achavam que tinha que ser estatal e aí a gente começa a perceber que era impossível, que era melhor negociar e incorporar o setor das filantrópicas. 290
\end{abstract}

Odorico de Andrade, o SUDS acolhia as seguintes idéias da VIII Conferência Nacional de Saúde, em seguida incorporadas pelo SUS: "a) unificação das ações e serviços de saúde dispersos entre vários ministérios, desarticulados e compartimentados; b) organização administrativa descentralizada e integrada; c) direito à saúde independente de o cidadão ser ou não um trabalhador participante do regime geral da Previdência Social; d) princípios e diretrizes únicos; e e) financiamento integrado e intergovernamental." (SANTOS, Lenir; ANDRADE, Luiz Odorico M. de. SUS: o espaço da gestão inovada e dos consensos interfederativos: aspectos jurídicos, administrativos e financeiros. Campinas: Instituto de Direito Sanitário Aplicado, 2007. p.32).

288 Como ressalta Telma Maria Menicucci, a idéia do movimento sanitário ao defender a "adoção do contrato público como regra jurídica de relacionamento entre o Poder Público e as instituições privadas de assistência médica tinha como objetivo definir a soberania do Poder Público e do interesse coletivo em detrimento de interesse particulares" (MENICUCCI, Telma Maria G. Público e privado na política de assistência à saúde no Brasil: atores, processos e trajetória. Rio de Janeiro: Fiocruz, 2007. p.193).

289 Ao tratar do tema da Reformulação do Sistema Nacional de Saúde, consta do Relatório Final da Conferência que: "O principal objetivo a ser alcançado é o Sistema Único de Saúde, com expansão e fortalecimento do setor estatal em níveis federal, estadual e municipal, tendo como meta uma progressiva estatização do setor. Os prestadores de serviços privados passarão a ter controlados seus procedimentos operacionais e direcionadas suas ações no campo da saúde, sendo ainda coibidos os lucros abusivos". Para tanto, ao tratar das relações entre o setor público e privado, a idéia firmada era a de estabelecer um novo contratopadrão, redigido sob os princípios do DIREITO PÚBLICO, passando o serviço privado a ser concessionário do Serviço público (BRASIL. Ministério da Saúde. VIII Conferência Nacional de Saúde. Relatório final. Brasília: Ministério da Saúde, 1986. Disponível em: <http://portal.saude.gov.br/portal/ arquivos/pdf/8_CNS_Relatorio\%20Final.pdf $>$. Acesso em: 26 jul. 2008).

290 BRASIL. Ministério da Saúde. Secretaria de Gestão Estratégica e Participativa. A construção do SUS: histórias da reforma sanitária e do processo participativo. Brasília: Ministério da Saúde, 2006. p.93. 
Na Assembléia Constituinte, ${ }^{291}$ instalada no ano subseqüente ao da VIII CNS, a elaboração do anteprojeto disciplinando o direito à saúde foi atribuída à Subcomissão de Saúde, Seguridade e Meio-Ambiente, uma das três subcomissões da Comissão da Ordem Social. Pode-se dizer que as discussões foram levadas a cabo sob a pressão de dois grandes grupos de interesse: (i) a do movimento sanitário, vinculado à ala esquerdista da época, na defesa da estatização progressiva da saúde e (ii) a da iniciativa privada, ligada à ala - à época denominada centrão e contrária à estatização de tais serviços. ${ }^{292}$ Além desses, tiveram relevo nas discussões o grupo corporativo estatal e o grupo das entidades filantrópicas.

Das discussões, pode-se perceber que grande parte das idéias defendidas pelo movimento sanitário foram incorporadas ao anteprojeto apresentado pela Subcomissão, no qual constava que:

(i) as ações de saúde configuram função de natureza pública;

(ii) o setor privado pode colaborar, mediante contrato de direito público, com as ações públicas de saúde;

(iii) têm preferência nessa colaboração as entidades sem fins lucrativos; e

(iv) é livre o exercício das atividades privadas de saúde, obedecidos os princípios da política nacional de saúde. ${ }^{293}$

Encaminhado o projeto à Comissão da Ordem Social, a saúde foi inserida no Capítulo da Seguridade Social, ao lado da Previdência e da Assistência Social. Em relação ao texto anterior:

291 Sobre o processo constituinte, conferir: PILATTI, Adriano. A constituinte de 1987-1988: progressistas, conservadores, ordem econômica e regras do jogo. Rio de Janeiro: Lumen Júris, 2008.

292 A leitura dos discursos proferidos na defesa de uma ou outra posição demonstra claramente tal o confronto entre estatização e privatização - Diário da Assembléia Nacional Constituinte. Disponível em: $<$ http://www.senado.gov.br/anais/>.

293 Expressamente no que se refere à participação privada, o texto apresentado assim dispunha: Art. $4 .^{\circ}$ As ações de saúde são funções de natureza pública, cabendo ao Estado sua normatização, execução e controle. $\S 1 .^{\circ} \mathrm{O}$ setor privado de prestação de serviços de saúde pode colaborar na cobertura assistencial à população, sob as condições estabelecidas em contrato de Direito Público, tendo preferência e tratamento especial as entidades sem fins lucrativos. (...) Art. $6 .^{\circ}$ É assegurado o livre exercício da atividade liberal em saúde e a organização dos serviços de saúde privados, obedecidos os preceitos técnicos determinados pela Lei e os princípios que norteiam a política nacional de saúde (os grifos não constam do original). 
(i) foi mantida a natureza pública das ações de saúde;

(ii) foi alterado o termo para definir a forma de participação privada no sistema de saúde, de colaboração para complementaridade, com a manutenção do vínculo por meio de contrato de direito público;

(iii) a preferência na participação privada passou a ser das entidades filantrópicas;

(iv) foi mantida a liberdade profissional na área da saúde; e

(v) foi expressamente vedada a destinação de recursos públicos à instituições privadas com fins lucrativos. ${ }^{294}$

Após uma série de emendas, a Comissão de Sistematização encaminhou ao Plenário projeto em que:

(i) suprimiu-se a menção à natureza pública das ações de saúde;

(ii) foi novamente alterado o termo para definir a forma de participação privada no sistema de saúde, a complementaridade foi trocada pela supletividade, com a manutenção do vínculo por meio de contrato de direito público;

(iii) a preferência na participação privada passou a ser tanto das entidades sem fins lucrativos quanto das filantrópicas;

(iv) foi mantida a liberdade profissional na área da saúde; e

(v) foi mantida a vedação à destinação de recursos públicos a instituições privadas com fins lucrativos. ${ }^{295}$

No Plenário, foi bastante discutida a natureza pública dos serviços de saúde, bem como as conseqüências de tal qualificação nas relações entre o Estado e a iniciativa privada,.

294 No que interessa a este estudo, o texto apresentado assim dispunha: Art. 55. As ações de saúde são de natureza pública, cabendo ao Estado sua regulação, execução e controle. Art. 56. É assegurada, na área da saúde, a liberdade de exercício profissional e de organização de serviços privados, na forma da lei e de acordo com os princípios da política nacional de saúde. $§ 1 .^{\circ}$ É vedada a destinação de recursos públicos para o investimento em instituições privadas de saúde com fins lucrativos. $\S 2 .^{\circ} \mathrm{O}$ setor privado de prestação de serviços de saúde pode participar de forma complementar na assistência à saúde da população sob as condições estabelecidas em contrato de direito público tendo preferência e tratamento especial as entidades filantrópicas (os grifos não constam do original).

295 Ao tratar das hipóteses de participação privada, assim expressava o projeto: Art. 232. (...) § 2. ${ }^{\circ}$ É vedada a destinação de recursos públicos para investimentos em instituições privadas de saúde com fins lucrativos. Art. 234. Cabe ao poder público a regulamentação, a execução e o controle das ações e serviços de saúde. $\S 1 .^{\circ}$ A assistência à saúde é livre à iniciativa privada que poderá participar de forma supletiva do sistema único de saúde, sob as condições estabelecidas em contrato de direito público, tendo preferência as entidades filantrópicas e sem fins lucrativos (os grifos não constam do original). 
Após uma série de propostas substitutivas apresentadas por diversos grupos, em linhas gerais, quanto à participação privada, pode-se dizer que:

(i) foi mantida a liberdade profissional na área da saúde, caracterizada como atividade de relevância pública;

(ii) foi restabelecida a forma de participação privada complementar no sistema de saúde, mas agora não apenas por meio de contratos de direito público, mas também de convênios; tal possibilidade de participação privada passou a ser prevista em dois dispositivos, que foram mantidos na versão final aprovada;

(iii) foi mantida a preferência na participação privada às entidades sem fins lucrativos e às filantrópicas; $\mathrm{e}$

(iv) foi mantida a vedação à destinação de recursos públicos a instituições privadas com fins lucrativos. ${ }^{296}$

Sem importantes alterações de conteúdo, em segunda votação foi aprovado o texto final que trata da participação privada na prestação de serviços de saúde, até hoje vigente. ${ }^{297}$

Esse foi o caminho percorrido até a consolidação da ordem constitucional da saúde no Brasil. Como se percebe, a série de discussões, de interesses envolvidos e de alterações, especialmente nos últimos momentos de elaboração do texto, fez da disciplina da saúde, em especial quanto às possibilidades de participação privada, matéria de complexa compreensão e efetivação. Se na opinião de Luís Roberto Barroso o texto da Constituição de 1988 é

296 Art. 230. As ações de saúde são de relevância pública, cabendo ao poder público dispor, nos termos da lei, sobre sua regulamentação, fiscalização e controle, devendo sua execução ser feita diretamente ou através de terceiros e também por pessoa física ou jurídica. (...) Art. 232. A assistência à saúde é livre à iniciativa privada. $\S 1 .^{\circ}$ As instituições privadas poderão participar de forma complementar do sistema único de saúde, segundo diretrizes deste, mediante contrato de direito público ou convênio, tendo preferência as entidades filantrópicas e as sem fins lucrativos. $\S 2 .^{\circ}$ É vedada a destinação de recursos públicos para auxílios e subvenções às instituições privadas com fins lucrativos (os grifos não constam do original).

297 Art. 197. São de relevância pública as ações e serviços de saúde, cabendo ao Poder Público dispor, nos termos da lei, sobre sua regulamentação, fiscalização e controle, devendo sua execução ser feita diretamente ou através de terceiros e, também, por pessoa física ou jurídica de direito privado. (...) Art. 199. A assistência à saúde é livre à iniciativa privada. $\S 1 .^{\circ}$ - As instituições privadas poderão participar de forma complementar do sistema único de saúde, segundo diretrizes deste, mediante contrato de direito público ou convênio, tendo preferência as entidades filantrópicas e as sem fins lucrativos. $§ 2{ }^{\circ}$ - É vedada a destinação de recursos públicos para auxílios ou subvenções às instituições privadas com fins lucrativos (os grifos não constam do original). 
prolixo, casuístico e corporativo, ${ }^{298}$ na disciplina da saúde, pode-se dizer que a utilização de tais adjetivos configura eufemismo.

3.1.2 Direito Fundamental à Saúde na Constituição Federal de 1988: de uma Consagração Tardia ao Desafio de uma Efetivação Incompleta

Como resultado do processo histórico acima referido, o texto constitucional brasileiro produziu importante avanço na disciplina da saúde, estabelecendo:

(i) seu reconhecimento expresso como direito fundamental;299

(ii) a competência comum para prestação dos serviços de saúde e a competência concorrente para legislar sobre proteção e defesa da saúde;300

(iii) a hipótese de intervenção federal e estadual no caso de descumprimento das transferências financeiras mínimas para Estados e Municípios; ${ }^{301}$

(iv) o dever compartilhado de proteção à saúde entre a própria pessoa, o Estado, a família e a sociedade; $302 \mathrm{e}$

298 BARROSO, Luís Roberto. O novo direito constitucional e a constitucionalização do direito. In: Temas de direito constitucional. Rio de Janeiro: Renovar, 2005. Tomo III. p.507.

299 Título II - Dos Direitos e Garantias Fundamentais. Art. 5. ${ }^{\circ}$ (...) Art. 6. ${ }^{\circ}$ São direitos sociais a educação, a saúde, o trabalho, a moradia, o lazer, a segurança, a previdência social, a proteção à maternidade e à infância, a assistência aos desamparados, na forma desta Constituição - (com redação dada pela Emenda Constitucional n. ${ }^{\circ}$ 26, de 2000, que incluiu dentre o rol de direitos sociais o direito à moradia).

300 Nesse sentido estabelecem os artigos 23, 24 e 30 do texto constitucional: Art. 23. É competência comum da União, dos Estados, do Distrito Federal e dos Municípios: (...) II - cuidar da saúde e assistência pública, da proteção e garantia das pessoas portadoras de deficiência; (...) Art. 24. Compete à União, aos Estados e ao Distrito Federal legislar concorrentemente sobre: (...) XII - previdência social, proteção e defesa da saúde; Art. 30. Compete aos Municípios: (...) VII - prestar, com a cooperação técnica e financeira da União e do Estado, serviços de atendimento à saúde da população.

301 São os chamados princípios sensíveis da Constituição Federal: Art. 34. A União não intervirá nos Estados nem no Distrito Federal, exceto para: (...) VII - assegurar a observância dos seguintes princípios constitucionais: b) direitos da pessoa humana; e) aplicação do mínimo exigido da receita resultante de impostos estaduais, compreendida a proveniente de transferências, na manutenção e desenvolvimento do ensino e nas ações e serviços públicos de saúde - (a alínea $e$ possui redação dada pela Emenda Constitucional n. ${ }^{\circ}$ 29, de 2000). Art. 35. O Estado não intervirá em seus Municípios, nem a União nos Municípios localizados em Território Federal, exceto quando: (...) III - não tiver sido aplicado o mínimo exigido da receita municipal na manutenção e desenvolvimento do ensino e nas ações e serviços públicos de saúde (o inciso III possui redação dada pela Emenda Constitucional n. ${ }^{\circ} 29$, de 2000).

302 Isso fica claro nos seguintes dispositivos constitucionais: Art. 227. É dever da família, da sociedade e do Estado assegurar à criança e ao adolescente, com absoluta prioridade, o direito à vida, à saúde, à alimentação, à educação, ao lazer, à profissionalização, à cultura, à dignidade, ao respeito, à liberdade e à convivência familiar e comunitária, além de colocá-los a salvo de toda forma de negligência, discriminação, 
(v) a disciplina das ações e serviços voltados à sua defesa, promoção, proteção e recuperação. ${ }^{303}$

No artigo 196, a Constituição de 1988 reafirmou expressamente o direito de todos à saúde, determinando ao Estado o dever de sua garantia, a ser implementada por meio de políticas sociais e econômicas com objetivo de: (i) reduzir o risco de doenças e outros agravos; e (ii) universalizar e igualar o acesso às ações e serviços para sua promoção, proteção e recuperação. É o que consta expressamente do referido dispositivo:

Art. 196. A saúde é direito de todos e dever do Estado, garantido mediante políticas sociais e econômicas que visem à redução do risco de doença e de outros agravos e ao acesso universal e igualitário às ações e serviços para sua promoção, proteção e recuperação.

Assim, em sua dimensão objetiva, a efetivação do direito à saúde - que envolve tanto o direito à prevenção de doenças e agravos quanto o direito à sua promoção, proteção e recuperação - deve ocorrer por meio da implementação de políticas públicas, ${ }^{304}$ as quais se

exploração, violência, crueldade e opressão. $§ 10^{\circ}$ - O Estado promoverá programas de assistência integral à saúde da criança e do adolescente, admitida a participação de entidades não governamentais e obedecendo os seguintes preceitos: (...) Art. 229. Os pais têm o dever de assistir, criar e educar os filhos menores, e os filhos maiores têm o dever de ajudar e amparar os pais na velhice, carência ou enfermidade. Art. 230. A família, a sociedade e o Estado têm o dever de amparar as pessoas idosas, assegurando sua participação na comunidade, defendendo sua dignidade e bem-estar e garantindo-lhes o direito à vida. Do mesmo modo, a Lei n. ${ }^{\circ} 8.080 / 90$, com precisão dispõe expressamente: Art. $2 .^{\circ}$ (...) $\S 2 .^{\circ} \mathrm{O}$ dever do Estado não exclui o das pessoas, da família, das empresas e da sociedade. Ainda que indiretamente, é o que consta também do artigo 13 do Código Civil Brasileiro: Art. 13. Salvo por exigência médica, é defeso o ato de disposição do próprio corpo, quando importar diminuição permanente da integridade física (...). Nesse sentido é a ressalva de Rogério Gesta Leal, em trabalho sobre o tema: "(...) cada caso envolvendo a prestação de saúde pública submetido ao Estado é merecedor de uma apreciação e ponderação em face de, no mínimo, duas variáveis necessárias: (a) a variável normativa-constitucional e infraconstitucional, enquanto direito fundamental assegurado à sociedade brasileira; (b) a variável responsabilidade institucional e familiar dispostas na estrutura normativa constitucional e infraconstitucional brasileira." (LEAL, Rogério Gesta. A quem compete o dever de saúde no direito brasileiro? Esgotamento de um modelo institucional. Revista de Direito do Estado, ano 2, n.8, out./dez. 2007. p.93).

303 Tal disciplina encontra-se expressa nos artigos 196 a 200 da Constituição Federal e compõe, ao lado da Previdência Social (artigos 201-202) e da Assistência Social (artigos 203-204), o capítulo denominado Da Seguridade Social, cuja definição, objetivos gerais e mecanismos de financiamento encontram-se previstos nos artigos 194 e 195 do texto constitucional.

304 Política pública é expressão polissêmica, vazia de conteúdo próprio, que compreende todos os instrumentos de ação dos governos e revela sua orientação em relação a cada dever estatal a ser cumprido. Na opinião de Richard Rose, a política pública é parte de uma relação de causa e efeito, na qual a atividade do Estado não é considerada em si mesma, mas em relação às intenções daqueles que a criaram e dos impactos por ela alcançados. Para o autor, uma atividade para ser observada ou verificada mais claramente que uma política pública, que é formada por um complexo de ações, intenções e conseqüências (ROSE, Richard. On the Priorities of Government: A developmental Analysis of Public policies. European Journal of Political Research, Amsterdam, n.4, p.248, 1976). Dessa forma, uma política pública concretiza-se por meio de leis e atos administrativos. A vinculação que atualmente se faz entre a atividade administrativa e 
encontram diretamente ligadas ao orçamento do Estado, ${ }^{305}$ e cujas diretrizes encontram-se definidas no próprio texto constitucional. ${ }^{306}$

Este é o ponto nodal a ser desatado, no qual se (des)encontram o mundo da política, do direito e da economia. ${ }^{307}$ A necessidade de enlaçar essas três pontas - vontade política, legislação adequada (inclusive leis orçamentárias) e suficiência de recursos -, entretanto, apenas se tornou marcante no momento em que, nos diversos Estados, os direitos a prestações

a implementação de políticas públicas é pertinente e decorre da transformação de uma Administração Pública passiva a uma Administração Pública ativa, responsável pela prestação de serviços aos cidadãos. Nesse sentido, tem razão Régis Fernandes de Oliveira, ao afirmar que políticas públicas referem-se a: "(...) providências para que os direitos se realizem, para que as satisfações sejam atendidas, para que as determinações constitucionais e legais saiam do papel e se transformem em utilidades aos governados." (OLIVEIRA, Régis Fernandes de. Curso de direito financeiro. São Paulo: RT, 2006. p.251). Da mesma forma, procede o entendimento de Maria Paula Dallari Bucci, para quem: "(...) políticas públicas são programas de ação governamental visando a coordenar os meios à disposição do estado e as atividades privadas, para a realização de objetivos socialmente relevantes e politicamente determinados." (BUCCI, Maria Paula Dallari. Direito administrativo e políticas públicas. São Paulo: Saraiva, 2006. p.241).

305 Nesse sentido, este autor consignou em trabalho acerca da relação entre direitos fundamentais e orçamento: "(...) com o surgimento do Estado Social e as novas formas de atuação na conformação da ordem econômica e social, o orçamento público abandona seu caráter de neutralidade e torna-se instrumento da Administração Pública, de forma a auxiliar o Estado nas várias etapas do processo administrativo: programação, execução e controle. Tal transformação das características e da importância do orçamento público surge no exato momento em que os objetivos, metas e programas - agora constantes dos textos constitucionais - passam a ter sua implementação condicionada à adoção, pelo Estado, de políticas públicas que os concretizem. Portanto, a noção moderna de orçamento é diretamente relacionada à noção de políticas públicas. Afinal, é a partir do Estado social que surge, por meio de políticas públicas - e do orçamento - a intervenção positiva do Poder Público na ordem econômica e na ordem social." (MÂNICA, Fernando B. Teoria da reserva do possível: direitos fundamentais a prestações e a intervenção do poder judiciário na implementação de políticas públicas. Revista Brasileira de Direito Público, Belo Horizonte, ano 5, n.18, p.170, jul./set. 2007). Nesse prisma, como sustentaram Stephen Holmes e Cass Sustein levar a sério os direitos fundamentais a prestações implica levar a sério a escassez, e com ela o orçamento (HOLMES, Stephen; SUNSTEIN Cass. The Cost of Rights. Why Liberty Depends on Taxes. New York: Norton and Company, 2000. p.94).

306 Sobre o tema, tem razão Sueli Gandolfi Dallari ao afirmar que a política pública de saúde tem sua primeira formulação na própria Constituição (DALLARI, Sueli Gandolfi. Políticas de estado e políticas de governo: o caso da saúde pública. In: BUCCI, Maria Paula Dallari (Org.). Políticas públicas: reflexões sobre o conceito jurídico. São Paulo: Saraiva, 2006. p.263). Isso porque, além de determinar objetivos a serem cumpridos, a Constituição brasileira trata de questões específicas, como, por exemplo, as hipóteses de participação privada (art. 197 e 199, $\S 1^{\circ}{ }^{\circ}$ ) e as atribuições do sistema único de saúde (art. 200). Entretanto, como assinala Gilberto Bercovici, tal formulação, que marca o dirigismo constitucional na área da saúde, não substitui a política, mas estabelece seu fundamento, sua premissa material, dentro do qual devem mover-se as políticas públicas (BERCOVICI, Gilberto. A problemática da constituição dirigente: algumas considerações sobre o caso brasileiro. Revista de Informação Legislativa, Brasília, ano 36, n.142, p.40, abr./jun. 1999).

307 Sobre o tema: COUTINHO, Diogo R. O Diálogo Caricato ente direito e economia. Valor Online, São Paulo, 01 dez. 2008. Disponível em: <www.valor online.com.br>. Acesso em: 01 dez. 2008; LOPES, José Reinaldo de Lima. Raciocínio jurídico e economia. Revista de Direito Público da Economia, Belo Horizonte, ano 2, n.8, p.137-170, out./dez. 2004; e MÂNICA, Fernando B. Racionalidade econômica e racionalidade jurídica na constituição de 1988. A\&C Revista de Direito Administrativo e Constitucional, Belo Horizonte, ano 8, v.32, p.121-132, abr./jun.. 2008. 
em sentido estrito deixaram de ser entendidos como meros objetivos abstratos e passaram a ser considerados como verdadeiros direitos de pessoas concretas. Nesse momento, passouse a reconhecer o caráter subjetivo do direito à saúde - configurado na possibilidade de reclamação em juízo da prestação decorrente de direitos fundamentais previstos diretamente no texto constitucional, independente de sua regulamentação pela via legislativa.

3.1.2.1 Teoria constitucional do direito à saúde: direitos fundamentais e constitucionalização do direito

No Brasil, apenas em 1988 estendeu-se, em sede constitucional, o direito à saúde a todas as pessoas. Assim, em tal setor, a discussão acerca da vinculação do legislador ao estabelecimento das políticas públicas para sua efetivação e o direito das pessoas de obter prestações do Estado diretamente em face da previsão constitucional do referido direito, apenas recentemente transformaram-se em objeto de debate doutrinário. ${ }^{308}$

Com a superação do antecedente período de exceção, sob a égide da Constituição de 1988, a doutrina jurídica brasileira passou a colocar os direitos fundamentais no centro do ordenamento jurídico, com irradiação de seus efeitos a todas as áreas do direito. Desde então, passa-se por um período de constitucionalização do direito brasileiro, o que implica

308 Prova disso é que os trabalhos em que a doutrina jurídica pátria dedicou-se ao estudo do direito à saúde são em sua maioria recentes. Dentre eles, podem ser relacionados: CASTRO, José A. Dias de. A questão do direito fundamental à saúde sob a ótica da análise econômica do direito. Revista de Direito Público da Economia - RDPE, Belo Horizonte, ano 6, n.21, p.149-158, jan./mar. 2008; FIGUEIREDO, Mariana F. Direito fundamental à saúde: parâmetros para sua eficácia e efetividade. Porto Alegre: Livraria do Advogado, 2007; LEAL, Rogério Gesta. A quem compete o dever de saúde no direito brasileiro? Esgotamento de um modelo institucional. Revista de Direito do Estado, ano 2, n.8, out./dez. 2007; LUCENA, Cíntia. Direito à saúde no constitucionalismo contemporâneo. In: ROCHA, Cármen Lúcia Antunes (Coord.). O direito à vida digna. Belo Horizonte: Fórum, 2004, p.245-269; MARTINS, Wal. Direito à saúde: compêndio. Belo Horizonte: Fórum, 2008; PEREIRA, Fernanda de Oliveira. Direito sanitário: a relevância do controle nas ações e serviços de saúde. Belo Horizonte: Fórum, 2004; PEREIRA, Hélio Dias. A responsabilidade pela saúde: aspectos jurídicos. Rio de Janeiro: Fiocruz, 1995; RAEFFRAY, Ana Paula O. de. Direito à saúde de acordo com a constituição federal. São Paulo: Quartier Latin, 2005; RAMOS, Marcelene C. da Silva. O direito fundamental à saúde na perspectiva da constituição federal. A\&C Revista de Direito Administrativo e Constitucional, Belo Horizonte, ano 5, n.22, p.147-165, out./dez. 2005; ROCHA, Julio César da. Direito da saúde. São Paulo: LTr, 1999; SARLET, Ingo Wolfgang. Algumas considerações em torno do conteúdo, eficácia e efetividade do direito à saúde na Constituição de 1988. Revista Diálogo Jurídico, Salvador, Centro de Atualização Jurídica, n.10, jan. 2002. Disponível em: <www.direitopublico.com.br>. Acesso em: 27 jul. 2007; TOJAL, Sebastião Botto de Barros. O direito regulatório do estado social e as normas legais de saúde pública. In: O direito sanitário na constituição brasileira de 1988: normatividades, garantias e seguridade social. Brasília: Organização Pan-Americana de Saúde, 1994. p.15-23; TOJAL, Sebastião Botto de Barros. Constituição dirigente de 1988 e o direito à saúde. In: MORAES, Alexandre (Org.). Os 10 anos da constituição federal. São Paulo: Atlas, 1999. p.33-44; WEICHERT, Marlon Alberto. Saúde e federação na constituição brasileira. Rio de Janeiro: Lumen Júris, 2004. 
a interpretação de cada norma jurídica à luz da Constituição Federal. No que tange ao direito à saúde, pode-se dizer que o desenvolvimento teórico acompanhou - a partir de 1988, com atraso, portanto - o caminho percorrido pela afirmação da teoria dos direitos fundamentais. ${ }^{309} \mathrm{O}$ entendimento positivista-legalista, segundo o qual o direito é a regra posta pelo legislador, cedeu espaço para uma teoria jurídica em que as novas funções estatais constitucionalmente previstas passaram a também ser reconhecidas como verdadeiras normas jurídicas aptas a provocar efeitos concretos. ${ }^{310}$

Importante contribuição nessa transformação da teoria jurídica, com reflexos recentes no Brasil, teve o pensamento de Ronald Dworkin e de Robert Alexy, em especial quanto ao entendimento de que os direitos fundamentais constituem princípios aptos a produzir

$309 \mathrm{Na}$ doutrina jurídica nacional, pode ser mencionada uma série de trabalhos recentes acerca da concretização dos direitos fundamentais sociais, dentre os quais: KELLER, Arno Arnoldo. O descumprimento dos direitos sociais: razões políticas, econômicas e jurídicas. São Paulo: LTr, 2001; KRELL, Andréas. Realização dos direitos fundamentais sociais mediante controle judicial da prestação dos serviços públicos básicos. Revista de Informação Legislativa, Brasília, ano 36, n.144, p.239-260, out./dez. 1999; KRELL, Andréas. Direitos sociais e controle judicial no Brasil e na Alemanha: os (des)caminhos de um direito constitucional comparado. Porto Alegre: Sergio Antonio Fabris, 2002; LEIVAS, Paulo G. Cogo. Teoria dos direitos fundamentais sociais. Porto Alegre: Livraria do Advogado, 2006; LOPES, José Reinaldo de Lima. Direitos sociais: teoria e prática. São Paulo: Método, 2006; PIOVESAN, Flávia. Justiciabilidade dos direitos sociais e econômicos no Brasil: desafios e perspectivas. Revista de Direito do Estado - RDE, Rio de Janeiro, ano 1, n.2, p.55-82, abr./jun. 2006; NOGUEIRA, Rafael. Reflexões acerca da efetivação dos direitos sociais. A\&C Revista de Direito Administrativo e Constitucional, Belo Horizonte, ano 6, n.25, p.41-66, jul./set. 2006.

310 As Constituições que consagraram em seus textos normas que estabelecem fins a serem alcançados pelo Estado por meio de prestações foram denominadas Constituições Programáticas, e as normas que estabeleceram tais tarefas, normas programáticas. Nesse sentido, pode-se verificar a conexão entre a Constituição Programática e a Constituição Dirigente. Esta última, na definição de Gomes Canotilho, é aquela que define fins e tarefas ao Estado (CANOTILHO, J. J. Gomes. Constituição dirigente e vinculação do legislador: contributo para a compreensão das normas constitucionais programáticas. 2. ed. Coimbra: Coimbra, 2001. p.224). Na doutrina brasileira grande relevância ocupa a doutrina trazida por José Afonso da Silva, com a publicação em 1967 da obra Aplicabilidade das Normas Constitucionais, acerca da classificação das normas constitucionais quanto à eficácia, em normas de eficácia direta, contida e limitada; esta última, segundo o autor, compreensiva das normas programáticas e dependente de interposição legislativa para produção de efeitos. Acontece que, José Afonso da Silva, na primeira edição que se seguiu à promulgação da Constituição de 1988, assim consignou a propósito das normas programáticas dirigidas à ordem econômica e social: "Não incluímos aqui nem o direito à saúde (art. 196), nem o direito à educação (art. 205), porque em ambos os casos a norma institui um dever correlato de um sujeito determinado: o Estado - que, por isso, tem a obrigação de satisfazer aquele direito. Se esta não é satisfeita, não se trata de programaticidade, mas de desrespeito ao direito, de descumprimento da norma." (SILVA, José Afonso. Aplicabilidade das normas constitucionais. 3.ed. São Paulo: Malheiros, 1998). Portanto, mesmo na teoria de José Afonso da Silva, muitas vezes invocada como obstáculo à concretização do direito à saúde, tal limite não existe, sendo possível a incidência de efeitos concretos decorrentes da previsão normativa constitucional. 
efeitos de maneira imediata, mesmo na ausência de interposição legislativa específica. ${ }^{311}$ Além disso, há que se citar a importante influência do pensamento constitucional português, marcado especialmente pela obra de Gomes Canotilho, publicada originalmente em 1982, intitulada Constituição Dirigente e Vinculação do Legislador: Contributo para a Compreensão das Normas Constitucionais Programáticas. Em tal obra, o autor referido defendeu a força normativa das normas de conteúdo programático constantes da então recém-promulgada Constituição portuguesa de 1976,312 aproxima-se da Constituição brasileira, com um caráter programático detalhado, o que se reflete, por exemplo, no tratamento minucioso dos deveres estatais em relação ao direito à saúde, constantes dos artigos 196 a 200 do texto constitucional pátrio. Nesse cenário, com o advento da Constituição de 1988, grande parte da doutrina brasileira passou a defender a constitucionalização do direito, 313 com a vinculação do intérprete, do aplicador, do julgador e do legislador às regras e aos princípios constantes na Constituição. ${ }^{314}$

311 Sobre o tema: DWORKIN, Ronald. Levando os direitos a sério. Trad. Nelson Boeira. São Paulo: Martins Fontes, 2002. (e edição original data de 1977); e ALEXY, Robert. Teoría de los Derechos Fundamentales. Trad. Carlos B. Pulido. 2.ed. Madrid: Centro de Estudios Políticos y Constitucionales, 2007 (a edição original é de 1986).

312 CANOTILHO, J. J. Gomes. Constituição dirigente e vinculação do legislador: contributo para a compreensão das normas constitucionais programáticas. 2. ed. Coimbra: Coimbra, 2001 (a primeira edição, como assinalado, é de 1982).

313 O que conduziu a uma evidente atenuação na dicotomia entre os dois grandes ramos do Direito, tradicionalmente conhecidos como direito público e direito privado. Desde que houve a constitucionalização do direito, o que ocorreu no Brasil após 1988, existe o direito e o regime jurídico de cada atividade. Se mais ou menos privado, mais ou menos público, com maior ou menor autonomia e controle de órgãos fiscalizadores, só o caso concreto é capaz de dizer. De qualquer forma, quando o fizer, fá-lo-á em termos específicos e não por meio de abstrações, que se tornam insuficientes e inúteis em termos analíticos e normativos. Na síntese de Almiro Couto e Silva: "Se, no século passado, a expressão sistema jurídico era quase sinônima de sistema de direito privado, desempenhando a idéia de codificação e de código um papel central e dominante, hoje é inquestionável que a noção que se possa ter de sistema jurídico, qualquer que seja ela (...) passa a ser conformada pela Constituição, com toda a sua constelação ou ordem de valores que abriga. Consequentemente, todo o ordenamento jurídico infraconstitucional, de forma mais ou menos intensa, é informado, vivificado, oxigenado e animado pelos preceitos maiores, pelos princípios e regras estampados na Constituição (...)." (SILVA, Almiro Couto e. Os indivíduos e o estado na realização de tarefas públicas. In: MELLO, Celso Antônio Bandeira de (Org.). Estudos em homenagem a Geraldo Ataliba: direito administrativo e constitucional. São Paulo: Malheiros, 1997. p.108).

314 É importante ressaltar que Gomes Canotilho, no prefácio da segunda edição de sua obra Constituição Dirigente e Vinculação do Legislador, consignou sua relativa mudança de opinião em relação às idéias constantes da obra. Em linhas gerais, o que sustentou o autor foi um deslocamento da Constituição como agente central na condução e concretização das tarefas assumidas pelo Estado; com isso, deixa-se de assumir um modelo estatizante único para oferecer a possibilidade de novos modelos de autodireção social. Isso consta expressamente nas páginas X e XIII da obra em referência. Além disso, Canotilho criticou a hipertrofia de imposições estatais decorrentes de momentos históricos de ruptura, com alta carga ideológica, bem como a consagração constitucional específica de tarefas, como, em seu exemplo, a gratuidade de todos os graus de ensino. Sustentou o autor lusitano expressamente que: "Uma Constituição deve estabelecer os fundamentos adequados a uma teoria da justiça, definindo as estruturas básicas da sociedade sem se comprometer com 
O resultado é que hoje tanto o direito à prevenção de doenças quanto o direito à promoção, proteção e recuperação da saúde configuram posições jus-fundamentais qualificadas como direitos subjetivos passíveis de tutela jurisdicional. Reconhecida sua densidade normativa, caracterizada pela possibilidade de produzir diretamente efeitos concretos, sua aplicação deve passar pelo processo de ponderação em face de outros princípios eventualmente incidentes na hipótese. ${ }^{315}$ Isso representa a necessidade de análise de cada caso e, como mencionado no

situações particulares" e concluiu: "(...) dir-se-ia que a Constituição Dirigente está morta se o dirigismo constitucional for entendido como normativismo constitucional revolucionário capaz de, só por si, operar transformações emancipatórias." (CANOTILHO, J. J. Gomes. Constituição dirigente e vinculação do legislador: contributo para a compreensão das normas constitucionais programáticas. 2. ed. Coimbra: Coimbra, 2001. fls. XXI-XXIX). As afirmações de Canotilho geraram discussões em solo brasileiro, de modo que foi organizado um encontro virtual com o próprio Canotilho, ao fim de esclarecer alguns pontos de sua mudança de posição. O resultado da conversa foi publicado em obra na qual, ao responder questão formulada por Marçal Justen Filho, Gomes Canotilho fez referência ao serviço nacional de saúde português, aceitando as idéias à época defendidas em Portugal de participação privada na prestação dos serviços, desde que garantidos os direitos à saúde previstos na Constituição: "(...) posso estar aberto a outros modos de concretização e legalização do dirigismo constitucional, mas não estou aberto, de forma alguma, à liquidação destas dimensões existenciais que estão subjacentes à directividade constitucional." (COUTINHO, Jacinto Nelson de Miranda (Org.). Canotilho e a constituição dirigente. Rio de Janeiro: Renovar, 2003. p.40 e 41). Tal ordem de observações demonstra a tendência teórica, inclusive por parte de um autor com grande influência no pensamento constitucional brasileiro, voltada ao reconhecimento de que o modelo estatizante único não deve prevalecer; e que a Constituição, ao invés de cristalizar soluções peremptórias, deve oferecer à Administração Pública a opção pela melhor solução, de acordo com a realidade, a técnica, as condições sociais e econômicas de cada momento, para concretizar os fins constitucionalmente estabelecidos.

315 Adota-se o entendimento de Robert Alexy, para quem a ponderação envolve a análise da dimensão do peso e da importância dos princípios envolvidos, a que o autor denomina lei de colisão (ALEXY, Robert. Teoría de los Derechos Fundamentales. Trad. Carlos B. Pulido. 2.ed. Madrid: Centro de Estudios Políticos y Constitucionales, 2007. p.70-71 e 91-92). Entende-se neste trabalho, também, com esteio em Luís Virgílio Afonso da SILVA, que do resultado do processo de ponderação ou sopesamento, é que se chegará ao que a doutrina costuma denominar mínimo existencial ou núcleo essencial dos direitos fundamentais. Dessa forma, não se sustenta a existência de limites imanentes aos direitos fundamentais, pois tais limites, que conformam seu conteúdo essencial ou mínimo existencial, apenas podem ser apreendidos no caso concreto e após a ponderação com outros princípios eventualmente colidentes na hipótese. Ressalte-se, ainda, que, quando determinado direito fundamental já foi objeto de regulamentação legal, a constitucionalidade de tal ato legislativo deve passar pela regra da proporcionalidade em face do direito fundamental em questão, submetendo-se, portanto, aos critérios da adequação, da necessidade $e$ da proporcionalidade em sentido estrito, que para o autor, na esteira de Robert Alexy, corresponde à ponderação. Sobre o tema: SILVA, Luís Virgílio Afonso da. O conteúdo essencial dos direitos fundamentais e a eficácia das normas constitucionais. 2005. Tese (Professor Titular) - Universidade de São Paulo, São Paulo, 2005. p.215-240 e 269-273. Nessa perspectiva, insta ressaltar a posição de Ricardo Lobo Torres, para quem apenas o mínimo existencial dos direitos sociais pode ser entendido como direito fundamental. Não obstante, o autor afirma que a distinção entre o mínimo existencial (direito fundamental) e os direitos sociais (não-fundamentais) configura um dos problemas mais difíceis da época atual e que a extensão do mínimo existencial e dos direitos sociais depende da respectiva ponderação diante dos casos concretos. Desse modo, pode-se verificar que, em última análise, o resultado a que chega a teoria de Ricardo Lobo Torres é o mesmo: a necessidade de ponderação entre os direitos sociais e outros direitos fundamentais para que se chegue à definição do que é o mínimo existencial, que para Lobo Torres constitui a jusfundamentalidade dos direitos sociais. Sobre o tema: TORRES, Ricardo Lobo. A metamorfose dos direitos sociais em mínimo existencial. In: SARLET, Ingo Wolfgang (Org.). Direitos fundamentais sociais: estudos de direito constitucional internacional e comparado. Rio de Janeiro: Renovar, 2003. p.1-46 (em especial, p.1, 15-16 e 29). 
Capítulo anterior, possibilita uma a interpretação e uma aplicação do direito menos mecânica, menos previsível e mais justa.

3.1.2.2 Direito à saúde como direito fundamental derivado dependente de prestações e submetido à lei

É importante notar, contudo, que no ordenamento pátrio, o direito fundamental à saúde encontra-se disciplinado tanto na Constituição Federal quanto na legislação infraconstitucional, de modo que se pode qualificá-lo tanto como um direito fundamental originário quanto como um direito fundamental derivado.

Direitos fundamentais originários podem ser entendidos como direitos previstos na Constituição e aptos a produzir efeitos independentemente de interposição legislativa, enquanto os de direitos fundamentais derivados configuram hipóteses em relação às quais houve interposição legislativa que regulamentou seu exercício. ${ }^{316}$

No ordenamento brasileiro, o direito à saúde, além do tratamento extensivo que lhe é dado pelo próprio texto constitucional, encontra-se disciplinado por lei, em especial pela Lei n. ${ }^{\circ}$ 8.080/90 - Lei Orgânica da Saúde, que dispõe sobre as condições para a promoção, proteção e recuperação da saúde e a organização e o funcionamento dos serviços respectivos. Nessa perspectiva, o direito à saúde, no direito pátrio, deve ser compreendido tanto em sua fundamentalidade originária quanto derivada, pois, apesar de disciplinado em nível infraconstitucional, eventuais omissões legislativas podem dar margem à aplicação direta da normatização constitucional.

Assim sendo, a busca pela produção de efeitos diretamente decorrentes da Constituição em grau mais amplo do que previsto na disciplina legal regulamentadora é plenamente possível, mas deve ser admitida nos casos em que se demonstre, pela via judicial, a inconstitucionalidade da regra (de)limitadora do direito constitucionalmente previsto.

Tal conformação do ordenamento jurídico da saúde faz com que a interferência do Poder Judiciário - com o objetivo de efetivar o direito à saúde em sua perspectiva prestacional possa ocorrer em três hipóteses:

316 Sobre o tema, conferir: ANDRADE, José Carlos Vieira de. Os direitos fundamentais na constituição portuguesa de 1976. Coimbra: Almedina, 1987. p.300-311; e SARLET, Ingo Wolfgang. A eficácia dos direitos fundamentais. 2.ed. Porto Alegre: Livraria do Advogado, 2001. p.276 e segs. 
(i) no caso de inércia do Poder Legislativo em regulamentar determinada questão específica ligada ao direito em referência;

(ii) no caso de descumprimento, pela Administração Pública, da legislação que regulamenta o referido direito; e

(iii) no caso em que a regulamentação do direito à saúde (de)limite de modo não constitucionalmente fundamentado o direito originário à saúde.

Em todos os casos é imprescindível a atuação do Poder Judiciário, sendo que, no último deles, a interferência judicial deverá ser realizada, com ainda mais cautela do que no caso de simples omissão legislativa ou descumprimento de dever legal, a fim de decidir pela inconstitucionalidade da norma (de)limitadora do direito fundamental à saúde. ${ }^{317}$

Essa ordem de idéias, compartilhada pela teoria constitucional contemporânea, não conduz à absolutização do direito à saúde, o que lamentavelmente ainda se encontra presente em uma série de decisões judiciais, as quais acabam por desconsiderar, em decisões de casos individuais, toda a organização do sistema público de saúde, provocando sua desestabilização e ofensa ao princípio da isonomia. ${ }^{318}$

Não há que se negar a importância do Poder Judiciário como guardião maior da Constituição e dos direitos fundamentais; não obstante, mormente no caso de direitos derivados, a disciplina infraconstitucional deve ser levada em conta no procedimento de ponderação de bens. ${ }^{319}$ Nessa sintonia, a jurisprudência recente do Supremo Tribunal Federal parece compartilhar tal pensamento, ao entender o direito à saúde como direito fundamental

317 Como ressalta Luís Roberto Barroso: "(...) havendo lei e atos administrativos implementando a Constituição e sendo regularmente aplicados, eventual interferência judicial deve ter a marca da autocontenção." (BARROSO, Luís Roberto. Da falta de efetividade à judicialização excessiva: direito à saúde, fornecimento gratuito de medicamentos e parâmetros para a atuação judicial. Revista Interesse Público, Belo Horizonte, n.46, p.52, nov./dez. 2007).

318 Sobre o tema, conferir considerações e compilação de julgados em: WERNER, Patrícia U. Pizarro. $\mathrm{O}$ direito social e o direito público subjetivo à saúde - o desafio de compreender um direito com duas faces. Revista de Direito Sanitário, São Paulo, v.9, n.2, p.92-131, jul./out. 2008.

319 Em decorrência de alguns excessos promovidos pelo Poder Judiciário na concessão direta, imediata e absoluta de medidas voltadas à efetivação, em casos individuais, do direito à saúde, numerosos estudos foram publicados, com o objetivo de discutir a questão e oferecer subsídios teóricos a uma interpretação constitucionalmente adequada do referido direito e dos direitos sociais em geral. Dentre eles, podem ser citados: ASSIS, Araken de. Aspectos polêmicos e atuais dos limites da jurisdição e do direito à saúde. Porto Alerge: Notadez, 2007; LEAL, Rogério Gesta. A efetivação do direito à saúde por uma jurisdição-serafim: limites e possibilidades. In: LEAL, Rogério Gesta; REIS, Jorge Renato dos. Direitos sociais e políticas públicas: desafios contemporâneos. Santa Cruz do Sul: EDUNISC, 2006. Tomo VI. p.1525-1542; VIEIRA, Fabiola Sulpino. Ações judiciais e o direito à saúde. Revista de Saúde Pública, São Paulo, v.42, n.2, abr. 2008. 
em sua vertente principiológica, a ser efetivado progressivamente, na medida do possível, sendo que seu descumprimento pela Administração Pública - consubstanciado na ausência de prestação dos serviços necessários a sua promoção, proteção e recuperação - deve ter como base a impossibilidade fática ou jurídica devidamente comprovadas. ${ }^{320}$

Como se verá adiante, mesmo que o direito à saúde possa ser vislumbrado sob a perspectiva de um direito de uma pessoa concreta a receber assistência individualizada e específica, a dimensão social, a repercussão coletiva e a incidência de outros direitos fundamentais na hipótese concreta devem ser levadas em conta. Afinal, não se trata, em última análise, de ponderar o direito à saúde, e mesmo o direito à vida, com princípios como o da legalidade e da separação de poderes; trata-se de ponderar o direito à vida e à saúde de determinadas pessoas em face do direito à vida e à saúde de outras pessoas.

Para os fins do presente trabalho, como já assinalado, importa compreender o direito à saúde na Constituição brasileira de 1988 e sua vinculação aos serviços públicos de saúde. Existe o direito fundamental originário e o conseqüente dever estatal de criar, por meio do processo democrático, estruturas e condições aptas, adequadas e viáveis à prestação dos serviços voltados à proteção, promoção e recuperação da saúde das pessoas que deles necessitarem.

Nesse sentido, se tem razão Sueli Gandolfi Dallari, ao afirmar que o direito de todos à saúde deve ser compreendido dentro dos parâmetros impostos pela mais atualizada

320 Como ilustração, pode-se colacionar parte da decisão em que o Supremo Tribunal Federal expressou tal posicionamento: "(...) É que a realização dos direitos econômicos, sociais e culturais - além de caracterizar-se pela gradualidade de seu processo de concretização - depende, em grande medida, de um inescapável vínculo financeiro subordinado às possibilidades orçamentárias do Estado, de tal modo que, comprovada, objetivamente, a incapacidade econômico-financeira da pessoa estatal, desta não se poderá razoavelmente exigir, considerada a limitação material referida, a imediata efetivação do comando fundado no texto da Carta Política. Não se mostrará lícito, no entanto, ao Poder Público, em tal hipótese - mediante indevida manipulação de sua atividade financeira e/ou político-administrativa - criar obstáculo artificial que revele o ilegítimo, arbitrário e censurável propósito de fraudar, de frustrar e de inviabilizar o estabelecimento e a preservação, em favor da pessoa e dos cidadãos, de condições materiais mínimas de existência. Cumpre advertir, desse modo, que a cláusula da "reserva do possível" - ressalvada a ocorrência de justo motivo objetivamente aferível - não pode ser invocada, pelo Estado, com a finalidade de exonerar-se do cumprimento de suas obrigações constitucionais, notadamente quando, dessa conduta governamental negativa, puder resultar nulificação ou, até mesmo, aniquilação de direitos constitucionais impregnados de um sentido de essencial fundamentalidade. (...)." (BRASIL. Supremo Tribunal Federal. ADPF n. ${ }^{\circ}$ 45, Rel. Min. Celso de Mello, julg. 29 abr. 2004). Sobre a evolução doutrinária e da jurisprudência dos tribunais superiores acerca da efetividade dos direitos sociais, em especial do direito à saúde - de uma visão meramente programática, passando por sua absolutização e chegando a um ponto de equilíbrio racional - conferir: MÂNICA, Fernando B. Teoria da reserva do possível: direitos fundamentais a prestações e a intervenção do poder judiciário na implementação de políticas públicas. Revista Brasileira de Direito Público, Belo Horizonte, ano 5, n.18, p.169-186, jul./set. 2007. 
doutrina constitucional, ${ }^{321}$ resta evidenciada a vinculação do legislador e do administrador público em efetivar na melhor medida possível os direitos fundamentais, ${ }^{322}$ levando em conta, para tanto, as condições econômicas, sociais e tecnológicas do momento histórico presente. Nessa linha, é importante destacar, como assinala João Carlos Loureiro, que não se deve entender o direito à saúde como um direito a ser saudável, mas como o direito de proteção à saúde, ${ }^{323}$ que envolve tanto (i) o direito a não sofrer violação por parte de terceiros (direito de defesa) e quanto (ii) o direito de obter ações e serviços voltados tanto à prevenção de doenças quanto à promoção, proteção e recuperação da saúde (direito a prestação em sentido estrito), tais quais previstos em lei (direito fundamental derivado).

Na segunda hipótese, respeitar o direito à saúde implica realizar o direito à saúde, dentre outras atividades, por meio da prestação de serviços públicos. Enquanto direito fundamental originário, o direito à saúde implica o dever estatal de atuar de modo a criar, na maior medida possível, os serviços de saúde voltados à sua promoção, proteção e recuperação. Considerando a existência de regulamentação infraconstitucional sobre o tema, a não prestação de determinados serviços voltados à garantia do direito à saúde - em que pese não haver sua definição específica em sede constitucional - deve ser entendida como uma restrição ao respectivo direito, que apenas se legitima por meio de uma justificativa de base constitucional.

Virgílio Afonso da Silva, ao analisar os motivos pelos quais há menor efetividade no Brasil dos direitos sociais, como é o caso da saúde, em relação aos demais direitos prestacionais em sentido amplo, conclui que:

(i) as condições para exercício dos direitos sociais ainda têm de ser criadas;

(ii) a criação de tais condições é mais cara;

321 DALLARI, Sueli Gandolfi. O conceito jurídico de saúde. In: saúde. São Paulo: Hucitec, 1995. p.33.

Os estados brasileiros e o direito à

322 Nesse sentido deve ser interpretado a parágrafo primeiro do artigo $5 .^{\circ}$ da Constituição Federal, que determina a aplicação imediata das normas definidoras de direitos fundamentais. Tal preceito aplica-se no processo de interpretação do direito à saúde, como princípio que objetiva otimizar sua efetividade.

323 LOUREIRO, João Carlos S. G. Direito à (proteção da) saúde. In: MIRANDA, Jorge. Estudos em homenagem ao professor Doutor Marcello Caetano. Lisboa: Faculdade de Direito da Universidade de Lisboa, 2006. v.1. p.674. Daí a possibilidade de delimitação técnica do direito em referência, como direito à prevenção de doenças, direito à proteção, direito à promoção e direito à recuperação da saúde. 
(iii) o custo para a criação de tais condições é maior porque cada direito social exige uma prestação estatal que é aproveitada apenas na efetivação do próprio direito. ${ }^{324}$

Levando adiante tal raciocínio, em sentido diverso do que parece sustentar referido autor, tanto os direitos à prestação em sentido amplo quanto os direitos à prestação em sentido estrito implicam atuação estatal voltada exclusivamente à efetivação do referido direito. Veja-se a própria comparação feita por Virgílio Afonso da Silva entre a efetivação do direito à saúde e o direito ao sufrágio: ambos dependem de uma estrutura voltada exclusivamente a sua satisfação - seja pela construção de um hospital, seja pela organização e manutenção de uma estrutura responsável pela realização das eleições. ${ }^{325}$

Com essa comparação, pode-se perceber que o problema da falta de efetividade do direito à saúde não consiste no fato de que hospitais servem apenas para prestar serviços de saúde; afinal, urnas eletrônicas também se prestam apenas para proporcionar o exercício do sufrágio. O problema é que os serviços de saúde são prestados de maneira individual a quem dele necessite e a infra-estrutura para a prestação do referido serviço não pode ser compartilhada para sua oferta a todos indistintamente, como referido no Item 2.2.2.

Em outras palavras: alguns direitos apenas podem ser garantidos de maneira universal e igualitária. Não se cogita, atualmente, restringir-se o sufrágio ou oferecer urnas eletrônicas apenas para algumas pessoas. A garantia do direito ao sufrágio apenas se realiza quando o exercício do referido direito é igual para todos. O mesmo raciocínio aplica-se, em grande medida, aos serviços públicos que exigem infra-estrutura para sua prestação, como é o caso, por exemplo, da energia elétrica e da telefonia. Ainda que seja passível de cobrança de tarifas a serem pagas por usuário individualizado, a qualidade de tais serviços não sofre grande variação decorrente de condições pessoais dos usuários dos serviços, pois o investimento em infra-estrutura acaba beneficiando a todos indistintamente (ou, ao menos, a grande parte das pessoas aptas a pagar pelos serviços).

324 Nas palavras do autor: "(...) a construção e manutenção de hospitais, contratação de médicos, compra de caros materiais hospitalares, organização de programas de combate a epidemias, entre outras coisas, só é aproveitado para a realização de um único direito social, o direito à saúde." (SILVA, Luís Virgílio Afonso da. $\mathbf{O}$ conteúdo essencial dos direitos fundamentais e a eficácia das normas constitucionais. 2005. Tese (Professor Titular) - Universidade de São Paulo, São Paulo, 2005. p.319-320).

325 SILVA, Luís Virgílio Afonso da. O conteúdo essencial dos direitos fundamentais e a eficácia das normas constitucionais. 2005. Tese (Professor Titular) - Universidade de São Paulo, São Paulo, 2005. p.307. 
Já o direito à saúde depende de estruturas próprias para sua efetivação, a qual deve ocorrer por meio de prestações individualizadas, exclusivas, e por vezes gratuitas. Em última análise, portanto, ainda que os três argumentos relacionados por Virgílio Afonso da Silva não sejam falsos, a ausência de efetividade do direito à saúde relaciona-se à noção econômica de bem público e bem privado. ${ }^{326}$ Ainda que o serviço de saúde seja considerado por muitos como um bem público, pois repercute no bem-estar de toda a sociedade, ele tem sido tratado em grande medida como bem privado, cuja individualização da oferta gera insuficiência de sua prestação pelo Estado.

Tal compreensão foi acolhida em decisão monocrática do Supremo Tribunal Federal, na qual o Ministro Gilmar Ferreira Mendes fez consignar:

\begin{abstract}
Em relação aos direitos sociais, é preciso levar em consideração que a prestação devida pelo Estado varia de acordo com a necessidade específica de cada cidadão. Assim, enquanto o Estado tem que dispor de um valor determinado para arcar com o aparato capaz de garantir a liberdade dos cidadãos universalmente, no caso de um direito social como a saúde, por outro lado, deve dispor de valores variáveis em função das necessidades individuais de cada cidadão. Gastar mais recursos com uns do que com outros envolve, portanto, a adoção de critérios distributivos para esses recursos. ${ }^{327}$
\end{abstract}

Assim, considerando ainda que do serviço público e gratuito de saúde dependem pessoas de baixa renda e baixo poder de reivindicação de direitos, a estrutura para sua efetivação acaba por não ser criada. Levando ao limite a linha de raciocínio, percebem-se, também, os motivos pelos quais o sistema público de saúde no Brasil é referência em serviços médicos de alta complexidade e de alto custo - os quais são demandados igualmente por pessoas de variadas classes sociais, inclusive as que possuem planos de saúde que não cobrem tais serviços, enquanto os mais pobres esperam horas na fila para atendimento básico e semanas ou meses para atendimento especializado ou cirurgias.

Nessa perspectiva deve ser enfrentado o desafio das Constituições contemporâneas, como é exemplo o direito à saúde no Brasil hoje: transformar textos que consagram direitos fundamentais a prestações em atos concretos que os realizem - dentre outras atividades, pela oferta de serviços públicos de saúde a todos que dele necessitem. Esse papel cabe ao

326 Conceitos clássicos da teoria econômica, o bem público pode ser entendido como bem ou serviço cujos benefícios se disseminam por toda a sociedade, enquanto o bem privado possui utilidade restrita àquela pessoa que o usufrui.

327 BRASIL. Supremo Tribunal Federal, Suspensão de Tutela Antecipada n. ${ }^{o}$ 278, Relator Ministro Presidente Gilmar Mendes, decisão proferida em 22 de outubro de 2008. 
Estado, por meio de uma Administração Pública que cumpra suas funções e que possa utilizar-se dos meios mais adequados para tanto.

\subsection{TEORIA DOS SERVIÇOS PÚBLICOS E ASSISTÊNCIA À SAÚDE}

A saúde é ao mesmo tempo dependente e condicionante da maioria dos direitos fundamentais. Dependente, porque o desrespeito aos demais direitos fundamentais afeta o bem-estar das pessoas; condicionante, porque despidas de saúde, as pessoas ficam impossibilitadas de usufruir plenamente uma série de direitos fundamentais constitucionalmente assegurados. ${ }^{328}$ Nesse viés, o rol de atividades estatais voltadas à garantia do direito à saúde tende a ser ilimitado e compõe o que se denomina, em termos gerais, de atividades de atenção à saúde. ${ }^{329}$ Tais atividades voltam-se tanto à garantia de outros direitos fundamentais que têm influência na saúde ${ }^{330}$ quanto à prestação de ações e serviços voltados especificamente

328 Sobre a concepção de saúde como qualidade de vida, conferir: MORAIS, José Luis B. de. Do direito social aos interesses transindividuais: o estado e o direito na ordem contemporânea. Porto Alegre: Livraria do Advogado, 2006. p.187-190. Sobre a saúde como um sistema, dependente de outros sistemas sociais: SCHWARTZ, Germano. Direito à saúde: efetivação em uma perspectiva sistêmica. Porto Alegre: Livraria do Advogado, 2001. p.85 e segs.

329 Como mencionado na Introdução deste trabalho, a Norma Operacional Básica do SUS n. ${ }^{\circ}$ 01/96, veiculada pela Portaria GM/MS n. ${ }^{\circ}$ 2.203, de 05 de novembro de 2006, estabelece que a atenção à saúde compreende três campos: (i) assistência à saúde, prestada, individual ou coletivamente, em especial no âmbito hospitalar, ambulatorial ou domiciliar; (ii) intervenções ambientais, em sentido amplo, incluindo condições sanitárias no ambiente de vida e de trabalho, controle de vetores e hospedeiros, e saneamento ambiental; e (iii) políticas externas ao setor de saúde, que congregam todos os demais fatores externos que incidem sobre a saúde das pessoas, como as relativas a políticas macro-econômicas, emprego, habitação, educação, lazer e qualidade dos alimentos (os grifos não constam do original).

330 Nesse sentido, documentos elaborados nas Conferências Internacionais de Promoção da Saúde, realizadas pela Organização Mundial da Saúde (OMS), como a Carta de OTTAWA para a Promoção da Saúde, de 1986, estabeleceram como pré-requisitos para a saúde: paz, habitação, educação, alimentação, renda, ecossistema estável, recursos sustentáveis, justiça social e eqüidade. Do mesmo modo, a Declaração de Jacarta, de 1997, ampliou o rol, relacionado à saúde: paz, abrigo, instrução, segurança social, relações sociais, alimento, renda, direito de voz das mulheres, um ecossistema estável, uso sustentável dos recursos, justiça social, respeito aos direitos humanos e eqüidade e, acima de tudo, a ausência de pobreza. Da mesma forma, a Lei n. ${ }^{\circ} 8.080 / 90$ expressa em seu artigo 3..$^{\circ}$ : A saúde tem como fatores determinantes e condicionantes, entre outros, a alimentação, a moradia, o saneamento básico, o meio ambiente, o trabalho, a renda, a educação, o transporte, o lazer e o acesso aos bens e serviços essenciais (...). Parágrafo único. Dizem respeito também à saúde as ações que (...) se destinam a garantir às pessoas e à coletividade condições de bem-estar físico, mental e social. 
à prevenção de doenças e à promoção, proteção e recuperação da saúde. Esta última categoria de atividades compõe o que se denomina assistência à saúde. ${ }^{331}$

Assim, além da tendência à ilimitação das atividades estatais indiretamente voltadas à garantia da saúde (atenção à saúde), também são ilimitadas outras atividades que diretamente garantem tal direito (assistência à saúde), em um grau de vinculação que varia conforme a natureza da prestação. Nessa perspectiva, poder-se-ia dizer que são duplamente ilimitadas as possibilidades de atuação estatal para garantia do direito à saúde.

As atividades de assistência à saúde compõem o que a Constituição Federal denomina o sistema único de saúde (SUS) e devem ser prestadas tanto pelo Estado quanto por terceiros contratados ou conveniados, com preferência das entidades filantrópicas e das sem fins lucrativos. Além disso, as entidades privadas possuem liberdade para prestar serviços de saúde independente de vínculo com o Estado; nesse último caso, os serviços prestados são qualificados como de relevância pública e estão sujeitos à regulamentação, à fiscalização e ao controle pelo Poder Público.

É de se ressaltar que a denominação sistema único de saúde (SUS) não tem como referente um sistema de saúde único, mas de um sistema dúplice. Tal duplicidade é conformada tanto pelo subsistema público - denominado SUS - quanto pelo subsistema

331 Com o objetivo de garantir o financiamento da assistência à saúde, por meio da Emenda Constitucional n. ${ }^{\circ} 29$, de 13 de setembro de 2000, foram acrescentados os parágrafos $2 .^{\circ}$ e $3 .^{\circ}$ ao artigo 198 da Constituição Federal, que prevêem a aplicação mínima por cada ente federativo, conforme valores a serem definidos em lei complementar. Atualmente encontra-se em tramitação no Congresso Nacional, o Projeto de Lei Complementar n. ${ }^{\circ} 121 / 2007$, já aprovado pelo Senado Federal em 6 de maio de 2008 e pendente de apreciação pela Câmara dos Deputados. De acordo com o artigo 18 do projeto em referência, são consideradas despesas com ações e serviços públicos de saúde aquelas voltadas para a promoção, proteção, recuperação e reabilitação da saúde que se enquadrarem em qualquer dos seguintes campos de atuação do Sistema Único de Saúde (SUS): I - vigilância em saúde, incluindo a epidemiológica e a sanitária; II - atenção integral e universal à saúde em todos os níveis de complexidade, incluindo a assistência terapêutica e a recuperação de deficiências nutricionais; III - capacitação do pessoal de saúde do SUS; IV - desenvolvimento científico e tecnológico e controle de qualidade promovidos por instituições do SUS; V - produção, aquisição e distribuição de insumos para os serviços de saúde do SUS, tais como imunobiológicos, sangue, hemoderivados, medicamentos e equipamentos médico-odontológicos; VI - saneamento básico de domicílios ou de pequenas comunidades, desde que aprovado pelo Conselho de Saúde do ente da Federação financiador da ação; VII - saneamento básico dos distritos sanitários especiais indígenas e de comunidades remanescentes de quilombos; VIII - manejo ambiental vinculado diretamente ao controle de vetores de doenças; IX - apoio administrativo realizado por instituições do SUS, desde que vinculado à execução das ações relacionadas neste artigo; X - gestão do sistema público de saúde e operação de unidades prestadoras de serviços públicos de saúde; XI - remuneração do pessoal de saúde em atividade nas ações de que trata este artigo, incluindo os encargos sociais; XII - construção, ampliação e reforma de estabelecimentos de saúde do SUS. Tal rol abrange atividades, como saneamento básico e manejo ambiental não são voltadas diretamente à promoção, proteção e recuperação de saúde, de modo que extrapolam o conceito de assistência, enquadrando-se muito mais no conceito de atenção à saúde. 
privado autônomo. ${ }^{332}$ No subsistema público, a prestação de serviços de saúde pode ocorrer por entidades de natureza pública e por entidades de natureza privada; já no subsistema privado autônomo, a prestação dos serviços pode dar-se por meio do subsistema de saúde suplementar, do qual fazem parte os planos privados de saúde, e do subsistema de desembolso direto e de desembolso indireto (categoria esta [desembolso indireto] em que podem ser enquadrados os cartões saúde, mencionados no Item 3.2.2.1).

Nesse cenário, resta evidenciado que com o SUS convivem formas privadas de prestação de serviços de saúde, tanto dentro do subsistema público (o que não retirara seu caráter público e único) como fora de tal subsistema.

Além das ações e serviços de saúde, referidos nos artigos 196, 197 e 198 do texto constitucional, o subsistema público possui competência para o desenvolvimento de uma série de atividades cujo rol encontra-se relacionado exemplificativamente no artigo 200 da Constituição Federal. ${ }^{333}$ Desse modo, para que se possam definir e analisar com clareza os limites e os mecanismos mais adequados para a participação privada na prestação de serviços públicos de saúde, é necessária a investigação do que se deve entender por serviços públicos

332 Ao contrário do que ocorreu no setor de saúde, como analisado no Item 3.1, a opção pela estatização de atividades privadas foi tomada, por exemplo, no caso das serventias do foro judicial, como determina o artigo 31 do Ato das Disposições Constitucionais Transitórias da Constituição de 1988.

333 Art. 200. Ao sistema único de saúde compete, além de outras atribuições, nos termos da lei: I - controlar e fiscalizar procedimentos, produtos e substâncias de interesse para a saúde e participar da produção de medicamentos, equipamentos, imunobiológicos, hemoderivados e outros insumos; II - executar as ações de vigilância sanitária e epidemiológica, bem como as de saúde do trabalhador; III - ordenar a formação de recursos humanos na área de saúde; IV - participar da formulação da política e da execução das ações de saneamento básico; V - incrementar em sua área de atuação o desenvolvimento científico e tecnológico; VI - fiscalizar e inspecionar alimentos, compreendido o controle de seu teor nutricional, bem como bebidas e águas para consumo humano; VII - participar do controle e fiscalização da produção, transporte, guarda e utilização de substâncias e produtos psicoativos, tóxicos e radioativos; VIII - colaborar na proteção do meio ambiente, nele compreendido o do trabalho. Tal elenco de atividades foi ampliado pela Lei n. ${ }^{\circ} 8.080 / 90$, que em seus artigos 5. ${ }^{\circ}$ e $6 .^{\circ}$, assim dispõe: Art. 5. ${ }^{\circ}$ São objetivos do Sistema Único de Saúde SUS: I - a identificação e divulgação dos fatores condicionantes e determinantes da saúde; II - a formulação de política de saúde destinada a promover, nos campos econômico e social, a observância do disposto no $\S 1 .^{\circ}$ do art. $2 .^{\circ}$ desta lei; III - a assistência às pessoas por intermédio de ações de promoção, proteção e recuperação da saúde, com a realização integrada das ações assistenciais e das atividades preventivas. Art. 6 . $^{\circ}$ Estão incluídas ainda no campo de atuação do Sistema Único de Saúde (SUS): I - a execução de ações: a) de vigilância sanitária; b) de vigilância epidemiológica; c) de saúde do trabalhador; e d) de assistência terapêutica integral, inclusive farmacêutica; II - a participação na formulação da política e na execução de ações de saneamento básico; III - a ordenação da formação de recursos humanos na área de saúde; IV - a vigilância nutricional e a orientação alimentar; V - a colaboração na proteção do meio ambiente, nele compreendido o do trabalho; VI - a formulação da política de medicamentos, equipamentos, imunobiológicos e outros insumos de interesse para a saúde e a participação na sua produção; VII - o controle e a fiscalização de serviços, produtos e substâncias de interesse para a saúde; VIII - a fiscalização e a inspeção de alimentos, água e bebidas para consumo humano; IX - a participação no controle e na fiscalização da produção, transporte, guarda e utilização de substâncias e produtos psicoativos, tóxicos e radioativos; X - o incremento, em sua área de atuação, do desenvolvimento científico e tecnológico; XI - a formulação e execução da política de sangue e seus derivados. 
de saúde, o que implica enfrentar um dos temas mais controvertidos na doutrina administrativista em todos os tempos.

\subsubsection{Serviços Públicos na Constituição de 1988}

Seguindo a linha adotada neste trabalho, de interpretar as hipóteses, os limites e os mecanismos de participação privada no serviço público de saúde com base na Constituição e não em conceitos cristalizados na doutrina, o raciocínio que segue busca utilizar a teoria administrativista como apoio para a compreensão do problema ora debatido, e não o inverso. 334

Nesse prisma, partindo da noção comumente difundida na doutrina pátria, ${ }^{335}$ de que o serviço público corresponde a uma prestação (critério objetivo ou material), realizada direta ou indiretamente pelo Estado (critério subjetivo), sob o regime de direito público (critério formal), direcionado a um fim de interesse público (critério teleológico), há que se promover sua filtragem com base na Constituição Federal. ${ }^{336}$ Afinal, entende-se que se o serviço público

334 Mesmo porque outra abordagem faria deste estudo mera repetição de idéias ou, no máximo, a seleção e aplicação de idéias antigas a um tema ainda não explorado pela teoria jurídica. Em qualquer caso, estaria prejudicada a originalidade do trabalho. Nessa perspectiva, como já ressaltado, busca-se, a partir do conhecimento da história e direito atuais, criar e projetar soluções para o futuro. Essa é a orientação firmada há alguns anos por Clèmerson Clève, que assim consignou: "Eis o momento de se propor um saber inserido na historicidade, resultado de uma relação de conhecimento do jurista com o mundo e, voltando-se para o futuro, apto a formular conceitos teóricos-práticos para mudá-lo. Um saber que, conhecendo o direito positivo, explique-o teoricamente, a sua lógica e o seu funcionamento, ao mesmo tempo em que, captando-o como resultante de relações de poder, promova e reclame a afirmação dos direitos necessários à defesa e à promoção da dignidade humana." (CLÈVE, Clèmerson Merlin. Temas de direito constitucional (e de teoria do direito). São Paulo: Acadêmica, 1993. p.208).

335 Como ilustração, pode-se mencionar a opinião de Celso Antônio Bandeira de Mello, comumente citado pela doutrina pátria, de acordo com o qual: "Serviço público é toda a atividade ou comodidade material destinada à satisfação da coletividade em geral, mas fruível singularmente pelos administrados, que o Estado assume como pertinente a seus deveres e presta por si mesmo ou por quem lhe faça as vezes, por um regime de Direito Público - portanto consagrador de prerrogativas de supremacia e de restrições especiais -, instituído em favor dos interesses definidos como públicos pelo sistema normativo." (MELlO, Celso Antonio Bandeira de. Curso de direito administrativo. 23.ed. São Paulo: Malheiros, 2007. p.652).

336 Como assinala Gilles Guglielmi, ao tratar dos serviços públicos:"As noções jurídicas não são permanentes, nem suscetíveis de delimitação absoluta. Sob o mesmo termo serviço público, os juristas de épocas diferentes recobriram realidades diferentes e com funções diferentes." (GUGLIELMI, Gilles. Introduction au droit des services publics. Paris: EJA, 1994. p.15). Nesse caminho, Eros Grau sustenta que o conceito é atemporal, enquanto a noção pode ser definida como o esforço sintético para produzir uma idéia que se desenvolve a si mesma por contradições e superações sucessivas e que é homogênea ao desenvolvimento das coisas (GRAU, Eros. A ordem econômica na constituição de 1988. 8.ed. São Paulo: Malheiros, 2003. p.116). 
não constitui um conceito lógico-jurídico, mas uma noção cujo conteúdo é passível de ser extraído da Constituição e da realidade histórica;337 e não de construções doutrinárias tradicionais e, possivelmente, desconectadas do que expressa o texto constitucional e a própria realidade social. Nessa perspectiva é a crítica de Fernando Herren Aguillar, para quem:

\footnotetext{
As contribuições doutrinárias para o conceito de serviço público têm apenas caráter didático, reportando-se os juristas não àquilo que determina a Constituição, mas àquilo que, em sua experiência pessoal, testemunharam como sendo genericamente serviço público. 338
}

A crítica é valida na medida em que neste trabalho busca-se a compreensão do que é o serviço público, e não do que se gostaria que ele fosse. Com isso, concorda-se com a advertência de Celso Antônio Bandeira de Mello, consignada sob a vigência da Constituição anterior, segundo a qual: "Pretender que certas atividades são 'em si mesmas' serviço público significa que, consagradas ou não legislativamente como tal, assim devem ser havidas. Um conceito desta ordem não serve para o jurista". 339

É de se ressaltar, de outro lado, que a Constituição Federal de 1988 traz balizamentos para a criação de serviços públicos, os quais devem ser observados pela lei que os cria. Portanto, não há serviços públicos 'em si mesmos', mas há critérios constitucionais que dirigem a criação de serviços públicos. Além disso, deve-se destacar que desde a promulgação do texto constitucional brasileiro, como assinalado neste trabalho, houve importante desenvolvimento da teoria jurídica pátria e relevante avanço tecnológico, os quais demandam uma renovada interpretação dos critérios constitucionalmente estabelecidos.

337 Não se trata da busca inalcançável de uma geometria jurídica, referida por Genaro R. Carrió ao tratar da imprecisão e nebulosidade de grande parte dos conceitos jurídicos (CARRIÓ, Genaro R. Notas sobre Derecho y Lenguage. 4.ed. Buenos Aires: Abeledo-Perrot, 1994); e tampouco de definir essências, mas de buscar balizamentos que viabilizem a aplicação de normas jurídicas, como assinalou Eros Grau (GRAU, Eros. A ordem econômica na constituição de 1988. 8.ed. São Paulo: Malheiros, 2003. p.75).

338 AGUILLAR, Fernando Herren. Controle social de serviços públicos. São Paulo: Max Limonad, 1999. p.134.

339 MELLO, Celso Antônio Bandeira de. Natureza e regime jurídico das autarquias. São Paulo: Revista dos Tribunais, 1968. p.12. 


\subsubsection{Referências constitucionais para a criação de serviços públicos}

O ponto de partida para uma análise jurídica do serviço público deve ser a Constituição Federal de 1988. Nela, é possível encontrar a utilização da expressão em sentido amplo, para se referir a toda e qualquer atividade desempenhada pelo Estado, ${ }^{340}$ como em sentido estrito, com referência a uma determinada modalidade de atividade administrativa prestacional em relação à qual o Estado assume a responsabilidade por sua oferta. Neste segundo caso, que interessa ao presente estudo, encontram-se referências constitucionais a três conjuntos de serviços públicos:

(i) aqueles expressamente qualificados como tais pelo próprio texto constitucional;

(ii) aqueles em relação aos quais a Constituição outorgou competência para sua exploração pelo Estado; e

(iii) aqueles em relação aos quais a Constituição Federal autorizou sua criação por lei.

$\mathrm{Na}$ primeira categoria encontram-se atividades como os serviços públicos de saúde, expressamente qualificadas como tais pela Constituição Federal no artigo 34, inciso VII, alínea $e$; no artigo 35, inciso III; no artigo 167, inciso IV; e no artigo 198 e seu parágrafo segundo; bem como no artigo 77 do Ato das Disposições Constitucionais Transitórias (ADCT). Tal é o número de dispositivos que atribuem expressamente a qualificação dos serviços de saúde como serviços públicos, que não resta outra alternativa a não ser reconhecê-los, no ordenamento pátrio, como o serviço público por excelência. ${ }^{341}$

340 Tal sentido é encontrado, dentre outros, no artigo 20, IV; artigo 37, XIII; artigo 39, § 7..$^{\text {; }}$ artigo 40, § 1. ${ }^{\circ}$, III e $\S 16$ da Constituição Federal. Essa noção ampla de serviços públicos, relacionada ao conjunto de atividades estatais, é típica da teoria francesa de serviço público, de acordo com a qual: "A idéia de serviço público é ligada a uma concepção ampla de missões do Estado e da Administração em geral, que além de manter a ordem pública, devem organizar a vida econômica, social, cultural fornecendo e gerando os bens e serviços úteis à coletividade." (MORAND-DEVILLER, Jacqueline. Cours de Droit Administratif. 7.ed. Paris: Montchrestien, 2001. p.17).

341 Além dos serviços públicos de saúde, apenas em duas outras hipóteses a Constituição Federal apresenta qualificação expressa de determinadas atividades com tais: (i) quando trata dos serviços públicos de transporte urbano; no artigo 30, inciso V; e (ii) quando se refere, em seu artigo 66 do Ato das Disposições Constitucionais Transitórias, ao serviço público de telecomunicações (os quais também haviam sido qualificados como públicos pelo inciso XI, do artigo 21 da redação original da Constituição Federal, alterada pela Emenda Constitucional n.8, de 15 de agosto de 1995). 
Na segunda categoria são relacionadas prestações cuja realização é atribuída pelo texto constitucional como competência do Estado. ${ }^{342}$ Dentre elas, podem-se destacar alguns setores em relação aos quais a competência para sua exploração foi atribuída à União Federal pelo artigo 21 da Constituição, como o serviço postal e o correio aéreo nacional (inciso X), os serviços de telecomunicações (inciso XI), os serviços de radiodifusão sonora, sons e imagens, o serviço de energia elétrica, a navegação aérea e aéreo-espacial, os serviços de transporte ferroviário e aquaviário (inciso XII), dentre outros. O serviço de saúde pode também ser enquadrado nessa categoria, nos termos do artigo 30, inciso VII da Constituição Federal, que além de qualificar expressamente o serviço de saúde como serviço público, atribui competência ao Município para sua prestação. ${ }^{343}$

É importante notar que a atribuição de competência para explorar ou manter determinado setor implica atribuição de responsabilidade estatal em garantir sua oferta, o que não significa que todo o setor de atividades deva ser qualificado como serviço público. Parte das atividades relacionadas, de acordo com o estágio de evolução tecnológica, social e econômica, pode ter sua prestação garantida satisfatoriamente pelo mercado, ${ }^{344}$ ou ainda pode ser prestada do modo desvinculado de qualquer critério que legitime sua qualificação

342 Conforme José Afonso da Silva, competência deve ser entendida como a faculdade juridicamente atribuída a uma entidade ou a um órgão ou agente do Poder Público para emitir decisões; ou, sob outro ângulo, competências correspondem às diversas modalidades de poder de que se servem as entidades estatais e órgãos para a realização de suas funções (SILVA, José Afonso da. Curso de direito constitucional positivo. 22.ed. São Paulo: Malheiros, 2003. p.477).

343 Art. 30. Compete aos Municípios: (...) VII - prestar, com a cooperação técnica e financeira da União e do Estado, serviços de atendimento à saúde da população.

344 É o caso típico do setor de energia elétrica, no qual até algum tempo atrás, não havia condições técnicas de segregação entre todas atividades envolvidas de geração até sua comercialização aos consumidores finais. Nessa época, todo o setor configurava serviço público e era explorado em regime de monopólio, por tratar-se, em tais condições, de um monopólio natural (situação na qual a prestação por um único agente possui custos mais baixos do que sua prestação em regime competitivo). Não obstante, com o desenvolvimento tecnológico recente, surgiu a possibilidade de segregação das atividades, de modo que foi implantado o regime de competição no âmbito, por exemplo, da geração de energia - de modo que diversos geradores têm acesso garantido à infra-estrutura de distribuição, ainda mantida em regime de monopólio (natural). O setor encontra-se disciplinado especificamente em lei - Lei n. ${ }^{\circ} 9.074$, de 07 de julho de 1995, em especial artigos 4. ${ }^{\circ}$ a 25, e Lei n. ${ }^{\circ}$ 9.427, de 26 de dezembro 1996, que instituiu a Agência Nacional de Energia Elétrica (ANEEL), entidade competente para regular e fiscalizar a produção, transmissão, distribuição e comercialização de energia elétrica. 
como serviço público. ${ }^{345}$ Em tais casos, nem todas as atividades integrantes de determinada área são qualificadas como serviço público. Dentro de um setor cuja competência para exploração foi atribuída a determinado ente estatal, a definição daquelas atividades especificamente qualificadas como serviço público deve constar da lei que regulamenta o respectivo setor. Em última análise, pode-se sustentar que a atribuição de competência a determinado ente federativo implica determinação para que a lei institua o regime jurídico que vai disciplinar a prestação de cada uma das atividades integrantes do setor, parte das quais será por ela qualificada como serviço público. ${ }^{346}$ Nesse sentido, compartilha-se da análise e da crítica de Carlos Ari Sundfeld:

\begin{abstract}
Quanto a mim, não consigo, ao examinar a Constituição, localizar onde estaria a definição desse regime jurídico único. O que encontro, em sucessivas passagens, é a previsão de que cabe às ' leis' disciplinar os direitos e deveres dos prestadores, de usuários e do Poder Público. Sendo bastante honesto, penso que essa crítica doutrinária [à possibilidade de exploração de atividades de competência do Estado sob o 'regime privado'] tem pouco de jurídica e muito de política, pois, de um lado, inspira-se no desejo de ver preservado o modelo estatal monopolista de exploração e, de outro, traduz grande desconfiança quanto à idoneidade do atual legislador para disciplinar os serviços (donde a pretensão de esses juristas concorrerem para o estabelecimento de rígidos limites ao poder de legislar sobre 'serviços públicos' por via de uma interpretação muito pessoal da Constituição). ${ }^{347}$
\end{abstract}

Quanto à terceria categoria de atividades em relação ao qual a Constituição prevê a criação de serviços públicos, não há qualificação expressa pelo próprio texto constitucional e tampouco a outorga de competência para a exploração de determinado setor de atividade; há apenas a previsão de critérios gerais para a criação de novos serviços públicos não previstos pelo texto constitucional. Tais critérios encontram-se dispostos no artigo 173 da Constituição, que assim dispõe:

345 Nessa hipótese, são comumente citados pela doutrina exemplos como a produção de energia elétrica para o consumo individual e os serviços de comunicação por rádio amador. Tais atividades, apesar de integrantes do setor de energia e do setor de telecomunicações, não apresentam os requisitos (abaixo analisados) necessários para sua qualificação como serviços públicos.

346 Isso implica reconhecer, obviamente, que a outorga de competência para que o Estado explore determinado setor restringe sobre ele a livre iniciativa, que poderá agir apenas nos termos da lei que regula o setor determinar.

347 SUNDFELD, Carlos Ari. Serviços públicos e regulação estatal. In: econômico. São Paulo: Malheiros, 2000. p.333-34. 
Art. 173. Ressalvados os casos previstos nesta Constituição, a exploração direta de atividade econômica pelo Estado só será permitida quando necessária aos imperativos da segurança nacional ou a relevante interesse coletivo, conforme definidos em lei. ${ }^{348}$

Tal interpretação não é acolhida pela doutrina predominante, que defende a aplicação dos critérios referidos apenas para os casos em que o Estado explore atividade econômica e não quando preste serviços públicos. Uma das mais veementes passagens em defesa da tese de que o artigo 173 traz critérios para a qualificação de determinada prestação como atividade econômica em sentido estrito e não como serviço público pode ser encontrada em Eros Roberto Grau, que assim escreveu:

$\mathrm{O}$ art. 173 do texto constitucional brasileiro evidentemente não respeita, restringindo-a - isso é óbvio, curial, evidente -, à conversão de qualquer dessas parcelas em serviço público, visto que cogita de atividade econômica em sentido estrito, aludindo imperativo da segurança nacional e relevante interesse coletivo. ${ }^{349}$

Não obstante, na página seguinte do mesmo trabalho, o próprio autor sustenta que a diferença entre uma prestação e outra é a de que enquanto o serviço público tem como pressuposto um interesse social, a atividade econômica em sentido estrito prestada pelo Estado tem como fundamento um interesse coletivo; noções que o próprio autor sustenta serem distintas, apesar de comporem a categoria interesse público. ${ }^{350}$ Acontece que, nos termos do que se vem expondo, a partir da contemporânea teoria dos direitos fundamentais, a dimensão do que deve ser considerado interesse geral, interesse coletivo, interesse social ou mesmo interesse privado apenas pode ser objetivada durante o processo de aplicação do direito, que envolve em grande parte dos casos a ponderação entre direitos fundamentais incidentes na hipótese.

348 Para Fábio Nusdeo, a segurança nacional configura o único bem de caráter integralmente coletivo, no sentido de que sua garantia atinge todos os cidadãos indistintamente (NUSDEO, Fábio. Curso de economia: introdução ao direito econômico. 4.ed. São Paulo: Revista dos Tribunais, 2005. p.41). A interpretação de tais critérios, portanto, depende da definição do que são bens coletivos, a qual apenas pode ser promovida por meio da interpretação e ponderação de princípios eventualmente incidentes em cada hipótese de criação de serviços públicos. Com isso, quer-se sustentar: (i) que há previsão constitucional expressa acerca dos critérios para criação de novos serviços públicos; (ii) tais critérios devem ser interpretados de acordo com a teoria constitucional emancipatória, fulcrada não nos interesses do Estado, mas nos direitos fundamentais.

349 GRAU, Eros. A ordem econômica na constituição de 1988. 8.ed. São Paulo: Malheiros, 2003. p.110.

350 GRAU, Eros. A ordem econômica na constituição de 1988. 8.ed. São Paulo: Malheiros, 2003. p.111. 
Sobre a questão, em que pese haver na doutrina numerosas tentativas de delimitação abstrata entre tais conceitos, pode-se sustentar que todas elas padecem de utilidade. A menção constitucional de tais expressões nada mais quer dizer que se trata de uma atuação a ser realizada apenas e tão-somente quando houver justificativa expressa de que ela é vinculada a determinado(s) direito(s) fundamental(is). ${ }^{351}$ Portanto, a menção constitucional a interesses coletivos deve ser entendida como resultado de um processo, e não como critério a priori. Com isso deve-se concluir hodiernamente que ao mencionar relevante interesse coletivo a Constituição Federal faz remissão aos direitos fundamentais. ${ }^{352}$

Seguindo essa ordem de idéias - sem grande aprofundamento na questão, que conforma tema tangencial do objeto do presente estudo -, entende-se inevitável sustentação de posição divergente da majoritária, com base nos seguintes fundamentos:

(i) segurança nacional e relevante interesse coletivo constituem fundamento de todos os serviços públicos direta (por qualificação expressa) ou indiretamente (por outorga de competência) previstos pela Constituição de 1988;353

351 Sob a ótica normativa constitucional, expressões similares, vinculadas a determinado interesse, podem ser encontradas nos seguintes artigos: (i) relevante interesse nacional - art. 148, II; (ii) relevante interesse público - art. $231, \S 66^{\circ}$; (iii) relevante interesse econômico e social - art. 71 do ADCT (com redação dada pela Emenda Constitucional n. ${ }^{\circ}$ 17, de 1997); (iv) relevante interesse social - art. 79 do ADCT (incluído pela Emenda Constitucional n. ${ }^{\circ} 31$, de 2000) e também no já comentado artigo 173 da Constituição, que prevê a exploração de atividade econômica pelo Estado quando necessário a imperativos de segurança nacional ou a relevante interesse coletivo.

352 Sobre as diversas acepções do termo interesse, conferir: MANCUSO, Rodolfo Camargo. Interesses difusos: conceito e legitimação para agir. 6.ed. São Paulo: Revista dos Tribunais, 2004. p.19-81. Sobre a análise do interesse público no âmbito do Direito Administrativo: JUSTEN FILHO, Marçal. Conceito de interesse público e a 'personalização' do direito administrativo. Revista Trimestral de Direito Público, São Paulo, n. 26, p.115-136, 1999; e MARQUES NETO, Floriano de Azevedo. Regulação estatal e interesses públicos. São Paulo: Malheiros, 2002.

353 Tal argumentação é auto-evidente e pode ser comprovada com cada um dos serviços públicos existentes no Brasil. A questão da vinculação dos serviços públicos aos direitos fundamentais, a partir dos quais deve ser interpretada a expressão relevante interesse coletivo, não apresenta grande dificuldade, pois, como já extensivamente ressaltado nesse trabalho, e sabido por todos, o que legitima a própria existência do Estado é a garantia de direitos, muitos dos quais dependentes de prestações realizadas pelo Estado. Já no que se refere aos imperativos de segurança nacional como fundamento para a qualificação de determinado serviço como público, o entendimento de Marçal Justen Filho basta para comprovar a tese defendida: "Tratar-se-ia de reconhecer que o instituto do serviço público se relaciona não apenas com a eficiência no modo de satisfazer necessidades essenciais, mas também como controle do poder econômico privado. (...) Também pode ocorrer que a relevância das atividades propicie tamanha quantidade de poder (político, econômico, cultural etc.) ao exercente da atividade que se imponha como necessária a intervenção estatal para produzir o equilíbrio social." (JUSTEN FILHO, Marçal. Teoria geral das concessões de serviço público. São Paulo: Dialética, 2003. p.34). Como se vê, na opinião do autor referido, e de vários outros, a segurança nacional - consubstanciada na contenção do poder de determinados agentes prestadores de serviços estratégicos - também constitui fundamento para a qualificação de determinados serviços como públicos. 
(ii) todos os serviços públicos, por envolverem prestação de determinada atividade necessitam de recursos escassos para a satisfação de necessidades tendencialmente ilimitadas e são, portanto, atividades econômicas; ${ }^{354}$

(iii) a argumentação de que o referido artigo 173 trata apenas de atividade econômica desempenhada pelo Estado (e não de serviço público) é débil, pois interpreta o caput do artigo em referência com base no disposto em seus parágrafos, 355 os quais têm como objeto uma situação específica - a prestação de atividade econômica por empresas estatais; $; 36$

(iv) o regime jurídico em que determinado serviço público será prestado é variável e não implica, necessariamente, seu monopólio pelo Estado, de modo que fica

354 Tal assertiva é irrefutável e já foi mencionada no Capítulo anterior quando se tratou da inviabilidade de separação entre o econômico e o social.

355 Art. 173. (...) § 1. ${ }^{\circ}$ A lei estabelecerá o estatuto jurídico da empresa pública, da sociedade de economia mista e de suas subsidiárias que explorem atividade econômica de produção ou comercialização de bens ou de prestação de serviços, dispondo sobre (parágrafo com redação dada pela Emenda Constitucional n. ${ }^{0} 19$, de 4 de junho de 1998): I - sua função social e formas de fiscalização pelo Estado e pela sociedade; II - a sujeição ao regime jurídico próprio das empresas privadas, inclusive quanto aos direitos e obrigações civis, comerciais, trabalhistas e tributários; III - licitação e contratação de obras, serviços, compras e alienações, observados os princípios da administração pública; IV - a constituição e o funcionamento dos conselhos de administração e fiscal, com a participação de acionistas minoritários; V - os mandatos, a avaliação de desempenho e a responsabilidade dos administradores (incisos incluídos pela Emenda Constitucional n. ${ }^{\circ} 19$, de 1998). $§ 2 .^{\circ}$ - As empresas públicas e as sociedades de economia mista não poderão gozar de privilégios fiscais não extensivos às do setor privado. $\S 3 .^{\circ}$ - A lei regulamentará as relações da empresa pública com o Estado e a sociedade. $\S 4 .^{\circ}$ - A lei reprimirá o abuso do poder econômico que vise à dominação dos mercados, à eliminação da concorrência e ao aumento arbitrário dos lucros. $\S 5$. $^{\circ}-$ A lei, sem prejuízo da responsabilidade individual dos dirigentes da pessoa jurídica, estabelecerá a responsabilidade desta, sujeitando-a às punições compatíveis com sua natureza, nos atos praticados contra a ordem econômica e financeira e contra a economia popular.

356 Nesse sentido, os requisitos previstos pelo artigo 173 da Constituição Federal vinculam tanto a criação de atividades econômicas prestadas pelo Estado em concorrência com entidades privadas, quanto nos casos em que o Estado assume para si a prestação dos serviços em regime de monopólio. Deve-se notar que tal raciocínio é intuitivamente promovido pela maioria dos autores que admitem a possibilidade de criação de serviços públicos não previstos pela Constituição Federal, mas que não reconhecem o artigo 173, caput, como seu fundamento legal. Como ilustração, pode-se analisar o pensamento de Alexandre Santos de Aragão. O autor sustenta não serem aplicáveis os requisitos do artigo 173 da Constituição Federal como critérios para a criação de novos serviços públicos, por entender que tal dispositivo aplica-se apenas à exploração de atividades econômicas em sentido estrito. Para o autor, tal entendimento decorre do fato de que a exploração pelo Estado das atividades referidas no artigo em referencia não exclui sua exploração em igualdade de condições com a iniciativa privada. Acontece que, Alexandre Aragão, além de não considerar a reserva de titularidade uma característica inalienável dos serviços públicos, ao tratar da fundamentação da qualificação de atividades como serviços públicos, enuncia critérios bastante semelhantes aos do artigo 173: "O fundamento último da qualificação jurídica de determinada atividade como serviço público é ser pressuposto da coesão social e geográfica de determinado país e da dignidade de seus cidadãos." (ARAGÃO, Alexandre Santos de. Direito dos serviços públicos. Rio de Janeiro: Forense, 2007. p.142, 157 e 531). 
reduzida a utilidade e dificultada a operacionalização prática da dicotomia serviço público $x$ atividade econômica prestada pelo Estado; $357 \mathrm{e}$

(v) outra interpretação, que não leve em conta tais requisitos, implica reconhecer a impossibilidade de criação de serviços públicos não previstos pela Constituição. ${ }^{358}$

3.2.1.2 A titularidade estatal e as conseqüências da qualificação de determinada atividade como serviço público

É importante ressaltar que titularidade estatal dos serviços públicos implica sua responsabilidade pela garantia da respectiva prestação, a ser conformada nos termos da lei que regulamenta o setor de atividades. Trata-se da 'garantia pública' pela prestação de determinadas atividades. ${ }^{359}$ Como expressou Maria Cristina Dourado: "(...) a titularidade

357 Assim, a ausência de um regime jurídico de serviço público implica a fuidez da dicotomia entre atividade de responsabilidade do Estado prestada como atividade econômica e atividade de responsabilidade do Estado prestada como serviço público. Nesse aspecto, o estatal funde-se com o público e com o econômico, pois o que justifica a intervenção estatal é a ligação aos direitos fundamentais aliada à insuficiência da respectiva prestação pelo mercado, o que apenas pode ser definido em cada caso concreto. Tal observação não passou despercebida por Dinorá Adelaide. M. Grotti, que assim consignou: "(...) a exploração em regime de direito privado e de mercado tem sido introduzida no âmbito dos serviços públicos, o que acaba acarretando a aproximação dos modelos e dos regimes jurídicos das duas atividades." (GROTTI, Dinorá Adelaide. M. O serviço público e a constituição brasileira de 1988. São Paulo: Malheiros, 2003. p.141). Tal ordem de idéias, somadas à análise de casos concretos e decisões judiciais acerca de empresas estatais que prestam tanto atividades econômicas quanto serviços públicos levaram Marçal Justen Filho a prever o que já se tornou realidade, corroborando a tese ora defendida. Nas palavras do autor: "(...) o futuro poderá trazer a constatação de que a distinção entre entidades prestadoras de serviço público e exploradoras de atividade econômica retratou a situação jurídica existente em um certo momento histórico." (JUSTEN FILHO, Marçal. Curso de direito administrativo. São Paulo: Saraiva, 2005. p.110). Com isso não se quer dizer que não haja diferença nos regimes jurídicos de uma entidade que presta serviços públicos e de outras que desempenha atividade econômica. Diferenças e repercussões existem, mas podem apenas ser definidas, em cada caso, com dificuldade, analisando-se a atuação concreta do ente respectivo, sob a luz dos critérios constitucionais e da lei que o disciplina. Nesse sentido, pode-se fazer menção à discussão um tanto quanto vazia travada no Supremo Tribunal Federal, Recurso Extraordinário 220.906/9, ao julgar se a Empresa Brasileira de Correio e Telégrafos (ECT) submete-se ao regime dos precatórios ou se a referida empresa pode sofrer penhora de seus bens em caso de execução. Sobre o tema: BRASIL. Supremo Tribunal Federal, Recurso Extraordinário n. ${ }^{\circ} 220.906-9$ Distrito Federal. Órgão Pleno. Rel. Min. Maurício Corrêa. Diário de Justiça, 14 de novembro de 2002.

358 Essa idéia, defendida por autores como Fernando Herren Aguilar, merece ser desprezada. De acordo com referido autor, os serviços públicos implicam regime de privilégio e exclusividade, de modo que não seria possível sua instituição por meio diverso de Emenda Constitucional (AGUILLAR, Fernando Herren. Controle social de serviços públicos. São Paulo: Max Limonad, 1999. p.131-134). Em que pese a fundamentação trazida pelo autor, deve-se notar que o serviço público não demanda necessariamente regime de privilégio e muito menos de exclusividade (monopólio). Além disso, como já sustentado, o artigo 173 não trata de atividades econômicas em sentido estrito.

359 CAÑADA, Isabel Maria V. Público y Privado em la gestión de la Segurida Social em Espana. Dimensión Jurídica. Granada: Comares, 2007. p.21. 
do serviço público resulta para o Estado o inafastável dever de realizá-lo de forma adequada ao pleno atendimento das necessidades dos cidadãos". ${ }^{360}$ Nesse mesmo sentido, segundo Juan Carlos Cassagne, a criação de um serviço público apenas expressa a decisão estatal de que determinada atividade sujeite-se às potestades administrativas mediante um regime especial, ${ }^{361}$ definido pela lei como o mais apto a garantir a efetiva prestação do serviço.

Como ressalta Odete Medauar, não se discute que o serviço público demanda a existência de um vínculo orgânico com a Administração Pública, ${ }^{362}$ pois é por meio dele que decorre sua responsabilidade pelo serviço, mesmo quando prestado por particulares. $\mathrm{O}$ que se sustenta é que esse vínculo não implica necessariamente a exclusividade da respectiva prestação pelo Estado. Assim deve ser entendida a titularidade estatal sobre os serviços públicos. Nesse contexto, a observação de Carlos Ari Sundfeld - segundo a qual, o objetivo da atribuição de competência para a prestação de serviços qualificados pelo autor como 'serviços sociais' não foi o de reservá-las, mas sim o de obrigar seu exercício ${ }^{363}$ - deve ser estendida a todos os serviços cuja competência foi outorgada pelo texto constitucional. De outro lado, a reserva de titularidade, o monopólio, a exclusividade da prestação pelo Estado, configuram exceções que apenas se justificam em casos específicos, por motivos de ordem econômica (monopólio natural) ou política (segurança nacional).

Essa ordem de idéias não é nova, mas tornou-se atual. Sua formulação inicial pode ser encontrada em León Duguit, que afirmava consistirem os serviços públicos em atividades, cambiáveis conforme o desenvolvimento da civilização, cuja prestação é obrigatória para os governantes, independente de sua prestação em regime de monopólio estatal. ${ }^{364}$ Não seria exagero, pois, afirmar que a noção de serviço público hoje albergada pela Constituição pátria representa uma volta à Duguit.

360 DOURADO, Maria Cristina C. de O. O repensar do conceito de serviço público. Revista Interesse Público, n.9, p.95, 2001.

361 CASSAGNE, Juan Carlos. El resurgimiento del servicio público y su adaptación en los sistemas de economia de mercado (hacia uma nova concepción). Revista de Administracion Pública, n.140, p.103, maio/ago. 1996.

362 MEDAUAR, Odete. Direito administrativo moderno. 11.ed. São Paulo: Revista dos Tribunais, 2007. p.315.

363 SUNDFELD, Carlos Ari. Fundamentos de direito público. 4.ed. São Paulo: Malheiros, 2001. p.84.

364 DUGUIT, León. Las Transformaciones del Derecho Público. Trad. Adolfo Posada y Ramon Jaen. 2.ed. Madrid: Francisco Beltran, 1926. p.100; e DUGUIT, León. Traité de Droit Constitucionnel. 2.ed. Paris: Ancienne Librairie Fontemoing, 1923. Tomo II. p.57. 
No plano constitucional, tal pensamento encontra expressão no artigo 37, § 6. ${ }^{\circ}$, que prevê a responsabilidade objetiva do Estado pela prestação de serviços públicos:

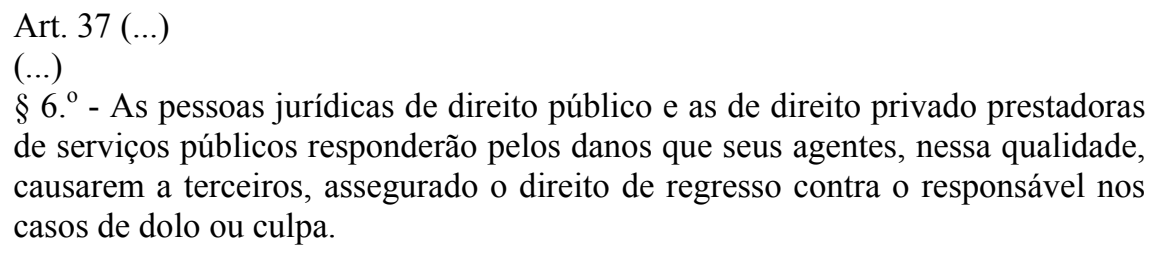
de serviços públicos responderão pelos danos que seus agentes, nessa qualidade, causarem a terceiros, assegurado o direito de regresso contra o responsável nos casos de dolo ou culpa.

Tal previsão impõe a que o prestador de um serviço público, tal qual definido em lei, assuma a responsabilidade por eventual prejuízo causado aos usuários dos serviços, tanto em casos de ação quanto de omissão, independente da existência de culpa. Nesse prisma, ao qualificar uma atividade como serviço público, o Estado assume a responsabilidade de garantir sua prestação de modo adequado - seja direta seja indiretamente. ${ }^{365}$ Com isso, caso não haja tal adequação, incide responsabilidade do prestador privado, nos casos de serviços públicos delegados; e responsabilidade do Estado, direta, caso seja ele o prestador do serviço.

3.2.1.3 A lei como interface entre a Constituição e os diversos estágios de desenvolvimento econômico, tecnológico e social

Cumpridos os requisitos dispostos no caput do artigo 173 da Constituição Federal, deve-se reconhecer a possibilidade de que a lei - criada e modificada de acordo com o desenvolvimento social, econômico e tecnológico de cada momento histórico - fixe a responsabilidade estatal pela prestação de determinada atividade, criando um serviço público. ${ }^{366}$ Além disso, (i) tanto a definição legal das atividades que compõem os serviços expressamente previstos como públicos (ii) quanto daquelas que fazem parte dos setores

365 A noção de serviço público adequado foi definida legislativamente pela Lei $\mathrm{n} .{ }^{\circ} 8.987$, de 13 de fevereiro de 1995, que trata das concessões e permissões de serviços públicos e pode ser utilizada como parâmetro para aferição da prestação dos serviços públicos de saúde. Nos termos da lei mencionada: Art. $6 .^{\circ}$ (...) $\S 1$. $^{\circ}$ Serviço adequado é o que satisfaz as condições de regularidade, continuidade, eficiência, segurança, atualidade, generalidade, cortesia, na sua prestação e modicidade das tarifas.

366 Entendimento diverso implica desconsiderar uma das mais importantes características dos serviços públicos: seu caráter evolutivo. Afinal, como consignou Odete Medauar: "Não se pode negar que o serviço público sempre refletiu a evolução da sociedade e do Estado, sendo afetado por fatores econômicos, sociais e tecnológicos." (MEDAUAR, Odete. Serviços públicos e serviços de interesse econômico geral. In: MOREIRA NETO, Diogo de Figueiredo (Coord.). Uma avaliação das tendências contemporâneas do direito administrativo. Rio de Janeiro: Renovar, 2003. p.115). 
em relação aos quais é atribuída competência para exploração pelo Estado deve observar os requisitos do artigo 173 do texto constitucional.

Nesse viés, em todas as hipóteses admitidas pelo ordenamento pátrio, é necessária a existência de lei que regulamente o funcionamento do respectivo serviço público; lei essa que deve (de)limitar o rol de atividades qualificadas como tal com base em duas ordens de critérios:

(i) os critérios constitucionais, consubstanciados na observância dos requisitos constantes do artigo 173 da Constituição Federal; e

(ii) os critérios econômicos e tecnológicos, caracterizados pela impossibilidade de oferecimento adequado da respectiva atividade prestacional pelo mercado e da possibilidade técnica de segregação de atividades dentro de um mesmo setor.

De acordo com esse entendimento, a lei é constitucionalmente apta a definir as atividades dentro de determinado setor que serão assumidas pelo Estado como sendo de sua responsabilidade, sendo assim qualificadas como serviços públicos. Do mesmo modo, na medida em que referida atividade não necessite mais da intervenção do Estado para garantia da oferta de sua prestação, a atividade poderá ser desqualificada como serviço público, nos termos da lei que regulamente o setor. ${ }^{367}$ Isso pode acontecer quando determinada prestação, levadas em conta a viabilidade técnica e a possibilidade de oferta adequada da atividade pelo mercado, deixe de ter indispensável sua garantia pelo Estado. ${ }^{368}$

A posição adotada neste trabalho implica a ampliação da noção de serviços públicos: de uma base eminentemente econômica, como aquela defendida por Adam Smith para um enfoque também social, baseado nos direitos a prestação em sentido estrito

367 Nesses termos, de acordo com a Constituição Federal, a criação de serviços públicos, definida por Vilar Palasí como publicatio (conferir Capítulo 2) depende de lei que encontre amparo no texto constitucional. Entretanto, ao contrário do forte viés econômico encontrado naquela noção inicial de publicatio, no cenário brasileiro atual, a criação de serviços públicos deve obedecer aos ditames constitucionais, os quais admitem a evolução da sociedade e da tecnologia e permitem que a lei acompanhe tal transformação, qualificando (publicatio) e desqualificando (despublicatio) como serviço público, com fundamento constitucional, determinada atividade específica. Afinal, como assinala Marçal Justen Filho: "A evolução histórica produzirá o surgimento de novas manifestações qualificáveis como serviço público, mas também poderá impor a exclusão de outras. Essa variação é tanto mais previsível quanto mais intensa for a dinâmica das modificações culturais e tecnológicas." (JUSTEN FILHO, Marçal. Teoria geral das concessões de serviço público. São Paulo: Dialética, 2003. p.34).

368 Nesse sentido, Luis Jordana de Pozas, já em 1949, assinalava que uma das funções públicas mais importantes é a de discernir em cada momento, quais necessidades são públicas e quais necessidades deixaram de sê-lo (JORDANA DE POZAS, Luis. Ensayo de una teoría del fomento en el Derecho Administrativo. Revista de Estudios Políticos, n.48, p.41, 1949). 
incorporados tácita ou expressamente nas constituições do século XX. Enquanto Smith, defendia a criação de serviços públicos com fundamento na necessidade de desenvolvimento do mercado e proteção da coletividade, a Constituição Federal de hoje exige que a criação de serviços públicos tenha como amparo a garantia de direitos fundamentais de cada ser humano - ainda que utilize em sua redação as expressões segurança nacional e relevante interesse coletivo.

Não obstante, para tanto, há que se levar em conta a questão econômica - a qual não esgota, mas compõe a realidade - o que, durante algum tempo, em especial na segunda metade do século XX, não foi observado pelo Estado, como analisado no item 2.3 do Capítulo anterior. 369

Conforme assinalado no Capítulo 2, sob a influência das idéias econômicas liberais, a noção de serviço público no Estado do século XIX era ligada ao oferecimento de utilidades fruíveis que apenas podiam ser disponibilizadas pelo mercado mediante a intervenção estatal. Como não era possível a interferência estatal na atividade econômica, criava-se um serviço público decorrente da necessidade do mercado, por meio da publicatio, e se outorgava sua exploração a um particular. Isso ocorreu com os primeiros serviços públicos, como o serviço de correios e de transporte ferroviário. Em sua origem, o serviço público nasceu ligado à criação de condições econômicas, por meio da intervenção jurídica, para que o particular explorasse determinada atividade. Exemplo dessa situação pode ser encontrado em Gaston Jèze, que narra um caso, julgado em 1901, no qual o Conselho de Estado francês proibiu a prestação de serviços de assistência médica gratuita a todos os habitantes de determinado município, por médico contratado pela administração municipal, dentre outros motivos, por ferir a livre concorrência com os outros dois médicos que exerciam suas atividades de medicina privada no local. ${ }^{370}$

369 Trata-se, pois, de se reconhecer definitivamente que o social e o econômico são indissociáveis e talvez, ao contrário do que mencionou Jaques Chevalier, em citação colacionada no Capítulo 2, não se trata de dois lados da mesma moeda, mas do mesmo lado da mesma moeda. Afinal, não é mais admissível, no atual estágio de desenvolvimento social e econômico, enxergar e tratar uma questão sem enxergar e tratar da outra. Nessa perspectiva, tem razão Alexandre Santos de Aragão ao afirmar que: "Os serviços públicos têm como objeto bens escassos, via de regra condicionantes da dignidade da pessoa humana, que se não passam a ser da responsabilidade do Estado, ficando apenas sob a gestão da livre iniciativa, não seriam eficientemente fornecidos a todas as regiões e classes sociais do país." (ARAGÃO, Alexandre Santos de. Direito dos serviços públicos. Rio de Janeiro: Forense, 2007. p.39).

370 JÈZE, Gaston. Princípios Generales del Derecho Administrativo. Trad. Julio M. Almagro. Buenos Aires: Depalma, 1949. Tomo II. p.395. 
Sob o ponto de vista histórico, com a crise econômica das primeiras décadas do século XX e com o surgimento de novas necessidades sociais e novos direitos, o Estado passou a assumir diretamente a prestação de uma série de serviços. E novamente, ao final do século XX, com nova crise econômica, retomou-se a metodologia de prestação dos serviços públicos por particulares. Entretanto, considerando que no período entre as crises econômicas do Estado houve a consagração dos direitos prestacionais em sentido estrito, a noção de serviço público alterou-se, passando a abranger também aquelas prestações oferecidas pelo Estado às pessoas que não possuem condições de obtê-las no mercado. Assim, como assinala Antonio-Enrique Perez Luño: "(...) no Estado social de Direito os poderes públicos assumem a responsabilidade de proporcionar à generalidade dos cidadãos as prestações e serviços públicos adequados para suprir suas necessidades vitais". ${ }^{371}$ Essa transformação fez alterar completamente a noção de serviço público: ao invés de instrumento dos interesses econômicos (ainda que travestidos de interesse público), ela se tornou instrumento da consecução de direitos (fundamentais).

Portanto, o raciocínio levado a cabo conduz à vinculação do serviço (público) ao direito (fundamental), com a colocação da pessoa como destinatária e sua dignidade como justificativa de sua prestação. Com esse novo foco, pode-se classificar a atuação estatal em determinados momentos históricos como serviços públicos, como fez Ruben Miguel Cítara, ao tratar das atividades de assistência à saúde assumidas pela coroa inglesa à época da referida Poor Law do século XVII. ${ }^{372}$

Assim, a conseqüência do pensamento ora defendido, ao contrário do que pode parecer à primeira vista, não afasta, mas aproxima a noção de serviço público de natureza econômica da noção de serviço público de natureza social, pois em ambos os casos trata-se de uma atividade prestacional voltada à consecução de um direito. ${ }^{373}$ Além disso, em um caso e em outro, é possível, em tese, ${ }^{374}$ a convivência da prestação de uma mesma atividade prestacional, tanto pelo Estado (como serviço público, sob responsabilidade estatal direta)

\footnotetext{
371 PEREZ LUÑO, Antonio-Enrique. Los Derechos Fundamentales. 6.ed. Madrid: Tecnos, 1995. p.193.

372 Sobre o tema: CITARA, Rubén Miguel. El servicio público. Buenos Aires: Ciencias de la Administración, 1995.

373 Tal ordem de idéias conduz à limitação da utilidade da dicotomia serviço público x serviço social: ambos são serviços públicos e devem ter sua prestação diretamente garantida pelo Estado nos temos da lei que disciplina o referido serviço.
}

374 Desde que haja condições tecnológicas para tanto. 
e pelo particular a ele vinculado (como serviço público delegado, sob a responsabilidade estatal indireta) quanto pelo particular autônomo (como atividade de prestação e responsabilidade privadas). ${ }^{375}$

Com isso, ressalte-se, não se quer dizer que o conceito de serviço público não exista, tenha desaparecido, tenha perdido sua importância; 376 e muito menos que o Estado brasileiro esteja caminhando em direção a uma desresponsabilização por sua prestação. Pelo contrário: com a argumentação ora esposada, busca-se demonstrar que a consagração expressa ou implícita de novos direitos, como direito à saúde, pelos textos constitucionais do século XX, e com muita peculiaridade a forma pela qual o tema saúde foi tratado pela Constituição Federal de 1988, demanda a oferta de serviços sob a responsabilidade direta do Estado. Em outras palavras, ao assumir a responsabilidade pela garantia do direito à saúde, o Estado assumiu a responsabilidade pela oferta a todos de uma série de atividades a serem definidas em lei, dentre as quais, os serviços públicos de saúde. ${ }^{377}$

375 Ressalvando-se que em um mesmo setor de atividades podem conviver serviços públicos prestados diretamente pelo Estado, serviços públicos prestados por particulares delegatários de serviço público e por particulares sem vínculo direto com o Estado. Por exemplo: determinado município possui um terreno no centro da cidade e nele pretende implantar um estacionamento ao fim de possibilitar maior comodidade a grande parte de sua população. É admissível a transferência de tal atividade a um ente particular que desenvolva a infra-estrutura e explore tal atividade por meio da cobrança de tarifas dos usuários? Logicamente a resposta deve ser afirmativa - desde que haja lei e seja realizada licitação, nos termos do artigo 173 e 175, ambos da Constituição Federal. Tal atividade será atividade econômica? Logicamente que sim, pois envolve a utilização de recursos escassos para a satisfação de necessidades ilimitadas (ou, no caso, não delimitadas e superiores à oferta). Tal atividade será serviço público? Podese sustentar que sim, pois sua criação deu-se por lei que qualificou a atividade como tal e outorgou sua exploração a um agente privado, mantendo-se a responsabilidade estatal pela prestação do serviço - que na hipótese configura pressuposto de direitos fundamentais, como o direito à locomoção (art. $5 .^{\circ}$, inciso XV da Constituição Federal). A questão é tratada por Alexandre Santos de Aragão em: ARAGÃO, Alexandre Santos. Delegações de serviços públicos. Revista de Direito da Energia, ano IV, n.6, p.87, nov. 2007.

376 Concorda-se, pois, com Jacques Chevalier que, na linha do que defendia Leon Duguit no início do século passado, sustenta constituir o serviço público de um só vez o fundamento e o limite do poder dos governantes: "(...) o poder dos governantes é justificado pela necessidade de satisfazer necessidades coletivas; mas não pode ir além daquilo que admite e exige a consciência social." (CHEVALIER, Jacques. Le Service Public. 6.ed. Paris: PUF, 2006. p.23).

377 É o que se depreende, por exemplo, do artigo 2. ${ }^{\circ}$ da Lei n. ${ }^{\circ}$ 8.080/90, ao determinar que o Estado deve prover as condições indispensáveis ao pleno exercício do direito fundamental à saúde. 
Por esse caminho, chega-se à conclusão natural e inevitável de que serviço público, nos termos da Constituição Federal de 1998, configura um conjunto de prestações em relação às quais o Estado assume a responsabilidade por sua oferta a todos que delas necessitarem:

(i) pelo regime mais adequado à atividade em questão; 378

(ii) pela própria Administração Pública ou por meio de vínculos com entes privados mais adequado à atividade em questão;

(iii) com grau de vinculação mais ou menos próximo deste ou daquele direito fundamental.

Como já ressaltado, tal entendimento configura retorno à concepção trazida por León Duguit no início do século passado. Esse autor, ao defender a alteração do fundamento do direito público - do conceito de soberania à noção de serviço público - antecipou o que viria a suceder-se com o desenvolvimento do Estado: de um Estado garantidor dos direitos individuais a um Estado garantidor tanto daqueles quanto dos direitos dependentes de prestações em sentido estrito - os quais foram incorporados nos textos constitucionais durante o século XX. Com a prestação de uma série de serviços públicos, ainda ligados à necessidade de promover o desenvolvimento econômico, por meio, sobretudo, da disciplina de monopólios naturais, o entendimento de Duguit foi criticado e sua teoria tida como insuficiente para explicar a existência dos serviços públicos. No entanto, com a afirmação dos direitos a prestações e com a evolução tecnológica que permitiu a segregação de atividades antes tidas como interdependentes e não passíveis de exploração em regime de competição, a teoria de Duguit volta a ter força e atualidade.

Nesse contexto, sob à luz da teoria dos direitos fundamentais, entende-se compatível com a Constituição Federal e com o atual estágio de desenvolvimento social, tecnológico, econômico pátrios, o conceito proposto por Leon Duguit, segundo o qual:

378 A variedade de regimes jurídicos a que se submetem os serviços públicos hoje foi bem ilustrada por Carlos Ari Sundfeld, que assim se manifestou: "(...) cada serviço estatal, hoje, é objeto de um universo jurídico com peculiaridades muito próprias, não mais sendo viável, portanto, explicar tudo globalmente. É preciso, agora, consultar as normas e verificar como, em relação a cada serviço e situação, manifestamse múltiplas e sofisticadas competências do Estado (legislativas, administrativas e jurisdicionais), que têm de ser identificadas analiticamente: habilitar empresas a atuar no mercado (concedendo, autorizando, permitindo, licenciando etc.), fixar ou controlar preços e tarifas, obrigar ao atendimento de certas demandas de consumidores, impor limites, encargos e sujeições em função do desempenho da atividade - e assim por diante." (SUNDFELD, Carlos Ari. Serviços públicos e regulação estatal. In: Direito administrativo econômico. São Paulo: Malheiros, 2000. p.32). (Coord.). 
(...) serviço público é toda a atividade cujo cumprimento deve ser assegurado, disciplinado e fiscalizado pelos governantes, por ser tal atividade indispensável à realização e ao desenvolvimento da interdependência social, e que por sua natureza não pode ser realizada satisfatoriamente senão pela intervenção da força governamental. 379

No caso da saúde, resta evidenciado que se trata de um serviço vinculado a um direito fundamental, sendo que a responsabilidade do Estado consiste na disponibilização permanente de atividades voltadas à sua promoção, proteção e recuperação, a quem deles necessite, nos termos e condições definidas em lei conforme o desenvolvimento social, econômico e tecnológico atuais. ${ }^{380}$

\subsubsection{Sistema Único de Saúde e o Regime Jurídico dos Serviços Públicos de Saúde}

O subsistema público de saúde, denominado pela Constituição Federal sistema único de saúde (SUS) é integrado por uma série de órgãos e entidades, públicos e privados, que têm como função primordial a prestação de ações e serviços de saúde. Os fundamentos da organização do subsistema referido encontram-se previstos no artigo 198 da própria Constituição Federal, que assim dispõe:

\footnotetext{
Art. 198. As ações e serviços públicos de saúde integram uma rede regionalizada e hierarquizada e constituem um sistema único, organizado de acordo com as seguintes diretrizes:

I - descentralização, com direção única em cada esfera de governo;

II - atendimento integral, com prioridade para as atividades preventivas, sem prejuízo dos serviços assistenciais;

III - participação da comunidade.
}

Tais diretrizes incidem sobre a organização de todo o subsistema público de saúde e, de modo reflexo, sobre cada uma das ações e dos serviços públicos nesse âmbito prestados.

379 DUGUIT, León. Traité de Droit Constitucionnel. 2.ed. Paris: Ancienne Librairie Fontemoing, 1923. Tomo II. p.55.

380 Novamente, a idéia defendida encontra fundamento no pensamento de León Duguit, o qual há muito tempo sustentou que o fundamento de todos os serviços públicos consiste em uma obrigação jurídica imposta ao Estado de assegurar ininterruptamente determinadas atividades consideradas de importância capital para a vida social (DUGUIT, León. Traité de Droit Constitucionnel. 2.ed. Paris: Ancienne Librairie Fontemoing, 1923. Tomo II. p.55). Nessa esteira, tem razão Floriano de Azevedo Marques Neto ao ressaltar que atualmente: "Se o Estado, pela Constitutição ou pela Lei, definiu que uma atividade é tão relevante para avocar para si o dever de oferecer a todo mundo, considerando-a serviço público, não há sentido que essa atividade seja oferecida de forma intermitente." (MARQUES NETO, Floriano de Azevedo. Concessões de serviços públicos. Boletim de Direito Administrativo - BDA, ano XXII, n.6, p. 648, jun. 2006). 
$\mathrm{Na}$ esteira do que foi acima consignado, os serviços públicos de saúde correspondem às atividades assistenciais ofertadas em caráter permanente, com o objetivo de promover, proteger e recuperar a saúde das pessoas, as quais são assumidas pelo Estado como sua responsabilidade e sujeitas a uma série de regras e princípios que conformam seu regime jurídico. ${ }^{381}$

Já as ações públicas de saúde devem ser entendidas em sentido mais amplo, para abarcar todas as atividades administrativas com o objetivo de promover, proteger ou recuperar a saúde das pessoas. José Cretella Júnior, ao comentar o artigo 194 da Constituição Federal, que trata do conjunto de ações destinadas a assegurar a saúde, a assistência e a previdência, assim consignou: "Ações é vocábulo aqui empregado pelo legislador constituinte no sentido de 'iniciativas', 'medidas', 'esforços', inclusive de natureza econômica (...)". ${ }^{382}$ Nessa esteira, não restam dúvidas de que no caso da saúde, as ações mencionadas no texto constitucional e na Lei Orgânica da Saúde envolvem não apenas atividades prestacionais em sentido estrito, mas também atividades relacionadas ao que a doutrina clássica denomina exercício do poder de polícia e fomento. ${ }^{383}$ Todas essas atividades são denominadas genericamente pela Constituição e pela lei ações públicas de saúde, as quais, evidentemente, são assumidas pelo Estado como sua responsabilidade. ${ }^{384}$ Entretanto, diferenciam-se dos serviços públicos de saúde em dois aspectos principais:

(i) as ações de saúde abrangem tanto atividades prestacionais quanto atividades de fomento e de polícia;

381 Afinal, como se observou acima, não existe um regime jurídico comum aos serviços públicos. Nesse sentido, Dinorá Adelaide M. Grotti enfatiza que em cada serviço público, variam os objetivos visados, a competência para prestação, as formas de organização e de gestão, a natureza jurídica da remuneração, a aplicação dos princípios de direito público e de direito privado (GROTTI, Dinorá Adelaide. M. O serviço público e a constituição brasileira de 1988. São Paulo: Malheiros, 2003. p.89).

382 CRETELLA JÚNIOR, José. Comentários à constituição brasileira de 1988. 2.ed. Rio de Janeiro: Forense Universitária, 1993. v.8. p.4.298.

383 Como se verifica, por exemplo, das atividades relacionados no artigo 200 da Constituição Federal e na Lei n. ${ }^{\circ} 8.080 / 90$, já referidas neste trabalho. As noções de fomento e poder de polícia serão analisadas no Capítulo seguinte.

384 A diferenciação entre atividades prestacionais de caráter eventual, as quais devem ser entendidas como ações, e as de caráter permanente, correspondentes aos serviços, pode ser encontrada no artigo $1 .^{\circ}$ da Lei n. ${ }^{\circ} 8.080 / 90$, que ao estabelecer sua abrangência, ao dispõe que a mesma regula, em todo o território nacional, as ações e serviços de saúde, executados isolada ou conjuntamente, em caráter permanente ou eventual, por pessoas naturais ou jurídicas de direito Público ou privado. 
(ii) as ações de saúde de natureza prestacional trazem a conotação de atividades desenvolvidas pontualmente, ${ }^{385}$ como, por exemplo, campanhas de vacinação, enquanto os serviços públicos são prestados de maneira contínua. ${ }^{386}$

Assim, atividades prestacionais permanentes de assistência à saúde das pessoas, assumidas pelo Estado como sua responsabilidade, devem ser qualificadas como serviço público: o serviço público de saúde. Nos termos da Lei n. ${ }^{\circ} 8.080 / 90$, interpretada sob a luz do texto constitucional, pode-se concluir que a responsabilidade direta do Estado pela prestação de serviços de saúde compreende a assistência terapêutica, inclusive farmacêutica. ${ }^{387}$ Por assistência terapêutica (nela incluída a farmacêutica), deve-se compreender todas as atividades especificamente voltadas à promoção, proteção e recuperação da saúde das pessoas, prestadas em ambiente ambulatorial, hospitalar e mesmo em outros locais, como o domicílio do paciente, tal qual previsto pelo artigo 19-I da Lei n. ${ }^{\circ} 8.080 / 90.388$

Considerando que os serviços públicos devem ser entendidos como as prestações em relação as quais o Estado assume, nos termos da lei, a garantia de seu fornecimento, de acordo com o regime jurídico mais adequado para cada atividade em cada momento histórico, pode-se definir qual é o regime jurídico dos serviços públicos de saúde, prestados tanto pelo Estado quanto por entidades privadas. Nesse condão, são princípios constitucionais

385 Em abono a tal entendimento, pode-se mencionar o artigo primeiro da própria Lei n. ${ }^{\circ}$ 8.080/90, que faz referência a ações e serviços, em caráter permanente ou eventual. Eis o que dispõe referido dispositivo: Art. $1 .^{\circ}$ Esta lei regula, em todo o território nacional, as ações e os serviços de saúde executados isolada ou conjuntamente, em caráter permanente ou eventual, por pessoas naturais ou jurídicas de direito Público ou privado.

386 Nesse passo, pode-se perceber que as ações de saúde são aquelas atividades voltadas preferencialmente à promoção e proteção da saúde, bem como à prevenção de doenças, enquanto os serviços públicos de saúde referem-se preferencialmente à recuperação da saúde. Entretanto, tal afirmação deve ser levada em conta com cautela, pois os conceitos de promoção, proteção e recuperação da saúde são interligados e devem ser garantidos de modo integrado, tal qual dispõe o artigo 198 da Constituição Federal.

387 Nesse sentido, dispõem o artigo 5. ${ }^{\circ}$, III; e o artigo 6. ${ }^{\circ}$, I, $d$ Lei n. $.^{\circ} 8.080 / 90$, colacionados em nota anterior. Além deles, a alínea $c$, do inciso I, do art. $6 .^{\circ}$ da lei em referência menciona também como atribuição do SUS a execução de ações de saúde do trabalhador, cuja assistência, evidentemente inserese no quadro maior da assistência terapêutica integral.

388 Art. 19-I. São estabelecidos, no âmbito do Sistema Único de Saúde, o atendimento domiciliar e a internação domiciliar. $\S 1 .^{\circ} \mathrm{Na}$ modalidade de assistência de atendimento e internação domiciliares incluem-se, principalmente, os procedimentos médicos, de enfermagem, fisioterapêuticos, psicológicos e de assistência social, entre outros necessários ao cuidado integral dos pacientes em seu domicílio. $\S 2 .^{\circ} \mathrm{O}$ atendimento e a internação domiciliares serão realizados por equipes multidisciplinares que atuarão nos níveis da medicina preventiva, terapêutica e reabilitadora. $\S 3 .^{\circ} \mathrm{O}$ atendimento e a internação domiciliares só poderão ser realizados por indicação médica, com expressa concordância do paciente e de sua família. (artigo integralmente incluído pela Lei n. ${ }^{\circ} 10.424$, de 2002). 
que conformam o regime jurídico dos serviços públicos de saúde, a universalidade e a igualdade do acesso e a integralidade do atendimento. ${ }^{389}$

\subsubsection{Universalidade e igualdade de acesso}

Por universalidade e igualdade do acesso deve ser entendida a responsabilidade estatal pela oferta de serviços de saúde a todas as pessoas que deles necessitarem, sem qualquer tipo de discriminação, exceto aquelas que encontram fundamento no próprio texto constitucional. Portanto, é de se ressaltar que a universalidade e a igualdade não configuram valores absolutos; ambas devem incidir no regime de prestação dos serviços de saúde após sua ponderação com outros valores acolhidos pela Constituição.

Levando-se em conta que os serviços de saúde são prestados tanto pelo Estado (direta ou indiretamente) quanto pela iniciativa privada, conforme determina o caput do artigo 199 da Constituição Federal, ${ }^{390}$ a universalidade e igualdade de acesso implicam a garantia de que todas as pessoas que necessitem de assistência à saúde obtenham atendimento - seja ele prestado pelo Estado, por entidade privada a ele vinculada ou por entidade privada autônoma. Esse é o entendimento adotado pela teoria constitucional contemporânea acerca dos direitos a prestações em sentido estrito, como é o caso da saúde. ${ }^{391}$

Como sustenta Robert Alexy, o direito à saúde, na perspectiva da prestação de serviços, é um direito que, se a pessoa que dele necessita tiver meios financeiros e o encontrar no mercado, poderá tê-lo concretizado também pela iniciativa privada. ${ }^{392}$ Para

389 Note-se que, enquanto a universalidade e igualdade constam da segunda parte do artigo 196 da Constituição Federal e voltam-se a todas as atividades de assistência à saúde, a integralidade do atendimento consta do inciso II do artigo 198 do texto constitucional, como uma diretriz a ser adotada para a organização de todo o sistema público de saúde. Não obstante, resta evidenciado que tais princípios incidem sobre a própria prestação estatal ou privada dos serviços públicos de saúde, conformando seu regime jurídico.

390 Art. 199. A assistência à saúde é livre à iniciativa privada.

391 A classificação das atividades prestacionais do Estado foi analisada no Capítulo 2 deste trabalho.

392 ALEXY, Robert. Teoría de los Derechos Fundamentales. Trad. Carlos B. Pulido. 2.ed. Madrid: Centro de Estudios Políticos y Constitucionales, 2007. p.443. Uma ressalva deve ser feita. Da assertiva de Alexy devem ser excluídos os serviços de assistência social, cuja natureza envolve a impossibilidade de seu pagamento. Nesse sentido, a Constituição brasileira é clara ao estabelecer que: Art. 203. A assistência social será prestada a quem dela necessitar, independentemente de contribuição à seguridade social, e tem por objetivos: I - a proteção à família, à maternidade, à infância, à adolescência e à velhice; II - o amparo às crianças e adolescentes carentes; III - a promoção da integração ao mercado de trabalho; IV a habilitação e reabilitação das pessoas portadoras de deficiência e a promoção de sua integração à vida 
tanto, há que se entender que o direito à saúde é um direito do qual são titulares pessoas singularizadas que demandam uma prestação estatal específica para satisfação de suas necessidades. ${ }^{393}$ Nessa perspectiva, os serviços públicos de saúde garantidos pelo Estado podem ter sua oferta delimitada a um grupo definido de usuários - aqueles incapazes de obter os serviços no mercado. ${ }^{394}$

A possibilidade de (de)limitação dos serviços públicos de saúde em relação aos usuários tem como ponto de partida o próprio texto do artigo 196 da Constituição Federal, que impõe ao Estado a garantia do direito à saúde mediante políticas públicas que visem à universalidade e à igualdade de acesso aos serviços de saúde - e não aos serviços públicos

comunitária; V - a garantia de um salário mínimo de benefício mensal à pessoa portadora de deficiência e ao idoso que comprovem não possuir meios de prover à própria manutenção ou de tê-la provida por sua família, conforme dispuser a lei. No mesmo sentido dispõe a Lei n. ${ }^{\circ}$ 8.742, de 7 de dezembro de 1993, conhecida como Lei Orgânica da Assistência Social (LOAS). Assim, afigura-se teratológica a previsão constante do Item 20.1 do anexo à Lei Complementar 104/2001, que trata das normas gerais do Imposto sobre Serviços de Qualquer Natureza e prevê a tributação de serviços de assistência social. Essa não é a sede para tal discussão, mas levando em conta o que consignou o Juiz da Suprema Corte norte-americana John Marshall, no início do século XIX, ao decidir o caso McCulloch v. Maryland - o poder de tributar envolver o poder de destruir -, a hipótese em tela parece ilustrar o que os penalistas denominariam de crime impossivel.

393 Como ressalta Marcello Caetano: "O serviço público propõe-se a satisfazer uma necessidade coletiva individualmente sentida." (CAETANO, Marcello. Manual de direito administrativo. 10.ed. Coimbra: Almedina, 1994. Tomo II. p.1067). Com esse enfoque, adiante retomado, o direito à saúde e o rol de serviços voltados à sua garantia devem ser efetivados individualmente, mas sua organização não pode perder de vista seu caráter geral.

394 Nos sistemas de saúde estrangeiros, encontra-se tal ordem de delimitação não apenas em sistemas segmentados, como é o caso dos Estados Unidos, mas também nos sistemas bismarckianos, nos quais a prestação dos serviços é delimitada e garantida apenas para aquelas pessoas vinculadas a determinada seguradora, pública ou privada. Já nos sistemas beveridgeanos, a delimitação não é assumida formalmente, mas materialmente e de modo perverso, pela insuficiência de serviços ofertados a quem deles necessita. Esse é o caso brasileiro, no qual tamanha é a delimitação de usuários aptos a utilizar o subsistema público de saúde, que nos últimos anos surgiu uma nova modalidade de prestação de serviços médicos: os chamados cartões de desconto ou cartões de saúde. Tais cartões consistem na intermediação de serviços médicos desempenhada por empresas ou entidades sem fins lucrativos que oferecem aos usuários do SUS todas as modalidades de assistência à saúde, como consultas, exames e cirurgias, por preços inferiores àqueles cobrados pelo mercado. Tal área de atuação informal (objeto, inclusive, de restrições por parte do Conselho Federal de Medicina, que tratou do assunto por meio da Resolução n. ${ }^{\circ}$ 1649, de 06 de novembro de 2002; e da Agência Nacional de Saúde Suplementar - ANS, que vetou o desempenho de tal atividade por planos privados de saúde, por meio da Resolução Normativa n. ${ }^{\circ} 40$, de 6 de junho de 2003) tem crescido exponencialmente nos últimos anos, sendo que os consumidores de tais serviços são os usuários do SUS que não possuem condições de contratar um plano privado de saúde e não obtém atendimento satisfatório pelo subsistema público 'universal e gratuito'. Portanto, a defesa de uma interpretação constitucional que admita a delimitação do rol de beneficiários, além de dotada de amparo normativo e teórico, encontra também apoio na realidade, de modo que nada mais se propõe do que, por meio da interpretação, reconhecer as limitações do SUS e propor soluções fundadas em padrões claros de justiça social, tal qual prevê o artigo $3 .^{\circ}$ da Constituição Federal ao relacionar os objetivos fundamentais da República Federativa do Brasil. 
de saúde. ${ }^{395}$ Assim, havendo a disponibilidade de serviços privados para pessoas com condições financeiras de pagar por eles, pode-se concluir que os princípios da universalidade e da igualdade estarão sendo respeitados.

Como sustenta Marçal Justen Filho:

(...) a prestação de serviços públicos por parte do Estado não se destina a uma sociedade civil homogênea. A posição dos diferentes segmentos da sociedade não é idêntica, relativamente ao problema da prestação de serviços. Há largos segmentos que apenas podem obter utilidades essenciais à manutenção e produção de sua dignidade através de serviços públicos. A diferença entre pobreza e riqueza, nos seus termos mais crus, relaciona-se com os serviços públicos. (...) a pobreza produz a dependência dos serviços públicos e a ineficiência estatal conduz à impossibilidade de existência digna. Os segmentos da população destituídos de recursos somente têm acesso a saúde, educação e serviços básicos através da atividade estatal. Em termos diretos, os cidadãos não se encontram em situação de igualdade em face do Estado e dos serviços públicos. ${ }^{396}$

Levando o raciocínio adiante, é perfeitamente possível a cobrança pela prestação de serviços de saúde de pessoas que tenham condições de pagar por eles e mesmo assim prefiram utilizar o serviço público de saúde. Isso não é novidade e encontra-se previsto no artigo 32 da Lei n. ${ }^{\circ}$ 9.656, de 3 de junho de 1998 - conhecida como Lei de Saúde Suplementar, que prevê o reembolso ao SUS do valor referente a serviços públicos de saúde

395 A literalidade do texto constitucional constitui elemento insuficiente, mas configura importante componente do processo de interpretação. Interpretar um preceito constitucional consiste em atribuir significado a um ou vários símbolos lingüísticos escritos na Constituição, com o objetivo de se obter possíveis e adequadas soluções para determinado problema. Desse modo, cumpre ressaltar que o exercício interpretativo não pode descaracterizar o texto legal ou constitucional, extirpando-o de seu sentido denotativo e extraindo dele significados que ultrapassam a sua letra. A idéia de limite à atividade interpretativa nas palavras postas no texto normativo constitucional é ressaltada por Gomes Canotilho, segundo o qual a função do intérprete é a de desvendar o sentido do texto, sem ir para além, e muito menos contra, o teor literal do preceito. Em outra passagem, expressa o autor: "A interpretação é uma actividade normativamente vinculada, constituindo a 'constitutio scripta' um limite ineliminável (Hesse) que não admite o sacrifício da primazia da norma em prol do problema (F. Müller)." (CANOTILHO, J. J. Gomes. Direito constitucional e teoria da constituição. 7.ed. Coimbra: Almedina, [s.d.]. p.1211 e 1212). No mesmo diapasão, Luís Roberto Barroso sustenta ser a interpretação gramatical o momento inicial do processo interpretativo, o substrato em que deve repousar o intérprete. Segundo o autor: "(...) a mesma linguagem que confere abertura ao intérprete há de se figurar como limite máximo de sua atividade criadora. As palavras têm sentidos mínimos que devem ser respeitados, sob o risco de se perverter o seu papel de transmissoras de idéias e significados. É a interpretação gramatical ou literal que delimita o espaço dentro do qual o intérprete vai operar, embora isso possa significar zonas hermenêuticas muito extensas." (BARROSO, Luís Roberto. Interpretação e aplicação da constituição. 5.ed. São Paulo: Saraiva, 2003. p.130). Também Miguel Reale, ao tratar da interpretação das leis, é claro ao afirmar que o primeiro dever do intérprete é analisar o dispositivo legal para obter seu pleno valor expressional (REALE, Miguel. Lições preliminares de direito. 14.ed. São Paulo: Saraiva, 1987. p.275). Logo, tem-se que a interpretação literal possui função de servir, tanto de base a partir da qual o intérprete constrói esta regra quanto de limite ao exercício interpretativo, impedindo compreensões diferentes daquelas constantes na redação do texto legal.

396 JUSTEN FILHO, Marçal. Sistema constitucional tributário: uma aproximação ideológica. Revista da Faculdade de Direito da Universidade Federal do Paraná, Curitiba, n.30, p.223-224, 1998. 
prestados a pessoas portadoras de planos privados de assistência à saúde que ofereçam cobertura de tais serviços. ${ }^{397}$ Portanto, a gratuidade não é um princípio constitucional do serviço público de saúde, e mesmo que o fosse, poderia ser (de)limitada, por meio de lei e com fundamento em outro(s) princípio(s) da Constituição Federal. ${ }^{398}$

Essa é a crítica que alguns autores, com razão, fazem à equivocada noção de que o Estado brasileiro assumiu a tarefa de oferecer serviços públicos de saúde gratuitos a todas as pessoas, independente de qualquer condição. Tal interpretação decorre de uma leitura apressada, isolada e débil do artigo 196 da Constituição Federal.

Acerca da gratuidade dos serviços de saúde, deve-se mencionar o disposto no artigo 43, da Lei Orgânica da Saúde: Art. 43. A gratuidade das ações e serviços de saúde fica preservada nos serviços públicos contratados, ressalvando-se as cláusulas dos contratos ou convênios estabelecidos com as entidades privadas. Em primeiro lugar, insta ressaltar que a lei deve ser interpretada de acordo com a Constituição Federal, e não o contrário. Em segundo lugar, o dispositivo em referência nada mais determina do que a manutenção, com ressalvas, da gratuidade dos serviços prestados por entidades privadas vinculadas ao SUS. Portanto, tal dispositivo, comumente mencionado como fundamento da gratuidade geral e

397 Eis o que dispõe o referido dispositivo da Lei n. ${ }^{\circ}$ 9.656/98: Art. 32. Serão ressarcidos pelas operadoras dos produtos de que tratam o inciso I e o $\S 1 .^{\circ}$ do art. $1 .^{\circ}$ desta Lei, de acordo com normas a serem definidas pela ANS, os serviços de atendimento à saúde previstos nos respectivos contratos, prestados a seus consumidores e respectivos dependentes, em instituições públicas ou privadas, conveniadas ou contratadas, integrantes do Sistema Único de Saúde - SUS. (a redação do artigo foi dada pela Medida Provisória n. ${ }^{0}$ 2.177-44, de 2001; não obstante, a redação original do artigo já previa o ressarcimento ao SUS). Sobre tema, conferir: SCHEFFER, Mario; BAHIA, Ligia. Planos e seguros privados de saúde no Brasil: lacunas e perspectivas da regulamentação. In: HEIMANN, Luiza S.; IBANHES, Lauro C.; BARBOZA, Renato (Orgs.). O público e o privado na saúde. São Paulo: Hucitec, 2005. p.153 e segs.; PASQUALOTO, Adalberto. A regulamentação dos planos e seguros de assistência à saúde: uma interpretação construtiva. In: MARQUES, Cláudia Lima; LOPES, José Reinaldo de Lima; PFEIFFER, Roberto A. C. Saúde e responsabilidade: seguros e planos de assistência privada à saúde. São Paulo: Revista dos Tribunais, 1999. p.61.

398 Tal determinação legal encontra-se prevista em sede constitucional para os casos, por exemplo do ensino, como consta dos seguintes dispositivos: Art. 205. A educação, direito de todos e dever do Estado e da família, será promovida e incentivada com a colaboração da sociedade, visando ao pleno desenvolvimento da pessoa, seu preparo para o exercício da cidadania e sua qualifícação para o trabalho. (...) IV - gratuidade do ensino público em estabelecimentos oficiais. Art. 208. O dever do Estado com a educação será efetivado mediante a garantia de: I - ensino fundamental, obrigatório e gratuito, assegurada, inclusive, sua oferta gratuita para todos os que a ele não tiveram acesso na idade própria; II progressiva universalização do ensino médio gratuito; (incisos I e II com redação dada pela Emenda Constitucional n. ${ }^{\circ}$ 14, de 1996) - (os grifos não constam do original). 
irrestrita dos serviços públicos de saúde, não se presta para tanto. Além disso, o próprio artigo 32 da Lei . $^{\circ} 8.080 / 90$, ao tratar das fontes de recursos do SUS diversas daquelas decorrentes do orçamento da Seguridade Social, em seus incisos II e V, menciona a possibilidade de cobrança de preços públicos, os quais podem incidir sobre a prestação de serviços, desde que não haja prejuízo da assistência à saúde. Assim, tendo a pessoa condições financeiras de pagar pelo serviço público de saúde, é admissível, nos termos da própria Lei Orgânica da Saúde, a cobrança pelos serviços. 399

399 Assinale-se que algumas Constituições estaduais inovaram o ordenamento constitucional e previram a gratuidade dos serviços de saúde, como, por exemplo, os Estados de São Paulo, Minas Gerais e Bahia, que assim estabeleceram em seus textos constitucionais: Constituição do Estado de São Paulo - Artigo 222 - As ações e os serviços de saúde executados e desenvolvidos pelos órgãos e instituições públicas estaduais e municipais, da administração direta, indireta e fundacional, constituem o sistema único de saúde, nos termos da Constituição Federal, que se organizará ao nível do Estado, de acordo com as seguintes diretrizes e bases: (...) V - gratuidade dos serviços prestados, vedada a cobrança de despesas e taxas, sob qualquer título. Constituição do Estado de Minas Gerais - Art. 186 - A saúde é direito de todos, e a assistência a ela é dever do Estado, assegurada mediante políticas sociais e econômicas que visem à eliminação do risco de doenças e de outros agravos e ao acesso universal e igualitário às ações e aos serviços para sua promoção, proteção e recuperação. Parágrafo único - $\mathrm{O}$ direito à saúde implica a garantia de: (...) III - dignidade, gratuidade e boa qualidade no atendimento e no tratamento de saúde. Constituição do Estado da Bahia - Art. 235 - As ações e os serviços de saúde pública e os privados, que os complementarem, mediante rede regionalizada e hierarquizada, que serão regulamentados na forma da lei, integram o Sistema Único de Saúde, de acordo com as seguintes diretrizes: (...) VI - proibição de cobrança ao usuário pela prestação de serviços públicos de assistência à saúde, executados diretamente pelo Poder Público ou pelo setor privado, especificamente através de contratos ou convênios. Dessa forma, tais Estados-membros, e outros que tenham adotado o mesmo princípio, na prestação de serviços no âmbito estadual, deverão fazê-lo gratuitamente (os grifos não constam dos originais). Além disso, algumas leis federais prevêem a gratuidade em relação a determinados serviços e medicamentos - o que corrobora a tese de que nem todos devem, necessariamente, sê-lo. Dentre as leis referidas, pode-se mencionar a Lei n. ${ }^{\circ} 8.069$, de 13 de julho de 1990, que determina o fornecimento gratuito de medicamentos, próteses e outros recursos relativos ao tratamento, habilitação ou reabilitação de crianças e adolescentes; a Lei n. ${ }^{\circ}$ 9.313, de 13 de novembro de 1993, que prevê o fornecimento gratuito de medicamentos para pacientes infectados pelo vírus HIV; a Lei n. ${ }^{\circ} 10.741$, de $1 .^{\circ}$ de outubro de 2003 , que determina o fornecimento gratuito de medicamentos, especialmente os de uso continuado, assim como próteses, órteses e outros recursos relativos ao tratamento, habilitação ou reabilitação aos idosos. Cumpre ressaltar por fim, a Lei estadual n. ${ }^{\circ}$ 9.908, de 16 de junho de 1993, do Rio Grande do Sul, a qual determina o fornecimento gratuito de medicamentos excepcionais para pessoas que não puderem prover as despesas com os referidos medicamentos, sem privarem-se dos recursos indispensáveis ao próprio sustento e de sua família. Note-se que a lei gaúcha realizou em sede legislativa a primeira etapa da ponderação indispensável à aplicação do direito, fixando critérios claros acerca da disponibilização de medicamentos. Tal critério encontra amparo constitucional e deve ser aplicado - nos casos em que não haja dispositivo legal específico - com base diretamente na Constituição Federal. Afinal, como já assinalado, e por todos sabido, não se vive mais o período do positivismo formalista, sendo que imprescindível é a análise de cada dispositivo legal em face da normatividade sistêmica da Constituição (o que deve ser feita, inclusive com o dispositivo da lei do Rio Grande do Sul em referência). Por fim, insta ressaltar que qualquer medicamento a ser dispensado gratuitamente deve ter sua aprovação condicionada pelos órgãos técnicos criados para a avaliação de sua segurança e de sua eficácia no tratamento de determinada doença. 
Ao tratar do assunto, tem razão Ricardo Lobo Torres ao consignar que: "(...) o acesso universal e igualitário às ações e serviços de saúde, assegurado no artigo 196 da Constituição, transformado em gratuito pela [interpretação inadequada da] legislação infraconstitucional, é utópico e gera expectativas inalcançáveis para os cidadãos". ${ }^{400}$ Tal assertiva pode ser inferida, por exemplo, (i) no âmbito normativo, da opção pela não consagração específica de direitos sociais pela Lei Fundamental de Bonn de 1949, ante a ineficácia social dos ditames consagrados pela Constituição de Weimar de 1919; e (ii) no âmbito científico, da mudança de opinião de Gomes Canotilho, ao relativizar seu conceito de Constituição Dirigente, de modo a abrir as possibilidades de efetivação dos fins do Estado por mecanismos não cristalizados no momento de elaboração da Constituição. ${ }^{401}$

A universalidade e igualdade de acesso aos serviços públicos de saúde, portanto, devem ser entendidas como a oferta de atendimento a todos os brasileiros e estrangeiros residentes em território nacional que deles necessitem, ${ }^{402} \mathrm{com}$ as ressalvas que a lei estabelecer, inclusive no que se refere à possibilidade de cobrança daqueles que tiverem

400 TORRES, Ricardo Lobo. A cidadania multidimensional na era dos direitos. In: (Org.). Teoria dos direitos fundamentais. 2.ed. Rio de Janeiro: Renovar, 2001. p.287. Essa era também a advertência de Eros Roberto Grau em obra de 1985, acerca da consagração de promessas vãs, promessas para não serem cumpridas, despidas de força jurídica e inseridas no texto constitucional com a função exclusiva de retardar sua efetiva conquista pela sociedade (GRAU, Eros Roberto. A constituinte e a constituição que teremos. São Paulo: Revista dos Tribunais, 1985. p.44-47).

401 Em trabalho que trata da gratuidade nos serviços de saúde, Gomes Canotilho analisou a técnica adotada pelo constituinte português, que optou pela articulação dos direitos sociais com políticas sociais, e pela vinculação do direito à saúde a uma política constitucional de realização da saúde com base no Serviço Nacional de Saúde universal e gratuito. Concluiu pela necessidade de desintroversão, a qual, segundo o autor passa pela desconstitucionalização das políticas sociais, sem a supressão dos direitos sociais do texto constitucional (CANOTILHO, J. J. Gomes. Metodologia "Fuzzy" e "Camaleões Normativos" na problemática actual dos direitos econômicos, sociais e culturais. In:

Estudos sobre direitos fundamentais. Coimbra: Coimbra, 2004. p.112). Tal pensamento do autor português vão ao encontro de seu posicionamento contrário à cristalização de determinadas políticas pelo texto constitucional e da necessidade de outorga de espaço ao legislador para que, conforme o processo de transformação social. Tal fato ocorreu em solo português, como já assinalado, com a relativização do conceito de gratuidade dos serviços de saúde, previsto originalmente pela Constituição de 1976, e posteriormente atenuado por meio de decisão da Corte Constitucional e de subseqüente emenda constitucional.

402 O critério da residência no Brasil encontra-se prevista no caput do artigo $5 .^{\circ}$ da Constituição Federal e deve ser aplicado também para os casos em que se trate de direitos sociais. Enquanto alguns países proíbem o ingresso em seu território de pessoas infectadas pelo vírus HIV, o Brasil recebe milhares de migrantes que vêm ao país com o objetivo de receber tratamento gratuito. Não raro encontram-se casos de medidas judiciais aforadas por estrangeiros por meio das quais buscam obter medicamentos não previstos como de fornecimento gratuito pelo Estado brasileiro. Tal situação revelaria o caráter humanitário do Estado brasileiro, não fosse a situação de extrema deficiência na oferta de serviços de saúde à maioria dos brasileiros que necessitam de atendimento público e gratuito. 
condições financeiras, ${ }^{403}$ e mesmo a negativa de prestação do serviço àqueles que, além condição financeira, encontrem o serviço disponibilizado pelo mercado. ${ }^{404}$

Nessa perspectiva, nos termos da Constituição Federal, tanto a universalidade quanto a igualdade devem ser materiais e não meramente formais. Devem ter como critério a finalidade da atuação estatal - como ponto de chegada e não como ponto de partida. Isso significa, como delineado no Capítulo 2, que a efetivação do direito à saúde, e dos direitos sociais em geral, demanda a análise no caso concreto da condição de cada pessoa e o tratamento discriminatório - ao qual a doutrina constitucional costuma denominar discriminação positiva. 405 Mesmo porque, em uma análise minuciosa, no âmbito da saúde pode-se verificar que doenças iguais não significam doentes com necessidades iguais. ${ }^{406}$ Ao tratar do tema, José Eduardo Faria, deixa clara tal característica, ao afirmar que:

403 Nesse sentido é o entendimento, dentre outros, de SARLET, Ingo Wolfgang. A eficácia dos direitos fundamentais. 8.ed. Porto Alegre: Livraria do Advogado, 2007. p.347-348; e SARLET, Ingo Wolfgang; FIGUEIREDO, Mariana F. Reserva do possível, mínimo existencial e direitos à saúde: algumas aproximações. In: SARLET, Ingo Wolfgang; TIMM, Luciano Benetti (Orgs.). Direitos fundamentais, orçamento e 'reserva do possível'. Porto Alegre: Livraria do Advogado, 2007. p.44 e segs.

404 Veja-se que isso é o que ocorre na realidade. Quem tem condições de buscar um tratamento de saúde privado, em especial por meio de planos de saúde, o faz. A observação de Esping-Andersen colacionada no Capítulo 2, de que a partir do momento em que se consolida determinado nível de assistência pública igualitária, naturalmente parte das pessoas tende a buscar novos mecanismos (privados) de assistência, deve ser relembrada. Nesse mesmo nível de investigação, deve-se assinalar, em especial no discurso dos supostos defensores do SUS, a seguinte frase adaptada de William Beveridge, também já citado, que costuma ser repetida: um SUS pobre para os pobres. Tal raciocínio é deslocado no tempo, contrário ao que determina à Constituição Federal e detrator do direito à saúde. O que se deve buscar, de acordo com a Constituição Federal, é a garantia do direito à saúde de todos por meio da prestação de serviços públicos a quem deles necessitar. A luta, portanto, não pode ocorrer no nível do ilusório de um SUS rico para todos, mas em um nível real de um SUS rico, forte e efetivo para quem dele necessite.

405 Nesse aspecto, é pertinente a comparação que se pode fazer com a consagração dos direitos fundamentais de primeira dimensão, tratados no Capítulo 2. Tais direitos tinham como pressuposto a igualdade formal de todas as pessoas, e levaram a situações de iniqüidade insuportáveis na sociedade. Da mesma forma, a universalidade e a igualdade formal na oferta de serviços públicos de saúde deixam de levar em consideração as desigualdades materiais entre os cidadãos e conduzem a situação de desigualdade real. Defender, pois, um SUS, universal e igualitário a todas as pessoas indistintamente, como se tais valores fossem absolutos, implica incorrer no mesmo equívoco que a história já demonstrou perturbador: seu resultado é mais iniqüidade, mais desigualdade e menos universalidade. Note-se que se está tratando dos serviços de saúde prestados no Brasil, em que convivem, sem delimitação de áreas de atuação a prestação pública e privada.

406 COHN, Amélia; NUNES, Edison; JACOBI, Pedro R.; KARSH, Ursula S. A saúde como direito e como serviço. 5.ed. São Paulo: Cortez, 2000. p.22. 
(...) os direitos sociais não configuram um 'direito de igualdade' baseado em regras de julgamento que implicam um tratamento uniforme; são, isto sim, um 'direito das preferências e das desigualdades', ou seja, um direito discriminatório com propósitos compensatórios; um direito descontínuo, pragmático, e por vezes até mesmo contraditório, quase sempre dependente da sorte de determinados casos concretos. ${ }^{407}$

Sob a mesma perspectiva, Fábio Konder Comparato, ao comentar os dispositivos que tratam do direito à saúde no já mencionado Pacto Internacional sobre Direitos Econômicos, Sociais e Culturais, consignou ser:

(...) indispensável que o sistema de saúde como um todo, sobretudo em países subdesenvolvidos ou profundamente inigualitários, seja organizado e supervisionado pelo Estado, e que os equipamentos públicos - hospitais, centros de pesquisa e laboratórios - sejam utilizados, prioritariamente, no atendimento de pessoas carentes. ${ }^{408}$

Nesse prisma, para os fins do presente estudo, cumpre ter claro que tanto a lei quanto o instrumento que regulamenta o vínculo entre o Estado e o particular prestador do serviço público de saúde poderão definir, com fundamento constitucional:

(i) critérios seletivos acerca das pessoas a serem assistidas; e

(ii) a possibilidade de cobrança dos serviços daqueles em condições financeiras de por eles pagarem. .09

407 FARIA, José Eduardo. O judiciário e os direitos humanos e sociais: notas para uma avaliação da justiça brasileira. In: (Org.). Direitos humanos, sociais e justiça. São Paulo: Malheiros, 2005. p.105.

408 COMPARATO, Fábio Konder. A afirmação histórica dos direitos humanos. 6.ed. São Paulo: Saraiva, 2008. p.357.

409 Outro argumento que corrobora o entendimento de que a Constituição Federal admite a cobrança por serviços públicos de saúde encontra-se no dispositivo que prevê a existência do salário mínimo: Art. 7. ${ }^{\circ}$ São direitos dos trabalhadores urbanos e rurais, além de outros que visem à melhoria de sua condição social: (...) IV - salário mínimo, fixado em lei, nacionalmente unificado, capaz de atender a suas necessidades vitais básicas e às de sua família com moradia, alimentação, educação, saúde, lazer, vestuário, higiene, transporte e previdência social, com reajustes periódicos que lhe preservem o poder aquisitivo, sendo vedada sua vinculação para qualquer fim (o grifo não consta do original). Ora, se o salário mínimo deve garantir o atendimento a necessidades vitais básicas com saúde, é evidente que nem todas as necessidades com saúde, nem mesmo as vitais, são necessariamente prestadas gratuitamente pelo Estado. De outro lado, o fato de que o salário mínimo no Brasil não é capaz de atender às necessidades previstas pelo dispositivo mencionado não retira a força do argumento ora defendido, segundo o qual apenas aqueles que tiverem condições de arcar com tais gastos - ou seja, recebam mais que um salário mínimo - podem sofrer cobrança pela prestação dos serviços. Por fim, como já mencionado, pode-se aduzir que, ao contrário do que faz com a saúde, no tratamento da educação a Constituição Federal prevê expressamente em seus artigos 206, IV e 208, I, a gratuidade do ensino público em estabelecimentos oficiais e do ensino fundamental. 
O que não se admite é a discriminação entre os serviços públicos prestados àqueles com condições de pagar pela prestação e aqueles que recebem o tratamento gratuito. Afinal, como consignou Rafael Bielsa:

\footnotetext{
O serviço gratuito deve gozar da mesma proteção jurídica que o serviço remunerado (...). Seria arbitrário que o Estado mantivesse em situação precária aquele que utiliza gratuitamente um serviço e pudesse negar sua prestação devido a ausência de pagamento. ${ }^{410}$
}

Nessa perspectiva, não se discorda de entendimentos como o de José Afonso da Silva, segundo o qual o direito à saúde:

(...) há de informar-se pelo princípio de que o direito igual à vida de todos os seres humanos significa também que, nos casos de doença, cada um tem o direito a um tratamento condigno e de acordo com o estado atual da ciência médica, independentemente de sua situação econômica, sob pena de não ter muito valor sua consignação em normas constitucionais. ${ }^{411}$

O que se defende é a possibilidade de que seja assumida a diversidade de situações pessoais, inclusive de ordem econômica, desde que tal ponto de partida conduza a um tratamento igualitário e não o contrário, como adverte o autor acima citado.

\subsubsection{Integralidade do atendimento}

A integralidade do atendimento, prevista pelo artigo 198 da Constituição Federal, configura uma das diretrizes a serem observadas na organização do subsistema público de saúde. Sua previsão possui, assim, alcance indireto sobre o regime jurídico de prestação dos serviços de saúde, os quais devem garantir o atendimento integral.

A Lei n. ${ }^{\circ} 8.080 / 90$, em seu artigo $7 .^{\circ}$, inciso II, estabelece que a integralidade da assistência, deve ser entendida como conjunto articulado e contínuo das ações e serviços preventivos e curativos, individuais e coletivos, exigidos para cada caso em todos os níveis de complexidade do sistema. Trata-se, pois, na opinião de alguns, da articulação entre as

410 BIELSA, Rafael. Derecho Administrativo. 5.ed. Buenos Aires: Roque Depalma, 1955. Tomo I. p.554.

411 SILVA, José Afonso da. Curso de direito constitucional positivo. 22.ed. São Paulo: Malheiros, 2003. p.307. 
ações e serviços, preventivos e curativos, individuais e coletivos, ${ }^{412}$ ou da indissociação entre prevenção e atenção curativa, ${ }^{413}$ a qual tem por objetivo reparar a dicotomia administrativa anterior à Constituição Federal de 1988, já assinalada neste trabalho, entre as ações preventivas de cunho coletivo e os serviços assistenciais da caráter individual. ${ }^{414}$ Assim, da mesma forma que os demais princípios consignados no artigo 198 da Constituição Federal, a aplicação do princípio da integralidade não se volta diretamente à prestação de cada serviço de saúde em si, mas à organização de todo o sistema público de saúde, que deve garantir prestações interligadas, voltadas tanto à prevenção quanto à cura de doenças. 415

Além disso, insta ressaltar que, como parte da seguridade social, os serviços de saúde submetem-se aos princípios constantes do artigo 194 da Constituição Federal, que no inciso III de seu parágrafo único assim dispõe:

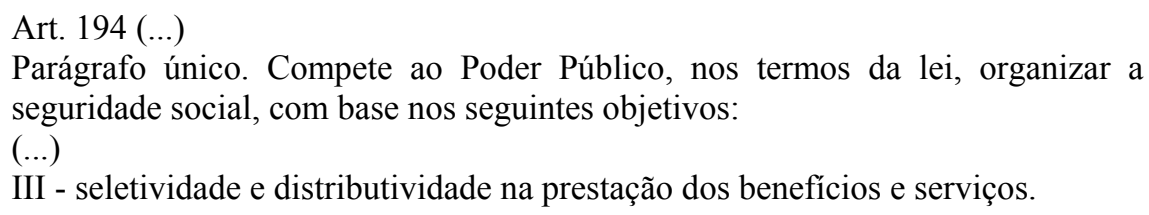

Esse é mais um argumento a reforçar a necessidade de delimitação dos serviços a serem prestados pelo Estado. Nesse sentido, têm razão Lenir Santos e Luiz Odorico de Andrade, ao sustentar que:

\begin{abstract}
A integralidade da assistência deverá pautar-se por regulamentos técnicos e científicos, protocolos de condutas, limites para incorporação de tecnologia, protocolos farmacológicos. A integralidade da assistência, sob esse ponto de vista, não é um conceito que admite toda e qualquer terapêutica existente ou demandada por um paciente ou profissional de saúde. Há que ter critérios científicos e técnicos atualizados para embasar a incorporação desta ou daquela tecnologia, desta ou
\end{abstract}

412 SILVA, José P. Vicente da; PINHEIRO, Roseni.; MACHADO, Felipe R. S. Necessidades, demanda e oferta: algumas contribuições sobre os sentidos, significados e valores na construção da integralidade na reforma do Setor de Saúde. Saúde em Debate, Rio de Janeiro, v.27, n.65, p.235, set./dez. 2003.

413 RODRIGUEZ NETO, Eleutério. Saúde: promessas e limites da constituição. Rio de Janeiro: FIOCRUZ, 2003. p.143.

414 Conferir Item 3.1.1, acima.

415 Essa perspectiva sistêmica reflete-se tanto na organização e funcionamento do próprio sistema quanto no respeito às pessoas que com ele colaboram. Nesse sentido, tem razão Diogo de Figueiredo Moreira Neto, para quem: "(...) o bem ou o serviço entregue à sociedade deve necessariamente garantir uma utilização eficiente por parte de seus destinatários, tal como razoavelmente estaria nas expectativas de todos os que para tanto contribuíram com seus recursos." (MOREIRA NETO, Diogo de Figueiredo. Quatro paradigmas do direito administrativo pós-moderno: legitimidade, finalidade, eficiência, resultados. Belo Horizonte: Fórum, 2008. p.135-136). 
daquela terapêutica ou medicamento. (...) As inovações tecnológicas na saúde e a indústria farmacêutica nem sempre têm os olhos humanitários - seu fim último não é a cura, mas o lucro dos acionistas. Por isso, se os sistemas públicos de saúde não tiverem critérios para a incorporação da tecnologia, não haverá recursos suficientes. 416

Nesse passo, a integralidade do atendimento não deve ser entendida como a imposição de utilização de todos os meios ao dispor da medicina moderna. Tal noção assemelha-se ao que determina o Código de Ética Médica, acerca da utilização pelo profissional do melhor do progresso cientifico em beneficio do paciente, denominado por Ronald Dworkin de princípio do resgate, ${ }^{417}$ e que se encontra delimitada no próprio diploma normativo médico. ${ }^{418}$ No estudo, Ronald Dworkin busca identificar critérios para a definição de quais prestações de assistência à saúde devem compor o rol de serviços públicos a serem disponibilizados pelo Estado.

Ao invés da utilização do princípio do resgate, materialmente inviável, Dworkin sugere a adoção do que ele denomina princípio do seguro prudente, o qual corresponderia basicamente a um plano de saúde privado escolhido por uma pessoa nas seguintes condições hipotéticas:

(i) uma sociedade em que a distribuição de riqueza seja justa (ao menos na opinião da pessoa em questão);

(ii) uma sociedade em que o conhecimento médico seja de domínio de todos; e

(iii) uma sociedade em que as empresas de planos de saúde não tenham informações acerca dos riscos de doença de cada pessoa ou grupo.

Nessas condições, a pessoa em questão, em uma situação de livre mercado, sem qualquer regulação, vai escolher e pagar por um plano que ofereça os serviços que mais bem atendam a seu interesse - de modo a garantir proteção por certo rol de intervenções médicas e possibilitar a aplicação de seus recursos pessoais em outras áreas, como

416 SANTOS, Lenir; ANDRADE, Luiz Odorico M. de. SUS: o espaço da gestão inovada e dos consensos interfederativos: aspectos jurídicos, administrativos e financeiros. Campinas: Instituto de Direito Sanitário Aplicado, 2007. p.144-145.

417 DWORKIN, Ronald. A justiça e o alto custo da saúde. In: A virtude soberana: a teoria e a prática da igualdade. Trad. Jussara Simões. São Paulo: Martins Fontes, 2005. p.431-449.

418 O Código de Ética Médica foi aprovado pela Resolução n. ${ }^{\circ}$ 1.246, de 08.01.88, do Conselho Federal de Medicina. O mesmo diploma, é importante ressaltar, delimita tal possibilidade, ao dispor que devem ser observadas as práticas reconhecidamente aceitas e com respeito às leis vigentes no país. 
educação e lazer. Esse rol de serviços médicos pelo qual optou a pessoa é aquele que se deve esperar obter por meio de um sistema público de saúde. ${ }^{419}$

A delimitação dos serviços de saúde a serem disponibilizados pelo Estado brasileiro já há tempos existente em países desenvolvidos, como analisado no Capítulo 2 - tornou-se objeto de discussão nos últimos anos, em especial, a propósito da multiplicação das medidas judiciais aforadas com objetivo de obter gratuitamente o fornecimento de medicamentos de elevado custo pelo Estado. ${ }^{420}$

Não obstante, o envolvimento da assistência farmacêutica deve ser restrito à sua utilização como mecanismo de apoio ao serviço público de saúde previsto na Constituição Federal. O mero fornecimento de medicamentos não configura serviço público, pois se refere a uma obrigação de dar e não a uma obrigação de fazer, de modo que sequer se afigura a noção de serviço. Nesse prisma, o fornecimento de medicamentos não é decorrência imediata do direito à saúde e não compõe de maneira isolada o dever constitucional do Estado prestar serviços públicos de saúde.

$\mathrm{Na}$ hipótese do presente trabalho, o fornecimento de medicamentos é restrito aos casos em que eles são ministrados em ambiente ambulatorial, hospitalar ou mesmo domiciliar como instrumento de apoio à prestação de um serviço. Em tais casos, a judicialização da assistência farmacêutica não configura prática corrente.

De qualquer forma, considerando que no Brasil tornou-se comum a obtenção de medidas judiciais com determinação para que o Estado forneça medicamento a todos que o requerem - na mesma sintonia do que se vem defendendo e em consonância com o que fazem países desenvolvidos,$-{ }^{421}$ encontram-se entendimentos na literatura constitucional e

419 DWORKIN, Ronald. A justiça e o alto custo da saúde. In: A virtude soberana: a teoria e a prática da igualdade. Trad. Jussara Simões. São Paulo: Martins Fontes, 2005. p.431-449.

420 A elevação dos custos de tais produtos farmacêuticos levou alguns países a adotar um campo específico de aplicação da teoria econômica, denominado de farmacoeconomia. Sobre o tema: VELÁSQUEZ, German. Farmacoeconomía: Evaluación científica o Estratégia Comercial? In: BERMUDEZ, Jorge A. Zepeda; BONFIM, José R. de Alcântara (Orgs.). Medicamentos e a reforma do setor de saúde. São Paulo: Hucitec, 1999. p.24.

421 Sobre a questão, conferir análise levada a cabo no Capítulo 2. 
sanitária pátrias que defendem categoricamente a (de)limitação não apenas dos medicamentos (e demais serviços) a serem ofertados pelo Estado, mas também a inibição da intervenção desmedida do Poder Judiciário em tal questão.

Ao tratar da questão, Oswaldo Yoshimi Tanaka assim consignou:

(...) tendo em vista que todo o provimento de medicamentos no sistema tem a mesma fonte de financiamento, temos um dilema. Ao prover, via judicial, medicamentos não padronizados e habitualmente mais caros, sem evidências que os efeitos na doença sejam realmente melhores, estaremos destinando mais recursos 'per capita' a poucos em detrimento de garantir para a maioria os medicamentos essenciais para controle das doenças mais freqüentes. ${ }^{422}$

No mesmo sentido, Luís Roberto Barroso, ao tratar de alguns excessos na concessão de liminares determinando o fornecimento de medicamentos, ressaltou que tais inconsistências colocam em risco a própria continuidade das políticas de saúde pública e desorganizam o sistema administrativo. Para o autor, o excesso de judicialização das decisões políticas pode levar à não realização prática da Constituição e, no caso dos medicamentos, pode significar a outorga de privilégios em detrimento da cidadania de todos. ${ }^{423}$ Trata-se de um novo modelo de privatização da saúde: medicamentos apenas às pessoas amparadas por decisões judiciais.

Seguindo o entendimento já analisado acerca do conteúdo dos direitos fundamentais, Luís Virgílio Afonso da Silva também teceu ressalvas à atuação judicial na concessão de medidas determinando o fornecimento gratuito de medicamentos não disponibilizados no âmbito do subsistema público de saúde:

422 TANAKA, Oswaldo Yoshimi. A judicialização da prescrição medicamentosa no SUS ou o desafio de garantir o direito constitucional de acesso à assistência farmacêutica. Revista de Direito Sanitário, São Paulo, v.9, n.1, p.142, mar./jun. 2008. No mesmo sentido, ressaltando o conteúdo do princípio da integralidade, Lenir Santos também criticou enfaticamente a concessão desmesurada de medidas judiciais que atacam a estrutura do sistema de saúde: "A integralidade vem sendo rompida pelo Poder Judiciário quando concede liminares em ações que visam à garantia do direito à saúde de forma transversa. $\mathrm{O}$ direito à saúde pode ser garantida ao indivíduo que respeita a organização jurídico-administrativa do sistema, desde que ela, é lógico, não seja organizada de modo a cercear o direto à saúde. (...) Não é possível o cidadão violar princípios e diretrizes do sistema, via Poder Judiciário, desrespeitando, muita vezes, o princípio da igualdade." (SANTOS, Lenir. Nota explicativa. In: RODRIGUEZ NETO, Eleutério. Saúde: promessas e limites da constituição. Rio de Janeiro: FIOCRUZ, 2003. p.142).

423 BARROSO, Luís Roberto. Da falta de efetividade à judicialização excessiva: direito à saúde, fornecimento gratuito de medicamentos e parâmetros para a atuação judicial. Revista Interesse Público, Belo Horizonte, n.46, p.35, nov./dez. 2007. 
(...) para dar ensejo a alguma intervenção do Judiciário nesse âmbito, não basta que se verifique que uma ação que poderia eventualmente realizar um direito fundamental não tenha sido realizada - por exemplo a compra de remédios pra determinada doença. É necessário, além dessa verificação, que se analise se há ou não há fundamentação jurídico-constitucional para a omissão. Somente nos casos de omissão infundada é que se poderia imaginar alguma margem de ação para os juízes nesse âmbito. ${ }^{424}$

Nessa perspectiva, resta claro que a definição de quais serviços de saúde, neles incluída a assistência farmacêutica, devem ser oferecidos pelo Estado envolve uma série de fatores em relação aos quais o Poder Judiciário não possui condições de analisar no caso individual e concreto. Assim, a decisão acerca de um tratamento não previsto em lei ou ato normativo, como os Protocolos Clínicos de Diretrizes Terapêuticas, ${ }^{425}$ no âmbito do subsistema público de saúde, não há que ser realizada na esfera médico-paciente e tampouco na esfera médico-paciente-juiz; a definição deve ocorrer em instâncias legalmente criadas para tanto, nas quais se possibilitem a discussão, a avaliação e a comprovação de todos os fatores envolvidos, bem como a viabilidade de sua extensão a todas as pessoas na mesma situação.

Por todos esses argumentos, é inevitável a consideração de que, nos casos em que a legislação não discipline adequadamente e a Administração Pública não atue de modo a criar e fazer funcionar tais instâncias, eventual medida judicial deve ser manejada e admitida em tal nível, para que se adotem determinados serviços assistenciais pelo subsistema público como um todo - e não em casos individuais. ${ }^{426}$

Entender o contrário implica reconhecer a dupla privatização da saúde: de um lado, pela indústria farmacêutica, que oferta produtos a serem fornecidos acriteriosamente pelo

424 SILVA, Luís Virgílio Afonso da. O conteúdo essencial dos direitos fundamentais e a eficácia das normas constitucionais. 2005. Tese (Professor Titular) - Universidade de São Paulo, São Paulo, 2005. p.332.

425 Sobre o tema, conferir: PICON, Paulo Dornelles. Protocolos clínicos e diretrizes terapêuticas: a evidência científica na prática do Sistema Único de Saúde. In: BRASIL. Conselho Nacional de Secretários de Saúde. Para entender a gestão do Programa de Medicamentos de dispensação em caráter excepcional. Brasília: CONASS, 2004. p.54-69.

426 No caso da assistência farmacêutica, considerando que os Protocolos Clínicos e Diretrizes Terapêuticas relacionam os medicamentos fornecidos pelo Estado, a discussão judicial deve ocorrer no âmbito da definição dos respectivos protocolos, cuja previsão deve ser atendida e não discutida em casos individuais. Nesse sentido: SARLET, Ingo Wolfgang; FIGUEIREDO, Mariana F. Reserva do possível, mínimo existencial e direitos à saúde: algumas aproximações. In: SARLET, Ingo Wolfgang; TIMM, Luciano Benetti (Orgs.). Direitos fundamentais, orçamento e 'reserva do possível'. Porto Alegre: Livraria do Advogado, 2007. p.46. 
Estado;427 de outro lado, pelos beneficiários das medidas judiciais, que obtêm medicamentos ou serviços não ofertados ao público em geral.

Independente disso, é importante deixar clara a possibilidade de que a lei delimite o conjunto de atividades a serem garantidas no âmbito do sistema público de saúde e que determinado instrumento contratual determine quais serviços públicos devem ser prestados pelo particular que participa do SUS, conquanto na articulação do sistema haja o equilíbrio entre as diversas atividades prestacionais que compõem a prevenção, promoção, proteção e recuperação da saúde.

\subsubsection{Relevância Pública dos Serviços de Saúde}

O direito à saúde compreende o direito à prestação de serviços individuais de saúde, os quais são assumidos pelo Estado como sua responsabilidade e garantidos a todas as pessoas que deles necessitem mediante atividades de assistência voltadas à proteção, promoção e recuperação saúde. Considerando que a tese ora defendida consiste na proposição de instrumental científico que permita a interpretação da Constituição e aplicação de mecanismos adequados à efetivação do direito à saúde por meio da participação privada nos serviços públicos de saúde, cumpre neste momento analisar a repercussão da qualificação dos serviços de saúde como serviços de relevância pública.

Inicialmente deixa-se claro que, nos termos do artigo 197 da Constituição Federal de 1988, todos os serviços de saúde possuem relevância pública, sejam eles prestados direta ou indiretamente pelo Estado, sejam eles prestados pela iniciativa privada de modo autônomo. Assim, a regulamentação, a fiscalização e o controle dos serviços de saúde previstos no artigo 197 da Constituição Federal aplicam-se também, evidentemente, aos serviços sob a responsabilidade do Estado. ${ }^{428}$ A análise histórica promovida no Item 3.1.1 corrobora

427 Nesse sentido, têm razão Lenir Santos e Luiz Odorico M. de Andrade, ao consignar que: "As inovações tecnológicas da saúde e a indústria farmacêutica nem sempre têm olhos humanitários - seu fim último não é a cura, mas o lucro dos acionistas." (SANTOS, Lenir; ANDRADE, Luiz Odorico M. de. SUS: o espaço da gestão inovada e dos consensos interfederativos: aspectos jurídicos, administrativos e financeiros. Campinas: Instituto de Direito Sanitário Aplicado, 2007. p.144-145).

428 Deve-se ressaltar, como fez Eros Roberto Grau, que a qualificação constitucional dos serviços de saúde como serviços de relevância pública não impede que a lei qualifique outras atividades prestacionais como tal e sobre ela defina o regime jurídico que proporcione sua oferta de modo a garantir determinado direito fundamental. Tanto isso é verdade que consta dentre as atribuições do Ministério Público zelar pelo respeito aos serviços de relevância pública - o que não faria sentido se o único serviço de relevância 
claramente tal entendimento, pois os sucessivos projetos de texto constitucional continham a expressão natureza pública, depois traduzida em relevância pública, voltada tanto aos prestadores privados vinculados ao Estado, os quais deveriam passar a firmar contratos de direito público e submeter-se a limitações no regime da prestação de serviços, quanto a entidades privadas que possuíam atuação independente do Estado.

A expressão serviços de relevância pública é utilizada apenas duas vezes na Constituição Federal: (i) para qualificar os serviços de saúde; e (ii) para se delimitar o rol de atribuições do Ministério Público. ${ }^{429}$ No caso dos serviços de saúde, sua qualificação em sede constitucional como de relevância pública não mais significa do que a ênfase atribuída pela Constituição de que tais atividades, independente da assunção da responsabilidade por sua oferta pelo Estado, devem ser regulamentadas, fiscalizadas e controladas - em um conjunto de atividades que tem recebido a designação geral de regulação. ${ }^{430}$

pública fosse o serviço de saúde (GRAU, Eros Roberto. O conceito de 'relevância pública' na constituição de 1988. In: DALLARI, Sueli Gandolfi et al. (Org.). O conceito constitucional de relevância pública. Brasília: Organização Panamericana da Saúde, 1992. p.13).

429 De acordo com a Constituição Federal: Art. 129. São funções institucionais do Ministério Público: (...) II zelar pelo efetivo respeito dos Poderes Públicos e dos serviços de relevância pública aos direitos assegurados nesta Constituição, promovendo as medidas necessárias a sua garantia.

430 Ao tratar do tema no contexto brasileiro, Carlos Ari Sundfeld assim consignou: "A regulação, enquanto espécie de intervenção estatal, manifesta-se tanto por poderes e ações com objetivos declaradamente econômicos (o controle de concentrações empresarias, a repressão de infrações à ordem econômica, o controle de preços e tarifas, a admissão de novos agentes no mercado) como por outros com justificativas diversas, mas efeitos econômicos inevitáveis (medidas ambientais, urbanísticas, de normalização, de disciplina das profissões etc.) Fazem regulação autoridades cuja missão seja cuidar de um específico campo da atividades considerado em seu conjunto (o mercado de ações, as telecomunicações, a energia, os seguros de saúde, o petróleo,), mas também aquelas com poderes sobre a generalidade dos agentes da economia (exemplo: órgãos ambientais). A regulação atinge tanto os agentes atuantes em setores ditos privados (o comércio, a indústria, os serviços comuns - enfim, as 'atividades econômicas em sentido estrito') como os que, estando especialmente habilitados, operam em áreas de reserva estatal (prestação de 'serviços públicos', exploração de 'bens públicos' e de 'monopólios 'estatais')." (SUNDFELD, Carlos Ari. Serviços públicos e regulação estatal. In: (Coord.). Direito administrativo econômico. São

Paulo: Malheiros, 2000. p.318). Para Marçal Justen Filho, a regulação é reflexo da ampliação das competências públicas atinentes ao controle-regulação das atividades desempenhadas pelos particulares. Com isso, o Estado passa a determinar os fins primordiais a realizar e os meios utilizáveis para tanto e as decisões empresariais privadas, inclusive no âmbito tecnológico, passam a depender da aprovação estatal prévia ou de fiscalização permanente. Reduz-se sensivelmente a margem de autonomia privada, produzindo-se a funcionalização das atividades desempenhadas pelos particulares (JUSTEN FILHO, Marçal. O direito das agências reguladoras independentes. São Paulo: Dialética, 2002. p.29). Como observa Gaspar Ariño Ortiz, o objetivo da regulação não é tanto controlar as empresas quanto proteger a sociedade nas atividades que resultam essenciais para sua vida e seu bem-estar (CASSAGNE, Juan Carlos; ARIÑO ORTIZ, Gaspar. Servicios públicos, regulación y renegociación. Buenos Aires: Abeledo Perrot, 2005. p.20). É importante notar que no setor de saúde, além da regulação sobre os serviços públicos, que é exercido pelos próprios órgãos do sistema público de saúde - SUS (tanto que, recentemente foi editada pelo Ministério da Saúde a Portaria n. $^{\circ} 1.559$, de $1 .^{\circ}$ de agosto de 2008 , que institui a Política Nacional de Regulação do SUS), há duas agência estatais criadas para tal atividade: 
Além disso, cumpre ao Ministério Público zelar por seu respeito, ${ }^{431}$ e a qualificação dos serviços de saúde como serviços de relevância pública oferece lastro constitucional para a fundamentação de atividades de fomento estatal à prestação privada de serviços de saúde. ${ }^{432}$

Outra expressão similar é utilizada pela legislação para se referir a determinados serviços, dentre eles os serviços de saúde, os quais são sujeitos a um tratamento jurídico específico. Trata-se dos serviços essenciais. ${ }^{433}$ Assim, relevância pública e essencialidade são qualificações atribuídas indistintamente (i) a atividades assumidas como responsabilidade do Estado pela garantia de sua prestação e (ii) a atividades em relação às quais o próprio mercado é capaz de satisfazer sua prestação.

(i) a Agência Nacional de Saúde Suplementar - ANS, criada pela já referida Lei n. ${ }^{\circ}$ 9.961, de 28 de janeiro de 2000, com competência para regular o subsetor de saúde suplementar; e (ii) a Agência Nacional de Vigilância Sanitária, instituída pela Lei n. ${ }^{\circ} 9.782$, de 26 de janeiro de 1999, com competência para regulação de atividades relacionadas à vigilância sanitária. Sobre a regulação no Brasil, conferir também: CUÉLLAR, Leila. As agências reguladoras e seu poder normativo. São Paulo: Dialética, 2001; MOTTA, Roberto Ferreira. Agências reguladoras. Barueri: Manole, 2003.

431 Nesse aspecto, a disposição não produz efeitos práticos, pois dentre as atribuições do Ministério Público consta zelar pelo efetivo respeito dos Poderes Públicos e dos serviços de relevância pública aos direitos assegurados nesta Constituição. Assim, sendo os serviços de saúde um dos mecanismos de efetivação do direito à saúde, a atuação do Ministério Público no zelo pelo respeito ao direito à saúde, implica necessariamente o zelo pelos serviços de saúde.

432 Sobre o tema, ainda que com pontos de divergência com a tese ora esposada, em especial no que se refere ao conceito de serviço público, imprescindível é a análise das considerações traçadas por Paulo Modesto em: MODESTO, Paulo. Reforma do estado, formas de prestação de serviços ao publico e parcerias público-privadas: demarcando as fronteiras dos conceitos de 'serviço público', serviços de relevância pública' e 'serviços de exploração econômica' para as parcerias público-privadas. In: SUNDFELD, Carlos Ari (Coord.). Parcerias público-privadas. São Paulo: Malheiros, 2005. p.433-486.

433 Em seu art. 9. ${ }^{\circ}$, a Constituição Federal dispõe sobre o direito de greve dos trabalhadores, sendo que no $\S$ 1. ${ }^{\circ}$ determina que a lei definirá os serviços ou atividades essenciais e disporá sobre o atendimento das necessidades inadiáveis da comunidade. A mesma referência é trazida pelo artigo $114, \S 3$. $^{\circ}$ do texto constitucional. Já no artigo 30, ao atribuir competência aos municípios, a Constituição determina que cumpre a estes, organizar e prestar, diretamente ou sob regime de concessão ou permissão, os serviços públicos de interesse local, incluído o de transporte coletivo, que tem caráter essencial. Fica evidente, neste caso, a qualificação de um serviço público como um serviço de caráter essencial, assim como o serviço público de saúde é qualificado como serviço de relevância pública. Já no artigo 37 da Constituição Federal, em seu inciso XXII se não menciona serviços essenciais, mas atividades essenciais, qualificando como tais as administrações tributárias dos entes federativos. Tal expressão, atividades e não serviços, reforça o argumento aqui defendido de que a função pública é atribuição de funcionários públicos e não pode ser delegada, ao contrário dos serviços públicos, cuja prestação pode ser ofertada tanto pelo mercado quanto pelo Estado (direta ou indiretamente). 
$\mathrm{Na}$ esteira do que se vem afirmando, concorda-se com José Luis Lopez-Muñiz, pra quem:

\begin{abstract}
Por mais vitais que sejam para os cidadãos e seus direitos fundamentais, os serviços essenciais não têm que estar necessariamente em mãos públicas, e tampouco sob a responsabilidade gestora dos poderes públicos. Se os particulares, os agentes econômicos privados se mostram capazes de satisfazê-los eficazmente, exercendo seus direitos e liberdades econômicas em um regime de concorrência no mercado, sob a regulação que se entenda adequada, não há porque permitir maior intervenção nem protagonismo estatal. Pense-se, por exemplo, em um serviço essencial como o abastecimento alimentar e o farmacêutico. ${ }^{434}$
\end{abstract}

Tanto uma quanto outra qualificação (relevância pública e essencialidade) decorrem, é certo, da vinculação em maior ou menor grau de determinada atividade aos direitos fundamentais, já que todas as atividades realizadas no Estado brasileiro possuem como diretriz os direitos fundamentais. 435

A qualificação de determinados serviços como essenciais gera efeitos jurídicos como aquele definido pelo artigo 58 da Lei n. ${ }^{\circ}$ 8.666, de 21 de junho de 1993, que prevê a ocupação provisória pela Administração Pública de bens móveis e imóveis a eles vinculados;436 e aqueles efeitos definidos pela Lei . $^{0}$ 7.783, de 28 de junho de 1989, que regulamenta o direito de greve. Neste último caso, dentre os serviços qualificados pela lei em referência como essenciais, ${ }^{437}$ o direito de greve sofre restrições, de modo que cumpre aos trabalhadores manter a prestação daquela parcela dos serviços indispensáveis à sobrevivência, saúde $e$

434 LOPEZ-MUÑIZ, José Luis. Servicio Público, Servicio Universal y 'Obligación de Servivio Público' em la Perspectiva del Derecho Comunitário: Los Servicios Essenciales y sus Regímenes Alternativos. In: Os caminhos da privatização da administração pública. Coimbra: Coimbra, 2001. p.270.

435 E, em apoio a tal entendimento, já sustentado mais de uma vez neste trabalho, pode-se citar o artigo 170 da Constituição Federal, que vincula a atividade econômica à finalidade de assegurar a todos uma existência digna conforme os ditames da justiça social. Portanto, a dignidade da pessoa humana e a justiça social, denominadores, na hipótese do artigo em referência, dos direitos fundamentais, vinculam toda e qualquer atividade que envolva a utilização de recursos limitados para a satisfação de necessidades humanas.

436 Art. 58. O regime jurídico dos contratos administrativos instituído por esta Lei confere à Administração, em relação a eles, a prerrogativa de: (...) V - nos casos de serviços essenciais, ocupar provisoriamente bens móveis, imóveis, pessoal e serviços vinculados ao objeto do contrato, na hipótese da necessidade de acautelar apuração administrativa de faltas contratuais pelo contratado, bem como na hipótese de rescisão do contrato administrativo (os grifos não constam do original).

437 Art. 10 São considerados serviços ou atividades essenciais: I - tratamento e abastecimento de água; produção e distribuição de energia elétrica, gás e combustíveis; II - assistência médica e hospitalar; III - distribuição e comercialização de medicamentos e alimentos; IV - funerários; V - transporte coletivo; VI - captação e tratamento de esgoto e lixo; VII - telecomunicações; VIII - guarda, uso e controle de substâncias radioativas, equipamentos e materiais nucleares; IX - processamento de dados ligados a serviços essenciais; X - controle de tráfego aéreo; XI compensação bancária (os grifos não constam do original). 
segurança da população. 438 Veja-se que a legislação qualificou um nível ainda mais específico de serviços dentre os serviços essenciais, em relação aos quais deve incidir $o$ princípio da continuidade.

Tal princípio remete aos repetitivamente mencionados princípios do serviço público, consagrados pela obra do francês Louis Rolland e difundidos amplamente na doutrina administrativista pátria. ${ }^{439}$ Não obstante, na linha do que se vem defendendo, ainda que a continuidade seja uma das características dos serviços públicos, ela não constitui elemento suficiente que os diferencie de outras atividades privadas de relevância pública ou essenciais não qualificadas como tal. 440 Tal princípio decorre, portanto, não da qualificação de determinada atividade como serviço público, mas da necessidade de sua manutenção, a qual pode ser garantida independente de sua assunção como responsabilidade do Estado.

438 Essa é a determinação expressa do parágrafo único do artigo 11 da lei em referência, que assim dispõe: Art. 11. Nos serviços ou atividades essenciais, os sindicatos, os empregadores e os trabalhadores ficam obrigados, de comum acordo, a garantir, durante a greve, a prestação dos serviços indispensáveis ao atendimento das necessidades inadiáveis da comunidade. Parágrafo único. São necessidades inadiáveis, da comunidade aquelas que, não atendidas, coloquem em perigo iminente a sobrevivência, a saúde ou a segurança da população. É de se destacar que a parte final do dispositivo colacionado induz à conclusão que todo e qualquer serviços que implique o perigo referido deve ser considerado essencial e ter sua paralisação balizada nos termos da própria Lei. Com isso, não restam dúvidas de que o rol disposto no artigo 10 é meramente exemplificativo. Por fim, insta ressaltar o entendimento finalmente consolidado do Supremo Tribunal Federal (Mandados de Injunção n. ${ }^{\circ} 670$, n. $^{\circ} 708$ e n. ${ }^{\circ} 712$ ) de que a lei em referência seja aplicada em todos os casos, também aos servidores públicos, com as devidas adaptações, incluindo a possibilidade de critérios mais severos de continuidade do serviço, até que seja editada lei específica prevista pelo inciso VII do artigo 37 da Constituição Federal. A decisão atinge qualquer função pública desempenhada por servidores públicos, o que inclui os serviços públicos prestados diretamente pelo Estado, corroborando o argumento ora defendido.

439 Segundo tal teoria, são princípios dos serviços públicos a continuidade - a qual já fora ressaltada por León Duguit e decorre da própria natureza da atuação estatal; a mutabilidade - que deve ser compreendida como a possibilidade de alteração da forma de prestação dos serviços e mesmo da qualificação de determinada atividade como serviço público; e igualdade - que consiste no oferecimento de condições de acesso a determinado serviço a todos, levando em conta para isso a possibilidade de discriminação fundamentada na Constituição e voltada à consecução de um direito fundamental.

440 Nessa linha de argumentação é sintomático o disposto no artigo 22 da Lei n. ${ }^{\circ} 8.078$, de 11 de setembro de 1990 - conhecida como Código de defesa do Consumidor. Tal dispositivo trata especificamente dos serviços públicos e determina que, dentre eles, os essenciais sejam prestados de forma contínua. Tal referência deve ser levada em conta com cautela, pois se de acordo com os critérios constitucionais, a criação de um serviço público depende de fatores que necessariamente o vinculam aos direitos fundamentais - decorrentes da interpretação da segurança nacional e do relevante interesse coletivo - a essencialidade é marca dos serviços públicos. Não obstante, como já assinalado, o dispositivo em referência parece reconhecer que existem serviços cuja regularidade da prestação é mais ou menos essencial - serviços dos quais determinado direito fundamental é mais ou menos dependente. 
O que se quer sustentar com a argumentação aqui disposta é que a relevância e a essencialidade variam conforme o serviço em questão, sendo que seu tratamento legal independe de sua qualificação como serviço público. Afinal, como assinalado acima, a qualificação de determinada atividade como serviço público depende de sua vinculação com os direitos fundamentais - expressados na Constituição Federal como segurança nacional e relevante interesse coletivo - conjugada com a inaptidão do mercado em provêla independente de sua assunção pelo Estado. Assim, descumpridos tais critérios e inexistindo lei que fixe vínculo orgânico com a Administração Pública, não há que se falar em serviços públicos. 441

Possuem relevância pública tanto subsistema de desembolso direto quanto o subsistema de saúde suplementar, ${ }^{442}$ sendo que este último possui disciplina específica, constante da já mencionada Lei n. ${ }^{0}$ 9.656/98 - Lei de Saúde Suplementar, que regulamenta os planos privados de assistência à saúde, ${ }^{443}$ e da Lei n. ${ }^{\circ} 9.961$, de 28 de janeiro de $2000,{ }^{444}$ que criou

441 Desse modo, como resta evidenciado, noções como serviços de utilidade pública, serviços públicos impróprios e serviços públicos virtuais, não raro encontrados na doutrina, não são serviços públicos. Na maioria das vezes, por sua relevância e essencialidade, são objeto regulação específica, sem, no entanto, configurar responsabilidade do Estado, materializada pela existência de um vínculo orgânico que a defina.

442 Sobre o tratamento jurídico da saúde suplementar, conferir: CECHIN, José. A história e os desafios da saúde suplementar: 10 anos de regulação. São Paulo: Saraiva, 2008; CUNHA, Paulo César Melo. Regulação jurídica da saúde suplementar no Brasil. Rio de Janeiro: Lumen Júris, 2003. MARQUES, Cláudia Lima; LOPES, José Reinaldo de Lima; PFEIFFER, Roberto A. C. Saúde e responsabilidade: seguros e planos de assistência privada à saúde. São Paulo: Revista dos Tribunais, 1999; REIS, Carlos Octávio Ocké. Os planos de saúde no Brasil: um estdudo sobre o mercado, os gastos e a regulação. 2002. 134p. Tese (Doutorado em Saúde Coletiva) - Curso de Pós-Graduação em Saúde Coletiva, Universidade do Estado do Rio de Janeiro, Rio de Janeiro, 2002; REIS, Carlos Octávio Ocké. O estado e os planos de saúde no Brasil. Revista do Serviço Público, ano 51, n.1, p.123- 147, jan./mar. 2000; SCHEFFER, Mario; BAHIA, Ligia. Planos e seguros privados de saúde no Brasil: lacunas e perspectivas da regulamentação. In: HEIMANN, Luiza S.; IBANHES, Lauro C.; BARBOZA, Renato (Orgs.). O público e o privado na saúde. São Paulo: Hucitec, 2005. p.127-168.

443 Os incisos I e II do artigo primeiro da Lei em referência, com redação dada pela Medida Provisória n. ${ }^{\circ}$ 2.177-44, de 2001, traz as seguintes definições: I - Plano Privado de Assistência à Saúde: prestação continuada de serviços ou cobertura de custos assistenciais a preço pré ou pós estabelecido, por prazo indeterminado, com a finalidade de garantir, sem limite financeiro, a assistência à saúde, pela faculdade de acesso e atendimento por profissionais ou serviços de saúde, livremente escolhidos, integrantes ou não de rede credenciada, contratada ou referenciada, visando a assistência médica, hospitalar e odontológica, a ser paga integral ou parcialmente às expensas da operadora contratada, mediante reembolso ou pagamento direto ao prestador, por conta e ordem do consumidor. II - Operadora de Plano de Assistência à Saúde: pessoa jurídica constituída sob a modalidade de sociedade civil ou comercial, cooperativa, ou entidade de autogestão, que opere produto, serviço ou contrato de que trata o inciso I deste artigo.

444 Resultado da conversão em lei da Medida Provisória n. ${ }^{\circ} 1.928$, de 25 de novembro de 1999. 
a Agência Nacional de Saúde, ente estatal competente para a regulação, normatização, controle e fiscalização das atividades que garantam a assistência suplementar à saúde. ${ }^{445}$

Até a edição da Lei da Saúde Suplementar, as relações entre clientes de serviços privados de saúde e as operadoras dos planos sofriam a incidência da Lei n. ${ }^{\circ} 8.078$, de 11 de setembro de 1990 - Código de Defesa do Consumidor (CDC). A partir de então, a legislação consumerista passou a ter aplicação subsidiária, já que a lei dos planos de assistência à saúde trata o tema de maneira específica. Já no que se refere ao sistema de desembolso direto, no qual o cliente paga diretamente ao prestador pelos serviços, incidem as disposições do Código de Defesa do Consumidor. ${ }^{446}$

Nesse passo, cumpre investigar até que ponto as disposições do CDC são aplicáveis aos serviços públicos de saúde. Afinal, se nos termos do que se vem sustentando, o direito à saúde é concretizado tanto pela prestação de serviços sob a responsabilidade do Estado quanto pela prestação privada, em face do princípio geral da isonomia e do princípio específico da igualdade de acesso aos serviços de saúde, não deve ser admitido tratamento, especialmente na lei, desigual entre consumidores de serviços privados de saúde e usuários do subsistema público de saúde. Em termos mais claros, não é admissível que o consumidor da mercadoria saúde ocupe posição jurídica privilegiada em face do usuário do serviço público de saúde.

A discussão insere-se no debate entre a qualificação da pessoa que necessita do serviço público como cliente-consumidor de um serviço privado e como cidadão-usuário de um serviço público. Na linha aqui defendida, segundo a qual o serviço público é assumido como atividade prestacional a ter seu fornecimento garantido pelo Estado, é evidente que a relação entre o usuário e o prestador de um serviço público deve ser entendida na perspectiva de um sujeito detentor de direitos nos termos da lei que regula sua prestação. Nos casos em que o serviço é prestado de forma gratuita, o serviço público deve submeter-

445 Eis o que dispõe o artigo $1 .^{\circ}$ da lei em referência: Art. 1. ${ }^{\circ}$ É criada a Agência Nacional de Saúde Suplementar - ANS, autarquia sob o regime especial, vinculada ao Ministério da Saúde, com sede e foro na cidade do Rio de Janeiro - RJ, prazo de duração indeterminado e atuação em todo o território nacional, como órgão de regulação, normatização, controle e fiscalização das atividades que garantam a assistência suplementar à saúde.

446 Afinal, trata-se de uma relação de prestação de serviços, conceituada pelo Código de Defesa do Consumidor nos seguintes termos: Art. 1. ${ }^{\circ}$ (...) $§ 2 .^{\circ}$ Serviço é qualquer atividade fornecida no mercado de consumo, mediante remuneração, inclusive as de natureza bancária, financeira, de crédito e securitária, salvo as decorrentes das relações de caráter trabalhista. 
se apenas ao que dispõe o artigo 22 do CDC que, ${ }^{447}$ em uma análise acurada, não trata de relação consumerista, mas de relação decorrente de lei, de índole estatutária, mesmo porque, nos termos do parágrafo $2 .^{\circ}$ do artigo $3 .^{\circ}$ da lei em referência, a prestação de serviços objeto de disciplina pelo Código do Consumidor há de ser remunerada. ${ }^{448}$

Nesse prisma, pode-se perceber que a disposição constante do artigo 22 do Código de Defesa do Consumidor tem como objetivo fazer com que o cidadão usuário dos serviços públicos de saúde não fique menos protegido do que o cliente consumidor dos serviços privados de saúde. ${ }^{449}$ Como assinalado neste trabalho, a garantia do direito à saúde e o cumprimento do dever do Estado realizam-se pela oferta de serviços de saúde a todos que dele necessitam no Brasil - como serviços públicos ou como serviços privados, gratuitamente ou mediante remuneração.

Como ressaltou Michel Croizier, a noção de serviço público não pode configurar justificativa para a ineficiência e desrespeito dos direitos do usuário. ${ }^{450}$ É evidente que o direito não deve ser confundido com mercadoria; mas é mais evidente ainda que um direito fundamental como a saúde deve ser mais bem protegido do que um simples bem privado. Portanto, tratar o cidadão como consumidor, na medida em que detentor de direitos exigíveis ante o prestador, acerca da qualidade e efetiva prestação dos serviços públicos, não significa diminuir sua condição de cidadão, mas significa respeitar o direito de todos, inclusive daqueles que não têm condições de satisfazer suas necessidades no mercado - na condição de consumidor.

Considerando que a prestação dos serviços públicos de saúde tem sido promovida em caráter gratuito, ainda que assim não determine a Constituição Federal, não se verifica

447 Art. 22. Os órgãos públicos, por si ou suas empresas, concessionárias, permissionárias ou sob qualquer outra forma de empreendimento, são obrigados a fornecer serviços adequados, eficientes, seguros e, quanto aos essenciais, contínuos.

448 Art. 3. ${ }^{\circ}$ (...) $§ 2 .^{\circ}$ Serviço é qualquer atividade fornecida no mercado de consumo, mediante remuneração, inclusive as de natureza bancária, financeira, de crédito e securitária, salvo as decorrentes das relações de caráter trabalhista.

449 Sobre o tema, ainda que na perspectiva de serviços públicos remunerados, conferir: PEREIRA, César A. Guimarães. Usuários de serviços públicos: usuários, consumidores e os aspectos econômicos dos serviços públicos. São Paulo: Saraiva, 2006 (em especial, p.133-242).

450 Nas palavras do autor: "A imagem do serviço público no sentido tradicional e sagrado é ainda amplamente utilizada, mas de fato não é senão um biombo, uma escusa, para escapar à pressão do cliente." (CROZIER, Michel. Estado modesto, estado moderno: estratégia para uma outra mudança. Trad. J. M. Vilar de Queiroz. Brasília: Fundação Centro de Formação do Servidor Público - FUNCEP, 1989. p.169). 
na hipótese a incidência das regras estabelecidas pelo Código de Defesa do Consumidor. ${ }^{451}$ No caso dos serviços de saúde, a proteção dos usuários foi estabelecida por ato normativo, intitulado Carta dos Direitos dos Usuários da Saúde, com base nos direitos:

(i) ao acesso ordenado e organizado ao sistema de saúde;

(ii) ao tratamento adequado e efetivo para seu problema;

(iii) ao tratamento humanizado, acolhedor e livre de qualquer discriminação (preconceito de raça, cor, idade ou orientação sexual, estado de saúde ou nível social);

(iv) ao tratamento que respeite a sua pessoa, seus valores e seus direitos;

(v) ao comprometimento dos gestores da saúde para que os princípios anteriores sejam cumpridos; além da responsabilidade pessoal para que seu tratamento aconteça de forma adequada. .52

Note-se que tal rol de direitos tem como objeto tanto os serviços públicos quanto os serviços privados de saúde, o que demonstra a proximidade entre os regimes jurídicos de um e de outro. O que os diferencia, como ressaltado, é o vínculo orgânico que materializa a responsabilidade do Estado pela prestação dos serviços de saúde qualificados como serviços públicos de saúde.

Por fim, insta ressaltar que, com objetivo de definir as linhas gerais da responsabilidade do Estado na prestação de serviços públicos, encontra-se em trâmite no Congresso Nacional Projeto de Lei Complementar n. ${ }^{\circ}$ 6.953, de 11 de junho de 2002, que regulamenta o inciso II do parágrafo único do artigo 175 da Constituição Federal, definindo os princípios gerais e os direitos dos usuários de serviços públicos.

451 Em sentido contrário, por tratar de hipóteses em que a regra é a prestação remunerada de serviços, a Lei n. ${ }^{\circ} 8.987$, de 13 de fevereiro de 1995 , conhecida como Lei de Concessões, prevê em seu artigo $7 .^{\circ}$ a aplicação subsidiária do Código de Defesa do Consumidor às relações decorrentes da prestação de serviços públicos concedidos ou permitidos.

452 Portaria MS/GM n. ${ }^{\circ} 675$, de 30 de março de 2006. 


\section{MECANISMOS E LIMITES DA PARTICIPAÇÃO PRIVADA NOS SERVIÇOS PÚBLICOS DE SAÚDE}

\subsection{DELIMITAÇÃO DA PARTICIPAÇÃO PRIVADA COMPLEMENTAR}

A participação privada no setor de saúde, como analisado nos Capítulos precedentes, esteve presente em todas as etapas de desenvolvimento do Estado. A grande transformação no setor de saúde, para usar expressão tornada clássica na teoria econômica por Karl Polanyi, ${ }^{453}$ ocorreu a partir do momento em que se consolidou a idéia de que a saúde constitui direito a ser garantido pelo Estado a todas as pessoas. Tal transformação teve Inglaterra, França início em meados do século passado, quando países com sistemas jurídicos tão diferentes como e Alemanha passaram a garantir progressivamente a universalização do acesso aos serviços de saúde - seja por meio da ampliação do sistema de seguros sociais, seja por meio da criação de sistemas nacionais de saúde.

A partir do momento em que se consolidou o entendimento de que a saúde é um direito a ser garantido pelo Estado, por uma série de atividades dentre as quais a prestação de serviços, independente da previsão constitucional do direito à saúde e independente da previsão constitucional da existência de serviços públicos de saúde, todos os países passaram a prestá-lo - direta ou indiretamente. Essa observação conduz à indagação da necessidade e da importância de previsão constitucional acerca do direito e dos serviços públicos de saúde. Tal questionamento, entretanto, apenas pode ser respondido em cada contexto social, histórico e normativo. No caso do Brasil, a importância da consagração foi alta, pois tem proporcionado a conscientização de grande parcela da população de que os serviços de saúde consistem em direitos a serem exigidos em face do Estado e não em favores a serem prestados pelo detentor de determinado cargo político.

As funções do Estado na organização e no funcionamento dos sistemas de saúde, portanto, apenas recentemente ganharam relevo. Tal característica, aliada ao desenvolvimento da tecnologia médica nos últimos anos, fez com que se desenvolvessem um conjunto normativo e uma estrutura administrativa para regular as atividades estatais e não-estatais

453 POLANYI, Karl. A grande transformação: as origens de nossa época. Trad. Fanny Wrobel. 2.ed. Rio de Janeiro: Elsevier, 2000. 
voltadas à garantia do direito à saúde. 454 Dentre as funções do Estado para a manutenção dos sistemas aptos a promover tal direito, merecem destaque:

(i) a formulação e o planejamento de políticas públicas;

(ii) o financiamento das atividades públicas e incentivo às atividades privadas;

(iii) a regulação de todo o setor; e

(iv) a prestação dos serviços. ${ }^{455}$

No Brasil, a exemplo do que aconteceu em países como Portugal e Espanha, o reconhecimento da saúde como direito de todos - a ser garantido por um sistema público apto a oferecer assistência a todas as pessoas que dela necessitar - apenas foi consagrado em fins do século passado. ${ }^{456}$ Mais do que qualquer outro texto constitucional, com o objetivo de garantir a efetivação do direito à saúde, a Constituição brasileira de 1988 traçou detalhadamente as funções do Estado em relação à garantia do direito à saúde, em especial:

(i) estabelecendo as diretrizes da política de saúde a ser adotada; 457

(ii) atribuindo à lei complementar a definição dos padrões mínimos de financiamento das ações e serviços de saúde; 458

454 A disciplina de tais atividades - prestadas tanto pelo Estado quanto pela iniciativa privada - pode ser denominada Direito Sanitário. Para Julio César da Rocha: "O Direito Sanitário ou Direito da Saúde pode ser entendido como um conjunto de normas jurídicas reguladoras da atividade do Poder Público destinada a ordenar a proteção, promoção e recuperação da saúde e a organização e o funcionamento dos serviços correspondentes e asseguradores deste direito." (ROCHA, Julio César da. Direito da saúde. São Paulo: LTr, 1999. p.49). Para Fernando Aith: "O Direito Sanitário corresponde ao ramo jurídico que disciplina as ações e serviços públicos e privados de interesse à saúde. Ele é formado pelo conjunto de normas jurídicas (regras e princípios) que visa a efetivação do Direito à saúde e possui um regime jurídico específico." (AITH, Fernando Mussa A. Teoria geral do direito sanitário. 2006. Tese (Doutorado em Saúde Pública) - Faculdade de Saúde Pública, Universidade de São Paulo, São Paulo, 2006. p.115). Sobre o tema, conferir também: DALLARI, Sueli Gandolfi. Uma nova disciplina: o direito sanitário. Revista Saúde Pública, São Paulo, v.22, p.327-334, 1988.

455 Sobre o tema, conferir: CECHIN, José. A história e os desafios da saúde suplementar: 10 anos de regulação. São Paulo: Saraiva, 2008. p.49 e segs.

456 Como já mencionado, as transições portuguesa e espanhola no setor de saúde foram marcadas pelas respectivas constituições de 1976 e de 1978.

457 Art. 198 da Constituição Federal.

458 Parágrafos primeiro, segundo e terceiro do artigo 198 da Constituição Federal. A lei complementar prevista pela Constituição ainda não foi aprovada. Como mencionado no Item 3.2, tal regulamentação encontra-se em trâmite perante a Câmara dos Deputados - Projeto de Lei Complementar 121/2007. 
(iii) determinando que a regulamentação, a fiscalização e o controle do setor sejam realizados nos termos da lei; ${ }^{459} \mathrm{e}$

(iv) assumindo o dever de prestar serviços públicos de saúde, diretamente ou indiretamente, mediante a participação complementar da iniciativa privada. ${ }^{460}$

Ao contrário dos demais Estados analisados neste trabalho, a própria Constituição brasileira faz referência expressa à participação privada no sistema público de saúde. Com isso, a delimitação do caráter complementar de participação da iniciativa privada na prestação de serviços públicos de saúde implica a análise do alcance do conteúdo constitucional da complementaridade, a qual deve ter como referencial tanto (i) o texto da Constituição, quanto (ii) as condições históricas, sociais e econômicas atuais e aquelas existentes no momento de elaboração do texto constitucional.

O primeiro referencial, de índole jurídico-sistêmica, refere-se (i) ao tratamento constitucional do direito à saúde, (ii) à delimitação dos serviços de saúde e (iii) à definição de seu regime jurídico, objetos de investigação no Item 3.2. O segundo referencial, de caráter social, histórico e econômico, foi objeto de avaliação no Item 3.1, por meio do qual foi possível compreender o processo de estruturação do sistema de saúde hoje vigente no Brasil, marcado pela precedência de um período de exceção, no qual predominaram a centralização das decisões e a privatização dos serviços de saúde.

Por tais feixes devem ser iluminados os dispositivos constitucionais que especificamente prevêem a participação privada na prestação de serviços de saúde, previstos no artigo 197 e no parágrafo primeiro do artigo 199 da Constituição Federal, cuja transcrição merece destaque:

Art. 197. São de relevância pública as ações e serviços de saúde, cabendo ao Poder Público dispor, nos termos da lei, sobre sua regulamentação, fiscalização e controle, devendo sua execução ser feita diretamente ou através de terceiros e, também, por pessoa física ou jurídica de direito privado.

(...)

Art. 199. A assistência à saúde é livre à iniciativa privada.

459 Art. 197 da Constituição Federal.

460 Art. 197 e 199, $\S 10^{\circ}$ Destaque-se que a complementaridade consta também como princípio constitucional expresso no artigo 223 da Constituição Federal, que trata dos sistemas público de radiodifusão sonora e de sons e imagens. Sobre o tema, conferir: SCORSIM, Ericson Meister. Estatuto dos serviços de televisão por radiodifusão. 2007. 343p. Tese (Doutorado em Direito) - Curso de Pós-Graduação em Direito, Universidade de São Paulo, São Paulo, 2007. p.210 e segs. 
$\S 1 .^{\circ}$ - As instituições privadas poderão participar de forma complementar do sistema único de saúde, segundo diretrizes deste, mediante contrato de direito público ou convênio, tendo preferência as entidades filantrópicas e as sem fins lucrativos.

A Constituição Federal, portanto, ao disciplinar o direito à saúde, oferece expressamente a possibilidade de modernização da Administração Pública - tal qual o processo realizado em países que levam a sério o direito à saúde - por meio da participação consensual e negociada da iniciativa privada, tanto na gestão de determinadas unidades de saúde quanto na prestação de atividades específicas de assistência à saúde. Não obstante, considerando a complexidade dos dispositivos que tratam do tema, a ausência de estudos aprofundados e a repetição de opiniões firmadas com base em premissas desconectadas da ideologia constitucional, a Constituição Brasileira tem sofrido uma série de agressões, tanto por meio da já mencionada interpretação retrospectiva quanto por meio de atos normativos dotados de inconstitucionalidade.

O ideal estatizante da prestação de serviços como fórmula mais adequada à garantia do direito à saúde, há muito tempo abandonada em países democráticos, e não albergado pela Constituição de 1988, ainda possui adeptos em solo pátrio. Tal pensamento hermético, que tem permeado o imaginário jurídico e social no Brasil, ao contrário do que pensam seus arautos, não promove o direito à saúde, mas incentiva o atraso, a ineficiência e o enfraquecimento do próprio SUS.

Contratualização, flexibilidade, possibilidade de negociação, consensualismo e colaboração da iniciativa privada configuram importantes ferramentas da atuação administrativa pública deste século e têm sido adotadas com êxito no setor de saúde de todos os países em que a prestação de tais serviços é tida, para dizer o menos, como satisfatória. ${ }^{461}$ No Brasil, a especificidade e a complexidade do ordenamento constitucional da saúde, resultantes do embate entre ideologias opostas, tal qual delineado no Item 3.1, fazem dele um texto de difícil interpretação, mas suscetível a diversos modelos de efetivação, com base em diversas formas de participação privada. Entretanto, a implementação de tais instrumentos e a conseqüente efetivação do direito à saúde, não raro, esbarram na ausência de consenso hermenêutico e na própria resistência à mudança institucional - esse último, traço característico do atraso que marca a história do direito à saúde e, quiçá, do Estado brasileiro. ${ }^{462}$

\footnotetext{
461 Sobre o tema, conferir as considerações traçadas nos Itens 2.3 e 2.4 deste trabalho.

462 Atraso esse claramente perceptível pela análise promovida no Item 3.1.
} 
É tempo de interpretar a sério a ordem constitucional da saúde à luz da efetivação do respectivo direito. Para tanto, é importante a análise específica dos dispositivos acima mencionados, bem como dos instrumentos legais admitidos como mecanismos aptos a promover uma participação privada que fortaleça o sistema público de saúde e reforce a capacidade estatal de efetivar tal direito.

4.1.1 Complementaridade na Constituição Federal: a Ausência de Dever Estatal de Prestação Direta dos Serviços Públicos de Saúde

Ao contrário do que sustentam alguns autores e parte da jurisprudência pátria, a previsão constitucional da participação complementar da iniciativa privada no SUS não significa a atribuição de dever estatal de prestação direta dos serviços públicos de saúde. Não raro são encontradas nos tribunais brasileiros decisões que impedem a celebração de parcerias com a iniciativa privada com fundamento em suposto descumprimento da complementaridade da participação privada nos serviços públicos de saúde. Os efeitos jurídicos de tais decisões nos respectivos casos concretos e seu efeito reflexo na segurança jurídica acabam por prejudicar a evolução do direito, a modernização da Administração Pública e a efetivação do direito à saúde.

Como ilustração, pode-se mencionar o caso em que a administração de um município optou por firmar ajuste com a iniciativa privada sem fins lucrativos, ${ }^{463}$ a qual seria responsável por equipar o prédio, executar os serviços hospitalares e gerenciar toda a unidade, nos termos previstos pelo edital do processo de escolha. ${ }^{464}$ Contra tal atuação administrativa, foi ajuizada Ação Civil Pública, na qual o Ministério Público postulou intervenção jurisdicional que fizesse a Administração Pública abster-se de firmar o ajuste, dentre outros argumentos, com base no desrespeito ao caráter complementar da participação privada nos

463 Com amparo em lei municipal, sob a justificativa (i) da ausência de recursos para aquisição de equipamentos e contratação de funcionários para colocar em pleno funcionamento um prédio que havia sido construído para albergar um hospital público e (ii) da busca de maior eficiência da prestação privada dos serviços.

464 A modalidade de ajuste para a contração da entidade privada sem fins lucrativos foi o termo de parceria com entidade privada qualificada como OSCIP, hipótese de vínculo que será analisado no Item seguinte. 
serviços públicos de saúde. Na petição inicial de tal medida tem-se a seguinte assertiva, que não raro é encontrada em trabalhos acadêmicos sobre o tema: "(...) o próprio texto constitucional é muito claro ao definir que o serviço público de saúde deve ser prestado DIRETAMENTE pelo Poder Público". ${ }^{465}$

Note-se que tal argumento é utilizado de modo idêntico em várias medidas ajuizadas pelo Ministério Público das diversas unidades federativas. O item da petição inicial em comento, denominado 'O Papel complementar da iniciativa privada no SUS e a impossibilidade de lhe ser transferida a gestão de unidades de saúde e hospitais públicos', encontra-se transcrito, ipsis verbis, em outras ações do gênero. Como exemplo, pode-se mencionar a, adiante analisada, Ação Civil Pública ajuizada pelo Ministério Público Federal com objetivo de obstar a qualificação de entidades privadas de saúde como organizações sociais e a conseqüente celebração de contratos de gestão para a prestação de serviços públicos de saúde no Município de São Paulo - Processo n. ${ }^{0}$ 2006.61.00.009087-9, 3. ${ }^{a}$ Vara Cível da Justiça Federal de São Paulo.

Sobre o tema, há também um estudo, intitulado Fundamentos básicos para atuação do MPF contra a terceirização da gestão dos serviços prestados nos estabelecimentos de saúde, elaborado pelo Grupo de Trabalho da Saúde da Procuradoria dos Direitos do Cidadão do Ministério Público Federal. O trabalho, cujo conteúdo parece desatualizado (mas mantido no sítio do Ministério Público Federal) contém idéias similares às acima relatadas e, evidentemente, contrárias ao que se defende no presente estudo. ${ }^{466}$

Voltando à questão concreta sob análise, a liminar foi concedida e mantida pelo Tribunal de Justiça do Estado do Paraná; a sentença foi procedente e em grau de recurso foi mantida a decisão de primeiro grau, sendo que na ementa do julgado encontra-se o seguinte entendimento:

APELAÇÃO CÍVEL. CONSTITUCIONAL. ADMINISTRATIVO. AÇÃO CIVIL
PÚBLICA. TERMO DE PARCERIA FIRMADO ENTRE MUNICÍPIO E
ORGANIZAÇÃO DA SOCIEDADE CIVIL DE INTERESSE PUUBLICO - OSCIP.
TRANSFERÊNCIA, SENÃO TOTAL, QUASE QUE TOTAL, DOS SERVIÇOS
DE SAÚDE PÚBLICA MUNICIPAL À INICIATIVA PRIVADA. IMPOSSIBI-
LIDADE. VEDAÇÃO CONSTITUCIONAL. RECURSO DESPROVIDO.

465 PARANÁ (ESTADO). Vara Cível e Anexos da Comarca de Palotina, Processo n. ${ }^{0}$ 2006.00.00.0544. p.7.

466 Sobre o tema, conferir: <http://pfdc.pgr.mpf.gov.br/grupos-de-trabalho/saude/RelatrioTerceirizaoGTSaude.pdf $>$. Acesso em: 15 nov. 2008. 
1. Os servicos públicos de saúde, nos termos do art. 199, $\& \quad 1^{\circ} .^{\circ}$ da Constituicão Federal, devem ser prestados diretamente pelo Estado, cabendo à iniciativa privada, no que diz respeito ao sistema único de saúde, apenas e tão-somente atividades complementares, mediante contrato de direito público ou convênio.

2. Restando demonstrado nos autos que o Município de Palotina pretende transferir a administração do único hospital público municipal à iniciativa privada, inclusive com o repasse à instituição que for administrá-lo das verbas que lhe cabem no Sistema Único de Saúde, certo ser afirmado, como decidido pelo ilustre magistrado de primeiro grau de jurisdição, que a atividade da instituição privada não será, no que diz respeito à saúde pública, complementar às do município. 467

Repare-se que a decisão colacionada menciona a suposta vedação constitucional à transferência da gestão de uma unidade hospitalar para a iniciativa privada sob o fundamento de que:

(i) apenas atividades de saúde complementares seriam aptas a sofrer tal transferência;

(ii) a gestão do único hospital público municipal pela iniciativa privada desrespeita o caráter complementar de tal participação, a qual, supostamente, deve ser exercida integral e diretamente pela própria Administração Pública municipal.

O entendimento adotado na decisão colacionada vai ao encontro do que grande parte da doutrina entende como sendo o conteúdo da complementaridade da participação privada na saúde. Essa é a opinião, por exemplo, de Maria Sylvia Di Pietro, para quem:

(...) a Constituição, no dispositivo citado $\left[\S 1 .^{\circ}\right.$ do art. 199], permite a participação de instituições privadas 'de forma complementar', o que afasta a possibilidade de que o contrato tenha por objeto o próprio serviço de saúde, como um todo, de tal modo que o particular assuma a gestão de determinado serviço. Não pode, por exemplo, o Poder Público transferir a uma instituição privada toda a administração e execução das atividades de saúde prestadas por um hospital público ou por um centro de saúde; o que pode o Poder Público é contratar instituições privadas para prestar atividades meio, como limpeza, vigilância, contabilidade, ou mesmo determinados serviços técnicoespecializados, como os inerentes aos hemocentros, realização de exames médicos, consultas etc. (...). ${ }^{468}$

467 PARANÁ (ESTADO). Tribunal de Justiça do Estado do Paraná, 5. . Câmara Cível, Apelação n. ${ }^{\circ}$ 426.165-4, Relator: Juiz Convocado Eduardo Sarrão, Diário de Justiça do Estado n. ${ }^{0}$ 7.684, de 22 ago. 2008 (os grifos não constam do original).

468 DI PIETRO, Maria Sylvia. Parcerias na administração pública. 5.ed. São Paulo: Atlas, 2005. p.243 (os grifos não constam do original). 
Na mesma linha, alguns autores chegam a sustentar posições extremas, como se percebe da seguinte passagem:

\begin{abstract}
A simples menção a uma participação complementar permite concluir que a Constituição concedeu primazia à execução do serviço público de saúde por uma rede própria dos entes federativos. Atendimento público através de serviços privados deve consistir em exceção, tolerável apenas se e enquanto não disponibilizado diretamente pelo Poder Público. ${ }^{469}$
\end{abstract}

Tal ordem de idéias afigura-se compatível com o ideal da ala mais radical do movimento sanitário brasileiro do final do século passado, que restou vencido já na VIII Conferência Nacional de Saúde, em 1986, tal qual analisado no Item 3.1.1.2. Portanto, desde a promulgação da Constituição de 1988, esse entendimento merece ser afastado.

Afinal, como demonstrado ao longo deste trabalho, a interpretação da Constituição deve levar em conta a realidade e deve ter como objetivo a máxima efetivação dos direitos fundamentais. Desse modo, considerando que a hipótese de maior eficiência na garantia do direito à saúde pode ser obtida por meio da prestação privada, não se justifica manter tal entendimento. A fixação dos limites entre a prestação estatal direta de serviços de saúde e sua prestação indireta, por meio de parcerias com a iniciativa privada, não pode ser encontrada na expressão geral, abstrata e despida de conteúdo como é a forma complementar da participação privada.

Insistir em tese oposta à ora defendida não apenas gera insegurança jurídica decorrente das ações patrocinadas, sobretudo, pelo Ministério Público -, mas também conduz a uma interpretação equivocada, segundo a qual a participação privada no sistema público de saúde deve ser tratada como transitória e improvisada, o que a tornaria instável e precária. Tais características dos vínculos firmados entre a Administração Pública e os prestadores privados constituem um dos graves problemas que afrontam os serviços públicos de saúde no Brasil.

A participação privada nos serviços de saúde, como demonstra a experiência histórica e internacional é indispensável, mas tanto mais se apresenta útil quanto mais estáveis e seguros os vínculos que a disciplinam. Apenas um Direito Administrativo apto a lidar com a complexidade atual do setor de saúde possibilitará a existência de uma Administração Pública forte e um Estado eficiente na garantia dos direitos fundamentais - especificamente o direito à saúde.

469 WEICHERT, Marlon Alberto. Saúde e federação na constituição brasileira. Rio de Janeiro: Lumen Júris, 2004. p.199 (os grifos não constam do original). 
Em apoio ao entendimento ora apresentado, parece razoável sustentar que a previsão constitucional constante do parágrafo primeiro do artigo 199, em que pese tratar da assistência à saúde, expressa a possibilidade de participação complementar da iniciativa privada em relação a todo o sistema público de saúde. Como já analisado no Item 3.2.2, o sistema público de saúde brasileiro tem como atribuições tanto a prestação de serviços públicos de saúde quanto o desenvolvimento de uma série de outras atividades, denominadas ações de saúde - relacionadas no artigo 200 da Constituição Federal e nos artigos $5 .^{\circ}$ e $6 .^{\circ}$ da Lei n. ${ }^{\circ} 8.080 / 90 .{ }^{470}$ Nessa perspectiva, pode-se concluir que a assistência prestada por meio da iniciativa privada deve complementar as atividades de competência do SUS, as quais não podem ser integralmente executadas por terceiros. Tal entendimento vai ao encontro do que dispõe ao artigo 197, que não faz qualquer balizamento à possibilidade de participação privada na prestação de serviços. Assim, quando a Constituição Federal menciona a complementaridade da participação privada no setor de saúde, ela determina que a participação da iniciativa privada deve ser complementar ao SUS, incluídas todas as atividades voltadas à prevenção de doenças e à promoção, proteção e recuperação da saúde, dentre as quais aquelas de controle e fiscalização. ${ }^{471}$

Nesse viés, em consonância com tudo o que foi consignado no Item 2.3, acerca das transformações da Administração Pública, o Supremo Tribunal Federal, em voto do então Ministro Sepúlveda Pertence, referindo-se ao artigo 197 da Constituição Federal foi categórico:

(...) Não apenas não há, no dever estatal para com a saúde, obrigação de prestação estatal direta, mas, ao contrário, a expressa previsão de sua prestação mediante colaboração de particulares, embora sujeitos à legislação, à regulamentação, à fiscalização e ao controle estatais. 472

470 Sobre o tema, conferir Item 3.2.

471 Com esse raciocínio, é importante destacar, não se está defendendo a participação privada em todos os serviços de saúde, mas a ausência de vedação constitucional para tanto, de modo que cada ente federativo, no exercício de sua competência para a organização administrativa dos serviços públicos, possa definir o melhor modelo, dentre aqueles legalmente admitidos, para a prestação dos serviços de saúde a todos aqueles que dele necessitarem. A Constituição brasileira não definiu uma forma privilegiada (pública ou privada) de prestação dos serviços públicos de saúde e a sua interpretação com base na efetivação dos direitos fundamentais corrobora tal interpretação.

472 BRASIL. Supremo Tribunal Federal. Ação Direta de Inconstitucionalidade n. ${ }^{\circ}$ 1923-5/DF, Tribunal Pleno, Relator Originário Min. Ilmar Galvão, Relator Min. Eros Grau, Diário de Justiça da União, 21 set. 2007. 
No mesmo sentido, referindo-se ao artigo 199 da Constituição Federal, tem razão Paulo Modesto, ao afirmar que:

\begin{abstract}
A declaração do direito à saúde como direito do cidadão e dever do Estado obriga a que o Estado garanta o direito à saúde e não que ofereça diretamente e de forma executiva o atendimento a todos os brasileiros. A palavra 'saúde', constante do art. 199 da Constituição, refere a um bem jurídico, a uma utilidade fruível pelo administrado, que deve ser assegurada pelo Estado, independente deste fazê-lo direta ou indiretamente, mediante emprego do aparato público ou da utilização de terceiros. ${ }^{473}$
\end{abstract}

No contexto brasileiro, conforme já assinalado, a assistência à saúde assumida pelo Estado como sua responsabilidade constitui o serviço público de saúde a ser prestado às pessoas que dele necessitarem, por meio de entidades públicas ou privadas, de acordo com o regime jurídico mais adequado à garantia de efetivação do direito à saúde, independente da natureza jurídica da entidade prestadora.

Mais do que manter uma discussão surda e um argumento vazio, há que se indagar, investigar e discutir as formas de articulação possíveis entre o Estado e outros setores para que o direito à saúde seja concretamente efetivado. Afinal, a interpretação do Direito por mera repetição de idéias não satisfaz aos fins que busca o Estado contemporâneo. Nesse sentido, precisas foram as palavras do Ministro do STF Gilmar Mendes em sua manifestação na ADIN 1.923, que negou o pedido cautelar de suspensão da eficácia de diversos dispositivos da Lei n. ${ }^{\circ}$ 9.637/98, que disciplina a celebração de contratos de gestão com entidades privadas qualificadas como organizações sociais:

O fato é que o Direito Administrativo tem passado por câmbios substanciais e a mudança de paradigmas não tem sido compreendida por muitas pessoas. Hoje, não há mais como compreender esse ramo do Direito desde a perspectiva de uma rígida dicotomia entre o público e o privado. O Estado tem se valido cada vez mais de mecanismos de gestão inovadores, muitas vezes baseados em princípios próprios do direito privado. ${ }^{474}$

473 MODESTO, Paulo. Convênio entre entidades públicas executado por fundação de apoio. Serviço de saúde. Conceito de serviço público e serviço de relevância pública na Constituição de 1988. Forma da prestação de contas das entidades de cooperação após a emenda constitucional n. ${ }^{\circ}$ 19/98. Revista Diálogo Jurídico, Salvador, n.11, p.8, fev. 2002. Disponível em: <http://www.direitopublico.com.br>. Acesso em: 28 mar. 2007.

474 BRASIL. Supremo Tribunal Federal, Ação Direta de Inconstitucionalidade n. ${ }^{\circ} 1923$ - DF, Relator Ministro Carlos Brito, Diário de Justiça, 01 ago. 2007. 
Em face da jusfundamentalidade do direito à saúde, a aplicação de tal entendimento torna-se ainda mais evidente. Alguns tribunais pátrios, como o Tribunal de Justiça do Estado de São Paulo, sinalizam tal compreensão, segundo a qual no centro da esfera hermenêutica deve constar o direito fundamental à saúde, cuja garantia não pode ficar à mercê de entraves formais despidos de utilidade. Eis o que consignou o referido tribunal em recente decisão:

\begin{abstract}
Sempre com a devida vênia, não mais se mostra possível a interpretação de norma constitucional que atribua ao Estado todos os deveres, impedindo-o de contar com auxílio, remunerado ou não, de entidades privadas para a consecução do bem comum. No caso concreto, ao munícipe doente não interessa saber se o médico que o atende é servidor público ou não. O que lhe interessa é que haja médico para atendê-lo e medicamento para curar sua doença ou ao menos minorar seu sofrimento.

Por isso não vislumbro clara e manifesta violação, ao menos no âmbito restrito deste recurso de agravo, ao artigo 199 da Constituição Federal que tornaria viável a suspensão da parceira. E, em tese, se mostra possível que alguns programas de saúde, voltados para temas mais sensíveis sejam transferidos a terceiros que tenham a capacidade tecnológica e gerencial de melhor atender à população pelo custo mais barato que o Estado poderia fazer. ${ }^{475}$
\end{abstract}

Nessa ordem de idéias, entende-se plenamente possível sustentar que da forma complementar de participação privada nos serviços públicos de saúde, prevista no parágrafo primeiro do texto constitucional, não é possível extrair qualquer limitação à esfera de atuação estatal direta e à esfera passivel de atuação privada contratada ou conveniada. Trata a previsão apenas da possibilidade de prestação tanto de uma forma (direta) quanto de outra (indireta).

A análise promovida nos projetos apresentados na Assembléia Constituinte de 1987-1988476 demonstra a utilização de expressões como colaboração, participação supletiva e participação complementar, cujo significado lingüístico é muito próximo. Tal variedade de expressões também pode ser percebida na análise do texto hoje vigente nas Constituições dos Estados-membros e nas Leis Orgânicas municipais. Ao exercer sua autonomia políticoadministrativa, prevista nos artigos 18, 25 e 29 da Constituição Federal, na disciplina de sua organização interna, Estados-membros e municípios utilizam variadas expressões para definir a participação privada nos serviços públicos de saúde:

475 SÃO PAULO (ESTADO). Tribunal de Justiça do Estado de São Paulo. Agravo de Instrumento n. ${ }^{\circ}$ 627.715-5/3-00 - SP. Relator: Des. Lineu Peinado. 07 de agosto de 2007. Disponível em: $<$ http://www.tj.sp.gov.br>. Acesso em: 20 out. 2008 (os grifos não constam do original).

476 Sobre o tema, conferir Item 3.1.1.2. 
(i) a própria forma complementar, como faz grande parte dos Estados-membros, como Bahia, Minas Gerais, Paraná, Pernambuco, Rio de Janeiro, Rio Grande do Sul e Santa Catarina e alguns municípios como o Recife; ${ }^{477}$

(ii) a forma suplementar, tal qual o caso, por exemplo, do Município de Curitiba;478

(iii) a forma supletiva, conforme consta, ilustrativamente, nas leis orgânicas dos municípios do Rio de Janeiro, Salvador e São Paulo;479

Além desses exemplos, há casos, como do Estado de São Paulo em que não se encontra qualquer expressão para qualificar a forma de participação privada, sendo prevista apenas a participação privada nos serviços de saúde. ${ }^{480}$

477 Constituição do Estado da Bahia: Art. 234, I. Constituição do Estado de Minas Gerais: Art. 188, V. Constituição do Estado do Paraná: Art. 171. Constituição do Estado de Pernambuco: Art. 160 e art. 164. Constituição do Estado do Rio de Janeiro: Art. 291. Constituição do Estado do Rio Grande do Sul: Art. 244, § 2. ${ }^{\circ}$. Constituição do Estado de Santa Catarina: Art. 156. Lei Orgânica do Município do Recife: Art. 147, II.

478 Lei Orgânica do Município de Curitiba: Art. 160. As instituições privadas poderão participar, de forma suplementar, do Sistema Único de Saúde, mediante contrato de direito público ou convênio, tendo preferência as entidades filantrópicas e as sem fins lucrativos, podendo a lei conceder isenções, em especial, as que prestem serviços de atendimento aos portadores de deficiência (os grifos não constam do original).

479 Lei Orgânica do Município do Rio de Janeiro: Art. 353 - Os serviços de saúde do Município são vinculados ao Sistema Único de Saúde, instituído pela legislação federal e mantido com recursos da União, do Estado e do Município. (...) $\S 2 .^{\circ}$ - As instituições privadas poderão participar do Sistema Único de Saúde do Município supletivamente, apenas em caráter eventual, obedecendo às diretrizes deste, mediante contrato de direito público, com parecer do Conselho Municipal de Saúde, observadas as seguintes condições: (...). Lei Orgânica do Município de Salvador: Art. 216. As instituições privadas poderão participar de forma supletiva do SUS segundo diretrizes, mediante contrato de direito público ou convênios, tendo preferência as entidades filantrópicas de utilidade pública e sem fins lucrativos. Lei Orgânica do Município de São Paulo: Art. 215 - As ações e serviços de saúde são de relevância pública, cabendo ao Município dispor sobre sua regulamentação, fiscalização e controle. $\S 1 .^{\circ}$ - As ações e serviços de saúde serão executadas preferencialmente de forma direta pelo poder público e supletivamente através de terceiros, assegurando o estabelecido no art. 199, da Constituição da República (os grifos não constam dos originais).

480 Constituição do Estado de São Paulo: Artigo 220 - As ações e os serviços de saúde são de relevância pública, cabendo ao Poder Público dispor, nos termos da lei, sobre sua regulamentação, fiscalização e controle. (...) $\S 44^{\circ}$ - A participação do setor privado no sistema único de saúde efetivar-se-á segundo suas diretrizes, mediante convênio ou contrato de direito público, tendo preferência as entidades filantrópicas e as sem fins lucrativos (os grifos não constam do original). Essa parece ter sido a opção adotada também pela Lei n. ${ }^{\circ}$ 8.212, de 24 de julho de 1991, conhecida como Lei Orgânica da Seguridade Social, que assim determina: Art. $2 .^{\circ}$ A Saúde é direito de todos e dever do Estado, garantido mediante políticas sociais e econômicas que visem à redução do risco de doença e de outros agravos e ao acesso universal e igualitário às ações e serviços para sua promoção, proteção e recuperação. Parágrafo único. As atividades de saúde são de relevância pública e sua organização obedecerá aos seguintes princípios e diretrizes: (...) f) participação da iniciativa privada na assistência à saúde, obedecidos os preceitos constitucionais (os grifos não constam do original). 
Nesse sentido, a complementaridade em si e todas as expressões utilizadas nas Constituições dos Estados-membros e nas Leis Orgânicas Municipais padecem de conteúdo próprio quando aplicadas à participação privada nos serviços públicos de saúde, pois não há delimitação também no objeto de referência - os serviços públicos de saúde prestados pelo Estado. ${ }^{481}$ Com esse raciocínio, pode-se perceber que a forma complementar de participação privada na assistência à saúde não configura, em si, limite à possibilidade de prestação de serviços públicos de saúde por particulares. ${ }^{482}$ Não é possível, sequer, extrair interpretação segundo a qual a participação de entidades de natureza pública é preferencial. ${ }^{483}$

Outro importante referencial para a compreensão do relacionamento entre a iniciativa privada e o sistema público pode ser encontrado em estudo da Organização para Cooperação e Desenvolvimento Econômico (OECD). ${ }^{484}$ Tal publicação propõe uma taxonomia acerca dos modelos de convivência entre o provimento estatal de serviços de saúde e o provimento de tais serviços por meio de seguros privados. ${ }^{485}$ A categorização apresentada, que restou acolhida pela doutrina acerca do tema, 486 não se refere especificamente à participação privada no sistema público de saúde, mesmo porque, em todos os Estados desenvolvidos, tal participação não encontra delimitação fixada na Constituição ou em lei. De qualquer

481 A questão foi tratada no Item anterior.

482 Nesse sentido, pode-se concordar com Sergio Pinto Martins, que, ao tratar da terceirização no Direito do Trabalho, assim consignou: "A complementariedade significa a ajuda do terceiro para aperfeiçoar determinada situação que o terceirizador não tem condições ou não quer fazer." (MARTINS, Sergio Pinto. A terceirização e o direito do trabalho. 8.ed. São Paulo: Atlas, 2007. p.23).

483 Como é o caso da participação das entidades filantrópicas e das sem fins lucrativos, adiante analisada. Em sentido contrário, defendendo a participação preferencial do poder público na prestação dos serviços, conferir: MARQUES NETO, Floriano de Azevedo. Público e privado no setor de saúde. Revista de Direito Público da Economia, Belo Horizonte, ano 3, n.9, p.129, jan./mar. 2003.

484 A OECD é uma organização não-governamental internacional, criada em 1961, resultado da transformação da Organização para a Cooperação Econômica Européia (OEEC), instituída em 1947. Atualmente a OECD conta com a participação de trinta países-membros e tem como foco de atuação oferecer apoio a governos com base em estudos, pesquisas e obtenção de informações nos diversos campos de interesse social e econômico. Sobre a entidade, conferir: http://www.oecd.org. Acesso em 17.10.2008.

485 OECD. Proposal for a Taxonomy of Health Insurance. Paris: OECD, 2004. 21p.

486 Nesse sentido, a proposta ora analisada pode ser encontrada, dentre outros, em: COLOMBO, F.; TAPAY, N. Private Health Insurance in OECD Countries: The benefits and Costs for Individuals and Health Systems. OECD Health Working Papers, n.15, OECD Publishing, 2004; CECHIN, José. A história e os desafios da saúde suplementar: 10 anos de regulação. São Paulo: Saraiva, 2008. p.59-60; OCKÉ-REIS, Carlos Octávio. Sistemas comparados de saúde: uma análise preliminar. Mimeo. 14p.; SANTOS, Isabela Soares; UGÁ, Maria Alicia D.; PORTO, Silvia Marta. O mix público-privado no sistema de saúde brasileiro: financiamento, oferta e utilização de serviços de saúde. Ciência e Saúde Coletiva, n.13, p.1431-1440, 2008. 
modo, o modelo é útil para a compreensão da participação privada complementar dentro do próprio sistema público de saúde brasileiro.

Segundo a proposta da $\mathrm{OECD}, 487$ a convivência entre a prestação pública e os seguros privados de saúde pode ocorrer das seguintes formas, com base nas funções desempenhadas pelos seguros privados:

(i) Forma primária: modelo em que a única opção disponível para determinadas pessoas terem acesso aos serviços de saúde são os seguros privados; tal hipótese pode ocorrer de duas maneiras:

- primária substitutiva: quando existe atendimento público, mas o indivíduo opta pelo seguro privado (abrindo mão da possibilidade de acesso aos serviços ofertados no âmbito público); exemplo: Alemanha.

- primária principal: quando não existe cobertura pública ou a cobertura não alcança todos os grupos sociais; exemplo: Estados Unidos.

(ii) Forma Complementar: quando, no âmbito público, a cobertura assistencial não oferece pagamento integral pelos serviços de saúde, de modo que as pessoas têm a opção de contratar seguros privados para pagar a diferença (co-pagamento) pelos serviços que necessitarem; exemplo: França.

(iii) Forma Duplicada: quando os seguros privados oferecem serviços também prestados no âmbito público, de modo que as pessoas têm opção por escolher uma ou outra forma de obtenção dos serviços de saúde; exemplo: Brasil.

(iv) Forma Suplementar: quando os serviços prestados no âmbito público são delimitados e os seguros privados são contratados para oferecer serviços não disponibilizados no âmbito público; tais serviços variam conforme o Estado e podem incluir serviços de reabilitação, tratamento dentário e medicamentos, ou mesmo hospedaria de categoria diversa; em alguns casos, o sistema de seguros privados pode oferecer os mesmos serviços daqueles ofertados no sistema público, o que o caracteriza como uma forma duplicada; exemplos: Inglaterra, Portugal e Espanha. ${ }^{488}$

487 OECD. Proposal for a Taxonomy of Health Insurance. Paris: OECD, 2004. p.18.

488 É importante notar que, como qualquer classificação, na maioria dos sistemas de saúde ocorre certo grau de interseção entre os modelos propostos, com a convivência em maior ou menor grau, de mais de uma forma de participação dos seguros privados. 
Para os objetivos do presente estudo, impende compreender que tanto a complementação quanto a suplementação possuem como referencial a prestação de serviços de saúde não ofertados no âmbito público. Ainda assim, ao menos no que se refere à suplementação, segundo a taxonomia da OECD, admite-se a possibilidade de que determinados serviços sejam prestados em duplicidade. No caso brasileiro, considerando que o sistema público de saúde propõe-se a prestar serviços em caráter universal e gratuito, sem delimitação de pessoas aptas a receber os serviços e sem delimitação do rol de serviços a serem prestados, a complementaridade - bem como as expressões adotadas pelas Constituições dos Estadosmembros e Leis Orgânicas Municipais - pode apenas ser compreendida como a possibilidade de prestação de serviços de modo duplicado, sendo que a expressão complementaridade deve ser entendida como a possibilidade de convivência entre a prestação pública e privada de serviços públicos de saúde. ${ }^{489}$

Fixadas tais considerações, pode-se perceber que o permissivo constitucional, traduzido nos artigos acima mencionados, não se refere à hipótese de incentivo estatal à prestação privada de serviços de saúde, mas de serviços públicos de saúde prestados por particulares. Essa ordem de idéias leva ao reconhecimento de que se trata da possibilidade de prestação de serviços públicos de saúde por particulares, a ser instrumentalizada por meio de ajustes celebrados com a iniciativa privada, os quais podem ter como objeto:

(i) um serviço ou um grupo de serviços internos relacionados à atividade-fim de uma entidade ou órgão público prestador de serviços de saúde;

(ii) a prestação de serviços por uma unidade privada dotada de infra-estrutura apta ao desenvolvimento das atividades ajustadas; ou

(iii) toda a gestão de uma unidade pública de saúde - incluindo, obviamente, atividades-fim, atividades-meio e atividades acessórias. ${ }^{490}$

489 Mesmo porque não consta do texto constitucional a preferência por esta ou aquela modalidade de prestação (direta ou indireta), como acontece com as entidades filantrópicas e sem fins lucrativos, em relação as quais tal preferência foi expressamente adotada em sede constitucional.

490 Nos termos da NOB 01/96, aprovada pela Portaria GM/MS n. ${ }^{\circ}$ 2.203/96, são atribuídos significados diversos para os termos gerência e gestão. Enquanto a gerência é conceituada como sendo a administração de uma unidade ou órgão de saúde, (ambulatório, hospital, instituto, fundação, etc.), que se caracteriza como prestador de serviços ao Sistema, a gestão é a atividade e a responsabilidade de dirigir um sistema de saúde (municipal, estadual ou nacional), mediante o exercício de funções de coordenação, articulação, negociação, planejamento, acompanhamento, controle, avaliação e auditoria. Nesse sentido, o ato normativo em referência qualifica como gestores do SUS os Secretários Municipais e Estaduais de Saúde e o Ministro da Saúde, que representam, respectivamente, os governos municipais, 
Tais hipóteses são admitidas pelo texto constitucional, que, além da referência à forma complementar de participação privada, estabelece a preferência das entidades filantrópicas e das sem fins lucrativos e menciona expressamente dois modelos de ajuste aptos a instrumentalizar a referida participação.

\subsubsection{Complementaridade na Regulamentação do SUS}

Como noção constitucional despida de conteúdo próprio e sem um referencial definido, a eventual (de)limitação da participação privada na prestação de serviços públicos de saúde deve ser buscada na regulamentação legal dos serviços de saúde, que se encontra consubstanciada, sobretudo, na Lei n. ${ }^{\circ}$ 8.080/90 - Lei Orgânica da Saúde.

$\mathrm{Na}$ Mensagem encaminhada pelo Poder Executivo, autor do projeto da lei referida, consta que:

Na lógica do SUS, é estabelecida ainda uma nova forma de relacionamento com os subsetores filantrópico e privado, baseado em normas éticas e na existência de qualidade da prestação de serviços. Não se contrapõem, aqui, os subsetores público e privado, mas é definida uma clara regra de convivência, cuja essência é a garantia da disponibilidade de serviços, com as qualificações requeridas, para o franco acesso dos usuários. 491

Entretanto, os dispositivos da Lei Orgânica da Saúde que tratam da delimitação da participação privada complementar, ao contrário do que menciona a Mensagem acima colacionada, não são precisos na definição dos limites, dos modelos de ajuste e dos procedimentos a serem seguidos para a mencionada convivência entre os prestadores públicos e os prestadores privados - ambos integrantes do sistema único de saúde.

estaduais e federal. Não obstante, por se tratar de termos consagrados na teoria jurídica, será adotado no presente trabalho o termo gestão, seguido da respectiva qualificação, para se referir tanto à administração de uma unidade (o que será mais freqüente) quanto para a gestão de todo o sistema público de saúde. De qualquer modo, importa ter claro que, nos termos do artigo 198, inciso I, da Constituição Federal, a gestão do sistema de saúde em cada um dos níveis federativos deve ser única e, evidentemente, realizada pelo Poder Público. Tal dispositivo constitucional não determina, entretanto, que a execução dos serviços seja desempenhada pela iniciativa privada. Nessa perspectiva, é pertinente a observação de Gilles Guglielmi, para quem: "Os órgãos encarregados da gestão são sempre aqueles de uma pessoa pública, pois o serviço público é uma atividade de interesse geral, garantido ou assumido por uma pessoa pública." (GUGLIELMI, Gilles. Introduction au droit des services publics. Paris: EJA, 1994. p.69).

491 Mensagem do Poder Executivo n. ${ }^{\circ}$ 360/89. 


\subsubsection{A Lei n. ${ }^{\circ}$ 8.080/90 e a insuficiência da cobertura assistencial}

$\mathrm{Na}$ disciplina legal do SUS, a previsão de participação da iniciativa privada complementar encontra-se consignada no parágrafo segundo do artigo $4 .^{\circ}$ da Lei n. ${ }^{\circ}$ 8.080/90, que meramente repete a previsão constitucional do caráter complementar da participação privada no SUS. 492

$\mathrm{O}$ artigo $7 .^{\circ}$ da Lei em referência também trata do tema e induz certa confusão ao mencionar serviços públicos de saúde e serviços contratados e conveniados, como se a segunda categoria não fosse também qualificada como serviço público - assumido pelo Estado como sua responsabilidade e executado por terceiros a ele vinculados. ${ }^{493}$ Tal tratamento legal pode conduzir a equívocos, já que no gênero serviços públicos de saúde podem ser encontrados tanto serviços prestados diretamente pelo Estado quanto serviços contratados e conveniados. 494

Seguindo o que dispõe a Lei Orgânica da Saúde, importante inovação, não constante do texto constitucional, é encontrada em seu artigo 24, que define ser a participação privada vinculada aos casos em que houver insuficiência na disponibilidade para a prestação de serviços por órgãos e entidades públicos. Eis o que prevê o referido artigo:

Art. 24. Quando as suas disponibilidades forem insuficientes para garantir a cobertura assistencial à população de uma determinada área, o Sistema Único de Saúde (SUS) poderá recorrer aos serviços ofertados pela iniciativa privada.

Nessa perspectiva, Floriano de Azevedo Marques Neto sustenta que a participação privada complementar na prestação de serviços de saúde deve ser entendida com base na idéia de subsidiariedade ao inverso do modo pelo qual costumeiramente se invoca referido

492 Art. 4. ${ }^{\circ} \mathrm{O}$ conjunto de ações e serviços de saúde, prestados por órgãos e instituições públicas federais, estaduais e municipais, da Administração direta e indireta e das fundações mantidas pelo Poder Público, constitui o Sistema Único de Saúde (SUS). (...) § 2. ${ }^{\circ}$ A iniciativa privada poderá participar do Sistema Único de Saúde (SUS), em caráter complementar (os grifos não constam do original).

493 Art. 7. $^{\circ}$ As ações e serviços públicos de saúde e os serviços privados contratados ou conveniados que integram o Sistema Único de Saúde (SUS), são desenvolvidos de acordo com as diretrizes previstas no art. 198 da Constituição Federal, obedecendo ainda aos seguintes princípios: (...) - (os grifos não constam do original).

494 Tal entendimento, já sustentado no Item 3.2, resta evidenciado no dispositivo seguinte, o artigo $8 .^{\circ}$ da Lei n. ${ }^{\circ} 8.080 / 90$, que insere os serviços prestados pela iniciativa privada na própria organização do subsistema público de saúde. Eis o que dispõe referido dispositivo: Art. 8. ${ }^{\circ}$ As ações e serviços de saúde, executados pelo Sistema Único de Saúde (SUS), seja diretamente ou mediante participação complementar da iniciativa privada, serão organizados de forma regionalizada e hierarquizada em níveis de complexidade crescente. 
princípio, já que a iniciativa privada, segundo tal entendimento, apenas deve prestar serviços públicos de saúde nos casos de deficiência do Estado em fazê-lo diretamente - e não o contrário. ${ }^{495}$ Nas palavras do autor:

Tanto a Constituição quanto a lei estabelecem de que forma tal participação se
dará. Ela se relaciona à idéia de insuficiência da rede pública de saúde, ou seja, à
idéia de subsidiariedade da rede privada em relação à rede pública, servindo
para suprir deficiências ou insuficiência da última. Assim é que o artigo 199,
\$ 1.
privada Constituição estabelece expressamente que a participação da iniciativa
privema Único de Saúde se dará "de forma complementar.

A rigor, a idéia defendida pelo autor, nos termos do que foi consignado acima, não decorre diretamente da Constituição, mas do dispositivo legal acima transcrito. A complementaridade, tal qual prevista na Constituição Federal, não permite tal conclusão, a não ser a partir de uma interpretação também inversa, tendo como ponto de partida a legislação infraconstitucional (o que evidentemente é inadmissível).

De qualquer forma, o entendimento de Floriano de Azevedo Marques Neto reflete o ditame legal acima transcrito e conduz a uma conclusão pertinente na medida em que na saúde, ao contrário do que em outros setores econômicos, não se aplica o princípio da subsidiariedade no sentido de que cumpre ao Estado apenas intervir nos casos em que a própria sociedade não possui condições de por si mesma suprir suas necessidades de tais serviços. ${ }^{497}$ Pelo contrário: como consignado no Item 3.1.2, é dever do Estado garantir o direito à saúde, o que inclui a prestação de serviços voltados à sua promoção, proteção e recuperação a todas as pessoas que deles necessitarem.

495 Em trabalho sobre o tema, José Alfredo Baracho aponta as duas formas de compreensão da subsidiariedade: (i) a idéia de algo que é secundário; e (ii) a idéia de algo que é supletivo - o que pode ser entendido como complementar e suplementar (BARACHO, José Alfredo de Oliveira. O princípio de subsidiariedade: conceito e evolução. Rio de Janeiro: Forense, 1997. p.24).

496 MARQUES NETO, Floriano de Azevedo. Público e privado no setor de saúde. Revista de Direito Público da Economia, Belo Horizonte, ano 3, n.9, p.112, jan./mar. 2003 (os grifos não constam do original).

497 O princípio da subsidiariedade foi expresso, ainda que de maneira implícita, pelo Papa Leão XIII, na Encíclica Rerum Novarum (1891), e mais tarde pelo Papa Pio XI na Encíclica Quadragésimo Anno (1931). Seu fundamento reside na anterioridade natural das pessoas e comunidades sobre o Estado, de forma que este deve, de um lado, respeitar a autonomia dos indivíduos e corpos intermediários, e de outro, auxiliá-los na consecução de seus fins. De um lado, esse princípio indica que uma entidade superior não deve atender ao interesse de uma coletividade inferior sempre que esta puder supri-lo de maneira eficaz; de outro, aponta para a atuação da entidade superior em todas as questões que a coletividade menor não tenha condições de resolver. $\mathrm{Na}$ ordem econômica brasileira, na qual vige o princípio da livre iniciativa, previsto pelo artigo 170 do texto constitucional, possui sua aplicação balizada pelos critérios constantes do artigo 173 da Constituição Federal, analisados no Item 3.2.1. 
Entretanto, duas observações devem ser referidas para tornar possível a aplicabilidade da participação privada subsidiária nos serviços públicos de saúde. Afinal, como consignou Gaspar Ariño-Ortiz, o princípio da subsidiariedade não possui valor e aplicabilidade igual em todos os tempos e em todos os Estados, de modo que sua concretização deve levar em conta a realidade histórica, social e cultural de cada país. ${ }^{498}$

A primeira observação reside na dificuldade de se definir as hipóteses em que se afigura presente a insuficiência da prestação estatal direta dos serviços de saúde (e a conseqüente possibilidade de prestação privada). Inicialmente, é possível argumentar que, se os serviços públicos de saúde podem ser prestados pelo Estado diretamente ou por terceiros - tal qual prevê o artigo 197 da Constituição Federal e o próprio parágrafo $1 .^{\circ}$ do artigo 199 - as disponibilidades apenas serão suficientes se a própria oferta de serviços públicos de saúde direta ou indiretamente (pela iniciativa privada) assim o forem. Além disso, como assinalado na Introdução deste trabalho, a cobertura assistencial universal, integral e gratuita à saúde jamais será suficiente. ${ }^{499}$ Isso porque, conforme já mencionado:

(i) o Brasil não investe o volume de recursos suficiente para sustentar um sistema público, gratuito e universal; 500

(ii) não há delimitação de um grupo de pessoas a serem atendidas pelo sistema público; 501

(iii) não há delimitação de um rol de serviços a serem disponibilizados no âmbito do sistema público e gratuito; $502 \mathrm{e}$

(iv) o próprio conceito de saúde adotado é amplo e aproxima-se de metas subjetivas e intangíveis como qualidade de vida e felicidade.

498 ARIÑO ORTIZ, Gaspar. Princípios de Derecho Público Económico. Granada: Comares, 1999. p.111 e segs.

499 Ainda que em alguns locais e momentos, como, por exemplo, na década de 1970, seja possível verificar a disponibilidade de leitos hospitalares superior à demanda, decorrente, sobretudo, de uma inadequada política pública e do privilégio à definição dos serviços ofertados pelos próprios prestadores.

500 Além do que, como mencionado no Item 3.2, a interpretação de tais princípios, sem alguns balizamentos, torna impossível, em qualquer hipótese, a suficiência de recursos.

501 Aquelas que não têm condições de obter os serviços de saúde no mercado.

502 E quando determinados atos normativos promovem tal delimitação, os mesmos tendem a ser ignorados pelo Poder Judiciário, como no caso do fornecimento gratuito de medicamentos, analisado no Item 3.2.2. 
Nesse contexto, a soma dos fatores mencionados - os quais decorrem da interpretação distorcida do ordenamento constitucional da saúde, aliada à característica dos serviços de saúde, nos quais a oferta induz a demanda ${ }^{503}$ e as necessidades são criadas pelas novas tecnologias $^{504}$ - conduz à impossibilidade permanente de oferecimento de uma cobertura assistencial suficiente. É importante lembrar que mesmo os países desenvolvidos, como já assinalado nos Capítulos 2 e 3, possuem disciplina consolidada e respeitada, que delimita o pacote de serviços prestados no âmbito público, admitem cobrança de parcela dos serviços e investem mais do que o Brasil em seus sistemas de saúde. 505

Em tais contextos, é possível a definição de conteúdos para conceitos como complementaridade, suplementaridade e supletividade com base na insuficiência de meios concretos para sua prestação. De outro lado, em um cenário no qual a prestação de serviços de saúde tende a ser infinita, a insuficiência da cobertura assistencial em determinada área tende a ser permanente. ${ }^{506}$ Assim, tal critério perde em grande parte sua utilidade. ${ }^{507}$

503 Afinal, como resume Susete Barboza França: "A única maneira do paciente saber se precisa ou não ir ao médico, é indo ao médico. Ao procurá-lo, ele também não tem qualquer liberdade de escolha sobre que tipo de serviços deve ser realizados e com que freqüência. É o médico quem decide, quem controla e determina todo o processo de cura, como também as atividades dos demais envolvidos, como enfermeiras e outros profissionais de saúde, que seguem suas instruções. O consumidor não pode atuar racionalmente neste mercado, já que ele não tem os conhecimentos técnicos necessários sobre a qualidade e o preço do serviço, que lhe permitiria selecionar entre as diversas alternativas. Ele aceita transferir ao médico o poder de escolha dos bens e serviços a serem consumidos. (...) Outra característica desse mercado e a associação estreita entre procura e oferta - uma parte significativa da procura pode ser induzida pela oferta. Assim, quanto maior a disponibilidade de recursos, como médicos e leitos, maior a demanda por serviços." (FRANÇA, Susete Barboza. A presença do estado no setor saúde no Brasil. Revista do Serviço Público, ano 49, n.3, p.86, jul./set. 1998).

504 POMPEU, João Cláudio Basso. A situação contratual da rede hospitalar privada vinculada ao SUS: alguns elementos para reflexão. 2004. 183p. Dissertação (Mestrado em Gestão de Sistemas e Serviços de Saúde) - Escola Nacional de Saúde Pública da Fundação Oswaldo Cruz, Brasília, 2004. p.30.

505 O tema foi analisado no Item 2.4 e retomado no Item 3.1.

506 Em alguns casos, pode ser caracterizada atualmente a suficiência da cobertura assistencial dos serviços públicos de saúde, como na hipótese (i) de um hospital público ter disponibilidade constante de estrutura física e humana para atendimento a todos que necessitarem; ou (ii) da existência de numerosas entidades privadas credenciadas para a prestação de determinados serviços, os quais supostamente possuem oferta maior que a demanda.

507 Afinal, no Brasil, não se verifica possível a definição de limites para a complementação de algo não apenas indefinido, mas supostamente (em termos jurídico-positivos) completo, pois universal (compreendido como ilimitado) e igualitário (compreendido como a impossibilidade de direcionamento do atendimento a determinados públicos). 
Dessa forma, e essa é a segunda observação a propósito da questão, outro balizamento deve ser levado em conta para a aplicação do princípio da subsidiariedade da participação privada nos serviços públicos de saúde: a eficiência na prestação dos serviços.

Nos termos do que se mencionou no Item 2.3, a eficiência é inerente ao próprio princípio da legalidade, sendo que em todos os casos nos quais haja justificativa constitucional que demonstre a maior eficiência quando determinado serviço de saúde seja prestado pela iniciativa privada vinculada ao Estado, é admitida sua participação. As transformações da Administração Pública, a exemplo de outros Estados, e a necessidade de mecanismos adequados para o desempenho de cada atividade estatal - à luz do permissivo constitucional constante dos artigos 197 e $199, \S 1 .^{\circ}$ - levam a essa conclusão.

Se o Estado brasileiro, em qualquer dos níveis federativos, objetiva ampliar a cobertura assistencial, diminuir os custos, melhorar a qualidade do atendimento, possibilitar maior controle sobre os serviços - é-lhe facultada, justificadamente, a opção pela participação privada complementar - a qual deve ser instrumentalizada pelo modelo de vínculo mais adequado ao respectivo caso concreto.

\subsubsection{Regulamentação infralegal do SUS e a noção de capacidade instalada}

Nos termos do inciso XIV, do artigo 16 da Lei Orgânica da Saúde, a direção nacional do SUS possui competência para elaborar normas para regular as relações entre o Sistema Único de Saúde (SUS) e os serviços privados contratados de assistência à saúde. ${ }^{508}$ Acontece que, enquanto a Constituição determina que a participação da iniciativa privada no SUS deve ocorrer de forma complementar e a Lei Orgânica da Saúde determina que o SUS poderá recorrer aos serviços da iniciativa privada quando as disponibilidades da rede pública forem insuficientes para garantir a cobertura assistencial, a normatização infralegal do sistema público de saúde não raro traz outras inovações que contrariam o texto constitucional e seguem uma linha de estatização dos serviços de saúde - não prevista na Constituição e tampouco na lei. 509

508 A questão da competência para disciplina da participação privada nos serviços públicos de saúde será analisada adiante, no Item 4.3.1.

509 Afinal, vedar a possibilidade de efetivação do direito à saúde, por meio da prestação de serviços públicos pela iniciativa privada, sem uma justificativa constitucional, implica violação da Constituição. Sobre o tema da restrição aos direitos fundamentais, conferir a análise promovida no Item 3.1.2. 
Como exemplo dessa tendência, pode-se mencionar a Portaria n. ${ }^{0} 3.277$, de 22 de dezembro de 2006, editada pelo Ministério da Saúde, a qual dispõe sobre a participação complementar dos serviços privados de assistência à saúde no âmbito do Sistema Único de Saúde. Tal ato normativo contém evidente inconstitucionalidade e ilegalidade ao restringir a participação privada, nos seguintes termos:

Art. 2. ${ }^{\circ}$ Quando utilizada toda a capacidade instalada dos serviços públicos de saúde, e comprovada e justificada a necessidade de complementar sua rede e, ainda, se houver impossibilidade de ampliação dos serviços públicos, o gestor poderá complementar a oferta com serviços privados de assistência à saúde. ${ }^{510}$

Ao prever a impossibilidade de ampliação dos serviços públicos o dispositivo em referência repete o mesmo equívoco já perpetrado expressamente pelo artigo $7 .^{\circ}$ e implicitamente pelo artigo 24 da Lei n. ${ }^{\circ} 8.080$, acima analisados, supondo não configurarem os serviços de saúde contratados e conveniados legítimos serviços públicos.

De outro lado, e mais grave, é a determinação de que a participação privada nos serviços públicos de saúde apenas deve ocorrer caso haja impossibilidade de ampliação da prestação dos serviços diretamente pelo Estado. Tal limitação revela evidente caráter estatizante, o qual se apresenta, como já assinalado, absolutamente incompatível com a opção oferecida pela Constituição Federal e pelas próprias Constituições estaduais para que cada ente federativo determine o modelo mais eficiente de concretização do direito à saúde.

A referência à capacidade instalada como critério a ser levado em conta para a participação privada na prestação de serviços públicos de saúde parece ter ganho relevo a partir de um parecer emitido pela Procuradoria da República no qual consta a seguinte conclusão:

\footnotetext{
(...) a correta leitura do art. 197 da CF (e face às demais regras vigentes) é a de que a execução dos serviços de saúde deve ser feita diretamente (pelo Estado) ou por terceiros (hospitais e unidades hospitalares de entidades filantrópicas que venham a integrar o SUS), os quais comparecem com sua capacidade instalada e em caráter complementar, e por pessoa física ou jurídica de direito privado (consultórios médicos e hospitais privados não filiados ao SUS). Todos exercem serviços de relevância pública, mas aqueles prestados pelo Estado são de natureza essencialmente pública, integral e universal, caracterizando-se como direito fundamental e dever do Estado. ${ }^{511}$
}

510 Os grifos não constam do original.

511 GONÇALVES, Wagner. Parecer sobre terceirização e parcerias na saúde pública. 1998. Mimeo. p.21 (os grifos não constam do original). 
A regulamentação infralegal do SUS manteve tal direção equivocada, ao estabelecer novos limites à participação privada, em especial no que se refere a um argumento inconstitucional: o de que a participação privada complementar deve ocorrer por meio da utilização da capacidade instalada das entidades privadas prestadoras de serviços públicos. Nesse sentido, a própria Portaria n. ${ }^{\circ} 3.277 / 2006$, em seu artigo 4. ${ }^{\circ}$, determina que:

Art. $4 .^{\circ}$ O estado ou o município, uma vez esgotada sua capacidade de oferta
de serviços públicos de saúde, deverá, ao recorrer ao setor privado, dar
preferência às entidades filantrópicas e às sem fins lucrativos. 512
Parágrafo único - Poderá fazer uso do instrumento de convênio quando for
estabelecida uma parceria para a prestação de serviços de saúde, entendida
como uma comunhão de interesses que observa os seguintes elementos:
(...)
III - utilização da capacidade instalada da entidade filantrópica ou da sem
fins lucrativos, incluídos os equipamentos médico-hospitalares para
atendimento de clientela particular, incluída a proveniente de convênios com
entidades privadas, somente será permitida após esgotada sua utilização em favor
da clientela universalizada e desde que estejam garantidos, no mínimo, $60 \%$
(sessenta por cento) da capacidade instalada para atendimento de pacientes
encaminhados pelo SUS. ${ }^{513}$

Entretanto, como já ressaltado no início deste Item, a utilização da capacidade instalada, entendida como a estrutura completa e em funcionamento de uma unidade privada prestadora de serviços de saúde, consiste em uma das hipóteses de participação privada no sistema único de saúde. Além dela, são admitidas tanto a transferência da gestão - ou gerência, no vocabulário do SUS, acima mencionado - de uma unidade pública quanto a contratação de determinadas atividades internas ou externas a uma unidade de saúde. Entender o contrário implica obstar a possibilidade de que a Administração Pública em cada caso concreto firme vínculos com o particular para que este preste determinado serviço ou grupo de serviços conforme sua necessidade.

Por fim, insta mencionar que nem todos os atos normativos são contaminados pela visão ideológica estatizante e deslocada no tempo e no espaço, como as acima transcritas. Nesse sentido, a Norma Operacional Básica - NOB/SUS n. ${ }^{\circ}$ 01/96, em seu Item n. ${ }^{\circ}$ 4, que trata do Sistema de Saúde Municipal, dispõe expressamente que:

512 O esgotamento da capacidade instalada da rede pública consta como requisito para a participação privada nos serviços públicos de saúde nos dois atos normativos anteriores que disciplinam o assunto. Trata-se do artigo $1 .^{\circ}$ e seu parágrafo $1 .^{\circ}$ da Portaria n. ${ }^{\circ} 1.286$, de 26 de outubro de 1993, e do artigo $2 .^{\circ}$ da Portaria n. ${ }^{\circ} 358$, de 22 de fevereiro de 2006, ambas do Ministério da Saúde.

513 Os grifos não constam do original. 
Os estabelecimentos desse subsistema municipal, do SUS-Municipal, não precisam ser, obrigatoriamente, de propriedade da prefeitura, nem precisam ter sede no território do Município. Suas ações, desenvolvidas pelas unidades estatais (próprias, estaduais ou federais) ou privadas (contratadas ou conveniadas, com prioridade para as entidades filantrópicas), têm que estar organizadas e coordenadas, de modo que o gestor municipal possa garantir à população o acesso aos serviços e a disponibilidade das ações e dos meios para o atendimento integral.

Isso significa dizer que, independentemente da gerência dos estabelecimentos prestadores de serviços ser estatal ou privada, a gestão de todo o sistema municipal é, necessariamente, da competência do poder público e exclusiva desta esfera de governo, respeitadas as atribuições do respectivo Conselho e de outras diferentes instâncias de poder. ${ }^{514}$

Tal entendimento merece ser louvado. No exercício de sua competência constitucional de garantia do direito à saúde, cumpre ao administrador público de cada ente federativo, observados os ditames constitucionais, optar pelos modelos de participação privada que mais eficientemente concretizem o referido direito. A natureza complementar da participação privada nos serviços públicos de saúde, bem como sua regulamentação pela Lei n. ${ }^{\circ}$ 8.080/90, interpretadas à luz dos direitos fundamentais, conduze a essa conclusão.

\subsection{PREFERÊNCIA PELAS ENTIDADES FILANTRÓPICAS E PELAS SEM FINS LUCRATIVOS}

A devida compreensão da previsão constitucional segundo a qual as entidades filantrópicas e as sem fins lucrativos devem ter preferência em relação às demais entidades na prestação de serviços públicos de saúde, prevista na parte final do parágrafo único do artigo 199 da Constituição Federal,515 implica a análise do desenvolvimento histórico de tais entidades no Brasil.

Tal estudo, ao contrário daquele promovido no Item 3.1.1, não tem como referência a prestação de serviços públicos de saúde, mas especificamente o incentivo estatal à prestação privada de tais serviços.

Há que se ressaltar, entretanto, a utilização de expressões distintas pelo texto constitucional para se referir à participação privada nos serviços públicos de saúde: o artigo 197 fala em terceiros, enquanto o parágrafo primeiro do art. 199 fala na participação de

514 Portaria GM/MS n. ${ }^{\circ} 2.203$, de 5 de novembro de 1996 (os grifos não constam do original).

515 O dispositivo consta também da Lei n. ${ }^{\circ}$ 8.080/90, nos seguintes termos: Art. 25. Na hipótese do artigo anterior [que trata da participação privada complementar], as entidades filantrópicas e as sem fins lucrativos terão preferência para participar do Sistema Único de Saúde (SUS). 
instituições privadas, com preferência das entidades filantrópicas e das entidades sem fins lucrativos. Como a interpretação dos dispositivos deve ser realizada em conjunto, mesmo porque tratam em grande medida do mesmo tema, pode-se concluir que:

(i) o artigo 197 permite a participação tanto de pessoas fisicas quanto de pessoas jurídicas na prestação dos serviços públicos de saúde;

(ii) o artigo 199 utiliza tanto a expressão instituição quanto a expressão entidade em seu sentido coloquial, para significar pessoa jurídica (tanto que no parágrafo segundo do mesmo artigo há menção expressa a instituições privadas com fins lucrativos). Portanto, ainda que se possa discutir o conceito de cada uma das expressões, resta evidenciado seu significado amplo adotado pela Constituição Federal de 1988 no tratamento da saúde. ${ }^{516}$

\subsubsection{Entidades sem Fins Lucrativos e Terceiro Setor}

Entidades sem fins lucrativos, como cediço, são pessoas jurídicas de direito privado em relação às quais não há distribuição de eventual lucro entre seus associados. A devida compreensão do óbice mencionado implica reconhecer a distinção, corrente na teoria econômica, entre o significado de superávit e de lucro.

De acordo com Paulo Sandroni, enquanto o lucro de ser entendido como o "(...) rendimento atribuído especificamente ao capital investido diretamente por uma empresa"; o superávit:

\footnotetext{
(...) significa uma receita superior à despesa decorrente de um aumento da arrecadação ou decréscimo dos gastos. Na balança comercial, significa um valor das exportações superior ao das importações. No balanço de pagamentos, significa que a soma de todas as entradas de divisas decorrentes das várias operações com o resto do mundo é superior às saídas de divisas originadas nessas mesmas operações. ${ }^{517}$
}

Portanto, deve ser ressaltado que as entidades sem fins lucrativos podem, evidentemente, obter resultados financeiros positivos; o que lhes é vedado é a transformação de tal resultado, denominado superavit, em lucro a ser distribuído a quem quer que seja. Todo o resultado positivo deve ser investido nas finalidades sociais da entidade.

516 Sobre o conceito técnico de instituição, conferir: BRAGA, Leopoldo. Do conceito jurídico de 'Instituições de Educação e Assistência Social'. 2.ed. Rio de Janeiro: Borsoi, 1971.

517 SANDRONI, Paulo. Novíssimo dicionário de economia. 10.ed. São Paulo: Best Seller, 2002. p.356 e 583. 
Na legislação brasileira, encontram-se referências à ausência de finalidade lucrativa, como na Lei n. ${ }^{\circ}$ 9.532, de 10 de dezembro de 1997, que utiliza a própria expressão superávit, para vedar sua distribuição; 518 e na Lei n. ${ }^{\circ}$ 9.790, de 23 de março de 1999, ${ }^{519}$ que se refere à não distribuição de excedentes operacionais. 520

Em virtude da importância de tais entidades - marcada pelo volume de pessoas, recursos e atividades por elas prestadas - nas últimas décadas do século passado consolidou-se a expressão terceiro setor, para se referir ao conjunto de pessoas jurídicas de direito privado, de finalidade não-lucrativa, criadas voluntariamente pela sociedade civil e dotadas de administração própria. ${ }^{521}$ Esse é o conceito adotado pelo Manual sobre as Instituições sem Fins Lucrativos no Sistema de Contas Nacionais, editado pela Organização das Nações Unidas, em conjunto com a Universidade Johns Hopkins. ${ }^{522}$

518 Art. 12 (...) $\S 3 .^{\circ}$ : Considera-se entidade sem fins lucrativos a que não apresente superávit em suas contas ou, caso o apresente em determinado exercício, destine referido resultado, integralmente, à manutenção e ao desenvolvimento dos seus objetivos sociais (parágrafo com redação dada pela Lei n. ${ }^{\circ}$ 9.718/98, de 27 de novembro de 1998). Outros diplomas legais fazem referência à ausência de finalidade lucrativa.

519 Trata-se da lei que prevê a celebração de termos de parceria com entidades qualificadas como Organizações da Sociedade Civil de Interesse Público - OSCIPs, analisada adiante no Item 4.3.2.2.

520 Art. $1 .^{\circ}(\ldots) \S 1 .^{\circ}$ Para os efeitos desta Lei, considera-se sem fins lucrativos a pessoa jurídica de direito privado que não distribui, entre os seus sócios ou associados, conselheiros, diretores, empregados ou doadores, eventuais excedentes operacionais, brutos ou líquidos, dividendos, bonificações, participações ou parcelas do seu patrimônio, auferidos mediante o exercício de suas atividades, e que os aplica integralmente na consecução do respectivo objeto social.

521 Expressões similares, com significados próximos, são encontradas nos diferentes países, conforme seu desenvolvimento histórico e cultural. Dente elas podem ser mencionadas terceiro sistema, economia social, economia solidária, organizações não-governamentais, organizações solidárias e mutualidades.

522 Sobre o tema, conferir: CUNILL GRAU, Nuria. Repensando o público através da sociedade: novas formas de gestão pública e representação social. Trad. Carolina Andrade. Rio de Janeiro: Revan; Brasília: ENAP, 1998; BRESSER-PEREIRA, Luiz Carlos; CUNILL GRAU, Nuria. Entre o estado e o mercado: o público não-estatal. Trad. Noêmia A. Espíndola. In:___ (Orgs.). O público não-estatal na reforma do estado. Rio de Janeiro: Ed. Fundação Getúlio Vargas, 1999. p.15-48; MORALES, Carlos Antonio. Provisão de serviços sociais através de organizações públicas não-estatais: aspectos gerais. In: BRESSER PEREIRA, Luiz Carlos; CUNILL GRAU, Nuria (Orgs.). O público não-estatal na reforma do estado. Rio de Janeiro: Editora Fundação Getúlio Vargas, 1999. p.51-86; CABRAL, Eloísa Helena de Souza. Terceiro setor: gestão e controle social. São Paulo: Método, 2007; MESTRINER, Maria Luiza. O estado entre a filantropia e a assistência social. São Paulo: Cortez, 2001. CAÑADA, Isabel Maria V. Público y Privado em la gestión de la Segurida Social em Espana. Dimensión Jurídica. Granada: Comares, 2007; BRESSER-PEREIRA, Luiz Carlos. Sociedade civil: sua democratização para a reforma do estado. In: BRESSER-PEREIRA, Luiz Carlos; WILHEIM, Jorge; e SOLA, Lourdes (Orgs.). Sociedade e Estado em transformação. São Paulo: UNESP; Brasília: ENAP, 1999. p.67-145; GIDRON, Benjamin; KRAMER, Ralph M.; SALAMON, Lester M. Government and the trhird sector: emerging relationships in welfare states. San Francisco: Jossey-Bass Publishers, 1992; HALL, Peter Dobkin. Inventing the nonprofit sector and other essays on philanthropy, voluntarism, and nonprofit organizations. Baltimore and London: The Jonhs Hopkins University Press, 1992; JAMES, Estelle. The 
Além de tais características, como este autor já teve a oportunidade de assinalar, é marca fundamental do terceiro setor sua vinculação aos direitos fundamentais - o que demanda, para a qualificação de determinada entidade como pertencente ao terceiro setor, a análise tanto da previsão estatutária quanto do efetivo desempenho de atividades voltadas à defesa, promoção e proteção de tais direitos. ${ }^{523}$

Nessa perspectiva, pode-se conceituar terceiro setor como o conjunto de entidades privadas, sem fins lucrativos e voluntárias, voltadas à consecução dos direitos fundamentais, seja pela prestação de serviços em colaboração com o Estado - seja pela reivindicação e construção de novos de direitos a serem respeitados tanto pelo Estado quanto pela própria sociedade.

A emergência do terceiro setor nas últimas décadas marca no cenário social, como assinalou Ruth Cardoso, o rompimento da dicotomia entre o público e o privado. ${ }^{524}$ De um cenário em que prevaleceu, conforme Boaventura de Sousa Santos, o princípio do mercado (sobretudo no século XIX) e outro cenário em que prevaleceu o princípio do Estado, o final do século passado marca a emergência do princípio da comunidade. ${ }^{525} \mathrm{Com}$ isso, torna-se

nonprofit sector in international perspective: studies in comparative culture and policy. New York and Oxford: Oxford University Press, 1989; SALAMON, Lester M.; ANHEIER, Helmut K.; LIST, Regina; TOEPLER, Stefan; SOKOLOWSKI, S. Wojciech; and Associates. Global civil society: dimensions of the nonprofit sector. Baltimore: The Jonhs Hopkins Center for Civil Society Studies, 1999; GHAUSPASHA, Aisha. Role of civil society organizations in governance. In: Public administration and democratic governance: governments serving citizens. $7^{\text {th }}$ Global Forum on Reinventing Government: Building Trust in Government, 26-29 june 2007, Viena, Austria. New York: United Nations, 2007. p.235-274; NOGUEIRA, Marco Aurélio. Um estado para a sociedade civil: temas éticos e políticos da gestão democrática. São Paulo: Cortez, 2004; FALCONER, Andres Pablo. A promessa do terceiro setor: um estudo sobre a construção do papel das organizações sem fins lucrativos e do seu campo de gestão. 1999. Dissertação (Mestrado) - Faculdade de Economia, Administração e Contabilidade da Universidade de São Paulo, São Paulo, 1999; FERREIRA, Sílvia Maria Dias. O papel das organizações do terceiro sector na reforma das políticas públicas de protecção social: uma abordagem teóricohistórica. 2000. Dissertação (Mestrado em Sociologia) - Faculdade de Economia, Universidade de Coimbra, Coimbra, 2000.

523 Sobre o tema, conferir: MÂNICA, Fernando Borges. Panorama histórico-legislativo do terceiro setor no Brasil: do conceito de terceiro setor à lei das OSCIP. In: OLIVEIRA, Gustavo J. de. (Coord.). Terceiro setor, empresas e estado: novas fronteiras entre o público e o privado. Belo Horizonte: Fórum, 2007. p.163-194.

524 Nas palavras da autora: "(...) o conceito de Terceiro Setor descreve um espaço de participação e experimentação de novos modelos de pensar e agir sobre a realidade social. Sua afirmação tem o grande mérito de romper com a dicotomia entre o público e o privado, na qual o público era sinônimo de estatal e o privado, de empresarial." (CARDOSO, Ruth. Fortalecimento da sociedade civil. In: IOSCHPE, E. B. (Org.). Terceiro setor: desenvolvimento social sustentado. 2.ed. São Paulo: Paz e Terra, 2000. p.8).

525 SANTOS, Boaventura de Sousa. A reinvenção solidária e participativa do estado. Mimeo. p.1. O desenvolvimento de atividades de assistência à saúde por organizações de entidades da sociedade e sua progressiva assunção pelo Estado foram analisados nos Itens 2.1 e 2.2. 
renovado o pensamento clássico de Jean Jacques Rousseau, ${ }^{526}$ acerca da importância da comunidade para a manutenção (ou alcance) do ponto de equilíbrio entre Estado, mercado e sociedade. 527

Não obstante, dentre os diversos desafios do terceiro setor nessa nova geografia social, encontra-se exatamente sua localização espacial. A disciplina das entidades que compõem o terceiro setor é extremamente complexa, especialmente em suas relações com o Estado, já que, ao passo em que colaboradoras na consecução dos direitos fundamentais, tais entidades devem ser fiscalizadas e controladas a fim de que se garanta a efetiva concretização de tais direitos sem que com isso se imponha um regime idêntico àquele aplicado sobre o próprio Estado. Nessa perspectiva, pode-se dizer que o terceiro setor não se localiza antes ou depois, acima ou abaixo dos demais setores - Estado e mercado - mas entre ambos, de modo que sua denominação mais adequada seria setor 1,5 (um vírgula cinco).

Se, de um lado, com a projeção da disciplina que regulamenta a atividade estatal às entidades do terceiro setor corre-se o risco de estatizar e, em última análise, aniquilar tais entidades da sociedade civil, de outro, deixar de disciplinar a atuação do terceiro setor, em especial nos casos em que haja alguma modalidade de apoio estatal ao desempenho de suas atividades, implica a possibilidade de esvaziamento da Administração Pública, do Direito Administrativo e do próprio Estado.

526 Já no Contrato Social de Jean Jacques Roussesau, em 1757, encontra-se a admissão de existência de pequenas sociedades parciais, desde que em grande número e sem privilégios especiais característicos do período estamental. Eis o que sustenta Rousseau: "Finalmente, quando uma dessas associações é tão grande que vence todas as outras, o resultado não é mais uma soma de pequenas diferenças, senão uma e única diferença; porque então já não existe a vontade geral, e a opinião que triunfa é só uma opinião particular. Para que haja pois a exata declaração da vontade geral, importa não haver no Estado sociedade parcial e que cada cidadão manifeste o seu próprio parecer. Tal foi a única e sublime instituição do famoso Licurgo. Se há sociedades parciais, cumpre multiplicá-las e impedir a sua desigualdade, como o fizeram Sólon, Numa e Sérvio. São essas as mais eficazes precauções, para que a vontade geral seja sempre clara, e não iluda o povo." (ROUSSEAU, Jean-Jacques. Do contrato social. Trad. Pietro Nassetti. São Paulo: Martin Claret, 2002. p.42).

527 No setor de saúde brasileiro, ressalte-se, são definidos claramente o papel do Estado, do mercado e do terceiro setor, sendo que este último pode ocupar duas posições na prestação dos serviços: (i) como prestador de prestador de serviços públicos, cuja responsabilidade foi e continua sendo do Estado; (ii) como prestador de serviços privados. Tal clareza da definição constitucional, não implicou, entretanto, a devida interpretação de tais normas e muito menos a devida efetivação infraconstitucional de modelos de ajuste que permitam uma e outra forma de atuação. Além disso, insta ressaltar que a própria Constituição Federal prevê a participação da comunidade não apenas na implementação de serviços públicos e privados de saúde, mas também na formulação das políticas públicas do setor, como consta expresso do artigo 198, inciso III do texto constitucional, regulamentado pela Lei n. ${ }^{\circ} 8.142$, de 28 de dezembro de 1990. 
Nesse contexto, a dificuldade de disciplinar a atuação das entidades do terceiro setor começa pela própria identificação de quais são as entidades que efetivamente colaboram com o Estado na efetivação dos direitos fundamentais. Para tanto, foram criadas durante o século XX algumas qualificações outorgadas pelo Estado brasileiro àquelas entidades que cumprissem determinados requisitos os quais foram eleitos como critérios para a distinção de atividades prestadas em colaboração com o Estado na efetivação dos referidos direitos. ${ }^{528}$

\subsubsection{Entidades Filantrópicas: Histórico e Perspectivas da Qualificação Legal}

Uma das qualificações criadas para tanto foi o denominado certificado de fins filantrópicos. Sua compreensão, como assinalado acima, implica a análise histórica e relaciona-se ao incentivo estatal às atividades ligadas aos direitos fundamentais.

Desde o final da década de 20 do século passado, as entidades prestadoras de serviços de interesse público recebiam auxílio do Estado por meio de pedidos endereçados ao Presidente da República, o qual concedia os recursos com base em critérios pouco definidos. Utilizava-se para tanto recursos advindos da chamada contribuição de caridade, cobrada sobre a importação de bebidas alcoólicas. ${ }^{529}$ Em 1931, foi criada a Caixa de Subvenções, ${ }^{330}$ a partir da qual o Ministério da Justiça passou a desempenhar a função de análise e fiscalização dos pedidos de subvenção social a partir de critérios previamente definidos. ${ }^{531}$ Finalmente, em 1938 foi criado o Conselho Nacional do Serviço Social -

528 Afinal, se a expressão terceiro setor é recente, a existência de entidades que podem ser consideradas como tais é anterior à existência do próprio Estado, de modo que tais qualificações, como se verá, surgiram antes da consagração da expressão terceiro setor. De outro lado, insta ressaltar que o reconhecimento estatal de entidades que promovem e defendem o respeito e a construção de novos direitos - ao que se denomina, em língua inglesa, lobby ou advocacy - apenas ocorreu em fins do século XX, no Brasil, por meio da qualificação de Organização da Sociedade Civil de Interesse Público - OSCIP, analisada adiante, no Item 4.3.

529 Decreto presidencial n. ${ }^{\circ}$ 5.432, de 10 de janeiro de 1928.

530 Decreto-Lei n. ${ }^{\circ} 20.351$, de 31 de agosto de 1931.

531 Surgem, assim, as subvenções sociais, cuja fonte de recursos permaneceu na contribuição de caridade até 1935, quando passam a contar com créditos orçamentários adicionais. Finalmente, a partir da Lei n. ${ }^{\circ} 1.493$, de 13 de dezembro de 1951, as subvenções sociais passam a ser previstas no orçamento geral da República. De acordo com a definição trazida pelo inciso VIII, do artigo $1 .^{\circ}$, da Instrução Normativa n. ${ }^{\circ}$ 1/97, da Secretaria do Tesouro Nacional, subvenção social é a transferência que independe de lei específica, a instituições públicas ou privadas de caráter assistencial ou cultural, sem finalidade lucrativa, com objetivo de cobrir despesas de custeio. 
CNSS, ${ }^{332}$ consolidando a aliança entre o Estado e a as entidades prestadoras de serviços de interesse público nas áreas da assistência social, saúde e educação.

Originariamente vinculado ao Ministério da Educação e da Saúde, o CNSS tinha como atribuições a regulamentação da assistência social no país, aí incluídas educação e saúde, bem como a avaliação de pedidos de subvenções, para posterior aprovação pelo Ministério e homologação pela Presidência da República. Entretanto, dada a enorme demanda por recursos públicos pelas entidades, esta se tornou a principal atividade do CNSS: analisar pedidos de subvenção. 533

Em 1951 o CNSS passou a não apenas analisar pedidos de subvenção, mas também a gerenciar o denominado Registro Geral de Instituições. ${ }^{534}$ Surgiu assim o também conhecido registro no CNSS, o qual acabou se tornando requisito para a concessão de benefícios fiscais às entidades prestadoras de serviços de interesse público. ${ }^{535}$ No final da década de 50 do século passado, por meio da Lei n. $^{\circ} 3.577$, de 4 de julho de 1959, foi oficializada a possibilidade de isenção fiscal da contribuição à previdência social, sendo que a lei instituidora do benefício determinou que teriam acesso à isenção apenas as entidades dotadas do certificado de fins filantrópicos. Surgiu nesse momento mais uma atribuição ao CNSS: fornecer o certificado de fins filantrópicos.

Com isso, deu-se o reconhecimento legal das assim conhecidas instituições filantrópicas. A concessão do certificado foi obstada no final da década de 70 do século

532 Decreto-Lei n. ${ }^{\circ} 525$, de $1 .^{\circ}$ de julho de 1938.

533 Também nesse período surgiu a Lei . $^{\circ}$ 91, de 28 de agosto de 1935, até hoje vigente, instituindo a conhecida declaração de utilidade pública. Trata-se de um reconhecimento do poder público federal às entidades dotadas de personalidade jurídica de direito privado, constituídas no país, que não remuneram seus dirigentes, que estejam em efetivo funcionamento e sirvam desinteressadamente à coletividade.

534 Lei n. $^{\circ} 1.493$, de 13 de dezembro de 1951.

535 A Constituição de 1934, em seu artigo 154, pela primeira vez determinou a vedação de tributação sobre os estabelecimentos particulares de educação gratuita, oficialmente considerados idôneos. A Carta Constitucional de 1946 estendeu o benefício, prevendo, em seu artigo 31, imunidade tributária a instituições de educação e de assistência social, desde que suas rendas sejam aplicadas integralmente no país para os respectivos fins. No final da década de 1930, começaram a ser previstas isenções a entidades prestadoras de serviços sociais, as quais foram consolidadas pelo Decreto-Lei n. ${ }^{\circ}$ 5.844/43. Em seguida, uma série de isenções e a possibilidade de dedução do imposto devido no caso de doações foram previstas pela legislação federal, mas agora com a exigência de que as entidades beneficiárias possuíssem o certificado no CNSS (Lei n. ${ }^{\circ} 2.756 / 56$ e Lei n. ${ }^{\circ} 3.470 / 58$ ) ou o título de utilidade pública (Decreto n. $\left.{ }^{\circ} 3.830 / 60\right)$. 
passado, por meio Decreto-Lei n. ${ }^{0} 1.572$ de 01 de setembro de 1977,536 e retomada efetivamente a partir do Decreto n. ${ }^{\circ} 752$, de 16 de fevereiro de 1993, que regulamentou o inciso II do artigo 55, da Lei n. ${ }^{\circ} 8.212$, de 24 de julho de 1991, que previa a certificação de fins filantrópicos como requisito para a isenção tributária de contribuições sociais.

Atualmente, o certificado de fins filantrópicos é denominado certificado de entidade beneficente de assistência social, tal qual previsto no parágrafo $3 .^{\circ}$ do artigo $9 .^{\circ}$ da Lei n. ${ }^{\circ}$ 8.742, de 7 de dezembro de 1993, conhecida como Lei Orgânica da Assistência Social (LOAS), com redação dada pela Medida Provisória n. ${ }^{\circ} 2.187-13$, de 24 de agosto de 2001.537 Sua concessão encontra-se regulamentada pelo Decreto n. ${ }^{\circ} 2.536$, de 6 de abril de 1998, o qual prevê uma série de requisitos gerais ${ }^{538}$ e alguns requisitos específicos para aquelas entidades que atuam na área da saúde, os quais conformam grande parte do que

536 O Decreto-Lei em referência revogou a Lei $n .^{0}$ 3577/59, mas manteve o direito adquirido das entidades aos benefícios fiscais decorrentes da certificação até então obtida.

537 Medida Provisória em vigor, nos termos do artigo 2. ${ }^{\circ}$ da Emenda Constitucional n. ${ }^{\circ} 32$, de 11 de setembro de 2001.

538 De acordo com a redação atual do artigo $3 .^{\circ}$ do Decreto em referência: Art. $3 .^{\circ}$ Faz jus ao Certificado de Entidade Beneficente de Assistência Social a entidade beneficente de assistência social que demonstre, cumulativamente: I - estar legalmente constituída no País e em efetivo funcionamento nos três anos anteriores à solicitação do Certificado; II - estar previamente inscrita no Conselho Municipal de Assistência Social do município de sua sede se houver, ou no Conselho Estadual de Assistência Social, ou Conselho de Assistência Social do Distrito Federal; III - estar previamente registrada no CNAS; IV aplicar suas rendas, seus recursos e eventual resultado operacional integralmente no território nacional e manutenção e no desenvolvimento de seus objetivos institucionais; V - aplicar as subvenções e doações recebidas nas finalidades a que estejam vinculadas; VI - aplicar anualmente, em gratuidade, pelo menos vinte por cento da receita bruta proveniente da venda de serviços, acrescida da receita decorrente de aplicações financeira, de locação de bens, de venda de bens não integrantes do ativo imobilizado e de doações particulares, cujo montante nunca será inferior à isenção de contribuições sociais usufruída; VII - não distribuir resultados, dividendos, bonificações, participações ou parcelas do seu patrimônio, sob nenhuma forma ou pretexto; VIII - não perceberem seus diretores, conselheiros, sócios, instituidores, benfeitores ou equivalente remuneração, vantagens ou benefícios, direta ou indiretamente, por qualquer forma ou título, em razão das competências, funções ou atividades que lhes sejam atribuídas pelos respectivos atos constitutivos; IX - destinar, em seus atos constitutivos, em caso de dissolução ou extinção, o eventual patrimônio remanescente a entidades congêneres registradas no CNAS ou a entidade pública; X - não constituir patrimônio de indivíduo ou de sociedade sem caráter beneficente de assistência social. XI - seja declarada de utilidade pública federal. $§ 1 .^{\circ}$ O Certificado de Entidade de Fins Filantrópicos somente será fornecido a entidade cuja prestação de serviços gratuitos seja permanente e sem qualquer discriminação de clientela, de acordo com o plano de trabalho de assistência social apresentado e aprovado pelo CNAS. $\S 2{ }^{\circ}$ O Certificado de Entidade de Fins Filantrópicos terá validade de três anos, a contar da data da publicação no Diário Oficial da União da resolução de deferimento de sua concessão, permitida sua renovação, sempre por igual período, exceto quando cancelado em virtude de transgressão de norma que regulamenta a sua concessão. $\S 3 .^{\circ}$ Desde que tempestivamente requerida a renovação, a validade do Certificado contará da data do termo final do Certificado anterior. 
dispõe o ato normativo em referência. ${ }^{539}$ Ressalte-se que a referida Lei n. ${ }^{0} 8.742 / 93$

extinguiu o CNSS e criou o CNAS - Conselho Nacional de Assistência Social, que assumiu

as atribuições daquele. ${ }^{540}$

539 Seguindo o que dispõe o artigo $3 .^{\circ}$ do Decreto $n .^{\circ} 2.536 / 98$, em sua redação atual, as entidades são requisitos aplicáveis a entidades voltadas ao desenvolvimento de atividades de saúde: Art. 3. ${ }^{\circ}$ (...) $§ 4 .^{\circ} \mathrm{A}$ instituição de saúde deverá, em substituição ao requisito do inciso VI, ofertar a prestação de todos os seus serviços ao SUS no percentual mínimo de sessenta por cento, e comprovar, anualmente, o mesmo percentual em internações realizadas, medida por paciente-dia. $\S 5 .^{\circ} \mathrm{O}$ atendimento no percentual mínimo de que trata o $\S 4 .^{\circ}$ pode ser individualizado por estabelecimento ou pelo conjunto de estabelecimentos de saúde da instituição. $\S 6 .^{\circ}(.$.$) § 7. { }^{\circ}$ A instituição de saúde deverá informar, obrigatoriamente, ao Ministério da Saúde, por meio de Comunicação de Internação Hospitalar - CIH, a totalidade das internações realizadas para os pacientes não usuários do SUS. $\S 8 .^{\circ}$ A instituição de saúde que presta serviços exclusivamente na área ambulatorial, deverá, em substituição ao requisito do inciso VI, comprovar anualmente a prestação destes serviços ao SUS no percentual mínimo de sessenta por cento. § 9. ${ }^{\circ}$ Quando a disponibilidade de cobertura assistencial da população pela rede pública de uma determinada área for insuficiente, os gestores do SUS deverão observar, para a contratação de serviços privados, a preferência de participação das entidades beneficentes de assistência social e as sem fins lucrativos. $\S 10$ Havendo impossibilidade, declarada pelo gestor local do SUS, na contratação dos serviços de saúde da instituição no percentual mínimo estabelecido nos termos do $\S 4 .^{\circ}$ ou do $\S 8 .^{\circ}$ deverá ela comprovar atendimento ao requisito de que trata o inciso VI, da seguinte forma: I - integralmente, se o percentual de atendimento ao SUS for inferior a trinta por cento; II - com cinqüenta por cento de redução no percentual de aplicação em gratuidade, se o percentual de atendimento ao SUS for igual ou superior a trinta por cento; ou III com setenta e cinco por cento de redução no percentual de aplicação em gratuidade, se o percentual de atendimento ao SUS for igual ou superior a cinqüenta por cento ou se completar o quantitativo das internações hospitalares, medido por paciente-dia, com atendimentos gratuitos devidamente informados por meio de CIH, não financiados pelo SUS ou por qualquer outra fonte. $\S 11$ Tratando-se de instituição que atue, simultaneamente, nas áreas de saúde e de assistência social ou educacional, deverá ela atender ao disposto no inciso VI, ou ao percentual mínimo de serviços prestados ao SUS pela área de saúde e ao percentual daquele em relação às demais. $\S 12 \mathrm{Na}$ hipótese do $\S 11$, não serão consideradas, para efeito de apuração do percentual da receita bruta aplicada em gratuidade, as receitas provenientes dos serviços de saúde. § $13 \mathrm{O}$ valor aplicado em gratuidade na área de saúde, quando não comprovado por meio de registro contábil específico, será obtido mediante a valoração dos procedimentos realizados com base nas tabelas de pagamentos do SUS. § 14 Em hipótese alguma será admitida como aplicação em gratuidade a eventual diferença entre os valores pagos pelo SUS e os preços praticados pela entidade ou pelo mercado. $\S 15$ $\S 16$ (...) $\S 17$ A instituição de saúde poderá, alternativamente, para dar cumprimento ao requisito previsto no inciso VI do caput deste artigo ou no $\S 4 .^{\circ}$, realizar projetos de apoio ao desenvolvimento institucional do SUS, estabelecendo convênio com a União, por intermédio do Ministério da Saúde, nas seguintes áreas de atuação: I - estudos de avaliação e incorporação de tecnologias; II - capacitação de recursos humanos; III - pesquisas de interesse público em saúde; IV - desenvolvimento de técnicas e operação de gestão em serviços de saúde. § 18 O Ministério da Saúde definirá, em portaria, os requisitos técnicos essenciais para o reconhecimento de excelência referente a cada uma das áreas de atuação previstas no $\S 17 . \S 19$ O recurso despendido pela entidade de saúde no projeto de apoio não poderá ser inferior ao valor da isenção das contribuições sociais usufruída. $\S 20$. O projeto de apoio será aprovado pelo Ministério da Saúde, ouvidas as instâncias do SUS, segundo procedimento a ser definido em portaria ministerial. $\S 21$ As instituições de saúde que venham a se beneficiar da condição prevista no $\S$ 17 poderão complementar as atividades de apoio com a prestação de serviços ambulatoriais e hospitalares, não remunerados, ao SUS, mediante pacto com o gestor local do SUS, observadas as seguintes condições: I - o valor previsto no caput não poderá ultrapassar trinta por cento do valor usufruído com a isenção das contribuições sociais; II - a instituição de saúde deverá apresentar, ao gestor local do SUS, plano de trabalho com previsão de atendimento e detalhamento de custos, os quais não poderão exceder o valor efetivamente despendido pela instituição; III - a demonstração dos custos a que se refere o inciso II poderá ser exigida mediante apresentação dos comprovantes necessários; IV - as instituições conveniadas deverão informar a produção nos Sistemas de Informação Hospitalar e Ambulatorial - SIA e SIH/SUS, com observação de não geração de créditos. $§ 22$ A participação de 
Atualmente encontra-se em trâmite perante a Câmara dos Deputados o Projeto de Lei n. ${ }^{\circ} 3.021 / 2007$, que propõe a revogação do Decreto ${ }^{\circ}{ }^{\circ} 2.536 / 98$ e do artigo 55 da Lei n. ${ }^{\circ} 8.212 / 91$, de modo a tratar em um único corpo normativo os critérios para a concessão do certificado de entidade beneficente de assistência social (previstos no decreto) e os requisitos para fruição da isenção de contribuições sociais (previstos na lei). ${ }^{541}$ Além disso, importante inovação trazida no projeto de lei citado refere-se à segregação e organização dos requisitos para entidades beneficentes que atuam na área de assistência social, saúde e educação, inclusive com a determinação de que os respectivos ministérios - Ministério do Desenvolvimento Social e Combate à Fome, Ministério da Saúde e Ministério da Educação sejam competentes para análise e outorga do certificado. ${ }^{542}$

\subsubsection{Do Fomento à Delegação: o Tratamento Constitucional da Participação Privada nos Serviços de Saúde}

Como se percebe da análise acima desenvolvida, a prestação de serviços de saúde por entidades sem fins lucrativos, em especial a partir do segundo quarto do século XX,

instituições de saúde em projetos de apoio previstos no $\S 17$ não poderá ocorrer em prejuízo de atividades assistenciais prestadas ao SUS. $§ 23$ O conteúdo e o valor das atividades desenvolvidas em cada projeto de apoio ao desenvolvimento institucional e de prestação de serviços ao SUS deverão ser objeto de relatórios semestrais, os quais serão encaminhados à área do Ministério da Saúde vinculada ao projeto de apoio e de prestação de serviços e ao CNAS, para fiscalização, sem prejuízo das atribuições dos órgãos de fiscalização tributária e previdenciária. § $24 \mathrm{O}$ CNAS, com o apoio dos Ministérios da Saúde e da Previdência Social, avaliará a correspondência entre o valor da isenção e o valor dos recursos despendidos pela instituição de saúde, com base na análise do custo contábil de cada projeto, considerando os valores de investimento e os componentes diretos e indiretos do referido custo.

540 Art. 33. Decorrido o prazo de 120 (cento e vinte) dias da promulgação desta lei, fica extinto o Conselho Nacional de Serviço Social (CNSS), revogando-se, em conseqüência, os Decretos-Lei . $^{\text {os }} 525$, de $1 .^{\circ}$ de julho de 1938, e 657, de 22 de julho de 1943. § 1. ${ }^{\circ}$ O Poder Executivo tomará as providências necessárias para a instalação do Conselho Nacional de Assistência Social (CNAS) e a transferência das atividades que passarão à sua competência dentro do prazo estabelecido no caput, de forma a assegurar não haja solução de continuidade. $\S 2 .^{\circ} \mathrm{O}$ acervo do órgão de que trata o caput será transferido, no prazo de 60 (sessenta) dias, para o Conselho Nacional de Assistência Social (CNAS), que promoverá, mediante critérios e prazos a serem fixados, a revisão dos processos de registro e certificado de entidade de fins filantrópicos das entidades e organização de assistência social, observado o disposto no art. $3 .^{\circ}$ desta lei.

541 A questão da imunidade das entidades do terceiro setor em relação às contribuições sociais, indevidamente denominadas de isenções tanto pelo $\S 7 .^{\circ}$ do artigo 195 da Constituição Federal quanto pela Lei n. ${ }^{o} 8.212 / 91$, já foi objeto de estudo por esse autor na obra: MÂNICA, Fernando Borges. Terceiro setor e imunidade tributária. Belo Horizonte: Fórum, 2005.

542 Atualmente todos os pedidos são analisados pelo Conselho Nacional da Assistência Social (CNAS), órgão vinculado ao Ministério do Desenvolvimento Social e Combate à Fome e que resultou da transformação do antigo CNSS por meio da Lei . $^{\circ} 8.742 / 93$, como já mencionado. 
passou a ser incentivada de modo formal pelo Estado brasileiro, por meio de subvenções concedidas para que entidades sem fins lucrativos atuassem em áreas como a saúde. A atuação estatal em relação a tais entidades deve ser compreendida como fomento ao desenvolvimento de atividades privadas consideradas relevantes pelo Estado.

A classificação das atividades do Estado em prestação de serviços públicos, polícia e fomento tornou-se clássica a partir do trabalho de Luis Jordana de Pozas que assim definiu a atividade de fomento: "(...) a ação da Administração destinada a proteger ou promover aquelas atividades, estabelecimentos ou riquezas prestadas por particulares e que satisfazem necessidades públicas ou se consideram de utilidade geral, sem usar a coação ou criar serviços públicos". ${ }^{543}$ A diferença entre fomento e prestação de serviços públicos é ressaltada por Juan Carlos Cassagne:

\footnotetext{
Difere também o fomento do serviço público na natureza e nos fins e, conseqüentemente, no regime jurídico que acompanha a realidade que conduz esse compromisso estatal. Efetivamente, enquanto o serviço público se concebe objetivamente como uma atividade prestacional intercorrente, de onde surge a necessidade, continuidade, etc. da prestação, o fomento aparece como uma ajuda, um estímulo, com o objetivo de que os particulares possam realizar suas próprias finalidades comerciais e industriais. ${ }^{544}$
}

Do mesmo modo, ao tratar do que denomina administração fomentadora, Carlos Ari Sundfeld sustenta que:

\footnotetext{
O fomento estatal à vida privada consiste a concessão de benefícios aos particulares, de modo a induzir suas ações em certo sentido. Quem não se dispõe a adotar o comportamento pretendido não é sancionado; apenas deixa de usufruir o benefício que teria, em caso contrário. 545
}

Não se tratava naquele contexto histórico, evidentemente, de prestação de serviços públicos, já que, no caso da saúde, especificamente, não havia sequer ocorrido seu reconhecimento como direito de todos e como responsabilidade do Estado. Acontece que, no período anterior à Constituição de 1988, um duplo fenômeno foi levado a cabo:

543 JORDANA DE POZAS, Luis. Ensayo de una teoría del fomento en el Derecho Administrativo. Revista de Estudios Políticos, n.48, p.46, 1949.

544 CASSAGNE, Juan Carlos. La Intercencion Administrativa. 2.ed. Buenos Aires: Abeledp-Perrot, 1994. p.91.

545 SUNDFELD, Carlos Ari. Direito administrativo ordenador. São Paulo: Malheiros, 1997. p.25. 
(i) de um lado, uma série de leis foram criadas para assegurar incentivo estatal, pela via financeira e tributária, inclusive por meio de convênios, ${ }^{546} \mathrm{com} \mathrm{o}$ objetivo de proporcionar atendimento às pessoas não participantes das CAPs e IAPs, bem como do INPS; $; 47$

(ii) de outro, com o aumento da população beneficiada pela atuação de tais entes, as instituições privadas - tanto as sem fins lucrativos quanto as com fins lucrativos - passaram a firmar ajustes para prestar serviços de saúde também no âmbito público.

Essa ambivalência explica, em certa medida, o movimento criado com o objetivo de tornar as relações entre o Estado brasileiro e os prestadores privados submetidas a normas de direito público. É que, ao lado da influência de prestadores privados na definição das políticas públicas de saúde, com base no tratamento curativo - mais rentável às empresas médicas -, como mencionado no Item 3.1.1, não havia nas relações entre Estado e prestadores privados a celebração de ajustes em que fossem previstos especificamente os deveres e responsabilidades das entidades privadas prestadoras de serviços públicos. Isso pode ser explicado, como dito acima, em parte, pela tradição de vínculos originalmente criados com objetivo de promover o incentivo a atividades privadas de saúde e não de regular a prestação privada de serviços públicos de saúde.

Não obstante, a transformação que a Constituição de 1988 promoveu no tratamento da saúde buscou alterar completamente a questão - o que não foi bem compreendido até o momento. Antes de 1988, as entidades sem fins lucrativos e as entidades filantrópicas eram vinculadas ao Estado com o objetivo de prover serviços tanto àquelas pessoas detentoras do direito à saúde, pois vinculadas ao mercado formal de trabalho, quanto àquelas pessoas despidas de tal direito constitucional. A partir de 1988, com a assunção do Estado brasileiro da responsabilidade pela garantia do direito à saúde a todas as pessoas, a atuação de tais entidades e o vínculo delas com o Estado foram absolutamente renovados. Essa era a intenção do movimento sanitarista: transformar a atuação das entidades privadas em serviços públicos de saúde, disciplinados por meio de convênios e contratos de direito público. Nas discussões e

546 Os convênios serão objeto de análise no Item 4.3.1.1.2, adiante.

547 Nesse sentido, pode-se mencionar a Lei n. ${ }^{\circ} 2.312$, de 3 de setembro de 1954, que assim dispunha: Art. $6 .^{\circ}$ O Governo estimulará e ajudará financeiramente a iniciativa privada, que com ele colaborará, nos serviços de saúde e de assistência, dentro da orientação traçada pelos órgãos competentes. 
nos projetos apresentados durante a Assembléia Constituinte de 1987-1988 fica clara a intenção de submeter os prestadores privados a regras que permitissem maior controle e fiscalização pelo Poder Público.

Portanto, se até então a relação travada entre o Estado e as entidades sem fins lucrativos era caracterizada pela compra de serviços e pela outorga de subvenções àquelas entidades prestadoras de serviços de saúde com base na caridade; desde 1988, o Estado brasileiro assumiu a garantia do direito à saúde a todas as pessoas que dele necessitem - de modo que os ajustes a serem celebrados com as entidades prestadoras passaram (ou deveriam passar) a um outro nível. Em poucas palavras, com a Constituição foi criado o serviço público de saúde, cuja prestação não foi definida como monopólio do Estado, sendo prevista a possibilidade de delegação à iniciativa privada a ser firmada por meio de diversos modelos de ajuste, os quais serão analisados no item seguinte.

De acordo com o entendimento adotado acerca dos serviços públicos, resta evidenciada que a delegação de serviços públicos implica a formação de um vínculo por meio do qual são estabelecidos direitos e deveres do Estado (responsável por sua oferta) e do particular (responsável por sua prestação aos usuários do serviço). A delegação de serviços públicos, portanto, não depende da exclusividade ou do monopólio estatal de determinada atividade e tampouco da impossibilidade de que o particular atue em determinada área sem vínculo com o Estado. A delimitação de tal convivência (entre a prestação de um serviço no âmbito público e no âmbito privado), como analisado no Item 3.2.1, deve constar da lei que regula o setor, sendo que no caso da saúde tal previsão possui sede constitucional. ${ }^{548}$

A preferência constante do texto constitucional pelas entidades filantrópicas hoje denominadas entidades beneficentes de assistência social - e pelas entidades sem fins

548 Essa compreensão de delegação de serviços públicos pode ser encontrada na doutrina, como, por exemplo, em: CHEVAlIER, Jacques. Le Service Public. 6.ed. Paris: PUF, 2006. p.102 e segs. Nesse sentido, como demonstrado neste trabalho, por força de dispositivos constitucionais expressos, não há fundamento que ampare posições como a de Arnold Wald e outros, segundo a qual não se admite a delegação de serviços de saúde (WALD, Arnold; MORAES, Luiza Rangel de; WALD, Alexandre de M. O direito de parceria e a nova lei de concessões (análise das leis 8.987/95 e 9.074/95). São Paulo: Revista dos Tribunais, 1996. p.71). Tal entendimento, hoje insustentável, foi defendido há muito tempo, como se percebe da seguinte passagem de Mário Masagão: "(...) mesmo no campo da ação social, no qual a iniciativa dos particulares concorre com a do Estado, há atividades especiais que, com caráter de serviço público, não podem ser transferidos da administração (federal, estadual ou municipal), para mãos de particulares. Isso acontece quanto aos serviços que não comportam especulação lucrativa, e quanto aos que possam exigir coação física sobre os administrados. (...) No serviços relativo à saúde pública, por exemplo, concorrem ambos os motivos de exclusão acima apontados." (MASAGÃO, Mário. Natureza jurídica da concessão de serviço público. São Paulo: Saraiva e Cia., 1933. p.23). 
lucrativos tem como objetivo obstar a mercantilização dos serviços públicos de saúde tal qual ocorrido no período anterior à Constituição de 1988. Além disso, a competição instalada entre as entidades sem fins lucrativos, ao contrário daquela existente entre empresas, não tem como base a obtenção de lucro, mas a eficiência e o reconhecimento pela prestação de serviços. Nesse sentido, tem razão Luiz Carlos Bresser-Pereira, para quem:

(...) no caso da assistência à saúde e da educação, as entidades sem fins lucrativos estão mais bem preparadas para lidar com esses assuntos vitais e delicados, que envolvem direitos humanos e essenciais. As empresas comerciais e industriais existem para competir por lucros, enquanto as organizações sem fins lucrativos (...) estão preparadas para competir por excelência e reconhecimento. ${ }^{549}$

Isso porque, como menciona Paulo Modesto, as entidades do terceiro setor são entidades sem dono, ${ }^{550}$ criadas e administradas pela própria sociedade civil com o objetivo de promover e defender direitos fundamentais. Não obstante, como assinalado acima, a efetiva inexistência de donos e a conseqüente atuação voltada à defesa de direitos dependem de uma disciplina jurídica que não suprima a capacidade de atuação privada, mas possibilite formas de fiscalização e controle sobre as mesmas; em especial nos casos em que tais entidades recebam alguma forma de benefício público, seja em decorrência do desempenho de atividades de relevância pública, seja em decorrência da prestação de serviços públicos. Tal disciplina, em grande medida, apenas pode ser visualizada por meio dos instrumentos que definam os vínculos a serem firmados entre as entidades em referência e o Poder Público. 551

549 BRESSER-PEREIRA, Luiz Carlos. Uma nova gestão para um novo modelo de estado: liberal, social e republicano. Revista do Serviço Público, ano 52, n.1, p.19, jan./mar. 2001.

550 MODESTO, Paulo. Convênio entre entidades públicas executado por fundação de apoio. Serviço de saúde. Conceito de serviço público e serviço de relevância pública na Constituição de 1988. Forma da prestação de contas das entidades de cooperação após a emenda constitucional n. ${ }^{\circ}$ 19/98. Revista Diálogo Jurídico, Salvador, n.11, p.8, fev. 2002. Disponível em: <http://www.direitopublico.com.br>. Acesso em: 28 mar. 2007.

551 Nessa perspectiva, o fato de existirem entidades do terceiro setor que exercem suas funções total ou substancialmente financiadas por recursos públicos não afeta sua condição de entidade do terceiro setor e tampouco revela qualquer desvio. Tal característica tem como conseqüência maior grau de fiscalização sobre as atividades desenvolvidas do que aquelas entidades que atuam de modo completamente autônomo. A tentativa de desqualificar o terceiro setor com base em tal argumento é frágil, mesmo porque é possível encontrar-se numerosas empresas privadas cuja fonte de receitas também é total ou principalmente decorrente de contratos celebrados com o Poder Público. A questão, portanto, deve ser tratada no âmbito do regime jurídico dos vínculos celebrados entre o ente privado e o ente público. 
Deve-se ressaltar que o dispositivo constitucional que prevê a preferência das entidades filantrópicas e das sem fins lucrativos deve ser interpretado em conjunto com as demais normas constitucionais e à luz da realidade, de modo que é possível a formação de vínculos com entidades com natureza lucrativa em todos os casos em que tal opção se mostre mais adequada à consecução do serviço público de saúde em questão. ${ }^{552}$ Além disso, o fomento estatal às entidades filantrópicas e às sem fins lucrativos para a prestação de serviços de saúde fora da esfera pública também é permitido - como se pode apreender do parágrafo segundo do artigo 199 da Constituição Federal, que veda a subvenção a entidades com fins lucrativos. ${ }^{553}$ Portanto, enquanto a delegação de serviços públicos de saúde às entidades filantrópicas e às sem fins lucrativos é preferencial, o fomento estatal à prestação de tais serviços por tais entidades no âmbito privado é exclusivo.

\subsection{MODELOS DE AJUSTE PARA A PRESTAÇÃO PRIVADA DE SERVIÇOS PÚBLICOS DE SAÚDE}

Ao contrário de outros setores, não houve no Brasil grande expansão da estrutura administrativa voltada à prestação de serviços de saúde na segunda metade do século XX. ${ }^{554}$ Como se pode verificar da análise levada a cabo no Item 3.1.1, a prestação de tais serviços no âmbito público foi marcada pela grande influência e pela importante presença do setor privado. Tanto isso é verdade que um dos objetivos do movimento sanitário, o qual ganhou

552 É evidente, portanto, que empresas privadas podem participar do sistema público de saúde, na condição de prestadoras de serviço público de saúde. Do mesmo modo, ao contrário do entendimento de alguns autores, como Sílvio Luís da Rocha, a prestação de serviços pela iniciativa privada - tanto dentro quanto fora do sistema público de saúde - jamais será de competição com os serviços públicos de saúde. Sua compreensão deve ser de colaboração, ou seja, a soma de esforços para garantir serviços de saúde a todos que dele necessitem. Sobre o tema: ROCHA, Sílvio Luís F. da. Tipos de planos e coberturas na lei 9.656/98. In: MARQUES, Cláudia Lima; LOPES, José Reinaldo de Lima; PFEIFFER, Roberto A. C. Saúde e responsabilidade: seguros e planos de assistência privada à saúde. São Paulo: Revista dos Tribunais, 1999. p.36. Na linha do que se sustentou no Item 3.2, seja a prestação qualificada como serviço público, seja meramente qualificada como serviço de relevância pública, na medida em que se prestem serviços de assistência à saúde as quem dele necessite, de modo gratuito ou remunerado, está-se colaborando com o Estado para a garantia do direito à saúde.

553 Art. 199 (...). § 2. ${ }^{\circ}$ - É vedada a destinação de recursos públicos para auxílios ou subvenções às instituições privadas com fins lucrativos.

554 Não se aplicam à área da saúde, portanto, assertivas como a de Caio Tácito, segundo o qual: "A curva ascendente de expansão da ação direta do Estado na atividade econômica e social alcança o seu ápice no início da década de 80." (TÁCITO, Caio. O retorno do pêndulo: serviço público e empresa privada: o exemplo brasileiro. Revista de Direito Administrativo, Rio de Janeiro, v.1, p.5, 1991). 
força em 1986, com a VIII Conferência Nacional de Saúde, foi a adoção de mecanismos de ajuste que submetessem os prestadores privados às políticas públicas.

Na saúde, a Constituição Federal de 1988 buscou iniciar um processo de publicização dos prestadores por meio da contratualização, a ser levada a cabo a partir de ajustes aptos a definir os deveres dos entes privados, bem como proporcionar seu controle e fiscalização. ${ }^{555}$

Ao tratar de questões formuladas pela Organização Panamericana de Saúde acerca do então discutido projeto de Constituição a ser votado pela Comissão de Sistematização da Assembléia Nacional Constituinte, ${ }^{556}$ Cármen Lúcia Antunes Rocha assim já se manifestara:

\begin{abstract}
O contrato administrativo para prestação dos serviços de saúde deverá esclarecer, em cada hipótese, as ações a serem levadas a efeito pelo contratado particular, explicitando-se no documento contratual as condições de sua execução, os prazos, as modalidades de comportamento $\mathrm{s}$ a serem adotados ou aceitáveis pela entidade pública. (...) Repita-se, ainda, aqui, que a garantia constitucional é da prestação de uma ação de saúde. Há que se assegurar a prestação, direta ou indireta, da prestação necessária e eficiente da atividade relativa à promoção, proteção e recuperação da saúde para o cumprimento integral da norma constitucional e contrato, por se embasar na lei e na própria Constituição, haverá que ser formalizado e interpretado neste sentido. A descrição do objeto do contrato e das condições de prestação do serviço devem ser explicitadas no documento formal do contrato, vez que não se admite, no direito brasileiro vigente, contrato verbal com a Administração Pública (..... ${ }^{557}$
\end{abstract}

Como assinalado anteriormente, trata-se de um processo de publicização e não de estatização da prestação privada de serviços de saúde: aquela (constante da Constituição) implica submeter os prestadores privados às regras acima referidas, com objetivo final de atender ao interesse das pessoas dependentes dos serviços e não aos interesses dos próprios prestadores; esta (não adotada na ordem constitucional da saúde) significa transformar prestadores de natureza privada em prestadores de natureza pública. ${ }^{558}$

555 Essa é a opinião consignada em estudo publicado pela Organização Mundial da Saúde: "Contratualização não significa privatização dos serviços de saúde. Como o Estado não pode eximir-se da responsabilidade pela garantia de funções essenciais na saúde, a contratualização com terceiros pode proporcionar a obtenção de maior controle sobre os prestadores privados nos países em desenvolvimento com fraca capacidade regulatória." (SIDDIQI, Sameen; MASUD Tayyeb Imran; SABRI, Belgacem. Contracting but not without cautin: experience with outsourcing oh health services in contries of the Eastern Mediterranean Region. Bulletin os the World Health Organization, n.84, november, 2006. p.872).

556 Sobre o tema, conferir Item 3.1.1.2.

557 ROCHA, Cármen Lúcia Antunes. O serviço público de saúde no direito brasileiro. Brasília: OPS, 1988. p.67.

558 Sobre o tema, conferir Item 2.4 . 
Ressalte-se que no período de transição para o novo modelo, subseqüente à promulgação do texto constitucional, os contratos com prestadores privados mantiveram-se sob a competência do INAMPS. Logo após a extinção da autarquia federal, cinco anos após a promulgação da Constituição de 1988,559 em cumprimento ao que já determinara a Lei n. ${ }^{\circ} 8.080 / 90$ acerca da competência dos municípios para a celebração de contratos e convênios com prestadores privados, ${ }^{560}$ foi editada pelo Ministério da saúde a Portaria n. ${ }^{\circ} 1.286$, de 26 de outubro de 1993, que estabelecia, inclusive, prazos para a contratualização com os prestadores privados de serviços públicos de saúde. ${ }^{561}$

No entanto, a determinação normativa foi em grande medida ignorada, ${ }^{562}$ de modo que o Ministério da Saúde (e não mais o INAMPS) continuou executando os repasses de recursos às entidades privadas prestadoras dos serviços, independente da formalização contratual - em clara afronta não apenas à referida portaria, mas à própria Constituição Federal. ${ }^{563}$ Pode-se verificar, pois, que desde a Constituição de 1988, muitos prestadores

559 O INAMPS foi extinto por meio da Lei n. ${ }^{\circ} 8.689$, de 27 de julho de 1993.

560 Art. 18. À direção municipal do Sistema de Saúde (SUS) compete: (...) X - observado o disposto no art. 26 desta Lei, celebrar contratos e convênios com entidades prestadoras de serviços privados de saúde, bem como controlar e avaliar sua execução; (o artigo 26 será adiante comentado).

561 Assim dispunha o referido ato normativo: Art. 11. Fica concedido o prazo de cento e oitenta dias, a contar da publicação desta Portaria, para Municípios e Estados celebrarem, mediante procedimento licitatório e conforme o disposto nesta Portaria, contratos referentes aos serviços de saúde que vêm sendo prestados pelo setor privado sem "termo de contrato" e à conta do extinto INAMPS. $\S 1 .^{\circ}$ Excepcionalmente, o prazo estabelecido pode ser prorrogado, mediante justificativa dos órgãos gestores, e aprovação da Comissão Intergestores Tripartite. $\S 2 .^{\circ}$ Decorrido o prazo de cento e oitenta dias, o Ministério da Saúde ficará exonerado da obrigação de pagar, diretamente ou mediante repasse de recursos a Municípios e Estados, serviços privados contratados em desconformidade com o disposto nesta Portaria, sejam com novos prestadores ou com prestadores anteriormente contratados pelo extinto INAMPS.

562 Como causas que dificultaram a contratualização dos prestadores privados de serviços públicos de saúde, João Cláudio Basso Pompeu relaciona: "O MS [Ministério da Saúde] repassou a responsabilidade de contratação aos municípios num momento em que não havia clareza das regras e competência de cada unidade federativa; os gestores públicos têm dificuldade em calcular a sua necessidade de serviços de saúde; os prestadores privados não queriam mudar uma lógica de produção que os favorecia; muitos prestadores privados estão em débito com os encargos sociais, o que impede sua contratação; a inexistência de contratação possibilita ao gestor público diminuir os recursos que ele pagará ao setor privado; a legislação brasileira não é adequada à contratação dos serviços de saúde." (POMPEU, João Cláudio Basso. A situação contratual da rede hospitalar privada vinculada ao SUS: alguns elementos para reflexão. 2004. 183p. Dissertação (Mestrado em Gestão de Sistemas e Serviços de Saúde) - Escola Nacional de Saúde Pública da Fundação Oswaldo Cruz, Brasília, 2004. p.116).

563 Além disso, o repasse de recursos a entidades privadas sem a devida formalização do respectivo vínculo, nos termos do artigo 60 e seguintes da Lei n. ${ }^{\circ} 8.666 / 93$, pode ser qualificado como ato de improbidade administrativa, nos termos da Lei n. ${ }^{0} 8.429$, de 2 de junho de 1992, que em seu artigo 10 dispõe: Art. 10. Constitui ato de improbidade administrativa que causa lesão ao erário qualquer ação ou omissão, dolosa 
privados de serviços públicos de saúde mantiveram-se sem qualquer lastro jurídico formal que disciplinasse adequadamente a prestação dos serviços, enquanto outros mantiveram os mesmos modelos de vínculos firmados no período anterior à Constituição de $1988 .{ }^{564}$

Mesmo com a fixação de garantias de repasses financeiros aos municípios, consolidadas durante o processo de estruturação do SUS pós-1988, a situação não demonstrou completa mudança. O próprio Ministério da Saúde, em publicação de 2007, intitulada Manual de Orientações para Contratação de Serviços no Sistema Único de Saúde, reconheceu e deu números ao descumprimento do ditame constitucional:

Poucos gestores implementaram a portaria [1.286/93], como demonstrado pelos dados do CNES - Cadastro Nacional dos Estabelecimentos de Saúde - que, tem um total de 92.950 estabelecimentos de saúde, sendo que 44.194 são privados. Desses estabelecimentos privados cadastrados, $89 \%$ prestam algum serviço ao Sistema Único de Saúde. O CNES demonstra que apenas 4.866 desses estabelecimentos possuem contratos firmados com o SUS. Portanto, temos um contingente de $87,6 \%$, sem contrato com o setor público e, os que o fizeram, na maioria das vezes, não atualizaram essas relações à luz das necessidades de oferta, ocorrendo o que poderíamos chamar de recontratação daqueles prestadores que já vinham participando da rede complementar e cujos contratos já estavam sem validade e sendo pagos por indenização. As compras foram ainda pela oferta e não fruto de planejamento conjunto entre os três gestores com avaliação das necessidades da população e da disponibilidade dos recursos financeiros. ${ }^{565}$

ou culposa, que enseje perda patrimonial, desvio, apropriação, malbaratamento ou dilapidação dos bens ou haveres das entidades referidas no art. $1 .^{\circ}$ desta lei, e notadamente: (...) II - permitir ou concorrer para que pessoa física ou jurídica privada utilize bens, rendas, verbas ou valores integrantes do acervo patrimonial das entidades mencionadas no art. $1 .^{\circ}$ desta lei, sem a observância das formalidades legais ou regulamentares aplicáveis à espécie; (...) VII - conceder benefício administrativo ou físcal sem a observância das formalidades legais ou regulamentares aplicáveis à espécie; VIII - frustrar a licitude de processo licitatório ou dispensá-lo indevidamente; IX - ordenar ou permitir a realização de despesas não autorizadas em lei ou regulamento; (...) XI - liberar verba pública sem a estrita observância das normas pertinentes ou influir de qualquer forma para a sua aplicação irregular.

564 Sobre o tema: MATOS, Carlos Alberto; POMPEU, João Cláudio. Where are the contracts? Analysis of the relation between private health services suppliers and the SUS. Ciência \& Saúde Coletiva, Rio de Janeiro, v.8, n.2, p.629-643, 2003; POMPEU, João Cláudio Basso. A situação contratual da rede hospitalar privada vinculada ao SUS: alguns elementos para reflexão. 2004. 183p. Dissertação (Mestrado em Gestão de Sistemas e Serviços de Saúde) - Escola Nacional de Saúde Pública da Fundação Oswaldo Cruz, Brasília, 2004.

565 BRASIL. Ministério da Saúde. Secretaria de Atenção à Saúde. Departamento de Regulação Avaliação e Controle de Sistemas. Manual de orientações para contratação de serviços no Sistema Único de Saúde. Brasília: Ministério da Saúde, 2007. p.6 (os grifos não constam do original). 
Atualmente, dentre as entidades privadas integrantes do Cadastro Nacional dos Estabelecimentos de Saúde (CNES), 566 conforme a categorização de prestadores adotada pelo Ministério da Saúde, pode-se perceber que pouco se alterou a situação acima relatada:

\begin{tabular}{|c|c|c|c|}
\hline $\begin{array}{c}\text { Indicadores Contratos/ } \\
\text { Convênios - Esfera administrativa: privada } \\
\text { Tipo de Unidade }\end{array}$ & $\begin{array}{l}\text { Total com } \\
\text { Contrato }\end{array}$ & $\begin{array}{l}\text { Total sem } \\
\text { Contrato }\end{array}$ & Total Geral \\
\hline Centro de Apoio à Saúde da Família & 0 & 5 & 5 \\
\hline Centro de Atenção Hemoterapia e/ou Hematologica & 4 & 13 & 17 \\
\hline Centro de Atenção Psicossocial & 6 & 20 & 26 \\
\hline Centro de Parto Normal - Isolado & 3 & 1 & 4 \\
\hline Centro de Saúde/Unidade Básica & 118 & 510 & 628 \\
\hline Clinica Especializada/Ambulatório de Especialidade & 4.130 & 18.875 & 23.005 \\
\hline Consultorio Isolado & 8.386 & 70.997 & 79.383 \\
\hline Cooperativa & 24 & 204 & 228 \\
\hline Farmácia & 3 & 101 & 104 \\
\hline Hospital Especializado & 361 & 626 & 987 \\
\hline Hospital Geral & 1.554 & 1.931 & 3.485 \\
\hline Hospital/Dia - Isolado & 56 & 250 & 306 \\
\hline Laboratório Central de Saúde Pública Lacen & 0 & 8 & 8 \\
\hline Policlínica & 644 & 2.496 & 3.140 \\
\hline Posto de Saúde & 73 & 112 & 185 \\
\hline Pronto Socorro Especializado & 23 & 73 & 96 \\
\hline Pronto Socorro Geral & 15 & 59 & 74 \\
\hline Unidade de Apoio Diagnose e Terapia (Sadt Isolado) & 3.556 & 10.471 & 14.027 \\
\hline Unidade Mista & 43 & 60 & 103 \\
\hline Unidade Móvel de Nível Pré-Hosp - Urgência/Emergência & 10 & 70 & 80 \\
\hline Unidade Móvel Fluvial & 1 & 7 & 8 \\
\hline Unidade Móvel Terrestre & 8 & 47 & 55 \\
\hline TOTAL & 19.018 & 106.936 & 125.954 \\
\hline
\end{tabular}

FONTE: BRASIL. Ministério da Saúde. Indicadores de contratos. (tabela). Secretaria de Atenção à Saúde, 2008. Disponível em: <http://cnes.datasus.gov.br/Mod_Ind_Contratos.asp>. Acesso em: 06 out. 2008.

É interessante notar que, de acordo com o CNES, do total de 62.134 entidades prestadoras de serviços ambulatoriais no âmbito público cadastradas no CNES:

(i) 177 são federais;

(ii) 1.613 são estaduais;

566 O Cadastro Nacional dos Estabelecimentos de Saúde - CNES, foi instituído pela Portaria MS/SAS n. ${ }^{\circ} 376$, de 03 de outubro de 2000, publicada no Diário Oficial da União de 04 de outubro de 2000. 
(iii) 50.594 são municipais; e

(iv) 9.750 são privadas (além dessas, outras 99.590 entidades privadas não prestam serviços no âmbito público). ${ }^{567}$

De outro lado, no setor hospitalar, das 6.101 unidades prestadoras de serviços ao SUS:

(i) 67 são federais;

(ii) 596 são estaduais;

(iii) 2.221 são municipais; e

(iv) 3.217 são privadas (sendo que o total de hospitais privados cadastrados é de 4.159). ${ }^{568}$

Tais números demonstram a importância extrema que possui a participação privada na prestação de serviços públicos de saúde em especial no setor hospitalar - no qual a organização e prestação dos serviços é mais complexa.

De qualquer modo, em ambos os casos resta evidenciado que a normatividade constitucional permanece de fato adormecida, pela inexistência de transposição de sua previsão abstrata para o plano dos fatos. Nesse sentido, já assinalava Konrad Hesse, segundo o qual:

\begin{abstract}
A Constituição transforma-se em força ativa se essas tarefas [impostas pela Constituição] forem efetivamente realizadas, se existir a disposição de orientar a própria conduta segundo a ordem nela estabelecida, se, a despeito de todos os questionamentos e reservas provenientes dos juízos de conveniência, se puder identificar a vontade de concretizar essa ordem. ${ }^{569}$
\end{abstract}

Nessa perspectiva, ao contrário do que defende o referido autor como requisito para a transformação do texto constitucional em força ativa, não parece não haver no Brasil consciência social geral e tampouco consciência dos principais responsáveis pela ordem

567 Informações disponíveis em: BRASIL. Ministério da Saúde. Estabelecimentos com tipo de atendimento prestado - ambulatório - particular. (tabela). DATASUS, 2008. Disponível em: $<$ http://tabnet.datasus. gov.br/ cgi/tabcgi.exe?cnes/cnv/atambbr.def>. Acesso em: 29 out. 2008.

568 Informações disponíveis em: BRASIL. Ministério da Saúde. Estabelecimentos com tipo de atendimento prestado - hospital - particular. (tabela). DATASUS, 2008. Disponível em: < http://tabnet.datasus. gov.br/ cgi/tabcgi.exe?cnes/cnv/atambbr.def>. Acesso em: 29 out. 2008.

569 HESSE, Konrad. A força normativa da constituição. Trad. Gilmar Ferreira Mendes. Porto Alegre, Sergio Antonio Fabris, 1991. p.19. 
constitucional acerca da determinação sob exame e de sua importância como instrumento de garantia do direito à saúde. ${ }^{570}$

\subsubsection{Hipóteses Constitucionalmente Previstas}

No ordenamento da saúde, o artigo 197 da Constituição Federal contém determinação expressa para que a prestação de serviços de saúde seja levada a cabo diretamente pelo Estado ou por terceiros. ${ }^{571}$ Portanto, considerando tratar-se de dever estatal voltado diretamente ao atendimento de necessidades sociais vitais, a hipótese constitucionalmente prevista não se refere à terceirização de atividades-meio ou acessórias, mas de atividades-fim do Estado, especificamente relacionadas ao seu dever de prestar serviços de saúde a quem deles necessitar. ${ }^{572}$ Além disso, o parágrafo primeiro do artigo 199 da Constituição Federal menciona hipóteses de delegação de serviços públicos de saúde por meio de contratos de direito público e de convênios. ${ }^{573}$

Assim, considerando, nos termos já analisados no Item 3.2, que os serviços públicos são relacionados a atividades-fim da Administração Pública, ${ }^{574}$ pode-se sustentar que o referido permissivo constitucional admite a delegação de uma atividade-fim do Estado,575

570 Note-se, de outro lado, que a previsão constitucional de contratualização dos serviços de saúde segue a tendência mundial adotada tanto em Estados de sistema bismarckiano como em Estados de sistema beveridgeano ou mesmo sistemas segmentados. Sobre a questão, conferir Item 2.4.

571 Art. 197. São de relevância pública as ações e serviços de saúde, cabendo ao Poder Público dispor, nos termos da lei, sobre sua regulamentação, fiscalização e controle, devendo sua execução ser feita diretamente ou através de terceiros e, também, por pessoa física ou jurídica de direito privado. Por terceirização, portanto, deve entender-se a execução de serviços realizada por pessoas físicas sem vínculo de natureza estatutária ou trabalhista com Estado ou por pessoas jurídicas de direito privado (os grifos não constam do original).

572 Nesse sentido considera-se útil a conhecida classificação de Renato Alessi, entre interesse público primário e interesse público secundário, aos quais podem ser reconduzidas as noções de atividade-meio ou acessória e de atividade-fim da Administração Pública. Sobre o tema: ALESSI, Renato. Sistema Istituzionale del Diritto Amministrativo Italiano. Milano: Giuffré, 1953. p.151 e segs.

573 Art. 199. (...) § $1 .^{\circ}$ - As instituições privadas poderão participar de forma complementar do sistema único de saúde, segundo diretrizes deste, mediante contrato de direito público ou convênio, tendo preferência as entidades filantrópicas e as sem fins lucrativos (os grifos não constam do original).

574 Sobre o tema, conferir: MEDAUAR, Odete. Direito administrativo moderno. 11.ed. São Paulo: Revista dos Tribunais, 2007. p.313.

575 Sobre o conceito de delegação adotado neste trabalho, conferir Item 4.2.3. 
o serviço público de saúde, por meio de diversos modelos de ajuste. ${ }^{576}$ Essa é também a opinião de Floriano de Azevedo Marques Neto que, ao tratar das hipóteses de participação privada nos serviços públicos de saúde previstas pelo parágrafo único do artigo 199 da Constituição Federal, assim consignou:

Embora não se fale em concessão ou permissão da prestação de serviços de saúde complementar ao SUS pela iniciativa privada, é certo que nestes casos há uma delegação por parte do poder público para que o particular preste, em nome do Estado (SUS), em caráter complementar (...) o serviço público. 577

Tal entendimento implica reconhecer que a teoria jurídica acerca da terceirização na Administração Pública deve levar em conta a diferença entre o setor de saúde e as demais áreas de atuação do Estado, inclusive em relação a outros setores da área social. ${ }^{578}$ É importante destacar, como feito no Capítulo 3, a especificidade da disciplina constitucional dos serviços de saúde em relação a outras atividades prestacionais estatais e a outras atividades privadas comumente a eles relacionadas, como previdência social, 579 assistência social,, 50 educação, ${ }^{581}$ cultura, ${ }^{582}$ desporto, ${ }^{583}$ ciência e tecnologia, ${ }^{584}$ e meio ambiente. ${ }^{585}$ Enquanto atividades como assistência social e educação constituem serviços públicos constitucionalmente

576 Dentre os quais: (i) a concessão e permissão de serviços públicos - nos termos do artigo 175; (ii) os contratos de direito público e os convênios - nos termos do parágrafo primeiro do artigo 199.

577 MARQUES NETO, Floriano de Azevedo. Concessão de serviço público sem ônus para o usuário. In: WAGNER Júnior. Direito público: estudos em homenagem ao professor Adilson de Abreu Dallari. Belo Horizonte: Del Rey, 2004. p.337 (os grifos não constam do original).

578 Nesse aspecto, definições como a de Dora Maria de Oliveira Ramos devem ser aplicadas com ressalvas ao setor de saúde. Segundo a autora: "Na Administração Pública, a terceirização pode ser entendida como [a] transferência para entidade privada, por meio de contrato de prestação de serviços ou de fornecimento de bens, da execução de atividade que não constitua o núcleo substancial do Estado, conservando a terceirizando a gestão estratégica e operacional da atividade contratada." (RAMOS, Dora Maria de Oliveira. Terceirização na administração pública. Informativo de Licitações e Contratos - ILC, n.93, p.916-920, nov. 2001. p.917). No caso da saúde, trata-se, evidentemente, do que a autora se refere como núcleo substancial do Estado, o qual pode, por dispositivo constitucional expresso, ser terceirizado.

579 Artigos 202 e 203 da Constituição Federal.

580 Artigos 23, II; 203; e 204 da Constituição Federal.

581 Artigos 205 a 214 da Constituição Federal.

582 Artigos 23, III, IV e V; 215; e 216 da Constituição Federal.

583 Artigo 217 da Constituição Federal.

584 Artigos 218 e 219 da Constituição Federal.

585 Artigo 23, VI; e 225 da Constituição Federal. 
qualificados como tais, as demais atividades não têm sua prestação constitucionalmente elevada à responsabilidade do Estado, cuja função restringe-se ao seu incentivo ou proteção. Além disso, no caso dos serviços públicos acima relacionados, não existe menção constitucional expressa acerca de modelos de ajuste aptos a instrumentalizar a participação privada em sua prestação - como acontece no caso da saúde.

Como demonstrado no Item 3.1.1, ao prever a prestação de serviços de saúde no âmbito público, sob a responsabilidade estatal, a opção constitucional brasileira foi por submeter os prestadores privados a um regime no qual fossem respeitadas as diretrizes do subsistema público de saúde (SUS), definidas pelo Estado brasileiro tanto na lei quanto na própria Constituição. Com tal desiderato, o parágrafo único do artigo 199 do texto constitucional previu a participação privada nos serviços públicos de saúde por meio de contratos de direito público ou convênios.

\subsubsection{Contratos de direito público}

Pode-se entender por contrato, conforme Antunes Varela, "o acordo vinculativo resultante da fusão de duas ou mais declarações de vontade contrapostas, mas harmonizáveis entre si, destinado a estabelecer uma regulamentação de interesses entre as partes".586 Nesse sentido, onde houver um consenso acerca do regulamento que discipline relações entre dois ou mais sujeitos, com efeito de criar, modificar ou extinguir direitos e obrigações para uma ou para ambas as partes, é possível verificar a existência de um contrato. 587

A utilização de tal modalidade de ajuste pelo Estado nem sempre foi admitida pela teoria publicista, sendo que o reconhecimento da possibilidade de existência de contratos de direito público obteve relutância na doutrina do início do século passado. ${ }^{588}$ José Casalta

586 VARELA, J. M. Antunes. Direito das obrigações: conceito, estrutura e função da relação obrigacional, fontes das obrigações, modalidades das obrigações. Rio de Janeiro: Forense, 1977. p.119.

587 Sobre o tema, conferir também: ROPPO, Enzo. O contrato. Trad. Ana Coimbra e M. Januário C. Gomes. Coimbra: Almedina, 1988. p.73 e segs.

588 Nesse sentido destaca-se a posição de Otto Mayer, no direito alemão, para quem a posição de supremacia da Administração Pública e a possibilidade de impor sua vontade por meio de atos administrativos impediam a existência de contratos administrativos. Sobre o tema, conferir: MAYER, Otto. Derecho Administrativo Alemán. Trad. Horacio H. Heredia e Ernesto Krotoschin. Buenos Aires: De Palma, 1949. Tomo I. p.125 e segs (a obra original é de 1903). 
Nabais relaciona os argumentos mais comumente sustentados como óbice à contratualização pública:

(i) o Estado não se relaciona por meio de vínculos horizontais baseados no consenso, e sim por imposição de seu poder;

(ii) ausência de autonomia da vontade da Administração Pública para contratar;

(iii) incompatibilidade do ajuste com o princípio da legalidade;

(iv) incompatibilidade da rigidez contratual em face da mutabilidade do interesse público;

(v) impossibilidade de contratação de objetos pretensamente fora do comércio jurídico. 589

Não obstante, como assinala Orlando Gomes, tais características, quando existentes, refletem particularidades dos contratos públicos - e não diferenças em sua estrutura e função, ou nos princípios a que se subordinam. ${ }^{590}$ Assim, ainda que não haja identidade plena, o contrato de direito público deve ser tratado pela doutrina como espécie diversa daquele de direito privado - ambos integrantes de uma categoria geral do contrato. Essa é também a opinião de Cretella Júnior, para quem:

\begin{abstract}
Paralelos aos contratos de direito privado caminham os contratos de direito público que, entretanto, com aqueles não se confundem, se bem que, ambos, filiados à figura genérica do contrato, em seus matizes particulares, se repartem, dicotomicamente, pelos dois ramos principais da ciência jurídica. ${ }^{591}$
\end{abstract}

Nessa ordem de idéias, Orlando Gomes relaciona dentre as subespécies de contratos de direito público:

a) os que celebram entre si algumas pessoas jurídicas de direito público interno, tais como os estipulados entre a União e algum Estado-membro, entre unidades da federação, entre qualquer destas e um município ou entre municípios. Tais acordos se realizam para que as partes alcancem o mesmo fim;

b) os que o Estado conclui com particulares ou outros entes públicos para a satisfação de interesses comuns, implicando disposição de direitos subjetivos patrimoniais (...) - o que não e sucede com os acordos primeiramente enunciados;

589 NABAIS, José Casalta. Contratos fiscais: reflexões acerca de sua admissibilidade. Coimbra: Coimbra, 1994. p.17 e segs.

590 GOMES, Orlando. Os contratos e o direito público. Revista da Procuradoria Geral do Estado de São Paulo, São Paulo, n.10, p.46, jun. 1977.

591 CRETELLA JÚNIOR, José. Tratado de direito administrativo. Rio de Janeiro: Forense, 1967. v.3. p.32. 
c) os contratos administrativos que se ajustam entre a Administração Pública e particulares para execução e desempenho de atividade do Estado, de interesse geral, que este não pode ou não quer exercer diretamente. 592

No mesmo sentido encontra-se o pensamento de Pedro Gonçalves, para quem os contratos de direito público constituem uma categoria da qual fazem parte diversos contratos, como, por exemplo, o contrato administrativo, os contratos fiscais, os contratos de direito constitucional (entre Estados-membros de uma federação), e os tratados e acordos internacionais (entre Estados, e entre esses e organizações internacionais). ${ }^{593}$

Em que pese a possibilidade de adoção de diversos critérios para a classificação dos contratos de direito público, além das acima mencionadas, resta evidenciado, para os fins do presente estudo, que ao se referir a tal expressão em seu artigo 199, parágrafo primeiro, a Constituição Federal trata dos contratos administrativos, já que a competência tanto para a prestação direta quanto para a celebração de ajustes para a prestação privada de serviços públicos de saúde pertence à Administração Pública, ${ }^{594}$ a qual vai celebrar ajustes para delegação de tais atribuições ao particular.

Adota-se neste trabalho, em relação aos contratos administrativos, posição segundo a qual não é possível a classificação dual dos contratos celebrados pela Administração Pública em contratos (de direito privado) da Administração e contratos administrativos. Nesse sentido, concorda-se com Agustín Gordillo, para quem:

(...) não há duas categorias de contratos, civis e administrativos, senão toda uma gama suscetível de classificação, que começa desde a) contratos celebrados pela administração em um virtual pé de igualdade jurídica com outro sujeito de direito público ou privado, ou mesmo b), em situação de desvantagem; ou c) com ligeiras notas de direito público a favor da Administração e, por fim, d) contratos em que aparece um crescimento de potestades e privilégios estatais. 595

592 GOMES, Orlando. Os contratos e o direito público. Revista da Procuradoria Geral do Estado de São Paulo, São Paulo, n.10, p.45-46, jun. 1977.

593 GONÇALVES, Pedro. O contrato administrativo (uma instituição do direito administrativo do nosso tempo). Coimbra: Almedina, 2003. p.55. No mesmo sentido, entendendo o contrato administrativo como subespécie do contrato de direito público, confiram-se: CRETELLA JÚNIOR, José. Tratado de direito administrativo. Rio de Janeiro: Forense, 1967. v.3. p.40; e MONCADA, Luís S. Cabral de. Estudo de direito público. Coimbra: Coimbra, 2001. p.27.

594 Nos termos do artigo 18, inciso X da Lei n. ${ }^{\circ}$ 8.080/90, tal competência é da direção municipal do sistema público de saúde - SUS, representada, nos termos do artigo 9. ${ }^{\circ}$, inciso III da mesma lei, pela Secretaria de Saúde ou órgão equivalente, vinculados ao Poder Executivo local.

595 GORDILlO, Agustín. Tratado de Derecho Administrativo: Parte General. 7.ed. Belo Horizonte: Del Rey e Fundación de Derecho Administrativo, 2003. Tomo I. p.XI-14. 
Nessa perspectiva, entende-se que os contratos administrativos podem ser qualificados como tais, pelo simples motivo de que um dos pólos da relação jurídica instaurada é ocupado pela Administração Pública - e não apenas aqueles em que é possível a detecção no ajuste das denominadas cláusulas exorbitantes, ${ }^{596}$ cuja previsão, por envolver prerrogativas não-disponíveis, não é admitida em favor do contratante privado.

No ordenamento pátrio, os assim chamados pela doutrina contratos (de direito privado) da administração, em relação aos quais supostamente não seria possível o exercício do poder exorbitante da vontade estatal, constam previstos no parágrafo terceiro do artigo 62 da Lei Geral de Contratos - Lei n. ${ }^{\circ}$ 8.666, de 21 de junho de 1993 - que determina expressamente que tais poderes exorbitantes serão também aplicados aos contratos da administração no que couber ${ }^{597}$ Tal disposição confirma a pequena utilidade da distinção ora tratada, em especial considerando possibilidade legalmente expressa de - em havendo justificativa constitucional - exercer a Administração Pública seu poder de supremacia em qualquer relação contratual. Portanto, não é a existência expressa do que a doutrina denomina cláusulas exorbitantes em determinado instrumento negocial, em tampouco a possibilidade de sua previsão (a qual é genérica), que faz do ajuste um contrato administrativo; mas a participação do Estado em um dos pólos da relação - só justificada por um fim relacionado à consecução, ainda que indiretamente, dos direitos fundamentais. 598

596 Héctor Jorge Escola sustenta a existência do interesse público como critério para a existência de um contrato administrativo. Não obstante, além da dificuldade de definição de interesse público, apenas sua existência no caso concreto é que vai justificar objetivamente a presença da Administração Pública em qualquer modalidade de ajuste. Daí a opção por um critério objetivamente aferível - vinculado à posição subjetiva da Administração Pública em um dos pólos do ajuste. Sobre a opinião do referido autor, conferir: ESCOLA, Héctor Jorge. ÉI Interés público como Fundamento del Derecho Administrativo. Buenos Aires: De Palma, 1989. p.157-181.

597 Art. 62 (...) $\S 3 .^{\circ}$ Aplica-se o disposto nos arts. 55 e 58 a 61 desta Lei [que tratam das formalidades e prerrogativas exorbitantes da Administração Pública] e demais normas gerais, no que couber: I - aos contratos de seguro, de financiamento, de locação em que o Poder Público seja locatário, e aos demais cujo conteúdo seja regido, predominantemente, por norma de direito privado; II - aos contratos em que a Administração for parte como usuária de serviço público.

598 Mesmo porque, como se refere Fernando Dias Menezes de Almeida, por vezes as prerrogativas especiais previstas em contratos celebrados pela Administração Pública, ao invés de servir como mecanismo facilitador do alcance da finaldiade estatal, acaba por gerar ineficiência e acomodação adminsitrativa. Sobre o tema, conferir: ALMEIDA, Fernando Dias Menezes de. Contratos administrativos. In: PEREIRA JÚNIOR, Antonio Jorge; e JABUR, Gilberto Haddad (Coord.). Direito dos contratos II. São Paulo: Quartier Latin, 2008. p.196 e segs. 
Tal tomada de posição é decorrência lógica daquela subjacente ao entendimento adotado acerca dos serviços públicos. Em primeiro lugar, porque a riqueza de hipóteses em que há contratação pela Administração Pública não permite uma rígida dicotomia; em segundo lugar porque não se encontra na Constituição Federal qualquer indício de tal linha divisória.

Ao tratar da competência legislativa privativa da União, o texto constitucional, no inciso XXVII do artigo 22, faz menção expressa a todas as modalidades de contratação; e no inciso XXI do artigo 37, o dispositivo constitucional trata genericamente da contratação de obras, serviços, compras e alienações. Com isso não se quer dizer que há apenas um modelo de contratos administrativos ou que em todos eles devem estar dispostas as mesmas cláusulas. O que se quer dizer é que existe uma imensa variedade de contratos administrativos e que o regime por eles previsto varia na mesma proporção, conforme as condições do caso concreto. Além disso, voltando à analogia com o raciocínio levado a cabo acerca dos serviços públicos, ${ }^{599}$ enquanto naqueles pode-se encontrar o traço comum da responsabilidade estatal pela garantia da respectiva prestação, nos contratos administrativos o traço comum a todas as suas espécies consiste na presença, em um dos pólos da relação, da Administração Pública.

Dessa análise pode-se concluir que todo o contrato administrativo é um contrato de direito público, mas nem todo contrato de direito público é necessariamente um contrato administrativo. Além disso, em todo contrato administrativo, em que há de um lado a Administração Pública e de outro um agente privado, existe a possibilidade de exercício de poderes da Administração Pública, independente de sua previsão no instrumento contratual.

$\mathrm{O}$ direito positivo pátrio faz referência à figura contratual quando trata dos mais diversos ajustes dos quais participa a Administração Pública. O já assinalado artigo 22, inciso XXVII da Constituição Federal menciona a competência privativa da União para legislar sobre normas gerais de contratação em todas as suas modalidades, para as administrações públicas diretas, autárquicas e fundacionais da União, Estados e Municípios, o que, evidentemente, implica reconhecer a existência de diversas modalidades de contratos administrativos - todas elas sujeitas às normas gerais editadas pela União. Da mesma

599 Sobre o tema, conferir Item 3.2. 
forma, o inciso XXI do artigo 37 do texto constitucional, trata da contratação de obras, serviços, compras e alienações. ${ }^{600}$

Seguindo tal previsão, na seara infraconstitucional, a Lei n. ${ }^{0} 8.666 / 93$ traz a disciplina geral dos contratos da Administração Pública; as leis que regulamentam as concessões e permissões de serviços públicos dispõem que tais ajustes ocorrerão por meio de contratos; ${ }^{601}$ a lei que regulamenta os consórcios e convênios de cooperação entre os entes federados, previstos pelo artigo 241 da Constituição, ${ }^{602}$ dispõe sobre a celebração de contratos de consórcio, contratos de repasse e contratos de programa; 603 e a própria lei que regulamenta os contratos da Administração Pública prevê sua aplicação também, no que couber aos convênios. ${ }^{604}$

Entende-se, pois, com base na teoria contratual contemporânea - acolhida pelo ordenamento jurídico pátrio - que em ajustes nos quais há definição de um regime jurídico consensual (ainda que com maior ou menor predominância do interesse estatal, por meio do exercício de seu poder exorbitante) que vincule as relações entre a Administração Pública e um particular, há um contrato de direito público da espécie contrato administrativo. ${ }^{605}$ Há que se indagar, portanto, na legislação que regulamenta a contratação pública administrativa,

600 Também em sede constitucional pode-se mencionar o ajuste a ser celebrado para ampliação da autonomia gerencial, orçamentária e financeira de órgãos e entidades da Administração Pública, denominado contrato, pelo parágrafo oitavo da Constituição Federal pelo parágrafo oitavo do artigo 37 da Constituição Federal, adiante mencionado. Não obstante, como se verá, por tratar de um ajuste a ser celebrado entre duas entidades ou órgãos públicos, referido contrato, conhecido como uma das modalidades de contrato de gestão, não se enquadra, nos termos deste trabalho, na categoria contrato administrativo, mas em outra espécie de contrato de direito público.

601 Lei n. ${ }^{\circ} 8.987$, de 13 de fevereiro de 1995 e Lei n. ${ }^{\circ} 11.079$, de 30 de dezembro de 2004, que regulamentam o artigo 175 da Constituição Federal.

602 Art. 241. A União, os Estados, o Distrito Federal e os Municípios disciplinarão por meio de lei os consórcios públicos e os convênios de cooperação entre os entes federados, autorizando a gestão associada de serviços públicos, bem como a transferência total ou parcial de encargos, serviços, pessoal e bens essenciais à continuidade dos serviços transferidos (artigo com redação dada pela Emenda Constitucional n. ${ }^{\circ}$ 19, de 1998).

603 Lei n. ${ }^{\circ}$ 11.107, de 6 de abril de 2005. Sobre o tema, conferir: MEDAUAR, Odete; OLIVEIRA, Gustavo, Justino. Consórcios públicos: comentários à lei 11.107/2005. São Paulo: Revista dos Tribunais, 2006. p.20 e segs.

604 Lei n. ${ }^{\circ} 8.666$, de 21 de junho de 1993, art. 116, adiante analisado.

605 Nesse sentido, conferir: MEDAUAR, Odete. Convênios e consórcios administrativos. Boletim de Direito Administrativo, São Paulo, v.11, n.8, p.456 e segs., ago. 1995. 
em que medida sua utilização é adequada a proporcionar a participação privada nos serviços públicos de saúde que, como assinalado no Item 4.1.1, pode ter como objeto:

(i) um serviço ou um grupo de serviços internos relacionados à atividade-fim de uma entidade ou órgão público prestador de serviços de saúde;

(ii) a prestação de serviços por uma unidade privada dotada de infra-estrutura apta ao desenvolvimento das atividades ajustadas; ou

(iii) toda a gestão de uma unidade pública de saúde - incluindo, obviamente, atividades-fim, atividades-meio e atividades-acessórias.

Nesse prisma, a Constituição Federal determina que o regime jurídico aplicável às entidades contratadas (em qualquer modalidade) para a prestação de serviços públicos de saúde deve ser o mesmo daquele aplicável à prestação direta pelo Estado. ${ }^{606}$ No entanto, apenas o artigo 175 determina que a regulamentação da concessão e da permissão de serviços públicos ocorra na forma da lei, enquanto o parágrafo primeiro do artigo 199 refere-se apenas à submissão às diretrizes do SUS. Contudo, considerando:

(i) o próprio artigo 175 da Constituição, por analogia;

(ii) o disposto no artigo 22, XXVII da Constituição Federal, que atribui competência à União para estabelecer normas gerais de contratação em todas as modalidades; 607

(iii) o disposto no artigo 61, $\S 1 .^{\circ}$, II, $c$ da Constituição Federal, que atribui ao Presidente da República a competência para propor leis que disponham sobre a organização administrativa e os serviços públicos - e que deve ser aplicado por simetria a Estados, Distrito Federal e Municípios; ${ }^{608}$

606 Isso porque o parágrafo primeiro do artigo 199 da Constituição Federal determina que a participação complementar das instituições privadas no SUS deve ocorrer segundo diretrizes deste. Além disso, a própria Lei n. ${ }^{\circ} 8.080 / 90$, no já mencionado artigo $7 .^{\circ}$, relaciona uma série de diretrizes a serem observadas tanto pelos prestadores públicos quanto pelos serviços privados contratados ou conveniados.

607 Art. 22. Compete privativamente à União legislar sobre: (...) XXVII - normas gerais de licitação e contratação, em todas as modalidades, para as administrações públicas diretas, autárquicas e fundacionais da União, Estados, Distrito Federal e Municípios, obedecido o disposto no art. 37, XXI, e para as empresas públicas e sociedades de economia mista, nos termos do art. 173, § 1. ${ }^{\circ}$, III (inciso com redação dada pela Emenda Constitucional n. ${ }^{\circ}$ 19, de 1998).

608 Art. 60. (...) $\S 1 .^{\circ}$ - São de iniciativa privativa do Presidente da República as leis que: (...) II - disponham sobre: (...) b) organização administrativa e judiciária, matéria tributária e orçamentária, serviços públicos e pessoal da administração dos Territórios. 
(iv) o disposto nos artigos 23, II e 24, XII, que definem a competência a ser exercida pelos entes políticos no setor de saúde; 609 e

(v) o princípio federativo;

Não restam dúvidas de que a delegação de serviços públicos de saúde depende de autorização legal do ente federativo responsável pela prestação do serviço, observadas as diretrizes do SUS previstas na legislação federal ${ }^{610}$ e as normas gerais de contratação previstas em lei editada pela União, passíveis de suplementação legal por Estados, Distrito Federal e Municípios. ${ }^{611}$

4.3.1.1.1 Normas gerais de contratação administrativa: hipóteses de aplicação da Lei n. ${ }^{\circ} 8.666 / 93$ aos serviços públicos de saúde

A Lei n. ${ }^{\circ}$ 8.666, de 21 de junho de 1993 regulamenta os já mencionados artigo 22, inciso XXVII e artigo 37, inciso XXI da Constituição Federal, estabelecendo normas gerais sobre contratação de obras, serviços, compras e alienações no âmbito de qualquer dos poderes do Estado. Sua aplicação deve ser, portanto, subsidiária, a todos os demais modelos específicos de contratos administrativos.

A primeira das observações a ser tecida refere-se ao próprio conceito de contrato adotado pelo parágrafo único do artigo $2 .^{\circ}$ da Lei. n. ${ }^{\circ} 8.666 / 93,{ }^{612}$ segundo o qual, independente

609 Art. 23. É competência comum da União, dos Estados, do Distrito Federal e dos Municípios: (...) II - cuidar da saúde e assistência pública, da proteção e garantia das pessoas portadoras de deficiência. Art. 24. Compete à União, aos Estados e ao Distrito Federal legislar concorrentemente sobre: (...) XII previdência social, proteção e defesa da saúde.

610 Não se deve admitir, assim, a submissão da autonomia dos entes federativos a eventuais atos normativos infralegais editados pela direção nacional do SUS que disciplinem as relações entre os entes federativos e os prestadores privados de serviços públicos de saúde, tal qual prevê o dispositivo constante do artigo 16, inciso XIV, da Lei . $^{\circ}$ 8.080/90. Tal previsão legal deve ser interpretada como outorga de competência para que sejam estabelecidos parâmetros a serem seguidos pelos entes federativos, os quais disciplinarão as relações com prestadores privados de serviços públicos de saúde por meio de lei, editada de acordo com as peculiaridades locais.

611 Sobre a competência da direção nacional do SUS para regular as relações com a iniciativa privada, conferir Item 4.1.2.2.

612 Art. 2. ${ }^{\circ}$ As obras, serviços, inclusive de publicidade, compras, alienações, concessões, permissões e locações da Administração Pública, quando contratadas com terceiros, serão necessariamente precedidas de licitação, ressalvadas as hipóteses previstas nesta Lei. Parágrafo único. Para os fins desta Lei, considera-se contrato todo e qualquer ajuste entre órgãos ou entidades da Administração Pública e particulares, em que haja um acordo de vontades para a formação de vínculo e a estipulação de obrigações recíprocas, seja qual for a denominação utilizada. 
da denominação utilizada, é contrato todo ajuste em que haja a estipulação de obrigações recíprocas. Como ressaltado acima, a reciprocidade de deveres contratuais não compõe a essência do contrato, que pode gerar direitos ou deveres para apenas uma das partes - o que revela uma impropriedade da definição legal. Tal observação não passou despercebida por Odete Medauar, que assim consignou:

(...) a reciprocidade como contraprestação exata de obrigações não caracteriza todos os contratos, tanto que Limongi França arrola, como tipo de contrato, o unilateral, em que uma pessoa se obriga perante outra, sem que da parte desta haja qualquer contraprestação, dando como exemplo a doação pura e simples (...). ${ }^{613}$

De qualquer modo, no caso da saúde, caso o ajuste implique o dever da Administração Pública de pagar pelos serviços e o dever do particular em prestá-los, nos termos pactuados, haverá um contrato. Trata-se, pois, de um contrato em favor de terceiros (os usuários do serviço público), no qual há direitos e deveres para ambas as partes. ${ }^{614}$ A possibilidade de contratação de serviços públicos de saúde encontra-se albergada no artigo $6 .^{\circ}$ da Lei n. ${ }^{\circ} 8.666 / 93$, que assim define:

Art. 6. ${ }^{\circ}$ Para os fins desta lei, considera-se:

(...)

II - Serviço - toda atividade destinada a obter determinada utilidade de interesse para a Administração, tais como: demolição, conserto, instalação, montagem, a operação, conservação, a reparação, adaptação, manutenção, transporte, locação de bens, publicidade, seguro ou trabalhos técnico-profissionais.

Em que pese as atividades relacionadas no inciso voltarem-se, em sua imensa maioria, a atividades-meio e acessórias, vinculadas ao funcionamento interno e aos interesses da própria estrutura administrativa, os serviços públicos de saúde - atividades-fim do Estado - podem ser enquadrados no conceito de trabalhos técnico-profissionais. Além disso, a expressão tais como constante do dispositivo, deixa claro seu caráter exemplificativo.

613 MEDAUAR, Odete. Convênios e Consórcios Administrativos. Revista Jurídica da Procuradoria Geral do Município de São Paulo, São Paulo, n.2, p.78, jun. 1996. Ressalte-se que o contrato de doação, mencionado na citação acima, é previsto pelo artigo 17 da própria Lei n. ${ }^{\circ}$ 8.666/93. Nesse sentido, podese sustentar, com Orlando Gomes, que todo o contrato é um negócio jurídico bilateral do ponto de vista de sua formação - pois exige o concurso de duas (ou mais) vontades; já do ponto de vista dos efeitos o contrato pode ser unilateral ou bilateral, conforme a distribuição dos direitos e deveres no ajuste (GOMES, Orlando. Contratos. 20.ed. Rio de Janeiro: Forense, 2000. p.71).

614 Com bilateralidade tanto na formação do vínculo quanto na distribuição de direitos e obrigações. 
A propósito dos trabalhos técnico-profissionais, o artigo 13 da lei ora tratada traz uma relação do que entende por serviços técnicos especializados, ${ }^{615}$ os quais, caso apresentem natureza singular e sejam prestados por profissionais ou empresas de notória especialização, tornam inexigível procedimento licitatório, nos termos do artigo 25, inciso II da mesma lei. ${ }^{616}$ Insta ressaltar que o referido artigo 13 apresenta certa impropriedade, pois não trata de hipóteses de inexigibilidade de licitação - já que o artigo 25, inciso II cria outros requisitos para tanto, e não trata das hipóteses do artigo $6 .^{\circ}$, inciso II, que menciona trabalhos técnico profissionais, sem referência a sua especialização.

De todo modo, no que tange aos serviços de saúde, insta ressaltar que (i) tais serviços, como já assinalado, encontram-se albergados pelo conceito de trabalhos técnicoprofissionais previsto pelo artigo 6, inciso II (e pelo caráter não exaustivo de tal dispositivo); e (ii) que o artigo 13, apesar de não fazer referência expressamente à assistência à saúde, traz um rol meramente exemplificativo, ${ }^{617}$ sendo que os serviços de saúde, também são qualificados como especializados. ${ }^{618}$ Assim sendo, ao passo que tanto o artigo $6 .^{\circ}$, inciso II, quanto o artigo 13 da Lei n. ${ }^{\circ}$ 8.666/93 oferecem suporte jurídico à contratação de serviços de saúde, sua dicção delimita a extensão de tal possibilidade. É que, como colacionado acima, eventual contratação deve ocorrer apenas e tão-somente no que se refere a trabalhos técnico-profissionais relacionados aos serviços de saúde, de modo que eventuais atividades

615 Art. 13. Para os fins desta Lei, consideram-se serviços técnicos profissionais especializados os trabalhos relativos a: I - estudos técnicos, planejamentos e projetos básicos ou executivos; II - pareceres, perícias e avaliações em geral; III - assessorias ou consultorias técnicas e auditorias financeiras ou tributárias (inciso com redação dada pela Lei n. ${ }^{\circ} 8.883 / 94$ ); IV - fiscalização, supervisão ou gerenciamento de obras ou serviços; V-patrocínio ou defesa de causas judiciais ou administrativas; VI - treinamento e aperfeiçoamento de pessoal; VII - restauração de obras de arte e bens de valor histórico.

616 Art. 25. É inexigível a licitação quando houver inviabilidade de competição, em especial: (...) II - para a contratação de serviços técnicos enumerados no art. 13 desta Lei, de natureza singular, com profissionais ou empresas de notória especialização, vedada a inexigibilidade para serviços de publicidade e divulgação (os grifos não constam do original).

617 Nesse sentido, confiram-se, por exemplo: PEREIRA JÚNIOR, Jessé Torres. Comentários à lei das licitações e contratações da administração pública. 6.ed. Rio de Janeiro: Renovar, 2003. p.164; e JUSTEN FILHO, Marçal. Comentários à lei de licitações e contratos administrativos. 12.ed. São Paulo: Dialética, 2008. p.163. Ao defender seu entendimento, Marçal Justen Filho exemplifica o caso de um determinado profissional de saúde que tenha desenvolvido uma técnica cirúrgica inovadora. Nesse caso, tem razão o autor ao sustentar que não haveria justificativa para que se negasse a caracterização de tal serviço como um serviço técnico-profissional pelo simples fato de não constar relacionado no artigo 13 da Lei n. ${ }^{\circ} 8.666 / 93$.

$618 \mathrm{O}$ desenvolvimento da técnica médica, em movimento paralelo à consagração do direito à saúde e ao aumento dos custos do setor foi analisado, especialmente, no Item 2.1.2, acima. 
de apoio, como segurança e limpeza, também podem ser contratados com base na Lei n. ${ }^{\circ} 8.666 / 93$, mas por meio de instrumentos específicos para tanto. ${ }^{619}$

Há que se ressaltar, além disso, a inadequação da Lei n. ${ }^{\circ} 8.666 / 93$ para a contratação de serviços públicos de saúde, pois a disciplina dela constante, como se pode perceber dos regimes de contratação - empreitada ou tarefa - não é perfeitamente compatível com a prestação dos serviços ora tratados. ${ }^{620}$ De um lado, a própria lei refere-se à tarefa como pequenos trabalhos por preço certo; de outro, a noção de empreitada, como ressalta Sergio Pinto Martins, relaciona-se a uma atividade braçal, vinculada a um determinado resultado concreto, ${ }^{621} \mathrm{o}$ que não corresponde à natureza dos serviços de saúde.

Essa observação vai ao encontro de uma dificuldade, característica do serviço público de saúde, que reforça a inadequação da Lei n. ${ }^{\circ} 8.666 / 93$ para disciplina de sua contratação. Trata-se da necessidade de critérios específicos para a fiscalização e controle da prestação dos referidos serviços, os quais não se encontram previstos no mencionado diploma legislativo. Tal característica dos serviços de saúde foi assinalada por Maria Sylvia Di Pietro, nos seguintes termos:

\footnotetext{
Quando se trata de atividade de natureza econômica, o estabelecimento de metas e o respectivo controle são muito mais fáceis, porque tal tipo de atividade permite maior objetividade em sua programação. Quando se trata de atividade social, como educação e saúde, é muito mais problemática a fixação de metas objetivas, com o estabelecimento de parâmetros que permitam controle adequado de resultados. As metas têm que ser muito mais qualitativas do que quantitativas, e a apreciação dos resultados exige pessoal altamente especializado e, provavelmente, demanda maior tempo de atuação para permitir avaliação precisa. ${ }^{622}$
}

619 Como já assinalado, não faz parte do presente trabalho a análise de atividades desvinculadas da prestação direta de serviços de saúde, como limpeza e segurança, as quais seguem disciplina própria e aplicável indistintamente a qualquer setor de atividades públicas.

620 As modalidades de empreitada e de tarefa são previstas no artigo 6. ${ }^{\circ}$, VIII e artigo 10 , II da Lei n. ${ }^{\circ} 8.666 / 93$.

621 MARTINS, Sergio Pinto. A terceirização e o direito do trabalho. 8.ed. São Paulo: Atlas, 2007. p.55.

622 DI PIETRO, Maria Sylvia Zanella. Privatização e o novo exercício de funções públicas por particulares. In: MOREIRA NETO, Diogo de Figueiredo (Coord.). Uma avaliação das tendências contemporâneas do direito administrativo. Rio de Janeiro: Renovar, 2003. p.438. 
Em unidades hospitalares essa definição é ainda mais complexa, como assinala Sheyla Maria Lima:

Em particular, no caso das organizações de saúde a avaliação de seus produtos é
considerada de extrema dificuldade. Na verdade, a organização hospitalar comporta
múltiplos processos de trabalho, uns mais padronizáveis e outros menos, que,
combinados, resultam no principal produto hospitalar: o paciente tratado. ${ }^{623}$

Apesar da inadequação da lei ora analisada, pode-se concluir pela admissibilidade de celebração de contrato administrativo de prestação de serviços técnico-profissionais para a delegação de uma tarefa vinculada ao serviço público de saúde, nos termos da Lei n. ${ }^{\circ} 8.666 . / 93.624$

Tal observação conduz à visualização de duas hipóteses em que se verifica possível a contratação de serviços públicos de saúde nos termos da lei em referência:

(i) serviços a serem prestados internamente a uma unidade pública de saúde;

(ii) serviços a serem prestados por uma estrutura própria externa à unidade pública de saúde. ${ }^{625}$

Insta ressaltar, como referido acima, que tais hipóteses referem-se a tarefas específicas da área de saúde, sendo vedada, por esse meio, a contratação de um agente privado para o desempenho de todo um complexo de outras atividades acessórias que envolve a prestação dos serviços de saúde, ${ }^{626}$ o que encontra óbice expresso nos parágrafos primeiro e segundo do artigo 23 da Lei n. ${ }^{\circ} 8.666 / 93 .{ }^{627}$

623 LIMA, Sheyla Maria L. O contrato de gestão e a conformação de modelos gerenciais para as organizações hospitalares públicas. Revista de Administração Pública - RAP, Rio de Janeiro, v.30, n.5, p.132, set./out. 1996.

624 Nem sempre tal hipótese vai se concretizar no âmbito dos serviços públicos de saúde como, por exemplo, no caso da contratação de um laboratório de análises clínicas que vai desempenhar atividades conforme a demanda encaminhada por uma unidade de saúde - a qual manterá contato com os pacientes.

625 É o que se denomina na língua inglesa contract out e contract in, os quais podem ser traduzidos como contratação externa e contratação interna. Sobre o tema, conferir: PAVIGANI, Enrico; COLOMBO, Alessandro. Analysing Patterns of Health Care Provision. Annex 7: Contracting for Health Services. World Health Organization. Disponível em: <http://www.who.int/hac/techguidance/tools/disrupted sectors/module_07/en/index13.html>. Acesso em: 16. out. 2008.

626 Não são admissíveis, portanto, contratos de prestação de serviços de saúde, nos termos da Lei n. ${ }^{\circ} 8.666 / 93$, com objeto genérico do tipo: contratação de empresa especializada em serviços médicos hospitalares, incluindo fornecimento de pessoal médico, de enfermagem, administrativo e de apoio com fornecimentos de materiais, medicamentos, exames de diagnóstico complementares, fornecimento de alimentação e roupa lavada. Tal hipótese foi objeto de análise no seguinte trabalho: CASTRO, José Nilo de; RODRIGUES, Tais Erthal; REIS, Luciana Andrade. Contrato de prestação de serviços médicos hospitalares: impossibilidade 


\subsection{Contratação interna e concurso público}

Deve ser mencionado que a contratação de trabalhos técnico-profissionais de saúde pela Administração Pública, mesmo que desempenhados em uma unidade pública de saúde, não implica burla ao princípio do concurso público. Insculpido no artigo 37, inciso II da Constituição Federal, ${ }^{628}$ assim como o princípio da licitação, consignado no inciso XXI do mesmo artigo, ${ }^{629}$ o princípio do concurso público possui duplo objetivo:

(i) garantir a igualdade de condições entre pessoas físicas e entre pessoas físicas ou jurídicas, respectivamente, de participar das atividades estatais; e

(ii) obter a colaboração privada mais vantajosa para a administração, de acordo com os critérios previamente estabelecidos - seja no edital do concurso público, seja no edital de licitação. ${ }^{630}$

Como mencionado no Item 3.2.1.3, a lei é apta a qualificar, com fundamento constitucional, determinadas atividades, de acordo com condições sociais, econômicas e tecnológicas, que devem ter a garantia de sua prestação assumida pelo Estado. A mesma lei

de prorrogação para que se atenda ao interesse público. Revista Brasileira de Direito Municipal RBDM, Belo Horizonte, ano 7, n.21, p.183-184, jul./set. 2006.

627 Art. 23 (...) $\S 1 .^{\circ}$ As obras, serviços e compras efetuadas pela administração serão divididas em tantas parcelas quantas se comprovarem técnica e economicamente viáveis, procedendo-se à licitação com vistas ao melhor aproveitamento dos recursos disponíveis no mercado e à ampliação da competitividade, sem perda da economia de escala. $\S 2 .^{\circ} \mathrm{Na}$ execução de obras e serviços e nas compras de bens, parceladas nos termos do parágrafo anterior, a cada etapa ou conjunto de etapas da obra, serviço ou compra, há de corresponder licitação distinta, preservada a modalidade pertinente para a execução do objeto em licitação (Redação dada pela Lei n. ${ }^{\circ} 8.883$, de 1994) - (parágrafos com redação dada pela Lei n. ${ }^{\circ} 8.883$, de 1994).

628 Art. 37. (...) II - a investidura em cargo ou emprego público depende de aprovação prévia em concurso público de provas ou de provas e títulos, de acordo com a natureza e a complexidade do cargo ou emprego, na forma prevista em lei, ressalvadas as nomeações para cargo em comissão declarado em lei de livre nomeação e exoneração (inciso com redação dada pela Emenda Constitucional n. ${ }^{0}$ 19, de 1998).

629 Art. 37 (...) XXI - ressalvados os casos especificados na legislação, as obras, serviços, compras e alienações serão contratados mediante processo de licitação pública que assegure igualdade de condições a todos os concorrentes, com cláusulas que estabeleçam obrigações de pagamento, mantidas as condições efetivas da proposta, nos termos da lei, o qual somente permitirá as exigências de qualificação técnica e econômica indispensáveis à garantia do cumprimento das obrigações.

630 Tal comparação é evidente e realça a semelhança que há entre a prestação direta e indireta de serviços, possibilidade prevista pela própria Lei n. $^{\circ} 8.666 / 93$, em seu artigo $6 .^{\circ}$, incisos VII e VIII e artigo 10 , incisos I e II. O que varia, de modo mais claro é a estabilidade do vínculo do prestador do serviço e as formas de controle e fiscalização das atividades desempenhadas. De qualquer modo, insta assinalar o óbvio: o Estado por si não é capaz de prestar qualquer tipo de atividade, as quais serão levadas a cabo, necessariamente, por pessoas com as quais são estabelecidas diversas modalidades de vínculos dentre os quais aqueles que se estabelecem por meio de concurso público ou de licitação. 
deve disciplinar as formas de prestação do respectivo serviço, podendo autorizar a transferência de sua execução a entidades particulares que o farão nos termos da lei e do contrato de delegação a ser celebrado. No caso da saúde, há qualificação constitucional do serviço como público, sendo que a regulamentação do setor encontra-se, em grande parte, plasmada na própria Constituição e na Lei n. ${ }^{\circ} 8.080 / 90$. Assim sendo, ao prever o texto constitucional que a execução dos serviços de saúde ocorrerá diretamente ou por meio de terceiros, a própria Constituição estabeleceu (o que a lei, em outros casos, poderia fazer) a possibilidade de contratação de determinados serviços de saúde a serem prestados no interior de unidades públicas de saúde.

A organização da atividade médica, como se sabe, possui características próprias, decorrentes de seu processo de trabalho e do ambiente em que se insere, o que faz dela uma das atividades mais complexas do mundo organizacional. ${ }^{631}$ Nessa perspectiva, segundo Pedro Ribeiro Barbosa:

Essa noção de complexidade encerra pelo menos duas dimensões, uma primeira relacionada à organização do trabalho em si, considerando tanto o processo quanto o produto. A segunda, em conseqüência, decorre das exigências para sua condução, o que significa a coordenação das ações específicas de cada parte desse trabalho, procurando atingir produtos e resultados globais em termos de eficiência e eficácia. Portanto, a perspectiva de construção de modelos gerenciais [e jurídicos] exige uma compreensão acerca da natureza particular de sua complexidade. ${ }^{632}$

Tal compreensão implica reconhecer que em algumas especialidades a rotina de trabalhos e a execução de serviços por meio de equipes fazem com que a rigidez do regime estatutário, mesmo do regime trabalhista, nem sempre seja adequada ao bom funcionamento dos serviços. Daí a possibilidade, decorrente de uma necessidade específica, de terceirização de determinadas tarefas a pessoas jurídicas que se encarreguem de garantir a efetiva prestação do serviço. ${ }^{633}$

631 LIMA, Sheyla Maria L. O contrato de gestão e a conformação de modelos gerenciais para as organizações hospitalares públicas. Revista de Administração Pública - RAP, Rio de Janeiro, v.30, n.5, p.104, set./out. 1996.

632 BARBOSA, Pedro Ribeiro. Gestão de hospitais públicos: maior autonomia gerencial, melhor performance organizacional com apoio em contratos de gestão. Revista do Serviço Público - RSP, ano 47, v.120, n.2, p.72, maio/ago. 1996.

633 Com tal raciocínio, a terceirização interna de determinados serviços médicos especializados deve ocorrer, sobretudo, por meio de pessoas jurídicas - as quais assumirão a responsabilidade, nos termos contratuais, de garantir a continuidade dos serviços. 
Não raro médicos contratados entram em férias e durante determinado período alguns procedimentos - como cirurgias, por exemplo - simplesmente deixam de ser realizados. Ou então, um ou mais profissionais de saúde pedem exoneração e o serviço fica parado até que seja realizado novo concurso público, ${ }^{634}$ para reposição de tais cargos ou empregos. Isso tudo sem contar a dificuldade que muitos gestores, em especial nos municípios de menor porte, enfrentam no que se refere à remuneração oferecida aos profissionais de saúde, a qual deve respeitar uma série de limitações impostas aos servidores públicos, e que acabam não atraindo o interesse de determinado profissionais especializados nesta ou naquela área. ${ }^{635}$

Por essa série de motivos, considerando o que consta expresso no artigo 197 da Constituição Federal e considerando que a exigência de concurso público é voltada à contratação de servidores públicos e não de toda e qualquer prestação a ser fornecida pelo Estado - em especial no caso da saúde, em que a própria Constituição prevê hipótese diversa - não resta fundamento ao argumento de que a contratação de serviços técnicos, profissionais e especializados, nos termos da Lei n. ${ }^{\circ}$ 8.666/93, para o desenvolvimento de tais atividades no interior de uma unidade pública de saúde configura qualquer atentado ao princípio do concurso público. ${ }^{636}$

634 Ou mesmo a contratação por tempo determinado para atender à necessidade temporária de excepcional interesse público, conforme previsto pelo inciso IX do art. 37 da Constituição Federal e regulamentado pela Lei n. $^{\circ} 8.745$, de 9 de dezembro de 1993, que não menciona a possibilidade de contratação de serviços de saúde (exceto atividades finalísticas do Hospital das Forças Armadas, nos termos do artigo $\left.2 .^{\circ}, \mathrm{VI}, d\right)$. Tal hipótese de contratação, por uma série de motivos que não cumpre aqui serem analisados, acaba, em grande medida, tornando-se, indevidamente, o modelo regular de contratação de determinadas atividades. Sobre o tema, conferir ainda posicionamento do STF acerca da impossibilidade de tal contratação nos casos de atividades permanentes: BRASIL. Supremo Tribunal Federal, Ação Direta de Inconstitucionalidade 2987/SC, Tribunal Pleno, Rel. Min. Sepúlveda Pertence, Diário de Justiça da União, 02 abr. 2004.

635 Sobre o tema, conferir: MÂNICA, Fernando Borges. O convênio como vínculo apto a instrumentalizar parceria público-privada para prestação de serviços de saúde em unidade hospitalar de média e alta complexidades. Revista de Direito do Terceiro Setor - RDTS, Belo Horizonte, ano 2, n.4, p.123-140, jul./dez. 2008.

636 Ressalte-se que, nos termos do que se consignou acima, a contração nos termos da Lei n. ${ }^{\circ} 8.666 / 93$ não se refere à mera interposição de mão-de-obra, mas a contrato de prestação de serviços. A principal diferença entre ambas as espécies de terceirização é a de que na mera alocação de mão-de-obra, é que nesta encontram-se presentes os quesitos que caracterizam a relação de trabalho, tais quais subordinação, pessoalidade, dependência econômica e habitualidade. 
Nesse sentido, em consonância com a análise promovida no Item 2.3.3, tem razão Marçal Justen Filho ao sustentar que:

É fundamental eliminar o preconceito de que as organizações estatais possuem
justificativa de existência em si mesmas. O Estado não existe para satisfazer suas
estruturas burocráticas internas nem para realizar interesses exclusivos de uma
classe dominante (qualquer que seja ela). (...) O direito administrativo - e o
Estado, assim como outras instituições não-governamentais que desempenham
atividades similares - somente se justificam como instrumentos para a realização
de direitos fundamentais, entre os quais avulta a dignidade humana. (...) O direito
administrativo disciplina a atividade administrativa de satisfação dos direitos
fundamentais, seja ela desempenhada pelo Estado ou por entidades não estatais.
O relevante, portanto, é a natureza da atividade e os fins a que ela se norteia, não
a qualidade do sujeitos que a desenvolve. ${ }^{637}$

Insta reconhecer que a prestação de serviços por servidores concursados nem sempre se revela possível (ou mesmo mais adequada) à efetiva prestação do serviço público de saúde. Desse modo, a contratação de terceiros nos termos da Lei n. ${ }^{\circ}$ 8.666/93 (apesar de sua inadequação ao serviço público de saúde) - por meio de procedimento licitatório - torna-se a opção a ser tomada pelo administrador público. Afinal, o serviço de saúde pública não é atribuição exclusiva do Estado, muito menos atribuição exclusiva de servidores ou empregados públicos. ${ }^{638}$

637 JUSTEN FILHO, Marçal. Curso de direito administrativo. São Paulo: Saraiva, 2005. p.3-4.

638 Entendimentos em sentido contrário são encontrados com freqüência na doutrina e na jurisprudência. A seguinte fundamentação, consignada em sentença prolatada por uma das Varas da Fazenda Pública do Estado do Rio de Janeiro, e mantida com seus fundamentos pelo Tribunal de Justiça daquele Estado, pode ser mencionada para sintetizar a exata compreensão que se busca combater no presente trabalho: "(...) Observa-se ainda, que a administração pública, é regida pelo princípio da eficiência, fato estritamente vinculada a prévia aprovação em concurso público, onde é demonstrado que o agente que irá prestar o serviço público, é o mais capacitado para o ato. O Estado ao prestar o serviço de saúde, deve faze-lo por agentes que integram cargos públicos, nas formas previamente previstas pelo Legislador Constituinte. Qualquer norma infraconstitucional, que permita a delegação e terceirização da prestação do serviço de saúde diretamente prestado pelo Poder Público, não encontra-se em consonância com os preceitos constitucionais e por via de conseqüência, será inconstitucional. A execução dos serviços de saúde diretamente realizada pelo Poder Público, não pode ser terceirizada ou delegada, por ser o serviço público indelegável, e não é passível de transferência ao particular. O que pode ocorrer, é o particular ser autorizado pelo Poder Público a exercer atividades inerentes a saúde, em órgão de execução próprio e desvinculados dos órgãos de execução do Poder Público. O legislador infraconstitucional, permitiu que nos casos em que haja insuficiência de servidores públicos, para garantir a cobertura assistencial a população de uma determinada área, recorrer aos serviços ofertados pela iniciativa privada. Deve ser observado, que tal medida é extremamente excepcional, pois deve a Administração Pública, em observância a execução dos serviços de saúde, realizar os concursos públicos necessários a lotarem os cargos públicos existentes, e no caso dos mesmos serem insuficientes, diligenciar a criação através de lei, de novos cargos para atender a demanda do serviço público. (....." (RIO DE JANEIRO (ESTADO). Juízo de Direito da 5. ${ }^{\text {a }}$ Vara da Fazenda Pública. Juiz de Direito Marcello de Sá Baptista). Sobre a questão, conferir também o acórdão que manteve a sentença por seus próprios fundamentos: RIO DE JANEIRO (ESTADO). Tribunal de Justiça. Nona Câmara Cível. Apelação Cível n. ${ }^{\circ}$ 2322/2002. Relator: Desembargador Joaquim Alves de 
É evidente, ressalte-se uma vez mais, que o permissivo legal e constitucional restringe-se à contratação de trabalhos técnico-profissionais, caracterizados como tarefas, e não mera interposição de mão-de-obra, a qual encontra objeção, inclusive, pela Justiça do Trabalho. ${ }^{639}$ Resta claro, portanto, que não incide sob a hipótese o disposto no parágrafo segundo do artigo 37 da Constituição Federal, que prevê a nulidade do ato de nomeação em cargo ou emprego público sem a realização do respectivo concurso. ${ }^{640}$

\subsection{Contratação externa, licitação e credenciamento}

A questão do procedimento licitatório previsto pela Lei n. ${ }^{\circ} 8.666 / 93$, no que tange à contratação dos serviços de saúde, revela outra inadequação da lei em referência ao setor ora tratado. Como já mencionado, a formalidade do procedimento, aliada aos critérios de julgamento - criados com o objetivo de proporcionar aferição das melhores propostas em serviços que apresentem resultado concretamente aferível - não são os mais adequados para a contratação de tais serviços. Sobre o tema, Carlos Ari Sundfeld, referindo-se ao DecretoLei n. ${ }^{\circ} 2.300 / 1986$ e à Lei n. $.^{\circ} 8.666 / 93$ que o substituiu, explica que tais características decorrem do momento histórico em que se vivia à época da edição dos referidos atos normativos. Segundo o autor:

Brito, julgamento em 30 de fevereiro de 2002. O processo, que trata de contratação de cooperativa para prestação de serviços públicos de saúde, encontra-se pendente de julgamento, em sede de Recurso Extraordinário, perante o Supremo Tribunal Federal.

639 O tema é tratado na seara trabalhista pela Súmula n. 331 do Tribunal Superior do Trabalho, que assim dispõe: CONTRATO DE PRESTAÇÃO DE SERVIÇOS. LEGALIDADE (mantida) - Res. 121/2003, DJ 19, 20 e 21.11.2003. I - A contratação de trabalhadores por empresa interposta é ilegal, formando-se o vínculo diretamente com o tomador dos serviços, salvo no caso de trabalho tem-porário (Lei $n^{\circ}$ 6.019, de 03.01.1974). Súmulas A-97. II - A contratação irregular de trabalhador, mediante empresa interposta, não ge-ra vínculo de emprego com os órgãos da administração pública direta, indireta ou fundacional (art. 37, II, da CF/1988). III - Não forma vínculo de emprego com o tomador a contratação de serviços de vigilância (Lei $\mathrm{n}^{\circ}$ 7.102, de 20.06.1983) e de conservação e limpeza, bem como a de serviços especializados ligados à atividade-meio do tomador, desde que ine-xistente a pessoalidade e a subordinação direta. IV - O inadimplemento das obrigações trabalhistas, por parte do empregador, implica a responsabilidade subsidiária do tomador dos serviços, quanto àquelas obrigações, inclusive quanto aos órgãos da administração direta, das autarquias, das fundações públicas, das empresas públicas e das sociedades de economia mista, desde que hajam participado da relação processual e constem também do título executivo judicial (art. 71 da Lei $n^{\circ}$ 8.666, de 21.06.1993). Tal determinação, ressalte-se, não se aplica ao caso ora tratado, em que a Administração Pública contrata a prestação de determinado serviço de saúde, mesmo que internamente a uma unidade pública. Sobre o tema, conferir: SOUTO, Marcos Juruena Villela. Direito administrativo das concessões. 5.ed. Rio de Janeiro: Lumen Júris, 2004. p.355 e segs.

640 Art. 37 (...) $\S 2 .^{\circ}$ - A não observância do disposto nos incisos II [que trata da investidura em cargo ou emprego público por meio de concurso público] e III implicará a nulidade do ato e a punição da autoridade responsável, nos termos da lei. 
Todas essas normas (...) foram feitas tendo como preocupação central os contratos então importantes: as empreitadas de obra pública (o chamado 'contrato de obras'). $\mathrm{O}$ resultado foi uma disciplina normativa exigindo rigidez no procedimento, objetividade absoluta no julgamento (em regra, feita pelo menor preço, e a definição prévia, pela Administração, de todos os detalhes das prestações do contratado (...). ${ }^{641}$

Nesse contexto, considerando a inadequação da Lei n. $^{\circ} 8.666 / 93$ e sob a justificativa de que quanto mais prestadores privados vinculados ao sistema público houver, maior a cobertura e mais eficiente o subsistema público - os gestores locais costumam utilizar para a contratração de prestadores privados externos o procedimento conhecido como credenciamento.

Ainda que não mencionado expressamente na Lei n. ${ }^{\circ} 8.666 / 93,{ }^{642}$ o credenciamento deve ser entendido, no âmbito do serviço público de saúde, como o procedimento realizado para a contratação de prestadores privados de serviços de saúde no caso em que caracterizada a inexigibilidade de licitação, ${ }^{643}$ em face da opção pela contratação do maior número de prestadores possível - o que implica a impossibilidade de competição. ${ }^{644}$

É importante ressaltar, contudo, que devem ser previstos em edital, nos termos da Lei n. ${ }^{\circ} 8.666 / 93$, os requisitos a serem cumpridos pelos prestadores privados, ${ }^{645}$ bem como

641 SUNDFELD, Carlos Ari. Guia jurídico das parcerias público-privadas. In: privadas. São Paulo: Malheiros, 2005. p.20.

Parcerias público-

642 Pode-se encontrar menção ao credenciamento no setor de saúde na já referida Lei n. ${ }^{\circ} 6.229 / 75$, que previa em seu artigo 1. ${ }^{\circ}$, inciso II, alínea $c$, a competência do Ministério da Previdência e Assistência Social para: credenciar, para integrarem o subsistema público, instituições de finalidade não lucrativa que prestem serviços de saúde às pessoas. Note-se que na alínea seguinte, consta a competência do mesmo órgão para: prestar diretamente serviços de saúde às pessoas, ou contrata-los com entidades de fins lucrativos ou não, sujeitando-as a fiscalização permanente.

643 Nos termos do caput do artigo 25 da lei em referência, que assim dispõe: Art. 25. É inexigível a licitação quando houver inviabilidade de competição (...).

644 Deve ser ressaltada a existência de outras hipóteses em que a figura do credenciamento é utilizada, como nos casos em que se atribui a execução material de atividades relacionadas ao exercício do poder de polícia. Sobre o tema, conferir: DALLARI, Adilson de Abreu. Credenciamento. In: DALLARI, Adilson de Abreu; MELLO, Celso Antonio Bandeira de (Org.). Estudos em homenagem a Geraldo Ataliba. São Paulo: Malheiros, 1997. p.38-54.

645 Ao tratar do credenciamento de entidades privadas para a prestação de serviços de saúde para seus próprios servidores, o Tribunal de Contas da União fixou uma série de requisitos a serem observados em tal procedimento, os quais podem ser utilizados como parâmetro para o procedimento de contratação no âmbito público: "1 - dar ampla divulgação, mediante aviso publicado no Diário Oficial da União e em jornal de grande circulação local, podendo também a Administração utilizar-se, suplementarmente e a qualquer tempo, com vistas a ampliar o universo dos credenciados, de convites a interessados do ramo que gozem de boa reputação profissional; 2 - fixar os critérios e exigências mínimas para que os interessados possam credenciar-se, de modo que os profissionais, clínicas e laboratórios que vierem a ser credenciados tenham, de fato, condições de prestar um bom atendimento, sem que isso signifique restrição indevida ao credenciamento; 3 - fixar, de forma criteriosa, a tabela de preços que remunerará os 
os termos do contrato a ser celebrado, com o respeito ao regime previsto nos artigos 54 e seguintes da lei referida. Ressalte-se que o edital de credenciamento pode prever prazos para apresentação de propostas, de modo que, enquanto vigentes os contratos dele decorrentes e inexistente a necessidade de celebração de novos ajustes - não há que se manter a possibilidade permanente de credenciamento de novos prestadores. Afinal, a ordem constitucional da participação privada nos serviços públicos de saúde demanda a delimitação e o controle do número de prestadores privados dos respectivos serviços. ${ }^{646}$

Assim, os agentes privados credenciados devem celebrar, nos termos do que se tem assinalado, contrato administrativo com o gestor estatal dos serviços públicos de saúde. Credenciamento, implica, portanto, contratação. Na hipótese, os usuários dos serviços terão a oportunidade de escolha dentre os agentes privados contratados (credenciados), quais serão remunerados pela prestação de cada serviço. Essa condição, como se pode perceber, assemelha-se à noção de delegação de serviços públicos em caráter competitivo. Afinal, havendo mais de um prestador, haverá competição na busca de usuários de seus serviços.

Levando adiante o raciocínio, como se verá adinate, pode-se aproximar a contratação de serviços públicos de saúde em unidades externas às estruturas públicas à própria concessão de serviços públicos, a qual, como se verá, deve ser visualizada como o trespasse de toda a gestão de um serviço ao particular.

diversos itens de serviços médicos e laboratoriais e os critérios de reajustamento, bem assim as condições e prazos para o pagamento dos serviços faturados; 4 - consignar vedação expressa do pagamento de qualquer sobretaxa em relação à tabela adotada, ou do cometimento a terceiros (associação de servidores, p. ex.) da atribuição de proceder ao credenciamento e/ou intermediação do pagamento dos serviços prestados; 5 - estabelecer as hipóteses de descredenciamento, de forma que os credenciados que não estejam cumprindo as regras e condições fixadas para o atendimento, sejam imediatamente excluídos do rol de credenciados; 6 - permitir o credenciamento, a qualquer tempo, de qualquer interessado, pessoa física ou jurídica, que preencha as condições mínimas exigidas; 7 - prever a possibilidade de denúncia do ajuste, a qualquer tempo, pelo credenciado, bastando notificar a Administração, com a antecedência fixada no termo; 8 - possibilitar que os usuários denunciem qualquer irregularidade verificada na prestação dos serviços e/ou no faturamento; e 9 - fixar as regras que devam ser observadas pelos credenciados no atendimento (como p. ex. proibição de que o credenciado exija que o usuário assine fatura ou guia de atendimento em branco)." (BRASIL. Tribunal de Contas da União. Processo n. ${ }^{\circ}$ 016.522/95-8. Plenário. Relator: Ministro Homero Santos. Diário Oficial da União, 28 dez. 1995, p.22549. Disponível em: $<\mathrm{http}$ :/contas.tcu.gov.br/portaltextual/ServletTcuProxy>. Acesso em: 11 nov. 2008).

646 Sobre o tema, conferir: ARAGÃO, Alexandre Santos. Delegações de serviços públicos. Revista de Direito da Energia, a. IV, n. 6, nov. 2007, p. 124 e segs.; e MARQUES NETO, Floriano de Azevedo. Público e privado no setor de saúde. Revista de Direito Público da Economia, Belo Horizonte, ano 3 , n.9, p.126, jan./mar. 2003. 
Não obstante, críticas são tecidas contra o credenciamento dos prestadores privados de saúde por duas grandes ordens de motivos. A primeira refere-se ao fato de que os credenciados, historicamente, acabam deixando de celebrar os contratos de prestação de serviços, em evidente ilegalidade, já ressaltada. A segunda - ligada à primeira - decorre do fato de que o credenciamento de entidades privadas prestadoras de serviços públicos de saúde sofre grande influência do interesse dos próprios prestadores, que buscam ter seus serviços ofertados também no âmbito público, e não das necessidades detectadas pelo gestor do sistema. ${ }^{647}$ Nesse segundo aspecto é que insurgiu o movimento sanitário na defesa da adoção dos contratos de direito público para a disciplina das relações com prestadores privados - tal qual prevê hoje a Constituição Federal. ${ }^{648}$

No Manual de Atuação Jurídica em Saúde Pública editado pelo Ministério da Saúde em 2003 também consta crítica às relações entre a Administração Pública e os prestadores privados de serviços de saúde, baseadas na ausência de formalização de contratos e no mero credenciamento dos serviços, tanto antes quanto depois da Constituição Federal de 1988:

\begin{abstract}
A relação do Estado brasileiro com o setor de serviços de saúde, apesar de mais de uma década de uma nova ordem institucional sobre o sistema, ainda é marcada por vícios clientelistas e muita promiscuidade institucional, o que a faz se transformar num problema de gestão difícil de ser enfrentado no SUS. Vários fatores interferem diretamente nesta questão. Dentre eles, a lógica do financiamento que, ao longo do século passado, privilegiou o investimento nas instituições privadas e o financiamento do seu custeio, baseado na compra de serviços hospitalares (privados), na lógica da 'compra de procedimentos médicos' como se mercadoria fossem (...).

Na prática da gestão do sistema, especialmente do Sistema Municipal de Saúde, onde os prestadores privados de serviços de saúde exercem maior poder de pressão, por motivos óbvios, mas também, no âmbito dos Sistemas Estaduais, existe uma resistência imensa em se submeterem à regulação administrativa (contratação, controle e avaliação) e ao controle social do serviço como parte do Sistema único. Resistem que estes serviços sejam de 'relevância pública' e que a relação com o setor público deva se dar pelas 'diretrizes do poder público' e com 'contratos de direito público'. Preferem ser chamados de 'credenciados' e não ter vínculo formalizado com o sistema, porque a demanda chegará de qualquer maneira e quanto mais 'precarizada' estiver a relação com o poder público, maiores são as possibilidades de comercializar a relação com os usuários. ${ }^{649}$
\end{abstract}

647 Além disso, pode-se mencionar que, ao passo que um grande número de prestadores de serviços públicos de saúde oferece, ao menos em tese, maior facilidade de acesso às pessoas, a fiscalização da prestação dos respectivos serviços torna-se acentuada.

648 Sobre o tema, conferir Item 3.1.2.

649 BRASIL. Ministério da Saúde. Secretaria de Gestão do Trabalho e da Educação na Saúde. Departamento da Educação na Saúde. Direito sanitário e saúde pública: manual de atuação jurídica em saúde pública e coletânea de leis e julgados em saúde. ARANHA, Márcio Iorio (Org.). Brasília: Ministério da Saúde, 2003. v.2. p.106 e 108 . 
Tais insurgências corroboram a necessidade - não obstante seja admissível a inexigibilidade de realização de certame nos casos em que o gestor do sistema decida em determinado momento, nos termos da política pública adotada, pela contratação de um número irrestrito de prestadores privados - de que com cada um dos prestadores seja firmado um contrato administrativo no qual constem os direitos e deveres de cada uma das partes.

Além disso, a possibilidade de contratação de prestadores privados de serviços públicos de saúde para exercício de suas atividades em estruturas públicas - contratação interna - por meio de credenciamento revela-se em grande medida prejudicada, haja vista a provável possibilidade de existência de um maior número de prestadores interessados do que comporta a estrutura em que os serviços serão prestados. Nesse caso, há que se promover o certame licitatório, tal que previsto na Lei n. ${ }^{0} 8.666 / 93$, em que pese sua inadequação para a melhor escolha do prestador privado dos serviços públicos de saúde, como já assinalado.

\subsubsection{A natureza contratual dos convênios com a iniciativa privada}

Além dos contratos de direito público, o parágrafo primeiro do artigo 199 da Constituição Federal menciona a figura dos convênios como modalidade de vínculo apto a proporcionar a participação privada nos serviços públicos de saúde. A natureza contratual dos convênios pode ser comprovada por meio da análise da teoria dos contratos, tal qual sua construção originária no direito privado, sua transposição para o direito público e sua atual alocação como categoria da teoria geral do direito.

A dicotomia entre contratos e convênios na doutrina brasileira parece ter origem em uma distinção insuficientemente importada do direito privado. Naquela seara jurídica, é clássica a distinção entre os contratos de intercâmbio e os contratos de comunhão de escopo, sob o argumento de que, enquanto nos primeiros haveria oposição de interesses, nos segundos ocorreria soma de esforços para um objetivo comum. 650

$650 \mathrm{Na}$ doutrina publicista brasileira, a dicotomia foi analisada por Eros Grau, que consignou: "Se nos contratos de intercâmbio o elemento fundamental é o sinalagma - vínculo de recíproca dependência entre as obrigações do contrato bilateral -, na associação, como na sociedade e no consórcio, o elemento fundamental é o escopo (objetivo) comum." Assim, segundo o autor, ao contrário dos contratos de intercâmbio, nos quais os interesses das partes são opostos (o prejuízo dele é meu lucro), nos contratos de comunhão de escopo há paralelismo de interesses. Nas palavras do autor: "Se um dos contratantes sofre prejuízo, os outros também o suportam. Do espírito de solidariedade de interesses que os caracteriza, o lema: a vantagem dele é a minha vantagem, a minha vantagem é a sua vantagem." (GRAU, Eros. Licitação e contrato administrativo (estudos sobre a interpretação da lei). São Paulo: Malheiros, 1995. p.91-92). 
Tal análise pode ser encontrada, por exemplo, em Tullio Ascarelli, que vincula $a$ identidade de objetivos aos contratos plurilaterais, ${ }^{651}$ e em Rudolf von Jhering, que associa tal modalidade de ajuste aos contratos de associação. Nas palavras de Jhering:

A distinção lógica destas duas formas de vida comercial assenta na distinção entre a diversidade e a identidade do fim. No escambo, a finalidade de um é diversa da do outro, e justamente aí reside a razão por que eles trocam; na sociedade, o fim, o alvo é o mesmo, e exatamente em função disso é que eles se associam. ${ }^{652}$

Entretanto, é necessário ressaltar, como fez Tullio Ascarelli, que tanto nos contratos de associação quanto nos contratos de troca, é possível notar a presença de interesses antagônicos das partes envolvidas. Segundo o autor:

\begin{abstract}
Por um lado, parece-me inegável que, na constituição da sociedade, as várias partes têm interesses antagônicos, exatamente como nos contratos de escambo; por exemplo, no que respeita a avaliação das respectivas contribuições; à determinação da respectiva ingerência na administração; à distribuição dos lucros e das perdas. Cada sócio visa a tirar da própria contribuição o máximo de lucro, pondo-se, destarte, em conflito com os demais. No contrato de sociedade o direito é tão consciente deste contraste que intervém (com as normas sobre a sociedade leonina) para limitar equitativamente as possíveis desproporções entre os sócios. ${ }^{653}$
\end{abstract}

Nesse sentido, Ascarelli buscou demonstrar que tanto uma modalidade quanto outra são espécies de um mesmo gênero contratual - assim como o convênio deve ser entendido como uma espécie de contrato. Entretanto, a doutrina administrativista pátria (com repercussão normativa) manteve a distinção de que os convênios (para Ascarelli, contratos

651 Segundo Ascarelli: "À pluralidade corresponde a circunstância de que os interesses contrastantes das várias partes devem ser unificados por meio de uma finalidade comum; os contratos plurilaterais aparecem como contratos de comunhão de fim. Cada uma das partes obriga-se, de fato, para com todas as outras, e para com todas as outras adquire direitos; é natural, portanto, coordena-los, todos, em torno de um fim, de um escopo comum. O conceito de 'fim ou escopo' do contrato, quando entendido em sentido genérico, identifica-se com a função típica do próprio contrato (por exemplo, troca de coisa por preço); permanece, em princípio, no campo dos motivos, quando entendido em relação a uma atividade ulterior das partes, para cuja realização seja concluído o contrato. Nos contratos plurilaterais, ao contrário, o escopo, em sua precisa configuração em cada caso concreto (por exemplo, constituição de uma sociedade para a compra e venda de livros), é juridicamente relevante. Constitui o elemento 'comum', 'unificador' das várias adesões, e concorre para determinar o alcance dos direitos e deveres das partes." (ASCARELLI, Tullio. Problemas das sociedades anônimas e direito comparado. Campinas: Bookseller, 2001. p.395396 (a primeira edição é de 1945). Em sentido próximo, conferir: COMPARATO, Fabio Konder. Novos ensaios e pareceres de direito empresarial. Rio de Janeiro: Forense, 1981. p.44 e segs.

652 JHERING, Rudolf von. A finalidade do direito. Trad. Heder K. Hoffmann. Campinas: Bookseller, 2002. Tomo I. p.94-95.

653 ASCARELLI, Tullio. Problemas das sociedades anônimas e direito comparado. Campinas: Bookseller, 2001. p.376-377. 
plurilaterais) não possuem natureza contratual, mas de atos complexos caracterizados pela convergência de interesses. ${ }^{654}$

Não se desconhece que a análise acima desenvolvida tem como objeto o direito empresarial, no qual os agentes são movidos pela racionalidade econômica, consubstanciada, sobretudo, pela busca da maximização da riqueza. ${ }^{655}$ Não obstante, o alerta é válido também para os ajustes firmados entre a Administração Pública e a iniciativa privada (mesmo sem finalidade lucrativa) a qual, evidentemente, apresenta interesses próprios os quais são, em parte, desvinculados da exclusiva busca pelo resultado comum que conforma o objeto do convênio. ${ }^{656}$

Nesse prisma, entendimentos segundo os quais nos contratos há oposição de interesses enquanto nos convênios há convergência de interesses não revelam visão integral da questão e partem de um pressuposto inexistente, e, por que não dizer, mítico. Não obstante, na doutrina pátria, autores como Maria Sylvia Di Pietro, ${ }^{657}$ Edmir Netto de Araújo, ${ }^{658}$ Diógenes Gasparini, ${ }^{659}$ Toshio Mukai, ${ }^{660}$ dentre outros, mencionam a existência de interesses opostos como fator que distingue os contratos em face dos convênios. ${ }^{661}$

654 O ato complexo, conforme sustenta José Manuel Sérvulo Correia, corresponde a uma relação jurídica em que se tem: "(...) de um lado, a Administração, investida em interesses públicos cuja prossecução caiba, como atribuição às pessoas colectivas cujos órgãos se pronunciam e, de outro, um administrado, mero destinatário passivo do comando (...)." (CORREIA, José Manuel Sérvulo. Legalidade e autonomia contratual nos contratos administrativos. Coimbra: Almedina, 1987. p.352). Tal modelo de relação jurídica, marcada pela unilateralidade, cada vez mais é menos utilizada, inclusive nas relações em que a Administração Pública exerce sua atividade de fomento a atividades privadas, como se verá adiante.

655 A questão foi tratada nos itens 2.3 e 3.1 .2 .

656 Mesmo o Poder Público possui interesses que se poderiam classificar como egoísticos, como mencionado em Item anterior acerca da distinção entre interesse público primário e interesse público secundário.

657 DI PIETRO, Maria Sylvia Z. Parcerias na administração pública. 5.ed. São Paulo: Atlas, 2005. p.246.

658 ARAÚJO, Edmir Netto de. Curso de direito administrativo. 2.ed. São Paulo: Saraiva, 2006. p.684.

659 GASPARINI, Diógenes. Direito administrativo. 9.ed. São Paulo: Saraiva, 2004. p.399.

660 MUKAI, Toshio. Contratos públicos: as prerrogativas da administração e os direitos das empresas contratadas (segundo as leis n. ${ }^{\text {os }} 8.666 / 93$ e 8.883/94). Rio de Janeiro: Forense Universitária, 1995. p.4.

661 Ressalte-se que, enquanto a definição legal de contratos, acima mencionada fala em reciprocidade de obrigações, na definição de convênios prevista pelo Decreto federal n. ${ }^{\circ} 6.170$, de 25 de julho de 2007, há referência à reciprocidade de interesses. Tal fator de discriminação, em especial nos casos de ajuste entre entidades públicas e privadas, como assinalado, revela-se de diminuta utilidade. 
Além disso, se nos convênios há oposição de interesses, pode-se ressaltar que hodiernamente se reconhece também nos contratos a colaboração entre as partes como uma de suas características centrais. ${ }^{662}$ Como bem resumiu Calixto Salomão Filho:

\begin{abstract}
A concepção clássica do contrato sempre viu nele representados interesses contrapostos. A disciplina passou então a ser interpretada em função dessa concepção, de contraposição de interesses. O que se pretende demonstrar é exatamente o oposto, i.e., de que o contrato só tem sentido lógico e teleológico enquanto disciplina criadora de convergência de interesses entre as partes, enquanto estrutura capaz de organizar os interesses das partes conflitantes. ${ }^{663}$
\end{abstract}

Essa transformação do enfoque atribuído ao contrato privado foi anotada por Romeu

Felipe Bacellar Filho, que, ao tratar de sua aproximação com os contratos administrativos, assim consignou:

Todavia, se, na vigência do antigo Código Civil brasileiro, os contratos de direito privado estavam alicerçados em princípios opostos aos contratos administrativos, as recentes alterações do novo Código Civil caminham num sentido de aproximação dos institutos. O 'pacta sunt servanda', que constituíam mola mestra dos contratos regidos pelo direito privado, foi substituído pelo princípio da função social dos contratos (...). A concepção social do contrato apresenta-se, modernamente, como um dos pilares da teoria contratual. Defronta-se com o vetusto princípio do 'pacta sunt servanda' (...) para, atenuando a autonomia da vontade, promover a realização da justiça comutativa. A moldura limitante do contrato tem o escopo de acautelar as desigualdades substanciais entre os contraentes, como adverte José Lourenço, valendo como exemplos os contratos de adesão. O negócio jurídico haverá de ser fixado em seu conteúdo, segundo a vontade das partes. Esta, todavia, apresenta-se auto-regrada em razão e nos limites da função social, princípio determinante e fundamental que, tendo origem na valoração da dignidade humana (art. 1. ${ }^{\circ} \mathrm{CF}$ ), deve prescrever a ordem econômica e jurídica. 664

Nesse sentido, resumindo o pensamento atual acerca da utilização dos contratos nas relações administrativas, pode-se citar Maria João Estorninho, que ressalta a recente

662 Sobre o tema: MACEDO JÚNIOR, Ronaldo Porto. Contratos relacionais e defesa do consumidor. São Paulo: Max Limonad, 1998. p.189 e segs.

663 SALOMÃO FILHO, Calixto. Breves Acenos para uma análise estruturalista do contrato. Revista de Direito Público da Economia - RDPE, Belo Horizonte, ano 5, n.17, p.51, jan./mar.2007.

664 BACELLAR FILHO, Romeu Felipe. Contrato administrativo. In: Direito administrativo contemporâneo: estudos em memória do professor Manoel de Oliveira Franco Sobrinho. Belo Horizonte: Fórum, 2004. p.317. Sobre o desenvolvimento da teoria contratual no direito brasileiro, especialmente em face da Constituição Federal de 1988 e do novo Código Civil - Lei n. ${ }^{0}$ 10.406, de 10 de janeiro de 2002, conferir, respectivamente: AZEVEDO, Antonio Junqueira de. Princípios do direito contratual e desregulamentação do mercado - Direito de exclusividade nas relações contratuais de fornecimento - Função social do contrato e responsabilidade aquiliana do terceiro que contribui para inadimplemento contratual. Revista dos Tribunais, ano 87, v.750, p.113-120, abr. 1998; e NEGREIROS, Teresa. Teoria do contrato: novos paradigmas. 2.ed. Rio de Janeiro: Renovar, 2006. 
transição de uma Administração autoritária a uma Administração soberana consensual. 665 Assim, não se deve olvidar que também nos contratos podem ser observados interesses convergentes.

É importante destacar, por fim, a necessidade de superação da inadequação regulamentar que decorre do tratamento quase idêntico que é dado a convênios voltados a disciplinar ajustes de natureza diversa:

(i) os contratos de fomento, entre um ente público e um ente privado, para o incentivo de atividades privadas de interesse do Poder Público, nas quais a Administração Pública exerce efetivamente uma posição de supremacia e tem condições de estabelecer requisitos acerca do procedimento a ser adotado pela entidade privada - ainda que esta mereça segurança quanto ao objeto contratado; $666 \mathrm{e}$

(ii) os contratos interadministrativos 667 entre dois entes públicos para realização de objetivos comuns ${ }^{668}$ - como se verifica em ordenamentos estrangeiros, por exemplo, com as federações de municípios em Portugal, as agrupaciones de

665 ESTORNINHO, Maria João. A fuga para o direito privado: contributo para o estudo da actividade de direito privado da administração pública. Coimbra: Almedina, 1996. p.44.

666 Afinal, na Administração Pública contemporânea, em que a participação do particular como prestador de atividades privadas de interesse público torna-se cada vez mais importante, mesmo em sua atividade de fomento, cumpre ao Poder Público assumir deveres e oferecer garantias ao particular de que os deveres assumidos - no caso de incentivo - serão devidamente cumpridos. Assim, características tornadas clássicas no ordenamento brasileiro por Hely Lopes Meirelles, e até hoje repetidas, inclusive pelos atualizadores da obra do saudoso autor, como a precariedade do ajuste, a ausência de vinculação contratual, a possibilidade de denúncia a qualquer momento e liberdade de ingresso e retirada dos partícipes, não são essenciais aos contratos de fomento. Sobre o tema (em posição oposta à ora defendida): MEIRELLES, Hely Lopes. Direito administrativo brasileiro. 33.ed. São Paulo: Malheiros, 2007. p.408.

667 Os quais, de acordo com a classificação neste trabalho adotada, por não envolver a relação entre a Administração Pública e um ente privado, não configuram contrato administrativo, mas contrato de direito público.

668 Neste ponto, merece crítica o Decreto federal n. ${ }^{\circ} 6.170 / 2007$, pois trata, salvo algumas exceções, indistintamente (i) dos convênios de órgãos e entidades públicas entre si e (ii) dos convênios entre órgãos e entidades públicas com entidades privadas sem fins lucrativos. De acordo com o referido decreto, considera-se convênio: "acordo, ajuste ou qualquer outro instrumento que discipline a transferência de recursos financeiros de dotações consignadas nos Orçamentos Fiscal e da Seguridade Social da União e tenha como partícipe, de um lado, órgão ou entidade da administração pública federal, direta ou indireta, e, de outro lado, órgão ou entidade da administração pública estadual, distrital ou municipal, direta ou indireta, ou ainda, entidades privadas sem fins lucrativos, visando a execução de programa de governo, envolvendo a realização de projeto, atividade, serviço, aquisição de bens ou evento de interesse recíproco, em regime de mútua cooperação". Em atendimento à decisão do Plenário do Tribunal de Contas da União, constante do Item 9.1 do Acórdão 2066/2006, publicado no Diário Oficial da União em 13 de dezembro de 2006, informações acerca da transferência de recursos federais a entidades privadas por meio de convênios ou outros instrumentos congêneres podem ser encontradas no sítio: <https://www.convenios.gov.br/portal/>. Acesso em: 07 nov. 2008. 
municípios na Espanha, os syndicats intercommunaux na França. ${ }^{669}$ Apenas nesta segunda hipótese deve ser utilizada a expressão convênio, tal qual sua atual previsão constitucional (à exceção do artigo 199, parágrafo primeiro): para fazer referência a ajustes celebrados entre entes federativos em cada uma das hipóteses constitucionalmente previstas.

Considerando que o convênio é, em qualquer hipótese, modalidade de contrato, sua regulamentação deve ocorrer por lei, conforme o já mencionado artigo 22, inciso XXVII da Constituição Federal. ${ }^{670}$ A Lei n. ${ }^{0} 11.107 / 05$ resolveu parte da questão, ao regulamentar o artigo 241 da Constituição Federal; resta consolidar-se entendimento de que os convênios são modalidades de contratos e submetem-se integralmente à Lei n. ${ }^{\circ}$ 8.666/93 - ao menos até que seja editada outra lei que discipline especificamente a modalidade de contrato de fomento.

\subsection{Histórico dos convênios na saúde}

Uma breve análise histórica do direito público pátrio demonstra que a figura dos convênios foi usada inicialmente para a celebração de ajustes entre entidades públicas e posteriormente foi utilizada para regulamentar também a concessão de incentivos a entidades privadas. A focalização de tal estudo no setor de saúde revela claramente tal transição.

Na Lei n. ${ }^{\circ}$ 2.312, de 3 de setembro de 1954, que dispõe sobre Normas Gerais sobre Defesa e Proteção da Saúde, uma série de dispositivos fazem referência à celebração

669 Sobre o tema, conferir: ANDRADE, Luciano Benévolo de. Curso moderno de direito administrativo. São Paulo: Saraiva, 1975. p.84-85; e SZKLAROWSKY, Leion Fredja. Os convênios administrativos. Convênio - Contrato administrativo - Consórcio administrativo - Constituição federal - Decreto-Lei 2.300/86 e legislação pertinente - Doutrina e jurisprudência do TCU. Revista dos Tribunais, ano 80, v.669, p.40 e segs., jul. 1991.

670 Nos contratos de fomento, submetidos a normas gerais hoje previstas pela Lei n. ${ }^{\circ} 8.666 / 93$, não se opõe a que o ente fomentador, desde que no exercício de tal função e nos termos da legislação eventualmente disciplinadora da área em questão, possa criar determinados requisitos para que a entidade fomentada aplique de maneira adequada os recursos objeto de incentivo. Tal possibilidade pode ser prevista no próprio instrumento contratual ou em ato normativo do ente fomentador. Afinal, como consignou Ângela Cássia Costaldello: "A demonstração da melhor opção de gasto do dinheiro público deve ser exposta de modo inequívoco por aqueles particulares que recebem do erário benefícios públicos. A exigência [de processo licitatório pelo particular], nesse sentido, não fere o princípio da legalidade, mas redunda na aplicação do princípio da juridicidade, que contém - e, sobretudo, protege os cofres públicos." (COSTALDELLO, Ângela Cássia. Entidades privadas que recebem recursos públicos: Necessidades de Licitar. Boletim Informativos de Licitações e Contratos, Curitiba, v.82, 2000. p.990). 
de convênios, todos eles envolvendo duas entidades públicas. ${ }^{671}$ Já no regulamento da referida lei - Decreto n. ${ }^{\circ}$ 49.974-A, de 21 de janeiro de 1961 -, além de referências a convênios entre entes públicos, há menção a convênios com entidades privadas, os quais são mencionados tendo como objetivo fomentar o desenvolvimento de atividades privadas de saúde. ${ }^{672}$ Eis o que prevê o artigo $7 .^{\circ}$ do referido ato normativo:

Art. $7 .^{\circ}$ Os órgãos públicos competentes estimularão a iniciativa privada que vier a colaborar com os serviços de saúde, dentro da orientação por estes traçada.

$\S 10^{\circ} \mathrm{O}$ Governo poderá subvencionar a iniciativa privada de reconhecido mérito para a execução de serviços de saúde, firmando convênios para esse fim e exercendo a fiscalização do fiel cumprimento destes.

$\S 2 .^{\circ} \mathrm{A}$ inobservância dos dispositivos contratuais ou reguladores das concessões financeiras inabilitará as organizações de que trata este artigo a receberem auxílios. ${ }^{673}$

Seguindo tal linha, o Decreto-Lei n. ${ }^{\circ}$ 200, de 25 de fevereiro de 1967, que dispõe sobre a organização da Administração Federal trata genericamente dos convênios entre entes públicos ${ }^{674}$ e, ao se referir especificamente à Política Nacional de Saúde, prevê a celebração de convênios com a iniciativa privada. ${ }^{675}$

671 Como se percebe dos artigos $3 .^{\circ}, c ; 9 .^{\circ}, \S 2 .^{\circ} ; 14$; e 21 da lei citada, que assim dispõem: Art. $3 .^{\circ}$ Ao órgão federal de saúde ainda incumbe: (...) c) firmar convênios com Estados, Distrito Federal e Territórios, proporcionando-lhes recursos técnicos e financeiros, coordenando-lhes a ação, e estimulando-lhes o trabalho; (...) Art. 9..$^{\circ}$ (...) $§ 2 .^{\circ}$ Os Estados, Territórios e o Distrito Federal poderão firmar convênios com a União, através de órgãos de saúde, para maior desenvolvimento do sistema de assistência médica, sanitária, hospitalar e medicamentosa, sujeitos às normas federais. (...) Art. 14. Para evitar a introdução e expansão no país das doenças previstas como importância internacional, o órgão federal de saúde manterá, um serviço de portos e fronteiras que, entre suas atribuições, velará pela aplicação das recomendações prescritas no código sanitário panamericano e outros códigos e convênios internacionais subscritos pelo Brasil. (...) Art. 21. O Governo Federal através do seu órgão de saúde, firmará convênios com os Estados e Territórios, proporcionando-lhes meios técnicos e financeiros para a fixação, fora das capitais, de médicos e enfermeiros, dentistas, farmacêuticos e outros profissionais necessários aos serviços de assistência médico-social (os grifos não constam do original).

672 A utilização de convênios como mecanismos de regulamentação de outorga de subvenção ou contribuição a entidades privadas pode ser encontrada em atos normativos anteriores, como o Decreto n. ${ }^{\circ} 29.425$, de 2 de abril de 1951, e na Lei n. ${ }^{\circ} 1.493$, de 13 de dezembro de 1951.

673 Além dele, trata o ato normativo em referência de convênios com entidades privadas nos artigos 76 e 78 parágrafo único (os grifos não constam do original).

674 Art. 10. A execução das atividades da Administração Federal deverá ser amplamente descentralizada. (...) $\S 5 .^{\circ}$ Ressalvados os casos de manifesta impraticabilidade ou inconveniência, a execução de programas federais de caráter nitidamente local deverá ser delegada, no todo ou em parte, mediante convênio, aos órgãos estaduais ou municipais incumbidos de serviços correspondentes (os grifos não constam do original) .

675 Art. 156. A formulação e Coordenação da política nacional de saúde, em âmbito nacional e regional, caberá ao Ministério da Saúde. $\S 1 .^{\circ}$ Com o objetivo de melhor aproveitar recursos e meios disponíveis e de obter maior produtividade, visando a proporcionar efetiva assistência médico-social à comunidade, 
Em sede constitucional, a referência a convênios consta em diversos artigos da Constituição de 1967,676 e da Constituição de 1969, ${ }^{677}$ todos eles fazendo referência a ajustes celebrados entre entes públicos. Na Constituição Federal de 1988, consta previsão de celebração de convênios no artigo 37, inciso XXII, ${ }^{678}$ no artigo 39, § 2. ${ }^{\circ},{ }^{679}$ no artigo 71 , inciso VI, ${ }^{680}$ e no já citado artigo 241 da Constituição Federal. ${ }^{681}$ Todos eles referem-se a

promoverá o Ministério da Saúde a coordenação, no âmbito regional das atividades de assistência médicosocial, de modo a entrosar as desempenhadas por órgãos federais, estaduais, municipais, do Distrito Federal, dos Territórios e das entidades do setor privado. $§ 2^{\circ}$ Na prestação da assistência médica dar-se-á preferência à celebração de convênios com entidades públicas e privadas, existentes na comunidade (os grifos não constam do original).

676 Art. $8 .^{\circ}(\ldots)$ (..) $1 .^{\circ}$ - A União poderá celebrar convênios com os Estados para a execução, por funcionários estaduais, de suas leis, serviços ou decisões. (...) Art. 13 (...) $§ 3 .^{\circ}$ - Para a execução, por funcionários federais ou municipais, de suas leis, serviços ou decisões, os Estados poderão celebrar convênios com a União ou os Municípios. (...) Art. 16 (...) $\S 44^{\circ}$ - Os Municípios poderão celebrar convênios para a realização de obras ou exploração de serviços públicos de interesse comum, cuja execução ficará dependendo de aprovação das respectivas Câmaras Municipais. (...) Art. 19 (...) $§ 7 .^{\circ}$ - Mediante convênio, a União, os Estados, o Distrito Federal e os Municípios poderão, delegar, uns aos outros, atribuições de administração tributária, e coordenar ou unificar serviços de fiscalização e arrecadação de tributos. (...) Art 27. Sem prejuízo do disposto no art. 25, os Estados e Municípios, que celebrarem com a União convênios destinados a assegurar a coordenação dos respectivos programas de investimento e administração tributária, poderão participar de até dez por cento na arrecadação efetuada, nos respectivos territórios, proveniente dos impostos referidos no art. 22, n.IV e V, excluído o incidente sobre fumo e bebidas (os grifos não constam do original).

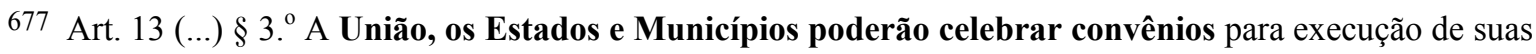
leis, serviços ou decisões, por intermédio de funcionários federais, estaduais ou municipais. (...) Art. 23 (...) $\S 6 .^{\circ}$ As isenções do imposto sobre operações relativas à circulação de mercadorias serão concedidas ou revogadas nos termos fixados em convênios, celebrados e ratificados pelos Estados, segundo o disposto em lei complementar (os grifos não constam do original).

678 Art. 37 (...) XXII - as administrações tributárias da União, dos Estados, do Distrito Federal e dos Municípios, atividades essenciais ao funcionamento do Estado, exercidas por servidores de carreiras específicas, terão recursos prioritários para a realização de suas atividades e atuarão de forma integrada, inclusive com o compartilhamento de cadastros e de informações fiscais, na forma da lei ou convênio (inciso incluído pela Emenda Constitucional n. ${ }^{\circ}$ 42, de 19.12.2003).

679 Art. 39 (...) § 2. ${ }^{\circ}$ A União, os Estados e o Distrito Federal manterão escolas de governo para a formação e o aperfeiçoamento dos servidores públicos, constituindo-se a participação nos cursos um dos requisitos para a promoção na carreira, facultada, para isso, a celebração de convênios ou contratos entre os entes federados. (parágrafo com redação dada pela Emenda Constitucional n. ${ }^{\circ}$ 19, de 1998).

680 Art. 71. O controle externo, a cargo do Congresso Nacional, será exercido com o auxílio do Tribunal de Contas da União, ao qual compete: (...) VI - fiscalizar a aplicação de quaisquer recursos repassados pela União mediante convênio, acordo, ajuste ou outros instrumentos congêneres, a Estado, ao Distrito Federal ou a Município;

681 Art. 241. A União, os Estados, o Distrito Federal e os Municípios disciplinarão por meio de lei os consórcios públicos e os convênios de cooperação entre os entes federados, autorizando a gestão associada de serviços públicos, bem como a transferência total ou parcial de encargos, serviços, pessoal e bens essenciais à continuidade dos serviços transferidos (artigo com redação dada pela Emenda Constitucional n. ${ }^{\circ} 19$, de 1998). Além disso, são mencionados convênios entre Estados no artigo 41, §3. ${ }^{\circ}$ do Ato das Disposições Constitucionais Transitórias. 
ajustes celebrados entre entes federativos. A única previsão constitucional de convênio com a iniciativa privada é exatamente aquela contida na ordem da saúde - especificamente no parágrafo primeiro do artigo 199 do texto constitucional.

Tal análise, conjugada ao estudo da evolução dos serviços públicos de saúde no Brasil, ${ }^{682}$ permite perceber que a insuficiência da oferta de serviços públicos de saúde no âmbito do sistema bismarckiano - vigente em grande parte do século XX no Brasil - fez com que o Estado brasileiro incentivasse entidades privadas a prestar tal serviço no âmbito privado. Isso ocorreu mediante subvenções que passaram a ser disciplinadas por um modelo de ajuste até então utilizado para regulamentar relações entre entes públicos: o convênio. ${ }^{683}$

Não obstante, como já assinalado, a Constituição Federal de 1988 marcou a transição do sistema de saúde brasileiro, que passou a garantir o direito à saúde e conseqüente prestação de serviços voltados a sua promoção, proteção e recuperação a todos que deles necessitem. Assim, ao lado dos convênios, os quais disciplinam a relação de fomento estatal à prestação de serviços privados de saúde, foram previstos os contratos, por meio dos quais se delega a prestação de serviços públicos de saúde a entidades privadas.

Nesse contexto, a existência do termo convênios no parágrafo único do artigo 199 da Constituição Federal, como analisado no Item 3.1.1.2, inserido na última etapa de delibe-ração do projeto de texto constitucional, pode ser explicada pela tradição de celebração de tal modalidade de ajuste, que evidentemente não se coaduna com o objetivo de regulamentar a prestação de serviços públicos de saúde - mas de fomentar sua prestação privada. ${ }^{684}$

Dessa forma, a utilização dos convênios como mecanismo de participação privada nos serviços públicos de saúde deve ser afastada. Em tais casos (de prestação de serviços públicos) - independente da denominação legal do instrumento que vincule o prestador

682 Sobre o tema, conferir Item 3.1.1.

683 Tal transição não merece críticas, pois quando as entidades federais, estaduais e municipais passaram a se utilizar dos convênios para a celebração de parcerias com entidades privadas para a regulamentação, as subvenções passaram a ser regulamentadas. A vantagem trazida pelos convênios refere-se à responsabilidade assumida pelos entes parceiros quanto à aplicação dos recursos. Se anteriormente, nas subvenções, os recursos repassados eram investidos em despesas gerais de custeio da entidade privada, nos convênios o repasse de recursos passa a depender da aprovação de planos de aplicação e contraprestação, o que permitiu maior controle sobre os gastos da entidade conveniada.

684 Note-se que, como mencionado no Item 4.2.3, é também dever do Estado fomentar a prestação privada de serviços privados de saúde, de modo que é admissível a celebração de convênios para tanto - mas não para sua prestação no âmbito público (sob a responsabilidade do Estado). 
privado e da existência (ou não) de finalidade lucrativa - a disciplina jurídica geral a ser aplicada é aquela dos contratos administrativos - com sujeição integral à Lei n. ${ }^{\circ}$ 8.666/93.

Tal entendimento afasta grave insegurança jurídica proporcionada pela redação do artigo 116 da Lei de Licitações, ${ }^{685}$ que determina a aplicação dos dispositivos da referida lei no que couber aos contratos. ${ }^{686}$ É que, dada a indeterminação da expressão no que couber, muitas hipóteses de aplicabilidade do procedimento de licitação acabam não se submetendo a ela. ${ }^{687}$ Por isso, a adequada compreensão e correta utilização dos convênios são imprescindíveis à atuação da Administração Pública nos limites estabelecidos por dita lei. Assim, em todos os casos em que houver um ajuste entre a Administração Pública e a iniciativa privada no qual sejam previstos direitos e deveres resta configurada hipótese de contrato administrativo, e inexistindo lei específica sobre determinada modalidade de contrato, sempre cabe a aplicação da Lei n. ${ }^{\circ} 8.666 / 93$ quanto ao procedimento licitatório e exigências contratuais, mesmo porque são previstas pela própria lei em referência hipóteses de dispensa e de inexigibilidade de realização do torneio. 688

Afinal, há contrato em todas as hipóteses nas quais houver uma avença em que haja deveres a serem cumpridos por uma das partes, inclusive nos casos em que o objetivo seja o fomento a determinada atividade. Tal observação permite a especificação do regime jurídico dos convênios entre a Administração Pública e a iniciativa privada. Nesse sentido, tem-se que os convênios com particulares constituem uma dentre as inúmeras modalidades

685 Art. 116. Aplicam-se as disposições desta Lei, no que couber, aos convênios, acordos, ajustes e outros instrumentos congêneres celebrados por órgãos e entidades da Administração.

686 Ressalte-se que, sendo os assim denominados convênios entre a Administração Pública e entidades privadas uma modalidade de contrato, a Lei n. ${ }^{\circ} 8.666 / 93$ é aplicável a todas as esferas da federação na condição constitucionalmente prevista pelo já citado artigo 22, inciso XXVII, de norma geral.

687 Nesse sentido é a advertência de Odete Medauar: "No tocante aos convênios entre órgãos estatais e entidades particulares, o que, sobretudo, fundamenta a desobrigação de licitação é a especificidade do objeto e da finalidade. No entanto, se a Administração pretender realizar convênio para resultado e finalidade que poderão ser alcançados por muitos, deverá ser realizada licitação ou se abrir a possibilidade de se conveniar sem limitação, atendidas as condições fixadas genericamente; se assim não for, haverá ensejo para burla, acobertada pela acepção muito ampla que se queira dar aos convênios." (MEDAUAR, Odete. Direito administrativo moderno. 11.ed. São Paulo: RT, 2007. p.229).

688 Artigos 24 e 25 da Lei n. ${ }^{\circ} 8.666 / 93$. 
de contrato administrativo, ao qual é possível e mais adequado, como já assinalado, denominar contratos de fomento. ${ }^{689}$

\subsection{Contratos de prestação de serviços e contratos de fomento}

O fator de discriminação entre contratos de prestação de serviços (com ou em delegação de serviços públicos) e contratos de fomento (denominados de maneira geral pelo direito pátrio de convênios, ajustes e outros instrumentos congêneres) deve ser encontrado na função administrativa que compõe a causa do ajuste. ${ }^{690}$ Como assinalado neste trabalho, se a configuração de um contrato administrativo depende da presença da Administração Pública em um dos pólos da relação contratual, o interesse específico por ela buscado no ajuste - devidamente fundamentado no processo de contratação - pode definir a modalidade de ajuste e o regime a ser seguido:

(i) se o objetivo é a obtenção de serviços de interesse do próprio poder público (o Estado como usuário direto), trata-se de contrato de prestação de serviços;

689 Nesse sentido, tem razão Marçal Justen Filho ao sustentar que: "A contratação administrativa também se revela como um relevante instrumento de implementação de políticas públicas no âmbito econômico e social. Os valores desembolsados pelo Estado por meio de contratos administrativos tornam-se um meio não apenas de satisfazer necessidades imediatas do Estado. Passam a ser um instrumento de incentivo e fomento a atividades reputadas como socialmente desejáveis. (...) Pode-se aludir, então, a uma função social (ou 'extra-econômica') dos contratos administrativos. A expressão indica a utilização dos contratos administrativos para a promoção concomitante de fins adicionais à direta e imediata satisfação de necessidades dos entes administrativos." Nesse sentido, o autor cita como exemplos o artigo 24, XIII da Lei n. ${ }^{\circ} 8.666 / 93$, que prevê a dispensa de licitação para contratação de determinadas entidades voltadas ao desenvolvimento social e a Lei Complementar 123, de 14 de dezembro de 2006, que dá preferência à contratação de micro-empresas e empresas de pequeno porte (JUSTEN FILHO, Marçal. Comentários à lei de licitações e contratos administrativos. 12.ed. São Paulo: Dialética, 2008. p.12). No mesmo sentido, ressaltando a utilização dos contratos com objetivo de fomentar atividades privadas, Jean Rivero, ao tratar da Administração Contratual, assim consignou: "O processo contratual encontrou recentemente novas e múltiplas aplicações. A Administração utiliza-o para orientar a ação dos particulares num sentido conforme o interesse geral: em troca dos compromissos que eles assumem, concede-lhes vantagens de diversa ordem." (RIVERO, Jean. Direito administrativo. Trad. Rogério E. Soares. Coimbra: Almedina, 1981. p.131).

690 Como sustenta Edmir Netto de Araújo: "Em matéria de negócio jurídico administrativo, interessa a vontade negocial (...)." A tal assertiva, entende-se adequado incluir: a vontade negocial da Administração Pública. Sobre o tema (em posição divergente da ora adotada), conferir: ARAÚJO, Edmir Netto de. Curso de direito administrativo. 2.ed. São Paulo: Saraiva, 2006. p.683. 
(ii) se o objetivo é a prestação de serviços públicos a terceiros (o Estado como usuário indireto), trata-se de contrato de delegação de serviços públicos; ${ }^{691}$

(iii) se o objetivo é o incentivo a atividades privadas que se alinham às políticas públicas de determinado órgão estatal, trata-se de contrato de fomento.

A substituição da expressão convênios em sua perspectiva público-privada pela expressão contratos de fomento, além de encontrar respaldo nos fundamentos acima delineados, cristaliza formalmente uma característica material da Administração Pública contemporânea: o respeito aos direitos dos administrados. Ainda que em sua atividade de fomento a Administração Pública não aja em cumprimento a um dever prestacional e não assuma a responsabilidade pela efetiva prestação do serviço a quem dele necessitar, é importante ao administrado dispor de segurança jurídica quanto ao cumprimento pelo Poder Público de eventuais deveres assumidos por meio do ajuste que disciplina a relação de fomento à respectiva atividade privada. ${ }^{692}$ Assim, afasta-se outra característica nociva comumente atribuída aos convênios: a precariedade do vínculo.

Já a diferença na disciplina do referido ajuste pode ser concentrada no conjunto de cláusulas a serem impostas pela Administração Pública ao agente privado para garantia de que a utilização dos recursos públicos ocorra exclusivamente e da melhor forma possível na consecução do objeto contratado. Daí a discussão de medidas para que a entidade privada conveniada (fomentada) tenha seu regime jurídico definido por regras que garantam a atuação direcionada à consecução do objetivo comum pactuado, ${ }^{693}$ como, por exemplo, exigência de licitação e processo seletivo para contratação de pessoal.

691 Se o contrato tiver como objeto a gestão de um serviço, como a remuneração do agente privado contratado relacionada ao resultado das atividades prestadas, trata-se de um contrato administrativo de delegação da espécie concessão ou permissão.

692 Tal característica aproxima o regime do contrato de prestação de serviços do regime do contrato de fomento.

693 Medidas essas que se inserem na atual crise da disciplina jurídica do terceiro setor, mencionada no Item 4.1.3, segundo a qual as entidades privadas que compõem o setor, ocupam posições mais ou menos próximas do Estado, com maior ou menor incidência das limitações à autonomia da vontade. Tal zona de penumbra proporciona, em especial no caso dos convênios, o direcionamento de recursos públicos transferidos pela via do convênio não ao objeto comum pactuado, mas a interesses egoísticos do parceiro privado ou de seus associados. 
Nesse prisma, é evidente que o processo de seleção para contratação previstos pela Lei n. ${ }^{0} 8.666 / 93$ não são adequados para tal escolha, ${ }^{694}$ de modo que se entende necessária a edição de lei, nos termos do artigo 22, inciso XXVII, definindo as normas gerais de contratos de fomento - passíveis de serem suplementadas por Estados, Distrito Federal e Municípios. Tais normas têm como objetivo trazer segurança jurídica e tratamento adequado às entidades que recebem incentivo estatal e não raro, sob o fundamento da vaga expressão no que couber do artigo 116 da Lei n. ${ }^{\circ} 8.666 / 93$, são submetidas a um regime jurídico idêntico àquele imposto às entidades públicas, o qual é marcado pela rigidez. ${ }^{695}$

De qualquer modo, independente da denominação legal que se adote, não restam dúvidas de que, no caso específico do parágrafo primeiro do artigo 199 da Constituição Federal, onde se lê convênios deve-se ler contratos de delegação de serviços. A celebração de convênios (contratos de fomento) com entidades privadas tem o objetivo de incentivar a prestação privada de serviços de saúde e não o de promover a prestação privada de serviços públicos de saúde.

\subsubsection{Modalidades de Contrato Administrativo Recentemente Criadas para Prestação Privada de Serviços de Saúde}

Desde o momento em que foi promulgada no Brasil a Constituição Federal de 1988, ${ }^{696}$ uma série de transformações tem ocorrido no Direito Administrativo e no tratamento legal dos serviços de saúde em diversas partes do globo. Tal compreensão, aliada à análise que se fez do processo constituinte de 1987-1988, ${ }^{697}$ tornou possível compreender a adoção no Brasil de um sistema nacional de saúde, criado ao exemplo de

694 O que não significa dizer que, no caso de fomento, independente de sua forma de instrumentalização - se por via contratual ou não - não haja necessidade de realização de procedimento de escolha das pessoas beneficiadas. Havendo limitação do incentivo estatal aos possíveis interessados, há que se realizar procedimento de escolha com supedâneo nos princípios constitucionais da Administração Pública. Afinal, como ressalta Carlos Ari Sundfeld: "(...) a exigência de certame não se justifica pelo fato de travar-se contrato, mas sim porque a administração vai conferir a alguém algum benefício singular e insuscetível de extensão a todos os interessados aptos." (SUNDFELD, Carlos Ari. Licitação e contratos administrativos. 2.ed. São Paulo: Malheiros, 1994. p.15).

695 Sobre o tema, conferir Item 4.3.2.2.

696 Como analisado nos Itens 2.3 e 2.4 .

697 Sobre o tema, conferir Item 3.1.2. 
sistemas os quais, já naquela época, haviam demonstrado necessidade de reformulação. Nesse contexto, tem razão Eleonor Conill ao afirmar que:

\begin{abstract}
A reforma sanitária brasileira pode ser considerada como uma reforma tardia, preconizando princípios democráticos racionalizadores com a formulação e implementação do Sistema Único de Saúde/SUS numa conjuntura neoliberal. Apesar de avanços no plano político-administrativo, reconhecem-se dificuldades no plano operativo e no modelo assistencial. ${ }^{698}$
\end{abstract}

É que, nas décadas de 70 e 80 do século passado, a experiência de países desenvolvidos na prestação de serviços de saúde demonstrou a necessidade de transformações: inicialmente para conter o avanço exponencial dos custos do setor e, em segundo lugar e mais importante, para possibilitar a racionalização do investimento de recursos públicos voltados à área e a transparência das atividades desenvolvidas. Assim, sistemas de saúde de diversas naturezas passaram a sofrer alterações, com a adoção de novas modalidades de ajuste entre o Estado e os prestadores privados.

O próprio texto constitucional brasileiro oferece lastro jurídico a que o subsistema público de saúde acompanhe o desenvolvimento social, econômico e tecnológico, de modo a proporcionar a adoção de mecanismos de atuação administrativa compatíveis com a realidade em que se vive. Para tanto, é necessário que a interpretação do ordenamento jurídico da saúde, como se tentou demonstrar no Capítulo anterior, acompanhe as transformações pelas quais tem passado todo o direito brasileiro desde o advento do novo texto constitucional. ${ }^{699}$ É necessário ter em mente, conforme salienta Odete Medauar, que as funções e responsabilidades que a sociedade demanda exigem atualização permanente da Administração, não

698 CONILL, Eleonor Minho. Epidemologia e sistemas de saúde. In: ARANHA, Márcio Iório (Org.). Direito sanitário e saúde pública: coletânea de textos. Brasília: Ministério da Saúde, 2003. v.1. p.215. Além disso, como assinala Pedro C. Lima de Farias: "O período pós-constituinte vem se caracterizando pela descontinuidade administrativa gerada pela instabilidade das estruturas criadas, transformadas ou extintas para responder pelas políticas de governo, o que tem afetado particularmente a implementação de políticas sociais, aí incluídas as áreas de previdência, saúde e assistência social." (FARIAS, Pedro C. Lima de. A seguridade social no Brasil e os obstáculos à sua implementação. Brasília: MARE/ENAP, 1997. p.57).

699 Nesse sentido, ao contrário do alerta deduzido por Maria Sylvia Di Pietro, no setor de saúde mais do que o Direito Administrativo estar passando à frente do Direito Constitucional, a interpretação da ordem constitucional da saúde é que não tem acompanhado a transformação da realidade social e a evolução da teoria constitucional (DI PIETRO, Maria Sylvia. Parcerias na administração pública. 5.ed. São Paulo: Atlas, 2005. p.47). 
como um processo acabado, mas em contínua adaptação. ${ }^{700}$ Nesse sentido, tem razão Floriano de Azevedo Marques Neto, que sobre o tema consignou: "É fato que os constitucionalistas e dentre nós, muitos administrativistas, não se aperceberam ainda do grau de complexidade que o regime constitucional do SUS enseja". ${ }^{701}$

Em que pese o grau de variação decorrente de características históricas, sociais e culturais de cada Estado, podem ser citados três grupos de características comuns aos processos de reformas na área da saúde sob o ponto de vista do direito comparado:

(i) manutenção da garantia universal do direito à saúde;702

(ii) delimitação dos serviços prestados pelo Estado;

(iii) aumento das possibilidades de contratualização e participação da iniciativa privada na prestação dos serviços.

As características (i) e (ii) acima mencionadas foram objeto de análise no cenário brasileiro no Item 3.2.2, enquanto as hipóteses genéricas de contratualização administrativa foram tratadas no Item 4.3.1.

Como se pode perceber, ganhou força a idéia de cooperação, predominante na visão contemporânea dos contratos, como assinalado acima. Tal viés foi incorporado pela legislação por meio da adoção da expressão parceria, ${ }^{703}$ presente em todas as leis adiante

700 MEDAUAR, Odete. O direito administrativo em evolução. 2.ed. São Paulo: Revista dos Tribunais, 2003. p.133.

701 MARQUES NETO, Floriano de Azevedo. Público e privado no setor de saúde. Revista de Direito Público da Economia, Belo Horizonte, ano 3, n.9, p.136, jan./mar. 2003.

702 Com a ressalva que nos Estados Unidos da América o sistema público não é ofertado a todos, mas exclusivamente às pessoas que não possuem condições de pagar por planos e serviços de saúde privados - o que, de certa forma, não obnubila a garantia universal do respectivo direito - como analisado no Item 3.2.2. Além dos Estados Unidos, também deve ser ressaltado que outros Estados, como a Holanda e a França, contém opção ou mesmo determinação de que determinadas parcelas da população - com renda mais elevada - utilizem o sistema privado de saúde. Sobre o tema, conferir o Item 2.4.

703 Para Carlos Ari Sundfeld, são características das parcerias a existência de interesses comuns, a formação de uma relação contínua e a execução prolongada no tempo. Segundo o autor, são exemplos de parcerias público-privadas a concessão de serviço público, os contratos de gestão com organizações sociais e os termos de parceria com as OSCIP (SUNDFELD, Carlos Ari. Guia jurídico das parcerias públicoprivadas. In: __ Parcerias público-privadas. São Paulo: Malheiros, 2005. p.18). Na opinião de Paulo Modesto, são características gerais das parcerias: "(a) voluntariedade da adesão ao ajuste; (b) a convergência de interesses; (c) a complementariedade de encargos; (d) a atenuação no emprego de prerrogativas exorbitantes por parte da Administração, com vistas a não inibir o interesse do parceiro privado; (e) a flexibilidade dos arranjos institucionais viabilizadores do ajuste de interesses." (MODESTO, Paulo. Reforma do estado, formas de prestação de serviços ao publico e parcerias públicoprivadas: demarcando as fronteiras dos conceitos de 'serviço público', serviços de relevância pública' e 'serviços de exploração econômica' para as parcerias público-privadas. In: SUNDFELD, Carlos Ari (Coord.). Parcerias público-privadas. São Paulo: Malheiros, 2005. p.449). 
analisadas e utilizada com o sentido de ressaltar o caráter consensual da avença e a disciplina não como uma relação entre duas partes com interesses próprios (opostos ou não), mas como uma relação social complexa que extrapola os limites interpartes do ajuste.

No entanto, os modelos adiante analisados enfrentam um duplo desafio:

(i) fazer com que as entidades privadas vinculadas ao subsistema público de saúde submetam-se ao regime jurídico dos serviços públicos de saúde ${ }^{704}$ - com o aprimoramento dos mecanismos de acompanhamento, controle e fiscalização;

(ii) oferecer às entidades prestadoras dos serviços a flexibilidade necessária ao desempenho das atividades de assistência à saúde sem a submissão aos procedimentos formais da legislação que incide sobre entidades estatais.

Acerca desse segundo desafio, tem razão Gustavo Justino de Oliveira, ao criticar o excessivo grau de dependência constitucional da Administração Pública, a qual deve ser investida de poderes normativos suficientes à consecução de suas atividades. Nas palavras do autor:

\begin{abstract}
Ainda que dotada de inúmeras especificidades e condicionamentos derivados da titularidade pública de seu objeto, a gestão pública há de ser (i) dinâmica, (ii) plenamente qualificada para interagir com a população e (iii) voltada à busca da máxima eficiência em suas atividades. Ao lado disso, há de estar provida de estrutura organizacional e normativa apta a adaptar-se às novas demandas individuais da sociedade brasileira. Sendo assim, o minucioso tratamento normativo da Carta de 1988 colide frontalmente com este ideário contemporâneo da Administração Pública, consistindo em um empecilho para a concretização de sua maior finalidade, qual seja, a de agir a serviço dos cidadãos. ${ }^{705}$
\end{abstract}

$\mathrm{Na}$ ordem constitucional da saúde, tal dependência decorre, em grande medida, da equivocada interpretação e regulamentação do direito à saúde, em especial no que tange à prestação de serviços públicos voltados à sua garantia. Dentre as dificuldades enfrentadas especificamente pelas unidades públicas de saúde, na opinião do Conselho Nacional de Secretários de Saúde (CONASS), em publicação de 2008, encontram-se relacionadas:

704 Afinal é necessário que qualquer modalidade de ajuste em que se transfira a execução dos serviços à iniciativa privada resguarde os corolários de tal condição, os quais podem ser concentrados no já referido parágrafo $6 .^{\circ}$ do artigo 37 da Constituição Federal, como analisado no Item 3.2.

705 OLIVEIRA, Gustavo H. Justino de. Contrato de gestão na administração pública brasileira. 2005. 522p. Tese (Doutorado em Direito) - Curso de Pós-Graduação em Direito, Universidade de São Paulo, São Paulo, 2005. p.64. 
- Dificuldades de contratação, principalmente para incorporar e/ou repor recursos humanos com agilidade, considerando as especificidades da área da Saúde Pública, como, por exemplo, para serviços de urgência/emergência.

- Dificuldades de incorporar recursos humanos de acordo com a quantidade e a necessidade dos serviços e o perfil da clientela atendida.

- Dificuldades de reposição do estoque de insumos diversos e de manutenção de equipamentos de saúde.

- Falta de capacidade de gerência dos hospitais públicos que dificulta a adoção de mecanismos eficientes e resolutivos que qualifiquem o cuidado e permitam o monitoramento e avaliação dos resultados.

- Problemas no financiamento das unidades em decorrência da forma atual de remuneração por produção de serviços.

- Elevado custo de manutenção.

- Falta de racionalização interna que provoca desperdícios notadamente na área de logística de insumos.

- Dificuldade de aplicar nas rotinas das unidades de saúde as políticas de ciência e tecnologia e de economia à saúde (avaliação de novas tecnologias e de medicamentos).

- Baixa produtividade.

- Dificuldade de investimentos em equipamentos médico-hospitalares e de informática.

- Desmotivação dos trabalhadores devido à inexistência de mecanismos de gerência na administração direta que estimulem uma maior produtividade, qualidade e eficiência.

- Problemas com o registro da produção de serviços, que em geral é inferior ao realizado, em virtude de uma cultura institucional que não valoriza esse procedimento administrativo em unidades públicas.

- Falta de flexibilidade administrativa, especialmente em relação à gestão orçamentária/financeira, de recursos humanos e processos de compras.

- Dificuldades na aplicação de uma política salarial diferenciada e flexível para profissionais em diferentes áreas de especialização. ${ }^{706}$

Nessa sintonia, não se discorda do diagnóstico da saúde no Brasil apresentado pelo Ministério da Administração Federal e Reforma do Estado (MARE), publicado em 1998:

O problema fundamental enfrentado pela assistência ambulatorial e hospitalar é o da baixa qualidade dos serviços. Estes não estão disponíveis para a população nem na quantidade nem na qualidade minimanente desejável. $O$ cidadão é obrigado a longas esperas para atendimento, que, na maioria das vezes, se demonstra precário, embora com condições de resolubilidade. (...) A grande massa da população brasileira, entretanto, continua a depender do SUS, que, carente de recursos, e com um sistema administrativo ainda indefinido, não atende aos princípios propostos. Na prática, não é universal, [e] não garante eqüidade (...). ${ }^{707}$

706 BRASIL. Conselho Nacional de Secretário de Saúde. Festão e financiamento do Sistema Único de Saúde. Brasília: CONASS, 2008. p.14.

707 BRASIL. Ministério da Administração Federal e da Reforma do Estado. A reforma administrativa do sistema de saúde. Brasília: Maré, 1998. p.12. 
Pode-se verificar, assim, no cenário social pátrio, que se de um lado não houve a contratualização pública dos prestadores privados de saúde, tal qual previsto pela Constituição Federal; de outro, a prestação de tais serviços diretamente pelo poder Público também não ofereceu soluções satisfatórias - em grande medida, em face das limitações constitucionais gerais impostas a sua atuação.

Nessa perspectiva, considerando que as respostas ao desafio de tornar mais adequado o serviço público de saúde no Brasil não são encontradas na Lei n. ${ }^{\circ}$ 8.666/93, como acima assinalado, foram criados novos modelos de ajuste, os quais devem passar pelo filtro constitucional do ordenamento da saúde. ${ }^{708}$ Com isso, deve ser repetido o alerta já consignado, segundo o qual os serviços de saúde possuem características própria e regulação constitucional específica - o que demanda uma disciplina, das relações com a iniciativa privada diversa daquela voltada a outros setores.

\subsubsection{Contratos de concessão administrativa}

Insta ressaltar, como já assinalado acima, que as hipóteses previstas pelo artigo 175 da Constituição admitem a delegação de serviços públicos de saúde. ${ }^{709}$ Entendimento em contrário decorre, sobretudo, de um duplo equívoco comumente encontrado na literatura jurídica:

708 Mesmo porque, as inovações adiante analisadas devem ser interpretadas e aplicadas de acordo com o que se consignou, sobretudo no Capítulo 3, acerca do direito à saúde e da responsabilidade do Estado pela garantia da prestação dos serviços voltados a sua garantia. Além disso, tal interpretação e aplicação devem ser levadas a cabo a fim de que se evite o reconhecimento da pertinência de críticas aos novos modelos de atuação na área da saúde, como aquelas, por exemplo, recentemente tecidas por Jairnilson Silva Paim e Carmen Fontes Teixeira, para quem: "A reforma neoliberal iniciada na década passada, centrada num modelo gerencialista e na desresponsabilização do Estado para com parcela significativa dos direitos sociais conquistados, além de não resolver os problemas mencionados [implementação das políticas do SUS], criou outros [problemas] com a disseminação de organizações sociais, OSCIPs, cooperativas e outras formas de terceirização da gestão e precarização do trabalho em saúde. A polarização entre a administração direita e a desresponsabilização estatal embotou a busca de alternativas que, respeitando os princípios e diretrizes da Reforma Sanitária e do SUS, fossem capazes de superar os problemas aludidos e assegurassem efetividade, qualidade e eficiência nos serviços prestados pelo SUS." (PAIM, Jairnilson Silva; TEIXEIRA, Carmen Fontes. Configuração institucional e gestão do Sistema Único de Saúde: problemas e desafios. Ciência e Saúde Coletiva, v.12, p.1820, nov. 2007).

709 Tanto a concessão quanto a permissão de serviços públicos, nos termos do artigo 175 da Constituição Federal, configuram mecanismos contratuais de delegação de serviços públicos, sujeitos à licitação. A diferença mais importante entre ambas constante da Lei $n .{ }^{0} 8.987 / 95$ refere-se à precariedade do vínculo firmado por meio da permissão, o que induz a sua menor adequação à estabilidade que se espera da prestação de um serviço público como o de saúde. 
(i) o de que apenas é possível a concessão de serviços privativos do Estado;

(ii) o de que os serviços públicos de saúde devem ser prestados de maneira exclusivamente gratuita; ${ }^{710}$ e por conseqüência, de que não é possível a concessão de serviços nos casos em que não há pagamento por parte dos usuários.

O primeiro dos equívocos decorre de uma visão tradicionalista, formada em uma realidade não mais existente, em que se considerava a separação estanque entre a esfera de prestação de serviços públicos (dotados de titularidade exclusiva do Estado) e a esfera de atividades privadas (de domínio da iniciativa particular), em grande medida decorrente da impossibilidade de segregação de atividades dentro de um mesmo setor de competência estatal. ${ }^{711}$ Tal concepção, da qual se discorda, encontra eco em Marcello Caetano, para quem:

O serviço público, para ser concedido, tem de estar legalmente subtraído à livre
concorrência. A atividade só pode ser concedida a certa pessoa se não for livre o
seu exercício por qualquer pessoa. Por isso é pressuposto da concessão que tal
atividade constitua objeto das atribuições da entidade concedente com exclusão
de qualquer outra entidade pública ou particular. ${ }^{712}$

No Brasil, o mesmo pensamento é defendido por Celso Antônio Bandeira de Mello, segundo o qual apenas há concessão de serviço público na hipótese em que o Estado considera o serviço em causa como próprio e privativo. Segundo o autor: "Por isto não caberia cogitar de outorga de concessão a alguém para que preste serviços de saúde ou de educação, já que nem uma nem outra dessas atividades se constituem em serviços privativos do Estado". ${ }^{713}$

Com o devido respeito a tais posicionamentos, entende-se que eles tendem a desaparecer por meio do processo natural de evolução científica, mencionado no Item 2.3, que deve acompanhar as transformações sociais e jurídico-positivas, as quais claramente se apresentam no setor de saúde.

710 Assertiva que não pode ser extraída em termos absolutos do texto constitucional brasileiro e tampouco da legislação pátria, como analisado no Item 3.2.2.

711 O tema foi tratado no Item 3.2, onde se encontra consignada o posicionamento adotado acerca da concepção e possibilidades de exploração dos serviços públicos.

712 CAETANO, Marcello. Manual de direito administrativo. 10.ed. Coimbra: Almedina, 1994. Tomo II. p.1100.

713 MELLO, Celso Antonio Bandeira de. Curso de direito administrativo. 23.ed. São Paulo: Malheiros, 2007. p.691. 
O outro equívoco acima mencionado pode ser dividido em duas ordens de análise. A primeira consiste na premissa falsa de que o serviço público de saúde deve, necessariamente, ser prestado de maneira gratuita. Nos termos do que foi exposto no Item 3.2.2, não existe previsão legal ou constitucional acerca da gratuidade dos serviços públicos de saúde. Assim, opiniões como a de Maria Sylvia Di Pietro, segundo a qual sendo a saúde prestada de maneira necessariamente gratuita, a ela não se aplicam a concessão e a permissão, ${ }^{714}$ merecem ser levadas em conta com a devida ressalva, pois apoiadas em uma compreensão que não encontra amparo constitucional e legal.

Nesse sentido, considerando a possibilidade de cobrança pela prestação dos serviços públicos de saúde, seria possível, nos termos da Lei Geral de Concessões e Permissões Lei n. $^{\circ} 8.987$, de 13 de fevereiro de 1995 - a delegação de serviços públicos de saúde a entidades privadas por meio de concessão ou permissão. Em tal hipótese, obviamente tratar-se-ia de delegação da gestão de todo um serviço de saúde a uma entidade privada com fins lucrativos, incluídas atividades instrumentais e acessórias, bem como a possibilidade de cobrança de tarifa dos usuários - tal qual previsto no artigo 9. ${ }^{\circ}$ da Lei n. ${ }^{\circ} 8.987 / 95.715$ A crítica a ser feita no caso consiste na dificuldade de composição entre os interesses privados de obtenção de lucro com a natureza essencialmente ligada aos direitos fundamentais, característica dos serviços de saúde.

De outro lado, mesmo se considerada a gratuidade como requisito para a prestação dos serviços públicos de saúde no Brasil, a hipótese de concessão não deve ser afastada. Afinal, de acordo com a doutrina contemporânea do Direito Administrativo, não é o pagamento pelos serviços realizado pelos usuários que caracteriza a concessão de serviços públicos, mas a atribuição ao agente privado de certa margem de autonomia de gestão e de risco pelo empreendimento - o que em grande parte ocorre por meio da vinculação, em alguma medida, da remuneração do parceiro privado ao resultado dos serviços prestados, mesmo que tal pagamento seja efetuado em todo ou em parte pelo próprio Poder Público. $\mathrm{Na}$ doutrina estrangeira, tal hipótese de concessão de serviços tem sido reconhecida, como se pode perceber do pensamento de Pedro Gonçalves acerca do ordenamento português:

714 DI PIETRO, Maria Sylvia. Parcerias na administração pública. 5.ed. São Paulo: Atlas, 2005. p.243.

715 Art. 9. ${ }^{\circ}$ A tarifa do serviço público concedido será fixada pelo preço da proposta vencedora da licitação e preservada pelas regras de revisão previstas nesta Lei, no edital e no contrato. 
(...) o facto de a remuneração pelos utentes ou da assunção de um risco pelo concessionário serem eventualmente normais no regime da concessão não exclui a natureza concessória do contrato em que a Administração assume o dever de remunerar, total ou parcialmente, o concessionário, nem mesmo o contrato em que ela assume a álea econômico-financeira inerente à gestão do serviço; para que possa falar-se de 'concessão de um serviço público', essencial é que a gestão (autônoma) do serviço seja transferida por um acto constitutivo de uma relação jurídica administrativa. ${ }^{716}$

$\mathrm{Na}$ doutrina francesa também tem sido ampliada a noção de concessão de serviço público, para alcançar uma série de modalidades de ajuste nos quais a relação entre Administração Pública e prestador de serviço, bem como a forma de pagamento, é bastante variável. ${ }^{717}$ Em outros países europeus a hipótese também é admitida, sendo comumente citados os exemplos dos pedágios-sombra, na Espanha, e as concessões sem custo para o usuário - SCUT, em Portugal.

Assim, a concessão de serviço público deve ser entendida hodiernamente como a delegação do respectivo serviço nas hipóteses em que sua gestão seja transferida ao particular, que vai exercê-la em nome próprio de modo a assumir parte dos riscos envolvidos na atividade delegada.

No Brasil, a questão ganhou novos contornos com a edição da Lei n. ${ }^{\circ} 11.079$, de 30 de dezembro de 2004, conhecida como Lei das Parcerias Público-Privadas, que ampliou o rol de modalidades de concessão. ${ }^{718}$ Além de prever expressamente a possibilidade de

716 GONÇALVES, Pedro. Concessão de serviços públicos. Coimbra: Almedina, 1999. p.145-146 (os grifos não constam do original).

717 Um panorama sobre a experiência internacional em concessões de serviços públicos pode ser encontrada em: WALD, Arnold; MORAES, Luiza Rangel de; WALD, Alexandre de M. O direito de parceria e a nova lei de concessões (análise das leis 8.987/95 e 9.074/95). São Paulo: Revista dos Tribunais, 1996. p.56-69.

718 Trata-se de norma geral, nos termos no artigo 22, inciso XXVII da Constituição Federal. Em alguns Estados-membros - ao contrário da lei federal, que não especifica claramente as áreas de aplicação das parcerias público-privadas - a saúde é expressamente prevista. Tal é o caso, por exemplo, das seguintes unidades federativas: Bahia, Lei Estadual n. 9.290 de 27 de dezembro de 2004, Art. 5. ${ }^{\circ} \S 2 .^{\circ}$ As atividades descritas nos incisos do caput deste artigo, preferencialmente, estarão voltadas para as seguintes áreas: I - educação, saúde e assistência social; Minas Gerais, Lei Estadual n. ${ }^{\circ} 14.868$ de 16 de dezembro de 2003, Art. 5. ${ }^{\circ} \S 1 .^{\circ}$ As atividades descritas nos incisos do caput deste artigo poderão ser desenvolvidas nas seguintes áreas: I - educação, saúde e assistência social; Piauí, Lei Estadual n. ${ }^{\circ} 5.494$ de 19 de setembro de 2005, Art. 4. ${ }^{\circ}$ Parágrafo Único - As atividades descritas nos incisos do caput deste artigo, preferencialmente, estarão voltadas para as seguintes áreas: I - educação, saúde e assistência social; Rio Grande do Norte, Lei Complementar n. ${ }^{\circ} 307$, de 11 de outubro de 2005, Art. 3. ${ }^{\circ}$ Os contratos de PPP poderão ser celebrados em uma das seguintes áreas: I - educação, saúde e assistência social; e Santa Catarina, Decreto n. ${ }^{\circ} 1.932$, de 14 de junho de 2004, Art. $4 .^{\circ} \S 1 .^{\circ}$ As atividades descritas nos incisos do caput deste artigo poderão ser desenvolvidas, preferencialmente, nas seguintes áreas: I - educação, saúde e assistência social (os grifos não constam dos originais). 
co-pagamento por parte do Poder Público, por meio da denominada concessão patrocinada, já admitida implicitamente pela Lei Geral de Concessões, ${ }^{719}$ foi criada a concessão administrativa. Com isso, o modelo de concessão previsto pela Lei n. ${ }^{0} 8.987 / 95$ passou a ser especificado pela qualificação de (concessão) comum, e a remuneração dos serviços prestados realizada direta e integralmente pelos usuários dos serviços passou a identificar uma das modalidades de concessão (a concessão comum).

Nos termos do parágrafo $2 .^{\circ}$ do artigo $2 .^{\circ}$ da lei em referência tal modalidade de concessão é entendida como o contrato de prestação de serviços de que a Administração Pública seja a usuária direta ou indireta, ainda que envolva execução de obra ou fornecimento e instalação de bens.

Não restam dúvidas, portanto, quanto à possibilidade de utilização da concessão administrativa, tanto para serviços de utilidade direta da Administração Pública ${ }^{720}$ quanto para a delegação de serviços públicos, como os de saúde de modo gratuito aos usuários, com pagamento pelo poder público, a ser fixado com base na utilização dos serviços. ${ }^{721}$

719 Na concessão patrocinada o Estado responsabiliza-se por parte do pagamento ao prestador privado dos serviços públicos concedidos. Nos termos do parágrafo primeiro do artigo 2 . $^{\circ}$ da Lei n. ${ }^{\circ} 11.079 / 2004$ : Concessão patrocinada é a concessão de serviços públicos ou de obras públicas de que trata a Lei $n^{\circ}{ }^{\circ}$ 8.987, de 13 de fevereiro de 1995, quando envolver, adicionalmente à tarifa cobrada dos usuários contraprestação pecuniária do parceiro público ao parceiro privado. Tal hipótese não apresenta inovação material, pois era admitida tanto pela Lei n. ${ }^{\circ} 8.987 / 95$ quanto era reconhecida pela doutrina. $\mathrm{Na}$ lei, pode-se mencionar o artigo 11 da Lei de concessões, que previa a possibilidade de receitas alternativas à cobrança de tarifa dos usuários. Na doutrina, pode-se mencionar a definição de Marçal Justen Filho, para quem: "(...) concessão de serviço público é um contrato plurilateral, por meio do qual a prestação de um serviço público é temporariamente delegada pelo Estado a um sujeito privado que assume seu desempenho diretamente em face dos usuários, mas sob o controle estatal e da sociedade civil, mediante remuneração extraída do empreendimento, ainda que custeada parcialmente por recursos públicos." (JUSTEN FILHO, Marçal. Teoria geral das concessões de serviço público. São Paulo: Dialética, 2003. p.96). Nesse contexto, segundo Carlos Ari Sundfeld, são objetivos da nova disciplina das concessões patrocinadas: "A concessão patrocinada já era viável anteriormente, pois adicionais de tarifa podiam ser pagos como receita complementar (Lei das Concessões, art. 11). Cuidados de responsabilidade fiscal na assunção desses compromissos financeiros [do Poder Público em face do prestador privado] já eram devidos (Constituição Federal, art. 167; Lei n. ${ }^{\circ}$ 4.320/1964; e Lei de Responsabilidade Fiscal, Lei Complementar 101/2000). O que fez a Lei das PPPs foi reafirmar essas exigências (art. 10) e criar limites específicos para as despesas com contratos de PPP (art. 22 e 28). O objetivo claro é reforçar a responsabilidade fiscal (Lei das PPPs, art. 40, IV)." (SUNDFELD, Carlos Ari. Guia jurídico das parcerias público-privadas. In: Malheiros, 2005. p.23).

720 O que implica reconhecer a possibilidade de concessão de atividades-meio, não qualificadas como serviços públicos.

721 A previsão legal faz referência tanto a atividades-meio quanto a atividades-fim da Administração Pública, de modo que seriam possíveis concessões administrativas tanto de serviços instrumentais ou acessórios quanto de serviços públicos. A utilização do modelo de ajuste para esses últimos, entretanto, é de grande valia, como enfatiza Adilson Dallari: "As PPPs servem, exatamente, para conferir viabilidade 
No entanto, é preciso ressaltar que há uma série de requisitos para a adoção da concessão administrativa. A Lei das PPPs tem como objetivo a obtenção de colaboração privada para investimentos em infra-estrutura, em relação aos quais o retorno do investimento privado fica condicionado à operação da estrutura criada. Isso fica evidenciado pelos valores e prazos previstos como condição para a adoção dos contratos referidos pela lei. ${ }^{722}$ Portanto, como assinala Marçal Justen Filho, a concessão administrativa deve ser utilizada nos casos em que não existe serviço público, ${ }^{723}$ afinal, a criação da infra-estrutura para sua prestação constitui parte essencial do referido contrato.

$\mathrm{Na}$ experiência internacional, pode-se mencionar a concepção original inglesa das Private Finance Initiatives (PFI). ${ }^{724}$ É interessante notar que na Inglaterra a contratação por meio de parcerias público privadas é realizada pelos próprios hospitais, os quais possuem natureza quase-pública (os trusts), ${ }^{725}$ para ampliação da estrutura física com a conseqüente exploração pelo parceiro privado de atividades acessórias, como hospedaria, lavanderia e refeitório. Nesse passo, ao contrário do que se mencionou acima, na experiência inglesa da PFI, os serviços de saúde foram mantidos no âmbito público, enquanto os serviços de apoio é que foram terceirizados para a entidade privada parceira. ${ }^{726}$

econômica a serviços públicos essenciais, mas de baixa rentabilidade econômica, ou seja, em situações nas quais, sabidamente, não existe possibilidade de assegurar a sustentabilidade dos serviços exclusivamente pelo pagamento de tarifas por parte dos usuários. (...) O desafio, agora, está no encontro de formas que permitam levar avante serviços públicos essenciais mas não sustentáveis. Não se discute a absoluta necessidade de investir em determinados setores estratégicos não-sustentáveis; o problema está em fazer para que isso seja economicamente e juridicamente possível." (DALLARI, Adilson de Abreu. Parcerias em transporte público. In: SUNDFELD, Carlos Ari. Parcerias público-privadas. São Paulo: Malheiros, 2005. p.358 e 360).

722 Art. $2 .^{\circ}(\ldots) \S 4 .^{\circ}$ É vedada a celebração de contrato de parceria público-privada: I - cujo valor do contrato seja inferior a R $\$ 20.000 .000,00$ (vinte milhões de reais); II - cujo período de prestação do serviço seja inferior a 5 (cinco) anos; ou III - que tenha como objeto único o fornecimento de mão-deobra, o fornecimento e instalação de equipamentos ou a execução de obra pública.

723 JUSTEN FILHO, Marçal. A PPP brasileira e as lições do passado. In: TALAMINI, Eduardo; JUSTEN, Mônica Spezia. Parcerias público-privadas: um enfoque multidisciplinar. São Paulo: Revista dos Tribunais, 2005. p. 19 .

724 A questão foi referida no Item 2.4.

725 Sobre o tema, conferir Item 2.4.2.

726 Sobre a experiência inglesa na adoção de PPPs no setor de saúde, conferir: BROADBENT, Jane; GILL, Jas; LAUGHLIN, Richard. The Private Finance Initiative in the National Health Service. London: CIMA, 2004. 
Outra experiência de parcerias público-privadas no setor de saúde que merece menção é a portuguesa. ${ }^{727}$ Nesse país, ao contrário da Inglaterra, há projetos de concessão que envolvem a prestação do próprio serviço de saúde e não apenas de atividades acessórias, algo sem precedentes na Europa. ${ }^{728}$ Segundo Jorge Abreu Simões, o modelo de PPP adotado em Portugal tem como base um contrato de gestão cujo objeto envolve desde a concepção, o financiamento, a conservação e exploração de ativos infra-estruturais até a gestão dos hospitais, incluindo a prestação dos serviços clínicos. ${ }^{729}$ Tais mudanças tornaram-se objeto de intensas discussões, as quais se encontram na pauta social e política portuguesa, como se percebe, por exemplo, da leitura de dois artigos publicados em 2008 por Boaventura de Sousa Santos, em jornal de grande circulação em Portugal, alertando para os perigos da influência de interesse privados na definição de políticas públicas de saúde. ${ }^{730}$

No contexto brasileiro, embora não se tenha conhecimento de experiências de concessões administrativas no setor de saúde, com exceção de alguns projetos ainda não implementados, como no Município de Recife, deve-se destacar que os contratos de concessão administrativa são reconhecidamente contratos de alta complexidade, pois envolvem uma série de variáveis, alto valor e longo prazo, o que faz com que os riscos tanto para o agente privado quanto para o Poder Público sejam de difícil mensuração. Tais características, somadas à natureza dos serviços de saúde, marcada pelo avanço da tecnologia e imprevisibilidade da demanda, induzem a que seja adotada máxima cautela na celebração de tais ajustes. Tal advertência deve ser ressaltada ainda mais levando-se em conta algumas experiências

727 Referida no Item 2.4.2.

728 SANTOS, Boaventura de Sousa (Dir. Científico). Parcerias público-privadas e justiça: uma análise comparada das diferentes experiências. Coimbra: Centro de Estudos Sociais, 2007. p.2.

729 Assim, segundo o autor, o modelo português de PPP assenta-se em um binômio um concurso público um contrato de gestão, mas é implementado por meio de duas sociedades: "Uma sociedade gestora - a entidade gestora do estabelecimento hospitalar - assume a gestão geral do estabelecimento hospitalar e a prestação dos serviços clínicos durante um prazo de 10 anos, prorrogável de acordo com a observação de um conjunto de condições objetivas. A outra sociedade gestora - a entidade gestora do edifício hospitalar assume a prestação dos serviços infra-estruturais durante um período contratual previsível de 30 anos, sendo responsável pela concepção, construção, manutenção do edifício e infra-estruturas hospitalares, bem como pelas actividades de hard facilities managment." (SIMÕES, Jorge Abreu. As parcerias públicoprivadas no sector de saúde em Portugal. Revista Portuguesa de Saúde Pública, v.4, p.85, 2004).

730 SANTOS, Boaventura de Sousa. É a saúde, estúpido! Visão, 14 fev. 2008; e SANTOS, Boaventura de Sousa. Saúde: do serviço ao negócio. Visão, 28 ago. 2008. Uma análise do andamento dos projetos de PPP na saúde em Portugal pode ser encontrada em: PORTUGAL. Tribunal de Contas. Relatório de Acompanhamento das PPP - Saúde 2006, n.1/07, 25p., 2007. 
internacionais mal-sucedidas, como no caso da Austrália. ${ }^{731}$ Nesse sentido, é o alerta de Gustavo Justino de Oliveira, segundo o qual: "Cumpre colocar em relevo ser primordial ao Estado permanentemente capacitar-se para evoluir em um processo de auto-renovação, por meio de ajustes e transformações, a serem concretizados de modo gradual". ${ }^{732}$

De qualquer forma, no que se refere à admissibilidade especificamente de concessão administrativa de serviços públicos de saúde, não se verifica qualquer impedimento constitucional, de modo que por meio dela podem ser concedidos tanto a gestão de todo o conjunto de serviços quanto apenas parcela deles - sejam os serviços de saúde, sejam as atividades acessórias.

\subsubsection{Contratos de gestão}

Outra modalidade de concessão de serviços públicos de saúde foi criada em nível federal pela Lei n. $^{\circ}$ 9.637, de 15 de maio de $1998,{ }^{733}$ que prevê a possibilidade de transferência de determinadas atividades estatais a uma entidade privada sem fins lucrativos qualificada como organização social (OS). ${ }^{734}$ Trata-se, conforme entendimento adotado neste trabalho, de concessão de serviços públicos de saúde, ${ }^{735}$ pois o ajuste possibilita o trespasse da

731 Sobre o tema, conferir: EDWARDS, Pam; SHAOUL, Jean; STAFFORD, Anne; ARBLASTER, Lorna. Evaluating the operation of PFI in roads and hospitals. London: Certified Accountants Educational Trust, 2004.

732 OLIVEIRA, Gustavo Justino. Estado contratual, direito ao desenvolvimento e parceria público-privada. In: TALAMINI, Eduardo; JUSTEN, Mônica Spezia. Parcerias público-privadas: um enfoque multidisciplinar. São Paulo: Revista dos Tribunais, 2005. p.19. No mesmo sentido, assinalando a necessidade de parcimônia na incorporação do novo modelo, conferir: FERNANDES, Jorge Ulisses Jacoby. Parcerias público-privadas, controle e eficiência. Fórum de Contratação e Gestão Pública FCGP, Belo Horizonte, ano 7, n.76, p.7-13, abr. 2008 (os grifos não constam do original).

733 Resultado da conversão da Medida Provisória n. ${ }^{\circ}$ 1.648-7, de 23 de abril de 1998.

734 Nos termos do artigo $1 .^{\circ}$ da lei em referência: O Poder Executivo poderá qualificar como organizações sociais pessoas jurídicas de direito privado, sem fins lucrativos, cujas atividades sejam dirigidas ao ensino, à pesquisa científica, ao desenvolvimento tecnológico, à proteção e preservação do meio ambiente, à cultura e à saúde, atendidos aos requisitos previstos nesta Lei. Verifica-se, portanto, que podem ser qualificadas como organizações sociais entidades que desenvolvem atividades qualificadas (como é o caso da saúde e da educação) ou não (como é o caso da cultura e do meio ambiente) como serviços públicos.

735 Nesse sentido: SUNDFELD, Carlos Ari. Guia jurídico das parcerias público-privadas. In: Parcerias público-privadas. São Paulo: Malheiros, 2005. p.88. 
gestão do serviço, que será gerenciado e executado pela entidade privada, ${ }^{736}$ a qual assumirá os riscos inerentes ao gerenciamento de todas as atividades envolvidas na prestação dos serviços e com base em tal prestação será remunerada pelo ente estatal. ${ }^{737}$

Não obstante, o artigo $5 .^{\circ}$ da lei mencionada determina que o vínculo a ser firmado com a entidade privada, denominado contrato de gestão, tem como objetivo o fomento e a prestação de atividades voltadas ao ensino, pesquisa científica, desenvolvimento tecnológico, proteção do meio ambiente, cultura e saúde. ${ }^{738}$ Eis o teor do referido dispositivo legal:

736 A natureza privada das organizações sociais qualificadas como tais pelo Poder Executivo federal pode ser contestada. É que, nos termos da Lei n. ${ }^{\circ}$ 9.637/98, em que pese tratar-se de pessoa jurídica de direito privado, a outorga do título de organização social depende da participação de representantes do Poder Público no órgão colegiado superior da entidade. Tal determinação, que não foi seguida por uma série de leis estaduais sobre o tema, consta do artigo $2 .^{\circ}$, inciso I, alínea $d$, e artigo $3 .^{\circ}$, inciso I,alínea $a$, que assim dispõem: Art. 2. ${ }^{\circ}$ São requisitos específicos para que as entidades privadas referidas no artigo anterior habilitem-se à qualificação como organização social: I - comprovar o registro de seu ato constitutivo, dispondo sobre:(...) d) previsão de participação, no órgão colegiado de deliberação superior, de representantes do Poder Público e de membros da comunidade, de notória capacidade profissional e idoneidade moral; Art. 3. ${ }^{\circ} \mathrm{O}$ conselho de administração deve estar estruturado nos termos que dispuser o respectivo estatuto, observados, para os fins de atendimento dos requisitos de qualificação, os seguintes critérios básicos: I - ser composto por: a) 20 a $40 \%$ (vinte a quarenta por cento) de membros natos representantes do Poder Público, definidos pelo estatuto da entidade. Tal característica aproxima as $O S$ federais do modelo britânico das trusts, entidades tidas como quase-públicas, mencionadas no Item 2.4.2. Sobre o tema, conferir também: TANAKA, Oswaldo Yoshimi; OLIVEIRA, Vanessa Elias de. Reforma(s) e estruturação do sistema de saúde britânico: lições para o SUS. Saúde e Sociedade, v.16, n.1, jan./abr. 2007.

737 É importante ressaltar que a doutrina pátria denomina também de contrato de gestão outra figura contratual de características distintas daquela ora analisada. Trata-se do contrato trazido pela Emenda Constitucional n. ${ }^{\circ} 19$, de 4 de junho de 1998 , que inseriu o parágrafo $8 .^{\circ}$ no artigo 37 do texto constitucional, com a seguinte redação: Art. 37 (...) $§ 8 .^{\circ}$ A autonomia gerencial, orçamentária e financeira dos órgãos e entidades da administração direta e indireta poderá ser ampliada mediante contrato, a ser firmado entre seus administradores e o poder público, que tenha por objeto a fixação de metas de desempenho para o órgão ou entidade, cabendo à lei dispor sobre: I - o prazo de duração do contrato; II - os controles e critérios de avaliação de desempenho, direitos, obrigações e responsabilidade dos dirigentes; III - a remuneração do pessoal (parágrafo incluído pela Emenda Constitucional n. ${ }^{\circ}$ 19, de 1998). Tal modelo de ajuste, em que pese ter objetivo análogo ao daquele celebrado com organizações sociais $-a$ flexibilização do regime de atuação da Administração Pública, como se verá adiante - tem como partes duas entidades públicas, de modo que, nos termos do que se entende no presente trabalho (conferir Item 4.3.1.1.), não pode ser qualificado como contrato administrativo, mas contrato de direito público. Além disso, como resta evidenciado, não se trata de mecanismo de participação privada na prestação de serviços, mas de gestão de atividades pela própria Administração Pública. Sobre o contrato de gestão nessa sua vertente interadministrativa ou intra-administrativa, conferir: OLIVEIRA, Gustavo H. Justino de. Contrato de gestão na administração pública brasileira. 2005. 522p. Tese (Doutorado em Direito) - Curso de Pós-Graduação em Direito, Universidade de São Paulo, São Paulo, 2005. p.269 e segs.

738 Não são apenas serviços públicos, portanto, as atividades aptas à prestação privada disciplinada pelo contrato de gestão previsto na Lei n. ${ }^{\circ}$ 9.637/98, de modo que, evidentemente, o vínculo fírmado nem sempre vai configurar concessão de serviço público. 
Art. 5. ${ }^{\circ}$ Para os efeitos desta Lei, entende-se por contrato de gestão o instrumento firmado entre o Poder Público e a entidade qualificada como organização social, com vistas à formação de parceria entre as partes para fomento e execução de atividades relativas às áreas relacionadas no art. $1 .{ }^{\circ}$.

Da leitura do artigo colacionado é possível inferir que por meio do contrato de gestão há, de um lado, o fomento estatal e, de outro, a execução privada da atividade fomentada. Entretanto, nos casos em que tal modalidade de vínculo for utilizada para a transferência de atividades qualificadas como serviço público a serem desenvolvidas pelo agente privado sob o respectivo regime jurídico, não se tratará de fomento, mas de delegação de serviço público. Tal observação confirma o que foi assinalado acima acerca da dificuldade de distinção, em especial na saúde, do regulamento estabelecido pelos contratos de prestação de serviços e pelos contratos de fomento (convênios).

Interessante ilustração dessa aproximação pode ser verificada na decisão do Tribunal de Justiça do Estado de São Paulo que, no início do ano de 2007, julgou improcedente a Ação Direta de Inconstitucionalidade contra a Lei do Município de São Paulo - que instituiu o Contrato de Gestão no âmbito daquela unidade federativa. ${ }^{739}$ No voto do Desembargador Renato Nalini, relator do processo, encontra-se a seguinte passagem, que trata o contrato de gestão como um mecanismo de incentivo para que os entes privados prestem serviços de saúde:

\footnotetext{
O Estado precisa estimular os particulares a assumirem os encargos dos quais ele não consegue se desincumbir a contento. No plano da saúde, a participação da iniciativa privada no SUS é imprescindível. Se deixar de estimulá-la, a Administração Pública estará a cometer inconstitucionalidade por omissão, eis que deixará de dar conseqüências práticas ao princípio da eficiência, um dos fundamentos a que está subordinada.

É natural que o conservadorismo e até a formação jurídica arcaizante recebam com estranhamento o fenômeno do Terceiro Setor. Mas foi a vontade constituinte que o reconheceu. E a legislação infraconstitucional já contemplou as ONGs, de advento menos recente e a realidade nova das OSCIPs. ${ }^{740}$
}

Acontece que, como assinalado, ao passo em que prevê novo modelo de ajuste para a prestação privada dos serviços, (i) se as atividades fomentadas forem qualificadas

739 Trata-se da Lei municipal n. ${ }^{\circ}$ 14.132, de 24 de janeiro de 2006, que prevê a qualificação e a conseqüente possibilidade de celebração de contrato de gestão com entidades que prestem serviços exclusivamente na área de saúde.

740 SÃO PAULO (ESTADO). Tribunal de Justiça do Estado de São Paulo. Ação Direta de Inconstitucionalidade n. ${ }^{\circ}$ 130.726-0/700, Órgão Especial, Relator Desembargador Renato NALINI, julgamento em 28 fev. 2007. 
pela Constituição ou pela lei como serviços públicos, e (ii) se tiverem na disciplina contratual a manutenção das características que as qualificam como tais, o incentivo mencionado terá como objeto não a prestação de serviços privados de saúde, mas a prestação de serviços públicos de saúde - o que fará do ajuste um contrato de concessão.

O alargamento da noção de concessão, como assinalado acima, oferece resultados práticos, decorrentes da teoria acerca da concessão de serviços públicos. Nesse sentido, é a ressalva de Odete Medauar, segundo a qual: "O serviço é concedido, mas permanece serviço público; a concessão não configura abandono, desligamento total. O Estado continua 'fiador' da execução perante a coletividade". ${ }^{741}$ Com isso, ao se tratar o contrato de gestão, em determinadas hipóteses, como é o caso do serviço público de saúde, como uma concessão, mais firme deve ser o vínculo e maior a responsabilidade estatal pela efetiva prestação do serviço - o que vai se comprovar pelos dispositivos contratuais em questão.

Nessa perspectiva, Marçal Justen Filho assinala que: "(...) é imperioso verificar a natureza jurídica do ato pactuado sob a denominação de contrato de gestão. O regime jurídico aplicável dependerá da identificação do substrato da relação jurídica pactuada". 742 A categorização do vínculo deve ser buscada não em sua denominação ou em critérios abstratos e desconexos do caso concreto, mas na disciplina específica do ajuste.

No caso da saúde, setor em relação ao qual a Constituição expressamente prevê a possibilidade de prestação privada de serviços públicos por meio de contratos, a indagação a ser realizada a propósito do contrato de gestão reside em verificar se sua previsão legal permite a manutenção do regime que o qualifica. ${ }^{733}$ Em outras palavras, há que se verificar se a previsão legal do contrato de gestão permite uma disciplina contratual que mantenha a responsabilização do Estado pela oferta dos serviços e garanta sua prestação a quem deles necessitar.

741 MEDAUAR, Odete. A figura da concessão. In: (Coord.). Concessão de serviço público. São Paulo: Revista dos Tribunais, 1995. p.13.

742 JUSTEN FILHO, Marçal. Comentários à lei de licitações e contratos administrativos. 12.ed. São Paulo: Dialética, 2008. p.36.

743 Como analisado no Item 3.2, não é o regime jurídico que define se determinada atividade configura um serviço público, mas a qualificação de determinada atividade como tal implica que a lei (ou mesmo a Constituição, acontece parcialmente com a saúde) defina o regime jurídico mais adequado para sua garantia. Em outras palavras, se o serviço público corresponde a uma atividade em relação à qual o Estado assume a responsabilidade por sua garantia a todos que dele necessitarem, o vínculo que estabelece a prestação privada de tal serviço há de proporcionar um regime adequado para tanto. 
Um indício da resposta a tal indagação pode ser encontrado no próprio artigo 18 da Lei n. ${ }^{\circ} 9.637 / 98$, que assim dispõe:

Art. 18. A organização social que absorver atividades de entidade federal extinta
no âmbito da área de saúde deverá considerar no contrato de gestão, quanto ao
atendimento da comunidade, os princípios do Sistema Único de Saúde, expressos
no art. 198 da Constituição Federal e no art. $7 .^{\circ}$ da Lei n. ${ }^{\circ}$ 8.080, de 19 de
setembro de 1990.

Em que pese a determinação legal ter como objeto restrito o desempenho de atividades de saúde antes prestadas por entidade pública, trata-se de admissão expressa de que o vínculo a ser firmado pode disciplinar a concessão de serviço público de saúde. Resta verificar se o regime previsto pela lei em referência é adequado. Para tanto, é útil analisar uma das origens do contrato de gestão no direito brasileiro, vinculada à prestação de serviços públicos de saúde.

Trata-se da experiência da Fundação das Pioneiras Sociais, instituída por autorização da Lei n. ${ }^{0}$ 3.736, de 22 de março de 1960, que autorizou a incorporação da Associação das Pioneiras Sociais, para atuação em áreas como assistência médica, social, moral, educacional de pessoas pobres. Em 1991, a Lei n. $^{\circ} 8.246$, de 22 de outubro daquele ano autorizou o Poder Executivo a instituir o Serviço Social Autônomo das Pioneiras Sociais, ${ }^{744}$ com atuação restrita à área da saúde e com sua gestão a ser supervisionada pelo Ministério da Saúde, por meio de um contrato de gestão celebrado com a entidade. ${ }^{745}$ Tal contrato deveria, nos termos do artigo $3 .^{\circ}$ da Lei em referência, oferecer a possibilidade de flexibilização do regime imposto pela Constituição Federal aos entes públicos ao passo em que previa critérios de fiscalização e controle baseados nos resultados obtidos. ${ }^{746}$

744 Art. 1. ${ }^{\circ}$ É o Poder Executivo autorizado a instruir o Serviço Social Autônomo Associação das Pioneiras Sociais, pessoa jurídica de direito privado sem fins lucrativos, de interesse coletivo e de utilidade pública, com o objetivo de prestar assistência médica qualificada e gratuita a todos os níveis da população e de desenvolver atividades educacionais e de pesquisa no campo da saúde, em cooperação com o Poder Público.

745 A transição prevista pela lei ocorreu nos termos dos Decretos n. ${ }^{\circ} 370$ e 371 , ambos de 20 de dezembro daquele ano de 1991.

746 Art. 3. ${ }^{\circ}$ Competirá ao Ministério da Saúde supervisionar a gestão do Serviço Autônomo Associação Sociais, observadas as seguintes normas: (...) III - observado o disposto nesta lei, o Ministério da Saúde e a Secretaria da Administração Federal definirão os termos do contrato de gestão, que estipulará objetivamente prazos e responsabilidades para sua execução e especificará, com base em padrões internacionalmente aceitos, os critérios para avaliação do retorno obtido com a aplicação dos recursos repassados ao Serviço Social Autônomo Associação das Pioneiras Sociais, atendendo ao quadro nosológico brasileiro e respeitando a especificidade da entidade; IV - o orçamento-programa do Serviço Social Autônomo Associação das Pioneiras Sociais para a execução das atividades previstas no contrato de gestão será submetido anualmente ao Ministério da Saúde; V - a execução do contrato de gestão será supervisionada pelo Ministério e fiscalizada pelo Tribunal de Contas da União, que verificará, 
A justificativa para a edição da lei e a celebração do contrato de gestão da entidade que administra a hoje conhecida Rede Sarah Kubitschek de Hospitais do Aparelho

Locomotor foi exatamente possibilitar uma administração compatível com os objetivos da unidade de saúde em referência e não com os meios impostos pela Constituição Federal à atuação administrativa em geral. Além disso, por meio do contrato de gestão foram garantidos os recursos necessários ao cumprimento das finalidades da entidade - a adequada prestação dos serviços públicos de saúde, com observância das diretrizes estabelecidas pelo SUS.

O êxito da experiência da Rede Sarah de Hospitais, ainda que no decorrer do tempo tenha havido a necessidade de ajustes e aprimoramentos no vínculo contratual e nos

especialmente, a legalidade, legitimidade, operacionalidade e a economicidade no desenvolvimento das respectivas atividades e na conseqüente aplicação dos recursos repassados ao Serviço Social Autônomo Associação das Pioneiras Sociais, que será avaliada com base nos critérios referidos no inciso III deste artigo; VI - para a execução das atividades acima referidas, o Serviço Social Autônomo Associações das Pioneiras Sociais poderá celebrar contratos de prestação de serviços com quaisquer pessoas físicas ou jurídicas, sempre que considere ser essa a solução mais econômica para atingir os objetivos previstos no contrato de gestão, observado o disposto no inciso XV deste artigo. VII - o contrato de gestão assegurará ainda à diretoria do Serviço Social Autônomo Associação das Pioneiras Sociais a autonomia para a contratação e a administração de pessoal para aquele Serviço e para as instituições de assistência médica, de ensino e de pesquisa por ele geridas, sob regime da Consolidação das Leis do Trabalho, de forma a assegurar a preservação dos mais elevados e rigorosos padrões de atendimento à população; VIII - o processo de seleção para admissão de pessoal efetivo do Serviço Social Autônomo Associação das Pioneiras Sociais deverá ser precedido de edital publicado no Diário Oficial da União e constará de etapas eliminatória, classificatória e de treinamento, observadas as peculiaridades de cada categoria profissional; IX - o contrato de gestão conferirá à diretoria poderes para fixar níveis de remuneração para o pessoal da entidade, em padrões compatíveis com os respectivos mercados de trabalho, segundo o grau de qualificação exigido e os setores de especialização profissional; X - o contrato de gestão estipulará a obrigatória obediência, na relação de trabalho do Serviço Social Autônomo Associação das Pioneiras Sociais com o pessoal por ele contratado, aí incluído os membros da diretoria, aos seguintes princípios: a) proibição de contratação de servidores e empregados públicos em atividade; b) tempo integral; c) dedicação exclusiva; d) salário fixo, proibida a percepção de qualquer vantagem ou remuneração de qualquer outra fonte de natureza retributiva, excetuados proventos de aposentadoria ou pensão ou renda patrimonial; XI - o contrato de gestão poderá ser modificado, de comum acordo, no curso de sua execução, para incorporar ajustamentos aconselhados pela supervisão ou pela fiscalização, exceto no que se refere aos princípios da relação de trabalho enunciados no item $\mathrm{X}$, que não poderão deixar de ser observados, sob pena de demissão por justa causa do emprego que os transgredir; XII - o Serviço Social Autônomo Associação das Pioneiras Sociais apresentará anualmente ao Ministério da Saúde e ao Tribunal de Contas da União, até 31 de janeiro de cada ano, relatório circunstanciado sobre a execução do plano no exercício findo, com a prestação de contas dos recursos públicos nele aplicados, a avaliação do andamento do contrato e as análises gerências cabíveis; XIII - no prazo de trinta dias, o Ministério da Saúde apresentará parecer sobre o relatório do Serviço Social Autônomo Associação das Pioneiras Sociais ao Tribunal de Contas da União, que julgará a respectiva prestação de contas e no prazo de noventa dias, emitirá parecer sobre o cumprimento do contrato de gestão; XIV - o Tribunal de Contas da União fiscalizará a execução do contrato de gestão durante o seu desenvolvimento e determinará, a qualquer tempo, a adoção das medidas que julgar necessárias para corrigir falhas ou irregularidades que identificar, incluindo, se for o caso, a recomendação do afastamento de dirigente ou da rescisão, pelo Ministério da Saúde, do referido contrato, que somente será renovado se a avaliação final da execução do plano plurianual demonstrar a consecução dos objetivos preestabelecidos; XV - o Serviço Social Autônomo Associação das Pioneiras Sociais fará publicar no Diário Oficial da União, no prazo de noventa dias a partir da sua instituição, o manual de licitações que disciplinará os procedimentos que deverá adotar, objetivando a plena consecução dos incisos V e VI do art. 3. ${ }^{\circ}$ desta lei. 
mecanismos de controle, influenciou a criação da Lei n. ${ }^{\circ}$ 9.637/98 e serviu como importante fundamento no voto do Ministro Gilmar Mendes, que indeferiu a medida cautelar na Ação Direta de Inconstitucionalidade interposta contra referida lei, tendo inclusive implicado a mudança de posição do Ministro Eros Grau, que houvera votado pelo deferimento da cautelar. ${ }^{747}$

A criação do contrato de gestão com organizações sociais - sob a influência, na área da saúde, da experiência acima narrada - encontra-se inserida no que se convencionou denominar processo de reforma do Estado brasileiro, levado a cabo na década de 1990, seguindo o modelo idealizado pelo Ministério da Administração Federal e da Reforma do Estado (MARE) e direcionado a alcançar maior efetividade e eficiência nas atividades da Administração Pública.

No que tange ao setor de saúde, o Plano de Reforma do Estado classificou a prestação de tais serviços em uma das quatro categorias em que foi dividida a ação estatal. Tal categoria de atividades foi assim conceituada:

\begin{abstract}
Setor de serviços não-exclusivos do Estado: abrange atividades que não implicam a imposição unilateral da vontade do Estado e que são prestadas simultaneamente pelo Estado, pela iniciativa privada e pelas entidades do terceiro setor. Em qualquer hipótese, devem ser apoiados pelo Estado, em razão de serem fundamentais para a sociedade. É o caso dos serviços públicos sociais - assistência social, saúde, ensino, cultura - além de atividades ligadas à ciência e à tecnologia. ${ }^{748}$
\end{abstract}

No que se refere ao setor dos serviços não-exclusivos do Estado, a proposta de reforma levada a cabo defendia que a modalidade mais adequada à eficiência na prestação de tais serviços seria a propriedade pública não-estatal. Introduziu-se, assim, o conceito de propriedade (i) pública, não por pertencer ao Estado, mas porque tais entidades desempenhariam serviço de interesse público e (ii) não-estatal, por não integrarem a estrutura organizacional administrativa do Estado. Nesse contexto, inserem-se, nos termos propostos, as organizações sociais: entidades privadas a serem incentivadas pelo Estado para a prestação de determinadas atividades consideradas relevantes.

Não obstante, como se tem demonstrado, a saúde constitui dever do Estado e os serviços voltados à sua garantia são qualificados como serviços públicos. Assim, nos termos

747 BRASIL. Supremo Tribunal Federal. Ação Direta de Inconstitucionalidade n. ${ }^{\circ}$ 1923-5/DF, Tribunal Pleno, Relator Originário Min. Ilmar Galvão, Relator Min. Eros Grau, Diário de Justiça da União, 21 set. 2007.

748 BRASIL. Presidente. Plano Diretor da Reforma do Aparelho do Estado: Presidência da República, Câmara da Reforma do Estado, Ministério da Administração Federal e Reforma do Estado, 1995. p.51. 
do entendimento ora adotado, a utilização do contrato de gestão para a prestação de tais serviços deve implicar sua concessão, com a manutenção da responsabilidade do Estado pela prestação do serviço. Em outras palavras, a única interpretação admissível para a celebração de contratos de gestão para a prestação de serviços públicos de saúde indica que tal ajuste importa a concessão do serviço, que permanece público e sujeito à responsabilidade do Estado. Daí ter-se sustentado acima que o contrato de gestão é um mecanismo de concessão de serviços públicos de saúde. ${ }^{749}$

O regime geral para disciplina do contrato de gestão previsto pela Lei n. ${ }^{\circ}$ 9.637/98 é mais adequado à contratação externa de serviços públicos de saúde (e à delegação da gestão de uma unidade pública de saúde) do que aquele previsto pela Lei n. ${ }^{\circ}$ 8.666./93, pois privilegia a negociação, a responsabilização por eventuais desvios e o controle dos resultados alcançados, além de fazer referência à garantia, por meio de previsão orçamentária, dos recursos necessários ao alcance das metas ou, em outras palavras, no caso ora analisado, à devida prestação dos serviços públicos de saúde. ${ }^{750}$ Nesse sentido, subsidiariamente à Lei

749 Assim é, por exemplo, compreendido o contrato de gestão celebrado no âmbito do sistema nacional de saúde português. De acordo com o artigo $8 .^{\circ}$ do Decreto-Lei n. $.^{\circ} 185 / 2002$ daquele país: 1 - O contrato de gestão tem por objecto principal assegurar as prestações de saúde promotoras, preventivas ou terapêuticas, correspondentes ao serviço público de saúde através de um estabelecimento de saúde, ou parte funcionalmente autónoma, integrado ou a integrar no Serviço Nacional de Saúde. 2 - O contrato de gestão pode ainda ter por objecto a concepção, construção, financiamento, conservação e exploração do estabelecimento, ou de parte funcionalmente autónoma. 3 - As partes no contrato de gestão são a entidade pública contratante e a entidade gestora. 4 - A entidade pública contratante é o Estado ou qualquer outra pessoa colectiva pertencente ao Ministério da Saúde ou integrada no Serviço Nacional de Saúde. No preâmbulo do Decreto-Lei n. ${ }^{\circ} 185 / 2002$ consta expressamente que: "O contrato de gestão reveste, assim, a natureza de verdadeiro contrato de concessão de serviço público, embora a sua designação pretenda clarificar que, no âmbito da saúde, o Estado mantém em maior grau a responsabilidade, designadamente porque é necessário que todos os cidadãos, sem exceção, tenham acesso a cuidados de saúde através de um Serviço Nacional de Saúde que observe as características de generalidade e universalidade, ainda que com o concurso de outras entidades na sua gestão (os grifos não constam do original).

750 Tais previsões encontram-se dispostas, sobretudo, nos seguintes preceitos: Art. $6 .^{\circ} \mathrm{O}$ contrato de gestão, elaborado de comum acordo entre o órgão ou entidade supervisora e a organização social, discriminará as atribuições, responsabilidades e obrigações do Poder Público e da organização social. Parágrafo único. O contrato de gestão deve ser submetido, após aprovação pelo Conselho de Administração da entidade, ao Ministro de Estado ou autoridade supervisora da área correspondente à atividade fomentada. Art. 7. ${ }^{\circ} \mathrm{Na}$ elaboração do contrato de gestão, devem ser observados os princípios da legalidade, impessoalidade, moralidade, publicidade, economicidade e, também, os seguintes preceitos: I - especificação do programa de trabalho proposto pela organização social, a estipulação das metas a serem atingidas e os respectivos prazos de execução, bem como previsão expressa dos critérios objetivos de avaliação de desempenho a serem utilizados, mediante indicadores de qualidade e produtividade; II - a estipulação dos limites e critérios para despesa com remuneração e vantagens de qualquer natureza a serem percebidas pelos dirigentes e empregados das organizações sociais, no exercício de suas funções. Parágrafo único. Os Ministros de Estado ou autoridades supervisoras da área de atuação da entidade devem definir as demais cláusulas dos contratos de gestão de que sejam signatários. Art. $8 .^{\circ}$ A execução do contrato de gestão celebrado por 
n. ${ }^{\circ} 9.637 / 98$, no caso de tais serviços públicos, na ausência de legislação própria, deve ser aplicada a lei geral de concessões para a disciplina do ajuste.

No que se refere ao procedimento para a escolha da entidade com que a Administração Pública vai celebrar contrato de gestão para a prestação de serviços públicos de saúde, considerando que a Lei n. ${ }^{\circ}$ 9.637/98 não trata do assunto, deve ser aplicado o entendimento exposto no Item 4.3.1.1. Como se trata de hipótese de concessão de serviço público, não havendo disposição legal específica, ${ }^{751}$ nos termos do que possibilita o artigo 37, inciso XXI da Constituição Federal, ${ }^{752}$ (i) ao invés de ser aplicado o procedimento previsto pela Lei n. ${ }^{\circ} 8.666 / 93$, o qual, em que pese as hipóteses de inexigibilidade e dispensa de sua realização (ii) deve ser aplicado, conforme sugere Marçal Justen Filho, o procedimento previsto pelos

organização social será fiscalizada pelo órgão ou entidade supervisora da área de atuação correspondente à atividade fomentada. $\S 1 .^{\circ}$ A entidade qualificada apresentará ao órgão ou entidade do Poder Público supervisora signatária do contrato, ao término de cada exercício ou a qualquer momento, conforme recomende o interesse público, relatório pertinente à execução do contrato de gestão, contendo comparativo específico das metas propostas com os resultados alcançados, acompanhado da prestação de contas correspondente ao exercício financeiro. $§ 2{ }^{\circ}$ Os resultados atingidos com a execução do contrato de gestão devem ser analisados, periodicamente, por comissão de avaliação, indicada pela autoridade supervisora da área correspondente, composta por especialistas de notória capacidade e adequada qualificação. $\S 3 .^{\circ}$ A comissão deve encaminhar à autoridade supervisora relatório conclusivo sobre a avaliação procedida. Art. 9. ${ }^{\circ}$ Os responsáveis pela fiscalização da execução do contrato de gestão, ao tomarem conhecimento de qualquer irregularidade ou ilegalidade na utilização de recursos ou bens de origem pública por organização social, dela darão ciência ao Tribunal de Contas da União, sob pena de responsabilidade solidária. (...) Art. 12. Às organizações sociais poderão ser destinados recursos orçamentários e bens públicos necessários ao cumprimento do contrato de gestão. $\S 11^{\circ}$ São assegurados às organizações sociais os créditos previstos no orçamento e as respectivas liberações financeiras, de acordo com o cronograma de desembolso previsto no contrato de gestão. $\S 2$. $^{\circ}$ Poderá ser adicionada aos créditos orçamentários destinados ao custeio do contrato de gestão parcela de recursos para compensar desligamento de servidor cedido, desde que haja justificativa expressa da necessidade pela organização social. $\S 3$. $^{\circ}$ Os bens de que trata este artigo serão destinados às organizações sociais, dispensada licitação, mediante permissão de uso, consoante cláusula expressa do contrato de gestão.

751 Ressalte-se que a hipótese de dispensa de licitação inserida na Lei n. ${ }^{\circ}$ 8.666/93, em conjugação com a edição da Lei n. ${ }^{\circ} 9.637 / 98$ não se refere à celebração do contrato de gestão com a organização social, mas da contratação de serviços previstos em tal contrato. Eis o teor do dispositivo em questão: Art. 24. É dispensável a licitação: (...) XXIV - para a celebração de contratos de prestação de serviços com as organizações sociais, qualificadas no âmbito das respectivas esferas de governo, para atividades contempladas no contrato de gestão (inciso incluído pela Lei n. ${ }^{\circ}$ 9.648, de 27 de maio de 1998).

752 Art. 37 (...) XXI - ressalvados os casos especificados na legislação, as obras, serviços, compras e alienações serão contratados mediante processo de licitação pública que assegure igualdade de condições a todos os concorrentes, com cláusulas que estabeleçam obrigações de pagamento, mantidas as condições efetivas da proposta, nos termos da lei, o qual somente permitirá as exigências de qualificação técnica e econômica indispensáveis à garantia do cumprimento das obrigações. 
artigos 14 e seguintes da Lei n. $^{\circ} 8.987 / 95$, os quais muito mais se aproximam do objeto a ser contratado. ${ }^{753}$

Nesse sentido, vale ressaltar a advertência de Benedito Porto Neto, segundo a qual:

\begin{abstract}
A licitação (...) não pode desviar a Administração Pública dos objetivos por ela perseguidos. Ela não é uma finalidade em si mesmo, mas mero instrumento para, uma vez definido o interesse público, selecionar propostas vantajosas para implementá-lo e com dispensa de tratamento isonômico. ${ }^{754}$
\end{abstract}

De qualquer modo, parece incontestável que a entidade a ser escolhida para a gestão de uma unidade pública de saúde ou para a prestação de serviço público de saúde em sua própria estrutura deve comprovar não apenas sua existência prévia, mas capacidade técnica de realização dos serviços concedidos. ${ }^{755}$

De outro bordo, insta ressaltar que, em se tratando de contrato de gestão de serviço público de saúde, é evidente que não se aplica à entidade privada o dever contratar por meio do procedimento de licitação previsto pela Lei n. ${ }^{\circ} 8.666 / 93$. Em primeiro lugar, porque tal lei não se aplica a entidades privadas; em segundo lugar porque a própria Lei n. ${ }^{0}$ 9.637/98 prevê a edição, pela organização social, de um estatuto de compras e serviços; ${ }^{756}$ em terceiro lugar, porque não se trata de fomento estatal a uma entidade privada, o que de certa forma justificaria a determinação da entidade fomentadora acerca do modo de aplicação dos recursos envolvidos; em quarto lugar, a própria lei em referência prevê mecanismos de

753 JUSTEN FILHO, Marçal. Comentários à lei de licitações e contratos administrativos. 12.ed. São Paulo: Dialética, 2008. p.331. O mesmo deve ser dito em relação à possibilidade de subcontratação de determinadas atividades pela organização social: tal hipótese deve ser em regra admitida e regulamentada no termo de contrato.

754 PORTO NETO, Benedito. Licitação para contratação de parceria público-privada. In: SUNDFELD, Carlos Ari. Parcerias público-privadas. São Paulo: Malheiros, 2005. p.142.

755 Nesse sentido, ao contrário da lei federal, algumas leis estaduais, como a Lei do Estado de São Paulo Lei n. ${ }^{\circ} 846$, de 4 de junho de 1998 - exige que se comprovem, para qualificação como organização social e conseqüente celebração do contrato de gestão, a existência e a prestação de serviços de saúde por um período prévio de cinco anos. Sobre a experiência da gestão das organizações sociais de saúde, em especial, no Estado de São Paulo, conferir: TANAKA, Oswaldo Y; MELO, Cristina (Orgs.). Inovação e gestão: a organização social no setor saúde. São Paulo: Annablume/Fapesp, 2002.

756 Art. 17. A organização social fará publicar, no prazo máximo de noventa dias contado da assinatura do contrato de gestão, regulamento próprio contendo os procedimentos que adotará para a contratação de obras e serviços, bem como para compras com emprego de recursos provenientes do Poder Público. 
controle e fiscalização, com ênfase em metas e objetivos a serem alcançados; em quinto lugar, porque a imposição do dever de licitar - e de outros deveres formais impostos à Administração Pública - retira a própria essência do contrato de gestão, que é o de transferir a gestão para uma entidade privada.

Sobre o tema, decisão de primeiro grau proferida pela Justiça Federal do Estado de São Paulo, em ação judicial já referida neste trabalho, considerou ilegal a contratação de organizações sociais prestadoras de serviços públicos de saúde em face da ausência de processo licitatório para escolha da entidade parceira. ${ }^{757} \mathrm{Em}$ que pese toda a argumentação do Ministério Público Federal, como aquela acerca da (inexistente) determinação constitucional de prestação direta dos serviços de saúde pelo Estado, ${ }^{758}$ a sentença prolatada tem como fundamento estritamente a ausência de procedimento licitatório para escolha da entidade privada. ${ }^{759}$

Além disso, com as ressalvas acima consignadas, não há em tese óbice a que a gestão de uma unidade pública, com trespasse de recursos físicos, humanos e financeiros, seja transferida a um ente privado. Imprescindível é que do ajuste constem mecanismos

757 A lei municipal em referência é a já mencionada Lei n. ${ }^{\circ}$ 14.132/06. Em seu artigo 5. ${ }^{\circ}$, referido ato legislativo dispõe acerca da dispensa de licitação para celebração do contrato de gestão, nos seguintes termos: Art. 5. ${ }^{\circ}$ Para os efeitos desta lei, entende-se por contrato de gestão o instrumento firmado entre o Poder Público e a entidade qualificada como organização social, com vistas à formação de parceria entre as partes para fomento e execução de atividades relativas às mencionadas em seu art. 1. ${ }^{\circ}$ (dispositivo com redação dada pela Lei n. $^{\circ} 14.482$, de 16 de julho de 2007). $§ 1 .^{\circ}$ É dispensável a licitação para a celebração dos contratos de que trata o "caput" deste artigo, nos termos do art. 24, inciso XXIV, da Lei Federal n. ${ }^{\circ} 8.666$, de 21 de junho de 1993, com a redação dada pela Lei Federal n. ${ }^{\circ}$ 9.648, de 27 de maio de 1998. § 2. ${ }^{\circ}$ O Poder Público dará publicidade da decisão de firmar cada contrato de gestão, indicando as atividades que deverão ser executadas, nos termos do art. $1 .^{\circ}$ desta lei. $\S 3 .^{\circ}$ A celebração de cada contrato de gestão poderá ser precedida de processo seletivo quando mais de uma entidade qualificada como organização social manifestar expressamente interesse em prestar o serviço objeto da parceria, na mesma unidade administrativa, nos termos regulamentados pelo Poder Executivo (dispositivo com redação dada pela Lei n. ${ }^{\circ} 14.482$, de 16 de julho de 2007). $\S 4 .^{\circ}$ O contrato de gestão poderá ser firmado com a entidade qualificada como organização social associada a instituições sem fins lucrativos, com as quais mantenha termo de parceria, na forma e condições que dispuser decreto do Executivo (dispositivo com redação dada pela Lei n. ${ }^{0}$ 14.482, de 16 de julho de 2007) - (os grifos não constam do original).

758 Mencionada no Item 4.1.1.

759 SÃO PAULO (ESTADO). 3. ${ }^{a}$ Vara Cível da Justiça Federal. Processo n. ${ }^{\circ}$ 2006.61.00.009087-9. Juíza Federal Maria Lucia Lencastre URSAIA. Sentença prolatada em 26 ago. 2008. 
que possibilitem a fiscalização e controle acerca da utilização de tais recursos. ${ }^{760}$ Como assinalado, uma organização social que presta serviço público de saúde é uma entidade privada concessionária de um serviço público que deve ter autonomia para gerenciamento de suas atividades, com controle dos resultados baseado nos critérios a serem definidos no termo do contrato de gestão - o qual deve conter cláusulas específicas acerca dos deveres do prestador privado quanto ao atendimento às diretrizes do subsistema público de saúde.

\subsubsection{Termos de parceria}

Um ano após a publicação da Lei das Organizações Sociais, foi aprovada a Lei n. ${ }^{\circ} 9.790$ de 23 de junho de 1999, que criou mais uma modalidade de qualificação outorgada pelo poder público a entidades do terceiro setor denominada Organização da Sociedade Civil de Interesse Público (OSCIP), ${ }^{761}$ e instituiu a possibilidade de celebração de um outro novo instrumento de ajuste com o poder público, denominado termo de parceria.

O crescimento expressivo do número de entidades do terceiro setor e a diversificação de suas áreas de atuação, somados à relevância constitucional outorgada à participação da sociedade civil na consecução dos objetivos do Estado brasileiro induziu a adoção de um novo mecanismo de apoio do Estado às entidades do terceiro setor. ${ }^{762}$ Assim, a Lei das

760 Novamente, assinalando o exemplo do Estado de São Paulo, é importante destacar que alguns entes federativos permitem apenas a celebração de contratos de gestão para a ampliação da estrutura apta a oferecer os serviços, e não para o trespasse de estruturas públicas já existentes. Nos termos do que se consignou no Item 4.1, ambas as hipóteses são permitidas pela Constituição Federal, desde que fundamentadas. No caso de mera transferência da gestão de uma unidade pública, há que se demonstrar o aumento na eficiência dos serviços a serem prestados. Tal demonstração, como parece evidente, nem sempre é possível ocorrer a priori, daí a utilização de experiências externas e internas, bem e mal sucedidas, acerca dos modelos de gestão na saúde, como mecanismos de comparação para que administradores públicos possam, com respeito à legislação setorial e regional, decidir pelo modelo mais adequado. Tal observação implica reconhecer que também na Administração Pública, para que ocorra o processo de evolução e desenvolvimento em suas atividades prestacionais, deve ocorrer um processo de tentativas, erros e acertos - com a conseqüente adoção do melhor modelo. No cenário brasileiro da saúde pública, pior do que bem intencionadas tentativas de adotar novos modelos de prestação dos serviços públicos de saúde é a manutenção da inércia - e da conseqüente insuficiência quantitativa e qualitativa dos serviços ofertados pelo Estado.

761 Art. 1. ${ }^{\circ}$ Podem qualificar-se como Organizações da Sociedade Civil de Interesse Público as pessoas jurídicas de direito privado, sem fins lucrativos, desde que os respectivos objetivos sociais e normas estatutárias atendam aos requisitos instituídos por esta Lei.

762 Como já consignou este autor: "(...) a disciplina jurídica até então vigente, da outorga de títulos e certificados como requisitos para obtenção de incentivos públicos era pautada (i) pelo burocratismo excessivo, (ii) pela sobreposição de certificações, (iii) pela ausência de critérios claros e transparentes para a obtenção dos reconhecimentos e (iv) pela constante influência política nos processos de 
OSCIP nasceu com o escopo de trazer critérios legais objetivos e aptos a definir quais entidades efetivamente possuem caráter público.

Para tanto, dada a dificuldade de uma definição do que seja interesse público, a Lei.$^{\circ}{ }^{9}$ 9.790/99 optou por trazer uma lista com todas as entidades cuja natureza impede a obtenção da qualificação de $\operatorname{OSCIP}^{763}$ e outra lista com todas as atividades cujo desenvolvimento possibilita a qualificação. ${ }^{764}$ De outro lado, com o objetivo de facilitar a obtenção de apoio estatal a suas atividades, a lei em referência previu o referido modelo de ajuste denominado termo de parceria.

Note-se que a disciplina legal dos termos de parceria em muito se assemelha à dos contratos de gestão, de modo que as observações acerca daquele modelo de ajuste podem, em grande medida, ser aplicadas aos serviços de saúde prestados por meio de termos de parceria. A própria definição legal do vínculo é extremamente semelhante, como se percebe do seguinte dispositivo legal:

qualificação e de outorga dos benefícios." (MÂNICA, Fernando Borges. Panorama histórico-legislativo do terceiro setor no Brasil: do conceito de terceiro setor à lei das OSCIP. In: OLIVEIRA, Gustavo J. de. (Coord.). Terceiro setor, empresas e estado: novas fronteiras entre o público e o privado. Belo Horizonte: Fórum, 2007. p.186).

763 Art. 2. ${ }^{\circ}$ Não são passíveis de qualificação como Organizações da Sociedade Civil de Interesse Público, ainda que se dediquem de qualquer forma às atividades descritas no art. $3 .{ }^{\circ}$ desta Lei: I - as sociedades comerciais; II - os sindicatos, as associações de classe ou de representação de categoria profissional; III - as instituições religiosas ou voltadas para a disseminação de credos, cultos, práticas e visões devocionais e confessionais; IV - as organizações partidárias e assemelhadas, inclusive suas fundações; $\mathrm{V}$ - as entidades de benefício mútuo destinadas a proporcionar bens ou serviços a um círculo restrito de associados ou sócios; VI - as entidades e empresas que comercializam planos de saúde e assemelhados; VII - as instituições hospitalares privadas não gratuitas e suas mantenedoras; VIII - as escolas privadas dedicadas ao ensino formal não gratuito e suas mantenedoras; IX - as organizações sociais; X - as cooperativas; XI - as fundações públicas; XII - as fundações, sociedades civis ou associações de direito privado criadas por órgão público ou por fundações públicas; XIII - as organizações creditícias que tenham quaisquer tipo de vinculação com o sistema financeiro nacional a que se refere o art. 192 da Constituição Federal.

764 Art. 3. ${ }^{\circ}$ A qualificação instituída por esta Lei, observado em qualquer caso, o princípio da universalização dos serviços, no respectivo âmbito de atuação das Organizações, somente será conferida às pessoas jurídicas de direito privado, sem fins lucrativos, cujos objetivos sociais tenham pelo menos uma das seguintes finalidades: I - promoção da assistência social; II - promoção da cultura, defesa e conservação do patrimônio histórico e artístico; III - promoção gratuita da educação, observando-se a forma complementar de participação das organizações de que trata esta Lei; IV - promoção gratuita da saúde, observando-se a forma complementar de participação das organizações de que trata esta Lei; V - promoção da segurança alimentar e nutricional; VI - defesa, preservação e conservação do meio ambiente e promoção do desenvolvimento sustentável; VII - promoção do voluntariado; VIII - promoção do desenvolvimento econômico e social e combate à pobreza; IX - experimentação, não lucrativa, de novos modelos sócioprodutivos e de sistemas alternativos de produção, comércio, emprego e crédito; $\mathrm{X}$ - promoção de direitos estabelecidos, construção de novos direitos e assessoria jurídica gratuita de interesse suplementar; XI promoção da ética, da paz, da cidadania, dos direitos humanos, da democracia e de outros valores universais; XII - estudos e pesquisas, desenvolvimento de tecnologias alternativas, produção e divulgação de informações e conhecimentos técnicos e científicos que digam respeito às atividades mencionadas neste artigo. 
Art. 9. ${ }^{\circ}$ Fica instituído o Termo de Parceria, assim considerado o instrumento passível de ser firmado entre o Poder Público e as entidades qualificadas como Organizações da Sociedade Civil de Interesse Público destinado à formação de vínculo de cooperação entre as partes, para o fomento e a execução das atividades de interesse público previstas no art. $3 .^{\circ}$ desta Lei. ${ }^{765}$

Não obstante, algumas peculiaridades deste modelo de ajuste merecem análise.

Em primeiro lugar, a Lei n. ${ }^{\circ} 9.790 / 99$ prevê expressamente em seu artigo 3. ${ }^{\circ}$, inciso IV, como uma das áreas de atuação das OSCIPs a promoção gratuita da saúde, observando-se a forma complementar de participação das organizações de que trata esta Lei. Tal forma complementar poderia ser entendida como a complementaridade da participação privada na prestação de serviços públicos de saúde, tal qual a previsão do artigo 199, parágrafo primeiro da Constituição Federal. No entanto, a mesma referência consta da lei quando se refere

765 O mesmo se passa com a regulamentação do vínculo, que em linhas gerais pode ser compreendido pela análise dos seguintes dispositivos: Art. 10. O Termo de Parceria firmado de comum acordo entre o Poder Público e as Organizações da Sociedade Civil de Interesse Público discriminará direitos, responsabilidades e obrigações das partes signatárias. $§ 1 .^{\circ}$ A celebração do Termo de Parceria será precedida de consulta aos Conselhos de Políticas Públicas das áreas correspondentes de atuação existentes, nos respectivos níveis de governo. $\S 2{ }^{\circ}$ São cláusulas essenciais do Termo de Parceria: I - a do objeto, que conterá a especificação do programa de trabalho proposto pela Organização da Sociedade Civil de Interesse Público; II - a de estipulação das metas e dos resultados a serem atingidos e os respectivos prazos de execução ou cronograma; III - a de previsão expressa dos critérios objetivos de avaliação de desempenho a serem utilizados, mediante indicadores de resultado; IV - a de previsão de receitas e despesas a serem realizadas em seu cumprimento, estipulando item por item as categorias contábeis usadas pela organização e o detalhamento das remunerações e benefícios de pessoal a serem pagos, com recursos oriundos ou vinculados ao Termo de Parceria, a seus diretores, empregados e consultores; V - a que estabelece as obrigações da Sociedade Civil de Interesse Público, entre as quais a de apresentar ao Poder Público, ao término de cada exercício, relatório sobre a execução do objeto do Termo de Parceria, contendo comparativo específico das metas propostas com os resultados alcançados, acompanhado de prestação de contas dos gastos e receitas efetivamente realizados, independente das previsões mencionadas no inciso IV; VI - a de publicação, na imprensa oficial do Município, do Estado ou da União, conforme o alcance das atividades celebradas entre o órgão parceiro e a Organização da Sociedade Civil de Interesse Público, de extrato do Termo de Parceria e de demonstrativo da sua execução física e financeira, conforme modelo simplificado estabelecido no regulamento desta Lei, contendo os dados principais da documentação obrigatória do inciso $\mathrm{V}$, sob pena de não liberação dos recursos previstos no Termo de Parceria. Art. 11. A execução do objeto do Termo de Parceria será acompanhada e fiscalizada por órgão do Poder Público da área de atuação correspondente à atividade fomentada, e pelos Conselhos de Políticas Públicas das áreas correspondentes de atuação existentes, em cada nível de governo. $§ 1$. $^{\circ}$ Os resultados atingidos com a execução do Termo de Parceria devem ser analisados por comissão de avaliação, composta de comum acordo entre o órgão parceiro e a Organização da Sociedade Civil de Interesse Público. $§ 2{ }^{\circ}$ A comissão encaminhará à autoridade competente relatório conclusivo sobre a avaliação procedida. $\S 3 .^{\circ}$ Os Termos de Parceria destinados ao fomento de atividades nas áreas de que trata esta Lei estarão sujeitos aos mecanismos de controle social previstos na legislação. Art. 12. Os responsáveis pela fiscalização do Termo de Parceria, ao tomarem conhecimento de qualquer irregularidade ou ilegalidade na utilização de recursos ou bens de origem pública pela organização parceira, darão imediata ciência ao Tribunal de Contas respectivo e ao Ministério Público, sob pena de responsabilidade solidária. 
às atividades de educação, as quais também devem ser prestadas em caráter complementar, ${ }^{766}$ o que retira tal condição como especificidade decorrente do tratamento constitucional dos serviços públicos de saúde.

No que se refere à gratuidade, deve ser destacada a previsão do Decreto n. ${ }^{\circ} 3.100$, de 30 de junho de 1999, que regulamenta a lei em referência, assim dispõe:

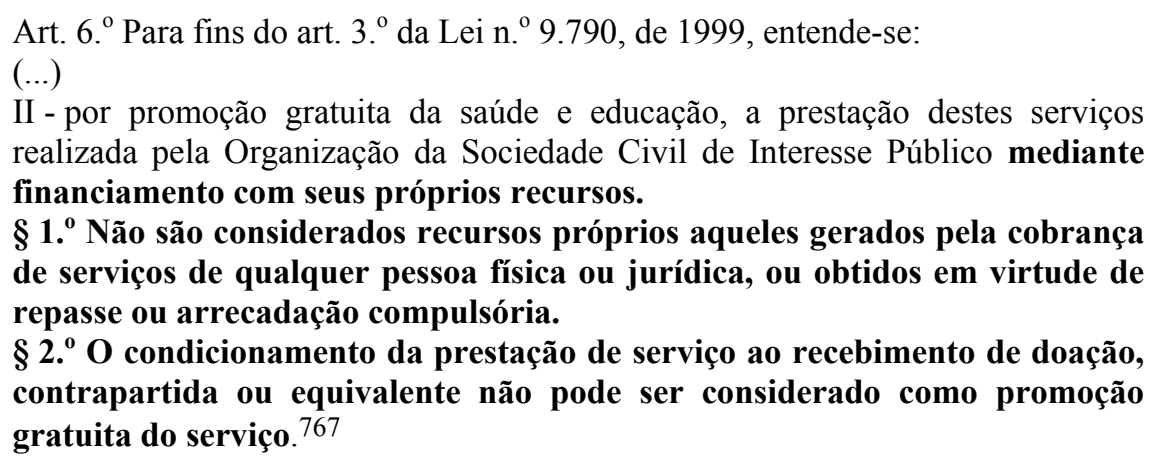

Tal disposição é, evidentemente, ilegal e ilógica, além de praticamente inviabilizar a existência de OSCIPs voltadas exclusivamente à saúde. Se os serviços devem ser prestados gratuitamente e se é vedado qualquer tipo de repasse para seu financiamento, resta apenas a hipótese de prestação integral das atividades de saúde com base em trabalho voluntário.

Além disso, a Lei n. ${ }^{\circ}$ 9.790/99 determina as possíveis configurações das atividades desenvolvidas pelas OSCIPs:

\begin{abstract}
Art. 3. ${ }^{\circ}(\ldots)$
Parágrafo único. Para os fins deste artigo, a dedicação às atividades nele previstas configura-se mediante a execução direta de projetos, programas, planos de ações correlatas, por meio da doação de recursos físicos, humanos e financeiros, ou ainda pela prestação de serviços intermediários de apoio a outras organizações sem fins lucrativos e a órgãos do setor público que atuem em áreas afins.
\end{abstract}

Tais hipóteses de atuação, ainda que o dispositivo peque por falta de clareza, indicam que o objeto dos termos de parceria, o qual evidentemente deve ser compatível com a área de atuação da entidade, terão duração definida no tempo - como se depreende das expressões projetos, programas, planos e ações correlatas - e (ou) consistirão em atividades de apoio a outras entidades públicas ou privadas. Em ambas as hipóteses, não se

766 Art. 3. ${ }^{\circ}$ (...) III - promoção gratuita da educação, observando-se a forma complementar de participação das organizações de que trata esta Lei.

767 Os grifos não constam do original. 
trata de participação privada na execução de serviços públicos de saúde, mas, possivelmente, participação privada em ações de saúde - conforme a noção adotada no Item 3.2.2.

Portanto, em que pese a importância das OSCIPs para a implementação de políticas públicas, sua concepção e sua natureza, nos termos da Lei n. ${ }^{\circ}$ 9.790/99, revelam sua inadequação para a formação de vínculo por meio do qual sejam prestados serviços públicos de saúde por entes privados qualificados como tais. Isso não significa dizer, como assinalado, que ações de saúde não possam ser levadas a cabo por meio de OSCIPs, como é o caso, por exemplo de alguns programas federais, como o Programa Saúde da Família. ${ }^{768} \mathrm{O}$ que se quer sustentar é que os termos de parceria, ainda que possuam previsão legal próxima daquela dos contratos de gestão previstos pela Lei n. ${ }^{\circ} 9.637 / 98$, configuram modelos de ajuste voltados à disciplina de ações de saúde não qualificadas como serviços público de saúde.

Além disso, ao contrário da Lei das Organizações Sociais, a Lei das OSCIPs não faz referência à observância pelas entiudades privadas assim qualificadas, das diretrizes do SUS, o que também conduz ao entendimento de que tal vínculo (o termo de parceria) não tem como objeto atividades qualificadas como serviços públicos de saúde.

768 Sobre o tema, conferir: OLIVEIRA, Gustavo Justino de; MÂNICA, Fernando Borges. Agentes comunitários de saúde: reflexões sobre a emenda constitucional n. ${ }^{\circ}$ 51, de 14 de fevereiro de 2006, e a lei federal n. ${ }^{\circ} 11.350$, de 05 de outubro de 2006. Belo Horizonte: Fórum, 2009. 


\section{CONCLUSÕES}

A análise da participação privada na assistência à saúde, desde a consolidação do Direito Administrativo até sua consagração como direito fundamental, demonstrou que, ao assumir a responsabilidade pelo direito à saúde das pessoas, o Estado passou a desenvolver uma série de atividades prestacionais, entre elas a prestação de serviços públicos voltados à garantia daquele direito.

O estudo da disciplina jurídica adotada por Estados estrangeiros para regular a prestação de serviços de saúde, aliado à análise dos modelos de prestação de tais serviços no Brasil, pré e pós-Constituição de 1988, permitiu que fossem descortinadas algumas inconsistências na interpretação e regulamentação do texto constitucional pátrio.

Tanto as insuficiências apontadas quanto as soluções encampadas, reforçadas ou mesmo lançadas nesta tese, não serão neste momento retomadas ou resumidas, o que implicaria possibilidade de simplificação de raciocínio, desvirtuamento de idéias e empobrecimento do próprio trabalho. Por outra trilha, o que se fará neste instante é a avaliação dos resultados obtidos, a medição de suas conseqüências e a formulação de propostas voltadas à adequação da participação privada nos serviços públicos de saúde no Brasil.

Este estudo guiou-se pela busca de soluções jurídicas aptas a promover a efetivação do direito à saúde por meio da análise dos mecanismos de participação privada na prestação dos respectivos serviços públicos. Ressalte-se a análise levada a cabo, no mesmo passo em que não partiu da premissa, não conclui que a participação privada na prestação de serviços de saúde é em si boa ou má. Ademais, restou evidenciada a imprescindibilidade da participação privada na prestação dos serviços de saúde, os quais necessitam ser delimitados, para que possam ser devidamente controlados e adequadamente prestados.

A prestação de serviços de saúde passa por um processo de crise e reformulação no mundo todo. Os Estados estrangeiros analisados neste estudo possuem algumas características próprias e certos traços comuns, dentre os quais podem ser ressaltadas (i) a tendência à universalização do acesso, (ii) a delimitação dos serviços prestados e (iii) a possibilidade de contratualização e negociação da entidade responsável pela garantia do serviço com prestadores públicos e privados. Ao contrário do que muitos imaginam, em Estados como França, Alemanha e Inglaterra, a prestação dos serviços de saúde garantidos pelo Estado é em grande medida realizada por entidades privadas, sujeitas ao controle estatal e disciplinadas por meio de contratos. 
Se a contratualização - com entes públicos, privados e outros de natureza híbrida teve inicialmente o objetivo de reduzir custos, sua utilização até o momento em países estrangeiros, em que pese a existência de experiências mal-sucedidas, comprovou sua aptidão para racionalizar despesas e proporcionar mecanismos mais eficientes de controle e de transparência. Daí a atual importância dos contratos para a prestação de serviços de saúde garantidos pelo Estado em todo o mundo.

A contratualização com a iniciativa privada para a prestação de serviços públicos de saúde, tal qual prevista pela Constituição brasileira, permite a necessária delimitação dos serviços públicos a serem prestados por cada ente prestador, algo imprescindível ao funcionamento do subsistema público de saúde nacional. A experiência comparada na disciplina dos serviços de saúde demonstra um dado inelutável: um sistema de saúde pode ser universal e igualitário apenas na medida em que se delimitem a relação de serviços prestados e (ou) a relação de usuários atendidos. Como visto neste trabalho, os Estados que adotam sistema de financiamento universal (como é o caso brasileiro) oferecem uma parcela de serviços públicos de saúde a todas as pessoas e deixa outros serviços para que a iniciativa privada deles se encarregue.

No Brasil, a disjunção entre a interpretação descuidada do texto Constitucional e a realidade apenas pode ser corrigida se forem aceitas (de)limitações formais no que se entende por universalidade do acesso. Afinal, tais (de)limitações materiais já ocorrem na medida em que todas as pessoas que possuem condições financeiras buscam outra alternativa de assistência à saúde - como a saúde suplementar, o desembolso direto ou mesmo o sistema de cartões saúde.

É importante ter claro que defender o direito constitucional à saúde não implica defender a estatização, e tampouco defender a privatização; implica defender mecanismos que privilegiem melhores modelos de efetivação da prestação dos serviços. A complementaridade da participação privada na prestação de serviços públicos de saúde prevista pela Constituição constitui noção despida de conteúdo, de modo que a defesa do direito à saúde corresponde à defesa da prestação efetiva dos serviços públicos a todos que deles necessitem, por entidades públicas ou privadas vinculadas ao Estado por meio de contratos.

Essa compreensão demanda seja o setor de saúde no Brasil visualizado em seu conjunto, não apenas por um olhar focado nos serviços prestados pelo subsistema público de saúde e muito menos na prestação de serviços de saúde por entidades de natureza estatal. A regulamentação do SUS, à luz da complementaridade da participação privada, deve inserir-se 
no comportamento administrativo contemporâneo, de um Estado que não mais ocupa o centro das relações sociais, mas coordena iniciativas as mais diversas, sem a desresponsabilização estatal pela garantia de serviços de saúde, que têm constitucionalmente assegurada sua qualificação como serviços públicos.

A participação privada na prestação de serviços públicos de saúde deve ocorrer por meio de contratos de prestação de serviços (para serviços internos a uma unidade pública) ou por meio de contratos de concessão, concessão administrativa e contratos de gestão (para os casos de contratualização externa ou de trespasse da gestão de uma unidade pública). Em todos os casos, do vínculo a ser firmado com o ente privado decorrem:

(i) a manutenção do equilíbrio econômico-financeiro dos contratos, nos termos do artigo 37, inciso XXI da Constituição Federal, ${ }^{769}$ e da própria Lei Orgânica da Saúde, ${ }^{770}$ o que resulta no reconhecimento do direito dos prestadores privados à manutenção e eventual recomposição pela insuficiente remuneração paga pelo Estado, nos termos das tabelas de procedimentos do SUS; e

(ii) a responsabilidade objetiva do prestador do serviço, nos termos do artigo 37, parágrafo sexto da Constituição Federal.771

A Constituição Federal de 1988 previu expressamente a hipótese de contratualização dos serviços públicos de saúde com a iniciativa privada, e diversos modelos de ajuste recentemente criados permitem tal participação. Não obstante, a complexidade do SUS, em

769 Art. 37 (...) XXI - ressalvados os casos especificados na legislação, as obras, serviços, compras e alienações serão contratados mediante processo de licitação pública que assegure igualdade de condições a todos os concorrentes, com cláusulas que estabeleçam obrigações de pagamento, mantidas as condições efetivas da proposta, nos termos da lei, o qual somente permitirá as exigências de qualificação técnica e econômica indispensáveis à garantia do cumprimento das obrigações.

770 Art. 26. Os critérios e valores para a remuneração de serviços e os parâmetros de cobertura assistencial serão estabelecidos pela direção nacional do Sistema Único de Saúde (SUS), aprovados no Conselho Nacional de Saúde. § 1.o Na fixação dos critérios, valores, formas de reajuste e de pagamento da remuneração aludida neste artigo, a direção nacional do Sistema Único de Saúde (SUS) deverá fundamentar seu ato em demonstrativo econômico-financeiro que garanta a efetiva qualidade de execução dos serviços contratados. $§ 2$.o Os serviços contratados submeter-se-ão às normas técnicas e administrativas e aos princípios e diretrizes do Sistema Único de Saúde (SUS), mantido o equilíbrio econômico e financeiro do contrato.

771 Artigo 37 (...) $\S 6^{\circ}$ As pessoas jurídicas de direito público e as de direito privado prestadoras de serviços públicos responderão pelos danos que seus agentes, nessa qualidade, causarem a terceiros, assegurado o direito de regresso contra o responsável nos casos de dolo ou culpa. 
especial considerando a extensão populacional e territorial do Estado brasileiro, demanda: (i) a edição de lei nacional, nos termos do artigo 22, inciso XXVII do texto constitucional, ${ }^{772}$ que contenha normas gerais definindo as hipóteses, o procedimento e os critérios de escolha, bem como os mecanismos de fiscalização e controle de prestadores privados de serviços públicos de saúde; e (ii) a edição de leis locais disciplinando especificamente a organização de tais serviços. Se não preenchidas essas lacunas, a insegurança, a falta de consenso e o predomínio de posições ideologizadas muitas vezes farão com que oportunidades de evolução quantitativa e qualitativa na oferta de serviços públicos de saúde sejam perdidas.

A eficiência na prestação dos serviços públicos de saúde não existe como meta abstrata, sendo que sua concretização depende da definição dos objetivos a serem alcançados, o que deve ocorrer em harmonia com a realidade social, econômica e tecnológica de cada momento - por meio de leis que sejam capazes de promover tal tradução e, por isso, dignas de obter reconhecimento social e observância judicial. A melhor maneira de não concretizar um objetivo é mantê-lo vago, abstrato, genérico e, portanto, inalcançável. Um conceito demasiadamente alargado de saúde e de serviço público de saúde, aliado à restrição das possibilidades de flexibilização dos meios para alcançar sua efetivação (inclusive no que se refere à participação privada nos serviços públicos de saúde), conforma uma equação em que o resultado tende a ser zero. A solução do problema, portanto, começa pela definição do resultado, de forma a que os fatores envolvidos possam ser - e sejam - utilizados da maneira mais adequada.

772 Art. 22. Compete privativamente à União legislar sobre: (...) XXVII - normas gerais de licitação e contratação, em todas as modalidades, para as administrações públicas diretas, autárquicas e fundacionais da União, Estados, Distrito Federal e Municípios, obedecido o disposto no art. 37, XXI, e para as empresas públicas e sociedades de economia mista, nos termos do art. $173, \S 1^{\circ}$, III; (inciso com redação dada pela Emenda Constitucional no 19, de 1998). 


\section{REFERÊNCIAS}

ACIOLE, Geovani Gurgel. A saúde no Brasil: entre o estado e o mercado. 2005. Tese (Doutorado) - Universidade Estadual de Campinas, Faculdade de Ciências Médicas, São Paulo, 2005.

AGUILLAR, Fernando Herren. Controle social de serviços públicos. São Paulo: Max Limonad, 1999.

AITH, Fernando Mussa A. Teoria geral do direito sanitário. 2006. Tese (Doutorado em Saúde Pública) - Faculdade de Saúde Pública, Universidade de São Paulo, São Paulo, 2006.

ALESSI, Renato. Sistema Istituzionale del Diritto Amministrativo Italiano. Milano: Giuffré, 1953.

ALEXY, Robert. Teoría de los Derechos Fundamentales. Trad. Carlos B. Pulido. 2.ed. Madrid: Centro de Estudios Políticos y Constitucionales, 2007.

ALMEIDA, Célia Maria de. Reforma do estado e reforma de sistemas de saúde: experiências internacionais e tendências de mudança. Ciência \& Saúde Coletiva, v.4, n.2, p.263-286, 1999.

ALMEIDA, Fernando Dias Menezes de. Contratos administrativos. In: PEREIRA JÚNIOR, Antonio Jorge; e JABUR, Gilberto Haddad (coord.). Direito dos contratos II. São Paulo: Quartier Latin, 2008.

ALVES, Márcio J. Martins. Sistema Único de Saúde: de que sistema se trata? 2006.Tese (Doutorado) - Programa de Pós-Graduação em Saúde Coletiva, Instituto de Medicina Social da Universidade do Estado do Rio de Janeiro, Rio de Janeiro, 2006.

ANDRADE, José Carlos Vieira de. Os direitos fundamentais na constituição portuguesa de 1976. Coimbra: Almedina, 1987.

ANDRADE, Luciano Benévolo de. Curso moderno de direito administrativo. São Paulo: Saraiva, 1975. 
ANDRADE, Mônica Viegas; BARROS LISBOA, Marcos de. Velhos dilemas no provimento de bens e serviços de saúde: uma comparação dos casos canadense, inglês e americano. Nova Economia, v.10, n.2, p.73-116, dez. 2000.

ARAGÃO, Alexandre Santos. Delegações de serviços públicos. Revista de Direito da Energia, ano IV, n.6, p.79-149, nov. 2007.

Direito dos serviços públicos. Rio de Janeiro: Forense, 2007.

ARAÚJO, Edmir Netto de. Curso de direito administrativo. 2.ed. São Paulo: Saraiva, 2006. ARIÑO ORTIZ, Gaspar. Princípios de Derecho Público Económico. Granada: Comares, 1999.

Privatización y Liberalización de Serviçios. Madrid: Universidad Autônoma de Madrid, 1999.

Empresa Pública, Empresa Privada, Empresa de Interés General. Cizur Menor: Aranzadi, 2007.

AS INVASÕES BÁRBARAS (filme). Direção: Denys Arcand. Produção: Daniel Louis. Canadá; França: Astral Films, 2003. 1DVD (99 min). Distribuição no Brasil: Europa Filmes.

ASCARELLI, Tullio. Problemas das sociedades anônimas e direito comparado. Campinas: Bookseller, 2001.

ASSIS, Araken de. Aspectos polêmicos e atuais dos limites da jurisdição e do direito à saúde. Porto Alerge: Notadez, 2007.

AZEVEDO, Antonio Junqueira de. Princípios do direito contratual e desregulamentação do mercado - Direito de exclusividade nas relações contratuais de fornecimento - Função social do contrato e responsabilidade aquiliana do terceiro que contribui para inadimplemento contratual. Revista dos Tribunais, ano 87, v.750, p.113-120, abr. 1998.

BACELLAR FILHO, Romeu Felipe. Contrato administrativo. In: Direito administrativo contemporâneo: estudos em memória do professor Manoel de Oliveira Franco Sobrinho. Belo Horizonte: Fórum, 2004. 
Direito administrativo e o novo código civil. Belo Horizonte: Fórum, 2007.

BAGANHA, Maria Ioannis; PIRES, Joana Sousa R. S. O sector da saúde em Portugal: funcionamento do sistema e caracterização sócio profissional. Oficina do Centro de Estudos Sociais da Faculdade de Economia da Universidade de Coimbra, Coimbra, n.182, dez. 2002.

BARACHO, José Alfredo de Oliveira. O princípio de subsidiariedade: conceito e evolução. Rio de Janeiro: Forense, 1997.

BARBOSA, Pedro Ribeiro. Gestão de hospitais públicos: maior autonomia gerencial, melhor performance organizacional com apoio em contratos de gestão. Revista do Serviço Público - RSP, ano 47, v.120, n.2, p.67-97, maio/ago. 1996.

BARER, Morris L. Hospital financing in Canada. US Congress, Office of Technology Assessment. Hospital financing in seven countries. Washington (DC): US Government Printing Office, 1995.

BARROS, Elizabeth. Financiamento do sistema de saúde no Brasil: marco legal e comportamento do gasto. Brasília: OPAS: Ministério da Saúde, 2003.

BARROSO, Luís Roberto. Interpretação e aplicação da constituição. 5.ed. São Paulo: Saraiva, 2003.

. O direito constitucional e a efetividade de suas normas: limites e possibilidades da constituição brasileira. 7.ed. Rio de Janeiro: Renovar, 2003.

. O novo direito constitucional e a constitucionalização do direito. In: Temas de direito constitucional. Rio de Janeiro: Renovar, 2005. Tomo III.

. Da falta de efetividade à judicialização excessiva: direito à saúde, fornecimento gratuito de medicamentos e parâmetros para a atuação judicial. Revista Interesse Público, Belo Horizonte, n.46, p. 31-61, nov./dez. 2007.

BERCOVICI, Gilberto. A problemática da constituição dirigente: algumas considerações sobre o caso brasileiro. Revista de Informação Legislativa, Brasília, ano 36, n.142, p.3551, abr./jun. 1999. 
BERTOLLI FILHO, Cláudio. História da saúde pública no Brasil. 4.ed. São Paulo: Ática, 2008.

BEVERIDGE, Willian. Social Insurance and Allied Services. New York: The Macmillam Company, 1942.

BIELSA, Rafael. Derecho Administrativo. 5.ed. Buenos Aires: Roque Depalma, 1955. Tomo I.

BINENBOJM, Gustavo. Uma teoria do direito administrativo: direitos fundamentais, democracia e constitucionalização. Rio de Janeiro: Renovar, 2006.

BOBBIO, Norberto. A era dos direitos. Trad. Carlos Coutinho. Rio de Janeiro: Campus, 1992.

O futuro da democracia. Trad. Marco Aurélio Nogueira. 8.ed. São Paulo: Paz e Terra, 2002.

A grande dicotomia: público/privado. In: Estado, governo, sociedade: para uma teoria geral da política. Trad. de Marco Aurélio Nogueira. 10.ed. São Paulo: Paz e Terra, 2003.

. A grande dicotomia. In: . Da estrutura à função: novos estudos de teoria do direito. Trad. Daniela B. Versiani. Barueri: Manole, 2007.

Liberalismo e democracia. Trad. de Marco Aurélio Nogueira. 6.ed. São Paulo: Brasiliense, 2007.

BOBBIO, Norberto; MATTEUCCI, Nicola; PASQUINO Gianfranco. Dicionário de política. Trad. Carmen Varriale et. al. 12.ed. Brasília: Universidade de Brasília, 2004. v.1. BONAVIDES, Paulo. Teoria do estado. 3.ed. São Paulo: Malheiros, 1999. . Do estado liberal ao estado social. 7.ed. São Paulo: Malheiros, 2001. . Curso de direito constitucional. 13.ed. São Paulo: Malheiros, 2003.

BOYER, Marcel. Le secteur privé dans un système de santé public: France et Pays Nordiques. CIRANO Working Papers 2008s-06, Montreal, fev. 2008. 
BRAGA, Leopoldo. Do conceito jurídico de 'Instituições de Educação e Assistência Social'. 2.ed. Rio de Janeiro: Borsoi, 1971.

BRASIL. Conselho Nacional de Secretários de Saúde. SUS: avanços e desafios. 2.ed. Brasília: CONASS, 2006.

BRASIL. Conselho Nacional de Secretário de Saúde. Festão e financiamento do Sistema Único de Saúde. Brasília: CONASS, 2008.

BRASIL. Diário da Assembléia Nacional Constituinte. Disponível em:

$<$ http://www.senado.gov.br/anais/>. Acesso em: 26 jul. 2008.

BRASIL. Ministério da Administração Federal e da Reforma do Estado. A reforma administrativa do sistema de saúde. Brasília: Maré, 1998.

BRASIL. Ministério da Saúde. VIII Conferência Nacional de Saúde. Relatório final. Brasília: Ministério da Saúde, 1986. Disponível em: <http://portal.saude.gov.br/portal/ arquivos/pdf/8_CNS_Relatorio\%20Final.pdf>. Acesso em: 26 jul. 2008.

BRASIL. Ministério da Saúde. Secretaria de Gestão do Trabalho e da Educação na Saúde. Departamento da Educação na Saúde. Direito sanitário e saúde pública: manual de atuação jurídica em saúde pública e coletânea de leis e julgados em saúde. ARANHA, Márcio Iorio (Org.). Brasília: Ministério da Saúde, 2003. v.2.

BRASIL. Ministério da Saúde. Secretaria de Gestão Estratégica e Participativa. A construção do SUS: histórias da reforma sanitária e do processo participativo. Brasília: Ministério da Saúde, 2006.

BRASIL. Ministério da Saúde. Secretaria de Atenção à Saúde. Departamento de Regulação Avaliação e Controle de Sistemas. Manual de orientações para contratação de serviços no Sistema Único de Saúde. Brasília: Ministério da Saúde, 2007.

BRASIL. Ministério da Saúde. Estabelecimentos com tipo de atendimento prestado ambulatório - particular. (tabela). DATASUS, 2008. Disponível em:

$<$ http://tabnet.datasus.gov.br/ cgi/tabcgi.exe?cnes/cnv/atambbr.def $>$. Acesso em: 29 out. 2008. 
BRASIL. Ministério da Saúde. Estabelecimentos com tipo de atendimento prestado hospitalar - particular. (tabela). DATASUS, 2008. Disponível em: $<$ http://tabnet. datasus.gov.br/cgi/tabcgi.exe?cnes/cnv/atintbr.def $>$. Acesso em: 29 out. 2008.

BRASIL. Ministério da Saúde. Indicadores de contratos. (tabela). Secretaria de Atenção à Saúde, 2008. Disponível em: <http://cnes.datasus.gov.br/Mod_Ind_Contratos.asp> . Acesso em: 06 out. 2008.

BRASIL. Presidente. Plano Diretor da Reforma do Aparelho do Estado: Presidência da República, Câmara da Reforma do Estado, Ministério da Administração Federal e Reforma do Estado, 1995.

BRASIL. Supremo Tribunal Federal, Ação Direta de Inconstitucionalidade 2987/SC, Tribunal Pleno, Rel. Min. Sepúlveda Pertence, Diário de Justiça da União, 02 abr. 2004.

BRASIL. Supremo Tribunal Federal, Ação Direta de Inconstitucionalidade n. ${ }^{\circ} 1923$ - DF, Relator Ministro Carlos Brito, Diário de Justiça, 01 ago. 2007.

BRASIL. Supremo Tribunal Federal. Ação Direta de Inconstitucionalidade n. ${ }^{0}$ 1923-5/DF, Tribunal Pleno, Relator Originário Min. Ilmar Galvão, Relator Min. Eros Grau, Diário de Justiça da União, 21 set. 2007.

BRASIL. Supremo Tribunal Federal, Mandado de Segurança n. ${ }^{\circ}$ 26330/DF, Medida Cautelar, Relatora Ministra Carmen Lúcia Antunes da Rocha, decisão proferida pelo Ministro Gilmar Mendes, Diário de Justiça da União, 05 fev. 2007.

BRASIL. Supremo Tribunal Federal, Recurso Extraordinário n. ${ }^{\circ}$ 220.906-9 Distrito Federal. Órgão Pleno. Rel. Min. Maurício Corrêa. Diário de Justiça, 14 nov. 2002.

BRASIL. Supremo Tribunal Federal, Suspensão de Tutela Antecipada n. ${ }^{\circ}$ 278, Relator Ministro Presidente Gilmar Mendes, julg. 22 out. 2008.

BRASIL. Supremo Tribunal Federal. ADPF n. ${ }^{\circ}$ 45, Rel. Min. Celso de Mello, julg. 29 abr. 2004. BRASIL. Tribunal de Contas da União. Processo n. ${ }^{\circ}$ 016.522/95-8. Plenário. Relator: Ministro Homero Santos. Diário Oficial da União, 28 dez. 1995, p.22549. Disponível em: $<$ http://contas.tcu.gov.br/portaltextual/ServletTcuProxy>. Acesso em: 11 nov. 2008. 
BRESSER-PEREIRA, Luiz Carlos. Sociedade civil: sua democratização para a reforma do estado. In: BRESSER-PEREIRA, Luiz Carlos; WILHEIM, Jorge; e SOLA, Lourdes (Orgs.). Sociedade e Estado em transformação. São Paulo: UNESP; Brasília: ENAP, 1999. . Uma nova gestão para um novo modelo de estado: liberal, social e republicano. Revista do Serviço Público, ano 52, n.1, p.5-24, jan./mar. 2001.

BRESSER-PEREIRA, Luiz Carlos; CUNILL GRAU, Nuria. Entre o estado e o mercado: o público não-estatal. Trad. Noêmia A. Espíndola. In: (Orgs.). O público não-estatal na reforma do estado. Rio de Janeiro: Ed. Fundação Getúlio Vargas, 1999.

BROADBENT, Jane; GILL, Jas; LAUGHLIN, Richard. The Private Finance Initiative in the National Health Service. London: CIMA, 2004.

BROWN, Lawrence. Comparing Health Systems in Four Countries: Lessons for the United States. American Journal of Public Health, v.93, n.1, p.52-56, January 2003.

BRUCE, Maurice. The Rise of Welfare State. English Social Police: 1601-1971.

London: World University, 1972.

BUCCI, Maria Paula Dallari. Direito administrativo e políticas públicas. São Paulo: Saraiva, 2006.

BUENO, José Antônio Pimenta. Direito público brasileiro e a análise da constituição do Império. Brasília: Senado Federal, 1978.

BURDEAU, François. Histoire de l'administration française: Du $18 .^{\circ}$ au $20 .^{\circ}$ siécle. 2.ed. Paris: Montcherestien, 1994.

BUSSE, Reinhard; RIESBERG, Annette. Health care systems in transition: Germany. Copenhagen, WHO Regional Office for Europe on behalf of the European Observatory on Health Systems and Policies, 2004.

CABRAL, Eloísa Helena de Souza. Terceiro setor: gestão e controle social. São Paulo: Método, 2007.

CAETANO, Marcello. Manual de direito administrativo. 10.ed. Coimbra: Almedina, 1994. Tomo II. 
CAMACHO, Joana M. Socías. Fundaciones del sector público: en especial, el ámbito sanitario. Madrid: Iustel, 2006.

CAMPOS, Juarez de Queiroz. Políticas e sistemas de saúde. São Paulo: Jotacê, 1993.

CAÑADA, Isabel Maria V. Público y Privado em la gestión de la Segurida Social em Espana. Dimensión Jurídica. Granada: Comares, 2007.

CANADÁ. Supreme Court of Canada. Chaoulli v. Quebec. 09 jun. 2005. [2005] 1 SCR 791, 2005 SCC 35.

CANOTILHO, J. J. Gomes. Direito constitucional e teoria da constituição. 7.ed. Coimbra: Almedina, [s.d.].

Constituição dirigente e vinculação do legislador: contributo para a compreensão das normas constitucionais programáticas. 2. ed. Coimbra: Coimbra, 2001. . Metodologia "Fuzzy" e "Camaleões Normativos" na problemática actual dos direitos econômicos, sociais e culturais. In: . Estudos sobre direitos fundamentais. Coimbra: Coimbra, 2004.

CARDOSO, Ruth. Fortalecimento da sociedade civil. In: IOSCHPE, E. B. (Org.). Terceiro setor: desenvolvimento social sustentado. 2.ed. São Paulo: Paz e Terra, 2000. CARRIÓ, Genaro R. Notas sobre Derecho y Lenguage. 4.ed. Buenos Aires: AbeledoPerrot, 1994.

CARTER, Larry E. Health Care Reform: policy innovations at the state level in the United States. New York: Garland, 1998. . The Emergence of Modern Health Systems. In: . Health Care Reform: policy innovations at the state level in the United States. New York: Garland, 1998.

CARVALHO, Gilson. O financiamento público da saúde no bloco de constitucionalidade. In: ARANHA, Márcio Iório (Org.). Direito sanitário e saúde pública: coletânea de textos. Brasília: Ministério da Saúde, 2003. v.1. 
CASSAGNE, Juan Carlos. La Intercencion Administrativa. 2.ed. Buenos Aires: Abeledp-Perrot, 1994.

El resurgimiento del servicio público y su adaptación en los sistemas de economia de mercado (hacia uma nova concepción). Revista de Administracion Pública, n.140, p.5-13, maio/ago. 1996.

CASSAGNE, Juan Carlos; ARIÑO ORTIZ, Gaspar. Servicios públicos, regulación y renegociación. Buenos Aires: Abeledo Perrot, 2005.

CASTRO, José A. Dias de. A questão do direito fundamental à saúde sob a ótica da análise econômica do direito. Revista de Direito Público da Economia - RDPE, Belo Horizonte, ano 6, n.21, p.149-158, jan./mar. 2008.

CASTRO, José Nilo de; RODRIGUES, Tais Erthal; REIS, Luciana Andrade. Contrato de prestação de serviços médicos hospitalares: impossibilidade de prorrogação para que se atenda ao interesse público. Revista Brasileira de Direito Municipal - RBDM, Belo Horizonte, ano 7, n.21, p.181-190, jul./set. 2006.

CASTRO, Maria Helena L. A relação entre o público e o privado no sistema de saúde brasileiro: repensando o papel do estado. 2006. Tese (Doutorado em Saúde Coletiva) Instituto de Medicina Social, Universidade do Estado do Rio de Janeiro, Rio de Janeiro, 2006.

CECHIN, José. A história e os desafios da saúde suplementar: 10 anos de regulação. São Paulo: Saraiva, 2008.

CHEVALLIER, Jacques. Science administrative. 3.ed. Paris: Presses Universitaires de France, 2002.

Le Service Public. 6.ed. Paris: PUF, 2006.

CITARA, Rubén Miguel. El servicio público. Buenos Aires: Ciencias de la Administración, 1995.

CLÈVE, Clèmerson Merlin. Temas de direito constitucional (e de teoria do direito). São Paulo: Acadêmica, 1993. 
A eficácia dos direitos fundamentais sociais. Revista Crítica Jurídica, n.22, p.1729, jul./dez. 2003.

COHN, Amélia; NUNES, Edison; JACOBI, Pedro R.; KARSH, Ursula S. A saúde como direito e como serviço. 5.ed. São Paulo: Cortez, 2008.

COLOMBO, F.; TAPAY, N. Private Health Insurance in OECD Countries: The benefits and Costs for Individuals and Health Systems. OECD Health Working Papers, n.15, OECD Publishing, 2004.

COMPARATO, Fabio Konder. Novos ensaios e pareceres de direito empresarial. Rio de Janeiro: Forense, 1981.

. A afirmação histórica dos direitos humanos. 6.ed. São Paulo: Saraiva, 2008. Réquiem para uma constituição. In: FIOCCA, Demian; GRAU, Eros Roberto (Orgs.). Debate sobre a constituição de 1988. São Paulo: Paz e Terra, 2001.

CONILL, Eleonor Minho. Epidemologia e sistemas de saúde. In: ARANHA, Márcio Iório (Org.). Direito sanitário e saúde pública: coletânea de textos. Brasília: Ministério da Saúde, 2003. v.1.

. Sistemas comparados de saúde. In: CAMPOS, Gastão W. de Souza; MINAYO, Maria Cecília de S.; AKERMAN, Marco; DRUMOND JÚNIOR, Marcos; CARVALHO, Yara Maria de. Tratado de saúde coletiva. Rio de Janeiro: Hucitec, 2006.

CORREIA, José Manuel Sérvulo. Legalidade e autonomia contratual nos contratos administrativos. Coimbra: Almedina, 1987.

COSSALTER, Philippe. XXIII - A 'Private Finance Iniciative'. In: TALAMINI, Eduardo; JUSTEN, Mônica Spezia. Parcerias público-privadas: um enfoque multidisciplinar. São Paulo: Revista dos Tribunais, 2005.

COSTA, Nilson do Rosário; SILVA, Pedro Luís B.; RIBEIRO, José Mendes. Inovações organizacionais e de financiamento: experiências a partir do cenário institucional. In: NEGRI, Barjas; DI GIOVANNI, Geraldo (Orgs.). Brasil: radiografia da saúde. Campinas: UNICAMP, 2001. 
COSTALDELLO, Ângela Cássia. Entidades privadas que recebem recursos públicos:

Necessidades de Licitar. Boletim Informativos de Licitações e Contratos, Curitiba, v.82, p. $988-998,2000$.

COUTINHO, Diogo R. O Diálogo caricato ente direito e economia. Valor Online, São Paulo, 01 dez. 2008. Disponível em: <www.valor online.com.br>. Acesso em: 01 dez. 2008.

COUTINHO, Jacinto Nelson de Miranda (Org.). Canotilho e a constituição dirigente. Rio de Janeiro: Renovar, 2003.

CRAWLEY, Corina. Inventory of major form privatization initiatives in Canada's health care system. [s.1.]: CUPE, 2004.

CRETELLA JÚNIOR, José. Tratado de direito administrativo. Rio de Janeiro: Forense, 1967. v.3.

. Comentários à constituição brasileira de 1988. 2.ed. Rio de Janeiro: Forense Universitária, 1993. v.8.

CROZIER, Michel. Estado modesto, estado moderno: estratégia para uma outra mudança. Trad. J. M. Vilar de Queiroz. Brasília: Fundação Centro de Formação do Servidor Público - FUNCEP, 1989.

CUÉLLAR, Leila. As agências reguladoras e seu poder normativo. São Paulo: Dialética, 2001.

CUNHA, Paulo César Melo. Regulação jurídica da saúde suplementar no Brasil. Rio de Janeiro: Lumen Júris, 2003.

CUNILL GRAU, Nuria. Repensando o público através da sociedade: novas formas de gestão pública e representação social. Trad. Carolina Andrade. Rio de Janeiro: Revan; Brasília: ENAP, 1998.

DAIN, Sulamis; JANOWITZER, Rejane. A saúde complementar no contexto dos sistemas de saúde: a experiência internacional. In: BISOTO JÚNIOR, Geraldo; SILVA, Pedro L. de Barros; DAIN, Sulamis (Orgs.). Regulação do setor de saúde nas Américas: as relações entre o público e o privado numa abordagem sistêmica. Brasília: Organização PanAmericana da Saúde, 2006. 
DALLARI, Adilson de Abreu. Credenciamento. In: DALLARI, Adilson de Abreu; MELLO, Celso Antonio Bandeira de (Org.). Estudos em homenagem a Geraldo Ataliba. São Paulo: Malheiros, 1997. Parcerias em transporte público. In: SUNDFELD, Carlos Ari. Parcerias públicoprivadas. São Paulo: Malheiros, 2005.

DALLARI, Sueli Gandolfi. O conceito jurídico de saúde. In: Os estados brasileiros e o direito à saúde. São Paulo: Hucitec, 1995. . Uma nova disciplina: o direito sanitário. Revista Saúde Pública, São Paulo, v.22, p.327-334, 1988.

. Políticas de estado e políticas de governo: o caso da saúde pública. In: BUCCI, Maria Paula Dallari (Org.). Políticas públicas: reflexões sobre o conceito jurídico. São Paulo: Saraiva, 2006.

DI PIETRO, Maria Sylvia Zanella. Privatização e o novo exercício de funções públicas por particulares. In: MOREIRA NETO, Diogo de Figueiredo (Coord.). Uma avaliação das tendências contemporâneas do direito administrativo. Rio de Janeiro: Renovar, 2003.

. Parcerias na administração pública. 5.ed. São Paulo: Atlas, 2005.

DIAZ, Jose Ramon. Estado Social e Derechos de Prestacion. Madrid: Centro de Estudos Constitucionales, 1989.

DOCTEUR, Elizabeth; OXLEY, Howard. Health-Care Systems: Lessons from the Reform Experience. Paris: OECD, 2003.

DOURADO, Maria Cristina C. de O. O repensar do conceito de serviço público. Revista Interesse Público, n.9, p.86-96, 2001.

DOUVEN, Rudy; MOT, Esther; POMP, Marc. Health care reform in the Netherlands. Die Volkswirtschaft, v.3, 2007.

DRUCKER, Peter. Uma era de descontinuidade: orientações para uma sociedade em mudança. Trad. J. R. Brandão de Azevedo. Rio de Janeiro: ZAHAR, 1970. 
DUGUIT, Léon. Traité de Droit Constitucionnel. Paris: Fontemoing, 1911. Tomo II. . Traité de Droit Constitucionnel. 2.ed. Paris: Ancienne Librairie Fontemoing, 1923. Tomo II.

Las Transformaciones del Derecho Público. Trad. Adolfo Posada y Ramon Jaen. 2.ed. Madrid: Francisco Beltran, 1926.

DWORKIN, Ronald. Levando os direitos a sério. Trad. Nelson Boeira. São Paulo: Martins Fontes, 2002.

. A justiça e o alto custo da saúde. In: . A virtude soberana: a teoria e a prática da igualdade. Trad. Jussara Simões. São Paulo: Martins Fontes, 2005.

EDWARDS, Pam; SHAOUL, Jean; STAFFORD, Anne; ARBLASTER, Lorna.

Evaluating the operation of PFI in roads and hospitals. London: Certified Accountants Educational Trust, 2004.

ENTHOVEN, Alain C. The History and Principles os Managed Competition. Health Affairs, v.12, 1993.

ERRERA, Paul. Traité de Droit Publique Belge. Paris: V. Giard \& E. Brière, 1909. ESCOLA, Héctor Jorge. Él Interés público como Fundamento del Derecho Administrativo. Buenos Aires: De Palma, 1989.

ESPING-ANDERSEN, Gosta. As três economias políticas do Welfare State. Revista de Cultura e Política, n.24, p.85-116, set. 1991.

. O futuro do Welfare State na nova ordem mundial. Revista de Cultura e Política, n.235, p.73-111, 1995.

ESTORNINHO, Maria João. A fuga para o direito privado: contributo para o estudo da actividade de direito privado da administração pública. Coimbra: Almedina, 1996.

FALCONER, Andres Pablo. A promessa do terceiro setor: um estudo sobre a construção do papel das organizações sem fins lucrativos e do seu campo de gestão. 1999. Dissertação (Mestrado) - Faculdade de Economia, Administração e Contabilidade da Universidade de São Paulo, São Paulo, 1999. 
FARIA, José Eduardo. O judiciário e os direitos humanos e sociais: notas para uma avaliação da justiça brasileira. In: (Org.). Direitos humanos, sociais e justiça. São Paulo: Malheiros, 2005.

FARIAS, Pedro C. Lima de. A seguridade social no Brasil e os obstáculos à sua implementação. Brasília: MARE/ENAP, 1997.

FERNANDES, Jorge Ulisses Jacoby. Parcerias público-privadas, controle e eficiência. Fórum de Contratação e Gestão Pública - FCGP, Belo Horizonte, ano 7, n.76, p.7-13, abr. 2008.

FERRARESE, Maria Rosaria. Diritto e mercato. Torino, Itália: Giappichelli, 1992.

FERRAZ JÚNIOR, Tércio Sampaio. Função social da dogmática jurídica. São Paulo: Max Limonad, 1998.

FERREIRA FILHO, Manoel Gonçalves. Direitos humanos fundamentais. São Paulo: Saraiva, 1995.

FERREIRA, F. A. Gonçalves. Política de saúde em portugal: uma experiência de definição legislativa e de organização dos serviços. Lisboa: Sopime, 1972.

FERREIRA, Sílvia Maria Dias. O papel das organizações do terceiro sector na reforma das políticas públicas de protecção social: uma abordagem teórico-histórica. 2000.

Dissertação (Mestrado em Sociologia) - Faculdade de Economia, Universidade de Coimbra, Coimbra, 2000.

FIGUEIREDO, Mariana F. Direito fundamental à saúde: parâmetros para sua eficácia e efetividade. Porto Alegre: Livraria do Advogado, 2007.

FORSTHOFF, Ernst. Tratado de Derecho Administrativo. Trad. Lesgaz Lacambra; Garrido Falla; y Gomes de Ortega y Junge. Madrid: Instituto de Estudios Politicos, 1958. FOUCAULT, Michel. A política de saúde no século XVIII. In: Microfísica do poder. Trad. Roberto Machado. 25.ed. Rio de Janeiro: Graal, 2008.

. O nascimento da medicina social. In: Microfísica do poder. Trad. Roberto Machado. 25.ed. Rio de Janeiro: Graal, 2008. 
. O nascimento do hospital. In:

Microfísica do poder. Trad. Roberto

Machado. 25.ed. Rio de Janeiro: Graal, 2008.

FRANÇA, Susete Barboza. A presença do estado no setor saúde no Brasil. Revista do Serviço Público, ano 49, n.3, p. 83-98, jul./set. 1998.

FURTADO, Celso. O capitalismo global. 5.ed. São Paulo: Paz e Terra, 2001.

GALBRAITH, John Kennet. A economia das fraudes inocentes: verdades para o nosso tempo. Trad. Paulo A. Soares Barbosa. São Paulo: Companhia das Letras, 2004.

GARCÍA DE ENTERRÍA, Eduardo. Revolucion Francesa y Administracion

Contemporânea. 4.ed. Madrid: Civitas, 1994.

GARCÍA-PELAYO, Manuel. Las transformaciones del Estado contemporâneo. 2.ed. Madrid: Alianza, 1988.

GARRIDO FALLA, Fernando. Tratado de Derecho Administrativo. 9.ed. Madrid: Centro de Estudos Constitucionales, 1985. v.1.

GASPARINI, Diógenes. Direito administrativo. 9.ed. São Paulo: Saraiva, 2004.

GERLINGER, Thomas; URBAN, Hans-Jürgen. From heterogeneity to harmonization? Recent trends in European health policy. Cadernos de Saúde Pública, Rio de Janeiro, v.23, s.2, p.133-142, 2007.

GHAUS-PASHA, Aisha. Role of civil society organizations in governance. In: Public administration and democratic governance: governments serving citizens. $7^{\text {th }}$ Global Forum on Reinventing Government: Building Trust in Government, 26-29 june 2007, Viena, Austria. New York: United Nations, 2007.

GIANNINI, Massimo Severo. Il Publico Potere: Stati e Amministrazioni Publiche. Bolonha: Il Mulino, 1986.

GIDRON, Benjamin; KRAMER, Ralph M.; SALAMON, Lester M. Government and the trhird sector: emerging relationships in welfare states. San Francisco: Jossey-Bass Publishers, 1992. 
GIOVANELLA, Lígia. Solidariedade ou competição?: políticas e sistema de atenção à saúde na Alemanha. Rio de Janeiro: Fiocruz, 2001.

GIOVANELLA, Ligia; FLEURY, Sonia. Universalidade da atenção à saúde: acesso como categoria de análise. In: EIBENSCHUTZ, Catalina (Org.). Política de saúde: o público e o privado. Rio de Janeiro: Fiocruz, 1996.

GOMES, Orlando. Os contratos e o direito público. Revista da Procuradoria Geral do Estado de São Paulo, São Paulo, n.10, p. 45-55, jun. 1977.

Contratos. 20.ed. Rio de Janeiro: Forense, 2000.

GONÇALVES, Pedro. Concessão de serviços públicos. Coimbra: Almedina, 1999. O contrato administrativo (uma instituição do direito administrativo do nosso tempo). Coimbra: Almedina, 2003.

GONÇALVES, Wagner. Parecer sobre terceirização e parcerias na saúde pública. 1998. Mimeo.

GORDILLO, Agustín. Tratado de Derecho Administrativo: Parte General. 7.ed. Belo Horizonte: Del Rey e Fundación de Derecho Administrativo, 2003. Tomo I.

GRAU, Eros Roberto. A constituinte e a constituição que teremos. São Paulo: Revista dos Tribunais, 1985.

Direito, conceitos e normas jurídicas. São Paulo: Revista dos Tribunais, 1988.

O conceito de 'relevância pública' na constituição de 1988. In: DALLARI, Sueli Gandolfi et al. (Org.). O conceito constitucional de relevância pública. Brasília: Organização Panamericana da Saúde, 1992.

. Licitação e contrato administrativo (estudos sobre a interpretação da lei). São Paulo: Malheiros, 1995.

A ordem econômica na constituição de 1988. 8.ed. São Paulo: Malheiros, 2003.

GREEN, David G.; IRVINE, Benedict. Health Care in France and Germany: Lessons for the UK. London: Civitas, 2001. 
GROTTI, Dinorá Adelaide. M. O serviço público e a constituição brasileira de 1988.

São Paulo: Malheiros, 2003.

GUEDES, Ana Claudia; DYRDA, Tomasz. Service and site co-operation between private health care centres as a possible response to emerging economic and medical issues.

EUROPHAMILI-AESCULAPIUS Professional Study, Rennes: ENSP, 2002.

GUEDES, Marques. O plano Beveridge. 2.ed. Lisboa: Século, [s.d].

GUERRA, Rafael. SOS saúde. Folha de S. Paulo, São Paulo, 03 jun. 2008, p.A3.

GUGLIELMI, Gilles. Introduction au droit des services publics. Paris: EJA, 1994.

GUIMARÃES, Luisa; FREIRE, José-Manuel. Los temas de salud en La Unión Europea: su impacto em la sanidad española. Cadernos de Saúde Pública, Rio de Janeiro, s.23, p.143-154, 2007.

GUIMARÃES, Luisa; GIOVANELLA, Lígia. Integração européia e políticas de saúde: repercussões do mercado interno europeu no acesso aos serviços de saúde. Cadernos de Saúde Pública, Rio de Janeiro, v.22, n.9, p.1795-1807, 2006.

HALL, Peter Dobkin. Inventing the nonprofit sector and other essays on philanthropy, voluntarism, and nonprofit organizations. Baltimore and London: The Jonhs Hopkins University Press, 1992.

HAM, Chris. The background. In: Health Care Reform: Learning from International Experience. Buckingham: Open University Press, 1997. . The United Kingdom. In: . Health Care Reform: Learning from International Experience. Buckingham: Open University Press, 1997.

HEALTH CANADA. O sistema de cuidados de saúde do Canadá. Ottawa, Canadá: [s.n.], 1999.

HESSE, Konrad. A força normativa da constituição. Trad. Gilmar Ferreira Mendes. Porto Alegre, Sergio Antonio Fabris, 1991.

HOLMES, Stephen; SUNSTEIN, Cass. The Cost of Rights. Why Liberty Depends on Taxes. New York: Norton and Company, 2000. 
HUMBOLDT, Wilhelm von. Os limites da ação do estado. Trad. Jesualdo Correia. Rio de Janeiro: Topbooks, 2004.

JAMES, Estelle. The nonprofit sector in international perspective: studies in comparative culture and policy. New York and Oxford: Oxford University Press, 1989.

JELLINEK, Georg. Teoría General del Estado. Trad. de Fernando Rios Urruti. 2.ed. México: Continental, 1958.

JÈZE, Gaston. Princípios Generales del Derecho Administrativo. Trad. Julio M. Almagro. Buenos Aires: Depalma, 1949. Tomo II.

JHERING, Rudolf von. A finalidade do direito. Trad. Heder K. Hoffmann. Campinas: Bookseller, 2002. Tomo I.

JORDANA DE POZAS, Luis. Ensayo de una teoría del fomento en el Derecho Administrativo. Revista de Estudios Políticos, n.48, p.41-54, 1949.

JUAN, José Joaquim. Situação atual da reforma sanitária na Espanha. In: BUSS, Paulo Marchiori; LABRA, Maria Eliana. Sistemas de saúde: continuidades e mudanças. Rio de Janeiro: Hucitec e Fiocruz, 1995.

JUSTEN FILHO, Marçal. Sistema constitucional tributário: uma aproximação ideológica. Revista da Faculdade de Direito da Universidade Federal do Paraná, Curitiba, n.30, p. 215-233, 1998.

. Conceito de interesse público e a 'personalização' do direito administrativo. Revista Trimestral de Direito Público, São Paulo, n. 26, p.115-136, 1999.

. O direito das agências reguladoras independentes. São Paulo: Dialética, 2002. . O direito das agências reguladoras. São Paulo: Dialética, 2002.

. Teoria geral das concessões de serviço público. São Paulo: Dialética, 2003. . A PPP brasileira e as lições do passado. In: TALAMINI, Eduardo; JUSTEN, Mônica Spezia. Parcerias público-privadas: um enfoque multidisciplinar. São Paulo: Revista dos Tribunais, 2005. 
. Curso de direito administrativo. São Paulo: Saraiva, 2005.

. Comentários à lei de licitações e contratos administrativos. 12.ed. São Paulo: Dialética, 2008.

KELLER, Arno Arnoldo. O descumprimento dos direitos sociais: razões políticas, econômicas e jurídicas. São Paulo: LTr, 2001.

KLAZINGA, Niek. The Dutch health care system. In: Descriptions of health care systems: Germany and the Netherlands. [on line] The Commonwealth fund, p.5. Disponível em: $<$ http://www.allhealth.org/briefingmaterials/CountryProfiles-FINAL1163.pdf $>$. Acesso em: 11 jun. 2008.

KRELL, Andréas. Realização dos direitos fundamentais sociais mediante controle judicial da prestação dos serviços públicos básicos. Revista de Informação Legislativa, Brasília, ano 36, n.144, p.239-260, out./dez. 1999.

Direitos sociais e controle judicial no Brasil e na Alemanha: os (des)caminhos de um direito constitucional comparado. Porto Alegre: Sergio Antonio Fabris, 2002.

KUHN, Thomas S. A estrutura das revoluções científicas. Trad. Beatriz Boeria e Nelson Boeira. 9.ed. São Paulo: Perspectiva, 2007.

LAFER, Celso. A reconstrução dos direitos humanos: um diálogo com o pensamento de Hannah Arendt. São Paulo: Companhia das Letras, 2006.

LANDIN, Leilah. Para além do mercado e do estado?: filantropia e cidadania no Brasil. Rio de Janeiro: ISER, 1993.

LEAL, Rogério Gesta. A efetivação do direito à saúde por uma jurisdição-serafim: limites e possibilidades. In: LEAL, Rogério Gesta; REIS, Jorge Renato dos. Direitos sociais e políticas públicas: desafios contemporâneos. Santa Cruz do Sul: EDUNISC, 2006. Tomo VI.

Estado, administração pública e sociedade: novos paradigmas. Porto Alegre: Livraria do Advogado, 2006.

. A quem compete o dever de saúde no direito brasileiro? Esgotamento de um modelo institucional. Revista de Direito do Estado, ano 2, n.8, p.91-110, out./dez. 2007. 
LEE, Michael. Private and National Health Services. Policy Studies Institute, London, 1978.

LEIVAS, Paulo G. Cogo. Teoria dos direitos fundamentais sociais. Porto Alegre: Livraria do Advogado, 2006.

LEONARDO, Rodrigo Xavier. As associações sentido estrito no direito privado. 2006. Tese (Doutorado) - Curso de Pós-Graduação em Direito, Universidade de São Paulo, São Paulo, 2006.

LIMA, Juliano de Carvalho. História das lutas sociais por saúde no Brasil. Trabalho Necessário, ano 4, n.4, 2006. Disponível em: <http://www.uff.br/trabalhonecessario/ Juliano\%20TN4.htm>. Acesso em: 11 ago. 2008.

LIMA, Sheyla Maria L. O contrato de gestão e a conformação de modelos gerenciais para as organizações hospitalares públicas. Revista de Administração Pública - RAP, Rio de Janeiro, v.30, n.5, p.101-138, set./out. 1996.

LOBATO, Lenaura de Vasconcelos. Reforma do estado no setor de saúde no Reino Unido e nos Estados Unidos. In: HUSENMAN, Samuel et. al. Reforma do estado no setor de saúde: os casos da Catalunha, Canadá, Reino Unido e Estados Unidos. Brasília: ENAP, 1997. (Cadernos ENAP, 13).

LOPES, José Reinaldo de Lima. Raciocínio jurídico e economia. Revista de Direito Público da Economia, Belo Horizonte, ano 2, n.8, p.137-170, out./dez. 2004.

. Direitos sociais: teoria e prática. São Paulo: Método, 2006.

LOPEZ-MUÑIZ, José Luis. Servicio Público, Servicio Universal y 'Obligación de Servivio Público' em la Perspectiva del Derecho Comunitário: Los Servicios Essenciales y sus Regímenes Alternativos. In: Os caminhos da privatização da administração pública. Coimbra: Coimbra, 2001.

LOTTENBERG, Claudio. A saúde brasileira pode dar certo. São Paulo: Atheneu, 2007.

LOUREIRO, João Carlos S. G. Direito à (proteção da) saúde. In: MIRANDA, Jorge.

Estudos em homenagem ao professor Doutor Marcello Caetano. Lisboa: Faculdade de Direito da Universidade de Lisboa, 2006. v.1. 
LUCENA, Cíntia. Direito à saúde no constitucionalismo contemporâneo. In: ROCHA, Cármen Lúcia Antunes (Coord.). $O$ direito à vida digna. Belo Horizonte: Fórum, 2004, p.245-269.

MACEDO JÚNIOR, Ronaldo Porto. Contratos relacionais e defesa do consumidor. São Paulo: Max Limonad, 1998.

MANCUSO, Rodolfo Camargo. Interesses difusos: conceito e legitimação para agir. 6.ed. São Paulo: Revista dos Tribunais, 2004.

MÂNICA, Fernando Borges. Terceiro setor e imunidade tributária. Belo Horizonte: Fórum, 2005.

. Teoria da reserva do possível: direitos fundamentais a prestações e a intervenção do poder judiciário na implementação de políticas públicas. Revista Brasileira de Direito Público, Belo Horizonte, ano 5, n.18, p.169-186, jul./set. 2007.

Panorama histórico-legislativo do terceiro setor no Brasil: do conceito de terceiro setor à lei das OSCIP. In: OLIVEIRA, Gustavo J. de. (Coord.). Terceiro setor, empresas e estado: novas fronteiras entre o público e o privado. Belo Horizonte: Fórum, 2007.

Racionalidade econômica e racionalidade jurídica na constituição de 1988. A\&C Revista de Direito Administrativo e Constitucional, Belo Horizonte, ano 8, v.32, p.121132, abr./jun. 2008.

. O convênio como vínculo apto a instrumentalizar parceria público-privada para prestação de serviços de saúde em unidade hospitalar de média e alta complexidades. Revista de Direito do Terceiro Setor - RDTS, Belo Horizonte, ano 2, n.4, p.123-140, jul./dez. 2008.

MARQUES, Cláudia Lima; LOPES, José Reinaldo de Lima; PFEIFFER, Roberto A. C. Saúde e responsabilidade: seguros e planos de assistência privada à saúde. São Paulo: Revista dos Tribunais, 1999.

MARQUES NETO, Floriano de Azevedo. Regulação estatal e interesses públicos. São Paulo: Malheiros, 2002. 
. Público e privado no setor de saúde. Revista de Direito Público da Economia, Belo Horizonte, ano 3, n.9, p.105-154, jan./mar. 2003.

Concessão de serviço público sem ônus para o usuário. In: WAGNER Júnior.

Direito público: estudos em homenagem ao professor Adilson de Abreu Dallari. Belo Horizonte: Del Rey, 2004.

Concessões de serviços públicos. Boletim de Direito Administrativo - BDA, ano XXII, n.6, p.645-654, jun. 2006.

MARTINS, Sergio Pinto. A terceirização e o direito do trabalho. 8.ed. São Paulo: Atlas, 2007.

MARTINS, Wal. Direito à saúde: compêndio. Belo Horizonte: Fórum, 2008.

MASAGÃO, Mário. Natureza jurídica da concessão de serviço público. São Paulo: Saraiva e Cia., 1933.

MATIAS-PEREIRA, José. Curso de administração pública: foco nas instituições e ações governamentais. São Paulo: Atlas, 2008.

MATOS, Carlos Alberto; POMPEU, João Cláudio. Where are the contracts? Analysis of the relation between private health services suppliers and the SUS. Ciência \& Saúde Coletiva, Rio de Janeiro, v.8, n.2, p.629-643, 2003.

MAYER, Otto. Derecho Administrativo Alemán. Trad. Horacio H. Heredia e Ernesto Krotoschin. Buenos Aires: De Palma, 1949. Tomo I.

MEDAUAR, Odete. O direito administrativo em evolução. São Paulo: Revista dos Tribunais, 1992.

. A figura da concessão. In: (Coord.). Concessão de serviço público. São

Paulo: Revista dos Tribunais, 1995. Convênios e consórcios administrativos. Boletim de Direito Administrativo, São Paulo, v.11, n.8, p.451-461, ago. 1995. Convênios e Consórcios Administrativos. Revista Jurídica da Procuradoria

Geral do Município de São Paulo, São Paulo, n.2, p.69-89, jun. 1996. 
. O direito administrativo em evolução. 2.ed. São Paulo: Revista dos Tribunais, 2003.

Serviços públicos e serviços de interesse econômico geral. In: MOREIRA NETO, Diogo de Figueiredo (Coord.). Uma avaliação das tendências contemporâneas do direito administrativo. Rio de Janeiro: Renovar, 2003.

Direito administrativo moderno. 11.ed. São Paulo: Revista dos Tribunais, 2007.

MEDAUAR, Odete; OLIVEIRA, Gustavo, Justino. Consórcios públicos: comentários à lei 11.107/2005. São Paulo: Revista dos Tribunais, 2006.

MÉDICI, André Cezar. A economia das reformas em saúde. Porto Alegre: IAHCS, 1997.

MEIRELLES, Hely Lopes. Direito administrativo brasileiro. 33.ed. São Paulo:

Malheiros, 2007.

MELLO, Celso Antônio Bandeira de. Natureza e regime jurídico das autarquias. São Paulo: Revista dos Tribunais, 1968.

Funerais da Constituição de 1988. In: FIOCCA, Demian; GRAU, Eros Roberto (Orgs.). Debate sobre a constituição de 1988. São Paulo: Paz e Terra, 2001.

Curso de direito administrativo. 23.ed. São Paulo: Malheiros, 2007.

MELO, Marcus André; COSTA, Nilson do Rosário; SILVA, Pedro Luís B. Inovações organizacionais em política social: o caso da Grã-Bretanha. Revista do Serviço Público, ano 50, n.3, p.5-31, jul./set. 1999.

MENDELSON, Michael; DIVINSKY, Pamela. Canada 2015: globalization and the future of Canada's health care. Ottawa: Caledon Institute of Social Policy, 2002.

MENICUCCI, Telma Maria G. Público e privado na política de assistência à saúde no Brasil: atores, processos e trajetória. Rio de Janeiro: Fiocruz, 2007.

MESTRINER, Maria Luiza. O estado entre a filantropia e a assistência social. São Paulo: Cortez, 2001. 
MINVWS - Ministerie van Volksgezondheid, Welzijn en Sport. Exceptional medical expenses act. 2007. Disponível em: $<$ http://www.minvws.nl/en/themes /exceptionalmedical-expenses-act/>. Acesso em: 11 jun. 2008.

MINVWS - Ministerie van Volksgezondheid, Welzijn en Sport. The new care system in the Netherlands. Den Haag, Holanda, 2006. Disponível em: <http://www.minvws.nl/en/ folders/z/2006/the-new-health-insurance-system-in-three-languages.asp $>$. Acesso em: 11 jun. 2008.

MIRANDA, Jorge. Manual de direito constitucional. Coimbra: Coimbra, 1988. Tomo IV. MODESTO, Paulo. Reforma do estado, formas de prestação de serviços ao publico e parcerias público-privadas: demarcando as fronteiras dos conceitos de 'serviço público', serviços de relevância pública' e 'serviços de exploração econômica' para as parcerias público-privadas. In: SUNDFELD, Carlos Ari (Coord.). Parcerias público-privadas. São Paulo: Malheiros, 2005.

. Convênio entre entidades públicas executado por fundação de apoio. Serviço de saúde. Conceito de serviço público e serviço de relevância pública na Constituição de 1988. Forma da prestação de contas das entidades de cooperação após a emenda constitucional n. ${ }^{\circ}$ 19/98. Revista Diálogo Jurídico, Salvador, n.11, p.8, fev. 2002. Disponível em: <http://www.direitopublico.com.br>. Acesso em: 28 mar. 2007.

MONCADA, Luís S. Cabral de. Estudo de direito público. Coimbra: Coimbra, 2001.

MORAIS, José Luis B. de. Do direito social aos interesses transindividuais: o estado e o direito na ordem contemporânea. Porto Alegre: Livraria do Advogado, 2006.

MORALES, Carlos Antonio. Provisão de serviços sociais através de organizações públicas não-estatais: aspectos gerais. In: BRESSER PEREIRA, Luiz Carlos; CUNILL GRAU, Nuria (Orgs.). O público não-estatal na reforma do estado. Rio de Janeiro: Editora Fundação Getúlio Vargas, 1999.

MORAND-DEVILLER, Jacqueline. Cours de Droit Administratif. 7.ed. Paris: Montchrestien, 2001. 
MOREIRA NETO, Diogo de Figueiredo. Mutações do direito administrativo. Rio de Janeiro: Renovar, 2000.

Quatro paradigmas do direito administrativo pós-moderno: legitimidade, finalidade, eficiência, resultados. Belo Horizonte: Fórum, 2008.

MOREIRA, Vital. Administração autônoma e associações públicas. Coimbra: Coimbra, 1997.

Organização administrativa. Coimbra: Coimbra, 2001.

O fim da gratuidade do SNS. Jornal Público, Lisboa, 14 de setembro de 2004.

MOTTA, Roberto Ferreira. Agências reguladoras. Barueri: Manole, 2003.

MUISER, Jorine. The new Dutch health insurance scheme: challenges and opportunities for better performance in health financing. Genéve: World Health Organization, 2007.

MUKAI, Toshio. Contratos públicos: as prerrogativas da administração e os direitos das empresas contratadas (segundo as leis $n{ }^{\text {os }} 8.666 / 93$ e 8.883/94). Rio de Janeiro: Forense Universitária, 1995.

MÜLLER, Friedrich. Concretização da constituição. In: . Métodos de trabalho em direito constitucional. Trad. Peter Naumann. 3.ed. Rio de Janeiro: Renovar, 2005.

NABAIS, José Casalta. Contratos fiscais: reflexões acerca de sua admissibilidade. Coimbra: Coimbra, 1994.

A face oculta dos direitos fundamentais: os deveres e os custos dos direitos. Revista de Direito Público da Economia - RDPE, Belo Horizonte, ano 5, n.20, p.153-182, out./dez. 2007.

NEGREIROS, Teresa. Teoria do contrato: novos paradigmas. 2.ed. Rio de Janeiro: Renovar, 2006.

NHS History. Disponível em: <http://www.nhs.uk/aboutnhs/nhshistory/pages/nhs history.aspx $>$. Acesso em: 11 set. 2008. 
NOGUEIRA, Marco Aurélio. Um estado para a sociedade civil: temas éticos e políticos da gestão democrática. São Paulo: Cortez, 2004.

NOGUEIRA, Rafael. Reflexões acerca da efetivação dos direitos sociais. A\&C Revista de Direito Administrativo e Constitucional, Belo Horizonte, ano 6, n.25, p.41-66, jul./set. 2006. NORONHA, José Carvalho de; UGÁ, Maria Alicia Dominguez. O sistema de saúde dos Estados Unidos. In: BUSS, Paulo Marchiori; LABRA, Maria Eliana. Sistemas de saúde: continuidades e mudanças. Rio de Janeiro: Hucitec e Fiocruz, 1995.

NOVAIS, Jorge Reis. Contributo para uma teoria do estado e do direito: do estado de direito liberal ao estado social e democrático de direito. Coimbra: Coimbra, 1987.

NUNES, A. J. Avelãs. Os sistemas econômicos. Coimbra: Universidade de Coimbra, 1997. NUSDEO, Fábio. Curso de economia: introdução ao direito econômico. 4.ed. São Paulo: Revista dos Tribunais, 2005.

OCKÉ-REIS, Carlos Octávio. Sistemas comparados de saúde: uma análise preliminar. Mimeo.

OECD. Proposal for a Taxonomy of Health Insurance. Paris: OECD, 2004.

OLIVEIRA, Gustavo Justino de. Contrato de gestão na administração pública brasileira. 2005. Tese (Doutorado em Direito) - Curso de Pós-Graduação em Direito, Universidade de São Paulo, São Paulo, 2005.

. Estado contratual, direito ao desenvolvimento e parceria público-privada. In: TALAMINI, Eduardo; JUSTEN, Mônica Spezia. Parcerias público-privadas: um enfoque multidisciplinar. São Paulo: Revista dos Tribunais, 2005.

OLIVEIRA, Gustavo Justino de; MÂNICA, Fernando Borges. Agentes comunitários de saúde: reflexões sobre a emenda constitucional n. ${ }^{\circ} 51$, de 14 de fevereiro de 2006, e a lei federal n. ${ }^{\circ} 11.350$, de 05 de outubro de 2006. Belo Horizonte: Fórum, 2009.

OLIVEIRA, Régis Fernandes de. Curso de direito financeiro. São Paulo: RT, 2006. 
PAIM, Jairnilson da Silva. O pensamento do movimento sanitário: impasses e contradições atuais no marco da relação público-privado no SUS. In: HEIMANN, Luiza S.; IBANHES, Lauro C.; BARBOZA, Renato (Orgs.). O público e o privado na saúde. São Paulo: Hucitec, 2005.

PAIM, Jairnilson Silva; TEIXEIRA, Carmen Fontes. Configuração institucional e gestão do Sistema Único de Saúde: problemas e desafios. Ciência e Saúde Coletiva, v.12, p.1819-1829, nov. 2007.

PARANÁ (ESTADO). Tribunal de Justiça do Estado do Paraná, 5. Câmara Cível, Apelação n. ${ }^{\circ}$ 426.165-4, Relator: Juiz Convocado Eduardo Sarrão, Diário de Justiça do Estado n. ${ }^{\circ} 7.684,22$ de ago. 2008.

PARANÁ (ESTADO). Vara Cível e Anexos da Comarca de Palotina, Processo n. ${ }^{\circ} 2006.00 .00 .0544$.

PASQUALOTO, Adalberto. A regulamentação dos planos e seguros de assistência à saúde: uma interpretação construtiva. In: MARQUES, Cláudia Lima; LOPES, José Reinaldo de Lima; PFEIFFER, Roberto A. C. Saúde e responsabilidade: seguros e planos de assistência privada à saúde. São Paulo: Revista dos Tribunais, 1999.

PAVIGANI, Enrico; COLOMBO, Alessandro. Analysing Patterns of Health Care Provision. Annex 7: Contracting for Health Services. World Health Organization. Disponível em: <http://www.who.int/hac/techguidance/tools/disrupted_sectors/module 07/en/index13.html>. Acesso em: 16. out. 2008.

PEREIRA JÚNIOR, Jessé Torres. Comentários à lei das licitações e contratações da administração pública. 6.ed. Rio de Janeiro: Renovar, 2003.

PEREIRA, César A. Guimarães. Usuários de serviços públicos: usuários, consumidores e os aspectos econômicos dos serviços públicos. São Paulo: Saraiva, 2006.

PEREIRA, Fernanda de Oliveira. Direito sanitário: a relevância do controle nas ações e serviços de saúde. Belo Horizonte: Fórum, 2004.

PEREIRA, Hélio Dias. A responsabilidade pela saúde: aspectos jurídicos. Rio de Janeiro: Fiocruz, 1995. 
PEREZ LUÑO, Antonio-Enrique. Los Derechos Fundamentales. 6.ed. Madrid: Tecnos, 1995.

PICON, Paulo Dornelles. Protocolos clínicos e diretrizes terapêuticas: a evidência científica na prática do Sistema Único de Saúde. In: BRASIL. Conselho Nacional de Secretários de Saúde. Para entender a gestão do Programa de Medicamentos de dispensação em caráter excepcional. Brasília: CONASS, 2004.

PILATTI, Adriano. A constituinte de 1987-1988: progressistas, conservadores, ordem econômica e regras do jogo. Rio de Janeiro: Lumen Júris, 2008.

PIOVESAN, Flávia. Justiciabilidade dos direitos sociais e econômicos no Brasil: desafios e perspectivas. Revista de Direito do Estado - RDE, Rio de Janeiro, ano 1, n.2, p.55-82, abr./jun. 2006.

POLANYI, Karl. A grande transformação: as origens de nossa época. Trad. Fanny Wrobel. 2.ed. Rio de Janeiro: Elsevier, 2000.

POMPEU, João Cláudio Basso. A situação contratual da rede hospitalar privada vinculada ao SUS: alguns elementos para reflexão. 2004. Dissertação (Mestrado em Gestão de Sistemas e Serviços de Saúde) - Escola Nacional de Saúde Pública da Fundação Oswaldo Cruz, Brasília, 2004.

PORTO NETO, Benedito. Licitação para contratação de parceria público-privada. In: SUNDFELD, Carlos Ari. Parcerias público-privadas. São Paulo: Malheiros, 2005. PORTUGAL. Tribunal de Contas. Relatório de Acompanhamento das PPP - Saúde 2006, n.1/07, 25p., 2007.

RAEFFRAY, Ana Paula $O$. de. Direito à saúde de acordo com a constituição federal. São Paulo: Quartier Latin, 2005.

RAMOS, Dora Maria de Oliveira. Terceirização na administração pública. Informativo de Licitações e Contratos - ILC, n.93, p.916-920, nov. 2001.

RAMOS, Marcelene C. da Silva. O direito fundamental à saúde na perspectiva da constituição federal. A\&C Revista de Direito Administrativo e Constitucional, Belo Horizonte, ano 5, n.22, p.147-165, out./dez. 2005. 
REALE, Miguel. Teoria do direito e do estado. São Paulo: Livraria Martins, 1940.

Lições preliminares de direito. 14.ed. São Paulo: Saraiva, 1987.

REIS, Carlos Octávio Ocké. O estado e os planos de saúde no Brasil. Revista do Serviço Público, ano 51, n.1, p.125-150, jan./mar. 2000.

Os planos de saúde no Brasil: um estdudo sobre o mercado, os gastos e a regulação.

2002. Tese (Doutorado em Saúde Coletiva) - Curso de Pós-Graduação em Saúde Coletiva, Universidade do Estado do Rio de Janeiro, Rio de Janeiro, 2002.

REXACH, Ángel Menéndez. Formas Jurídicas de Gestión de los Servicios Sanitários. In: PAREJO, Luciano; LOBO, Félix; VAQUER, Marcos (Coords.). La Organización de los Servicios Públicos Sanitários. Madrid: Marcial Pons, 2001.

RIBEIRO, José Mendes. Reforma do sector público hospitalar: programa de empresarialização de 34 hospitais portugueses. Revista Portuguesa de Saúde Pública, v.4, p.65-77, 2004. . Financiamento e desenho institucional no setor de saúde nos Estados Unidos da América. In: BISOTO JÚNIOR, Geraldo; SILVA, Pedro L. de Barros; DAIN, Sulamis (Orgs.). Regulação do setor de saúde nas Américas: as relações entre o público e o privado numa abordagem sistêmica. Brasília: Organização Pan-Americana da Saúde, 2006. RIO DE JANEIRO (ESTADO). Juízo de Direito da 5. ${ }^{a}$ Vara da Fazenda Pública. Juiz de Direito Marcello de Sá Baptista.

RIO DE JANEIRO (ESTADO). Tribunal de Justiça. Nona Câmara Cível. Apelação Cível n. ${ }^{\circ}$ 2322/2002. Relator: Desembargador Joaquim Alves de Brito, julg.30 fev. 2002.

RIVERO, Jean. Direito administrativo. Trad. Rogério E. Soares. Coimbra: Almedina, 1981. ROCHA, Cármen Lúcia Antunes. O serviço público de saúde no direito brasileiro. Brasília: OPS, 1988.

ROCHA, Julio César da. Direito da saúde. São Paulo: LTr, 1999. 
ROCHA, Sílvio Luís F. da. Tipos de planos e coberturas na lei 9.656/98. In: MARQUES, Cláudia Lima; LOPES, José Reinaldo de Lima; PFEIFFER, Roberto A. C. Saúde e responsabilidade: seguros e planos de assistência privada à saúde. São Paulo: Revista dos Tribunais, 1999.

RODRÍGUEZ MEDINA, Carmen. Salud Pública y Assistência Sanitária em la União Europea: Uma Unión más cercana al ciudadano. Granadada: Comares, 2008.

RODRIGUEZ NETO, Eleutério. Saúde: promessas e limites da constituição. Rio de Janeiro: FIOCRUZ, 2003.

ROPPO, Enzo. O contrato. Trad. Ana Coimbra e M. Januário C. Gomes. Coimbra: Almedina, 1988.

ROSANVAllON, Pierre. A crise do estado-providência. Trad. Joel Pimentel de Ulhôa. Goiânia: UFG; Brasília: UNB, 1997.

ROSE, Richard. On the Priorities of Government: A developmental Analysis of Public policies. European Journal of Political Research, Amsterdam, n.4, 1976.

ROSEN, George. Da polícia médica à medicina social. Trad. Ângela Loureiro. Rio de Janeiro: Graal, 1980.

A History of Public Health. Baltimore: Johns Hopkins University, 1993.

ROUSSEAU, Jean-Jacques. Do contrato social. Trad. Pietro Nassetti. São Paulo: Martin Claret, 2002.

SALAMON, Lester M.; ANHEIER, Helmut K.; LIST, Regina; TOEPLER, Stefan; SOKOLOWSKI, S. Wojciech; and Associates. Global civil society: dimensions of the nonprofit sector. Baltimore: The Jonhs Hopkins Center for Civil Society Studies, 1999.

SALOMÃO FILHO, Calixto. Breves Acenos para uma análise estruturalista do contrato. Revista de Direito Público da Economia - RDPE, Belo Horizonte, ano 5, n.17, p.41-74, jan./mar.2007. 
SÁNCHES-CARO, Javier. Régimen Jurídico de las Nuevas Formsa de Gestión em la Sanidad Española (la perspectiva del Instituto Nacional de Salud). In: PAREJO, Luciano; LOBO, Félix; VAQUER, Marcos (Coords.). La Organización de los Servicios Públicos Sanitários. Madrid: Marcial Pons, 2001.

SANDIER, Simone; PARIS, Valérie; POLTON, Dominique. Health care systems in transition: France. Conpenhagen: WHO Regional Office for Europe on behalf of the European Observatory on Health Systems and Policies, 2004.

SANDRONI, Paulo. Novíssimo dicionário de economia. 10.ed. São Paulo: Best Seller, 2002. SANTOS, Boaventura de Sousa. Pela mão de Alice: o social e o político na pós-modernidade. 7.ed. São Paulo: Cortez, 2000.

. (Dir. Científico). Parcerias público-privadas e justiça: uma análise comparada das diferentes experiências. Coimbra: Centro de Estudos Sociais, 2007.

. É a saúde, estúpido! Visão, 14 fev. 2008.

. Saúde: do serviço ao negócio. Visão, 28 ago. 2008.

A reinvenção solidária e participativa do estado. Mimeo.

SANTOS, Isabela Soares; UGÁ, Maria Alicia D.; PORTO, Silvia Marta. O mix públicoprivado no sistema de saúde brasileiro: financiamento, oferta e utilização de serviços de saúde. Ciência e Saúde Coletiva, n.13, p.1431-1440, 2008.

SANTOS, Lenir. Nota explicativa. In: RODRIGUEZ NETO, Eleutério. Saúde: promessas e limites da constituição. Rio de Janeiro: FIOCRUZ, 2003.

SANTOS, Lenir; ANDRADE, Luiz Odorico M. de. SUS: o espaço da gestão inovada e dos consensos interfederativos: aspectos jurídicos, administrativos e financeiros. Campinas: Instituto de Direito Sanitário Aplicado, 2007.

SÃO PAULO (ESTADO). 3. ${ }^{a}$ Vara Cível da Justiça Federal. Processo n. ${ }^{\circ}$ 2006.61.00.009087-9. Juíza Federal Maria Lucia Lencastre URSAIA. Julg. 26 ago. 2008. 
SÃO PAULO (ESTADO). Tribunal de Justiça do Estado de São Paulo. Ação Direta de Inconstitucionalidade n. ${ }^{\circ}$ 130.726-0/700, Órgão Especial, Relator Desembargador Renato NALINI, julg. 28 fev. 2007.

SÃO PAULO (ESTADO). Tribunal de Justiça do Estado de São Paulo. Agravo de Instrumento n. ${ }^{\circ}$ 627.715-5/3-00 - SP. Relator: Des. Lineu Peinado. Julg. 07 ago. 2007. Disponível em: $<$ http://www.tj.sp.gov.br>. Acesso em: 20 out. 2008.

SARLET, Ingo Wolfgang. A eficácia dos direitos fundamentais. 2.ed. Porto Alegre: Livraria do Advogado, 2001.

Algumas considerações em torno do conteúdo, eficácia e efetividade do direito à saúde na Constituição de 1988. Revista Diálogo Jurídico, Salvador, Centro de Atualização Jurídica, n.10, jan. 2002. Disponível em: <www.direitopublico.com.br> . Acesso em: 27 jul. 2007.

A eficácia dos direitos fundamentais. 8.ed. Porto Alegre: Livraria do Advogado, 2007.

SARLET, Ingo Wolfgang; FIGUEIREDO, Mariana F. Reserva do possível, mínimo existencial e direitos à saúde: algumas aproximações. In: SARLET, Ingo Wolfgang; TIMM, Luciano Benetti (Orgs.). Direitos fundamentais, orçamento e 'reserva do possível'. Porto Alegre: Livraria do Advogado, 2007.

SCHEFFER, Mario; BAHIA, Ligia. Planos e seguros privados de saúde no Brasil: lacunas e perspectivas da regulamentação. In: HEIMANN, Luiza S.; IBANHES, Lauro C.; BARBOZA, Renato (Orgs.). O público e o privado na saúde. São Paulo: Hucitec, 2005.

SCHWARTZ, Germano. Direito à saúde: efetivação em uma perspectiva sistêmica. Porto Alegre: Livraria do Advogado, 2001.

SCLIAR, Moacyr. Do mágico ao social: trajetória da saúde pública. 2.ed. São Paulo: Senac, 2005.

SCORSIM, Ericson Meister. Estatuto dos serviços de televisão por radiodifusão. 2007. Tese (Doutorado em Direito) - Curso de Pós-Graduação em Direito, Universidade de São Paulo, São Paulo, 2007. 
SEITENFUS, Ricardo. Manual das organizações internacionais. Porto Alegre: Livraria do Advogado, 1997.

SÈROUSSI, Roland. Introdução ao direito inglês e norte americano. Trad. Renata M. Cordeiro. São Paulo: Landy, 1999.

SICKO (Filme). Direção: Michael Moore. Produção: Michael Moore. Estados Unidos: Dog eat Dog Films, 2007. 1 DVD (123 min). Distribuição no Brasil: Europa Filmes.

SIDDIQI, Sameen; MASUD Tayyeb Imran; SABRI, Belgacem. Contracting but not without cautin: experience with outsourcing oh health services in contries of the Eastern Mediterranean Region. Bulletin os the World Health Organization, n.84, november, 2006.

SIEYÈS, Emmanuel Joseph. A constituinte burguesa. Qu'est-ce que lê Tiers État? 4.ed. Trad. Norma Azevedo. Rio de Janeiro: Lumen Juris, 2001.

SILVA, Almiro Couto e. Os indivíduos e o estado na realização de tarefas públicas. In: MELLO, Celso Antônio Bandeira de (Org.). Estudos em homenagem a Geraldo Ataliba: direito administrativo e constitucional. São Paulo: Malheiros, 1997.

SILVA, Antônio Carlos Pacheco e. Direito à saúde (documentos da atividade parlamentar). [s.1.]: [s.n.], 1934.

. Serviços sociais. São Paulo: [s.n.], 1937.

SILVA, José Afonso da. Curso de direito constitucional positivo. 5.ed. São Paulo: Malheiros, 1989.

. Aplicabilidade das normas constitucionais. 3.ed. São Paulo: Malheiros, 1998. . Curso de direito constitucional positivo. 22.ed. São Paulo: Malheiros, 2003.

SILVA, José P. Vicente da; PINHEIRO, Roseni.; MACHADO, Felipe R. S. Necessidades, demanda e oferta: algumas contribuições sobre os sentidos, significados e valores na construção da integralidade na reforma do Setor de Saúde. Saúde em Debate, Rio de Janeiro, v.27, n.65, p.234-242, set./dez. 2003. 
SILVA, Luís Virgílio Afonso da. O conteúdo essencial dos direitos fundamentais e a eficácia das normas constitucionais. 2005. Tese (Professor Titular) - Universidade de São Paulo, São Paulo, 2005.

. A constitucionalização do direito. São Paulo: Malheiros, 2008.

SIMÕES, Jorge Abreu. As parcerias público-privadas no sector de saúde em Portugal.

Revista Portuguesa de Saúde Pública, v.4, p.79-90, 2004.

SINGER, Paul; CAMPOS, Oswaldo; OLIVEIRA, Elizabeth. Prevenir e curar: o controle social através dos serviços de saúde. Rio de Janeiro: Forense Universitária, 1988.

SMITH, Adam. Inquérito sobre a natureza e as causas da riqueza das nações. Trad. Luís C. de Aguiar. 4.ed. [s. 1.]: Fundação Calouste Gulbenkian, 2006. v.2.

SOUTO, Marcos Juruena Villela. Desestatização, privatização, concessões e terceirizações. 3.ed. Rio de Janeiro: Lumen Juris, 2000.

Direito administrativo das concessões. 5.ed. Rio de Janeiro: Lumen Júris, 2004.

SUNDFELD, Carlos Ari. Licitação e contratos administrativos. 2.ed. São Paulo: Malheiros, 1994.

Direito administrativo ordenador. São Paulo: Malheiros, 1997. . A administração pública na era do direito global. In: SUNDFELD, Carlos Ari; VIEIRA, Oscar Vilhena. Direito global. São Paulo: Max Limonad, 1999. Serviços públicos e regulação estatal. In: (Coord.). Direito administrativo econômico. São Paulo: Malheiros, 2000.

. Fundamentos de direito público. 4.ed. São Paulo: Malheiros, 2001.

. Guia jurídico das parcerias público-privadas. In: . Parcerias público-privadas. São Paulo: Malheiros, 2005. 
SZKLAROWSKY, Leion Fredja. Os convênios administrativos. Convênio - Contrato administrativo - Consórcio administrativo - Constituição federal - Decreto-Lei 2.300/86 e legislação pertinente - Doutrina e jurisprudência do TCU. Revista dos Tribunais, ano 80, v.669, p.39-47, jul. 1991.

TÁCITO, Caio. O retorno do pêndulo: serviço público e empresa privada: o exemplo brasileiro. Revista de Direito Administrativo, Rio de Janeiro, v.1, p.1-10, 1991.

TANAKA, Oswaldo Yoshimi. A judicialização da prescrição medicamentosa no SUS ou o desafio de garantir o direito constitucional de acesso à assistência farmacêutica. Revista de Direito Sanitário, São Paulo, v.9, n.1, p.139-143, mar./jun. 2008.

TANAKA, Oswaldo Y; MELO, Cristina (Orgs.). Inovação e gestão: a organização social no setor saúde. São Paulo: Annablume/Fapesp, 2002.

TANAKA, Oswaldo Yoshimi; OLIVEIRA, Vanessa Elias de. Reforma(s) e estruturação do sistema de saúde britânico: lições para o SUS. Saúde e Sociedade, v.16, n.1, p.7-17, jan./abr. 2007.

TANNER, Michael. The grass is not always greener: a look at the national health care systems around the world. Policy Analysis, Washington (DC), n.613, mar. 2008.

TEMPORÃO, José Gomes. O desafio de financiar o SUS. Folha de S. Paulo, São Paulo, 03 de junho de 2008, p.A3.

TOCQUEVILlE, Alexis de. A democracia na América. Trad. Neil R. da Silva. 4.ed. Belo Horizonte: Itatiaia, 1998.

TOJAL, Sebastião Botto de Barros. O direito regulatório do estado social e as normas legais de saúde pública. In: O direito sanitário na constituição brasileira de 1988: normatividades, garantias e seguridade social. Brasília: Organização Pan-Americana de Saúde, 1994.

Constituição dirigente de 1988 e o direito à saúde. In: MORAES, Alexandre (Org.).

Os 10 anos da constituição federal. São Paulo: Atlas, 1999. 
TORRES, Ricardo Lobo. A cidadania multidimensional na era dos direitos. In:

(Org.). Teoria dos direitos fundamentais. 2.ed. Rio de Janeiro: Renovar, 2001. A metamorfose dos direitos sociais em mínimo existencial. In: SARLET, Ingo Wolfgang (Org.). Direitos fundamentais sociais: estudos de direito constitucional internacional e comparado. Rio de Janeiro: Renovar, 2003.

VALK, Loes Van Der. Public Policy and Private Interests in Social Insurance Legislation: The case of United Kingdom and Netherlands. In: RANDERAAD, Nico (Ed.). Mediators between State and society. Hilversum: Verloren, 1998.

VARELA, J. M. Antunes. Direito das obrigações: conceito, estrutura e função da relação obrigacional, fontes das obrigações, modalidades das obrigações. Rio de Janeiro: Forense, 1977.

VEDEL, Georges; DELVOLVÉ, Pierre. Droit administratif. Paris: Presses Universitaires de France, 1984.

VELÁSQUEZ, German. Farmacoeconomía: Evaluación científica o Estratégia Comercial? In: BERMUDEZ, Jorge A. Zepeda; BONFIM, José R. de Alcântara (Orgs.). Medicamentos e a reforma do setor de saúde. São Paulo: Hucitec, 1999.

VEN, Wynand van de. The Netherlands. In: HAM, Chris. Health Care Reform: Learning from International Experience. Buckingham: Open University Press, 1997.

VERGARA, Patrícia Lopes. Titularidad em el Servicio Público. Revista de Derecho Administrativo, ano 11, n.30-32, 1999.

VIEIRA, Fabiola Sulpino. Ações judiciais e o direito à saúde. Revista de Saúde Pública, São Paulo, v.42, n.2, p.365-369, abr. 2008.

VILLAR PALASÍ, José Luis. La intervencion administrativa en la industria. Madrid: Instituto de Estudios Politicos, 1964.

WALD, Arnold; MORAES, Luiza Rangel de; WALD, Alexandre de M. O direito de parceria e a nova lei de concessões (análise das leis 8.987/95 e 9.074/95). São Paulo: Revista dos Tribunais, 1996. 
WEBER, Albrecht. Estado social, direitos fundamentais sociais e segurança social na República Federal da Alemanha. Trad. Andréas Sanden e Ana F. Sanden. In: BARROS, Sérgio R. de; ZILVETI, Fernando Aurélio. Direito constitucional: estudos em homenagem a Manoel Gonçalves Ferreira Filho. São Paulo: Dialética, 1999.

WEICHERT, Marlon Alberto. Saúde e federação na constituição brasileira. Rio de Janeiro: Lumen Júris, 2004.

WERNER, Patrícia U. Pizarro. O direito social e o direito público subjetivo à saúde - o desafio de compreender um direito com duas faces. Revista de Direito Sanitário, São Paulo, v.9, n.2, p.92-131, jul./out. 2008.

WOLKMER, Antonio Carlos. História do direito no Brasil. 4.ed. Rio de Janeiro: Forense, 2007.

WORLD HEALTH ORGANIZATION. World health statistics 2007. Genebra: WHO Press, 2007.

\section{Sites consultados:}

http://www.un.org/spanish/aboutun/unmember.htm

http://www.vatican.va/holy_father/leo_xiii/encyclicals/documents/hf_l-xiii_enc_ 15051891_rerum-novarum_po.html http://www.opas.org.br/opas.cfm e http://www.paho.org/english/paho/member-states.htm http://datafolha.folha.uol.com.br/po/ver_po.php?session=787 http://www.senado.gov.br/anais/ http://pfdc.pgr.mpf.gov.br/grupos-de-trabalho/saude/RelatrioTerceirizaoGT-Saude.pdf https://www.convenios.gov.br/portal/ 